\title{
Als de Koning dit eens wist...! : over gezag en kennis, onschendbaarheid en onfeilbaarheid, in hun onderlinge historie
}

Citation for published version (APA):

Krol, C. B. (1994). Als de Koning dit eens wist...! : over gezag en kennis, onschendbaarheid en onfeilbaarheid, in hun onderlinge historie. [Doctoral Thesis, Maastricht University]. Maklu. https://doi.org/10.26481/dis.19941103ck

Document status and date:

Published: 01/01/1994

DOI:

10.26481/dis.19941103ck

Document Version:

Publisher's PDF, also known as Version of record

Please check the document version of this publication:

- A submitted manuscript is the version of the article upon submission and before peer-review. There can be important differences between the submitted version and the official published version of record.

People interested in the research are advised to contact the author for the final version of the publication, or visit the DOI to the publisher's website.

- The final author version and the galley proof are versions of the publication after peer review.

- The final published version features the final layout of the paper including the volume, issue and page numbers.

Link to publication

\footnotetext{
General rights rights.

- You may freely distribute the URL identifying the publication in the public portal. please follow below link for the End User Agreement:

www.umlib.nl/taverne-license

Take down policy

If you believe that this document breaches copyright please contact us at:

repository@maastrichtuniversity.nl

providing details and we will investigate your claim.
}

Copyright and moral rights for the publications made accessible in the public portal are retained by the authors and/or other copyright owners and it is a condition of accessing publications that users recognise and abide by the legal requirements associated with these

- Users may download and print one copy of any publication from the public portal for the purpose of private study or research.

- You may not further distribute the material or use it for any profit-making activity or commercial gain

If the publication is distributed under the terms of Article $25 \mathrm{fa}$ of the Dutch Copyright Act, indicated by the "Taverne" license above, 
Als de Koning dit eens wist...! 
Van dit proefschrift verschijnt een handelseditie in de lus Commune Reeks onder ISBN nummer 9062154360 


\title{
Als de Koning dit eens wist...!
}

\author{
Over gezag en kennis, \\ onschendbaarheid en onfeilbaarheid, \\ in hun onderlinge historie
}

\section{PROEFSCHRIFT}

ter verkrijging van de graad van doctor aan de Rịksuniversiteit Limburg te Maastricht, op gezag van de Rector Magniticus, Prof.dr. H. Philipsen, volgens het besluit van het College van Dekanen, in het openbaar te verdedigen op donderdag 3 november 1994 om 14.00 uur

door

Charel Bastiaan Krol 
Promotor:

Co-promotoren:

Beoordelingscommissie:
Prof.mr. C. Flinterman

Dr. F. van Dun

Dr. R.E. de Winter

Prof.mr. F.A.M. Stroink (voorzitter)

Prof.dr. H.F.M. Crombag

Prof.dr. E. Blankenburg (VU Amsterdam)

Prof.dr. R. van Caenegem (Universiteit Gent) 
Voor Bastiana Johanna Geertruida Moleveld en vonr Carel Willem Krol die op 9 december 1960 tot hun grote vreugde van de Heere een zoon kregen. 
De tekst van dit proefschrift is afgesloten in oktober 1993. 


\section{Verantwoording}

Op zoek naar de steen der wijzen?

Sleutel van het geheimenis des levens, die dus tot eeuwige jeugd de toegang zou ontsluiten, is evenwel de steen der wijzen een dood ding, op een verborgen plaats te vinden door wie hem daama voorgoed zal bezitten.

Wie vindt, bezit, wie bezit, heeft; en heeft niets meer te doen.

Niets hoeft hij meer na te streven.

Wat is een mens zonder doen, wat is een mens zonder streven?

De vinder eindigt als de vondst: Een dood ding.

Deze paradox verschuilt zich in de sage van de steen der wijzen.

In mijn onderzoek tot ontplooiing komend, openbaart zich als de oorsprong ervan een filosofie.

Zij loochent de vondst en het bestaan van een steen der wijzen.

Geen dood ding kan het leven ontsluiten.

Er is alleen het leven zelf, dat zich voortdurend ontsluit en altijd gesloten blijft.

Dat altijd voor het grijpen ligt. en altijd voortvluchtig is.

Geenszins zou deze filosofie het zoeken verbieden, en evenmin verklaart zij het nutteloos.

Elk hoeft immers maar te grijpen om woorden te vinden dit het uiterste vatten.

Het sprekende woord ís leven.

Toch is nooit een woord voorgoed. Het woord, eenmaal gesproken, is dood.

Het blijt machteloos achter wanneer het leven zich in vernieuwing ontplooit.

Dit hoewel het ooit leven heeft uitgedrukt; en hoewel het leven in vernieuwing juist zichzelf blijft.

Ook hier is de paradox; zij kan echter ruiterlijk worden erkend.

Het eenmaal gesproken ware woord zal een knellende band zijn voor wie het onveranderlijk wil handhaven ook als de ontwikkeling voortgaat.

De eenmaal gevonden steen der wijzen zou de eerst gelukkige vinder dwingen tot de rust van de dood; wie nog zou willen voortgaan, dient de steen te dragen, te torsen als een steeds zwaarder last, als een molensteen om de hals.

Dode dingen moeten gedragen worden.

Het leven daarentegen draagt zélf.

Februari 1990 

. 


\section{Een woord vooraf}

"Bzzzzz!" Het venijnige geluid van een zoemer. De quiz-master dringt aan: "Het antwoord moet nú komen..." Dan, onverbiddelijk: "Ja, uw tijd is om."

Hadden we maar meer tijd gehad, dan was het antwoord ons wel te binnen geschoten. Iets meer tijd, het goede antwoord lag ons voor in de mond!

Het is met een huiver dat ik nu dan mijn boek openleg. Ik had een idee dat aardig leek, en eenvoudig te realiseren: een beginsel van Nederlands staatsrecht, de koninklijke onschendbaarheid en ministeriële verantwoordelijkheid, in verbinding brengen met de mythe van de altijd goede koning. Ik begreep het niet, en na alle uitstel, wroeten en piekeren, vind ik nog dat ik het onvoldoende begrijp. Hoe zal het er dan op papier uitzien?

Het idee dwong me universeel te denken. Tal van vakgebieden, domein van specialisten en elk goed voor een oeverloze lektuur, betrad ik onbevoegd. Het verwijt van pretentie ligt voor de hand. Ooit kreeg ik, maar vriendschappelijk en in alle welwillendheid, de waarschuwing niet te veel te willen; het ontlokte me een verantwoording, hier te vinden vóór het voorwoord.

De wijde strekking van het onderzoek had ook een plezierige zijde. Het experimentele, het grasduinen: Ik kwam in aanraking met allerlei theorieën en allerlei mensen, soms heel onverwachts, soms met een enkel woord dat ze zelf onmiddellijk vergaten maar dat bij mij jaren meeging. Wie me door drukwerk verder hielp, kan men in de literatuurlijst nalezen. Het is maar een greep.

Anderen, die me mondeling hielpen; anderen, uit de tijd dat het moeilijk was, die het soms makkelijker, soms moeilijker maakten: Rini Eijs te Maastricht, br. Pieter van Ginneken en br. Frans Huiting te Oosterhout, Sef Imkamp te 's-Gravenhage, Johannes Maks te Delft, Magda Pontier te Utrecht, J.-Jacques Rouquet in Toulouse, en fr. François Stoop in Taizé, Frankrijk. Ook weer een greep. Ik betreur het, niet elke ontmoeting van deze jaren te kunnen vermelden, en vrees juist de belangrijkste bijdragen over het hoofd te zien, omdat ze vanzelfsprekend waren en me volledig eigen werden.

Gebruikelijk is dat een schrijver zijn raadslieden verschoont van alle gebreken en misslagen die nog in het boek zouden zijn. Het gaat mij moeilijk af, zoals een eventuele lezer na het beëindigen van dit boek vanzelf zal verstaan.

Ik leg mijn boek met een huiver open. Heeft de onvolledigheid, het onvoltooide te maken met de aard van het onderwerp? Het onderzoek is een poging binnen te dringen in de mysteriën van machtsuitoefening en menselijke verhoudingen, graven in funda- 
menten met ingang noch uitgang. Weer een waarschuwing: "On gardera daIns leur pénombre les secrets du roi." Is er niet alleen een te hoog grijpen, ook een zich vergrijpen?

Ik denk 't niet. Een echte Koning heeft van ernstig onderzoek niets te vrezen; ee $I_{n}$ echte Koning legt graag verantwoording af. Zijn macht is niet op angst gegrond en ze izal niet zomaar uiteengerafeld haar kracht verliezen. Want zijn geheim is altijd groter dan de grootste onthulling.

Hoeveel je ook ziet, steeds is er meer te zien. Graag was ik nog een tijdje doorigegaan met de studie van deze dingen!

Maar mijn tijd is om. Het antwoord moet nú komen.

Oktobe,r 1992 


\section{Inhoud}

Verantwoording $\ldots \ldots \ldots \ldots \ldots \ldots \ldots \ldots \ldots \ldots \ldots \ldots \ldots \ldots \ldots \ldots$

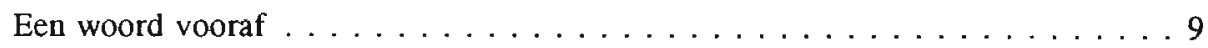

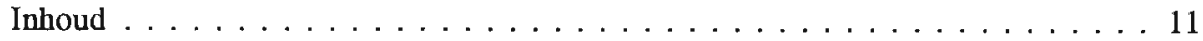

\section{Inleiding}

Hoofdstuk 1

Inleiding

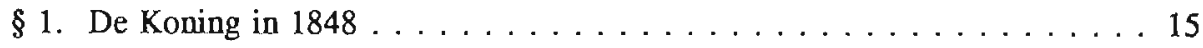

$\S 2$. De Koning als machteloze $\ldots \ldots \ldots \ldots \ldots \ldots \ldots \ldots \ldots$

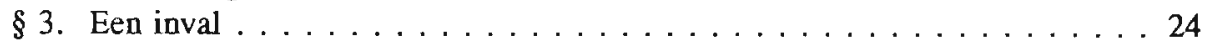

$\S 4 . \ldots$ en andere problemen . . . . . . . . . . . . . . 26

§5. Vragen, en een methode $\ldots \ldots \ldots \ldots \ldots \ldots \ldots \ldots \ldots$

\section{De Koning}

Hoofdstuk 2

De Koning als beeld Gods $\ldots \ldots \ldots \ldots \ldots \ldots \ldots \ldots$

Hoofdstuk 3

De Koning als gemeenschap $\ldots \ldots \ldots \ldots \ldots \ldots \ldots \ldots \ldots$

Hoofdstuk 4

De Koning ais gerechtigheid $\ldots \ldots \ldots \ldots \ldots \ldots \ldots$ 
De mythe

Hoofdstuk 5

De mythe van de goede Koning .

Hoofdstuk 6

De goede Koning in Nederland

Hoofdstuk 7

De mythe van het goede 1848

\section{Uitleiding}

Hoofdstuk 8

God als het beeld van de Koning .

Een woord achteraf . . . . . . . . . . . . . . . . . . . . 247

Literatuurlijst . . . . . . . . . . . . . . . . . . . . . . . . . 249

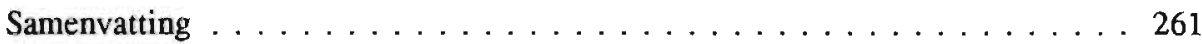

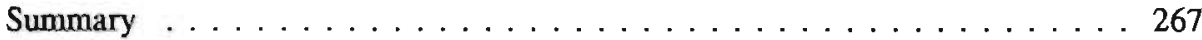

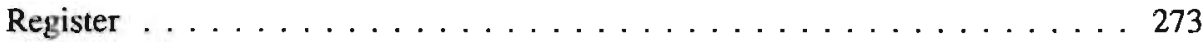

Curriculum vitae . . . . . . . . . . . . . . . . . . 277 
Inleiding 


\section{Hoofdstuk 1}

\section{Inleiding}

\section{$\S 1$. De koning in 1848}

Voor een boek dat over Nederlands staatsrecht moet gaan, is 1848 een goed begin. In het jaar 1848 immers kreeg de Nederlandse staat een nieuw uiterlijk; verregaande herziening van de grondwet vestigde een staatsvorm die tot vandaag in grote trekken werd gehandhaafd. Al is sedertdien veel gewijzigd, de hoofdlijnen staan ook thans zoals ze toen zijn getrokken. Nog in 1975, tijdens de voorbereidingen van de jongste omvangrijke grondwetsherziening, in 1983 voltooid, werd die schertsend betiteld als "een face lift van een oude dame". 'Meer niet. Onze huidige grondwet en ons huidige staatsrecht hebben zodoende hun oorsprong in de gebeurtenissen en in de gedachten van het jaar 1848.

Het had er in 1848 uitgezien alsof door heel Europa de bliksem gelijktijdig insloeg. Het werelddeel was nog lang niet van de Franse Revolutie bekomen toen het revolutionaire ideeēngoed, dat zich, gedragen door de beweging van het 'liberalisme', wijd had verbreid, opnieuw tot uitbarsting kwam. Het begon als toen in Frankrijk en breidde zich razendsnel uit; Europa schudde op haar grondvesten, overal was omwenteling van staatkundige verhoudingen. De Oostenrijkse kanselier Metternich, internationaal de naam van orde en behoud, tuimelde van zijn zetel en vluchtte in vermomming naar Engeland. Hevige schrik heerste bij de gezetenen.

En Nederland? Kon de revolutie Nederland voorbijgaan? Koning Willem II wachtte niet af. Hij riep op 13 maart de voorzitter van de Tweede Kamer bij zich en verklaarde zijn bereidheid tot een verregaande herziening van de grondwet, met inwilliging van belangrijke liberale eisen. De koning had, zei hij, het besluit hiertoe alleen genomen, zonder zijn ministers te raadplegen of ook maar in te lichten. Eigenlijk een flagrante schending van de oude grondwet; die bepaalde dat koninklijke besluiten pas rechtsgeldig waren wanneer een minister ze had ondertekend. Het werd wel in het voorbijgaan opgemerkt, maar de vloedgolf van revolutionaire gebeurtenissen overspoelde het. Een detail, verwaarlooshaar. 
En dat terwijl ministers tot 1848 meermaals op grondwetsherziening hadden aangedrongen! Tot 1848 had Willem II steeds geweigerd. Nu ging de herziening dan door, maar zij stonden als tegenstanders te kijk. Begrijpelijk dat ze "zeer gebelgd" waren, zoals Aeneas Mackay, dienstdoend kamerheer van de koning, in zijn dagboek noteerde. $\mathrm{Ze}$ kwamen op 15 maart bijeen, stelden de situatie vast, besloten gezamenlijk ontslag te vragen en kregen het dezelfde dag. Op dat bericht, vertelt een ander dagboek, was het "hoerah en Oranje Boven in Den Haag en in heel Nederland"; optochten met muziek en fakkels trokken rond, ovaties aan de koning. ${ }^{2}$

Blijdschap, want de baan was vrij voor de nieuwe tijd. Op 17 maart benoemde Willem II een kommissie, met opdracht de grondwet van het Koninkrijk der Nederlanden te herschrijven; de liberale hoogleraar Johan Rudolf Thorbecke, die enkele jaren eerder naam had gemaakt met zijn Aanteekening op de Grondwet, werd voorzitter. Een vlotte kommissie. Binnen een maand, op 11 april, mocht de koning het ontwerp van de kommissie in ontvangst nemen en zeven maanden later, door enig touwtrekken tussen diverse instanties ontstond vertraging, werd tenslotte op 3 november de nieuwe grondwet plechtig afgekondigd.

Een grondwet vol liberale nieuwigheden, men zou er lang aan moeten wennen. Met name een beginsel dat volgens uitspraken van de Tweede Kamer niet langer in de grondwet mocht ontbreken; de kommissie-Thorbecke had het overgenomen en thans stond het te lezen in artikel 53:

"De Koning is onschendbaar; de ministers zijn verantwoordelijk."

"Niet langer mocht ontbreken"? Het is flauw uitgedrukt. De regel van koninklijke onschendbaarheid en ministeriële verantwoordelijkheid was al die jaren een heet hangijzer geweest, een twistpunt waarin zich alle revolutionaire hartstocht leek te verzamelen. Toen het beginsel in 1815, twee grondwetten eerder, werd voorgesteld, had het een heftige diskussie tot onmiddellijk gevolg gehad; het bleef tot 1848 hoofdzaak van de politieke strijd en niets werd bij de herziening vuriger verlangd dan dat het ministerie voortaan verantwoordelijk zou zijn. Ze doen, schreef De Gids in 1847 schamper, alsof ministeriële verantwoordelijkheid de "treurigen toestand, waaronder wij gebukt gaan, plotseling opheffen en als met den slag eener tooverroede in een staat van ongekenden bloei en welvaart herscheppen zoude". ${ }^{3}$

Artikel $53 \mathrm{Gw} 1848$ was niet zomaar een artikel. Volgens Johannes Bosscha, schrijvend als oud-minister, vijftien jaar later, had in de tijd van 1848 de mening geheerst, dat een verantwoordelijk ministerie "het bolwerk, de hoeksteen, het plegtanker, het palladium is van een constitutioneel Gouvernement". De overdrijving in deze woordenreeks doet vermoeden dat hij het zelf niet erg heeft geloofd, maar inderdaad, een pamfletschrijver noemde in 1848 dit artikel het "gewigtigste", en verklaarde: ${ }^{4}$

2. Duyverman 36, 40; Boogman 51 .

3. Buys I, 180: Bosscha 47/48: De Gids II (1847) B., blz. 780; vgl. Groen van Prinsterer, Bijdrage 12 (Verspreide geschrifien $I I .162$ ).

4. Bosscha 47; J. van 's Gravenween, Het onwerp van grondwet, apill 1848. Vergeleken mer de grondwet van 1848, Amhen 1848, blz. 6-7. 
"In dat Artikel alleen, met eenige weinige vrijzinniger of meer bepaald ontwikkelde beschikkingen, uit dat Artikel voortgevloeid. zoude de voornaamste herziening der Grondwet hebben kunnen bestaan ..."

Later zou de liberale boogleraar Johan Theodoor Buys, gezaghebbend kenner van het Nederlandse staatsrecht, werkelijk in art. 53 "de hoofdgedachte van de constitutionele monarcbie" erkennen. " Konstitutionele monarchie: een koningschap gebonden aan grondwettelijke regels was het uitgesproken politieke doel van de Nederlandse liberalen geweest; in 1848 en speciaal door artikel 53 hadden zij het bereikt.

Een artikel dus om zuinig op te zijn. Het bleef sindsdien onverkort in de grondwet; geen wijziging en geen wijzigingsvoorstel heeft nog letter of leesteken aangetast. In 1980 lichtte de ministerraad toe: ${ }^{6}$

"In haar compacte formulering geeft de bepaling uitdrukking aan een fundamenteel beginsel van ons staatsrecht. Nu men met deze formule sinds meer dan een eeuw vertrouwd is gerakt en deze geen enkel nisverstand wekt achten wij het juist dit beginsel in dezelfde bewoordingen te handhaven."

Toch is dan intussen iets veranderd: Het beginsel, anderhalve eeuw terug fel omstreden, werd ons sedertdien vertrouwd, het werd onmisbaar, door niemand meer bestreden of betwijfeld. "Geen enkel misverstand", schreef de regering en de literatuur valt haar bij. Het artikel roept geen meningsverschil meer op; een bespreking zou de moeite niet lonen omdat, in de woorden van een recent proefschrift, "de betekenis van de ministeriële verantwoordelijkheid voor het optreden van de Koning uit een oogpunt van democratie niet bijzonder problematisch is." Uit Engeland, de bakermat van het beginsel, vernemen we hetzelfde geluid; en in de bibliotheken die ik aandeed was de literatuur over dit onderwerp in zeker tien jaar niet meer aangevraagd. ${ }^{7}$

Het lijkt er dus op dat een eindoordeel is bereikt, algemeen en onwrikbaar: Wie nog iets nieuws aan de regel van koninklijke onschendbaarheid en ministeriële verantwoordelijkheid zou willen beleven, is tot machteloosheid gedoemd.

\section{§ 2. De koning als machteloze}

Wat betekende artikel 53 van de grondwet van 1848 ? Wat betekent de regel die thans artikel 42 lid 2 van de grondwet is? De staatsrechtelijke literatuur verwart misschien op het eerste gezicht door de uiteenlopende formuleringen, maar bij nader toezien blijkt al snel een hechte overeenstemming. De ministeriële verantwoordelijkheid is inderdaad uit het oogpunt van demokratie niet bijzonder problematisch; want demokratie wil zeggen dat het volk de politieke touwtjes in handen heeft, en waar het volk regeert, daar kan

5. Buys, Studiën 128.

6. Tweede Kamer 1979/1980, 16035 nr. 3.

7. H.G. Lubberdink, De betekenis van de ministeriële verantwoordelijkheid voor de organisatie van het openbaar hcstuur. Deventer 1982. blz. 5.

Over Engeland Dodd 191: J. Jowell en D. Oliver (eds.). The changing constitution, 2e druk Oxford 1989. blz. 55 . 
geen koning nog zijn dwingende wil opleggen. Art. $53 \mathrm{Gw} 1848$ hield in dat de koning de hoogste macht verloor, terwijl het Nederlandse volk voortaan zelf de beslissende stem zou zijn in de staatkundige besluitvorming.

De Siamese tweeling van koninklijke onschendbaarheid en ministeriële verantwoordelijkheid is een staatsrechtelijke regel, die de verhouding tussen drie staatsorganen bepaalt: ten eerste de koning, ten tweede de ministers en ten derde het parlement, dat bij ons de Staten-Generaal heet. De koning staat buiten de werkelijke politiek; verheven boven de partijen die zich in het parlement aftekenen is hij een symbool van de nationale eenheid; hij legt voor genomen besluiten geen verantwoording af en kritiek die zulke besluiten losmaken raakt hem niet. De ministers voeren het beleid, ze zijn verantwoording schuldig aan het parlement, mogen zich niet achter bevelen of uitspraken van de koning verschuilen, en zijn dus afhankelijk van de politieke krachtsverhoudingen in het parlement, die ontstaan uit rechtstreekse verkiezingen. Het parlement is de vertegenwoordiging van het volk.

Het komt erop neer dat de koning geen macht of bevoegdheid meer heeft. Of mag je het zo niet zeggen? Juristen houden soms vast aan de officiële leer van het koninklijk geheim; wellicht oefent onze vorst (of, nu al meer dan honderd jaar, onze vorstin) grote macht, maar bet onttrekt zich aan de waarneming, want het gaat schuil achter de ministeriële verantwoordelijkheid. Of ze wijzen op de periode na verkiezingen, wanneer een nieuw kabinet wordt gevormd. De koningin staat dan in het middelpunt; ze vraagt van alle zijden advies en benoemt tenslotte degene die de nieuwe ministerraad bijeenbrengt. Haar invloed zou hier groot zijn.

Maar de journalist Van Wijnen schreef, niet ten onrechte, dat het de oudere en meer behoudende staatsrechtgeleerden zijn die de vorst nog enige macht toekennen. Hijzelf oordeelde scherp dat het "geheim van Noordeinde" alle inhoud mist: "er is niets te verbergen". ${ }^{8}$ En de kabinetsformatie? Wordt het resultaat niet veeleer bepaald door de uitslag van de verkiezingen, door de overeenstemming der partijprogramma's, door het onderhandelen van de toekomstige partners in de ministerraad? Alom, in juridische en historische teksten, wordt erkend dat 1848 de regeermacht heeft verplaatst van de koning naar de ministers; in handboeken staatsrecht voor leken en studenten wordt ronduit gesteld dat de konstitutionele vorst geen bevoegdheden heeft, zelfs geen vrijheid van meningsuiting, omdat al wat hij zegt onder de verantwoordelijkheid van de minister valt. ${ }^{9}$ Politikologen en joumalisten, minder dan juristen aan de regel gehecht, zonder vooroordeel op zoek naar de macht, vinden het niet eens nodig in hun verhandelingen de vorst ook maar te noemen.

De vorstin, al staat het nergens in de wet, wordt geacht te ondertekenen wat de minister haar voorlegt; ze mag protesteren, ze mag verlangen dat haar mening wordt verwerkt, maar uiteindelijk beslist de minister. ${ }^{10}$ Het verhaal van de Belgische koning Boudewijn, voor wie ook het beginsel der onschendbaarheid geldt, is een zonneklare illus-

8. Van Wijnen 30. 48; Van Maarseveen 497; de uitdrukking "geheim van Noordeinde" is door Oppenheim bedacht, zis De Vries 1.

9. H.A.H. Toomvliet, De staatsinrichting, Utrecht/Antwerpen 1984, blz. 99.

10. Van Wijnen 31, 82; Ch.J. Enschedé. De burger en het recht. Over macht, gezag en democratie, Amsterdam 1988, blz. 95/96. 
tratie. Toen het Belgische parlement een wet op de abortus had aangenomen, besloot Boudewijn dat hij het niet met zijn geweten kon overeenbrengen de wet door zijn koninklijke handtekening te bezegelen. "Geldt de gewetensvrijheid voor allen behalve voor de Koning?" Men vond een noodoplossing: De koning was even geen koning meer, zolang als nodig was om de wetgevingsprocedure te voltooien. Boudewijn's gewaagde optreden bezorgde hem zware kritiek, ronduit hoon. Had hij dan werkelijk niet begrepen dat de konstitutionele koning zich maar heeft neer te leggen bij de uitkomst van het demokratische proces?

Heeft de konstitutionele monarch nog macht? Te bedenken is, dat de koningen oorspronkelijk over de volheid der macht in de samenleving beschikten. Zij besloten als hoogste instantie, ze regeerden in de volle zin des woords; de minister was hun gehoorzaamheid verschuldigd, hij was dienaar, om het koninklijke bevel uit te voeren. Zo beschouwd, is duidelijk dat de bordjes volledig zijn verhangen. Vroeger overwoog de vorst of hij het advies van zijn minister zou opvolgen, nu overweegt de minister of hij met adviezen van de koningin zal rekening houden. De vorst bezit misschien een rest van macht; maar een marge van eigen inschatting had voorheen ook de minister. Een ingrijpende omkering van zaken, en onweerstaanbaar. Het heeft daarom iets van onwillig en vruchteloos tegenspartelen, wanneer een groot handboek van ons staatsrecht, inderdaad uit de behoudende school, nog een uiterste poging doet om in strijd met de zichtbare werkelijkheid, louter op grond van de grondwetstekst, althans een gelijkwaardigheid tussen de vorst en de ministers vol te houden. "

-De minister heeft het initiatief en doet de zaken met de koning af. De voorstelling dat de minister besluit en dat de koning zo nodig mede-ondertekent, zosls hel wel eens is geformuleerd, moge de praktijk van alledag goed weergeven, rechtens blijt het bij een nevenschikking. "

De onschendbare koning van 1848 is een roi fainéamt, een koning die niet doet. Met andere woorden, een staande formule die in de vorige eeuw tijdens diskussie hierover voortdurend werd gebruikt: Le roi règne et ne gouverme pas, De koning heerst maar hij regeert niet. De macht beleid te maken ging over naar de ministers, die niet meer 's konings bevelen zouden opvolgen maar moesten letten op de wensen en de krachtsverhoudingen in het parlement, de volksvertegenwoordiging. Voor deze omwenteling was ten onzent het "beroemde" artikel 53 "beslissend"; de betekenis van 1848 kan daarom "moeilijk worden overschat". ${ }^{12}$ De reden dat het beginsel van koninklijke onschendbaarheid en ministeriële verantwoordelijkheid pas na veel strijd werd bevochten, laat zich dan eenvoudig raden: Het zijn natuurlijk de koningen en hun aanhang geweest die zich met hand en tand tegen de invoering van het artikel hebben verzet; niemand, iedereen weet het, geeft zijn macht gemakkelijk prijs.

Al in 1815: Nederland en België waren samengevoegd en nu zat men bijeen om een grondwet voor het Verenigd Koninkrijk te schrijven, op hasis van de Nederlandse

11. Van der Pot-Donner 395.

12. De drie uitdrukkingenachtereenvolgensbij: Uwe Becker (ed.). Maatschappij, machs, Nederlandse politiek. Een inleiding in de politicke wetenschap. Amsterdam 1990, blz. 146; Willem Drees, in Tamse 135; J.H. von Santen, in Grote Winkler Prins encyclopedie XIX (8e druk), blz. 203, i.v. Revolutiejaar 1848. 
grondwet van 1814. Van de kant der Belgen werd voorgesteld de onschendbaarheid van de koning en verantwoordelijkheid van de ministers in de grondwet op te nemen, maar toen een kommissie daarover aan de vergadering rapport uitbracht, viel de voorzitter, Gijsbert Karel van Hogendorp, uit: "wil de commissie ons de Engelsche principes komen opdringen? - die verlamming van het koninklijk gezag zal ik steeds bestrijden; - alzoo zouden de ministers niet ministers zijn van den Koning maar van de Staten Generaal; - dit strijdt tegen onze beginselen en zeden." Een verhit heen-en-weer, met de uitkomst dat het beginsel verdween. ${ }^{13}$

Maar het spook liet zich niet bezweren. Koning Willem I had in 1815 laten weten dat hij het Belgische voorstel uiterst gevaarlijk vond; beter beviel hem een andere bepaling die wel de definitieve grondwetstekst haalde, artikel 73: "De Koning alleen besluit". Voortvarend trok Willem I alle macht aan zich, regerend als een verlicht despoot. ${ }^{14}$ Zoveel hij kon regelde hij de zaken bij Koninklijk Besluit, omdat hij op die manier de handen vrij had. Bij officiële wetgeving was hij grondwettelijk verplicht met de StatenGeneraal samen te werken. Een "besluitenregeering", smaalde men. Echter, steeds weer en steeds meer stuitte hij op verzet, dat telkens via de ministers werd uitgespeeld. Het maakte de koning in 1820 eens heel boos: ${ }^{15}$

\footnotetext{
"Waarom beschuldigen zij de ministers? Wat zijn de ministers? Volstrekt niets... lk kan zonder ministers regeren. of, wanneer ik het goedvind. wie mij goeddunkt aan het hoofd van de ministeriëele departementen plaatsen, al was het ook een van mijne palfreniers: want $i k, i k$ alléén ben de man die handel. en voor de daden der regering verantwoordelijk is."
}

Het is duidelijk, de standpunten lagen lijnrecht tegenover elkaar: De koning wilde zeif handelen en verantwoordelijkheid dragen, de ministers zouden eenvoudig gehoorzamen; de eis van de nieuwe tijd was daarentegen dat de ministers zouden handelen, de koning slechts zou volgen. Willem I had heel goed door wat hem te wachten stond en wilde niet wijken. Een hooglopend konflikt verzuurde zijn ambtstermijn, de moeizame eenheid van België en Nederland stond op springen, en weer was er de roep om ministeriële verantwoordelijkheid, en weer werd het de koning te veel. Een delegatie uit het zuiden liet hij in 1829 met moeite uitspreken, de lippen samengeknepen; toen barstte hij uit dat ze hem wilden maken als de heidense afgodsbeelden waar de bijbel van spreekt, die een mond hebben maar niet spreken kunnen, die voeten hebben en niet lopen: ${ }^{16}$

\footnotetext{
"On veut la responsabilitẻ ministérielle! pourquoi? pour transférer la monarchie dans les chainbres! car un ministre responsable n'est plus l'agent du roi mais des chambres. ... On veut me fáire roi constilutionnel. semblable à ces dieux des païens qui os habent ct non loquuntur; qui pedes habent et non ambulant."
}

13. Colenbrander II, p. 111,114,116, 117, 141-144, 147, 150,151/152

14. De term komt van de historikus A. Goslinga: overigens leunen deze regels op P.J. Oud, Honderd jaren, vele edities.

15. Sirtema van Grovestins 190

16. E.C. de Gerlache, Histoire du Royaume de's Pays-Bas depuis 1814 jusqu'en 1830, in Oeuves complètes II. Brussel 1859. blz. 215. 
Ik ben koning van de Lage Landen, besloot Willem I; ik ken mijn recht, ik ken mijn plicht; ik zal de grondwet die ik bezwoer met al mijn kracht handhaven. Kort na deze gebeurtenis verscheen de Koninklijke Boodschap van 11 december 1829, een openlijke en felle bevestiging van 's konings standpunt. Ze sloeg in als een bom en de onenigheid laaide des te hoger op.

België ging voor de koning verloren. Onmiddellijk na het winnen van de zelfstandigheid werd daar de eigen koning grondwettelijk onschendbaar gemaakt. ${ }^{17} \mathrm{Het}$ verloste echter Willem I niet van zijn probleem. De roep om ministeriële verantwoordelijkheid bleef hem achtervolgen totdat hij in het laatste jaar van zijn regime, in 1840 , er niet meer aan ontkwam enigermate toe te geven. Bij grondwetswijziging werd in dat jaar de strafrechtelijke ministeriële verantwoordelijkheid ingevoerd. Voor de wettigheid van koninklijke besluiten was voortaan een handtekening van de minister vereist, het 'contraseign'; de minister zou aansprakelijk zijn wanneer door het besluit een bestaande wet was geschonden. Een beperkte verantwoordelijkheid dus, die uitsluitend de wettigheid van overheidsmaatregelen betrof, en die als middel slechts strafrechtelijk optreden toeliet. Voor de grondwetswijziging van kracht werd, trad Willem I af.

Acht jaar later, in 1848, zou Willem II de volledige ministeriële verantwoordelijkheid in de grondwet laten schrijven; het blijft overigens een merkwaardige omstandigheid dat hij daartoe de regeling van 1840 met voeten heeft getreden. De politieke ministeriēle verantwoordelijkheid werd ingevoerd, naast en zelfs in plaats van de strafrechtelijke: Ministers konden njet meer alleen op de wetmatigheid, voortaan ook op de doelmatigheid van regeringsbesluiten worden aangesproken. Heel het beleid was daardoor in beginsel aan parlementaire instemming gebonden. Het drong maar langzaam tot Willem II door. Op 17 maart 1848 wilde hij nog eigener beweging een bestuurlijke post vergeven en kreeg prompt te verstaan dat deze benoeming nu van de minister afhing: "Z.M. verbleekte op het rëele van het verlies van magt. " ${ }^{18}$ Hij stierf precies een jaar na dato.

Willem III trad aan. Hem viel de lastige taak te beurt als koning het nieuwe stelsel realiteit te geven. Geen geschikte figuur! Al tijdens de grondwetsherziening had hij ernstig bezwaar gemaakt en aangekondigd de troon straks niet te aanvaarden. Nu zette hij zich over zijn afkeer heen, maar de samenwerking tussen hem en de ministers verliep stroef. Ze waren in zijn ogen bemoeizuchtig, hij leek, noteerde een minister, te denken "dat hij als Koning slechts heeft te spreken om te worden en te kunnen worden gehoorzaamd." Willem III weigerde zijn ministerie te kiezen naar de zetelverdeling tussen de partijen in de Tweede Kamer, en hij werd boos bovendien, net als zijn grootvader: ${ }^{19}$

\footnotetext{
"Redenen w'arom hij wil of niel wil gett hij nimmer. Vraagt men hem naar redenen dan vindt hị dat zeer ongepast. hij wordt boos. beweer dat nen hem de hand wil forceren en zween bij hoog en bij laag dat hij dit nimmer zal toelaten. Nochthans, als de minister het noodzakelijk acht, zwicht hij ten slotte loch. en helaas soms onder klaarblijkelijk vertoon van gebrek aan waardigheid, en nog veelal om er later over te w'rokkin."
} 
Door dergelijke getuigenissen kreeg Willem III een twijfelachtige reputatie. Hij heeft altijd een slechte pers gehad en niet onverdiend; wat moet je met een konstitutioneel vorst die niet terugdeinst voor uitspraken als deze: "'t Ministerie moet de Kamer aan den haak laten verrotten". ${ }^{20}$ Maar dan is er ook zijn weemoedige en lang niet onredelijke klacht, als de ministers weer wat hadden verzonnen: "maar men denke toch ook eens om den Koning, die in dit alles maar heeft mede te werken ". ${ }^{21}$

Al met al kostte het enkele jaren eer de bedoeling van artikel 53 politieke werkelijkheid werd. Pas twintig jaar na 1848 , na drie aanvaringen tussen koning, ministers en parlement, in 1853, 1866 en 1868, werd vaste leer dat de koning zou wijken voor de ministers, de ministers voor het parlement, zoals het parlement voor het volk. ${ }^{22}$ De politieke verantwoordelijkheid werd hoofdzaak; de strafrechtelijke bleef bewaard voor noodgevallen. Geen handeling van de vorst kon zich aan de parlementaire kritiek onttrekken; heel het beleid viel onder de ministeriële verantwoordelijkheid. En de vertrouwensregel ontstond: Ministers die het parlementaire vertrouwen verloren dienden af te treden; het koninklijke recht ministers te benoemen werd aldus een formaliteit, een bevestiging van de parlementaire uitspraak.

Het had tot gevolg dat de koning de aktieve politiek verliet. Onvermijdelijk, maar het bleef een gevoelig punt. In 1884 durfde een progressieve liberaal, Sam van Houten, ronduit te zeggen hoe het ervoor stond: De kroon was in ons staatsstelsel nog maar een ornament. Hij kreeg meteen een tik op de vingers van de katholieke staatsman Herman Schaepman, volgens de geschiedschrijver "onder bijval van alle partijen ${ }^{n}{ }^{23}$

\footnotetext{
"Die geachte spreker toch schijnt daarbij alleen aan dic gebouwen te denken. die in dén rococostijl opgetrokken zijn. Het is inderdaad eene eigenaardigheid van dien stijl, dat het constructieve en het ornament zijn gescheiden, en het ornament gemeenlijk inderdaad niets anders is dan een bijkomend ding. Mar in den bouwstijl, dien onze vaderen hebben lief gehad, is zoowel het constructieve lid als het sierasd te zamen verbonden tot een geheel en strekt dit, wat inderdaad niets anders schijm dan een sieraad, wel degelijk tot instandhouding van het gebouw. Wanneer ik nu denk aan de plaats van de Kroon in het Staatsgebouw van ons Nederland, dan denk ik aan den sluitsteen in het gewelf, die te gelijker tijd is een sieraad en tevens het constructieve lid, dat geheel den hoog opstrevenden bouw te zamen houdt."
}

Een bloemrijk weerwoord, maar de loop der dingen heeft Van Houten in het gelijk gesteld; hij wordt nog heden ten dage met instemming aangehaald. Nederland werd wat de koning en de konservatieven immer als een angstbeeld voor zich zagen: een republiek plus een koning. Dat wil zeggen, het konstruktieve en het ornamentele waar Schaepman van sprak, raakten gesicheiden. "In het tastbare, meetbare vlak", schreef Donner (volgens Van Wijnen een "behoudende" staatsrechtgeleerde). "functioneert het koningschap maar bij uitzondering of van terzijde". ${ }^{24}$ Werkelijke macht past niet bij

20. C.B. Wels, "De formatie van het eerste ministerie-Thorbecke", in Bijdragen en mededelingen van het Historisch Genonischap 76 (1962), blz, 277.

21. De Vries 4.

22. Ook deze historie in Oud. Hondert jaren: en in vrijwel alle handboeken Nederlands staatsrecht.

23. Handelingen der Staien-Generaal. Vereenigde zirting. 1884. blz. 9. 13: Van Welderen Rengers 639/ 640.

24. Donner. in Tamse 219. 
de monarchie. Haar uiteindelijke waarde is als symbool van nationele eenheid; de macht van de koning is de macht van het emotionele. En het emotionele mag er weliswaar zijn, maar het moet niet de werkelijkheid van de politieke gang van zaken beïnvloeden. $^{2 s}$

Het volk spreekt, het gezag volgt; zo wil het de leer der demokratie. De historie van artikel 53 is niet een toevalligheid, louter van belang voor juristen. Artikel 53 herbergt een absolute eis van demokratisch bestuur, dat geen bevoegdheid zal bestaan zonder haar keerzijde, de verantwoordelijkheid aan de burgers. Uit de onschendhaarheid, die onverantwoordelijkheid is, volgt daarom onverbiddelijk dat de koning zijn macht verliest. ${ }^{26}$ Artikel 53 verbeeldt het historische proces van demokratisering dat de afgelopen paar eeuwen heel Europa heeft beheerst; soms ging in de woelingen het koningschap ten onder, soms bleef het overeind, zoals in Engeland, België, Scandinavië, maar dan altijd tegen de prijs van de macht. De grondwet van 1848 was voor Nederland een mijlpaal in deze ontwikkeling; het jaar dat de vrijheid der medezeggenschap "definitief" schonk. ${ }^{27} \mathrm{Om}$ die reden wekt het, behalve meewarigheid, ook enige verontrusting wanneer blijkt dat Nederlanders nog steeds de nieuwe verhoudingen niet begrijpen.

Want, jawel, er zijn mensen die het nog steeds niet begrijpen. Tientallen jaren na 1848 , in $1900 \mathrm{kwam}$ een jurist in het geweer omdat hij algemeen de overtuiging aantrof, de "volkswaan" zei hij, als zou de vorstin persoonlijk gratie verlenen, naar de inspraak van haar hart. ${ }^{3}$ Smeekschriften werden in het rijtuig van de koningin geworpen en begenadigden waren haar persoonlijk dankbaar; van de minister wist men niet. Zeker, gratie is karakteristiek verbonden met de glans van het koningschap, maar ook los daarvan bleef de misvatting onuitroeibaar dat bij onze vorstin werkelijke macht zou berusten. De oud-ministers Willem Drees en Anne Vondeling vertelden, nog maar een kwart eeuw geleden, dat de koningin dikwijls brieven ontvangt van burgers die bezwaar maken tegen een ministerieel besluit. Ministers krijgen te horen dat een ontevredene het ook nog wel "hogerop" kan zoeken, en aan de koningin schrijven. ${ }^{29}$

Het brengt ons in de sfeer van koningin Juliana's zeventigste verjaardag, toen men een kinderkoor liet voordragen: ${ }^{30}$

Kinderen, slaap maar zacht.

Juliana houdt de wacht.

Bij kinderen, daar hoort dit denken thuis. Ik weet van een moeder die haar zoontje probeerde uit te leggen hoe Nederland wel een koningin heeft, maar het de ministers zijn

25. Er is scheiding gemaakt tussen het staatsrechtelijke en het sociaal-psychologische, schrijf Belinfante 84.

26. Kranenburg 108: Belinfante 22, 85, 90.

27. A.J.C. Rüter, Historische studies over mens en samenleving, Assen 1967, blz. 358 .

28. D. Simons, "Een paar opmerkingen over de toepassing van het gratierechi". in Tijdsehrift voor straf. recht 13 (1900) blz. 388-389.

29. Willem Drees. De vorming van het regeringsbelcid, Assen 1965, blz. 2: Anne Vandeling, Nasmaak en vorprocf. Een handvol ervaringen en idecën. Amsterdam 1968, blz. 46.

30. Hugo Arlman/Gerard Mulder, Van de prins geen kwaad. Prins Hendrik de andere dossiers van Oranje, 4e druk Amsterdam 1988, blz. 9. 
die regeren. Hij begreep er niets van: Een koning is toch een Koning? De regels van de konstitutionele monarchie passen niet in de wereld van het kinderlijk verstand; ze werden door volwassenen bedacht en het is slechts voor volwassenen weggelegd ze te begrijpen.

\section{§ 3. Een inval}

Ach, zo'n kind toch, zou je denken. Maar pas op. Sinds eeuwen her waarschuwt het Evangelie ons niet op kinderen neer te zien; wie niet wordt als een kind, luidt het letterlijke woord, kan bet Koninkrijk niet binnengaan. Bij kinderen bestaat een bijzondere affiniteit met koningschap, die geen tekort is, gebrek aan inzicht, maar juist een openstaan voor diepere betekenis. De lezer heeft het wellicht al gevoeld: De keurige en volwassen overzichtelijkheid van de afgelopen bladzijden kan geenszins op onkwetsbaarheid bogen. Hoe glashelder ze scheen, er blijft een mogelijkheid dat de historie van de onschendbaarheid in Nederland bij nader inzien troebel zou blijken. Een verrassing is nooit uit te sluiten.

Verrassingen? Het begint als onopmerkelijke kleinigheid, een veertje dwarrelend op de wind en zich zomaar ergens neervlijend, toevallig en zonder gewicht. Een losse gedachte zoals die gebeuren, een persoonlijke belevenis die op het eerste gezicht geen belofte van wetenschappelijke waarde in zich draagt. Voor de onschendbaarheid wordt dikwijls een Engelse zegswijze gebezigd: The King can do no wrong. Getuige de Nederlandse politikoloog Hans Daalder, over de herziening van 1848: "It introduced the Joctrine that the King could do no wrong, coupled with full ministerial responsibility. " 31 De koninklijke onschendbaarheid en het beginsel dat de koning geen kwaad kan doen, gelden als synonieme uitdrukkingen. Elk voor zich beduiden ze een onmisbaar bestanddeel van ons moderne monarchaal-demokratische staatsrecht, een sleutelwoord dat volledig buiten gevaar van misverstand kan worden aangehaald, een vast baken: De koning werd onschendbaar, dat wil zeggen onmachtig, zodat Nederland als demokratie is gewaarborgd. Plots echter schoot me te binnen hoe gedurende de jaren dertig in het fascistische Italie van Benito Mussolini een leuze galmde; een leuze die te vinden was in reglementen en leerboekjes, te lezen op affiches die Italië bedekten: Mussolini ha sempre ragione, Mussolini heeft altijd gelijk. ${ }^{32} \mathrm{Niet}$ een willekeurige fraze, een vergeten uithoek van het bestel, maar in die enkele woorden de samenvatting van heel het diktatoriale systeem; we houden er zonder meer aan vast dat de leider altijd gelijk heeft, dat wil zeggen, hij duldt geen tegenspraak.

Toen sprong in het oog hoe de Engelse lijfspreuk en de Italiaanse frappant overeenkomen. Welk verschil valt naar de letter der tekst aan te wijzen tussen een leider die nimmer verkeerd doet en een leider die altijd gelijk heeft? Geen verschil. The King can do no wrong en Mussolini ha sempre ragione zeggen, op de keper beschouwd, het-

31. Hans Daalder, Politiek en historie. Opstellen over Nederlandse politiek en vergelijkende politieke wetenschap. Amsterdam 1990, blz. 32.

32. James Joll, Europe since 1870. An intemational history. Penguin Books 2e druk reprint 1978, blz. 346. 
zelfde. Later bleek dat de vergelijking wel 's eerder werd gemaakt; een Italiaanse journalist legde in 1939 de twee zegswijzen naast elkaar: ${ }^{33}$

\footnotetext{
"De slogan van de [fascistische] plaatselijke groepen, Mussolini ha sempre ragione, doet denken aan het beginsel 'The King can do no wrong', en wordt logisch vertaald in het beginsel van de onverantwoordelijkheid van het staatshoofd, een onverantwoordelijkheid die echter zijn apolitieke karakter toestaat."
}

De overeenkomst is letterlijk maar bizar. Immers, The King can do no wrong betekent in ons staatsrecht dat de vorst is ingesloten door demokratische waarborgen tegen alleenheerschappij; hij werd buiten de macht verwezen, is eigenlijk, hoor de kinderlijke reaktie van een kleine jongen, geen Koning meer. Maar Mussolini ha sempre ragione heeft juist de tegenovergestelde betekenis. De leider is oppermachtig, zonder weerga in het politieke bestel, een ware Leider. The King can do no wrong: De heerser heeft niets voor 't zeggen, is heerser alleen in naam. Mussolini ha sempre ragione: De heerser heeft alles voor het zeggen, een heerser in de volste zin des woords.

Voor de hand ligt, de gelijkenis als zinloos weg te wuiven; het reële verschil tussen fascistisch Italië en demokratisch Nederland is te groot. Zou niet een simpele verklaring zijn dat The King can do no wrong een vaste partner heeft, de ministeriële verantwoordelijkheid? De verantwoordelijke minister heeft de onfeilbare koning stevig ingekapseld, onschadelijk voorgoed. We weten evenwel nog niet of onder Mussolini misschien iets dergelijks als ministeriële verantwoordelijkheid heeft bestaan; het zou kunnen. ${ }^{34}$ En bovendien, zelden of nooit wordt het voorgesteld alsof men aan de koninklijke onschendbaarheid ministeriële verantwoordelijkheid heeft toegevoegd, en zo het bestel gewijzigd. Doorgaans, zie Daalder, luidt het verhaal dat onschendbaarheid en ministeriële verantwoordelijkheid te zamen zijn ingevoerd; meer nog, vaak wordt gezegd dat 1848 ministeriële verantwoordelijkheid bracht en daarom ook, ervan afhankelijk, de onschendbaarheid van de koning. The King can do no wrong was vrucht van 1848 .

Zodat een vraag rijst: Hoe is het mogelijk dat een demokratisch en een diktatoriaal staatsbestel zich op hetzelfde woord beroepen? De vraag kan zeer fundamenteel worden opgevat: Wat is het verschil tussen diktatuur en demokratie? Geen geringe vraag; een ware quaestie, aangaande gezag en vrijheid, die thuishoort in de politieke wijsbegeerte. Heel wat zwaarwichtiger dan de eerste aanleiding, het toevallige vergelijken van The King can do no wrong en Mussolini ha sempre ragione kon doen vermoeden. Hoewel, konden we dit niet vermoeden? Het grondwetsartikel heette immers een hoeksteen van de parlementaire demokratie; vandaar dat het ons met belangrijke vragen in aanraking brengt. Maar het radikale, het tegenstrijdige van de gelijkenis tussen Engels en Italiaans staatsbeginsel blijft een verrassing die we niet zomaar doorgronden.

We belanden in een geheel van wat wisselvallige overwegingen. Het Nederlandse staatsrecht verlangt rond het beginsel van koninklijke onschendbaarheid en ministeriële verantwoordelijkheid geen nieuw onderzoek; de zaak is klip en klaar. De overeenkomst tussen The King can do no wrong en Mussolini ha sempre ragione plaatst dan een

34. Het zou kunnen? Het kon. Zoals blijken zal. 
vraagtekentje, maar vluchtig; een toevalligheid, aardig, zonder betekenis, en niets om lang bij stil te staan. Toch geeft ze aanleiding tot gewichtige vragen, van welke de verreikende en blijvende waarde niet kan worden betwijfeld. Zou de vergelijking dan toch zin hebben? Kan ze de bespreking van wijsgerige vraagstukken, gezag en vrijheid, mens en staat, vooruit brengen, of alleen al illustreren? En weer aarzeling. Is de kloof tussen oorzaak en gevolg niet veel te groot? Wordt zo niet het terloops ontwaren van een mug beantwoord met in stelling brengen van grof geschut?

Aarzeling, daarom. Is er iets aan de hand, of niet? Is er reden een nader onderzoek in te stellen of niet? Laten we voor alles, niet te ver van huis, nogmaals artikel 53 van de grondwet van 1848 bezien. Liggen er oneffenheden in haar geschiedenis, oneffenheden die de gladde gelijkmatigheid van het bestaande inzicht opruwen en hernieuwd onderzoek naar de betekenis van het artikel rechtvaardigen? Aanknopingspunten die ons reeds dichter brengen tot begrip van die merkwaardige gelijkenis tussen de twee staatsspreuken, het Engelse The King can do no wrong en het Italiaanse Mussolini ha sempre ragione? Het is een eerste verkenning; levert ze resultaat en belooft ze nog meer, dan zal het nodig zijn een werkelijk onderzoek aan te gaan en alsdan ook af te bakenen.

\section{§ 4. ... En andere problemen}

De onschendbaarheid en de onwerkzaamheid dekken elkaar volkomen; de koning werd onschendbaar, zeggen we, en daardoor machteloos. Zo leeft het, meende ik, en zo wordt het bijvoorbeeld in een syllabus van de Groningse universiteit aan de studenten uitgelegd: ${ }^{35}$

-De positie van de Koning(in) in het staalsbestel kan als volgı worden omsehreven. Hij of zij is staatshoofd en makt deel uil van de regering. maar is politiek gezien geen regeringsleider. Sterker nog, de Koning(in) blijft zoveel mogelijk builen de politiek. hetgeen moge blijken uit de formule: de Koning is onschendbaar; de ministers zijn verantwoordelijk:"

Ik kursiveerde. Uit de formule van artikel 53 zou duidelijk blijken dat het staatshoofd zich ophoudt buiten de politieke werkelijkheid. Is dat waar? Blijkt het duidelijk? Wat betekent, op zich, de term 'onschendbaar'? Waarom zou die betekenen dat de regeermacht niet bij de vorst, maar bij de ministers ligt? Als het zo was bedoeld, waarom werd het dan niet in ronde woorden gezegd? Om de koning en andere behoudzuchtigen zand in de ogen te strooien? Vergeefse moeite; telkens lazen we al hoe zij de toekomst haarscherp zagen.

De betekenis van artikel 53 is minder onomstotelijk dan ze nu wel schijnt, sterker nog, men had er destijds grote moeite mee. Een juridisch proefschrift uit 1855 noemde de ministeriële verantwoordelijkheid "welligt het allermoeijelijkste staatsregtelijke vraagstuk, waarover de grootste staatslieden het oneens zijn". ${ }^{36}$ En art. 53 stond niet alleen; behalve dat kende Thorbecke's grondwet nog twee artikelen over de ministeriële verant- 
woordelijkheid, art. 73 en art. 159. Artikel 73 bepaalde over de ministers dat hun verantwoordelijkheid bij wet zou worden geregeld en de Tweede Kamer kreeg daarom, al in 1849 , een wetsvoorstel over de ministeriële verantwoordelijkheid te behandelen; het debat was vol verzuchtingen: "wat met dit ontwerp werd bedoeld?" Of de regering "een klaar denkbeeld zich gevormd had van het daarin te behandelen onderwerp"? Dat het ontwerp "van gewigtigen en moeijelijken aard" was; een "uiterst moeijelijk onderwerp". Het wetsvoorstel werd enkele malen teruggestuurd, de procedure verliep traag en slecht. ${ }^{37}$

Verscheidene vragen speelden door het debat. Wat was de verhouding tussen de artikelen 53, 73 en 159? Doelden ze alle op een en dezelfde verantwoordelijkheid, of was er een verschil? De Kamerleden spraken van staatkundige verantwoordelijkheid, strafrechtelijke, financiële, morele, civiele, kollektieve, en elk gebruikte een andere indeling. ${ }^{38}$ $\mathrm{Nu}$ eens was de verantwoordelijkheid in haar geheel staatkundig, dan weer strafrechtelijk. Of stonden die soorten naast elkaar? Moest deze wet alle verantwoordelijkbeid regelen, of uitsluitend de strafrechtelijke? Het draaide erop uit dat de strafrechtelijke verantwoordelijkheid het onderwerp van de wet zou zijn; maar was die al niet vastgelegd in het Wetboek van Strafrecht, zoals voor iedere burger? Moest de wet alle ministeriële misdrijven behandelen, ook algemene misdrijven die de minister tijdens zijn ambtstermijn zou plegen, of alleen staatkundige misdrijven, of alleen de misdrijven die hij in opdracht van de koning had gepleegd?

Technische, juridische kwesties. Een strijd om de macht tussen koning en parlement, zoals de gangbare leer van de onschendbaarheid en de ministeriële verantwoordelijkheid zou doen verwachten? Er lijkt geen sprake van. Toen de herziening van 1848 haar beslag kreeg was weliswaar de klacht geuit dat zij 's konings recht verkortte, maar de minister van justitie wimpelde het af: "Ik acht het overbodig verder het beweren te wederleggen, dat het koninklijk gezag eene vermindering zou ondergaan. " 39 Tijdens de behandeling van het wetsvoorstel kwam dit onderwerp nauwelijks ter sprake. Een enkele toespeling, en dan ontkennend: "Men had geen oogmerk de Koninklijke magt te verzwakken, maar integendeel stelde men zich ten doel om haar te verhorgen. " Kamerlid Groen van Prinsterer hield vast aan "het zelfstandig en onafhankelijk vorstelijk gezag; een Koning die regeert over, niet onder het Volk"; de ministeriēle verantwoordelijkheid moest niet worden opgevat als een "wegcijfering van den Koning". ${ }^{0}$

Maar hier schuilt misschien een addertje onder het gras? Guillaume Groen van Prinsterer, de christelijke, anti-revolutionaire politikus, had zich altijd verzet tegen het liberale bewegen. Hij had de koninklijke onmacht zien aankomen en kleurrijke uitdrukkingen verzonnen om het beeld van de toekomst afschrikwekkend te schilderen: De koning zou slechts een figurant zijn, de griffier der Tweede Kamer, een speelpop der

37. Handelingen van de Tweede Kamer der Staten-Generaal 1848/1849, blz. 229ff., 261ff., $518 f f$. , Bijlagen $1849 \mathrm{blz} .35 f$.

38. Er is in die tijd wel beweerd dat heel de ministeriële verantwoordelijkheid opging in de civiele plicht tot schadevergoeding wegens onrechtmatige daad. C.B.M. Toullicr, Le droit ciril francais, suivant l'ordre du Code XI, 3e druk Brussel 1824, blz. 216.

39. Voorduin $118,178$.

40. Handelingen 1848/1849. blz. 528, 542; Bijlagen 1849, blz. 264. 
fakties, het "met kroon en scepter fraai uitgedoscht hoofd" van de regering, geen autokraat maar automaat; geen koning bij de gratie Gods, maar volksambtenaar door de genade van het volk; eigenlijk zou de minister tekenen en de koning bet contraseign hebben, er was geen koninklijke autokratie meer, alleen nog koninklijke autografie. ${ }^{41}$ Is bij Groen en bij anderen van zijn richting de wens de vader van de gedachte geweest? Hebben zij de betekenis van art. 53 naar hun hand gezet om de koninklijke volmacht te handhaven? Zat de strijd tussen liberalen en behoudenden verstopt in een ogenschijnlijk technische diskussie? Verdedigden liberalen een meer gedurfde lezing van het artikel? Toch niet. Floris Adriaan van Hall, voor en na 1848 minister in verschillende kabinetten, behoorde tot de liberale partij; hij had sinds 1830 herhaaldelijk bij de koning aangedrongen op ministerièle verantwoordelijkheid, maar toen hij in 1853 opnieuw aan het roer kwam stelde hij nadrukkelijk op de voorgrond, "dat de regeering van den Koning uitging, en dat de Ministers door hun raad, uitvoering en medewerking de verantwoordelijkheid op zich namen". ${ }^{42}$

En de staatsrechtgeleerde Buys, "een der meest erkende en geliefde organen van de liberale of oud-liberale partij in ons land", besprak de koninklijke onschendbaarheid in zijn kommentaar op de grondwet; hartstochtelijk ontkende hij, nog in 1883, dat de koning buiten de politiek zou staan: ${ }^{43}$

\footnotetext{
"Dus opgevat wordt de leer der koninklijke onschendbaarheid een onvermengd kwaad, want zij leidt er toe om, in strijd met de constitutie, den Koning uit de constitutie te bannen en tot volkomen machteloosheid te doemen. ... Men schrijft bij een dergelijke verklaring van het leerstuk der onschendbarheid niet enkel eene fictie in de Grondwet, maar een leugen, waartegen het openbar geweten protesteer. Onze Grondwet is intusschen aan die leugen volkomen vreemd; zij betwist den Koning het recht van handelen niet ... maar bepaalt eenvoudig - en die hepaling is eene zeer stellige werkelijkheid, -- dat de Koning wegens het gebruik dat hij maakt van zijne koninklijke macht niet ter verantwoording kan worden geroepen."
}

Ruim na 1848 hebben deze liberalen, die niet de minsten waren, overtuigd en zelfs fel weersproken dat hun stelsel de koning zijn regeermacht zou ontnemen. Het lijkt daarom onjuist, of op z'n minst voorbarig dat de machteloosheid van de koning het streven van de 19 e eeuwse liberalen zou zijn geweest. Neem Anton Reinhard Falck, volgens Thorbecke een ware liberaal; hij zag rond 1840 als Nederlands gezant in Brussel hoe bet daar toe ging en maakte spottende grapjes over de Belgische roi fainéant: "terwijl de responsable Excellentien tobben, ligt de Majesteit onverantwoordelijk te spartelen in uitheemsche wateren! " 4

"Un vrai Roi fainéant. zeggen de bedillers -- un vrai Roi constitutionnel, zeggen de vrienden, die gedaan werk heeft, als hij maar eens in ' 1 jaar Ministers kiest en dagelijks de besluiten teekent, die zij hem gelieven voor te leggen."

41. Groen, Bijdrage 76 (Verspreide geschriften II, 205): Grondwetherziening 11, 22.

42. Suttorp 107: Van Welderen Rengers 101.

43. Herinneringen uit de levensjaren van Mr. H.P.G. Quack 18341914(corspr. 1915) SUN reprint Nijmegen 1977. blz. 202: Buys I, 191.

44. Brieven van A.R. Falck 1795-1843. 2e druk 's-Gravenhage 1861. blz. 381, 392, $409 / 410$. 
En hadden zij gewild, dan nog was het hun onmogelijk geweest door onschendbaarheid de vorst tot politieke onmacht te veroordelen. Thans heerst, lijkt me, een algemene overtuiging dat de koninklijke onschendbaarheid door artikel $53 \mathrm{Gw} 1848$ werd gevestigd, met alle staatsrechtelijke gevolgen van dien. ${ }^{45}$ Deze overtuiging spreekt uit leerboeken, encyclopedieën, krante-artikelen; het is echter een vergissing. De onschendbaarheid dateert zeker niet van 1848 , maar is juist vanouds een vast beginsel geweest in alle monarchieën. Een koning was te allen tijde, per definitie, onschendbaar. De kommissie die in de grondwetsvergadering van 1815 over het beginsel moest rapporteren, stelde: ${ }^{46}$

\footnotetext{
"Het grondbeginsel van de onschendbaarheid van 's Konings geheiligde persoon is noch in deze Vergadering, noch in deze commissie betwist geworden; men heeft integendeel gemeend dat het overtollig zoude zijn, eene watheid die ieder gevoelt uit te drukken, en van een staatkundig axioma melding te maken."
}

Inderdaad beeft niemand in het debat dat volgde, hoe hoog het ook liep, deze stelling aangevochten. Tijdens de rumoerige jaren ema niet anders. Tot 1848 heeft nooit iemand, konservatief of liberaal, betwijfeld dat de koning onschendbaar was en moest blijven. Het gegeven raakte daama vrijwel volledig in het vergeetboek. Het wordt zelden vermeld, en dan meestal in oude of meer specialistische literatuur, of in dubbelzinnige termen; termen die weliswaar ruimte laten voor de ouderdom van de koninklijke onschendbaarheid, maar door argeloze lezers ongetwijfeld worden aangenomen als bevestiging van het heersende beeld: De koning werd onschendbaar verklaard, de grondwet vermeldde voor het eerst de koninklijke onschendbarbeid, en dergelijke. De enkele historikus die blijk geeft de $19 \mathrm{e}$ eeuwse uitspraken te hebben opgevangen, had echter geen gelegenheid ze uit te werken en gewaagde, zonder toelichting, van de "buiten kijf gewaande onschendbaarheid". ${ }^{47}$

De ouderdom van de onschendbaarheid wordt dus ternauwernood opgemerkt; en in elk geval spreekt niemand hardop de fundamentele betekenis van dit gegeven uit: Want als de onschendbaarheid vanouds vaste eigenschap van de monarchie was, dan heeft de grondwet van 1848 in dit opzicht aan de Nederlandse staatsinrichting niets veranderd. We hebben daarmee, binnen de ruimte van deze enkele bladzijden, al een hele weg afgelegd. Eerst bleek dat art. 53 voor tijdgenoten helemaal niet zo duidelijk was als wij thans zouden denken; vervolgens dat vooraanstaande liberalen niet de bedoeling hadden met dit artikel de koning zijn macht te ontnemen; tenslotte dat de herziening van 1848 , wat de onschendbaarheid van de koning betreft, geen breuk maar louter voortzetting is geweest.

Ontdekkingen die hier goed van pas komen. We waren immers uit op een verkenning van het terrein, om te beoordelen of een speurtocht naar innerlijk verband tussen de twee leuzen Mussolini ha sempre ragionc en The King can do no wrong enige kans van slagen heeft. Die kans leek uitermate klein omdat op het eerste gezicht een enorme

45. Eén uit velen, A.J.C. Rüter, Historische studies over mens en samenleving. Assen 1967, blz. 379, 404: De koning werd onschendbaar.

46. Colenbrander II, 143.

47. Struycken 366; Van der Poi-Donner 386: Donner, in Tamse 215/216: Bornewasser 77, 85. 
afstand de twee scheidt. De Italiaanse formule verleende aan de heerser opperste macht, terwijl de Engelse hem juist de macht uit handen moest slaan. Maar nu zou blijken dat de onschendbaarheid des konings, de Nederlandse uitdrukking voor The King can do no wrong, niet de eigenschap was van gedemokratiseerde monarchie, maar van monarchie op zich. Dat brengt de twee spreuken opeens een grote sprong dichter tot elkaar; zou bet beginsel The King can do no wrong inderdaad een eigenschap zijn van alle monarchie, passend bij de alleenheerschappij van de klassieke monarchen, dan ware wellicht de kloof tussen die Engelse spreuk en het Italiaanse Mussolini ha sempre ragio$n e$, de leus van moderne alleenheerschappij, al bijna overbrugd.

Aardig, jawel; maar zeker niet belangwekkend. Goed, laat er een verwantschap bestaan tussen de regeerwijzen van monarch en diktator, laten zo de twee staatsspreuken, de Engelse en de Italiaanse, meer dan we dachten overeenkomen, toch blijft onloochenbaar dat de konstitutionele monarchie er heel anders uitziet. En de reden lijkt eenvoudig aan te wijzen. Wat heeft bij ons scheiding gemaakt tussen de vroegere absolute en de huidige demokratische monarchie? Indien niet de regel dat de koning geen kwaad kan doen, niet de onschendbaarheid, omdat zij al bestond, dan heel eenvoudig dit, het verbinden van een ander beginsel aan de onschendbaarheid: volledige ministeriële verantwoordelijkheid. De revolutie van 1848 zit 'm dan in de invoering van ministeriële verantwoordelijkheid; die gaf de doorslag en daarom heeft artikel 53 zo'n enorme indruk gemaakt.

Maar ook hier bestaat misverstand. Doorgaans wordt het verloop beschreven zoals dat hierboven gebeurde: in 1840 werd strafrechtelijke verantwoordelijkheid van ministers ingevoerd, in 1848 gevolgd en voltooid door de politieke verantwoordelijkheid. De tweede, als een uitbreiding en voltooiing, sluit logisch op de eerste aan. Maar ministers die in 1840 moesten zeggen wat naar hun mening het gevolg was van de grondwetswijziging, antwoordden dat die naar hun inzien niets had veranderd. ${ }^{48}$ Hoe kon dat? Alleen behoudzucht misschien? Ging het erom de bepaling te kleineren zodat hij weinig effekt zou hebben? We hebben even eerder hetzelfde gedacht van het Kamerdebat na 1848. Opnieuw nee; het blijkt mogelijk de wetsgeschiedenis van de ministeriële verantwoordelijkheid heel anders te zien.

Reeds de grondwet van 1814 heeft verklaard dat ministers konden worden vervolgd ter zake van ambtsmisdrijven; ze zouden terechtstaan voor de Hoge Raad. Een vanzelfsprekendheid, meenden de leden der grondwetskommissie in 1815, net als de onschendbaarheid van de vorst: ${ }^{49}$

"Evenzeer heeft niemand in twijfel getrokken, dat Ministers die hunnen pligt overtreden, volgens de wetten vervolgd en gestraft kunnen worden."

De grondwet van 1815 nam bijgevolg de bepaling in artikel 177 over, daarna de grondwetten van 1840 en 1848 , en ook heden ten dage staat hij nog in de grondwet. Dan konden dus de ministers al sedert 1814 strafrechtelijk worden aangesproken! Ministers hebben dat in Kamerdebatten ook aangevoerd. Alweer een verwarring die gedurende heel

48. Bosscha 38.

49. Colenbrander II, 143. 
de strijd rond de ministeriële verantwoordelijkheid het debat heeft bemoeilijkt. De Koninklijke Boodschap van 11 december 1829 had de ministeriële verantwoordelijkheid scherp afgekeurd; op 20 januari 1831 zei de minister van buitenlandse zaken in de Tweede Kamer dat ministerièle verantwoordelijkheid "thans geen deel van ons staatsregt uitmaakt". Maar in $1840 \mathrm{zag}$ de regering af van een voorstel tot ministeriële verantwoordelijkheid, want, stelde zij verrassend, die is reeds "met ronde woorden in art. 177 der Grondwet geschreven". so

\footnotetext{
"De Grondwet behoeft dus niet elders in algemeene bewoordingen het beginsel uit te drukken, dat de ministers verantwoordelijk zijn, ten ware men door die uitdrukking meer zoude bedoelen, dan haar 177 ste artikel medebrengt in harr 73 ste artikel toelaat."
}

Het parlement liet zich niet afschepen, drong aan en won het pleit. De strafrechtelijke ministeriële verantwoordelijkheid werd in art. 75 van de nieuwe grondwet herhaald, met in art. 76 de toevoeging dat voor de geldigheid van officiële besluiten het 'contraseign', de ministeriële handtekening was vereist. Waarom? Welke inzet, welk belang kon deze grondwetswijziging hebben indien de Nederlandse ministers al sinds 1814 ononderbroken strafrechtelijk vervolgbaar zijn geweest? We nemen nog eens aan, dat het ging om de hoogste macht in de staat; het parlement trachtte die op de koning te veroveren door naast diens onschendbaarheid de ministeriële verantwoordelijkheid te planten. Het laatste citaat zinspeelt erop: Men wilde artikel 73, "De Koning alleen besluit", van haar kracht beroven.

Hoe dan? Oorspronkelijk besliste de koning, of een van hem afhankelijke ambtenaar, de procureur-generaal, over het al dan niet vervolgen van een minister. Weer de koning, die alles in de eigen hand wilde houden! Het parlement eiste nu het recht zelf te vervolgen, of tenminste vervolging te kunnen afdwingen. Er was derhalve geen strijd over invoering van strafrechtelijke verantwoordelijkheid voor ministers, maar er was een strijd tussen koning en parlement over de vraag wie het recht zou hebben vervolging aanhangig te maken, met de achterliggende gedachte dat diegene de minister en daarmee het beleid zou beheersen.

Van Hogendorp was indertijd, in zijn Schers die als uitgangspunt zou dienen voor de grondwet van 1814, heel ver gegaan; volgens zijn tekst zou inderdaad de minister "op aanklagt van de Staten Generaal" worden vervolgd. ${ }^{51}$ Van Hogendorp's voorstel verdween onnaspeurlijk. Of liever, het werd verdraaid zodat er niets van overbleef. De grondwet van 1814 bepaalde in artikel 104 dat voor vervolging van een minister "uitdrukkelijk verlof" was vereist van de Staten-Generaal; die konden vervolging dan wel tegenhouden, maar niet op gang brengen. De kommissie-De Coninck probeerde in 1815 nogmaals dat de Staten-Generaal zelf een minister in staat van beschuldiging zouden mogen stellen; weer mislukte het. De grondwet van 1815 ging opnieuw niet verder dan het vereiste van "uitdrukkelijk verlof" door het parlement.

50. Handelingen van de Tweede Kamer der Siaten-Generaal 1830/1831, blz. 81: Bijlagen 372; Ibidem 1840, Bijlagen 494.

51. Heel deze historie in Oud 1, 250 ff. 
Het maakt de strijd van 1840 wellicht begrijpelijk, maar het resultaat niet. Waarom kreeg 1840 een grote naam? Indien we de geschiedenis van de strafrechtelijke ministeriēle verantwoordelijkheid in dit licht beschouwen, klopt de reaktie van de ministers in 1840 volkomen; inderdaad is de grondwetswijziging van dat jaar zonder inhoud geweest. Bepaald werd namelijk dat de ministers verantwoordelijk zouden zijn voor overtreding van enige wet, en dat ze zouden terechtstaan voor de Hoge Raad: niets dan wat al in art. $177 \mathrm{Gw} 1815$ stond. Het centrale punt, het recht strafvervolging te beginnen, bleef onveranderd. Meer invloed dan door haar "uitdrukkelijk verlof" werd het parlement niet gegund. Een oplossing dus, maar een oplossing die meer moeilijkheden dan uitkomst brengt!

Want wanneer is nu die strijd beslecht? Wanneer kreeg het parlement recht ministers te vervolgen? En het antwoord moet luiden: in 1848 . Pas de grondwet van 1848 brengt de strafrechtelijke bevoegdheid die het parlement verlangde. Sindsdien konden ministers worden vervolgd "hetzij van Koningswege, hetzij van wege de Tweede Kamer", zie artikel 159. Zo schreef de liberale minister Van Hall nog in 1858 alsof er in het Nederlandse staatsrecht alleen strafrechtelijke verantwoordelijkheid was. ${ }^{52}$ Waarom werd dan artikel 53 beroemd? Dat deed niets dan ministers verantwoordelijk verklaren, een vage, nietszeggende uitdrukking, overbodig naast het afdoende artikel 159 . Wat was nu politieke, volledige ministeriële verantwoordelijkheid, en waardoor is ze aangebracht? Hoe is mogelijk dat algemeen de jaartallen 1840 en 1848 heel anders worden opgevat dan blijkens deze weergave zou moeten?

Laten we de oude verklaring, het streven de koning zijn macht te ontnemen, als de drijfveer achter alles, toch nog 'ns toepassen. Men joeg ogenschijnlijk op de ministers, maar eigenlijk op de koning. Het recht strafvervolging tegen ministers aanhangig te maken was een belangrijk instrument. Het jaar 1840 bracht een stap vooruit door het 'contraseign'; het betekende dat de strafrechtelijke verantwoordelijkheid niet slechts ministerieel handelen gold, maar zelfs handelingen die de minister als medewerker van de vorst had verricht. Het was gemakkelijk in te zien dat men via de minister uiteinclelijk op de koning mikte. De wijziging van 1848 voltooide het stelsel. De Tweede Kamer kon ministers nu zelf aanklagen en verkreeg op die manier een vaste greep op de politieke besluitvorming. De scherpe kantjes verdwenen. Met het uiterste machtsmiddel vrij ter beschikking hoefde de Kamer het niet meer zo ver te laten komen om de ministers naar haar hand te zetten.

De strafrechtelijke verantwoordelijkheid van ministers ontwikkelde zich tot een mildere vorm, de politieke. Het strafrecht bleef als aanvulling of voorwaarde op de achtergrond aanwezig, zonder ooit te hoeven optreden; de politieke verantwoordelijkheid nam de funktie van de strafrechtelijke over, en werd de hoofdzaak. De politieke verantwoordelijkheid is een zuiver parlementaire aangelegenheid. Ministers hebben de plicht het parlement naar waarheid over hun doen en laten te informeren, en buigen, of ruimen het veld indien hun beleid daar wordt afgekeurd. Dit heet de vertrouwensregel, het centrale leerstuk van de politieke verantwoordelijkheid; geen minister kan zonder parlementaire instemming, zodat hij gedwongen is zich te richten naar de meerderheid van 
stemmen in dit lichaam. Op die manier kreeg het parlement de macht over de ministers, en dus de hoogste macht, de macht die des konings was, in handen. Art. $53 \mathrm{Gw} 1848$ heeft dan deze vertrouwensregel, de politieke verantwoordelijkheid der ministers, vastgelegd.

Een lezing van de historie die, alweer, een kanttekening toelaat. Het opkomen van de vertrouwensregel, in de jaren na 1848 , had niet het karakter van een politieke strijd, gericht op 's konings macht, maar van een juridisch debat, een verschil van mening over een regel van Nederlands staatsrecht. Tegenstanders hadden een sterk argument; zij lazen in artikel 73 van de grondwet van 1848 dat de vorst ministers "naar welgevallen" benoemt en ontslaat, en naar hun oordeel pleegde de Tweede Kamer grondwetsschennis door benoeming van ministers te kritiseren of hun ontslag af te dwingen. Voorstanders weerspraken dat benoeming en ontslag van ministers boven parlementaire kritiek zou zijn; elke koninklijke beslissing viel onder de ministeriële verantwoordelijkheid. Aldus bijvoorbeeld Buys, nog in zijn handboek over de grondwet. Maar de strekking van deze leer, voegde hij er streng aan toe, was natuurlijk niet "om het groote beginsel te verzwakken, dat de Koning in de keuze zijner ministers vrij moet zijn. " 53 Buys, de liberaal, hield vierkant vol dat de koning naar eigen oordeel zijn ministers zou aanstellen en ontslaan; de Kamer mocht hem niet dwingen. Maar waartoe dan de parlementaire kritiek? In 1868 had Buys uitgelegd, naar eigen zeggen verlegen als iemand die moet betogen dat twee maal twee vier is, wat de Kamerleden te doen stond indien, zoals het meestal zou gaan, de minister zich niet aan enig misdrijf had schuldig gemaakt, maar eenvoudig had gefaald. "In het uiterste geval zullen zij hunne grieven aan den Koning mededeelen. Ziedaar de politieke gevolgen van de ministeriële verantwoordelijkheid. " Dat was alles! H.G. Lagemans, in zijn proefschrift van 1855 over de ministeriële verantwoordelijkheid, waagde zich iets verder. De Kamer mocht haar kritiek meedelen en dan nog de koning verzoeken "dat daarin voorzien worde". Maar, bijna haastig: "Het moet hier echter altijd bij een eerbiedig verzoek blijven." ${ }^{54}$

Het verhaal van 1848 kent dus onduidelijkheden en tegenstrijdigheden. Geen invoering van onschendbaarheid heeft de positie van de koning gewijzigd, geen blijk van een liberaal komplot om de koning zijn macht te ontfutselen, de gangbare weergave van de invoering der ministeriële verantwoordelijkheid bleek aanvechtbaar, de politieke verantwoordelijkheid heette verenigbaar met een sterke en zelfstandig besluitende vorst. Maar anderzijds lijkt het verhaal toch stand te houden; de strijd of het parlement strafrechtelijke procedures tegen ministers aanhangig mocht maken moest toch wel dienen om de koning zijn gezag over de ministers te ontnemen, en het vervolg, de opkomst van de politieke verantwoordelijkheid, de vertrouwensregel, kan nauwelijks een ander doel hebben gehad dan het verplaatsen van de koninklijke macht naar het parlement. Invoering van ministeriële verantwoordelijkheid, als partner van de vorstelijke onschendbaarheid, heeft daarom de scheiding tussen oude absolute en modeme demokratische monarchie voltrokken.

En opnieuw een tegenwerping. Het spreekt niet vanzelf dat de strafrechtelijke verantwoordelijkheid van ministers tot overname van 's konings regeermacht zou leiden; en

54. Buys, Studiēn 127: Lagemans 30. 
de politieke ministeriële verantwoordelijkheid lag niet noodzakelijk in het verlengde van de strafrechtelijke. Tegen het invoeren van strafrechtelijke ministeriële verantwoordelijkheid werd behalve de vermindering van de koninklijke macht een heel ander argument aangevoerd; een argument dat allerminst vooruitloopt op de politieke verantwoordelijkheid, omdat het louter strafrechtelijk is gedacht, en dat bovendien heel zijn kracht ontleent aan de vooronderstelling dat de vorst nog waarlijk zou regeren.

Neem nogmaals 1815, het Belgische voorstel. Voorzitter Van Hogendorp waarschuwde inderdaad tegen de verlamming van het vorstelijk gezag, maar aan de voorstanders werd tevens deze kritische vraag voorgelegd: "hoe zal men aan iemand eene misdaad maken van het executeren der bevelen van den Koning?" 55 De koning heeft de opperste macht, hij vaardigt zijn bevelen uit en de ondergeschikte, burger of minister, moet gehoorzamen. Hoe kun je ooit een minister zijn gehoorzaamheid verwijten? Deze diskussie stond op zich, zij is zelfs niet te rijmen met een strijd tegen de koninklijke macht, want ze vooronderstelt dat die onverlet blijft. Ze behandelde geen politieke of staatsrechtelijke, maar een strafrechtelijke, bijna ethische kwestie: Hoe kun je een ondergeschikte op z'n gedrag aanspreken? Is het aanvaardbaar iemand die bevelen opvolgde desondanks ter verantwoording te roepen?

Jazeker, vond een pamfletschrijver in 1849 . Het koningschap moest hoeksteen en grondslag van het staatsgebouw blijven, alle gezag zou van de troon neerdalen en de koning zou zelf bevelen; zelf niet aansprakelijk, zou zijn minister het wel zijn. ${ }^{56}$

\begin{abstract}
"Daar is het koningschap geene fictie, al is ook de monarch voor zijne daden niet aansprakelijk. Het overbrengen zijner verantwoordelijkheid op anderen is niet in strijd met zedelijkheid en regt, want de Koning geeft zijne bevelen. maar hij dwingt niemand om dezelve uittevoeren. Dan ecrst is de verantwoordelijkheid onregtvaardig, wanneer hij wordt aansprakelijk gesteld, die tot de uitvoering van eens anders bevelen is gedwongen, want dan straft men het werktuig in plaats van den werker, en dat is onredelijk. Maar hij, die vrijwillig eene regeringsdaad uitvoert, waarvan de uitvoering bij de wet was verboden, maakt die daad tot de zijne, en is teregt voor de gevolgen aansprakelijk."
\end{abstract}

De ministers moeten verantwoordelijk zijn, maar de koning blijft voluit regeren. Lagemans bepleitte in zijn proefschrift dezelfde verhouding. Ministers waren "zelfstandige ambtenaren", dienaren van de koning die zijn bevelen uitvoerden en doorgaven, maar die tevens zelfstandig beoordeelden wat ze deden; anders immers zou hun verantwoordelijkheid onbillijk zijn. Maar het was er, omgekeerd, verre vandaan dat ministers nu tegen de koning hun zin zouden mogen doorzetten. ${ }^{57} \mathrm{De}$ ministeriële verantwoordelijkheid moest, naar het inzicht van deze tijdgenoten, geenszins de vorstelijke bevelsmacht opheffen; waarom is dat dan toch gebeurd?

Misschien kan een argument helpen dat op deze bladzijden al vaker is gebruikt: De aangehaalde schrijvers vormden een achterhoede; de ministeriële verantwoordelijkheid

56. Th.V.H. van den Gheyn, De leer van de souvereiniteit des volks, verkondigd door Mr. C.W. Opzoomer, bestreden, Nijmegen 1849, blz. 29.

57. Lagemans $23,26$. 
zou ons staatsbestel grondig wijzigen, en zij voorzagen de toekomstige ontwikkelingen niet. Iets dergelijks is ook. wel over Buys gezegd: ${ }^{58}$

"Hij gaf licht als op den achtersteven van een bout, licht, dat enkel als witte trillende streep de golven dost zien die reeds doorkliefd zijn ..."

We wilden de demokratisering van de Nederlandse monarchie, zo niet aan de onschendbaarheid, indien die voor 1848 reeds gold, dan wel aan de ministeriële verantwoordelijkheid toeschrijven. Het moest toch ergens door komen! Maar ook dit beeld vervaagt dus bij nader toezien op de beschikbare gegevens. En nog een kink in de kabel. Dateert de ministeriële verantwoordelijkheid werkelijk van 1848 ? De Belgen pasten haar evenwel al twintig jaar eerder toe, tijdens hun opstand tegen Willem I; diens woedende uitbarsting, hierboven aangehaald, bewijst het. Grepen zij vast vooruit op de aanstaande officiële regeling? Wellicht; maar tegelijk was er een claim dat de ministeriële verantwoordelijkheid in Belgiè al in de 14 e eeuw had bestaan. ${ }^{59}$ En niet alleen Belgen verwezen zo ver terug. Tijdens het Kamerdebat van 1849 noemde Van Hall voorbeelden uit de $17 \mathrm{e}$ eeuw die aantoonden dat de ministeriële verantwoordelijkheid destijds bij ons reeds gold. ${ }^{\infty}$ Wat heeft 1848 dan aangebracht?

Het wordt tijd dat we Thorbecke er eens op naslaan. Want hij, Thorbecke, de belangrijkste invloed op onze grondwet van 1848, wat heeft hij over deze dingen gezegd? Heeft hij beter dan zijn tijd-en zelfs partijgenoten de uitwerking van art. 53 voorzien? Het blijkt dat hij geheel in de sfeer van de geschetste kwesties en standpunten verkeerde. In de tweede editie van zijn Aanteekening op de grondwet (1841-1843), algemeen opgevat als aankondiging van 1848, had hij uiteraard ook aandacht besteed aan het tweetal koninklijke onschendbaarheid en ministeriële verantwoordelijkheid. ${ }^{61}$ Geen makkelijke passages, in de gedrongen stijl die hem eigen was. Het is van belang ze even goed te bekijken, en ons daartoe een zekere uitvoerigheid in het citeren te veroorloven. Thorbecke gebruikte in het begrip 'onschendbaarheid', dat wij totnogtoe enkelvoudig zagen, een tweetal onderscheidingen, die elkaar overlappen en ook niet zeer helder zijn. Er was orn te beginnen enerzijds juridische onschendbaarheid, volgens Thorbecke de onschendbaarheid in engere zin, en anderzijds politieke onschendbaarheid, die beter 'onverantwoordelijkheid' kon heten. Op grond van de eerste zou een gerechtelijk oordeel, op grond van de tweede een publiek oordeel over de vorst zijn uitgesloten. De tweede uitsluiting fundeert de eerste: is het oordeel over de vorst in het algemeen niet toegelaten, dan zeker niet het gerechtelijke oordeel. Dit onderscheid, dat we elders nog niet vonden, zou heel goed kunnen stroken met het onderscheid tussen de strafrechtelijke oftewel juridische, en de politieke ministeriële verantwoordelijkheid; iets voor later.

58. Herinneringen wit de levenyaren van Mr. H.P.G. Quack 18341914. (oorspr. 1915) SUN reprint Nijmegen 1977, blz. 202.

59. Handelingen van de Eerste Kamer der Staten-Generaal 1829/1830, blz. 578; Van der Straeten I, blz. 14. 22; Ferdinand Henaux, Histoire du pays de Liege I, (oorspr. 1902) reprint Bnussel 1981, blz. VIII, 484.

60. Handelingen van de Tweede Kamer der Staten-Generaal 1848/1849. blz. 548: Godin de Beaufort 29. 61. Thobecke, Aanteekening I. 107-111. 188-204. 
Thorbecke stelde daarop de vraag of de onschendbaarheid grondwetsbepaling zou moeten worden, een vraag die hij liet vergezellen van het retorische: "Spreekt de onverantwoordelijkheid der oppermagt niet van zelfs?" Een kennelijke vingerwijzing dat ook Thorbecke de onschendbaarheid als een bestaande regel zag, voor en los van de latere grondwetswijziging van 1848. Toch bepleitte hij opname in de grondwet, met behulp van een tweede onderscheiding, die slecht bij de vorige paste, en daarenboven innerlijk tegenstrijdig werd uitgewerkt. Thorbecke stelde, dat de oppermacht (toch) niet vanzelfsprekend onverantwoordelijk was; maar in die verantwoordelijkheid mocht de gebruiker van de macht, de persoon van de koning, niet worden meegesleept. Vermelding van onschendbaarheid in de grondwet diende om de persoon van de vorst te beschermen tegen konstitutionele aansprakelijkheid.

Maar Thorbecke, schijnt het, sprak zich vervolgens tegen. Twee bladzijden later zou de onschendbaarheid juist niet de persoon van de koning beschermen, maar de abstrakte staat, die misschien mag worden opgevat, of eigenlijk alleen maar kán worden opgevat als een ander woord voor de 'oppermacht':

\footnotetext{
"Wanneer de Engelschen zeggen: de Koning kan niet dan goed doen: strekt dit niel tol waarborg bovenal van den persoon des Konings, maar van het regt en den Staat. Het beteekent niet, al wat de Koning doet, is regt; het beteekent, waar onregt is gehandeld, handelde de Koning niet; het koninklijk individu, dat onregt pleegde, houdt op Koning te zijn. Een persoon kan de hoogste magt slechts onder de voorwaarde bezitten. dat hij regt doe."
}

Hier verkeert de onschendbaarheid in haar totale tegendeel! De onschendbaarbeid beschermt de vorst niet, ze maakt dat hij, waar hij verkeerd bandelde, automatisch geen vorst meer is. Eerst als het ware semantisch: de vorst die misdoet mag de naam van vorst niet dragen. Maar de praktische uitwerking volgde uiteraard meteen. Een vorst die onwettig zou handelen, schreef Thorbecke, dient de kroon af te leggen. "Zijne onverantwoordelijkheid houdt op te werken, dewijl hij zelf haar vernietigt. " Thorbecke gaf ook een historisch voorbeeld van deze werking der onschendbaarheid:

\footnotetext{
"Laat de onschendbaarheidvan den Vorst in de Constitutie der voorouderenonder Philips II met zooveel woorden geschreven zijn. Wat zij deden, bleef volkomen regt. Lang streden zij, niet tegen den Landsheer, maar tegen zijn gouvernement. Eerst toen alle uitzigt was verdwenen om door Philips immer op eene met de wezenlijke eischen des Lands strokende wijs te worden geregeerd, zwoeren zij zijn persoon af."
}

Wat betekent dit? Wilde Thorbecke hier zeggen, net als Van Hall, dat behalve de koninklijke onschendbaarheid ook de ministeriële verantwoordelijkheid in Nederland al lang voor 1848 , zelfs in de $16 \mathrm{e}$ eeuw van kracht was? Wat kon 1848 dan uitrichten? Thorbecke repte in elk geval met geen woord van een koning die zijn macht voor onschendbaarheid zou inruilen. De onschendbaarheid betekende allerminst dat de vorst werkeloos zou worden; maar onschendbaarheid betekende dat de vorst recht doet.

En de ministeriële verantwoordelijkheid? Thorbecke zal toch de opeenvolging van strafrechtelijke en politieke verantwoordelijkheid hebben bedoeld, of tenminste haar gevolgen onderkend? Maar Thorbecke wees in zijn Aanteekening de politieke ministeriele verantwoordelijkheid af; de minister kon uitsluitend op grond van de wet verantwoordelijk zijn, beslist niet op grond van doelmatigheid of meningsverschil. Hij merkte op dat 
Engeland wel politieke verantwoordelijkheid kende, met het afkeurende kommentaar: "De britsche Staat heeft een sterke maag. " De ministeriële verantwoordelijkheid behoorde juridisch te zijn en anders niet.

Thorbecke's leer van de ministeriēle verantwoordelijkheid paste in de diskussie die we hierboven leerden kennen. Ze was sluitend juridisch opgevat, niet als voorbereiding van politieke verantwoordelijkheid, en niet als methode om de macht voor de volksvertegenwoordiging te veroveren. Thorbecke dacht enkel aan de morele en juridische verantwoordelijkheid van een ondergeschikte die in opdracht heeft gehandeld. En dat hier de kern zat leed voor Thorbecke nog niet de minste twijfel!

\begin{abstract}
"Bij ons verborg men zich, jaren lang, achter duistere of valsche voorstellingen, om het licht niel te zien. Anders ware men tot het eenvoudige beginsel der ministeriële aansprakelijkheid ligt doorgedrongen, en had in haar, beschreven of niet, een onmisbaar deel der Staalsregeling erkend.

De Koning bedient zich, hij kan niet anders, van ministers, of hoofden der depanemenlen van algemeen bestuur, tot uitvoering der wellen; waaronder al de wettige plichten van het koningschap worden verstaan. Met deze uitvoering begint de verantwoordelijkheid. $\mathrm{Zij}$ treft dus in de hoogste plaats de ministers, als eerste agenten der koninklijke regeermag!: zoodat hare daden evenzeer, als wat zij moest doen, persoonlijk ten hunnen laste komen.

Men heef de ministeriële asnsprakelijkheid, ten onregte zoo hel schijnt. eene fictie genoend, die de schuld van den Vorst op den minister legde. Hel is geene verantwoordelijkheid van een ander, die de minister overneemt. Zij kleeft aan zijn eigen feit, an de medewerking. wartie hij zich verbond. $Z$ ijne verantwoordelijkheid, ona fscheidbaar van het ambt, is die van een ieder. welke eene wet uit te voeren of te betrachten heef. Hij is van zelfs onderworpen aan het oordeel, dat zijne handelingen vergelijkt met de wet."
\end{abstract}

Bevel is geen bevel: "Een fiksch man", schreef Thorbecke in 1847, "doet voor uitwendigen, onredelijken dwang onder, maar weigert er het werktuig van te zijn. " ${ }^{62}$ Wie meewerkt is mee verantwoordelijk, en dat beginsel geldt in volle kracht, al zwijgt de grondwet ervan: "Deze stellingen zijn zoo helder en onbelwistbaar, dat het overbodig kan schijnen, ze in de Grondwet uit te drukken." Jaren later sprak Thorbeske niet anders; de morele kracht van de ministeriële verantwoordelijkheid, verklaarde hij tijdens een parlementair debat in 1854 , berust op de zekerheid dat de minister "zelfstandig, uit eigen overtuiging hebbe gehandeld". Tussen zijn persoonlijke papieren deze aantekening: "de voorwaarde van verantwoordelijkheid is zelfstandigheid. Die niet vrij is, wil en kan niet verantwoordelijk zijn". ${ }^{63}$

Wij, dit achteraf lezend, zouden kunnen zeggen dat de uitdrukking 'zelfstandig handelen' natuurlijk niet onschuldig is. Hoe kan er kracht uitgaan van een koninklijk bevel indien de minister niet dan naar eigen overtuiging handelt? Wordt hier niet overduidelijk hoe de vorst zijn macht aan de ministers kwijtraakte? En meer dan dat, blijkt niet onloochenbaar dat Thorbecke een heimelijke bedoeling had langs deze weg de bevelsmacht van de koning uit te hollen? De verdenking werd hem ook in 1854 meteen voor de voeten geworpen, hij zou aanhanger zijn van het Le roi règne et ne gouverne pas.

63. Bomewasser 72. 
Thorbecke gaf een week later terug dat men zijn "duidelijkste woorden" had miskend. De koning, onschendbaar, stond boven de partijen; maar hij regeerde: ${ }^{64}$

"... de Koning is en regeert, van wege zijne grondwettige roeping, boven alle partijen. De monarchie zal steeds een geluk, wellicht de grootste weldaad voor een land zijn, waar dat beginsel wordt betracht."

Alles goed en wel, maar Thorbecke, die in 1872 overleed, heeft tot die tijd de uitwerking van zijn artikel meebeleefd. Hoe dacht hij over het kernstuk van de politieke verantwoordelijkheid, de ontwikkeling van de vertrouwensregel? Ging hij niet zelf voorop? Inderdaad heeft Thorbecke de vertrouwensregel in zijn parlementaire redevoeringen gesteld: Een minister kan niet aanblijven wanneer de Staten-Generaal hem hun steun onthouden. Hij weersprak echter dat het parlement ministers zou mogen dwingen. De koning kon, eigener beweging, ministers ontslaan; en de ministers dienden, wanneer ze parlementaire steun ontbeerden, zelf ontslag aan de vorst te verzoeken.

Nogmaals uitvoerige citaten, uit 1841 en 1868. Men merke op met hoeveel stelligheid Thorbecke zich uitsprak; geen spoor van aarzeling, geen ogenblik de gedachte dat het straks anders zou kunnen gaan. En al die jaren bleef hij zichzelf gelijk. Van 1841 de Aanteekening: ${ }^{65}$

\footnotetext{
"Welk gevolg kan de verantwoording, hetzij aan den Koning, hetzij aan de Statengeneraal, zoo zij niet voldeed hebben? Van de zijde des Konings, dat hij zijn minister ontslaat. Van de zijde der Statengeneral, dat de meerderheid der eene of andere Kamer, ten einde den Koning te dwingen tot verandering van den persoon, den minister, die geregtelijk niet vervolgbaar schijnt, als in den parlementairen ban doe? Alle voorstellen, zijn departement aangaande, afwijze? Het middel, hoe gewoon in Engeland en Frankrijk om ministers te verkrijgen, aangenaam aan de Vertegenwoordiging, ware even onregtvaardig, als het doel. Men stelt dan willekeur tegenover willekeur; men wreekt een persoonlijk onregt op de zaak, en doet inbreuk op de constitutionele vrijheid der Kroon. Niets is ook meer geschikı om de ministeriële verantwoordelijkheid werkeloos te maken, dan wanneer de Vertegenwoordiging op de keus van het personeel der ministers invloed heeft, en dezen het begunstigde werktuig worden harer meerderheid. Daarentegen schijnt het allezins constitutioneel, en zal het in de meeste gevallen afdoende zijn, dat de Statengeneraal, des noods, hun bezwaar tegen de handelingen van den minister bij ernstig vertoog onder het oog des Konings brengen."
}

Het is de uiterste remedie, maar "des noods" kan het parlement de koning van haar bezwaren op de hoogte stellen! Geen sprake van een volgzame koning; geen sprake van een oppermachtig parlement. En een kwart eeuw later, dezelfde Thorbecke in 1868: ${ }^{66}$

\footnotetext{
"Een adres aan den Koning kan niet meer dan de eerbiedige voordracht bevalten van de grieven, die tegen het Ministerie bestaan ..."

"Ik wil de vrijheid der Kroon zooveel mogelijk gespaard zien. Ik wensch hier niet een Ministerie, dat enkel orgaan van eene meerderheid der Tweede Kamer zij. Ik verlang grooter zelfstandigheid voor de Kroon en hare Regeering. "
} 
Nooit heb ik mij als een minister der parlementaire meerderbeid, altijd als een minister des konings beschouwd, zei Thorbecke toen hij in datzelfde jaar bij de koning werd ontboden. ${ }^{67} \mathrm{Hij}$ wenste geen parlementaire heerschappij; de kroon zou zelfstandig en sterk zijn, maar de minister zou koninklijke bevelen alleen opvolgen indien hij met ze instemde; zodoende kon het parlement hem verantwoordelijk stellen zonder onrechtvaardig te zijn; en de koning zelf, zijn beslissingen en zjjn bevelen, bleven keurig gevrijwaard van openbare kritiek. Thorbecke doelde op een zelfstandige kroon en een zelfstandig parlement; ertussenin de minister, geroepen noch de koning noch het parlement klakkeloos te gehoorzamen, maar geroepen naar eigen overtuiging te handelen.

Een ingewikkelde konstruktie. Begrijpelijk gerroeg, vond de historikus Boogman, dat de Nederlandse ministers het in Thorbecke's precaire evenwicht niet lang hebben uitgehouden. De balans moest wel doorslaan en het zwaartepunt zou komen aan de zijde van de volksvertegenwoordiging of bij de ministers; de koning stond buitenspel. ${ }^{68}$ Goed beschouwd: Noch hetgeen Thorbecke schreef over de koninklijke onschendbaarheid, noch hetgeen hij schreef over de ministeriële verantwoordelijkheid lijkt te passen bij de huidige gang van zaken in ons staatsbestel. De liberale politikus Pieter Jacobus Oud merkte het honderd jaren na Thorbecke met bevreemding op: ${ }^{69}$

"Ik mis in Thorbeckes betoog toch juist datgene. wat het wezen der ministeriele verantwoordelijkheid uitmaakt."

En:

"Ik ... ben er niet in geslaagd mij een juiste voorstelling te maken van hetgeen Thorbecke nu eigeniijk bedoett."

We kunnen nog eens wijzen op het algemene menselijke gebrek aan vooruitziendheid: Thorbecke heeft, wordt gezegd, zelf de strekking van zijn stelsel niet ten volle beseft. ${ }^{20}$ Niks bijzonders, natuurlijk. Mensen bedenken van alles, proberen van alles, en de gevolgen zijn voor henzelf nog het meest verrassend. Waarom zou het bij Thorbecke anders zijn? Maar het argument verslijt; we hebben het nu wel erg vaak moeten gebruiken. En de opvattingen die we in de $19 \mathrm{e}$ eeuw vonden waren in vergelijking met de huidige niet zozeer vaag of onvoldragen, maar op zich best helder, en dan onverenigbaar met de modeme staatsrechtelijke leer.

En wellicht is het toch verkeerd de leer van de gehoorzame maar zelfstandige minister, die we vernamen bij Thorbecke, Van Hall, Lagemans, Buys, als een vergissing of kortzichtigheid opzij te leggen. "Bevel is geen bevel", gaf ik hierboven als samenvatting van die leer. Geen toevallig gekozen woorden, maar een uiterst belangrijk heginsel, uitgesproken door bet tribunaal van Neurenberg in 1946. Het Duitse fascistische totalitarisme was militair verslagen, het moest nog moreel worden vernietigd. De aangeklaagde oorlogsmisdadigers verweerden zich met een beroep op bevel van hogerhand: Befehl ist

67. Duyverman 174.

68. Boogman 94: Bornewasser 89.

69. Oud I, 257, 260 .

70. Drees, in Tamse 135. 
Befehl, zij konden niet anders dan gehoorzamen. Maar het Tribunaal antwoordde dat ieder een eigen verantwoordelijkheid behoudt voor zijn daden, ook wanneer hij bevelen opvolgt.

Een onverwachte wending brengt ons zo plotseling terug bij het $20 \mathrm{e}$ eeuwse totalitarisme. Hebben de onschendbaarheid, The King can do no wrong en Mussolini ha sempre ragione dan toch met elkaar te maken? Is Thorbecke's leer van de ministeriële verantwoordelijkheid, nu blijkt dat ze precies overeenkomt met het morele antwoord dat de verslagen fascisten van hun overwinnaars kregen, dan toch een diepere greep geweest? Maar waarom werd de regel die volgens Neurenberg voor alle beambten en militairen geldt, die inderdaad op het oog een algemeen karakter heeft, in 1848 uitsluitend maar met veel rumoer voor ministers vastgelegd?

En vanwaar dan nog de uitwerking dat de konstitutionele monarch zijn macht inleverde? Een historische toevalligheid? Men zegt dat Thorbecke een heerszuchtige natuur was, hij duldde de koning niet naast, laat staan boven zich; daarom heeft hij hem eruit gewerkt. Of het moeilijke karakter van koning Willem III: Ministers vertelden dat ze banger voor de vorst waren dan voor het parlement en daarom zoveel ze konden met het parlement regelden, en hem erbuiten hielden. ${ }^{71}$

Ontoereikende verklaringen. Wij zien het terugdringen van de koning uit de politiek in verband met het veldwinnen der demokratie in Europa; het verlies van de vorst was de winst van de demokratie. Een omvangrijk proces, dat veel dieper stak dan persoonlijke problematiek. Het verdwijnen van Willem III of van Thorbecke heeft daarom de ontwikkeling niet gewijzigd. En buitenlandse vorsten gingen dezelfde weg. Ook elders zijn vorsten van oude huizen buiten de dagelijkse politiek gedrongen. Geen beoefenaar van ons staatsrecht heeft art. 53 ooit als een gril van ene Thorbecke glimlachend terzijde geschoven; het werd onveranderlijk hoog aangeslagen, een grondslag van het bestel, in verband met heel de moderne politieke geschiedenis. Het valt niet te verwachten dat verwarringen rond art. $53 \mathrm{Gw} 1848$ dan onbetekenende aardigheidjes zouden zijn.

\section{$\S 5$. Vragen, en een methode}

De voorgaande bladzijden hadden geen kompleet of helder overzicht ten doel van alles wat het artikel 53 in die jaren rond 1848 beleefde. Deskundigen missen wellicht een en ander; zij krijgen bij voorbaat gelijk. Het doel was vragen op te roepen. Rond het thema van koninklijke onschendbaarheid en ministeriële verantwoordelijkheid heerst een zekere gerustheid, een vanzelfsprekendheid, en ik meende dat het geen kwaad kon in deze windstilte een beetje te blazen. Is de opzet geslaagd? Werd enige beroering teweeggebracht?

Als eerste vraagpunt kwam het zonderlinge vergelijken van The King can do no wrong en Mussolini ha sempre ragione ter sprake; maar uit de tekst ervoor zou ik al twee vreemde details willen lichten, die mede het verhaal van 1848 haar heldere eenvoud benemen. De eigenaardige handelwijze van koning Willem II: Waarom heeft hij in maart 1848 zijn revolutionaire besluit tot grondwetswijziging buiten de ministers om 
genomen, een overtreding van het grondwettig voorschrift van 1840 , en bovendien volslagen onnodig? En waarom, dit ten tweede, de uitbundige vreugde bij het volk wanneer ministers aftreden en een grondwet wordt gewijzigd? Het is er wel zeer ver vandaan dat in onze dagen op zodanige evenementen zo zou worden gereageerd!

En op de vergelijking van het Mussolini ha sempre ragione en The King can do no wrong, als eerste aanzet, volgde een hele reeks onduidelijkheden, aanwijsbaar in de $19 \mathrm{e}$ eeuwse geschiedenis van artikel 53. Waarom werd 's konings verlies van persoonlijke macht verhuld in de term 'onschendbaarheid'? Hoe zou de term dit verlies van macht kunnen betekenen? Waarom, toen de wet op de ministeriēle verantwoordelijkheid in de Tweede Kamer werd behandeld, het moeizame debat, vol onzekerheid, en met stellige ontkenning dat de macht van de koning moest verminderen? Een ontkenning die zelfs door liberalen scherp werd uitgesproken? Wat betekent het dat de koninklijke onschendbaarheid volgens meerdere getuigenissen helemaal niet in 1848 is ingevoerd, maar altijd van kracht geweest? Als liberalen niet de bedoeling hadden de koninklijke macht te ontledigen, en het beginsel der onschendbaarheid, vanouds geldend, die verandering niet bewerkte, hoe komt het dan dat de moderne vorst zijn macht verloor?

Door ministeriële verantwoordelijkheid? Maar van dit beginsel bleek dat het gangbare verhaal evenzeer twijfelachtig is. Strafrechtelijke en politieke verantwoordelijkheid werden niet achtereenvolgens, in elkaars verlengde, in 1840 en in 1848 van kracht. Het leek wel alsof er enkel een strijd was om strafrechtelijke ministeriële verantwoordelijkheid; weliswaar streefde het parlement er inderdaad naar de koning zijn alleenrecht op strafrechtelijke vervolging van de minister te ontnemen, hetgeen een strijd om de hoogste macht zou kunnen zijn, maar ook in dit verband werd weer ontkend dat men op de vorstelijke macht aasde. De redenering achter de strafrechtelijke ministeriële verantwoordelijkheid ontleende juist haar kracht en zin aan de vooronderstelling dat de vorst zou blijven regeren! Waarom ging dan voor de vorst zijn macht verloren?

Als de strafrechtelijke ministeriële verantwoordelijkheid aldus op zichzelf stond, een gesloten stelsel, hoe heeft dan de verhouding met de politieke ministeriële verantwoordelijkheid gelegen? Thorbecke sprak van de juridische en de politieke onschendbaarheid, een onderscheid dat thans niet meer wordt gemaakt; maar houdt het misschien verband met de twee genoemde soorten ministeriële verantwoordelijkheid, die ons wel bekend bleven, de strafrechtelijke, zeg juridische, en de politieke? Vanwaar Thorbecke's onopgemerkte verwarring van onschendbaarheid der oppermacht en des konings? Het is geen lichte verwarring, een spelfout die we al lezend vanzelf herstellen, maar een verwarring die diep ingrijpt, en het betoog innerlijk tegenstrijdig maakt. Waarom de verwijzingen, bij Thorbecke en anderen, naar een ministeriēle verantwoordelijkheid die lang voor 1848 zou hebben bestaan? Wat betekent die merkwaardige konstruktie, de poging gehoorzaamheid aan bevelen logisch te verenigen met eigen verantwoordelijkheid van de ondergeschikte? Het staatsrecht rond art. $53 \mathrm{Gw} 1848$ heeft haar volkomen vergeten; maar hoe kan het dat ze honderd jaar later, in Neurenberg 1946, terugkeert, weer als antwoord op een politiek stelsel van absoluut gezag? Toeval?

Een indrukwekkende verzameling vragen; waarmee we ook niet zomar weg weten. Als opbrengst van de eerste verkenning van het terrein, en gezien de oorspronkelijke eenstemmigheid rond artikel 53, geen slecht resultaat. Maar een warrige verzameling: grote vragen, kleine vragen, samenhangende, overlappende, historische, juridische. Kan dat 
allemaal voortkomen uit het ene afgemeten artikel 53? Verdienen ze aandacht? Neem die inval van de letterlijke gelijkenis tussen de Engelse vertaling der koninklijke onschendbaarheid, The King can do no wrong, en de Italiaanse leuze Mussolini ha sempre ragione. Een buitenissige gedachte, die klaarblijkelijk afketst op het vanzelfsprekende van artikel 53: The King can do no wrong betekent gedemokratiseerde, parlementaire monarchie, terwijl Mussolini ha sempre ragione de samenvatting is van diktatuur. Moeten we toezien hoe het verschil tussen demokratie en fascistische alleenheerschappij wordt uitgewist? De vergelijking heeft geen zin!

Maar hebben latere vondsten niet de indruk versterkt dat hier meer speelt dan enkel een taalkundige gril? Vondsten is, goed, eigenlijk nog teveel gezegd; vermoedens rezen. Er waren geluiden als zou de onschendbaarheid reeds voor 1848 hebben bestaan, zelfs als vast kenmerk van de klassieke, heersende monarch. Zou dat kloppen, dan kon op die manier de gelijkenis van de twee spreuken een heel eenvoudige verklaring krijgen. Zowel The King can do no wrong als Mussolini ha sempre ragione zou staan voor alleenheerschappij, terwijl de scheiding van 1848 , tussen absolute en demokratische monarchie, dan zou zijn gemaakt door de ministeriële verantwoordelijkheid. Ook deze opvatting kon echter niet zonder meer overeind blijven; de ministeriële verantwoordelijkheid dateert niet zuiver van 1848, sterker nog, we vingen geruchten op dat het beginsel lang voordien heeft gegolden. Maar dan waarschijnlijk als vroege voorloper van de demokratisering?

Laat ik er niet ombeen draaien: Het is inderdaad mogelijk, geheel afwijkend van het gangbare, een standpunt in te nemen van waaruit gezien de twee spreuken The King can do no wrong en Mussolini ha sempre ragione op één lijn liggen. Deze beschouwingswijze wordt ontsloten door een mythe, de vaak voorkomende mythe van de goede koning en zijn boosaardige raadgevers. Er is een eeuwenoud volksgeloof, telkens herkenbaar en misschien wel onuitroeibaar, dat de koning het goede wil voor iedereen, maar zijn dienaars hem misleiden en het land ten verderve voeren. Als de Koning het maar wist!, luidt de geijkte weeklacht. In de mythe, die zonder onderscheid woekert rond vroegere koningen en rond moderne diktators, vallen werkelijk de Engelse en de Italiaanse spreuken samen; een volledige gelijkenis, die dan èn de koninklijke onschendbaarheid, dat wil zeggen de positie van het staatshoofd, èn de ministeriële verantwoordelijkheid, dat wil zeggen de positie van de tweede man in het rijk, zal omvatten.

Deze mythe heeft invloed gehad op de vorming van artikel 53 van de grondwet van 1848. Uit historische bronnen is blijkbaar dat zij, zowel in Engeland als in Nederland trouwens, verweven is geweest met de ontwikkeling en grondwettelijke bevestiging van het beginsel der ministeriële verantwoordelijkheid. Het boek dat volgt behelst daarom een poging het verband tussen koningsmythe en staatsrecht te meten; een staatsrechtelijk onderzoek derhalve, maar ingebed in het historische en het psychologische. De historische uitgestrektheid van de koningsmythe wordt zover mogelijk afgepaald, en voorzichtig wordt naar haar oorsprong gezocht, in het psychologische, in de aard der mensen. De mythe van het koningschap en de mythische lezing van art. $53 \mathrm{Gw} 1848$ vormen het hart, de kern, het doel van dit boek. De bespreking ervan beslaat dan ook het grootste stuk, drie aaneengesloten hoofdstukken.

De mythische interpretatie van art. $53 \mathrm{Gw} 1848$ is de bijdrage van dit boek; maar ze moet worden voorbereid en begeleid. Het artikel heeft namelijk reeds een interpretatie, 
zoals hierboven weergegeven, die tamelijk algemeen wordt aangehangen, en die ik de liberale, of rationele zou willen noemen. Zij past in een geschiedbeschouwing aangaande Europa's staatkundige verleden: De Europese koningen, heersers die zich beriepen op godsdienstige mythen, werden verdreven door rationalisering en demokratisering. Rationele wetenschap ontmaskerde hun mythe, demokratische regeerwijzen vervingen hun willekeurige oppermacht. De liberale rechtsstaat werd regel. Mocht de koning blijven, dan zonder macht, verscholen achter ministers, zijn mythe krachteloos buiten de politieke werkelijkheid, waar alleen nog het beginsel van redelijkheid en debat heerst. De traditionele en de mythische lezing van artikel 53 lopen zeer uiteen. Naar rationele beschouwingswijze zijn The King can do no wrong en Mussolini ha sempre ragione tegengesteld, de een uitdrukking van demokratie, de ander van fascisme; in het mythische dekken ze elkaar precies, de ministeriële verantwoordelijkheid inbegrepen. Volgens de oorspronkelijke leer heeft het artikel de monarchie als politiek werkzame faktor beëindigd; de koning werd buiten de politieke werkelijkheid gedrongen, zijn mythe onschadelijk gemaakt, nog slechts toegelaten op een nauw begrensde plek, haar door de rede gewezen. Volgens de nieuwe beschouwingswijze heeft het artikel juist de koningsmythe bevestigd, haar niet opgesloten binnen de grenzen van het redelijke; integendeel, de mythe van het koningschap heeft in de redelijke grondwet van 1848 ongezien, dus onbeheerst, een ereplaats verworven. De rationele leer noemt demokratisering dat uiterlijk, opgelegd gezag wordt bedwongen; in de nieuwe beschouwing bestaat pas demokratie, vrijheid, ook staatkundig, indien mensen hun innerlijke afhankelijkheid van mythe en machtigen onderkennen en beheersen.

De twee bedoelde opvattingen van artikel 53 gaan dus ver buiten het grammatikale, ver buiten het loutere lezen van een tekst. Ze behoren thuis in twee geschiedbeschouwingen, om niet te zeggen wereldbeelden, en tussen die twee zullen we een radikale omslag moeten doormaken. Dat kan niet ineens. Het voorstel is daarom de wending als volgt te voltrekken. Na deze bladzijden, over de vragen en bedoelingen van het boek, de inleiding, komt eerst een hoofdstuk dat de gangbare interpretatie van art. $53 \mathrm{Gw} 1848$ plaatst in het bredere verband, historisch en internationaal, van de geschiedenis der Europese koningen; koninklijke onschendbaarheid en ministeriële verantwoordelijkheid als mijlpaal op het pad naar de liberale rechtsstaat.

Daarna twee hoofdstukken die het beeld van artikel 53, en zo ook van de historische ontwikkeling waarin dat was opgenomen, geleidelijk bijstellen. Eerst zal blijken dat de koninklijke onschendbaarheid niet van 1848 hoefde te dateren, maar voorheen heeft bestaan als eigenschap van elke, juist van de absolute koning. En de onfeilbaarheid, het onvermogen kwaad te doen waarvan de Engelse regel spreekt, is niet altijd als fiktie, maar ook wel als letterlijke waarheid opgevat. De twee hoofdstukken hangen onderling sterk samen. Onschendbaarheid staat in deze betekenis voor absoluut gezag, de onfeilbaarheid staat voor het beschikken over volkomen kennis, en tussen die twee is een intense wisselwerking: Indien ware kennis bestaat, dan behoort een gezag het voor haar op te nemen; indien gezag bestaat, dan hoort het uitsluitend goede waarheid op te leggen.

Twee nogal technische hoofdstukken; ik kan gelegenheidslezers, wie het meer om de hoofdzaak van het hoek te doen is, gerust aanraden ze terzijde te laten. Ze staan er natuurlijk, evengoed, niet voor niets. Na het hoofdstuk over de geschiedenis der Europese 
koningen en over hun verdwijnen door de moderne demokratisering, en de strekking van art. 53 die daarin past, wordt dat beeld door deze twee hoofdstukken vervormd, aangaande zowel het oude koningschap als de staatkundige modernisering van Europa, en ook weer toegepast op de Nederlandse monarchie en op het beginsel van onschendbaarheid en ministeriēle verantwoordelijkheid. De overeenkomsten tussen vroeger koningschap en moderne diktatoriale stelsels kunnen zo langzamerhand duidelijk worden, alsmede het effekt van de Europese demokratisering, die soms de weg was waarlangs monarchie totalitarisme werd. Daarna, in de drie hoofdstukken van de mythische beschouwingswijze, boeft het bijeenkomen van The King can do no wrong en Mussolini ha sempre ragione geen donderslag bij heldere hemel meer te zijn.

Bij de oorspronkelijke, rationele opvatting van artikel 53 werd een nieuwe beloofd, de mythische; twee hoofdstukken overbruggen de kloof. De bedoeling is duidelijk, de indeling overzichtelijk. Maar welke zin hebben nu al de vragen die eerder werden opgemaakt uit de historie van 1848 , en trouwhartig opgesomd? Hun prikkeling moest ons, vooreerst, in beweging brengen; zij zullen ook tijdens het boek de beweging gaande houden. De waslijst van vragen makkte dat we verder willen zien dan de traditionele leer, en het zoeken naar antwoorden zal in het vervolg onze voortdurende bezigheid zijn. De vragen keren met zekere regelmaat terug, afwisselend, naar aanleiding van nieuwe historische gegevens, dan hier dan daar, de een vaker dan de ander, in overeenstemming met hun belang, en vinden steeds, passend bij de fase van het onderzoek, een eigen antwoord. Deze aanpak maakt het betoog tot een voortgaande beweging, een ontdekkingsreis, en gedurende die reis doorlopen we als het ware vier landschappen, vier decors, waarin het koningschap en art. $53 \mathrm{Gw} 1848$ telkens anders figureren.

Vier decors: de traditionele opvatting, de mythische, en de twee tussenliggende. De vier kunnen op zichzelf staan, afgerond, volkomen; ze hebben met elkaar te maken, maar sluiten elkaar ook uit. Wat is nu koningschap, wat is de ware betekenis van het beginsel van koninklijke onschendbaarheid en ministeriële verantwoordelijkheid? Ik zou de mythische beschouwingswijze, die ik kortweg de bijdrage van dit boek noemde, willen zien als de grondigste en verreikendste, de sterkste van de vier; we verkrijgen de meeste en de beste antwoorden op onze vragen wanneer art. 53 daarin haar plaats heeft gevonden. Maar elk voor zich van de vier besprekingen heeft zin, en elk wordt gesteund door historisch materiaal. Daarom: Er is niet één, er zijn vele betekenissen van artikel 53, en het koningschap heeft meerdere gezichten. Straks worden opeenvolgend vier verhalen verteld, als het ware vier versies van het koningschap; de laatste beeft mijn voorkeur, maar geen van de vier is zonder werkelijkheidswaarde.

In de vierde versie vallen de twee spreuken The King can do no wrong en Mussolini ha sempre ragione samen; heel eenvoudig, vanzelf. Maar deze overeenstemming, een aardige uitkomst van het onderzoek, leidt onmiddellijk tot een minder aardige gevolgtrekking: Ongemerkt heeft een fascistisch beginsel zich in de Nederlandse grondwet genesteld. Hoe kan dit? Hoe moeten we nu denken over demokratisering, over gezag en vrijheid? Het boek mag niet eindigen zonder van die kwesties te reppen; maar dan alleen in de lijn van het voorgaande onderzoek. Het ware onjuist, een treden buiten de grenzen van het boek, indien dergelijke politiek filosofische kwesties nog in het algemeen zouden worden behandeld. Een enkel woord, in aansluiting bij, voortkomend uit het eerdere betoog. Twee vragen uit de bovenstaande lijst zullen daar, tenslotte, in een 
laatste hoofdstuk, van pas komen: Waarom verloor de koning zijn macht? En: Hoe valt werkelijke gezagsuitoefening te verenigen met een eigen verantwoordelijkheid van ondergeschikten?

Het boek gaat over onschendbare koningen en verantwoordelijke ministers; maar geen ander dan de koning zelve, en hij alleen, kan de hoofdpersoon zijn. Het boek gaat over koningschap; over de koning. De Koning-met-een-grote-K! Een koning, wat is dat eigenlijk? Waarop prompt als antwoord, even beknopt als omvattend, kan worden gezegd, namens John Case, een geleerde uit Oxford, in 1605: ${ }^{72}$

\footnotetext{
"Maior propositio consensu omnium summorum Philosophorum conceditur, quia sacrum est nomen regis, cum in eo Dei, iustitiae ac totius civitatis imago cemitur."

"Dit erkennen alle grote filosofen, dat de nam des konings heilig is, omdat in hem het beeld Gods, het beeld der gerechtigheid en hel beeld der gehele gemeenschap wordt gezien."
}

Zo zullen we de drie voorafgaande versies van het koningschap groeperen. De Koning als beeld Gods: Hoe de onberedeneerde oppermacht van de vroegere koning en diens steun in godsdienstige voorstellingen door de liberale rechtsstaat uit de weg werd geruimd. De Koning als Gemeenschap: Hoe de klassieke koning door de macht van zijn onschendbaarheid de gemeenschap der mensen bijeen hield; een onschendbaarheid die in de modernisering van Europa's politieke stelsels verdween. De Koning als Gerechtigheid: Hoe de koning vroeger kon denken voor zijn onderdanen hogere, absolute waarden te weten, een pretentie die onderging in de moderne relativering van het waarheidsbegrip. De vierde, mythische zienswijze van het monarchale kan daarna worden begrepen. 

De Koning 

Hoofdstuk 2

\section{De koning als beeld gods}

Wat de Koning is, iedereen weet het. Bij ieder zweven wel beelden van de ware koning, half uit de historie, half uit vertellingen. Waarlijk koning was bijvoorbeeld Lodewijk XIV van Frankrijk: oppermachtig, een wil die wet was, groots in alles, middelpunt van een schitterend hof. Maar we weten ook hoe na hem de pracht en de praal te niet gingen. Het volk, door moedige denkers voorgegaan, nam niet langer dat gezag van buiten en van boven kwam, onweerstaanbaar zodat de onderdanen alleen gehoorzaamheid restte; nam het niet langer dat regering een zaak van persoonlijke willekeur was. Gezag, werd het principe, moet berusten op de eerlijke innerlijke overtuiging van hen die eraan zijn ondergeschikt.

Indien werkelijk iedereen deze geschiedenis weet, dan omdat zij ons zo door de schoolboekjes werd bijgebracht. Een misschien ook wel naief verhaal, waarvan de geschiedschrijving en andere betrokken wetenschappen zich inmiddels een eindweegs hebben verwijderd. Het heerst desondanks, meen ik, nog steeds, als historische grondslag van de ideologie der liberale demokratische rechtsstaat. Het verleden van de Nederlandse grondwet, het Nederlandse staatsbestel, de Nederlandse monarchie, en vooral de regel van koninklijke onschendbaarheid en ministeriële verantwoordelijkheid, staan nog altijd in dit licht.

Nederland wordt geacht binnen die weinige jaren voor en na 1848 een staatkundige ontwikkeling te hebben doorgemaakt die elders eeuwen in beslag nam. Dat wil zeggen, elders in Europa; deze geschiedenis is in de eerste plaats Europees. De betrekkelijk korte historie van het Nederlandse koningschap weerspiegelt een lot dat, ruwweg gesproken, alle Europese koningen ten deel viel. We denken dan met name aan de Franse en Engelse monarchieën: de Franse als schoolvoorbeeld van koningschap, de Engelse als oorsprong van de leer der ministeriële verantwoordelijkheid.

Wij zullen derhalve in dit hoofdstuk buiten Nederland zien, om de wijdere historische en internationale achtergrond van het gangbare gedachtengoed rond art. $53 \mathrm{Gw} 1848$ in het oog te krijgen. Het verhaal van de Europese koningen, dat evenwel, volgende hoofdstukken zullen het duidelijk maken, slechts een verhaal mag heten. Een versie van het verhaal der koningen; de eerste. 
De koning was God op aarde. Ieder diende zich natuurlijk, naar de tekst van de bijbel en de leer der kerk, aan de overheid te onderwerpen als aan een instelling Gods, maar veel hoger nog werd de pretentie gevoerd. Niet maar vertegenwoordiger, niet maar stedehouder, zélf god was de koning. "Vous êtes des dieux", preekte de befaamde kanselredenaar Jacques-Bénigne Bossuet in 1662 Lodewijk XIV voor, met een citaat uit het boek der psalmen; op het aangezicht der koningen zag hij een merkteken van goddelijkheid geschreven. De Engelse koning Jakobus I had in 1609 niet ondergedaan: '

\footnotetext{
"Kings are iustly called Gods, for that they exercise a manner or resemblance of Diuine power vpon earth: For if you wil consider the Attributes to God, you shall see how they agree in the person of a King. God hath power to create, or destroy, make, or vnmake at his pleasure, to giue life, or send death, to iudge all. and to be iudged nor accomptable to none: To raise low things, and to make high things low at his pleasure, and to God are both soule and body due. And the like power haue Kings: they make and vnmake their subiects: they haue power of raising, and casting downe: of life, and of death: Iudges ouer all their subiects, and in all causes, and yet accomptable to none but God onely."
}

God en de koning waren één. De kroon met opstaande punten symboliseerde dat de ronding van 's konings hoofd niet gesloten was maar open naar boven. Goddelijke waarheid kwam van de lippen des konings; zijn woord was God's woord, zijn woord was wet. Wie dus in het politieke anders wilde, verzette zich behalve tegen de vorst, tegen God; en omgekeerd, wie in het religieuze anders wilde verzette zich behalve tegen God, tegen de vorst. Eerbied voor God was de grondslag van de eerbied voor de koning; de eerbied voor de koning was de grondslag van de samenleving. Wie religieus marchandeerde bracht eerst de kerk, automatisch ook de staat in gevaar. Ketters pleegden seditie, oproer. ${ }^{2}$

Van God vloeide een kosmische orde voort, die we sinds Arthur Lovejoy's boek Engelstalig de "Great chain of being" noemen. De leer gaat terug op de antieke wijsgerige stelsels van Plato en Aristoteles; ze hield stand tot, zeg, de 18e eeuw. Van hoog tot laag bestond een hechte hiërarchie met een vaste plaats voor elk schepsel. De samenleving weerspiegelde deze orde. Boven allen, op eenzame hoogte, de koning, onder hem ieder op een eigen plaats. Een struktuur met goddelijk gezag. Ieder behoorde te blijven ter plaatse waar zij of hij was gesteld, daar te arbeiden en daar tevreden te zijn. Een streven naar hoger zou het weefsel scheuren, uiteindelijk het geheel der samenleving bedreigen. Ambitie was tegen de natuur, het was rebellie tegen God die de kosmische en sociale hiërarchie in zijn wijsheid voor ieders bestwil had ingesteld. Ambitie was arrogantie.

Rond 1700 , de Franse hertog en aartsbisschop Fénelon: ${ }^{3}$

1. I Samuel 26:9: Psalm 82:6; Romeinen 13:1: Marin 21; James I. Works 61. 307

2. Bv. Leonard W. Levy. Treason against God. A history of the offense of blaspheny. New York 1981. blz. $313 / 314$.

3. Lovejoy 201, 206: Huizinga 67; Fénelon. Essai philosophique sur le gouvernement civil, 2 e druk 1721. Oeuvres V. Parijs 1838, blz. 55 . 


\begin{abstract}
-Violer les droits de la subordination établie est donc un crime de lese-majesté divine; vouloir renverser la supériorité des rangs, réduire les hommes à une égalité imaginaire, envier la fortune et la dignité des autres, ne se point contenter de la médiocrité et de la bassesse de son état, c'est blasphémer contre la Providence, c'est attenter sur les droits du souverain Père de famille, qui donne à chacun de ses enfants la place qui lui convient. Voilà le fondement sûr et immuable de toute autorité légitime."
\end{abstract}

Vooral ambitie de koning te spelen werd hoog opgenomen. In de $19 \mathrm{e}$ eeuw vertelde men elkaar hoofdschuddend hoe de gevoeligheid vroeger tot het absurde was doorgedreven. ${ }^{4}$ In de 15 e eeuw, toen Engeland werd verscheurd door burgeroorlog, de Wars of the Roses, en de koningen grote moeite hadden hun gezag af te dwingen, was er in Londen een herberg die The Crown heette. Het verhaal ging dat de waard ooit onder een glas bier bad gezegd dat zijn zoon The Crown, de kroon zou erven. "Deze zeer onschuldige scherts werd hem als misdaad aangerekend, en de rechters waren dom of bang genoeg om er een misdaad van gekwetste majesteit in te zien, en den kerel te doen ophangen."

De koning regeerde alleén. Laat niemand het wagen in zijn voorrecht te treden! Een verderf was het, een ontaarding van de 'orde van zaken', schreef Lodewijk XIV in zijn Mémoires, wanneer men zou menen dat het recht te besluiten aan onderdanen kon toekomen; het hoofd alleen beraadslaagt en beslist, de andere leden gehoorzamen. ${ }^{s} \mathrm{De}$ macht des konings moest in het rijk, trouwens ook daarbuiten, onweerstaanbaar zijn. Ongehoorzaamheid en opstand golden als ernstig vergrijp; ze werden met afschuwelijke; straffen betaald gezet. En als het nu eens aan de koning had gelegen? Als nu eens de; koning ondeugdelijk regeerde? Geen middel was het verdrukte volk toegestaan dan gebed tot God on redding. De gehoorzaamheid moest totaal zijn, drong een Frans pamflet aan; in 1649, de tijd dat een beweging, de Fronde, zich ondanks de geldende doktrine tegen de koning scheen te verzetten. ${ }^{6}$

"Tout ce qui s'Écarte lant soit peu de l'entière obéyssance, ouure la porte à la réuolté. dont la lémérité fait marcher d'vn pas égal ses raisons auec celles du Souuerain ..."

De kleinste scheur in het schild der gehoorzaamheid zou spoedig tot erger leiden. Zich 's konings recht aanmatigen, 's konings recht in twijfel trekken, zelfs de wijsheid van zijn maatregelen betwisten leverde majesteitsschennis op. Majesteitsschennis, crimen laesae maiestatis, was afkomstig uit het Romeinse recht. Het omvatte allerlei kwetsingen van het oppergezag; onder keizer Augustus voor het eerst ook aanranding in geschrifte. Lang na de ineenstorting van het Romeinse Rijk, pas na het vervagen van de droom dat het hersteld kon worden, werd de Romeinsrechtelijke majesteitsschennis door de koningen genaast, samen met ander keizerrecht, onder de stelregel dat een koning keizer is binnen zijn eigen rijk: Rex est imperator in regno suo. Verscheidene vormen van gebrek aan verschuldigde eerbied, die kennelijk voor toenmalig besef bijeen hoor-

4. Jacob van Lennep en Johannes ter Gouw, De withangleekens, in verband met geschiedenis en volksleven beschow d 1, (oorspr. 1868) reprins Den Haag z.j., blz. 146: Blackstone IV. 80.

5. Louis XIV. Oeuvres $I, 56 ; I I, 26$.

6. Moreau I, 229. 
den, waren in het delikt van majesteitsschennis samengebracht: godslastering, omdat de vorst stedehouder Gods is, en ook vadermoord, omdat de vorst vader des vaderlands wordt genoemd. ?

Wie de koning tegenwerkte bedreigde hem, wie hem weersprak onteerde hem. En nauwer nog werd de grens van het toelaatbare getrokken. Tegenspraak was eerroof, uiteraard, maar raakte niet de band der gehoorzaamheid reeds los waar koninklijke besluiten vrijuit werden besproken? Is niet twijfel in dergelijke diskussie bet vooronderstelde, en de twijfel tekort aan gehoorzaamheid? Ongehoorzaamheid, aldus Henry de Bracton (13e eeuw) in zijn grote boek over het Engelse recht, was ten strengste verboden, maar evenmin mocht wie ook zich aanmatigen over het handelen van de koning te diskussiēren: "Nemo quidem de factis suis praesumat disputare, nec multo fortius contra factum suum venire. ${ }^{8}$ Het verbod over 's konings doen en laten zelfs maar te disputeren maakte gedurende eeuwen furore.

Het is de leer van de arcana imperii, de geheimen van het rijk waarin geen onbevoegde zich mag mengen. Zelf doorgaans, heel konsekwent, onuitgesproken, beheerste deze leer eeuwenlang de politieke verhoudingen. Het was onderdanen eenvoudig niet geoorloofd de politieke gang van zaken te bespreken. In Frankrijk werd openbaar debat in de $17 \mathrm{e}$ en $18 \mathrm{e}$ eeuw herhaaldelijk bij dekreet verboden. De 'verlichte' koning van Pruisen, Frederik II, dacht er niet anders over en ook Engelse koningen toonden zich in de $17 \mathrm{e}$ eeuw erop gebeten. Toen het Parliament verklaarde dat staatszaken voor haar gepast onderwerp van debat waren, scheurde Jakobus I eigenhandig die bladzijde uit de notulen. Verbijsterd was hij eens geweest, koning Karel I, "many times amazed to consider by what eyes these things are seen, and by what ears they are heard". Het koninklijk gezag was beter af bij eerbiedige en zwijgzame verering dan bij openlijke debatten. ${ }^{9}$ Ongeoorioofd was het de sluier weg te rukken die het geheim van de koning bedekte. Tijdens de Franse Revolutie, die scherpe reaktie op koninklijk absolutisme, zou met afkeer worden opgehaald hoe rond de tronen stilte heerst. Volkomen stilte, op lege lof na. Karel van het Reve, schrijvend over de Russische monarchie, zette raillerend maar raak uiteen waarom zelfs instemming van onderdanen met de gevoerde politiek geen ruimte kan krijgen. Zou de overheid toelaten dat het volk beleid goedkeurt, dan kon gemakkelijk de mening insluipen dat het volk überhaupt recht heeft een mening over het vorstelijke doen te uiten, en dan wellicht ook afkeuring. Nee, stilte is veiliger. Zo ongeveer liet een Franse kanselier het zich in 1759 bijna onverboeds ontsnappen. $\mathrm{Na}$ de uitspraak dat het koninklijk gezag eerste beginsel van de staat was, vervolgde hij: "Il semble que c'est en doutter que de chercher à la justifier". Zelfs een al te nadrukkelijke rechtvaardiging van de monarchie zou het totale, het onontkoombare ervan op losse schroeven kunnen stellen. ${ }^{10}$

7. Tacilus, Annales 1.72; Kantorowicz, Sel. studies 165; Seller 285.

8. Bracton II. 33, 109.

9. Kantomwicz, "Mysteries of state", Sel. shudies 381-398 (cok $266 \mathrm{nt}$. 16); Baker 12, 33; Habermas 40; Dodd 17: Hill 38. 47.

10. Baker 4, 328 nt. 67; Karel van het Reve, Geschiedenis van de Russische literatmur. Van Vladimir de Heilige to Anton Tsjechov. (oorspr. 1985) Amsterdam 1990, blz. 181. 
den, waren in het delikt van majesteitsschennis samengebracht: godslastering, omdat de vorst stedehouder Gods is, en ook vadermoord, omdat de vorst vader des vaderlands wordt genoemd. ${ }^{\text {? }}$

Wie de koning tegenwerkte bedreigde hem, wie hem weersprak onteerde hem. En nauwer nog werd de grens van het toelaatbare getrokken. Tegenspraak was eerroof, uiteraard, maar raakte niet de band der gehoorzaamheid reeds los waar koninklijke besluiten vrijuit werden besproken? Is niet twijfel in dergelijke diskussie het vooronderstelde, en de twijfel tekort aan gehoorzaamheid? Ongehoorzaamheid, aldus Henry de Bracton (13e eeuw) in zijn grote boek over het Engelse recht, was ten strengste verboden, maar evenmin mocht wie ook zich aanmatigen over het handelen van de koning te diskussiēren: "Nemo quidem de factis suis praesumat disputare, nec multo fortius contra factum suum venire. ${ }^{8}$ Het verbod over 's konings doen en laten zelfs maar te disputeren maakte gedurende eeuwen furore.

Het is de leer van de arcana imperii, de geheimen van het rijk waarin geen onbevoegde zich mag mengen. Zelf doorgaans, heel konsekwent, onuitgesproken, beheerste deze leer eeuwenlang de politieke verhoudingen. Het was onderdanen eenvoudig niet geoorloofd de politieke gang van zaken te bespreken. In Frankrijk werd openbaar debat in de $17 \mathrm{e}$ en $18 \mathrm{e}$ eeuw herhaaldelijk bij dekreet verboden. De 'verlichte' koning van Pruisen, Frederik II, dacht er niet anders over en ook Engelse koningen toonden zich in de $17 \mathrm{e}$ eeuw erop gebeten. Toen het Parliament verklaarde dat staatszaken voor haar gepast onderwerp van debat waren, scheurde Jakobus I eigenhandig die bladzijue uit de notulen. Verbijsterd was hij eens geweest, koning Karel I, "many times amazed to consider by what eyes these things are seen, and by what ears they are heard". Het koninklijk gezag was beter af bij eerbiedige en zwijgzame verering dan bij openlijke debatten. Ongeoorloofd was het de sluier weg te rukken die het geheim van de koning bedekte. Tijdens de Franse Revolutie, die scherpe reaktie op koninklijk absolutisme, zou met afkeer worden opgehaald hoe rond de tronen stilte heerst. Volkomen stilte, op lege lof na. Karel van het Reve, schrijvend over de Russische monarchie, zette raillerend maar raak uiteen waarom zelfs instemming van onderdanen met de gevoerde politiek geen ruimte kan krijgen. Zou de overheid toelaten dat het volk beleid goedkeurt, dan kon gemakkelijk de mening insluipen dat het volk überhaupt recht heeft een mening over bet vorstelijke doen te uiten, en dan wellicht ook afkeuring. Nee, stilte is veiliger. Zo ongeveer liet een Franse kanselier het zich in 1759 bijna onverhoeds ontsnappen. Na de uitspraak dat het koninklijk gezag eerste beginsel van de staat was, vervolgde hij: "Il semble que c'est en doutter que de chercher à la justifier". Zelfs een al te nadrukkelijke rechtvaardiging van de monarchie zou het totale, het onontkoombare ervan op losse schroeven kunnen stellen. ${ }^{10}$

7. Tacitus, Annales 1.72; Kantorowicz. Sel. studies 165; Sellen 285.

8. Bracton II, 33, 109.

9. Kantorowicz. "Mysteries of state". Sel, studies 381-398 (ook 266 nt. 16); Baker 12, 33: Habermas 40, Dodd 17; Hill 38, 47.

10. Baker 4, $328 \mathrm{nt}$. 67; Karel van het Reve, Geschiedenis van de Russische literatuur. Van Vadimir de Heilige tot Anton Tsjechov, (oorspr. 1985) Amsterdam 1990, blz. 181. 
zen. De menselijke rede, de redelijkheid die ieder mens eigen is, moest het enige kriterium zijn; op de rede mocht elk zich verlaten. Zelfs als het indruiste tegen God en de koning? Descartes beweerde van niet; zijn methode gold slechts in de filosofie, religie en politiek waren zorgvuldig uitgezonderd. ${ }^{\text {is }}$

Het nageslacht verwierp de uitzondering. In het religieuze en in bet politieke zouden de Cartesiaanse twijfel en de Cartesiaanse rede hun klinkendste suksessen boeken. Anderhalve eeuw na Descartes schreef Immanuel Kant de uitdagende woorden, als het ware rechtstreeks gekeerd tegen de leer die koning Jakobus I zijn volk wenste op te leggen: ${ }^{16}$

"Unser Zeitalter ist das eigentliche Zeitalter der Kritik, der sich alles unterwerfen muss. Religion, durch ihre Heiligkeit, und Gesetzgebung. durch ihre Majestät, wollen sich gemeiniglich derselben entzichen. Aber alsdenn erregen sie gerechten Verdacht wider sich und kïnnen auf unverstellte Achtung nicht Anspruch machen. die die Veruunft nur demjenigen bewilligt, was ihre freie und öfientliche Prüfung hat aushalten können."

Rede was kritiek, kritiek was twijfel; de drie waren één. Het was de centrale boodschap van de $18 \mathrm{e}$ eeuw, die bij uitstek de eeuw der philosophes is geweest, dat alles zich moest onderwerpen aan kritiek, niets zich mocht onttrekken aan de toets der redelijkheid. Zeker religie en politiek niet! Rede werd het vaandel van vrijheid en emancipatie. Hoe zou het God en de koning onder het onbarmhartige licht van die moderne rede vergaan? Kant toetste in zijn Kritik der reinen Vermunft van 1781 de bewijzen die altijd voor het bestaan van God waren aangevoerd, en verwierp de een na de ander. Er bleek niet én steekhoudend wetenschappelijk argument te zijn om in God te geloven. Een zware slag voor de oude christelijke traditie.

En de koning? Verviel het oude geloof dan verviel zijn beroep op God; daarmee zijn recht van spreken. Men hoefde niet theoretisch even ver te komen als Kant, een eenvoudiger redenering volstond; ze is bijvoorbeeld te vinden bij David Hume en JeanJacques Rousseau. Wanneer we nog in God geloven, zelfs toegeven dat het koninklijk gezag door God is ingesteld, valt onmiddellijk aan te vullen dat ziekte, rampen en misdaad niet minder van hem afkomstig zijn. Toch hoeven we in die gevallen niet te berusten, het is heel normaal een dokter of de politie te roepen. Dat het gezag er was door God zegde niets over de rechtvaardigheid ervan. ${ }^{17}$

Had de koning nog iets anders in te brengen om zijn pretentie te staven? Eigenlijk niet. Overduidelijk wordt dat wanneer we ter illustratie Antoine Loisel opslaan. Loisel had in 1606 een samenvatting van het Franse recht gepubliceerd die veel invloed zou hebben. Onder de rechtsspreuken van zijn verzameling bevond zich, in feodale terminolo-

15. René Descartes, Discours de la méthode. in Ocuvres VI (ed. Adam-Tannery), blz. 8, 14, 28. Descartes' rede, volgens het "übliche Bild". betekende een nieuwe vrijheid, die alleen binding aan het eigen ik toestaat, zei nog eens Martin Heidegger, Die Frage nach dem Ding, in Gesamtausgabe XLI. blz. 97.99 .

16. Immanuel Kant, Kritik der reinen Vermunft. in Werke III (ed. Cassirer). blz. $7 \mathrm{nt}$.: Alexis de Toequeville. De la démocratic en Amérique, in Ocuvres 1.2 (ed. Mayer), blz. 13.

17. Hetzelfde argument bij Rousseau, Contrat social 1.3; Hume 444; Hegel, Vorlesungen 1818-1831, blz. 681: Van Sonsbeeck I, 20. 
gie: "Le Roy ne tient que de Dieu et de I'espée". Behalve God's wil hield niets de koning staande dan de scherpte van zijn zwaard. Wie deze regel had gekend en nu de onthutsende invloed van het moderne denken onderging, ontkwam niet aan de gevolgtrekking: Als de schaduw van God niet meer over de koning viel, werd zijn pretentie ontbloot als Jouter recht van de sterkste. ${ }^{18}$

Het recht van de sterkste is weliswaar macht en moeilijk te weerstaan, het is geen gezag. Mocht een samenleving zich erbij neerleggen dat de sterkste onder haar het voor het zeggen heeft? Nee natuurlijk; gezag vereist een morele grond. Maar wat kon nog machtsuitoefening in de gemeenschap rechtvaardigen? Na de weerlegging van het beroep op hogerhand belandde het denken vanzelf bij een beroep op lagerhand. Gezag dat uit de hoogte wetten oplegt, regels die uiterlijk zijn aan de onderdanen, heeft geen rechtvaardiging; gezag behoort slechts wetten af te kondigen die overeenkomen met, liefst voortkomen uit de innerlijke overtuiging van het volk.

Het volk bestaat immers uit mensen, allen begiftigd met de universele rede? Gezag moet zich derhalve verantwoorden aan de gemeenschap van redelijke burgers, het kan alleen gezag zijn voorzover het door de burgers innerlijk wordt erkend. Dit principe werd verbeeld door de theorie van het 'sociaal kontrakt'. Vanuit een denkbeeldige natuurlijke toestand van vrije en gelijke mensen was op een dag door algemene vrijwillige instemming de overheid in het leven geroepen. Uitsluitend deze persoonlijke toestemming, die daama impliciet bij de burgers zou bestaan, kon rechtvaardigen dat men zich aan gezag en wetten onderwierp.

Theoretisch was aldus de koninklijke pretentie geheel ondergraven; ze bleek zonder grond. Op zich al een hele toer, maar een tweede was de theorie praktisch te realiseren. Koningen geven zich niet zomaar gewonnen! Er ontwikkelde zich een strijd tussen koningen en volk, tussen absolutistische pretentie en demokratisch recht; een zware strijd, langlurig, die zich over eeuwen uitstrekte en overal een beetje anders verliep. In Engeland was de Civil War, midden 17e eeuw, een klimax; Engeland was er tijdig bij. Algemeen de meeste indruk maakte de Franse Revolutie, door haar hevigheid en internationale uitwerking, eind $18 \mathrm{e}$, begin $19 \mathrm{e}$ eeuw. De Russische, Duitse en Oostenrijkse keizers hielden lang stand, pas veel later, begin $20 \mathrm{e}$ eeuw, werden zij van de troon gestoten.

Steeds in deze revoluties, die we de burgerlijke noemen, was ondanks grote onderlinge verschillen de inzet ongeveer dezelfde, min of meer in de sfeer van het liberalisme. Want al is het liberalisme een verschijnsel van de $19 \mathrm{e}$ eeuw, ervoor onbekend, ema door andere geestesstromingen voorbijgestreefd, het beheerst toch ruimhartig het beeld van heel die uitgestrekte staatkundige historie. Regering voor en door het volk luidde telkens de eis, en globaal werden overal dezelfde bestanddelen in het staatsbestel verwerkt, barrières die de exclusieve oppermacht van de vorst indamden, of middelen die de volksinvloed vrij baan gaven. Aan vier ervan zullen we een enkel woord wijden: volkswil, grondwet, Trias politica en depersonalisatie.

Het hoogste beginsel van alle was dat de gemeenschap het laatste woord zou hebben. De onderdanen werden burgers, het volk heette soeverein en maakte aanspraak op de 
passende eerbied. In Engeland en Frankrijk ontstond in de $17 \mathrm{e}$ en $18 \mathrm{e}$ eeuw een publieke opinie, gedragen door leesgezelschappen, koffiehuizen, salons, tijdschriften; deze publieke opinie werd opgevat als uiting van de algemene rede. De bedoeling was de publieke opinie te kanaliseren en te laten uitmonden in de politieke besluitvorming. Een stelsel van periodieke verkiezingen en volksvertegenwoordiging in parlementen werd ontworpen en als drijvende kracht in het politieke systeem opgenomen. De monarchie werd demokratie. ${ }^{19}$

Aan de onvoorspelbaarheid en willekeur der vorsten diende paal en perk gesteld. Regeren zou niet vrij meer zijn, maar gebonden aan vaststaande en bekende wetten: "established standing laws, promulgated and known to the people", woorden van de Engelse filosoof John Locke, met name degene die zich voor dit beginsel sterk maakte. De eerste van die wetten zou de grondwet zijn. Boven de overheid uit zou haar een hoogste wet worden opgelegd, als een sociaal kontrakt tussen haar en de burgers, onveranderlijk zonder wederzijdse goedkeuring. De koning gekortwiekt! Indertijd was bet crimen laesae maiestatis geweest wetten een kontrakt te noemen; inbreuk op het uitsluitend koninklijke privilege van wetgeving. Nu zouden er regels komen die de overheid zelf behoorde na te leven. De monarchie werd rechtsstaat. ${ }^{30}$

Aan de leer van de Trias politica heeft de Franse baron Montesquieu zijn naam verbonden; hij had haar evenwel eenvoudig uit het Engelse politieke bestel afgelezen, waar de theorie lang voor hem, midden $17 \mathrm{e}$ eeuw, al werd uiteengezet. Het idee was de enkelvoudigheid van 's konings oppermacht te doorbreken en op die manier hem de mogelijkheid van ongebreidelde machtsontplooiing te ontnemen. De macht zou worden verdeeld over verscheidene, bij Montesquieu drie, organen, die elkaar onderling in evenwicht houden. Een stelsel van checks and balances. Opnieuw een nederlaag voor de koning; werd het vroeger als majesteitsschennis bestraft zijn macht te verkorten en aan anderen toe te delen, de splitsing van de volheid der macht in wetgevende, uitvoerende en rechtsprekende moest hij zich laten welgevallen. ${ }^{2 !}$

Depersonalisatie heeft meer weg van een anoniem proces. Lang geleden was het regeren de persoonlijke zaak van de koning, een scheiding tussen publieke en private sfeer werd niet gevoeld. Oorlog was geen zaak van algemeen belang, maar een persoonlijke "querelle" van de vorst; de staatskas was de schatkist des konings, het staatsrecht bestond alleen als 'vorstenspiegel', de traditionele en persoonlijke onderwijzing voor de vorst, soms in dichtvorm, hoe hij met wijsheid en goed gedrag het land kon besturen. Het koninklijke ambt was een persoonlijk bezit van de vorst; zo werden trouwens alle ambten gezien, hetgeen de leer van de Greal chain of heing, die ieder gebood zich aan de eigen maatschappelijke positie te houden, versterkte. Want een streven naar politieke aanstelling, door sollicitatie of verkiezingen, werd niet erkend; het was azen op andermans ambt, op diens bezit, Jus als diefstal of roof. ${ }^{22}$

Een langdurig proces van bewustwording heeft sedertdien scheiding gebracht tussen persoon en funktie, privé en publiek. Men begon de openbare financiën en het konink- 
lijk vermogen te onderscheiden; de vorsten hielden op in hun huwelijk en nageslacht openbare politiek te bedrijven, maar reserveerden deze aangelegenheden voor de persoonlijke levenssfeer. Een naam in dit verband is Jean Bodin, die in de 16e eeuw de diverse persoonlijke rechten van de koning samensmolt tot een abstrakt begrip, de soevereiniteit. Het begrip van oppermacht makkte zich los van de persoon van de koning; er groeide een staatsgedachte. Van de monarch kwam men uit bij de staat. ${ }^{n}$ Het viertal vormt een ingewikkeld samenstel van soms tegenstrijdige wensen. Hoe kan het volk de uiterste macht zijn, terwijl die macht in drieën is verdeeld? Hoe te verenigen dat overheidshandelen de volkswil moet volgen en tegelijkertijd gebonden is aan het recht? Filosofen als Kant en Hegel hebben door intens denkwerk de verwarde tendenzen tot eenheid gebracht, aansluitend bij de ontwikkelingen en organisatorische arbeid in de praktijk van de Engelse politiek en de Franse Revolutie. Door de gezamenlijke inspanning her en der zou tenslotte de klassieke monarchie in de modeme demokratische rechtsstaat uitmonden. Demokratie, recht, staat: demokratische rechtsstaat.

We vinden alle beginselen van de strijd tegen de koningen beknopt en keurig samengevat in een uitspraak van het Engelse Parliament, gedaan toen de Civil War op uitbreken stond: ${ }^{24}$

"... for the King, by his sovereignty, is not enabled to destroy his people, but to proteet and defend them; and the High Court of Parliament, and all other His Majesty's officers and ministers, ought to be subservient to that power and authority which the law hath placed in His Majesty to that purpose, though he himself, in his own person, should neglect the same."

Het citaat bevat in enen alle vier: volksbelang als hoogste norm, onderschikking der oppermacht aan de wet, wederzijdse kontrole tussen verscheidene machten, abstrahering van de koninklijke persoon. En met deze vier vorstenbedwingers is bovendien een vijfde verbonden: de ontwikkeling van de ministeriële verantwoordelijkheid.

\section{$\S 3$.}

Een van de specialisten in het Nederlandse staatsrecht, de Amsterdamse jurist Struycken, schreef ergens dat de geschiedenis zich voor de overgang van monarchie naur parlementair stelsel heeft bediend van eene list. " van de vorst te doorbreken, maar direkte konfrontatie zou om 's konings macht en majesteit, de gestrengheid van zijn straffen, voor de uitdager zeer riskant zijn. Een sluwe omweg liep via de ministers, de naaste dienaren van de vorst. De koning was dan wel buiten bereik, maar: "Princes must see and hear with other eyes and ears". Een uitspraak, gedaan in het Engelse Lagerhuis, 1625. Nog een tweede, uit 1628: "I do free my sovereign. He sees with other men's eyes and hears with other men's ears". ${ }^{26}$ En degene die het oor van de koning heeft, beschikt over de koers van het schip van staat;

25. A.A.H. Struycken, Grondwetsheraiening theorie en prakijk. Beschoitwingen over staatsrecht en staatkunde, Amhem 1913, blz. 106. 
wie was er die het niet wist? Door de fiktie dat uitsluitend ministers werden gekritiseerd, kon het parlement vrijuit over de politiek meespreken; de eer van de vorst bleef ongeschonden.

Het bleef niet bij meespreken; na het recht van het woord werd het recht van het laatste woord begeerd. Ministers waren net als ieder ander hun heer volkomen gehoorzaamheid verschuldigd; in een Frans pamflet ten tijde van de Fronde werd het als "crime manifeste", een klaarblijkelijk misdrijf betiteld, wanneer een minister anders wilde dan de koning. ${ }^{27}$ Het parlementaire streven daarentegen zou zijn de ministers bij te brengen, dat ze koninklijke orders naast zich neer moesten leggen indien deze in strijd waren met geldend recht of parlementaire uitspraak. Ministers waren niet langer gerechtigd hun verantwoordelijkheid voor het parlement af te wentelen met een beroep op bevel van hogerhand; betekende 'ministerieel handelen' voorheen: orders opvolgen, thans dienden zij zich een andere betekenis eigen te maken: 'verantwoordelijkheid aanvaarden'. Bovendien wilde het parlement greep krijgen op de benoeming van ministers, hetgeen, uitleg is overbodig, een sterke troef zou zijn om hen in het gareel te krijgen.

Nogmaals uit de tijd van de Fronde, de ernstige waarschuwing van iemand die het streven doorzag: ${ }^{29}$

\footnotetext{
"Ils veulent donner des Ministres au Roy, changeans ceux qui ne sont pas à leur gré: qui seroit proprement estre les maistres et les Directeurs du Conseil du Roy et de la personne du Roy mesme ..."
}

Waar en wanneer ontstond de ministeriële verantwoordelijkheid? Tijdens de Fronde, waarvan het hoogtepunt in 1649 viel, is er dus in Frankrijk sprake van geweest. Men zag echter geen kans door te zetten en de jaren erna brachten het tegendeel; een volle en onweerstaanbare ontplooiing van vorstelijk absolutisme, onder het bewind van de spreekwoordelijke zonnekoning Lodewijk XIV. Anderhalve eeuw later pas, in de Franse Revolutie, zou de ministeriële verantwoordelijkheid samen met al die andere vemieuwingen deel worden van het Franse staatsbestel, overigens om ogenblikkelijk door de versnelling der gebeurtenissen te worden achterhaald. Een hoofdstuk terug stuitten we op de Belgische en zelfs Nederlandse aanspraak dat die landen beel vroeger al ministeriële verantwoordelijkheid kenden. Wij kunnen deze beweringen later nog opnemen. Wat ervan zij: Algemeen geldt Engeland als de oorsprong van de ministeriēle verantwoordelijkheid; de geschiedenis van het beginsel werd daar geschreven. Eenmaal na vallen en opstaan tot klaarheid gebracht, is het uit de Engelse politieke struktuur door andere landen overgenomen.

Er gingen eeuwen overheen. ${ }^{30}$ Hoewel vroeg in de Engelse historie reeds sporen zichtbaar zijn van de ministeriële verantwoordelijkheid, duurde het tot de $19 \mathrm{e}$ eeuw eer het stelsel in de huidige zin als voltooid kon worden beschouwd. Al die tijd worstelden het parlement, speciaal het Lagerhuis, de House of Commons, en de koning om de eerste

27. Moreau II, 326: Dodd 5.

28. Roberts 88.

29. Moreau I, 238.

30. Over deze historie Roberts, Dodd, Berger, Chafee; ook nog wel de oudjes Mohl en Von Frisch. 
rang; gaandeweg verloor de koning het pleit. Het Lagerhuis richtte haar pijlen tegen de dienaren des konings, soms heel overtuigend, maar weinig wordt betwijfeld dat het haar om de koning zelf was te doen. Misverstand, het onvoorspelbare van ieder historisch verloop, onderscheid tussen die verder zien en die achter blijven: buiten deze aspekten lijkt eenstemmigheid te bestaan, toen bij deelnemers en nu bij historici, dat het Lagerhuis erop uit was de macht van de koning over te nemen. ${ }^{31}$

Net als in Nederland, vinden we in de Engelse geschiedenis achtereenvolgens strafrechtelijke en politieke verantwoordelijkheid. Het Lagerhuis veroverde aanvankelijk het recht van impeachment; het kon ministers in staat van beschuldiging stellen voor het Hogerhuis, de House of Lords, dat dan als rechter over hen oordeelde. De minister werd voor misdrijf aangeklaagd, tegen bem moest juridisch bewijs worden geleverd, het resultaat kon, in geval van een veroordelend vonnis, alleen oplegging van straf zijn. De bewijsvoering gaf grote moeite, want hoe kon het Lagerhuis precies weten wat koning en dienaar onderling verhandelden?

Soms zocht het parlement daarom haar toevlucht in de Act of Attainder, een parlementair dekreet dat de bedoelde minister simpelweg schuldig verklaarde en hem een straf oplegde. Het was niet bevredigend. De omslachtigheid en de gewelddadige afloop maakten deze aanpak onbruikbaar als politiek middel. De straffe impeachment vergleed tot een milder en moderner systeem: De minister werd niet meer als misdadiger aangeklaagd, hem werd rekenschap gevraagd van zijn misvattingen en falen; geen juridisch bewijs was meer vereist, een afkeurend oordeel op grond van algemeen inzicht was genoeg; de minister onderging niet meer een straf, met zijn aftreden was de zaak beëindigd. ${ }^{32}$

In 1642 brak de Engelse Burgeroorlog uit, een openlijk konflikt tussen koning Karel I en het parlement. In de jaren ervoor werkte het geschil natuurlijk al, zij het verborgen; juist toen zaten de ministers tussen hamer en aambeeld. Twee van hen verwierven treurige faam, de hertog van Buckingham en Thomas Wentworth, beter bekend als graaf van Strafford, de titel die Karel I hem een jaar voor zijn dood verleende. Buckingham, jarenlang door strafvervolging bedreigd, ontkwam uiteindelijk aan het fatale einde van een impeachment doordat in 1628 de dolk van een sluipmoordenaar het Lagerhuis te vlug af was. Strafford wist zich uit de greep van het Lagerhuis niet los te werken en eindigde zijn leven in 1641 op het schavot. Het is leerzaam een en ander uit de annalen van die bewogen periode te lichten.

Buckingham verdedigde zich in oude stijl: De handelingen die het Lagerhuis hem verweet had hij alle in opdracht van de koning verricht. Bij monde van Sir John Eliot, na een opsomming van zijn misdragingen, ontzegde het Lagerhuis hem in scherpe woorden zijn beroep; geen koninklijk bevel kon Buckingham's eigen verantwoordelijkheid opheffen. ${ }^{33}$

31. Roberts 23, 58, 72, 115, 241, 243: Dodd p. X/XI, 143; Berger 1, 2, 32; Holdsworth V1. 109

32. Gardiner 231 .

33. Holdsworth VI, 101. 
"... supposing even that he had not done that worse than all this, of now seeking to excuse himself therein by entitling it to his majesty; nay, my lords, I will say that if his majesty himself were pleased to have consented or to have commanded, which I cannot believe; yet this could no way salisfy for the duke, or make any extenuation of the charge ..."

Thomas Wentworth, toen nog niet in de adelstand verheven, lid van het Lagerhuis, ziedde van verontwaardiging bij Buckingham's beroep op de koning: "It makes my blood boil to hear this man lay all upon the King. " Een vurige aanhanger van de ministeriële verantwoordelijkheid! Hij zou een wonderlijke zwenking maken. Ruim tien jaar later was hij zelf 's konings naaste adviseur, en zat het Lagerhuis hém op de hielen; toen koos hij desondanks op zijn beurt de koninklijke wil tot voortdurende verdediging. ${ }^{34}$ Maar de opmars van het Parliament was niet te stuiten. Strafford delfde het onderspit; een jaar na zijn dood werd in de loop van een ander impeachment nogmaals geformuleerd dat geen koninklijk bevel onwettige daden verontschuldigt; de leer die de toekomst had. ${ }^{35}$

"But for the excuse under which he seeks to shelter himself, that is, the king's command, this adds more to his offence: a foul aspersion on his majesty, and wrong to his gracious master; for he could not but know that the king's command, in things illegal, is utterly frustrate, and of no effect ..."

En de koning dan? Liet hij eenvoudig alles over zich komen, zonder begrip, zonder reaktie? Nee; verscheidene malen heeft Karel I zich in de verwikkelingen gemengd, vooral om tegen te gaan dat het Lagerhuis zijn dienaren van hem scheidde. Precies als twee eeuwen later onże koning Willem I, beschouwde hij de aanval op ministers als een vermomde poging hem zijn macht afhandig te maken. Immers, ook na de dood van Buckingham liet de parlementaire kritiek niet af; was een duidelijker bewijs nodig dat het Lagerhuis zich van Buckingham als middel bediende, maar uiteindelijk op de koning mikte? Begin 1642, toen Karel I en het Lagerhuis nog in gesprek waren, vorderde het Lagerhuis recht van toezicht op de koninklijke ministers. Het antwoord van Karel I doet denken aan de verontwaardiging van koning Willem I in 1829: ${ }^{36}$

"These being passed, we may be waited on bare-headed, we may have our hand kissed, the style of Majesty continued to us ... we may have swords and maces carried betore us, and please ourself with the sight of a Crown and Sceptre ... but as to true and real power, we should remain but the out-side. but the picture, but the sign of a King."

Karel I kon niet gedogen dat het Parliament zijn ministers apart nam. Buckingharm, liet hij in 1626 nadrukkelijk weten, had gehandeld op koninklijk bevel. ${ }^{37}$

"... certain it is that I did command him to do what he hath done therein. I would not have the House to question my servants, much less one that is so near to me."

34. Roherts 68,88 .

35. Holdsworth VI, 101.

36. Roberts 72, 117: Gardiner 5, 97.

37. Gardiner 3, 96: Roberts 58-59. 
Op zulke interventies reageerde het Lagerhuis volslagen konsekwent en volslagen ongnjpbaar. Uiterst eenvoudig: Ook de bevelen van de koning en zelfs deze uitspraken werden geheel op rekening van de minister geschreven en als zijn werk aan parlementaire kritiek onderworpen. ${ }^{38}$

\footnotetext{
"And if there have been any commands ... pretended, the Duke's misinformations have procured them; for the laws of England teach us that Kings cannot command ill, or unlawful things."
}

Karel I had het wel goed gezien; als alles in de regering aan ministers werd toegeschreven, wat of waar was dan nog de koning? Eén persoonlijk privilege restte hem, het recht van gratie. De macht, door het Lagerbuis opgebouwd, zou tot niets ineenschrompelen indien de koning veroordeelde ministers gratie verleende. Een lek dat spoedig werd gedicht. Nadat Strafford bij Act of Attainder ter dood was veroordeeld, werd ongehoorde pressie op de vorst uitgeoefend om zjjn recht ongebruikt te laten; Strafford stierf. In 1679 maakte impeachment van de graaf van Danby een debat los over de toelaatbaarheid van het koninklijk pardon voor veroordeelde ministers; in 1701, zij het achter de feiten aan, werd in de Act of Settlement bepaald dat koninklijke gratie niet tegen de gevolgen van parlementair impeachment zou beschermen. Ministers in Engeland waren geleidelijk maar tenslotte volkomen aan de stemming van het Lagerhuis overgeleverd. ${ }^{39}$

De inzet en de afloop van de strijd tussen koning en parlement bevredigen ons. Het parlement heeft als haar hoge plicht opgevat de koninklijke eigenzinnigheid aan banden te leggen; zich tevens vormend tot volksvertegenwoordiging, baande zij de weg voor moderne demokratie. De kunstgreep van de ministeriële verantwoordelijkheid verhoogt bovendien de waardering. Het was een "geniale oplossing", "eine herrliche Frucht der englischen Staatsweisheit", de koning onschendbaar buiten spel te zetten en zijn ministers aan te tasten. ${ }^{*}$ Volkswil werd de doorslaggevende invloed maar ook de koning kon tevreden zijn: niemand kwam hem meer te na.

We nemen op de koop toe het tragische van de ernstige en pijnlijke misslagen. De onhandigheid politieke invloed door de strafrechtelijke impeachment te willen verwerven, heeft onnodige slachtoffers gemaakt. De geschiedschrijving oordeelt unaniem: de aanklacht tegen Strafford was zonneklaar onjuist, het vonnis een "schreiende Ungerechtigkeit", de terechtstelling een "judicial murder". Een "barbaarse" methode, zei Oud; gelukkig nam het fatsoenlijker systeem van de politieke verantwoordelijkheid haar plaats in. ${ }^{41} \mathrm{Al}$ bleef op de achtergrond het strafrecht dreigend aanwezig, het hoofdtoneel werd voortaan bezet door het spel van de politieke debatten. Eenmaal de politieke touwtjes onbetwist in handen, voelden parlementen geen behoefte meer ministers straf-

38. Roberts 59 .

39. Roberts 219, 326 .

40. Van Wijnen 125; Oud I, 227; Carl von Rotteck en Carl Welcker. Stoats-Lrikon oder Encyklopïdie der Staakisissenschafien XV, Altona 1843. blz. 640, i.v. Verantwortichkeit.

41. Mohl 23 ni.; Roberts 99; Wedgwood, Strafferd 285; Oud I, 248. 
rechtelijk klein te krijgen. Een bewijs te meer dat het steeds in werkelijkheid om de macht te doen was geweest!

\section{$\S 4$.}

De Nederlandse monarchie ligt ingebed in de Europese monarchale traditie; ze dateert pas van 1813, maar ze heeft volop deel aan de oude geschiedenis der Europese koningen, zoals hierboven weergegeven. En de algemene beweging naar demokratische rechtsstaat heeft ook haar meegevoerd. De ontwikkelingen werden hier reeds voor 1813 merkbaar; eerder, in de $18 \mathrm{e}$ eeuw, werd ten onzent al over ministeriële verantwoordelijkheid gesproken. Het is daarom nodig, voor een beter begrip van de Nederlandse monarchie en de grondwetsherziening van 1848, verder terug te gaan dan 1813 .

Want Nederland was in de $17 \mathrm{e}$ en $18 \mathrm{e}$ eeuw, in een tijd dat overal rondom koningen heersten, geen koninkrijk maar een republiek. En dan nog een verdeelde republiek, zo sterk, dat het land, naar sommigen zeiden, niet de Republiek der Zeven Verenigde Nederlanden behoorde te heten, de naam die gangbaar was, maar Vereniging van Zeven Nederlandse Republieken. Waren de zeven provincies onafhankelijke staten? Of ging de eenheid boven de verscheidenheid? De grondtekst van de Republiek, de Unie van Utrecht (1579), uit nood en in haast opgesteld, beslechtte het vraagstuk niet, dat bijgevolg twee eeuwen lang de omgang bemoeilijkte.

Een slepend konflikt, met twee kampioenen, enerzijds de stadhouders van het Huis van Oranje, die de eenheid voorstonden en het zwaartepunt van de staatkundige orde dus in de Generaliteit, de Staten-Generaal of misschien wel in zichzelf wilden zien; en anderzijds, van alle provinciale regeringen, vooral de Staten van Holland die, om de eigen onafhankelijkheid, als algemene regel hanteerden dat de provinciale staten opperst gezag hadden, soeverein, slechts in vrijwilligheid aan de Generaliteit gebonden. De tendens van de geschiedschrijving is, geloof $\mathrm{ik}$, dat de provinciale staten het meeste recht van spreken hadden.

De rommelige staatkundige orde leende zich niet voor strakke theoretische begrippen als soevereiniteit en majesteitsschennis. Ze werden toegepast, vooral door juristen, maar ze zouden nimmer onaantastbaar heersen als in bijvoorbeeld Frankrijk. ${ }^{42}$ Door het aanhoudende touwtrekken om de oppermacht kon die bij ons nooit tot onneembaar bolwerk worden; misschien ook door de vrijheidszin en tolerantie die we onszelf wel toeschrijven. Kenden wij, anders dan de monarchaal geregeerde volken om ons heen, staatkundige vrijheid? Vrijheid van meningsuiting? In Nederland kon meer dan elders, dat staat vast.

Evengoed werd over de Staten van Holland geschreven, door Abraham de Wicquefort, tijdgenoot, diplomaat, en de Staten niet ongunstig gezind, dat ze angstvallig voor aantasting van hun soevereiniteit waakten. Veelzeggend, verklaarden ze in 1654 officieel aan niemand verantwoording schuldig te zijn dan aan God; de taal van de koningen! In 1663 verdedigde ene Johan de Wit (niet de raadpensionaris) dat kerkgenootschappen de plicht hadden in openbare gebeden God's zegen over de Staten van Holland af te smeken, 
terwijl gebed voor de prins van Oranje, want de statelijke oppermacht was exclusief, verboden moest zijn. Bij de provinciale staten berustte volledige soevereiniteit; ze hadden niemand dan God boven zich, waren zelf afdruk van de glans van God's heerlijkheid. Het volk moest dus maar vast vertrouwen, "dat Godt haer die maght niet ghegheven heeft, nochte van haer niet ghebruyckt en wort, dan tot onsen besten ende nutten". ${ }^{43}$

Van hun kant bebben Orangisten bij gelegenheid eveneens de monarchale begrippen voor eigen kar gespannen; zo onder Willem III, toen het stadhouderschap zeer hoog in macht en aanzien stond. De bekende $18 \mathrm{e}$ eeuwse Nederlandse jurist Cornelis van Bynkershoek vond het maar niks: ${ }^{44}$

"De majesteit van Oranjen was quansuis gequetst, indien 'er iemand durfde tegen kikken, dat het gemenebest van zyn wenken alleen moest afhangen, want hy liel zo veel aan de overheden over, als Caesar aan Bibulus. God bewar ons weer voor zulke tyden."

Men heeft de wrijving tussen de regenten van de provinciale staten en de Oranjes wel in verband gebracht met de geschiedenis van de Europese koningen; Oranje stond voor monarchie, de vorstelijke pretentie en het streng religieuze, de regenten vertegenwoordigden tolerantie en zelfregering der burgerij. Op het einde van de $18 \mathrm{e}$ eeuw wierp de Franse Revolutie haar schaduw vooruit, en ook in ons land groeiden de kritische geschriften in getal. Het dagelijkse beleid, ekonomie en oorlogvoering werden venijnig besproken en bovendien was er toenemende aandrang op de noodzaak van staatsrechtelijke vernieuwing. Aan plannen voor een ander bestel geen gebrek.

De prinsgezinde edelman Willem baron Bentinck legde in 1749 aan stadhouder Willem IV een ontwerp voor. De prins, schreef hij, kon niet overal zijn, kon niet alles zelf doen, en had dus een raad van ministers nodig; hetrouwbare mensen die hem werk uit handen namen. ${ }^{45}$

\footnotetext{
"Il n'est pas possible que le Prince soit toujours partout, qu'il vaque à tout, ni qu'il fasse tout lui-même. Il faut qu'il fasse faire par d'autres ce qu'il ne peut faire lui-même, et qui doit être fait. Car les affaires doivent aller toujours comme une rivière qui coule et sans interruption."
}

Bentinck dacht aan vijf departementen. De prins moest met zijn ministers altijd één lijn trekken, voor het $\infty \mathrm{g}$ van de buitenwereld een onverbrekelijke eenheid. Ministers konden alleen optreden indien ze het volledige vertrouwen hadden èn van de prins, èn van het publiek. De prins bebield zijn oude macht en zou voor het algemene bestuur van de staatszaken zorgen. ${ }^{46}$ Bentinck repte niet van onschendbaarheid of ministeriële verantwoordelijkheid; maar een week na het schrijven van zijn memorie had hij, op

43. Wicquefor III. 102; Geheime resolutie Staten van Holland 9 mei 1654 , in Sccrete resolutien van de Edele Groot Mog. Hecren Staten van Holland en Westuriesland 1653-1668, deel I, Utrecht 1717, blz. 142: D.H. [Johan de Wit]. Public gebedt, ofic consideratien, reegens het nominatim bidden in de publique kercken voor particuliere persoonen; en specialijeken voor den jegenwoondigen Heere Prince van. Orangien, Amsterdam 1663, blx. 29, 30; vgl. Rowen, John de Witt 399.

44. Bynkershoek, Verhandelingen van staatszaken II. Leiden 1740 , blz. 48.

45. Groen, Archives, 4e serie deel I, blz. 355 .

46. Ibidem 356 . 
ziekenbezoek bij prinses Anna, de echtgenote van Willem IV, een toevallige gelegenheid om zijn standpunt alsnog duidelijk te maken.

Prinses Anna lag in bed. Het gesprek kwam op recente pamfletten waarin fel naar de prins, maar meer nog naar Bentinck werd uitgehaald. Anna zei dat het zo goed was, en Bentinck vroeg waarom. Net als in Engeland, zei de prinses, waar de koning onschendbaar is en de ministers kritiek verduren. Dat was heel wat anders, vond Bentinck; in Engeland deed de koning niets, de ministers deden alles, zodat het daar niet oneerlijk was indien de openbare kritiek hen trof. Bentinck ging naar huis, bitter dat het prinselijk paar bereid was hem voor falend beleid te laten opdraaien. Iedereen kon zien hoe onrechtvaardig dat was: "La fausseté de ce principe saute aux yeux. ${ }^{47}$

De stadhouder regeerde, en Bentinck voelde daarom kennelijk niets voor invoering van ministeriële verantwoordelijkheid. Toch ging het die kant uit. De behoefte aan een ministerraad die de stadhouder zou bijstaan werd sterker; ze werd bijvoorbeeld in 1781 door een delegatie van het Amsterdamse stadsbestuur aan Willem V overgebracht. En de publieke opinie speelde op, de stadhouder werd niet gespaard. Rijklof Michaël van Goens, wonderkind en literator, betreurde in een Polirick vertoog dat kritiek niet op ministers afstuitte maar de stadhouder direkt trof. ${ }^{4}$ De twee ideeën, een ministerraad en ministeriële verantwoordelijkheid kwamen als vanzelf samen. Laurens Pieter van de Spiegel, later raadpensionaris van Holland, bepleitte in 1782 bij de stadhouder dat hij een ministerraad zou instellen; de ministers zouden de stadhouder ontlasten, ${ }^{49}$

"...en (mag men er dit byvoegen) zoo er al eenig ongenoegen by de Natie ontstaat, het zou eerder vallen op de Ministers dan op de persoon van Zyn Hoogheid, gelyk in Engeland al het kwaad dat er gebeurt op rekening van het Ministerie wordt gesteld, en de Koning de eer en dank ontvangt van het goede."

Het lijkt of juist Oranje-gezinden destijds voor deze oplossing pleitten. Ze wilden door onschendbaarheid hun stadhouder de publieke kritiek besparen, niet hem zijn macht ontnemen. Een middel ter bescherming van het gezag. De Franse tijd en Willem V's uitwijken naar Engeland kwamen tussenbeide; daama zou het beginsel van koninklijke onschendbaarheid en ministeriële verantwoordelijkheid weer omgekeerd werken, als een wapen tegen de alleenheerschappij van het koninklijk gezag. Vanaf 1813 was Nederland een monarchie: Geen stadhouder Willem VI stapte op 30 november van dat jaar voor Scheveningen aan land, maar Willem I, soeverein vorst, spoedig koning.

Met in Engeland het stelsel der ministeriële verantwoordelijkheid bijna voltooid en in Frankrijk de aardschok van de Revolutie vlak achter de rug, kreeg Nederland een ouderwetse koning die niets uit handen gaf en stond op zijn eerbied. Hem weerspreken

\section{Ibidem 369 .}

48. Rijklof Michä̈l van Goens, Politiek vertoog over het waar sistema van de stad van Amsterdam, met relatie tot de algemeene belangens der Republiek, zo als hutzclve wit 's lands hisroricn kan worden opgemaakr. z.p. 1781. blz. 57-59: vgl. J.M. Peterse. "Publicist voor Oranje. Rijklof Michaël van Goens en De ouderwetse Nederlandsche patriot (1781-1783)". in Bijdragen en mededelingen betreffende de geschiedenis der Nederlanden 103 (1988) 182-208, blz. 204.

49. G.W. Vreede (ed.), Mr. Laurens Pieter van de Spicgel en zijne tijdgenooten 1737-1800). deel I. Middelburg 1875, hlz. 70 . 
was gewaagd, zelfs waar hij geen deskundigheid had. De koning zou eens op een tentoonstelling het mooiste schilderij uitzoeken, op voorwaarde, dit werd van tevoren afgesproken, dat de kunstkenner die hem vergezelde eerlijk zou zeggen of de koninlijke keus klopte. De koning koos, en het voorzichtige antwoord was: "Sire! het spijt mij, dat ik het zeggen moet: Uwe Majesteit vergist zich. " De verteller vond, jaren daarna, het nog nodig erbij te zeggen: "De Koning liet zich het antwoord welgevallen". so

$\mathrm{Al}$ eerder is ons duidelijk geworden hoe Willem I dacht over inmenging van burgers in zijn politieke beleid; niet toeschietelijk! De Napoleontische strafwet die toen bij ons van kracht was, oordeelde hij onvoldoende om zijn monopolie in te dekken; de vloed van kritiek die tijdens de Belgische onafhankelijkheidsoorlog over het beleid werd uitgestort, bracht hem tot een aanvulling in twee wetten, van 16 mei 1829 en 1 juni 1830 . Hoon en laster van de koninklijke waardigheid konden met maximaal vijf jaar gevangenis worden bestraft. Geen loos gebaar; nog in de jaren veertig, toen onder Willem II, zijn tal van mensen wegens staatkundige kritiek op grond van deze wetsbepalingen veroordeeld. ${ }^{\text {st }}$

In maart 1844 werd een landmeter uit Heerlen, Lintjens, voor de rechter gehaald. In een herberg, sprekend over de ingrijpende belastingwet van 1844, had hij een raadsel opgegeven: "Welk onderscheid er was tusschen het Gouvernement en een kleermaker?" Zoals het bij zulke raadsels meestal gaat, had hij zelf de oplossing verteld: "een kleermaker kleedt de menschen aan en het Gouvernement kleedt ze uit". Hij kreeg van de arrondissementsrechter te Maastricht de volle vijf jaar, plus veroordeling tot proceskosten. Misschien zou de herbergier van The Crown hem hebben benijd; wij van onze kant kunnen het vonnis niet eens meer begrijpen. ${ }^{\$ 2}$

Wanneer dergelijke zaken voor de rechter aanhangig waren, sprongen nogal 's dezelfde advokaten voor de beklaagde in de bres. Bijvoorbeeld Dirk Donker Curtius, geruime tijd meer spraakmakend liberaal dan Thorbecke, en later minister van justitie, benoemd op 19 maart 1848, in een chaotische tijd, toen zeer veel van zijn daadkracht en vaste hand afhing. $\mathrm{Zij}$ voerden in bun pleidooi een vast verweer aan: Goed, belediging van de koning was strafbaar, alleen, er was ook vrijheid van meningsuiting. De wet van 1829 had in artikel 4 beloofd:

- De bepalingen ... dezer Wel zullen het regt om over de handelingen der openbare magten zijne gedachten te kunnen uiten en die te beoordeelen, geenszins kunnen krenken."

Hoe was bescherming der koninklijke waardigheid met een vrije gedachtenwisseling te verenigen? De advokaten hadden hun antwoord klaar.

"Niet anders dan door te onderscheiden de daden van Regering en de bijzondere daden van den

Koning en van den leden van zijn Huis."

50. Jeronimo de Busch Kemper, Lenerkundige anteekeningen belrcffende de geschicdenis van her Nederlandsche staatsleven en staatsregt, Amsterdam 1871, blz. 515.

51. M. Schooneveld, Het wetboek van strafregt (Code Pinal) met aanteekeningen, 2e dnuk Amsterdam 1855, blz. 256-257\%.

52. Weekblad van het regt nr. 489, blz. 4; nr. 499, blz. 2; nr. 500 blz. 2 . 
Met andere woorden, door koning en ministers uiteen te halen. De verdediging tijdens deze processen adopteerde eenvoudigweg het beginsel van koninklijke onschendbaarheid en ministeriēle verantwoordelijkheid. ${ }^{53}$

Wie aanmerkingen had en die in geschrifte wilde luchten, deed goed alvast op het argument vooruit te grijpen. Eind 1845 verscheen in een rumoerig krantje, De staatkundige tooverlantaarn of utopisch-politische snelwagen, een scherpe kritiek van de troonrede die Willem II pas had uitgesproken. Kritiek, zou de advokaat naderhand uitleggen, in zuiver Kantiaanse zin, "dat is eene toetsing aan eigen oordeel en eigen wetenschap". De schrijver ving aan met uitdrukkelijke verzekering dat hij de koning niets kwalijk nam, al is twijfelachtig of zijn voorbehoud gelukkig uitpakte. ${ }^{54}$

\footnotetext{
"Wij stellen Hem niet, wiens mond ze uitsprak, verantwoordelijk voor de woorden die anderen Hem ingaven; vooreerst, ondat het geheel in strijd is met alle constitutionele begrippen, dat eenige aansprakelijkheid op het hoofd des Staats nuste ...; en ten andere, omdat aan dit Staatstuk onze Koning zeer stellig geheel vreemd is ... De Koning kan dat stuk niet gesteld hebben; in de eerste plaats omdat hij Koning is; en ten tweede, omdat Zijne Majesteit de Hollandsche taal niet genoeg magtig is, om zoo vele ronde volzinnen te kunnen zamenstellen. -
}

Ondanks deze goede woorden werd strafvervolging ingesteld. Niet tegen de schrijver, die onbekend was, maar tegen de drukker, Karel van Hulst te Kampen. Advokaat Boissevain wierp op dat de aanklacht een vergissing was; Nederland, niet aan koningschap gewoon, had nog niet begrepen dat een koning naar zijn aard geen verantwoordelijkheid erkent, onschendbaar is. De koning kon geen kwaad doen; geschiedde toch kwaad, dan niet door de koning qualitare qua, maar door de persoon. Goed beschouwd pleegden aanklager en rechters majesteitsschennis door de geuite kritiek op de koning toe te passen. ${ }^{\text {ss }}$

Het laatste verweer is bijna een grap. Het herinnert aan een joodse Witz uit het oude Rusland, toen eens een jood voor de rechter werd gesleurd, omdat hij volgens getuigen de tsaar een ezel had genoemd. Geschrokken verdedigt hij zich dat er een misverstand in het spel is, de opmerking sloeg op keizer Wilhelm II. Waarop de rechter hem streng aankijkt en zegt: Denk maar niet mij voor de gek te houden. Met een ezel kan alleen onze Nicolaas bedoeld zijn!

Boissevain's pleidooi, net als andere keren, baatte niet. De troonrede was naar het inzicht van de arrondissementsrechter te Zwolle een stuk van de koning zelf; Van Hulst werd bij vonnis van 15 januari 1846 veroordeeld tot twee jaar gevangenis en de kosten van het proces. Ruim twee jaar later, de revolutie van maart 1848 . Het beginsel dat steeds vergeefs voor de rechter was ingeroepen werd onomstotelijk van kracht als artikel 53 van de hervormde grondwet.

Met begrip voor het reusachtige belang van de regeling lezen we nu Thorbecke's woorden van 1841: ${ }^{36}$

54. De staatkundige tooverlantaam, of wopisch-politische snelwagen. Rijds af bij K. van Hulst te Kampen. 1846. deel II, blz. $1,32$.

55. Ibidem 16, 55, 68: Weekblad van het regi nr. 704, 709, 715

56. Aanteekening $I, 109$. 


\begin{abstract}
"Grondwetlige onverantwoordelijkheid van den Vorst is het middel, om de vrijheid van cordeel over die handelingen te verzekeren. Waar de eerste niet bestaat, is een van twee onvermijdelijk. Men moet of den hoogsten persoon in den Staat san dat oordeel onderwerpen, of dit aan banden leggen."
\end{abstract}

De jaren voor 1848 hadden 't zonder dit middel moeten stellen, met ernstige gevolgen; de grondwetsherziening gaf het, als een verlossing. Geen gevaar meer door kritische aanmerkingen vorstelijk ongenoegen op te wekken en strafvervolging te moeten ondergaan; er kwam ruimte voor eerlijke oppositie. Inderdaad een geniale vondst: Vroeger was openlijke gedachtenwisseling over politiek uitgesloten, omdat elke uiting de koninklijke majesteit schond; nu maakte de onschendbaarheid het onmogelijk nog majesteitsschennis te plegen. Het verbod werd niet opgeheven, maar overtreding werd eenvoudig onmogelijk verklaard! De koning werd kunstmatig aan de kritiek onttrokken, hij kreeg een plaats boven, althans buiten de politieke diskussie, die daardoor pas goed tot ontwikkeling kon komen.

Als fundamenteel beginsel was aanvaard dat machtsuitoefening op instemming van de gemeenschap hoort te berusten, een instemming die groeit tijdens en door het vrijmoedige politieke debat. Een debat tussen mensen die tegen kritiek kunnen, mensen die als het ware, wat van de koning werd gezegd, boven kritiek staan; weerwerk niet als een aantasting van persoonlijke eer opvatten. Het staatsrecht kent de majesteitsschennis niet meer, hoogstens het strafrecht; maar dan nog geldt het delikt uitsluitend zeer krenkende uitlatingen over de vorst, en het leidt een slapend bestaan. De majesteitsschennis verloor haar dreiging volledig; ze is onder ons alleen nog in zwang als losse uitdrukking voor alle gevallen van belediging en gekwetst zelfgevoel. Je moet tegen kritiek kunnen, want: Du choc des opinions jaillit la vérité! Waarheid ontspringt als meningen botsen. ${ }^{57}$

\title{
$\S 5$.
}

In deze samenleving van vrije diskussie, vrije invloed, zoveel als haalbaar tussen een aanzienlijk aantal burgers, zou besluitvorming langs natuurlijke weg uit de diskussie voortvloeien. Het meelevende volk geeft leiding aan de politiek. Niet de koning, het volk was soeverein, schreven Nederlandse pamflettisten in 1848, en uit dat beginsel volgden de verantwoordelijkheid der ministers en de onschendbaarheid van de koning. Het volk was volwassen geworden, het had vrijheid van oordelen en recht van spreken en recht van schrijven verworven. is

57. De uitdrukking werd in de 19e eeuw graag en vaak, en wordt ook heden ten dage in verhandelingen over het parlementaire stelsel nog aangehaald. Van Dale: geeft als bron de Franse dichter Colardeau (1732-1766).

58. G.L. Jansma van der Ploeg. Vrijheid van oonleelen, eene politische beschouwing. Den Haag/Amsterdam 1848, blz. 6-9; Dez. Heẹf Neêrlands volk een' wil'? Eene politische beschourwing. Den Haagl Amsterdam 1848. blz. 12-13. 
-Is dan het volk eenmaal gekomen tot den staat van meerdejirigheid, dan is het niet alleen bevoegd om zijne belangen waar te nemen, mar het is verpligt, ten duurste verpligt, ja, de noodzakelijkheid gebiedt het, om voor zijne belangen te zorgen, even als een meerderjarig persoon, die ophoudt een' voogd te hebben, van dat oogenblik af, wil hij zich handhaven in de rij zijns gelijken, genoodzaakt is zijne eigene belangen te behartigen, zonder meer op de hulp van den voogd te kunnen rekenen ..."

\title{
En de koning?
}

\begin{abstract}
"Die vorst zal niet meer kunnen zijn de man die regeer, want dat is het kenmerk der voogdijschap; maar alleen de man die regeren laat, en door welks asnwezen de voorwaarde eener geregelde regering wordt verzekerd, waarvan het 'gevolg is onschendbaatheid van zijn' persoon."
\end{abstract}

Een dringende vraag rijst evenwel: Indien het volk zichzelf regeert, wat doet de koning er nog toe? Onschendbaar buiten het debat, onmachtig buiten de besluitvorming, wat draagt hij bij? Hij is, antwoordden deze pamflettisten, "de altijd blijvende, onvergankelijke magt", "even onvergankelijk als het volk zelf". ${ }^{59} \mathrm{Zij}$ hadden hun antwoord afgeleid van de Duitse filosoof Hegel, die de vorst een orakel noemde. 's Konings handtekening is volgens Hegel heel zijn bijdrage, louter formeel; maar zoals de vlucht der vogels of de loop der sterren, beduidt zij zonder invloed op ze uit te oefenen, belangrijke gebeurtenissen. De maatschappelijke wisselwerking en verscheidenheid monden uit in de vorstelijke handtekening, die uiteindelijk de eenheid van de gemeenschap symboliseert. ${ }^{60}$

En wij kenden dit antwoord, omdat het, eenvoudiger, in onze inleidende boekjes over staatsrecht stond. Onze vorstin is symbool van de nationale eenheid, zij verbeeldt ons gevoel van saamhorigheid als Nederlands volk. We belanden hier bij minder verheven uitdrukkingen dan die van Hegel, onvriendelijker, al lijken ze hetzelfde te bedoelen. Want het gaat om irrationele sentimenten, die vroeger nogal eens het politieke beleid verstoorden. Geloof in God en trouw aan de koning hadden dikwijls gevaarlijke opwellingen in de politiek gebracht; nu behoorde alleen nog zuivere redelijkheid in het staatkundige de toon aan te geven, en de oude sentimenten werden geïsoleerd, onschadelijk voor de feitelijke en rationele gang van zaker. Maar helemaal lieten zij zich niet uitbannen.

Al moet regeren naar de rede zijn, de rede heeft geen glans. Een sprookje is nodig dat de saaie realiteit van het regeren kan verhullen, en daartoe dient het vorstenhuis. Het denkende deel der natie heeft de maskerade niet nodig, de massa wel. Aldus, onder anderen, de $18 \mathrm{e}$ eeuwse Engelse jurist William Blackstone. Een filosofische geest, zei hij, onderkent dat de vorst mens is als allen, een funktionaris, maar zal om het belang van de funktie meewerken; het volk evenwel zou onrustig worden bij de gedachte iemand als zichzelf te moeten gehoorzamen, het wil geloven dat wezens van hoger orde

59. C.W. Opzoomer, Volkswil en vije verkiezingen. Eene politische bijdrage, Leiden/Amsterdam 1848, blz. 22, 26.

60. Hegel, Vorlesungen 1817/1818. blz. 203-204. 
aan de regering zijn, supermensen. Daarom is het goed een vorstenhuis te hebben, iets dat de blik vangt, een symbool van volkseenheid en staatsgezag. ${ }^{61}$

Deze scheiding, tussen rede en sentiment, tussen werkelijkheid en symbool, hebben we eerder al in het Nederlandse staatsrecht aangetroffen, via de vinnige woordenwisseling tussen de Kamerleden Van Houten en Schaepman. Het onderscheid is in diezelfde tijd, dus ongeveer een eeuw na Blackstone, met kracht uitgesproken door de Engelsman Walter Bagehot: De konstitutionele monarch (dat was destijds Qucen Victoria) heeft, ronduit, niets van macht. Haar zijn uitsluitend deze drie rechten toebedeeld: "the right to be consulted, the right to encourage, the right to warn". Verder, vooral tegenover het parlement, staat ze machteloos; Bagehot schreef, met brute humor: ${ }^{62}$

"She must sign her own death-warrant if the two Houses unanimously send it up to her."

Waartoe dient dan die hele toestand van kroning en koetsen en eretitels? Louter en alleen om de aandacht van het domme volk af te leiden, terwijl achter de versierde voorgevel de werkelijke politiek, saai en onbegrepen, maar daadwerkelijk, doorgang vindt.

\footnotetext{
"But we have whole classes unable to comprehend the idea of a constitution -- unable to feel the least attachment to impersonal laws. Most do indeed vaguely know that there are some other institutions besides the Queen, and some rules by which she governs. But a vast number like their minds to dwell more upon her than upon anything else, and therefore she is inestimable."
}

Bagehot had sukses met zijn formuleringen; ze worden telkens weer aangehaald, ook door Nederlanders die het onderwerp behandelen, en het boek waarin hij ze schreef wordt nog herdrukt. Daarenboven bevestigen de feiten zijn opvattingen. Het lot van de Belgische koning Boudewijn, een paar jaar geleden, toen hij weigerde een wet op de abortus te ondertekenen, spreekt boekdelen. Bagehot lijkt dus wel gelijk te hebben; maar het is allemaal niet verheffend. De konstitutionele koning verwordt tot anachronisme, een komedie, door verstandigen tegen beter weten opgevoerd om de tragen van geest niet in hun gemoedsrust te storen. Een sussend verhaaltje voor degenen die niet aan redelijkheid en zelfbeschikking toe zijn.

Deze neerbuigendheid komt trouwens terug in de afloop van een andere ontwikkeling, evenwijdig aan de historie van de Europese monarchen. De Europese monarchale geschiedenis heeft ons nu de achtergrond van het Nederlandse koningschap getoond; ons huidige staatsrecht wortelt in een internationaal verleden. Maar we kunnen nog dieper grijpen, en nogmaals dezelfde geschiedenis hervinden. Het betreft 's konings enige superieur, de koning der koningen: God. Hij onderging in de afgelopen eeuwen precies dezelfde behandeling als de klassieke monarch. De oude orde had God en de koning op één lijn gesteld, de nieuwe zou het ook doen. Werden voorheen schennis van de aardse en de hemelse majesteit gelijkelijk door toedoen van de koning zwaar gestraft, zo moest, nu de koning geacht werd boven kritiek te staan, ook God het zich maar laten welgeval-

62. Bagehol 185/186. 199, 212; vgl. Van Wịnen 9. 247. 
len. Blasfemie werd uit het strafrecht verwijderd. "Der wirkliche grosse Geist verachtet die ihm angetanen Schmähredenen, und nur der straft, der sich getroffen findet. ${ }^{\text {}}{ }^{63}$ Geen slecht argument wellicht, maar weer diende verheffing boven kritiek om de onschendbare buiten de werkelijkheid te duwen. De staat draaide beter zonder de koning, de wereld kon zonder God toe. De moderne wetenschap, onderneming van de rede, ontwierp een kosmos die besloten lag in de wetten van oorzaak en gevolg, een dichte opeenvolging; God's steun of aanwezigheid waren niet meer nodig, hij kwam er niet eens meer tussen. Ook roi fainéant. In een vroeg stadium van de wetenschappelijke revolutie die het moderne wereldbeeld zou vormen was deze afloop verrassend voorzien door de Engelse theoloog Samuel Clarke, die bijna profetisch een vergelijking met de konstitutionele vorsten maakte, eer ze bestonden: ${ }^{64}$

\begin{abstract}
"Si un Roi avoit un Royaume, où tout se passeroit, sans qu'il y intervint, \& sans qu'il ordonnât de quelle maniere les choses se feroient; ce ne seroit qu'un Royaume de nom par raport à lui; \& il ne mériteroit pas d'avoir le titre de Roi ou de Gouverneur. Et comme on pourroit soupçonner avec raison que ceux qui prétendent, que dans un Royaume les choses peuvent aller parfaitement bien, sans que le Roi s'en mêle: comme on pourroit, dis-je, soupçonner qu'ils ne seroient pas fâchez de se passer du Roi; de même, on peut dire que ceux qui soûtiennent que l'Univers n'a pas besoin que Dieu le dirige \& le gouverne continuellement. avancent une Doctrine qui tend à le bannir du Monde."
\end{abstract}

En precies als met de koning zijn er voorlijken, moedigen die de konsekwenties overzien, en achterblijvers die het oude behoeven. De Duitse dichter Heinrich Heine legde het zonder omhaal bloot; hij is de evenknie in het religieuze, naar spot en boodschap, van Walter Bagehot. Immanuel Kant, aansluitend bij het werk van de Verlichtingsdenkers, had als een genadeloze hemelbestormer God en geloof aan de rede getoetst, en hun naar wetenschappelijke maatstaven het bestaansrecht ontzegd. Dit was ook, schreef Heine later, het uiteindelijke doel van heel de Kritik der reinen Vernunft geweest. Is het karwei volbracht, ligt het geloof in duigen, dan valt Kant's oog op zijn huisknecht, de trouwe Lampe, die het allemaal niet-begrijpend en met angstige ontzetting had zien gebeuren. Heine: ${ }^{\text {cs }}$

\footnotetext{
"Da erbarmt sich Immanuel Kant und zeigt, dass er nicht bloss ein grosser Philosoph, sondern auch ein guter Mensch ist, und er überlegt, und halb gutmüthig und halb ironisch spricht er: 'der alte Lampe muss einen Gott haben, sonst kann der arme Menseh nicht glüeklich seyn der Mensch soll aber auf der Welt glücklich seyn - das sagt die praktische Vernunft -- meinentwegen -- so mag auch die praktische Vemunt die Existenz Gottes verbürgen. "
}

Dus heeft Kant in de Kritik der praktischen Vernunft het geloof weer tevoorschijn getoverd, zij het als persoonlijke aangelegenheid, strikt buiten de objektieve wereld van

63. Sellert 427.

64. Recucil de diverses pieces, sur la philosophie, la religion naurelle, l'histoire, les mathematiques, \&c. Par Mrs. Leibniz, Clarke, Newion, \& autres autheurs célcbres I, Amsterdam 1720, blz. 10-11; Arthur Koestler. The sleepwalkers. A history of man's changing vision of the universe. Londen 1959, blz. 509; Alexandre Koyré. Du monde clos à l'univers infini. (oorspr. 1957) Gallimard 1988, blz. 289.

65. Heinrich Heine, Zur Geschichte der Religion und Philosophie in Deutschland, in Werke VIII-1 (ed. Düsseldorf), blz. 89 . 
natuurwetten en wetenschappelijke zekerheid. Wie wil mag gerust geloven, maar het blijve een eigen emotie. Er zijn verhalen overgeleverd van de dankbaarheid, ronduit opluchting waarmee Kant's kompromis in die tijd werd begroet. Men had de klem van de redelijke argumentatie erkend, voelde zich bijgelovig, maar kon er niet toe komen het geloof op te geven. Een lezer schreef dankbaar: ${ }^{6}$

"Ich ahndete, suchte, und fand in der Kritik das kaum mehr für möglich gehaitene Mittel, der unseligen Alternative zwischen Aberglauben und Unglauben überhoben zu scin."

Ruimte voor wetenschappelijkheid, voor de onweerlegbare kritiek van de rede, zonder dat die het einde van de religie betekenen! Theologie en staatsrecht kampten met hetzelfde probleem, en twee maal werd dezelfde oplossing aangedragen: een volstrekte scheiding tussen de kille werkelijkheid van rede en kritiek, en de kleur en verhevenheid van het sentiment. De opluchting die Kant's filosofie teweegbracht is dan ook te vergelijken met de onstuimige vreugde van 1848: Ruimte voor kritiek, vrijheid van oordeel, maar de koning blijft! Artikel 53 van de vernieuwde grondwet is een door-en-door Kantiaanse gedachte.

\section{$\S 6$.}

Dit hoofdstuk heeft, en zo was het ook bedoeld, de leer van het Nederlandse staatsrecht historisch bevestigd. Art. $53 \mathrm{Gw} 1848$ als een overwinning van vrijheid op vorstelijke willekeur. Het streven van de moderne tijd is vrije diskussie, volkswil, demokratie. De macht moest door list en geweld op de weerstreveade koningen worden veroverd, maar nu is de overwinning kompleet en de winst onbedreigd. Indien er nog koningen zijn, dan uitsluitend als souvenir, stevig onder de stolp, buiten het dagelijks bedrijf, een restant van vroeger tijd, terwille van de eenvoudigen, die iets willen hebben om naar te kijken. Het is een aantrekkelijke opvatting, speciaal voor ons die dit lezen, begrijpen en onszelf dus niet tot die eenvoudigen hoeven te rekenen.

Toch stuit ze tegen de borst. De monarchie een dure komedie, nog heden ten dage, terwijl de meesten beter weten, deftig volgehouden -- Bagehot. drijft zijn spot te ver. Moeten we echt van de onkreukbare Thorbecke geloven dat hij in een dergelijk lichtzinnig spel het koningschap tot een uitwendige versiering van de staat heeft willen maken? De onschendbare koning tot politieke machteloosheid wilde veroordelen? Al eerder, in de inleiding van dit boek, maakten we uit zijn eigen zeggen op van niet. Niet om de macht des konings over te dragen, maar omdat ministers vanzelf verantwoordelijk zijn, ook wanneer ze gehoorzaamden aan bevelen, moest artikel 53 grondwetsbepaling worden.

De koninklijke onschendbaarheid stond in deze opvatting niet voor verlies van macht, en de ministeriële verantwoordelijkheid niet voor politieke leiding der ministers. Thorbecke sprak van een moreel-juridisch probleem, onvergelijkbaar met onze hedendaagse politieke leer; en we vinden het, in dit internationale hoofdstuk, ook bij buitenlandse

66. Friedrich Paulsen, Immanuel Kant. Sein Leben und seine Lehre, (oorspr. 1898) Stuttgart 1924, blz. $6 / 7$. 
schrijvers, met name in Frankrijk en Duitsland. Men vroeg zich daar steeds weer af hoe iemand strafbaar kon zijn voor handelingen die de koning hem had opgedragen. Er werd gezegd dat de minister Prügelknabe was, souffre-douleur: zoals rijke jongetjes een slaafje hadden dat het pak slaag kreeg als zij stout waren geweest, zo ving een minister de straf op voor 's konings misdoen. ${ }^{67}$ Een weinig serieuze leer! Ze wordt spottend verbeeld in de volgende anekdote.

Een gala-diner aan het Engelse hof. Queen Victoria, haar ministers en tal van aanzienlijken tafelen mee. De konversatie is levendig maar beschaafd, dus gedempt. Onverhoeds ontsnapt aan Harer Majesteits natuurlijk lichaam een onwelvoeglijk geluid. Een oprisping, of erger. Pijnlijke stilte. De Queen kijkt zonder iets te zeggen haar tafelheer, de Prime Minister aan. Hij begrijpt waarop zij doelt, verheft zich van zijn zetel, schraapt de keel en spreekt: "Excuse me". Even later overkomt Hare Majesteit hetzelfde. Eer iemand kan reageren staat al een andere minister: "I'll take this one".

Flauwe onzin; want hoe zou het toelaatbaar zijn ministers te straffen voor misdragingen die hun door de vorst waren bevolen? Maar juist deze kwestie dook telkens op in de geschriften, het werd kennelijk beschouwd als de kern van het vraagstuk der ministeriële verantwoordelijkheid. Een oplossing werd aangedragen, in Duitsland al vroeg deze: De minister kan weigeren of zelfs aftreden; door mee te werken maakte hij de bevolen koninklijke maatregel tot zijn eigen, zodat het niet onredelijk was hem deswege te vervolgen. Deze leer, herkenbaar overeenkomstig de uiteenzettingen in Nederland van Thorbecke, Lagemans, Van den Gheyn, werd nog in 1904 te Berlijn als geldend verdedigd. ${ }^{68}$ Indien de onschendbaarheid zo werd opgevat, hoe kwam het dan tot de onmacht van de konstitutionele monarch?

Misschien aldus. Franse schrijvers die de verantwoordelijkheid van de minister eveneens als een moreel en juridisch vraagstuk behandelden, lieten zich verder voeren dan de Duitsers en eindigden inderdaad bij de roi fainéant. Als de koning onschendbaar is en de minister verantwoordelijk, stelde Benjamin Constant, politikus en toonaangevend schrijver over het onderwerp, dan spreekt vanzelf dat de ministers hun werk zelfstandig doen. Zouden ze passieve en blinde agenten van de koning zijn, dan was de verantwoordelijkheid absurd en oneerlijk. De burggraaf van Chateaubriand, militair, diplomaat, schrijver, iemand van een wisselvallige loopbaan, bevestigde Constant's stelling. In een geschriftje van 1816 over de Franse monarchie legde hij uit dat de koning zijn ministers hun gang moest laten gaan, want als uitvoerders van 's konings bevelen konden zij niet dan met grote onrechtvaardigheid voor hun daden worden vervolgd. Slechts zo was het redelijk: "Et tout cela est fondé en raison." $\theta$

\footnotetext{
"Car le roi étant environné de ministres responsables, tandis qu'il s"élêve au-dessus de toute responsabilité, il est évident qu'il doit les laisser agir d'après eux-mêmes, puisqu'on s'en prendra à eux seuls de l'événement. S'ils n'étoient que les exécuteurs de la volonté royale, il y auroit injustice à les poursuivre pour des desscins qui ne seroient pas les leurs."
}

67. Buddeus 5 ; Von Frisch 188

68. Buddeus 7: Mohl 65. 68: Von Frisch 192.

69. Constant 73: Chateaubriand 271 . 
Het is alsof we Willem Bentinck horen, aan het ziekbed van prinses Anna. Nee, indien de monarch (en zo zullen we de stadhouder nu ook maar even zien) onschendbaar wordt, dan moeten om der wille van de redelijkheid ministers onafhankelijk zijn in het regelen der staatszaken. En de Nederlandse pamflettisten van 1848 vullen aan: Waar het volk uiteindelijk de dienst uitmaakt, en waar om die reden de ministeriële verantwoordelijkheid wordt ingevoerd, daar zal de koning onschendbaar zijn, of niet zijn. Heeft op die manier toch het samenstel van onschendbaarheid en ministeriële verantwoordelijkheid de koning buiten de dagelijkse politiek geplaatst?

Maar nu lezen we onverhoeds weer: de koning moest onschendbaar worden, en daarmee zijn macht verliezen. Het is de oorspronkelijke leer, het uitgangspunt van dit boek; de inleidende paragrafen deden echter reeds vermoedens rijzen dat het anders is geweest. De onschendbaarheid, scheen het toen, was niet een nieuwtje van 1848, maar zij had vanouds bestaan. Het huidige hoofdstuk leverde trouwens stilletjes bevestiging. Onschendbaarheid betekent, zegt men, dat de vorst geen verantwoording aflegt; en in dit hoofdstuk zagen we dat juist de absolute koningen weigerden zich te verantwoorden, bewerende niemand dan God verantwoording schuldig te zijn. Was die onverantwoordelijkheid, en zo ook onschendbaarheid, inderdaad eigenschap van alle, niet slechts de konstitutionele monarchen?

En dan de taktiek van Donker Curtius en Boissevain, advokaten in de Nederlandse drukpersprocessen. $\mathrm{Zij}$ lijkt uitstekend te passen bij onze bestaande opvattingen over onschendbaarheid en ministeriële verantwoordelijkheid. De scheiding tussen koning en ministers diende om het gesprek te bevrijden, de koning zou buiten het bereik van kritiek komen. Alleen werd de koninklijke onschendbaarheid niet ingeroepen als een regel die wenselijk was, maar als een vanzelfsprekendheid. De monarch, en dan niet de konstitutionele monarch maar de monarch überhaupr, was per definitie onschendbaar; het lag niet aan een toekomstig grondwettelijk artikel 53, het lag aan de onwetendheid der Nederlanders dat de regel niet werd erkend.

De onschendbaarheid een kenmerk van alle koningschap, het axioma van de monarchie? Het wordt de hoogste tijd dit nader te bestuderen. En dat kan uitstekend in een groter verband; want de vraag naar vroegere onschendbaarheid, het zal wel blijken, laat zich goed met andere vragen, afkomstig uit de inleiding, verenigen: Wat was de juridische onschendbaarheid, de onschendbaarheid in engere zin waarvan Thorbecke sprak? Hoe bangt zij samen met de politieke onschendbaarheid die wij kennen? Is er een overeenkomst met het onderscheid tussen strafrechtelijke, of juridische, en politieke ministeriële verantwoordelijkheid? Indien vanouds de koninklijke onschendbaarheid gold, hoe verliep dan de overgang van oude naar moderne monarchie? Waarom moest de koning blijven regeren, en warom hield hij toch op?

Al deze vragen horen samen onder de kop van het hoofdstuk hiema: De Koning als gemeenschap. $\mathrm{Na}$ het verhaal in dit afgelopen hoofdstuk, een rweede versie van het verhaal der Europese koningen. We zullen zien. 



\section{Hoofdstuk 3}

\section{De koning als gemeenschap}

Nederlandse ministers noemden in 1980 het samenstel van koninklijke onschendbaarheid en ministeriële verantwoordelijkheid een formule zonder enig misverstand, ons allen vertrouwd. Het kan verkeren. Rond 1848 werd aanhoudend gestreden over de ware betekenis van het beginsel, een debat vol onderling verschil en innerlijke tegenstrijdigbeid. Ook tevoren, in Engeland, toen daar het beginsel werd uitgewerkt, had men het met moeite begrepen. Vooral de uitdrukking dat The King can do no wrong stichtte verwarring, want welke staatsrechtelijke zin kon schuilgaan in de klaarblijkelijke onwaarheid, dat de koning nimmer verkeerd zou doen? Onbegrip en meningsverschil, en niet alleen onder mannen van het vak.

Het voert ons opnieuw in een Londense taveerne, ditmaal The Mitre, in 1763. Een gezelschap uit de society zit aan. Onder de gasten Oliver Goldsmith, dichter, de geestrijke maar gevreesde Samuel Johnson, plus de gastheer, het Schotse zorgenkind en Johnson's beschermeling James Boswell, die het geval (uiteraard) heeft naverteld.' Goldsmith brengt de Engelse rechtsregel ter tafel, als welkome aanleiding voor een spitsvondig kruisen van de degens met Johnson. Met warmte verdedigt hij dat een zedelijke onwaarheid niet politiek waar kan zijn: The King can do no wrong, in z'n algemeenheid onwaar, is het derhalve ook als staatsrechtelijk beginsel.

Goldsmith had kunnen weten dat hij aan 't verkeerde adres is; Samuel Johnson laat met de monarchie niet spotten; hij geeft aan de verleiding van het steekspel niet toe maar zet de zaak in een forse handomdraai recht.

\footnotetext{
"Sir, you are to consider, that in our constitution, according to its true principles, the King is the head, he is supreme: he is above every thing. and there is no power by which he can be tried. Therefore, it is, Sir, that we hold the King can do no wrong: that whatever may happen to be wrong in government may not be above our reach. by being ascribed to Majesty. Redress is always to be had against oppression, by punishing the immediate agents."
}

In dezelfde tijd, van 1765 tot 1769 , publiceerde William Blackstone de vier delen van zijn Commentaries on the laws of England. Blackstone's rustige en doeltreffende proza 
bezorgden het werk een goede naam. Tot vandaag geldt hij als autoriteit en wie het fijne wil weten van The King can do no wrong gaat bij hem te rade. Toch lijkt het alsof net bij dit onderwerp de trefzekerbeid hem in de steek liet. Het Engelse recht, schreef Blackstone, had uitgemaakt dat de vorst geen kwaad kon doen zonder de medewerking van ministers, en zij werden dus met impeachments aangepakt. Maar: ${ }^{2}$

\footnotetext{
"But it is at the same time a maxim in those laws, that the king himself can do no wrong; since it would be a great weakness and absurdity in any system of positive law, to define any possible wrong, without any possible redress."
}

Het weerwoord van de intellektueel Johnson en de omschrijving van de specialist Blackstone zijn eensluidend: Tegen de koning bestaat geen juridisch middel en daarom stellen we dat hij geen kwaad kan doen. Een kleine eeuw later moest de Schot John Allen er hartelijk om lachen. Allen, typisch 19e eeuws liberaal in zijn opvattingen, van beroep chirurg, bracht in 1849 een boek over de geschiedenis van het Engelse koningschap op zijn naam. Hij stak de draak met Blackstone's omschrijving, die een gemakkelijk slachtoffer schijnt. Omdat er geen middel van herstel is, zou er geen schade kunnen zijn? Het klinkt werkelijk dwaas. ${ }^{3}$

"On this species of logic it may be remarked, that to say there can be no wrong because there is no redress for it, is as reasonable as to maintain there can be no disease for which a physician has not a cure...

Maar de geneeskunst zal het staatsrecht de wet niet voorschrijven. Ondanks Allen's satire stak in de schijnbare onzin van Blackstone een reëel probleem, fundamenteel en allerminst lachwekkend. Want de koning is meer dan het vorige hoofdstuk van hem liet zien, meer dan de overmacht en willekeur van een sterke persoonlijkheid. De koning staat voor rust en orde; hij is de noodzakelijke voorwaarde, de garantie dat mensen kunnen samenleven. En de sleutel van Jeze garantie is zijn unieke koninklijke gezag; zijn onschendbaarheid.

Laten we eerst de aansluiting met het voorgaande zoeken. Johnson's woorden doen bekend aan. De koning is de hoogste, niemand heeft het recht over hem te oordelen: Zo spraken immers de aloude machtige vorsten, die geen tegenspraak duldden? Maat de schoen wringt. Er is duidelijk sprake, niet van een politiek maar van een juridisch, een rechterlijk oordeel, en daardoor krijgt vanzelf het wrong een morele bijsmaak: niet een beoordelingsfout, een verkeerd inschatten van omstandigheden, maar wetsovertreding, zelfs kwaad.

Wij kennen de koninklijke onschendbaarheid als een politieke regel; ze blijkt hier een juridische regel te zijn. The King can do no wrong: De koning kan niet verkeerd doen omdat het recht tegen zijn misstappen machteloos staat. Een juridisch middel is niet voorhanden. Het dook al herhaaldelijk op, en het zal thans van groot belang blijken: Er was inderdaad onschendbaarheid voor 1848 en dat was een juridische onschendbaarheid; Thorbecke's onschendbaarheid in engere zin. 
De gedachtengang, die we doorgaans associëren met de Engelse filosoof Thomas Hobbes, is heel simpel en logisch. ${ }^{4}$ In een samenleving zonder gezag kunnen geschillen (die zeker zullen voorkomen, we kennen de mens!) slechts door de tegenstanders onderling worden opgelost. De een geeft de ander ongelijk en omgekeerd, dat is juist het geschil; dus hebben zij geen andere oplossing dan het uit te vechten. Dan zal natuurlijk altijd de sterkste winnen; het recht van de sterkste heerst onbelemmerd. Heeft geen van de partijen overwicht, dan blijven ze steken in een opeenvolging van wraak en weerwraak. Een cirkel van geweld, zonder uitweg.

Of zou het mogelijk zijn de anarchie te beteugelen, zodat recht de heerschappij van het geweld verdringt? Een hogere instantie moet worden opgericht, een scheidsgerecht, dat onafhankelijk en onpartijdig over de tweedracht oordeelt. Ruziënde partijen zullen daar verschijnen en door een gezaghebbend vonnis vernemen wie het gelijk aan zijn zijde heeft. Het is evenwel waarschijnlijk dat de verliezende partij zich niet vrijwillig aan het vonnis zal onderwerpen, hij zal misschien reeds bij voorbaat weigeren voor te komen. De hoge rechterlijke instantie kan deze moeilijkheid alleen het hoofd bieden wanneer ze beschikt over machtsmiddelen, wanneer ze alle partijen eventueel kan dwingen, dus sterker is dan zij. Opdat niet de sterkste het recht zou bepalen, moet het recht de sterkste zijn.

Europa is geen vreedzaam kontinent, eeuwenlang was het vol oorlog en geweld. Stammen, steden, dorpen, ridderorden, edelen, roversbenden, zelfs de geestelijkheid: Alles bevocht elkaar in slepende en bloedige konflikten, om grond, om geld, om godsdienst. Elke partij beoordeelde zelf het recht van de eigen zaak en riep dus moord en brand bij wat de tegenpartij deed. Een voortdurende chaos, waarin monarchie uitkomst kon brengen. Eén werd boven allen verheven, de koning. Hij ontwikkelde genoeg macht om elke partij in den lande te bedwingen en elke aantasting van zijn positie te keren. Geen partij mocht meer rechter in eigen zaak spelen, de koning werd hoogste rechter, zodat ieder konflikt binnen de koninklijke orde zou worden opgelost. Het koninklijk gezag zelf zou onbedreigd en onaantastbaar heersen, als onwrikbare grondslag van een ordelijke samenleving.

Een schoolvoorbeeld is de Franse koning Hendrik IV. Bij zijn aantreden in 1589 vond hij een omstreden troon en een land dat nog geen Frankrijk mocht heten; het werd door godsdiensttwisten verscheurd. Bij zijn dood in 1610, door sluipmoord, erfde zijn opvolger een gevestigd koninklijk gezag, een tamelijk betrouwbare vrede en de beginselen van een staatsapparaat. De les zou Frankrijk lang heugen. Honderd jaar later, ondanks bedenkingen bij de politiek van zijn Zonnekoning, liet aartsbisschop Fénelon er geen misverstand over bestaan. ${ }^{5}$

4. Vgl. Hobbes, Leviathan 1.13, 11.17 .

5. Fénelon, Essai philosophique sur le gouvemement civil, 2e druk 1721, Oenvres V, Parijs 1838, blz. 52. 
"L'ordre demande que la multitude ignorante et méchante ne soit pas libre de juger par ellemême, et de faire tout ce qu'elle croit à propos. Il est absolument nécessaire, à moins de vivre dans une anarchie affreuse, où le plus for fait tout ce qu'il veut, qu'il y ait quelque puissance suprême, aux décisions de laquelle tous soient soumis.

Il faut donc nécessairement que tout gouvernement soit absolu. ...

Par le pouvoir absolu, je n'entends autre chose qu'une puissance qui juge en dernier ressort. Dans tout gouvernement il faut qu'il y ait une telle puissance suprême; car, puisqu'on ne peut pas multiplier les puissances à l'infini, il faut absolument s'arrêter à quelque degré d'autorité supérieur à tous les autres, el dont l'abus soit réservé à la connoissance et à la vengeance de Dieu seul."

De koning was voor alles rechter; de hoogste instantie die recht spreekt tussen partijen in het land. Koninklijk gezag en rechterlijk gezag, werd tijdens de Fronde in Frankrijk geschreven, zijn twee onafscheidelijke zaken. ${ }^{6}$ Wezenlijk voor de bedoelde werking van het koningschap, verenigen en ordenen, is dat de vorst zelf zich aan geen enkele andere instantie zal onderwerpen. Of die instantie zou de hogere zijn, en de koning dan geen koning, òf er zouden twee hoogste instanties bestaan, twee nevengeschikte koningen; dan ware de samenleving verdeeld. Beide gevolgtrekkingen zijn ontoelaatbaar. Daarom kan geen enkel lichaam binnen de orde over de vorst vonnis vellen. Absoluut moest 's konings gezag zijn, ab-solutus: onttrokken aan elk ander, op zichzelf staande, onafhankelijk, volstrekt. '

Met nog een ander woord: onschendbaar; 'absoluut' en 'onschendbaar' zijn synoniemen. Koning Jakobus I sprak in 1609, woorden die we eerder lazen, dat de koning over allen oordeelt, maar niemand over de koning. ${ }^{8}$ Een gangbare zegswijze, reeds oud toen Jakobus haar citeerde; ze werd eeuwen eerder gebezigd voor de pausen, van wier machtsontplooiing de koningen veel hebben opgestoken: "et hic est papa: quia de omnibus habet judicare et de ipso nullus." 9 Net als de koning in zijn land, hadden pausen in de kerk erkenning van hun gezag als het hoogste en uiteindelijk enige geēist. Graag schermden ze met een uitspraak van de kerkvader Augustinus, de populaire maar onvriendelijke stelregel dat een zaak ten einde is wanneer Rome heeft gesproken: Roma locuta est, causa finita est.

De koning is onschendbaarheid, onschendbaarheid is de koning. Het einde van de tegenspraak, per definitie. Zou hij tegenspraak toestaan, dan geeft hij het koningschap op; wat overblijft zijn gesprekspartners, gelijkwaardigen. In de tijd van de Fronde, 1649, heeft een Fransman het dilemma in al haar eigenaardige ongrijpbaarheid geformuleerd; zijn pamflet werd in het vorige hoofdstuk aangehaald en we doen er goed aan het citaat van toen te herlezen in het licht van deze gedachtengang: ${ }^{10}$

6. Moreau II. 467; Baker 11.

7. Bracton II. 33; Baker 8/9.

8. James I, Works 61. 307/308: hierboven, b/z. 50.

9. Paul de Vorght. in L'infaillibilite' de l'eglise. Joumces aecuméniques de Cheverogne 25-29 Septembre 1961. blz. $121 \mathrm{nt} .84$; Wyduckel 880 .

De regel is nog altijd de grondslag van het kanonieke procesrecht. Can. 1556: "Prima sedes a nemine iudicatur".

10. Moreau I, 229. 


\begin{abstract}
"Si l'on en permet la moindre ouuerture, la Royaute cesse de l'estre et demeure litigieuse entre ceux qui estoient Suiets et celuy qui estoit Roy, mais ne sont plus ny l'vn ny l'autre, puisque leur position dépend de la décision de ce qu'on veut mettre en question pour sqaunir qui est celui qui en doit estre creu. ...

Tout ce qui s'écarte tant soit peu de l'entière obéyssance, ouure la porte à la réuolte, dont la témérité fait marcher d'vn pas égal ses raisons auec celles du Souuerain ..."
\end{abstract}

Eén dient het laatste woord te hebben, anders valt de samenleving uiteen; tegen zijn laatste woord mag geen weerwoord gelden. De stelling, langs deze weg uit de historie en volgens de logika ontwikkeld, schijnt eenvoudig en onweerlegbaar. Ze heeft evenwel enigszins verrassende gevolgen. Eigenschappen van de monarchie die eerder werden beschreven, die toen duidelijke kentekenen van tyrannie schenen, blijken nu voorwaarden van een vreedzame samenleving. De vorst moet onweerstaanbaar zijn en onweersproken, anders verliest hij simpelweg zijn waarde. Oppositie is vanzelfsprekend ontoelaatbaar, want het zou de wezenlijke uitwerking van het koningschap opheffen.

De koning kan aan niemand in het land verantwoording afleggen, want het zou betekenen dat er een instantie boven hem staat, die dan de eigenlijke koning moet heten. Een koning kan slechts God boven zich erkennen. Hij is, schreef Lodewijk XIV, aan heel het universum en aan alle eeuwen rekenschap verschuldigd, maar kan zich voor niemand verantwoorden, zonder zijn koninklijk geheim te onthullen. " Het is noodzaak dat de koning zijn doen en laten geheim houdt. Geen tegenspraak, dus zelfs geen openlijke bespreking, die tot tegenspraak zou kunnen verlokken: Slechts bij strikte handhaving van de arcana imperii kan het monarchaal gezag haar weldadige kracht behouden. Dit effekt breidt zich door heel de samenleving uit, met het doorzetten van 's konings gezag; en het gezag moet noodzakelijk overal doorzetten.

In de woelige wanorde van strijd en dreigende burgeroorlog was een vast punt gesteld: de koning. Pas door zijn onschendbaarheid is er een begin van samenleving. Nu moet alles zich gaandeweg rond hem rangschikken, alles zich richten naar hem als punt van oriëntatie. De koning, had Jakobus I gezegd, kan zijn onderdanen maken en breken, verheffen en vernederen, naar welgevallen. Heel de orde berust in hem en ieder gezag in de samenleving is van het koninklijke afgeleid. Opnieuw een bekend gegeven, in ander licht: de Great chain of being, de hiërarchie die van de koning voortvloeit, niet als willekeur der oppermacht, maar als ordenend beginsel. ${ }^{12}$

Wentworth, de latere graaf van Strafford, zei het in 1628 met een architektonische beeldspraak, die we overigens meteen herkennen van het debat tussen Schaepman en Van Houten in Nederland, 1884: De koning is de samenhang, de sluitsteen van het gewelf der samenleving. ${ }^{13}$

"The authority of a King is the keystone which closeth up the arch of urder and government which contains each part in due relation to the whole. and which onet shaken, infirm'd. all the frame falls together in a confused heap of foundation and battlement. of strength and beauly."

12. James I, Works 307; Louis XIV, Oeurres II. 29; Baker 22.5: Parker 91. 135/136.

13. Wedgwood. Strafford 75 
Allerlei beeldspraak was in gebruik om de hechte eenheid van vorst en volk uit te drukken, ontleend aan de natuur, de astronomie, de filosofie. Lodewijk XIV koos als zinnebeeld van zijn koningschap de zon, het absolute begin, want van haar stralen, die overal doordringen, hangt elke glinstering af. Van Aristoteles kwam de term primum movens, eerste beweger. Elke maatschappelijke beweging moest haar oorsprong erkennen in de vorst, wiens eerste bewegen zich door het gehele rijk voortplantte en overal eigen bewegingen van de onderdanen teweegbracht. De koning en zijn volk vormden een lichaam van hoofd en ledematen, een onlosmakelijk geheel; hoe zou het hoofd zonder lichaam, of evengoed het lichaam zonder hoofd toekunnen? ${ }^{14}$

Het was tegen de natuur tussen het belang van de vorst en het volksbelang te onderscheiden. En tegen de orde, tegen het welzijn van vorst en volk beide. Dus wie het toch probeerde stond schuldig aan verraad. Door de onlosmakelijke eenheid van koning en volk was binnen]andse oppositie ronduit onmogelijk. Wie zich tegen de koning keerde plaatste zich automatisch buiten de gemeenschap, een volksvijand. Er kon binnen de gemeenschap niet één plekje zijn, niet énn uithoek waar het koninklijk gezag niet zou gelden; nergens in de samenleving een platform los van de koning, waar een zelfstandig oordeel zou kunnen bestaan. ${ }^{\text {is }}$

De samentrekking van het recht in de vorst bracht een rechtsorde voort. Van de koning als hoogste rechter hingen alle plaatselijke rechters af; in de naam van de koning spraken ze recht. Blackstone drukte zeer sterk uit dat de koning als het ware alomtegenwoordig was. ${ }^{16} \mathrm{Hij}$ kan niet overal persoonlijk recht bedelen, maar de wet noemt hem in al zijn gerechtshoven aanwezig omdat de rechters spiegels zijn die het beeld des konings weerkaatsen. De koning trok het strafrecht aan zich. Misdrijven, voorheen een zaak tussen de betrokkenen, werden nu opgevat als inbreuk op de rechtsorde, de koninklijke vrede, en strafvervolging werd niet meer aan de mensen zelf overgelaten, het werd de eigen zaak van de vorst. Langs deze lijn door denkend, kon men soms elk delikt als majesteitsschennis beschouwen. ${ }^{17}$

Dit samenstel van ideeën, de unieke positie van de vorst, zijn onmisbaarheid en dergelijke, werd een twintigtal jaren voor de Franse Revolutie door Lodewijk XV ten overvloede nogmaals volledig van kracht verklaard, uit protest tegen nieuwlichterij die een eigen belang van het volk naast het koninklijke tot gelding wilde brengen: ${ }^{18}$

\footnotetext{
"Comme s'il étoit permis d'ignorer que c'est en ma personne seule que réside la puissance souveraine, dont le caractère propre est l'esprit de conseil, de justice et de raison. Que c'est de moi seul que les cours tiennent leur existence et leur autorité. Que la plénitude de cette autorité, qu'elles n'exercent qu'en mon nom. demeure toujours en moi et que l'usage n'en peut jamais être toumé contre moi. Que c'est à moi seul qu'appartient le pouvoir législatif, sans dépendance et sans partage. ... Que l'ordre public, tout entier, émane de moi. Que j’en suis le gardien suprême. Que mon peuple n'est qu'un avec moi et que les droits et les intérêts de La nation, dont on ose faire un corps séparé du monarque, sont nécessairement unis avec les miens et ne reposent qu'en mes mains."
}

14. Louis XIV, Oeuvres I, 196; Moreau I, 278 en II, 466; Baker 473; Marin 82, 86; Beik 150.

15. Marin 87.

16. Blackstone I, 260.

17. Blackstone I. 258 en IV, 2; Louis XIV. Oeuvres II, 93.

18. Baker 6 . 
Nederland stond niet buiten deze problematiek. Eenheid of verscheidenheid? In de Republiek der Zeven Verenigde Nederlanden ontbrak een duidelijk overkoepelend gezag, de zeven provinciēn konden alleen door vrijwillige overeenstemming gezamenlijk optreden; die te bereiken was telkens een buitengewoon lastige opgave. De zeven vormden trouwens ieder voor zich al een moeizame eenheid, door hun verwarde innerlijke staatkundige orde. Ononderbroken woedde een pennestrijd over de vraag of de landseenheid aanstelling van een "eminent hoofd" vergde, lees: een koning. Hiermee vermengd bestond de vraag of de stadhouders uit het Huis van Oranje al officieus, zonder een passende titel, door hun persoon de samenhang van de Republiek garandeerden. In 1749 spelde een Oranje-klant uit waarom verheffing van de prins tot stadhouder een vereiste was voor het welzijn van de Republiek: ${ }^{19}$

-... parce que sans ce Chèf, dont le principal emploi est de réuïnir les Esprits \& de maintenir la Concorde, la Constitution de la Républiqut tombe dans le plus afreux cahos. chaque Particulier ne pensant qu'à ses propres intérêts."

De strijd tussen Oranje en de regenten, andere twisten en partijschappen, maakten op den duur de Republiek onbestuurbaar en tenslotte ongenietbaar. In de $18 \mathrm{e}$ eeuwse plannen tot hervorming van de Republiek werd er toenemend van gesproken dat Oranje "eminent hoofd" of zelfs koning zou worden, maar pas na de onderbreking van de Franse tijd ging de kogel door de kerk. De verheffing van Oranje tot Nederland's monarch volgde rechtstreeks uit het verleden van de Republiek; het moest een definitief afscheid zijn van de vroegere verlammende onenigheden. De advokaat Boissevain, die in 1846 ten behoeve van zijn kliënt aanvoerde dat een koning naar zijn aard onschendbaar is, vertelde tevens welke afweging Nederland in 1813 had gemaakt. ${ }^{30}$

\footnotetext{
"Ziet, het was juist de wensch om zulk een oppersten scheidsregter te bezitten, een regter voor wiens beslissing alle partijschap, alle verdeeldheid, alle individuele neigingen zwichten zouden, welke bij ons de instelling van het koningschap ingaf."
}

Er was voor tijdgenoten veel aan gelegen. In 1832 ontving koning Willem I het rapport van een kommissie die mogelijkheden voor een nieuwe grondwet had onderzocht. Het beginsel van de koninklijke onschendbaarheid, werd gerapporteerd, diende buiten kijt te zijn, ook "onbeschreven", dat wil zeggen, ook indien de grondwet het niet zou vermelden. ${ }^{21}$

"Dit sluit in zich, dat de koning zoo houg verheven staat, dat deszelfs gezag aan geene verantwoording, in welken zin des woords ook, kan onderhevig zijn. Bij de aanranding van dit beginsel wordt de maatschappij telkens en hettig geschokt. ja is de ondergang nabij." rigée, châriée, đó purgée de ses faussetés par Mr. Rousser. Amsterdam 1749, blz. $137 \mathrm{nt}$.

20. De staatkundige tooverlantaam, of wopisch-politische snelwagen. Rijdt af bij K. van Hulst te Kampen, 1846. deel Il, blz. 44.

21. Kannegieter 114 
Na de omweg langs het absolute koningschap arriveren we door deze citaten opnieuw in de Nederlandse 19e eeuw, de tijd dat koninklijke onschendbaarheid het bij ons tot grondwetsartikel bracht. Een waardevolle omweg; de leer der absolute koningen heeft antwoorden aangereikt voor tal van kwesties, in vorige hoofdstukken opgeworpen. De oude, corspronkelijke onschendbaarheid kwam aan het licht, in samenhang met de onverantwoordelijkheid, als eigenschap van alle monarchie. Opgehelderd is, waarom ook voor 1848 de onschendbaarheid tijdens drukpersprocessen kon worden ingeroepen. De oude onschendbaarheid bleek samen te vallen met de juridische onschendbaarheid, een term die we in 1841 zonder begrip bij Thorbecke aantroffen. Het grote belang werd duidelijk van een vorst die boven de partijen weet te staan, en als toegift hervonden we Schaepman's woord over de koning als sluitsteen van het maatschappelijk gewelf, bij de Engelse staatsman Wentworth.

Een mooi resultaat dus, bevredigend, zij het dat de gevonden antwoorden ogenblikkelijk nieuwe vragen oproepen. De antwoorden zijn bijna zelf weer vragen. Goed, onschendbaarheid voor 1848 , ze is dus in dat jaar niet gekomen maar gebleven. Uitspraken als die van Thorbecke en Schaepman, over een koning boven de partijen en de koning als sluitsteen, hebben eenvoudig de oude monarchale traditie voortgezet. Alleen, wat maakte dan 1848 tot 1848 ? Vanwaar die onjuiste overtuiging dat de onschendbaarheid toen is ingevoerd? En toch zijn er ingrijpende en onmiskenbare veranderingen geweest; de klassieke monarchie ontwikkelde zich tot een parlementaire. Waardoor? Door de ministeriële verantwoordelijkheid? Hoe was dan haar werking, hoe haar bedoeling? Moest zij de koning het zwijgen opleggen? We zagen reeds van niet. Het zou ook uiterst onverstandig zijn geweest de koning tot een staatkundige nul terug te brengen. Zijn onaantastbare en onweerstaanbare macht maakt de samenleving mogelijk, zonder haar stort die in! Maar hoe komt het dan dat de vorst een politiek afwezige werd?

Of loopt de hoofdlijn anders? Deze oude onschendbaarheid, om welke de koning oppermachtig moest blijven, was naar haar aard juridisch; maar wij kennen zo'n koninklijke onschendbaarheid niet meer, de onschendbaarheid wordt thans politiek opgevat. Een geheimzinnige verschuiving, want hetzelfde gezegde The King can do no wrong, voor ons onmiskenbaar een politieke regel, was voor Johnson en Blackstone een juridische regel. Is de overgang van het oude stelsel naar het moderne een overgang van juridisch naar politiek koningschap geweest? Al deze vragen komen achtereenvolgens nog ter sprake.

\section{$\S 2$.}

Volgens het vorige hoofdstuk hadden Europese volkeren hun machtsbeluste vorsten moeten intomen om in vrijheid te kunnen leven; het tweetal koninklijke onschendbaarheid en ministeriële verantwoordelijkheid had mede hiertoe gediend. Dit hoofdstuk beneemt echter aan die weergave de grond. Want nu blijkt dat de koninklijke macht voorwaarde was voor burgerlijke vrede en welzijn; de koning stichtte orde, hij hield door zijn onschendbaarheid de samenleving bijeen. Een hoge waarde. Maar zo word onbegrijpelijk dat men tegen die instelling zou hebben gestreden.

Het maakt een nieuwe beschouwing van de ministeriële verantwoordelijkheid nodig. Heeft zij dan de koninklijke macht vernietigd? Was het haar doel vrijheid te veroveren door de vorst te verdringen? Nee, maar iets heel anders. De onweerstaanbare opper- 
macht van de vorst stelde een theoretisch probleem, dat helaas maar al te vaak tevens een historisch probleem was: Hoe kon men verzekeren dat de vorst zijn macht uitsluitend ten goede zou gebruiken? Opdat het volk in vrede en veiligheid zou kunnen leven was hij met macht en majesteit bekleed; maar hoe wist men of hij niet eens zelf zijn onderdanen zou bedreigen? En als hij het deed, hoe kon men het keren? Wat kon men beginnen indien de koning wel verkeerd deed?

Vanouds bestond een laatste redmiddel tegen de slechte vorst: opstand. Een verdrukt volk, anders tot gehoorzaamheid verplicht, zou het recht hebben de koning af te zetten indien hij weigerde rechtvaardig te regeren. Een oude regel zwierf rond in de rechtstheorie: Rex eris, si recte facis, si autem non facis, non eris, Koning zult ge zijn zo ge recht doet, indien ge het niet doet, zult ge niet koning zijn. ${ }^{22}$ Hoe kon men anders? Niet te verdragen is het wanneer onrecht het land bestuurt. Een koning die zich misdraagt verdient niet dat hij langer koning blijft; hij worde op staande voet ontslagen. Het recht van opstand is een vraagstuk van eeuwen her, maar nog klinkt het na wanneer Oud in zijn handboek van ons staatsrecht over het koningschap en de onschendbaarheid schrijft: ${ }^{23}$

\footnotetext{
"want een Koning, van wie zou worden geconstateerd, dat hij zich aan rechtsschennis heeft schuldig gemaakt, zou blijken niet meer te beschikken over de eigenschap, voor het bekleden zijner hoge waardigheid onmisbaar, het betonen van volstrekte eerbied voor het recht. Op hem zou maar é́n maatregel kunnen worden toegepast, men zou hem de koninklijke waardigheid moeten ontnemen."
}

Maar een koning is geen ambtenaar als alle andere. Zijn gezag draagt de samenleving, en trouwens, hij is een persoon met overweldigende macht. Men behoorde het omzichtig aan te pakken, herhaalde waarschuwingen moesten vooraf gaan, aanzienlijken moesten de leiding nemen. Dan nog. Zou de koning zomaar meewerken? Eerder was op strijd te rekenen; een keuze voor of tegen de koning, twee partijen, burgeroorlog. En wat gebeurt wanneer onderdanen niet langer onderdanig zijn? Derden grijpen als het gezag wegvalt hun kans, anarchie dreigt. Juist de koning was onze enige beschutting tegen de chaos van burgeroorlog en anarchie!

De gedachte dat de troon zou wankelen joeg schrik aan; opstand tegen de koning was geen recht maar spookbeeld, een nachtmerrie. Engeland had de pech het in de $17 \mathrm{e}$ eeuw door te maken, de Civil War. Moeilijke jaren. Achteraf vroeg de dichter John Dryden: "What prudent man a settled throne would shake?..." In 1776, honderd jaar na hem, stelde een Fransman zich voor dat enig mens de keten van het zijn, de samenhang van de sociale orde, die in de vorst haar vaste steun had, zou verstoren: "La seule idée de détruire cette chaîne précieuse devrait être effrayante." Angst heerste voor het onafzienbare van de gevolgen; veel liever dan dit ultimum remedium prezen deskundigen aan, indien de vorst ontspoorde, geduld te oefenen en tot God te bidden om uitredding. ${ }^{24}$ De koning vertegenwoordigde een zeer groot belang; met hem stond of viel de samenleving. Opstand bracht iedereen in gevaar, het zou tot algehele anarchie leiden. Dan maar

22. Wolzendorff $149 / 150$.

23. Oud I, 226.

24. Wedgwood, Poetry and politics 168; Baker 225. 
het omgekeerde: totaal gezag, zodanig dat tegenspraak en zelfs alle uitspraak verboden zou zijn. 's Konings gezag zij onbesproken, want het vooronderstelde van bespreking is twijfel, en twijfel is eigen oordeel, dus het einde van het gezag, straks het einde van de samenleving. We zagen in het vorige hoofdstuk dat monarchisten de koning voor ieder debat wilden behoeden; en we hadden van mensen als Edmund Burke en Joseph de Maistre, gezien hun uitvaren tegen de Franse Revolutie, wel verwacht dat ze een gewijde sluier over het gezag zouden willen draperen, met streng verbod een tipje op te lichten. ${ }^{25}$

Het leek diktatuur en onvrijheid, maar nu blijkt dat zij passen in een onontkoombare logika, die haar kracht niet intussen heeft verloren. Zelfs vooruitstrevende, revolutionaire filosofen, Kant, Hegel, anders niet voor een gewaagde these vervaard, waren even stellig in hun overtuiging dat het gezag verborgenheid behoeft. ${ }^{26}$ Kant vond het ongeoorloofd dat onderdanen over de oorsprong van het gezag zouden vernünfteln, vrijelijk en lichtzinnig redeneren. Van de noodzaak het gezag aan onwelvoeglijk oordeel te onttrekken zag Kant de uitdrukking in de leer dat de overheid van God is. En Hegel:

-Nur die Philosophie darf diese Majestäl denkend betrachten, denn jede andere Weise der Untersuchung. als die speculative der unendlichen, in sich selbst begründeten Idee, hebt an und für sich die Natur der Majestät auf:-

De majesteit van het gezag, de grondslag van de sociale orde, is op haar beurt zonder grond. Een idee, zegt Hegel, dat in zichzelf berust. Achter de koning gaat niets meer terug. Edmund Burke, staatsman en politiek schrijver, verbood onderzoek naar de oorsprong van het gezag, men fluistert: uit angst dat hij geen oorsprong zou vinden. Terecht. Een orde kan haar uitgangspunt niet ter diskussie stellen zonder zichzelf op te heffen. Zelfs goedkeuring wordt niet verdragen, we zagen dat in het vorige hoofdstuk, toen zelfs pogingen het koninklijk handelen te rechtvaardigen werden afgewezen. Want hoe zou je een maatstaf kunnen meten? Aldus komen we tot een onverwacbte, tweede oplossing voor het probleem van de slechte vorst: hij bestaat gewoonweg niet.

Het voorbeeld van de klassieke geometrie kan dit verduidelijken. Deze geometrie, verbonden met de naam Euklides, een wiskundige uit de Griekse oudheid, is opgebouwd zoals we thans het politieke bestel theoretisch lieten opbouwen. Euklides wilde alle bestaande metkundige kennis in onderlinge samenhang a priori afleiden uit zo min mogelijk vooronderstellingen. Zo vormde hij een gesloten, kompleet stelsel. Meetkundjge beweringen hingen niet meer in de lucht, ze hadden hun vaste fundament in het axioma; de innerlijke eenheid van !set axioma verzekerde dat ze onderling geen kontradiktie, geen strijd opleveren.

Alles hangt dan af van het axioma, de kwaliteit daarvan bepaalt de kwaliteit van het geheel. Maar het axioma zelf, het gewichtige beginpunt dat heel het systeem beheerst, aan welke strenge test wordt dat onderworpen? Geen enkele. Een test volgens de regels

25. Cobban 80, 89: De Maistre. Essai sur le principe générateur des constitutions politiques, in Oewres VII, Brussel 1838, blz. 211, 212, 219.

26. Immanuel Kant, Die Melaphysik der Sïten. Der Streit der Fakulläten, in Werke VII (ed. Cassirer), biz. 125: Hegel. Vorlcsungen 1818-1831, blz. 680. 
van de meetkunde is uitgesloten, want het stelsel en de meetkunde vallen nu samen. Hoe zouden we het axioma aan enigerlei stelling binnen het systeem kunnen toetsen? Elke erkende meetkundige stelling dankt nu haar bestaan aan het axioma, geen zou nog een onafhankelijke toetssteen kunnen zijn. Het axioma waarvan alles afhangt, hangt op haar beurt in de lucht.

Precies zo in het staatsrecht. De koning heeft met zijn unieke gezag het verdeelde volk tot eenheid gebracht; botsingen tussen burgers slepen niet meer onbeheerst eindeloze twist achter zich aan, ze worden opgevangen in de buffer van het koninklijk recht. Maar het koninklijke recht dat de orde stichtte, dat het uitgangspunt en de sluitsteen ervan is, kan binnen de orde niet onafhankelijk worden beoordeeld. Ieder oordeel is van het koninklijke afgeleid! Wie toch zelfstandig wil spreken, staat onmiddellijk los van de koning, buiten de gemeenschap, een vijand wiens woord men niet bespreekt maar bestrijdt. Geen eigen recht, geen privilege kan tegenover de vorst standhouden, want van zijn gezag is het uiteindelijk afkomstig. ${ }^{27}$

Net als het axioma in Euklides' meetkunde, is de vorst binnen de sociale orde onfeilbaar; formeel onfeilbaar, door zijn uitzonderlijke positie. Niets kan hem ertoe brengen ongelijk te bekennen. De koning kan geen kwaad doen: Deze benadering doet ons een geheel nieuwe betekenis aan de hand van het The King can do no wrong; de formele onfeilbaarbeid, als gevolg van het absolute vorstelijke alleenrecht. Karel I heeft het ingebracht toen hem, na het verliezen van de Civil War, een proces werd aangedaan dat tot zijn onthoofding in 1649 zou leiden. Hij bestreed de rechtsmacht van het hof en zei, precies volgens de theorie, dat hij alleen voor God en zijn geweten verantwoordelijk was. Derhalve: "I do not know how a King can be a delinquent." 28

Rond 1820 heeft een monarchist après la lettre onverschrokken deze uiterste konsekwentie van de monarchale theorie voorgestaan. Het maakte hem, Joseph de Maistre, verdreven door de Franse Revolutie, ambassadeur in Rusland, politiek schrijver, tot wen beruchte naam. Maistre stelde zonder aarzelen onfeilbaarheid, onschendbaarheid en absolutisme aan elkaar gelijk, als zuivere synoniemen. Hierin school de kern van de samenleving, de essentie van het gezag, dat er één zou zijn die oordeelt en niet wordt geoordeeld; één die onweerstaanbaar is; één die nimmer te horen krijgt dat hij zich heeft vergist. Volstrekte gelding van de formele onfeilbaarheid: ${ }^{29}$

\footnotetext{
"C'est en effet absolument la mềme chose dans la pratique. de n'être pas sujet à l'erreur, ou de ne pouvoir en être accusé. ... car tout jugement dont on ne peut appeler est el doit être tenu pour juste dans toute association humaine ...*
}

Het onvermijdelijke maar onthutsende gevolg van deze leer liet niet op zich wachten. De vraag of onze koning goed handelt is reeds buiten de orde, want de koning maakt uit wat goed is en wat kwaad. We kunnen het gezag geen norm opleggen, want het gezag stelt de norm. Het gezag is de norm. Ons enige uitgangspunt, aan niets te meten. Gezag is willekeur, per se. 
Die willekeur en de noodzakelijke verborgenheid van de macht, Maistre heeft ze levensecht en griezelig verbeeld in de figuur van de beul. Doorgaans eenzaam, uitgestoten, verafschuwd, een schaduw, komt hij plots in het middelpunt te staan waar misdrijf de orde verbrak. Wat de samenleving ten diepste bindt, het is zijn werk; de vreselijke wraak van een orde die zich wil handhaven. Wat per slot van rekening de wind eronder houdt, is niets dan onverantwoorde macht, de beul: ${ }^{30}$

"Otez du monde cet agent incompróhensible; dans l'instant même l'ordre fait place au chaos, les trônes s'abîment et la société disparaît."

Een onbegrijpelijke afloop. De orde, in het leven geroepen om de willekeur en het recht van de sterkste te beteugelen, scheept ons op met én die gewoonweg, zonder rechtvaardiging, allen te sterk is, en wiens doen heel de orde doortrekt, zodat tenslotte heel de orde louter macht tot basis heeft. Maistre was extreem, zijn faam komt niet van niks. Maar gedreven door de eigen logika, heeft de klassieke monarchale theorie soms niet anders gesproken dan hij, ronduit. Sir Robert Filmer, aanhanger van Karel I, heeft het in verscheidene geschriften voor zijn vorst opgenomen; we houden onszelf voor de gek, schreef hij, wanneer we denken dat regering zonder willekeur mogelijk is; we vergissen ons, want hetzij ze berust bij een enkeling, hetzij bij een vergadering, de macht zal onvermijdelijk arbitrair worden uitgeoefend. ${ }^{31}$

Het was om de publikaties van Filmer dat John Locke zich in 1690 aan het onderwerp waagde. Hij bestreed het absolute koningschap met haar eigen wapens. Origineel en geestig ontwierp hij een redenering als die ons zojuist overkwam, het doorvoeren van de monarchale theorie totdat zij in haar tegendeel verkeert. Aangenomen, een volk maakt de overgang van ongeregelde natuurtoestand naar de maatschappij doordat elk bet recht opgeeft rechter in eigen zaak te zijn; beslechting van geschillen wordt overgelaten aan een hoger gezag. Maar wat gebeurt wanneer een geschil ontstaat tussen een burger en degene die met het gezag is bekleed? Een instantie naast of boven de gezagsdrager kan er wegens de theorie niet zijn, hij zal dus, zonder mogelijkheid van hoger beroep, het geval zelf moeten berechten. En dus is hij, als enige, nog altijd rechter in eigen zaak! 32

"So that such a man, however entitled, Czar, or Grand Signior. or how you please, is as much in the state of Nature, with all under his dominion, as he is with the rest of mankind...

And hence it is evident that absolute monarchy, which by some men is counted for the only government in the world, is indeed inconsistent with civil society. and so can be no form of civil government at all."

Afgedaan. De innerlijke logika van het koninklijk gezag noodzaakt het zich nimmer te rechtvaardigen; goed, we besluiten dat het zonder rechtvaardiging is. Een handige ontmaskering, en klaarblijkelijk terecht; kan een samenleving toelaten dat ze naar willekeur wordt geregeerd? Maar de andere kant dan? De monarchale redenering scheen onont-

30. De Maistre, Les soirées de Saint-Petersbourg, in Oeuvres I. Brussel 1838, blz. 31 .

31. Greenleaf 91 .

32. Locke, Two trearises on civil government II. 90,91 . 
koombaar en niet kwalijk, maar in ons belang. Gezag vestigt een ordelijke en leefbare samenleving. Een halve eeuw na Locke was de Schotse wijsgeer David Hume niet van diens spitsvondigheid gediend: ${ }^{33}$

\footnotetext{
"What authority any moral reasoning can have, which leads into opinions so wide of the general practice of mankind ... it is easy to determine."
}

Hume had de waarde van het gezag onderkend; een lichtzinnig aantasten van de koning kan het land in diepe ellende dompelen. Voorzichtigheid is geboden! Maar we belanden aldus in een lastig dilemma: Enerzijds het risiko van een bloedige burgeroorlog, anderzijds bet willoos overgeleverd zijn aan de grillen van een vorst. Zonder koning, recht van de sterkste en willekeur; met koning, recht van de sterkste en willekeur. De redenering dwingt ons tot rusteloos laveren tussen de uitersten van anarchie en diktatuur. Of zou het mogelijk zijn een uitweg te vinden? Al eerder werd vermeld wat Locke tegen de onbeheersbaarheid van het absolute gezag in het veld bracht; de overheid zou zich moeten houden aan vaststaande en openbare wetten. Er mag weliswaar regering zijn, gezag, maar gebonden aan het recht kan het zich niet naar willekeur gedragen.

Locke's vondst was niet nieuw en Filmer had voor Locke reageerde deze oplossing reeds verworpen. ${ }^{34}$ Het hoogste gezag geeft immers zelf de wetten; wat kan een plicht betekenen die voorschrijft wetten volgens de eigen wetten te maken? Het sluit aan bij een zeer oude kwestie. Men stelt tegenover elkaar, in de eerste plaats, het Germaanse beginsel, dat de wet voor allen gelijkelijk geldt, ook voor de koning, en in de tweede plaats het Romeinsrechtelijke beginsel dat de vorst boven de wetten staat: Princeps legibus solutus. ${ }^{35}$ Het was altijd al onweersprekelijk dat vorsten gebonden waren aan het recht. Want recht was natuurrecht, het eeuwige en onvergankelijke recht dat in God en diens schepping besloten lag; de koning behoorde door zijn wetgeving dit hogere recht als het ware zichtbaar te maken. Hij gaf het slechts door, vanzelf dat hij zich niet aan de gelding ervan mocht onttrekken.

Tegelijk was hij degene die bepaalde hoe de wet zou luiden, de hoogste en dus uiteindelijk enige wetgever in het land. Indien het naar zijn oordeel nodig was, moest hij het recht hebben af te wijken. Zijn oordeel gaf de doorslag. De vorst was bovendien hoogste rechter en hoogste macht in het land, dus wie zou in staat zijn hem aan de wet te bouden? In dit licht voldoet Locke's oplossing geenszins; ze biedt niet meer dan een gewijzigde formulering van het monarchale dilemma: lemand moet de orde voor ons definiëren, een onschendbare; maar desalniettemin moet hij met ons in die orde gebonden zijn. Het is, oordeelde in deze eeuw de mediaevist Emst H. Kantorowicz, zoeken naar de kwadratuur van de cirkel. ${ }^{36}$

De regenstrijdigheid bleef eeuwenlang opspelen; hij stond bijvoorbeeld scherp afgetekend in Bracton's 13e eeuwse boek over het Engelse recht. Niemand kan 's konings gelijke zijn, stelde Bracton; had de koning in het rijk een gelijke, dan zou hij over

36. Kantorowicz, Two bodies 95 . 
diegene niet heersen, dus over diegene niet koning zijn. Een gelijke naast de koning is strijdig in zichzelf, onmogelijk; laat staan dus dat iemand hoger dan de vorst zou zijn. De koning is alleen onder God en, vervolgde Bracton zonder hapering, zonder een glimp van bewustzijn dat hij met een enkel woord een afgrond overbrugde: en onder de wet; want de wet maakt de koning. ${ }^{37}$

\begin{abstract}
"Parem autem non habet rex in regno suo. quia sic amitteret praeceptum. cum par in parem non habeat imperium. Item nec multo fortius superiorem. neque potentiorem habere debet, quia sic esset inferior sibi subiectis. et inferiores pares esse non possunt potentioribus. Ipse autem rex non debet esse sub homine sed sub deo et sub lege, quia lex facit ragem."
\end{abstract}

Maar wie maakt de wet? De koning! Een vicieuze cirkel. Men wist hem overigens met een handigheidje voor het oog weg te werken. In de 12e eeuw, eeuwen na de ondergang van het Romeinse Rijk, hervonden universitaire juristen het oude Romeinse recht en begonnen bet met ijver te bestuderen. Ze troffen toen de spreuk Princeps legibus solutus aan, maar behalve dat, ook een vingerwijzing om uit het dilemma dat ze stelde te geraken. Het was, werd ergens gezegd, de majesteit van een vorst waardig dat hij zich aan de wet gebonden zou erkennen. Vandaar reeds spoedig de vernuftige oplossing: Weliswaar is de vorst niet in juridische zin aan de wet gebonden, maar uit vrije wil houdt hij zich aan haar bepalingen. "Voluntate tamen sua seipsum subiicit." 38

De regel maakte school. Niemand minder dan Thomas van Aquino nam haar op in zijn Summa theologiae. De koning valt niet onder de dwang van de wet, schreef Thomas, en het is slechts vrijwilligheid dat hij zich voegt. Hij verwees naar de bijbelse koning David, die eens een onderdaan uit de weg ruimde om diens echtgenote te kunnen inpalmen. Door de profeet Nathan in zijn gezicht aangeklaagd, riep David uit dat hij tegen God alleen had gezondigd. Want, vulde een oud kommentaar aan, geen mens kan over de daden van een koning vonnis vellen: "Rex non habet hominem qui sua facta dijudicet $^{m} .{ }^{39}$

Vier eeuwen na Thomas, de Engelse koning Jakobus I: ${ }^{+0}$

"As likewise, although I haue said, a good king will frame all his actions to be according to the Law; yet is hee not bound thereto but of his good will ..."

Een wankele bodem! Terwijl heel onze wereld op de koning is gebouwd, dienen we in berusting af te wachten of hij ons gunstig gezind zal zijn? Het antwoord luidt onomwonden bevestigend. Als enige tegemoetkoming wordt ons gezegd, dat mensen in die hoge positie doorgaans rechtschapen karakters zijn. Men mag niet aannemen dat een vorst het recht zou willen omverwerpen, schreef in de $14 \mathrm{e}$ eeuw de Italiaan Baldus, een jurist van enorm gezag: "non presumitur princeps velle omnia iura subvertere". We moeten aannemen, dezelfde Baldus, een andere keer, dat niets de vorst behaggt dan recht te doen. "

37. Bracton II, 33.

38. Wyduckel 53: Bracton II, 305/306.

39. Psalm 51:6: Thomas van Aquino. Summa theologiae lazae. 96. 5: Wyduckel 131.

40. James 1, Works 63: Baker 29.

41. Wyduckel $82.83 \mathrm{nt} .115$. 
"Principi nihil praesumitur placere nisi iustum et aequum."

Drie eeuwen daama, in de strijd van de Fronde, Frankrijk 1649, wordt weer precies deze regel beide partijen voorgehouden. De wil van de koning, moeten we altijd veronderstellen, is volgens de wet: ${ }^{42}$

-... ses intentions, lesquelles on doit tousiours présumer n'estre point contraires aux loix de l'Estat et à la Iustice."

Ons gaat bij deze citaten een lichtje op. Ver van Nederland, ver van ons staatsrecht, ver van moderne demokratie stoten we op de formule die wij gebruiken om de regel van art. $53 \mathrm{Gw} 1848$ te verduidelijken: Het is een vooronderstelling, in het politieke gewoel 'nemen we aan', dat de vorst steeds het goede wil en doet. Na de formele onfeilbaarheid van daamet, wordt nu ten tweeden male door oude rechtstheorie een betekenis onthuld van The King can do no wrong; ditmaal het vertrouwen dat koningen op hun hoge post uit persoonlijk plichtsbesef het goede zullen zoeken, zelfs nu geen orgaan ze kan dwingen. In Oud's handboek van ons staatsrecht wordt het eeuwenoude vernuft herhaald dat de onschendbaarheid van de vorst geen vrijbrief voor losbandigheid is, maar een verwachting dat de vorst uit vrije wil wettig zal handelen. ${ }^{43}$

\footnotetext{
-Dit betekent niet, dat de Koning niet asn wet en recht zou zijn onderworpen. Het betekent integendeel, dat van hem wordt verwacht, dat hij zich uit het bewustzijn, dat zijn plicht hem dit gebied, steeds naar wet en recht zal gedragen. Dal hij anders zou handelen, wordt eenvoudig ondenkbaar geacht."
}

Wat is er toch voor bijzonders aan een koning? Mag van gewone mensen, vrije, verantwoordelijke burgers niet evenzeer worden verwacht dat ze zich uit innerlijk besef naar de wet gedragen? Is het niet een volwassen mens onwaardig, een teken van wantrouwen dat hem geen regel wordt opgelegd dan vergezeld van dreiging met straf? De mensen maken 't emaar, dat klopt. Maar als zij niet rechtuit kunnen leven, waarom zouden we dan een koning installeren, met grote macht, en van hem rustig vertrouwen dat hij geen kwaad in de zin heeft? De twee uitersten blijven de theorie parten spelen: Als een volk, aan zichzelf overgelaten, afglijdt naar chaos en burgeroorlog, dan zal een koning, aan zichzelf overgelaten, niet minder waarschijnlijk verworden tot tyran. Geloof aan zijn goede inborst is een dunne bescherming tegen 's konings overmacht; eerde, een vijgeblad dat de onopgeloste problematiek schaamtevol voor het oog moet verbergen.

Het blijft een heen en weer slingeren tussen die twee, het gezag, het behoud van de orde enerzijds, de waarborg tegen vorstelijke willekeur anderzijds. We vestigen een vast punt, dan raken we vast in hiërarchie; willen we nog verwrikken, dan komen we uit bij anarchie. Twee polen met een grote spanning. Die men tenslotte dan toch wist te ontladen, via een bliksemafleider: de minister. De openingswoorden van dit hoofdstuk, Samuel Johnson in 1763, kunnen nu in bun volle strekking doorzichtig worden; maar

43. Oud I, 226. 
het beste is bij Blackstone te zien hoe de behandelde problematiek uitloopt op ministeriële verantwoordelijkheid. ${ }^{44}$ Weer heel simpel.

De koning is soeverein, de hoogste macht, zonder weerga, onschendbaar; geen gerechtshof kan macht over hem uitoefenen: "Who shall command the King?" Tegelijk dient hij zich naar de wet te gedragen en wenst de gemeenschap een waarborg van zijn wettig gedrag. Men laat dus de vorst zijn volle oppermacht en het absolutisme van zijn voorrecht; zonder dat eindigt de samenleving. Desondanks krijgt de gemeenschap er een speld tussen. De koning zou niets kunnen verrichten indien zijn ministers bem niet hielpen. De gemeenschap zal daarom hen aangrijpen. Ontsporingen van de heerschappij worden in de minister gestraft. Niet een ontsnapt aan de kontrole. Een volkomen waarborg.

Het is deze opvatting die in Nederland nog in 1849, toen de Tweede Kamer debatteerde over het wetsontwerp op de ministeriële verantwoordelijkheid, werd voorgedragen. ${ }^{45}$

\begin{abstract}
"Neen. gewigtig zijn de attributen het koningschap opgedragen, en men leze slechts de afdeeling onzer Grondwet over de magt des Konings handelende, om zich te overtuigen dat de ministeriele verantwoordelijkheid, wel verre van de mag1 des Konings te verminderen. niets anders bedoell dan den waarborg der maatschappij voor de Koninklijke onschendbaarheid. Wanneer de Vorst geacht wordt nimmer iets verkeerd te doen en tot geene verantwoording van zijn gedrag kan geroepen worden, zoo behoor de Staat daarbij de genstheid te behouden dat de wetten zullen geèerbiedigd, dat het volksbelang zal behartigd worden."
\end{abstract}

\title{
$\S 3$.
}

Eens te meer kunnen we vaststellen: een "geniale vondst", "eine herrliche Frucht der englischen Staatsweisheit". De vicieuze cirkel werd met briljant gemak doorbroken, aan de koninklijke onschendbaarheid, voorwaarde van samenleving, de veiligheidsklep van de ministeriële verantwoordelijkheid gekoppeld. Het gezag onaantastbaar, en tegelijk de zekerheid dat het zich niet zal misdragen. Buitengewoon slim!

Intussen is het onderzoek er weer flink op vooruit gegaan. $\mathrm{Na}$ het achterhalen van de oude koninklijke onschendbaarheid, die een juridische onschendbaarheid was, werd bovendien een ander begrip van de ministeriële verantwoordelijkheid ontdekt; niet van oorsprong onafscheidelijk met de koninklijke onschendbaarheid, en zeker niet een voorwaarde voor de mogelijkheid ervan, maar nadien toegevoegd, en, naar haar aard, ook juridisch. Een strafrechtelijke verantwoordelijkheid. Het tweetal, juridische onschendbaarheid en juridische ministeriële verantwoordelijkheid, vormt een samenhangend, volledig stelsel, onderdeel van een samenleving die kennelijk juridisch werd gedacht.

Wanneer de koning onrechtmatig handelde, werd de minister strafrechtelijk aangepakt, opdat niet de overtreding ongestraft zou blijven en de samenleving zonder waarborg. Zó stak volgens Samuel Johnson en William Blackstone het systeem der ministeriële verantwoordelijkheid in elkaar. Of dat rechtvaardig was? De vraag moest wel opkomen 
en inderdaad werd ze, we hebben het al eerder gezien, tijdens de 19e eeuw druk besproken. Thorbecke wist een antwoord; hij noemde het "helder en onbetwisthaar", het "regte begrip", de kem van de ministerièle verantwoordelijkheid: Ja, al vaardigt de koning bindende bevelen uit, de minister blijft toch zelfstandig en daarom verantwoordelijk. En het is dan alsof hier, in de verhouding tussen koning en minister, heel het vraagstuk van de vorige paragraaf zich herhaalt: Kunnen we het gezag van boven onverkort in stand houden, en niettemin kontrole van beneden toelaten?

Sommige vragen beantwoord; andere bleven hangen of werden moeilijker. Vooral deze: Welke geheimzinnige omstandigheid heeft de koning zijn macht ontnomen? Niet invoering der onschendbaarheid, want onschendbaarheid ís oppermacht; niet ministeriële verantwoordelijkheid, want die omzeilde juist de koninklijke macht, met opzettelijke bedoeling haar onaangetast te bewaren. Maar de bedoeling kwam misschien niet uit? Of was ze onhaalbaar? Thorbecke's oplossing voor de strafrechtelijke ministeriële verantwoordelijkheid ging eenvoudig niet op; een papieren konstruktie, wordt wel gezegd. We lazen al hoe Constant en Chateaubriand in Frankrijk geen moeite hadden met de gevolgtrekking: Waar ministers verantwoordelijk zijn, moeten ze ook zelf, onathankelijk, het beleid voeren.

Of gebeurt er nog wat anders? Ligt in de onschendbaarheid iets, een eigenschap, een innerlijke noodzaak die haar tot onwerkzaamheid voert? Maakt de onschendbare oppermacht zichzelf onmogelijk? De onschendbaarheid diende als de uiterste en rechtmatige grondslag der samenleving; het koninklijke vonnis was de ultieme rechtshandeling, de uitspraak die per definitie geen hoger beroep meer toeliet. Precies deze bijzonderheid, eigen aan de vorst, dwong hem van handelen af te zien. Al in de $15 \mathrm{e}$ eeuw vertelden Engelse juristen hun koning dat hij als onschendbare zekere rechtshandelingen niet kon verrichten. Edward IV mocht in 1485 geen verdachte arresteren, want die zou, als de koning er verkeerd aan had gedaan, geen juridisch middel tegen het onrecht hebben. ${ }^{46}$

"Sir John Markham disoit au Roy Ed. le 4 qu'il ne poit arrester un home sur suspeceon de treason ou felon, sicome ascuns de ses lieges puissent, parce que s'il face tort, le pary ne poit aver accion."

Een sterk staaltje; de opperste macht moet werkeloos blijven, juist ondat ze de opperste macht is! Hier begint de ontlediging der vorstelijke macht, en zij voltrekt zich daama voor onze ogen. Want dit éne punt, de koninklijke onschendbaarheid, was de aanvang der samenleving. Haar werking behoorde zich tot elke hoek uit te strekken; wie aan deze werking niet onderworpen was, stond buiten de samenleving. Anderzijds was ontoelaatbaar dat de onderdaan geen verweer zou hebben; het absolute van 's konings oppermacht verplichtte hem zich van invloed te onthouden. Het is verbluffend tegenstrijdig: De koninklijke macht neemt af naarmate zij zich uitbreidt. Haar eigen sterkte duwt haar buiten de werkelijkheid.

We ontdekken deze merkwaardigheid nu in de rechtsgeschiedenis, en we kunnen haar in het theoretische uiteenzetten; ze wordt bovendien bevestigd door de beeldspraken die men voor het koningschap bezigde. Koningen noemden zich de zon, de bron van het 
licht, die alles beschijnt zodat het zichtbaar kan zijn; zelf waren zij echter niet te zien, zoals niemand in de zon kan kijken. En zij heetten de eerste aanzet van alle bewegen in de samenleving; de eerste heweger waar Aristoteles' wijsbegeerte van sprak, de primum movens, en die bij hem God is. Als oorsprong van alle beweging kan hij er daarom zelf geen deel aan hebben. Een onbewogen beweger.

We kunnen dezelfde dubbelzinnigheid nog op een andere manier in het oog krijgen. De onschendbare koning was onschendbaar opdat hij boven de staatkundige partijen zou staan; een neutrale en onweerlegbare rechter. Maar Benjamin Constant merkte in de $19 \mathrm{e}$ eeuw scherp op dat het vereiste van onpartijdigheid de vorst onverbiddelijk gebood nimmer werkelijke macht uit te oefenen. Door in te grijpen zou de koning zich in het gewoel van de partijen mengen en vanzelf mede partij zijn. Alleen wie toeziet kan buiten de partijen blijven; wie meedoet wordt ipso facto partij. Men had dit wel geweten, maar er geen bezwaar in gezien de vorst toch met macht uit te rusten; dientengevolge was hij weer in het politieke bewegen opgegaan: ${ }^{47}$

"De ce qu'on sentait vaguement que le pouvoir royal était par sa nature une autorité neutre, qui, renfermée dans ses limites, n'avait pas de prérogatives nuisibles, on en a conclu qu'il n'y aurait pas d'inconvénient à l'investir de ces prérogatives. et la neutralité a cessé. ... Mais on a concédé souvent cette autorité aux rois, parce qu'on les considérait comme désintéressés et impartiaux, et l'on a détruit, par cette concession. l'impartialité même qui lui servait de prétexte."

Het is een zonderlinge tegenstrijdigheid. De Franse historikus-filosoof Louis Marin heeft haar ook, weer anders, uitgedrukt, in het slotwoord, dus als de slotsom, van zijn boek over de absolute monarch. Niet de koning is absoluut, maar zijn officiejle portret, het heersende beeld; niet de koning regeert, maar zijn geheim, het arcanum imperii. Daarom is de absolute vorst als het ware een leeg monument. ${ }^{48}$

\footnotetext{
-Dis lors, si le monarque n'est absolu que dans son portrait officiel que ses sujets tirent de lui et qu'ils lui présentent pour tirer de lui ce qu'ils désirent et que lui seul possède, si le roi n'est Roi qu'en son portrait et si son secret, la pensée secrète de son secret, tellement secrète qu'il ne la pense pas, est qu'il n'est pas ce qu'il est. présence de son absence à soi, alors cette conjonction du portrait et du secret qui est celle de la représentation infinie et du pouvoir absolu signifie que le roi en son portrait, le monarque absolu, est un monument vide, un cénotaphe, un tombeau qui n'abrite aucun corps mais qui est dans sa vacuité même corps royal."
}

Poëtische woorden, die ineens grote diepte bereiken. We kunnen dit thans niet uitwerken, zullen het maar opvatten als een waardevolle vingerwijzing voor het probleem van de roi fainéant, en voor later bewaren.

In dit hoofdstuk alleen nog iets anders. De oude koninklijke onschendbaarheid, de juridische onschendbaarheid als kenmerk van alle koningen, is blootgelegd, en tevens het verband met de ministeriële verantwoordelijkheid. Beide, onschendbaarheid en ministeriële verantwoordelijkheid, werden oorspronkelijk juridisch opgevat en vormden een samenhangend theoretisch geheel, duidelijk te onderscheiden van het moderne politieke stelsel. Het blijkt zo onjuist de strafrechtelijke ministeriële verantwoordelijk- 
heid af te doen als een halve en onhandige voorloper van de politieke. De vraag, al vaker gesteld, hoe het van strafrechtelijke tot politieke ministeriële verantwoordelijkheid kwam, moet worden verenigd met een andere, namelijk hoe het van juridische tot politieke onschendbaarheid is gekomen. Kennelijk heeft een omvattende overgang plaatsgevonden van juridisch naar politiek denken over de samenleving.

Het brengt ons bij een kwestie die in het vorige hoofdstuk aan de orde werd gesteld: Hoe verliep de ontwikkeling van monarchie naar demokratische rechtsstaat? Toen leek het een strijd tegen de eigenzinnige koning; maar de koning, beseffen we nu, moest juist koste wat het kost overeind blijven. De vraag wordt derhalve hier nog eens opgenomen, met hetzelfde viertal van toen als leiddraad: volkswil, grondwet, trias politica en depersonalisatie. De vier schenen daar onmiskenbare bondgenoten van de koninklijke onschendbaarheid en ministeriële verantwoordelijkheid. Het wonderlijke is, in deze tweede versie van het verhaal der Europese koningen bebben ze integendeel het verdwijnen van de oude zuivere onschendbaarheid op hun geweten.

\section{$\S 4$.}

Een volkswil die in het politieke de uiterste norm zou stellen, de monarchist kon er niet aan geloven. Het volk had geen gemeenschappelijke wil, het viel in ruziënde partijen uiteen; precies deze omstandigheid had tot instelling van het koningschap genoopt. Bij invoering van openbaar debat en publieke opinie viel het ergste te vrezen. Sta geen diskussie toe, schreef de hertog van Newcastle aan zijn koning Karel II: "For controversy is a civil war with the pen which pulls out the sword soon afterwards. " 49 In Nederland werd voor 1848 herhaaldelijk ernstig gewaarschuwd dat ministeriële afhankelijkheid van de volksvertegenwoordiging tot partijzucht en herleving van oude tweedracht kon leiden. ${ }^{50}$ Onvoorstelbaar dat een politiek systeem ruimte zou scheppen waar verschillende partijen met elkaar om de macht konden dingen! Partijschap gold als een plaag die men ternauwernood, dankzij de koning te boven was gekomen.

Het plaatst een kanttekening bij de moeite die koningen hadden wanneer ze zich moesten schikken in een nieuwe positie als konstitutioneel monarch. Van hen werd voortitan gevraagd dat ze de keuze van hun ministers naar de verhoudingen in het parlement zouden richten. Maar vanuit het oude monarchale denken was dit ontoelaatbaar; ontoelaatbaar, in strijd met het wezen van de monarchie dat enige partij het koninklijk gezag voor de eigen kar zou spannen. Geen koning met een greintje plichtshesef kon zich tot een instrument van de parlementaire meerderheid laten vervormen. Hij allerminst mocht partijhoofd wezen.

Koning Willem III besefte dat heel goed toen hij aan zijn ministers opdracht gaf de Tweede Kamer te negeren. Hij wenste uitdrukkelijk niet te verworden tot zetbaas van een partij, zelfs niet van de meerderheid der Tweede Kamer, die er nog zeer ver vandaan was dat ze heel het volk zou representeren. ${ }^{51} \mathrm{Hij}$ reageerde in het voetspoor van

49. Christopher Hill, A turbulen, scditious and factious people: John Bunyan and his Church 1628-1688, Oxford 1989, blz. 125; Baker 365.

50. Colenbrander 10, 144; Kannegieter 162

51. Vgl. Van 't Veer 19-20. 
zijn voorvader, de stadhouder Willem III, die twee eeuwen eerder als koning van Engeland hetzelfde probleem voor zich kreeg. De koning-stadhouder liet met beslistheid weten: "I will be a King of my people and not a party". ${ }^{52}$

Een soortgelijke anekdote wordt in onze eeuw waarderend verhaald door de Engelse admiraal Sir John Fisher. Het was de tijd dat socialisten voor een maatschappelijk gevaar doorgingen, en toch had koning Edward VII meelevend geïnformeerd naar de maagkwaal van Keir Hardie, lid van het Lagerhuis en strijdbaar socialist. Fisher, een echte bulderbas, onbehouwen, maar rechtschapen en amusant, zei daarop tegen de koning dat hij er laaghartige sluwheid in zag: "a real low form of cunning". ${ }^{53}$

\footnotetext{
"By Jove, he went for me like a mad bull! and replied: 'You don't understand me! I am the King of ALL the People! No one has got me in their pockets, as some of them think they have!' and he proceeded with names I can't quote!"
}

Het regeren werd ondanks de bange vermoedens, in Engeland en in Nederland en elders, een aangelegenheid van partijen; de ernstige gevolgen die het vroeger zou hebben gehad, bleven merkwaardigerwijze uit. Want men heeft, dit in de eerste plaats, afgeleerd met wapens het eigen gelijk te bevechten; de partijstrijd beperkt zich nu tot woordenwisseling. Maar belangrijker nog: Het volk verenigt zich na diskussie vreedzaam in eenheid van wil, niemand betwist de meerderheid der volksvertegenwoordiging het recht de eigen zin door te zetten. De funktie van de vorst als hoogste rechter kon daarom volledig uit het bestel verdwijnen, en verdween zelfs uit de herinnering.

Het recht; kan een gemeenschap de koning verplichten niet buiten het recht te gaan? In de klassieke monarchie een gedurig en onoverwinnelijk vraagstuk. Het antwoord van de zuivere theorie moest ontkennen; het grondbeginsel van de orde behoort zelf niet tot die orde, het is binnen de orde niet te meten. Maar de wenselijkheid de koning aan de wet te binden drong zich op, te sterk voor een louter logisch tegenargument. In het middelpunt van de aandacht stond een eerste wet, een grondwet. De grondwet zou tussen vorst en volk een onwrikbare regel stellen. Maar een grondwet moet worden gehandhaafd en dat maakte weer een keuze onvermijdelijk: Of de koning bleef de hoogste in het bestel, òf de grondwet zou het worden; beide samen ging niet.

Aeneas Mackay gaf het eens met een rake opmerking weer, toen hij in 1858 bij koning Willem III op audiëntie was. Hij noemde als verschil tussen Groen van Prinsterer, de anti-revolutionair, en Thorbecke, de liberaal, dat Nederland volgens Groen een koningmet-een-grondwet had, volgens Thorbecke een grondwet-met-een-koning. ${ }^{54}$ De tweispalt is herkenbaar in enkele vraagstukken die nog lang in de wetenschap van het Nederlandse staatsrecht dwars lagen. Was niet in 1813 eerst Willem I tot vorst uitgeroepen, pas later onder zijn gezag een grondwet afgekondigd? Moest de grondwet, als hoogste, het koninklijk recht uitputtend beschrijven, of was het gezag des konings soevereiniteit,

52. Roberts 285,329 .

53. Memories by the admiral of the fleet Lord Fisher. Londen 1919, blz. 3 .

54. Duyverman 64. 
boven de grondwet uit, een algemeenheid die zich niet in enkele bepalingen liet opsluiten? ${ }^{5 s}$

Heel de verhouding tussen vorst en recht verschool zich fijnzinnig in de kwestie of onschendbaarheid een grondwetsartikel mocht worden. De koninklijke onschendbaarheid, zou ze werkelijk onschendbaarheid zijn, kon niets boven zich velen; als ze voortkwam uit een officiële verklaring, bijvoorbeeld een grondwetsartikel, dan zouden vanzelf de verklaring en de autoriteit die haar gaf, blijken hoger gezag te wezen. Met andere woorden: Wie de onschendbaarheid vastlegt, heft haar op. Een aardige paradox! Koning Lodewijk XVI van Frankrijk heeft het tot zijn schade ondervonden; bij wet onschendbaar verklaard, werd hij evengoed later na een gerechtelijk onderzoek ter dood veroordeeld. Toen de Revolutie er aan toe was, heeft ze de onschendbaarheid eenvoudig ingetrokken. Een subtiliteit die de koning het hoofd kostte.

De Duitse avonturier Friedrich Christian Laukhard was aan het front verzeild geraakt waar de internationale grootmachten en het volksleger van de Franse Revolutie tegenover elkaar stonden. Toen het Pruisische leger in 1793 haar winterkwartieren betrok, werd Laukhard's regiment te Höchst gelegerd. Men passeerde de tijd met praten en drinken. Eens kwam in een Gasthof, de Schwan, het gesprek op de ongelukkige Lodewijk XVI. Een ritmeester waarschuwde Laukhard achteraf dat de Pruisische troepen toch een houding moesten aannemen alsof ze vreselijk boos waren op de jongens die hun koning hadden terechtgesteld; want Laukhard had het die avond warm voor de revolutionairen opgenomen. ${ }^{\text {s6 }}$

\footnotetext{
"Ich weiss zwar recht wohl, dass 1789 ein Gesetz in Frankreich gemacht ist, nach welchem der Kōnig unverletzbar sein sollte. Allein dieses Gesetz konnte allenal, wie jedes andere, geändert und abgeschaff werden, sobald die Nation als die eigentliche und rechtmässige Gesetzgeberin einsah, dass es dem öffentlichen oder allgemeinen Wohl zuwider war."
}

De ontdekking van de onschendbaarbeid als vaste eigenschap van monarchie had ons op een vraag gebracht: Hoe ontstond de huidige overtuiging dat de onschendbaarheid in 1848 door een grondwetsartikel is ingevoerd? Een antwoord ligt thans binnen ons bereik. De konstitutionele gedachte, dat een grondwet het staatsbestel moet omspannen, bracht mee dat in het staatkundige niets mocht gelden dan alleen wat tot de grondwet te herleiden was. De onschendbare wet verdrong in het denken de onschendbare vorst van de eerste plaats. Het heeft denk ik te maken met de opkomst van het legisme, dat toentertijd de rechtswetenschap in haar ban kreeg: Er was voor een jurist uitsluitend positieve wet, daarbuiten niets.

Ten onzent was de verandering totaal, een bewustzijnsvernauwing die zich razendsnel voltrok. In de toespraken van Kamerleden schemerde al in 1849 een denkwijze als was de onschendbaarheid door de grondwet van 1848 gevestigd. Groen van Prinsterer zag de bui hangen en protesteerde dat de onschendbaarheid van de koning niet van een

55. Vgl. Buys I, 92-93, 196; Lohman 42, 43; Oud I, 6 en II, 194.

56. Friedrich Christian Laukhard, Leben und Schicksale von ihm selhst beschrieben, (0orspr. 1792) Leipzig 1989, blz. 227-228. 
grondwettelijk, bij afspraak invoeren der ministeriële verantwoordelijkheid afhing, maar op zichzelf stond: ${ }^{57}$

"De ministeriele verantwoordelijkheid is niet de voorwaarde der conventionnele onschend. baarheid des Konings, maar het gevolg der historische en grondwettige souvereiniteit."

Vergeefs. In zijn dissertatie van 1855 getroostte Lagemans zich moeite om met argumenten aan te tonen dat de onschendbaarheid ook wel zou gelden indien de grondwet haar niet vermeldde; zijn betoog zou een vreemde indruk hebben gemaakt in de grondwetskommissie van 1815 waar, andersom, bij het verzoek om opname in de grondwet de schouders werden opgehaald, omdat het niets zou bijdragen. Lagemans merkte zelfs met iets van verbazing op dat in 1815 over de onschendbaarheid geen diskussie was geweest; zo ver stond hij kennelijk al af van de toenmalige gedachtenwereld. Een ander voorbeeld is de Belgische advokaat Oswald de Kerchove de Denterghem, die in een bekroonde verhandeling over ministeriële verantwoordelijkheid uit 1867 beweerde, dat de vorst door de grondwetsbepaling onschendbaar was geworden. Een plotselinge vergetelheid; de geesten hebben zich aan de grondwet als hoogste norm gehecht. ${ }^{58}$

De trias politica verbrak de eenheid van de oppermacht; haar strekking is meteen duidelijk. Het splitsen van de hoogste macht in drie, de wetgevende, uitvoerende en rechtsprekende macht, onderving de oude logische valstrik dat een regering die aan wetten werd gebonden, alleen maar aan zichzelf gebonden zou zijn. Nu waren er meerdere gelijkwaardige organen die elkaar wederzijds in het gareel konden houden. De juridische koninklijke onschendbaarheid ging ten onder; de koning was niet Janger het hoofd der rechtspraak. Een idee dat monarchisten niet aanstond, want wat indien de drie machten niet tot samenwerking in staat zouden blijken en elkaar hardnekkig zouden dwarszitten? De impasse zou geen uitweg hebben.

Cornelis Felix van Maanen, minister van justitie onder koning Willem I, bestreed daarom in 1827 dat de vorst maar een der machten in de staat zou zijn. Neen, hij was tutor universae civitatis, niets dat het geheel aanging viel buiten zijn bevoegdheid. ${ }^{\natural}$

"Trouwens, hoe zoude dit ook mogelijk kunnen zijn, zonder de mogelijkheid der hevigste botsingen in den Staat, zonder het vestigen van een impcrilum in imperio, zonder verlies van die kostbare éénheid in den Staat, welke het groote voorregt is eener monarchale regering."

Ondanks het verzet en ondanks de sterke theoretische argumenten is de onafhankelijkheid van de staatsmachten ingeburgerd. Het stelsel van checks and balances bleek te werken en het verontrust niet meer. Het oude onschendbare koningschap had in dit bestel geen plaats meer; toch mocht de koning blijven. Niet meer de hoogste en enige, kreeg hij een plaats gewezen temidden van andere machten. Zelfs de onschendbaarheid bleef behouden; ironisch genoeg werd ze uitgerekend in verband met deze devaluatie voor het eerst officieel, grondwettelijk vastgelegd. Wat kon ze toen nog betekenen? Het 
is een beetje verrassend, maar de onschendbaarheid paste uitstekend in het systeem van de trias politica. Zij betrof niet langer het knooppunt van de rechtsorde, maar de verhouding tussen wetgevende en uitvoerende macht. De onschendbaarheid werd in plaats van juridisch, een parlementair, een politiek beginsel.

De drie machten, dit was de regel, dienden elkaar niet te overheersen. De vorst zou de uitvoerende macht bekleden, naast de wetgevende macht, er niet aan ondergeschikt. De wetgevende macht had niet het recht de vorst ter verantwoording te roepen; en dit zou voortaan diens onschendbaarheid zijn. De ministeriële verantwoordelijkheid paste hier goed bij. De wetgevende macht moest toch in staat zijn een oordeel te vellen over de uitvoering van haar wetten; welnu, de koning had immers medewerkers, de ministers, en die konden zonder bezwaar voor het principe van de machtenscheiding worden aangesproken.

Montesquieu zelf heeft het zo al gezien: ${ }^{60}$

\footnotetext{
"Mais ... le corps législatif ne doil point avoir le pouvoir de juger la personne, et par conséquent la conduite de celui qui exécute. Sa personne doit être sacrée, parce qu'étant nécessaire à l'Etat pour que le corps législatif n'y devienne pas tyrannique. dès le moment qu'il serait accusé ou jugé, il n'y aurait plus de liberté.

Dans ce cas l'Etat ne serait point une monarchie, mais une république non libre. Mais comme celui qui ex lois comme ministres, ... ceux-ci peuvent être recherchés et punis."
}

De staat is een gedachtending. De voormalige juridische onschendbaarheid van de koning vooronderstelde echter het werkelijke van een levende persoon. Slechts een tastbare koning, die te paard met groot gevolg door het land reiscle om twist te beslechten en zijn gezag op te leggen, kon voldoen aan de eis van de monarchale theorie, dat een vorst de rechtsorde zou funderen. Geen gedachte, een mens van vlees en bloed moest eenheid stichten. Toch heeft zich van de persoon des konings langzamerhand de staatsgedachte losgemaakt, en ook zij maakte een einde aan de juridische onschendbaarheid; eerst door de koning in zijn taak, het stichten van eenheid, te bedreigen, daarna, dit zullen we later zien, door die taak als een ware troonopvolgster over te nemen.

Het opduiken van de staatsgedachte bracht gevaar met zich mee. Toen men begon onderscheid te maken tussen de kroon en de koning, de soevereiniteit en de koning, ook wel de Koning-met-een-grote-K en de koning-met-een-kleine-k, raakte de voorzitter van het Engelse Hogerhuis, Lord Ellesmere, verontrust; het was, vond hij in 1609, alsof de koning werd gespleten, alsof er twee koningen waren, en twee koninkrijken. Het grote belang van de landseenheid stond op het spel. ${ }^{61}$ 


\begin{abstract}
-But in this new learning, there is one part of it so strange, and of so dangerous consequent, as I may not let it pass, viz. that the king is as a king divided in himselfe; and so as two kinges of two several kingdomes; and that there be severall allegeances, and several subjections due unto him respectively in regarde of his severall kingdomes, the one not participating with the other.

This is a dangerous distinction between the King and the Crowne, and between the King and the Kingdome: It reacheth too farre; I wish every good subject to beware of it."
\end{abstract}

Zuivere abstrakties, hetzij 'kroon' hetzij 'soevereiniteit' of 'staat', kunnen natuurlijk uit zichzelf geen politieke werking hebben. Iemand dient zich op te werpen om namens haar te spreken en te handelen. Wie mocht dat zijn? Niet de koning, want het abstrakte begrip bestond juist in onderscheid van hem. Een ander dus, een onderdaan of inwoner van het rijk zou het recht krijgen in naam van de staat de koning te weerstaan? Zo stond heel de koninklijke orde meteen op losse schroeven. Enkele tientallen jaren later zou inderdaad deze splitsing de twee partijen van de Engelse Burgeroorlog uiteen houden. Het Parliament achtte zich gerechtigd in naam van de Kroon, de Koning-met-grote-K, oorlog te voeren tegen de levende koning, de koning-met-kleine-k, Karel I. De staatsgedachte ondermijnde dus de koninklijke bevoegdheid van het laatste woord; Lord Ellesmere had de dreiging scherp onderkend.

\title{
$\S 5$.
}

De modernisering van de Europese politieke orde heeft niet de onschendbaarheid van de koning voortgebracht; integendeel, ze heeft zijn onschendbaarheid beëindigd. De vier faktoren demokratisering, rechtsstaat, machtenscheiding en depersonalisatie bliezen gezamenlijk het oude monarchale eenheidsbeginsel op; de samenleving werd veelhoofdig. In toenemende mate. De oude koninklijke volheid van macht is thans opgedeeld, verspreid over allerlei staatsorganen, langzamerhand steeds meer, een onafzienbare archipel van departementen, instanties, raden, kommissies. Wie in Den Haag het centrum van de macht wil zoeken, zei de Groningse historikus Kossmann in 1987, "zal tot het einde van zijn dagen door de wandelgangen blijven dwalen". ${ }^{62}$ De macht verdween uit het zicht, onvindbaar, versplinterd.

Vroegere angst werd evenwel niet bewaarheid. Het einde van de onschendbare koning heeft geen burgeroorlog tot gevolg gehad; ook zonder onaantastbare oppermacht kunnen we kennelijk één blijven. Waarom heeft de voorspelde ramp zich niet voorgedaan? Louis Marin zou zeggen: Het ging niet om de koning, het ging om zijn beeld. Een antwoord dat we meteen herkennen, omdat het zo in de staatsrechtelijke literatuur wordt gegeven. De koningin is symbool van onze nationale saamhorigheid. Maar zou Nederland zonder vorstenhuis uiteenspatten? En vroeger was het beeld van de koning volstrekt ontoereikend als garantie voor eenheid; de koning moest over de hoogste, onschendbare macht beschikken. Waarom hoeft dat nu niet meer? Hoe bestaat het dat enkel een symbool, zonder werkelijke macht, de mensen verenigt? 
De monarchie is hoogstens het uiterlijke teken van een diepere eenheid; deze ligt in de staatsgedachte. De koning was ondergegaan in een stortvloed van nieuwigheden: volksinvloed, wetgevende macht, bestuur, onafhankelijkheid van de rechtspraak, en dergelijke. Deze op zich onsamenhangende ideeēn moesten worden verenigd tot een begripsmatig geheel. Je kunt zeggen dat de staatsgedachte het verlangde theoretische onderdak beeft geboden. Het abstrakte begrip 'staat' werd als het ware gevuld met de voortbrengselen van moderne politiek en theorie. Zo kon een ingewikkeld samenstel van individuele burgers, funkties en organen, delen of soms maar splinters van de macht, samen het geheel dat 'staat' heet bouwen. Hegel, die de staatsgedachte filosofisch uitwerkte, schreef: ${ }^{63}$

"Der Staat muss betrachtet werden als ein grosses architektonisches Gebäude, eine Hieroglyphe der Vernunf, die sich in der Wirklichkeit darstellt ..."

Het is in de staat dat een volk tot eenheid wordt; we weten ons én als burgers van de Nederlandse staat, een demokratische rechtsstaat. Het antwoord helpt verder, maar het behoeft nog aanvulling. We hadden immers vastgesteld dat oorspronkelijk geen gedachte, maar alleen een sterke persoon de gemeenschap kan binden. Hoe kon dan desondanks een abstrakt begrip, het hersenspinsel 'staat', de taak van de onschendbare monarch overnemen? Het kon omdat de staatsgedachte werd gedragen door een bredere ontwikkeling. Hegel noemde de staat een "Hieroglyphe der Vermunft"; schitterend gezegd. De staat, een abstraktie, een bedenksel, is dus een bouwsel van de rede; want alleen het denken kan een gedachte maken.

We zagen in het vorige hoofdstuk dat de rede het oude koningschap heeft verjaagd; maar ze deed meer. De rede heeft het koningschap vervangen. Koningen waren het fundament van de samenleving geweest; zonder hen hadden onenigheid en twist geen eind. Maar de koning viel, en een nieuw fundament was nodig. Het werd de rede, een schepping, de bijdrage van de moderne filosofie. Net als in de wiskunde en de sociale orde, bestaat in de wijsbegeerte het verlangen een vaste grondslag te vestigen. Filosofen spreken van een Archimedisch punt; de Griekse denker Archimedes, uitvinder van technische snufjes, had eens gezegd dat hij slechts een plaats behoefde waar bij stevig zou staan, dan kon hij vandaar de wereld in beweging brengen.

Descartes heeft spannend verslag gedaan van zijn hardnekkige speurtocht naar het Archimedische punt, naar zekerheid in een wankele wereld. Geen maatstaf hield het uit onder de kritiek van zijn denken, tot hij ineens besefte bij al dit speuren steeds dezelfde maatstaf te hanteren, het denken zelf; de ratio openbaarde zich als de hoogste rechter. De Cartesiaanse rede was niet zozeer het opeisen van de vrijheid een eigen mening te vormen, zij bedoelde voor alles een fundamentum inconcussum te leggen, het onwrikbare fundament van een nieuwe wereldbeschouwing, die geen twijfelachtige bestanddelen zou hebben. ${ }^{(4)}$ Kant heeft het ooit krachtig en helder uitgedrukt; hij wenste, zei hij, met zijn Kritik der reinen Vernunft een wijsgerig stelsel te presenteren dat niets van 
te voren had aangenomen dan de rede zelf: "was noch nichts als gegeben zum Grunde legt, ausser die Vernunft selbst". ${ }^{65}$ De rede was de grondslag van de nieuwe wereldorde.

Een idee met verreikende invloed. De rede, eigen aan ieder mens op aarde, kon het middel zijn voor de omgang met volkeren ver weg, die het ondernemende Europa op haar ontdekkingsreizen had ontmoet. En zij overwon de godsdienstige geschillen van na de Reformatie, die de religie zelf niet had weten op te lossen. In de Franse Revolutie werd trots beweerd dat godsdienst alleen maar tweedracht zaaide, terwijl de rede niet verdeelde maar verenigde; het geloof moest daarom voor elk persoonlijk zijn, weg uit wetenschap en politiek, maar rationaliteit mocht de wereld bouwen. ${ }^{\circ}$ De Franse revolutie was zelf één grote poging het land van voren aan in te richten, naar redelijke maatstaven, met meetkundige zekerheid.

Een Duitse encyclopedie over staatsrecht schreef in 1843: ${ }^{67}$

\begin{abstract}
"Die Politik hat heut zu Tage ihre Vernunftepoche angetreten, sie strebt nach einer rein vernünftigen Begründung der staatsgesellschaftichen Verhältnisse. Sie will in Menschen den Bürger, aber nicht den Bekenntr einer bestimmten positiven Religion."
\end{abstract}

Toen de rede veld won heeft zij derhalve niet de samenleving ontbonden. Het was de grote angst van de toenmalige autoriteiten en inderdaad ging hun gezag eraan. Eerder evenwel dan vrijheidsdrang, was de rede ordeningsbeginsel. Uitgaande van innerlijke overtuiging, de eigen wil van ieder individueel mens, kon het denken toch een hechte en nieuwe orde opbouwen. Een klemmende redenering voerde van het vrije individu tot samenleving; een reeks dwingende argumenten verklaarde waarom mensen noodzakelijk tot samenleving komen. Elk vrij en redelijk mens zou zich er wel bij moeten neerleggen. Het is, opnieuw, de leer van het sociale kontrakt; haar uitwerking blijkt nu heel anders dan in het vorige hoofdstuk.

De Nederlandse liberaal Herman van Sonsbeeck, jurist, minister in het eerste kabinetThorbecke, vat de theorie van het sociaal kontrakt voor ons samen. Duidelijk is te zien hoe ze van rebels waagstuk, opeisen van persoonlijke vrijheid, een ondermijning van het gemeenschappelijk welzijn, zich thans een plaats had veroverd als onaantastbaar fundament van de nieuwe orde. ${ }^{68}$

\footnotetext{
"Welke gevoelens men ook omtrent den aard en het doel der Burger-maatschappij moge koesteren. van welke staatkundige meening men ook zijn moge. het is moeijelijk te ontkennen, dat regtszekerheid, dat veiligheid van persoon en goederen onder 's menschen eerste behoeften behooren. Zonder zekerheid van persoon en goederen is er aan geen bestaan, overeenkomstig met onze redelijke natuur, aan geene verstandelijke en zedelijke beschaving, ja, aan geen redelijk leven te denken. De mensch moet dus noodzakelijk zekerheid van persoon en eigendom willen; zulks niet te willen, zoude zijn niet te willen bestaan: een ongerijmdheid voorwaar, en
}

65. Kant, Prolegomena zu ciner jeden kinfigen Meraphysik, in Werke IV (ed. Cassirer). blz. 23.

66. Robert R. Palmer. Twelve who riled. The year of the Terror in the French Revolution. (oorspr. 1941) Princeton 1970, blz. 215-216.

67. Carl von Rotteck en Carl Welcker. Staats-Lexikon oder Encyklopädie der Staatswissenschafien XIV. Altona 1843 , blz. 818 .

68. Van Sonsbeeck 1, 14-15. 
volkomen strijdig met den redelijken mensch. Is het even min te ontkennen, dat buiten het maatschappelijk leven, buiten den Burgerstaat, er aan geene regtszekerheid te denken is; is het verder den mensch gegeven, door vereeniging van wil, met zijne natuurgenooten maatschappijen daar te stellen; aan deze, als het ware, bestaan en leven, ja regt en magt te geven, en wordt het dus doende mogelijk, zekerheid van eigendom, zekerheid van personen in te voeren, dan is het pligt, ja hooge noodzakelijkheid voor den redelijken mensch, den vrijen en ongebondenen natuurstast (den staat, die de vestiging der maatschappijen voorafgaat) met het maatschappelijk leven, met den Burgerstaat te verwisselen."

Voorheen berustte de staatkundige orde in de persoon van de koning; zij was in hem een gesloten systeern. Geen zelfstandig platform kon naast de koning bestaan en toch binnen het systeem plaats hebben. Nu was het de rede die een staatkundige orde voortbracht, als onschokbaar fundament. De staat, zei Hegel, was de belichaming van de rede, "das an und für sich Vernūnftige". En op haar beurt zou deze orde volmaakt sluiten. Johann Gottlieb Fichte, Hegel's land-, tijd-, en vakgenoot, schreef dat buiten de rede geen recht kon gelden. Wie zich tegen de rede verzette, plaatste zich daardoor meteen buiten de staatsgemeenschap, een buitenstaander en vijand die op geen recht als staatsburger meer aanspraak mocht maken. "Ausser dem Staate ist kein Recht. Niemand hat Recht, denn ein Staatsbürger." $\theta$

Wie heeft de vakante troon van de onschendbare koning bezet? In alle voorzichtigheid, passend bij de omvang van de kwestie, mag nu wellicht het antwoord luiden: een verwevenheid van rede en staatsgedachte. De strenge logika van de Duitse filosofen werd natuurlijk niet door iedereen aanvaard, en zeker vandaag verraadt ze zich als een verouderde klank. Toch beduidt ze een onderliggende stroom van Europese politieke theorie, zeker ook van toepassing in Nederland. Niet voor niets heeft Thorbecke zijn filosofische scholing in Duitsland gehaald; de Nederlandse grondwet van 1848 werd in dit gedachtenklimaat opgesteld. De leer dat het bestel niemand dan staatsburgers kan erkennen is trouwens niet van gisteren, zoals menig asielzoeker uit eigen ervaring kan beamen.

De geschiedenis van de rede kan ons nog voorthelpen met een ander vraagstuk, de overgang van het juridische naar bet politieke stelsel van onschendbaarheid en ministeriële verantwoordelijkheid. De rede, grondslag van het politieke gewelf, moest ook de sluitsteen wezen. Binnen de staat konden individuele burgers het woord voeren; verscheidene overheidsorganen konden naast elkaar bestaan, zonder overkoepelend gezag. Toch brak geen burgeroorlog uit, omdat dialoog het wapengeweld verdrong. De wens en het vertrouwen gingen hand in hand, dat geschillen voortaan in redelijkheid zouden worden opgelost. Diskussie, met de rede als leidsvrouwe, zou ruzie voorkomen; na eerlijke en redelijke afweging van argumenten zou vanzelf hlijken waar bet gelijk lag. Redelijkheid is het vooronderstelde van het modeme politieke debat.

Een ingrijpende verandering. Politiek was oorlog geweest, het werd dialoog. Vroegere koningen konren weinig meer dan een broze vrede handhaven en herstellen waar ze werd geschonden; hun taak, rechtspraak tussen twistende onderdanen, was overwegend juridisch. Maar toen diskussie geweld verving, werd de juridische onschendbaarheid tot politieke onverantwoordelijkheid. Gelijk op verouderde het juridische middel tegen de falende vorst; debat en moties in plaats van een strafvonnis, politieke ministeriële 
verantwoordelijkheid stond voorop, de strafrechtelijke kon achterwege blijven. Thorbecke schreef dat politieke onschendbaarheid aan juridische voorafgaat; in de logika mag dat waar zijn, in de historie lag de volgorde andersom. ${ }^{0}$

De diepliggende verschuiving van juridisch naar politiek denken heeft de koninklijke onschendbaarheid en de ministeriële verantwoordelijkheid meegetild. Het blijft evengoed merkwaardig, wat een bijzondere verandering deze begrippen hebben doorgemaakt, bijna onopgemerkt. Tal van formuleringen die wij vandaag voor de konstitutionele vorst gebruiken, werden vanouds op de absolute vorst toegepast: onschendbaar, onverantwoordelijk, boven de partijen, sluitsteen van het politieke gewelf, iemand van wie we aannemen dat hij steeds bet goede doet, iemand die uit vrije wil wettig handelt. De Nederlandse advokaten die in de vorige eeuw insprongen bij drukpersprocessen hebben geen overgang gezien, ze hanteerden de oude terminologie alsof er niets was gebeurd. Maar terwijl de koning vroeger het einde van alle tegenspraak was, staat hij thans buiten alle tegenspraak; terwijl zijn onschendbaarheid vroeger diende om partijstrijd te beëindigen, dient zij nu om de partijstrijd vrij baan te laten; en terwijl de koninklijke onschendbaarheid vroeger verhinderde dat wie ook zich aan 's konings gezag zou onttrekken, kreeg ze later bij ons de faam van een briljante vinding die het volk in de gelegenheid stelt haar eigen gang te gaan! 


\section{De koning als gerechtigheid}

Een terugblik. We dachten eerst dat het tweetal koninklijke onschendbaarheid en ministeriële verantwoordelijkheid diende om vrijheid en volksinvloed te verankeren. The King can do no wrong was een kunstgreep die verhoedde dat de koninklijke waardigheid in het politieke harrewarren zou worden besmeurd; de koning trok zich boven de dagelijkse politiek terug. Toen kwam een geheel andere betekenis naar boven; de onschendbare koning is hoogste rechter, sluitsteen van de orde, het uiteindelijke gezag. De ministeri-r èle verantwoordelijkheid had volgens deze zienswijze geenszins tot doel vrijheid van staatkundig oordeel in te voeren, laat staan het gezag omver te werpen; gezag is onmisbaar. Nee, maar ze moest garanderen dat de beslissingen van de hoogste macht juist zouden zijn.

Niet koningschap en vrijheid, maar koningschap en recht werden door artikel 53 van de grondwet van 1848 verenigd; aldus de uitkomst van het vorige hoofdstuk. We zullen dit spoor verder volgen, en nogmaals het perspektief zien verschuiven; een derde lezing van de koninklijke onschendbaarheid, een derde versie van het verhaal der koningen. Ging het vorige hoofdstuk over juridische onschendbaarheid, zeg maar over het gezag, en over de formele onfeilbaarheid van de koning die eruit volgde, het huidige hoofdstuk zal gaan over de waarheid van de macht. The King can do no wrong: De koning heeft het onveranderlijk en altijd bij het rechte eind; hij is onfeilbaar, in de gebruikelijke zin van het woord, laten we hier zeggen, hij is niet louter formeel maar inhoudelijk, materieel onfeilbaar. Hij beschikt over ware kennis.

Macht moet onvoorwaardelijk ten goede zijn; om wel te doen hebben wij over ons een koning aangesteld. Zou onze koning zich misdragen, dan voldeed hij niet aan de eisen van zijn ambt en was hij geen koning maar een schurk. Want echte koningen hebben geen behoefte aan een ministeriële beschermengel die hun misstappen voorkomt. Koningen handelen zoals koningen betaamt; de ware koning doet nimmer onrecht.

\section{$\$ 1$.}

Formele onfeilbaarheid: De koning, die troont op het toppunt van de gemeenschap, kan geen kwaad doen. Eén rechter moet als laatste uitspraak doen; voldoet de gemeenschap aan deze voorwaarde niet, dan splijt zij op den duur, onvermijdelijk. De vorst is het die eenheid en orde sticht door zijn unieke bevoegdheid als hoogste rechter. Elk rechterlijk 
vonnis in den lande wordt van zijn oordeel afgeleid; geen rechtspraak kan zich tegen de koninklijke uitspraak oprichten. De koning definieert in de samenleving door zijn goedkeuring wat goed is, door zijn afkeuring wat kwaad is. Zoals ook een rechter in het Amerikaanse Supreme Court eens tegen zijn confraters kon zeggen: "We are not final because we are infallible, we are infallible because we are final."

Orde koste wat het kost. Orde die elke weerstand breekt. Orde, zelfs indien ze tenslotte berust op de willekeur der koninklijke luimen. De gevolgtrekking verwordt, we zagen het eerder, tot onzin. Formele onfeilbaarheid is een somber en uitzichtloos.antwoord op de vraag naar gemeenschap. Kan echt alleen maar opgelegde rust, afgedwongen door geweld, de mensen verenigen? Is er geen andere weg om tot samenleving te komen? Iets anders dat mensen samenbrengt? Ware gemeenschap verlangt meer dan een punt waar bet tegenstreven stopt; zij moet gegrond zijn op een waarde die voor allen geldt, een waarheid die uitrijst boven individuele meningsverschillen; een waarheid die niet gebonden is aan beperkingen van persoon, plaats of tijd. We verlangen geen formeel, maar een inhoudelijk antwoord.

Er bestaan immers normen: algemene regels, die voor allen gelden. Zou ieder zich houden aan hetgeen zij voorschrijven, dan zou ook samenleving ontstaan, en op een meer aanvaardbare grondslag. Niet de wil van een enkele machtige zou eenheid vestigen, maar de norm die boven allen uitgaat. Niet willekeur zou heersen, maar recht. Een aantrekkelijke oplossing, heel wat beter dan de onweerstaanbare krachtpatser van de monarchale theorie; en ze lijkt voor het grijpen te liggen. De schijnbare eenvoud verbergt evenwel een moeilijk probleem.

Want goed en kwaad bestaan niet vanzelf, een menselijk oordeel maakt pas scheiding tussen deze twee. En dit oordeel kan niet worden overgelaten aan elk afzonderlijk. Hartstochten en inblazingen bederven het altijd; de samenleving zou spoedig alsnog eindigen in de wanorde van onderling krakeel. Het is de moraal van het bijbelboek Richteren, waar wordt verteld hoe zonder sterk gezag het volk Israël telkens weer de weg van het recht verliet en innerlijk verzwakte, een gemakkelijke prooi voor de buitenlandse vijand. De kroniekschrijver besloot vermanend: "In die dagen was er geen koning in Israēl; een ieder deed wat recht was in zijn ogen. " !

Toch weer de koning. Zonder hem gaat het kennelijk niet! Ditmaal echter, anders dan in het vorige hoofdstuk, is hij niet maar de sterkste jongen van de klas, die iedereen bang maakt zodat iedereen zich rustig houdt; niet maar de machtigste van de roofridders, die allen overmocht en nu ongestoord de vruchten van zijn onaantastbare oppermacht geniet. Want wij, de mensen die er niet in slagen vreedzaam naast elkaar te leven, omdat we vol zwakheid en slechte neigingen zijn; wij hebben de koning in zijn hoge ambt verheven om tussen ons recht te doen. Zijn vonnis stelt in ons aardse leven hogere normen tegenwoordig, waarheid en gerechtigheid. Niet overmacht en roof, maar dit is de essentie van het koningschap: warbeid en recht.

De koning is het die de algemene waarden in zich draagt; hij kent met volkomen zekerheid hun inhoud en hun gelding en zet zijn koninklijke macht in om ze zuiver te bewaren. De vorst sticht niet de orde, vanuit eigen vrije onherleidbare wil; hij vertegen- 
woordigt slechts de orde, wier oorsprong hoger is dan hij zelf, de orde die allen verplicht. Ook hem.

In de $13 \mathrm{e}$ eeuw, de Engelse jurist Bracton: ${ }^{2}$

"Ad hoc autem creatus est rex et electus, ut iustitiam faciat universis, et ut in eo dominus sedeat ... quia si non esset qui iustitiam faceret pax de facili posset exterminari ... Separare autem debet rex cum sit dei vicarius in terra ius ab iniuria, aequam ab iniquo, ut omnes sibi subiecti honeste vivant et quod nullus alium laedal, et quod unicuique quod suum fuerit recta contributione reddatur."

"Hiertoe is de koning aangesteld en gekozen, opdat hij sllen recht zou doen, en opdat de Heer in hem zetele ... want indien er geen zou zijn die recht doet, dan zou de vrede gemakkelijk kunnen worden verdreven ... De koning, aangezien hij de plaatsvervanger van God is op aarde, moet recht van onrecht onderscheiden, billijkheid van onbillijkheid. opdal al zijn onderdanen eerlijk zouden leven en zodat niemand een ander schade doet, en zodat aan elk door een betamelijke bijdrage wordt vergoed wat van hem was."

Wat was de naam van deze algemene waarde, de grondslag der samenleving, het kriterium dat ons in staat stelt boeven van welgezinden te onderscheiden? Bracton reikt ons het antwoord aan. De norm voor allen heette 'gerechtigheid', iustitia, een begrip dat we ons zeer ruim moeten voorstellen. Het is de tijd van een Platonisch-christelijke wereldbeschouwing. Voor het geestesoog zweefde een hoogste idee, het goddelijke. Al hetgeen goed is lag daarin besloten, en al hetgeen in de wereld aan goeds gebeurde was daarvan afgeleid. Tussen de verschillende hoge waarden bestond derhalve innerlijke verwantschap, een diepe overeenstemming. Gerechtigheid was waar, watheid was recht; eeuwige, onveranderlijke normen, berustend in God's wezen. Een psalmdichter spreekt tot God: ${ }^{3}$

"Uw gerechtigheid is gerechtigheid in eeuwigheid, en Uw wet is de warheid. ...

Het begin van Uw woord is waarheid, en in eeuwigheid is al het recht van Uw gerechtigheid."

Eeuwige gerechtigheid was een bovennatuurlijke norm, ver buiten de aardse wereld; maar de vorst diende haar door zijn rechtspraak en wetgeving tot een grijpbare werkelijkheid te maken. Dichters van vorstenspiegels schreven elkaar na dat onder de koninklijke deugden gerechtigheid de eerste rang bezette, de deugd waarin alle andere opgingen. Vrede en rust, het voortbestaan van de samenleving waren afhankelijk van de goddelijke gerechtigheid. En vorsten trokken zich de onderwijzing aan. Keizer Karel V in $1531:^{4}$

"... la justice est la principale \& plus nécessaire entre toutes vertus, pour establir \& conserver tous Règnes. Monarchies \& Principaultez \& les Roys \& Princes y règnans: \& que d'icelle deuement exerée \& administrée procède \& est gardée toute paix. coneorde \& transquilité entre les subject7. grands et petits ..." 
De kennis der gerechtigheid had alleen de vorst, door goddelijke gave, die hem verhief boven het beperkte inzicht van de enkele mens. De koning was, letterlijk, onfeilbaar. Een lofrede beweerde van de $13 \mathrm{e}$ eeuwse Duitse keizer Frederik II dat hij zich niet kon vergissen: "falli non potest". ${ }^{5}$ In deze atmosfeer maakte het vorstelijke absolutisme een andere indruk dan nu. Absolutisme stond niet voor willekeur; absoluut betekende volmaakt, zonder fout, zeker. Aan de absolute vorst werd geen gebrek gevonden. De koning verpersoonlijkte bet recht, bij was de lex animata, de levende wet, of de lex loquens, de sprekende wet. Hij droeg alle recht in het archief van zijn hart, in scrinio pectoris sui; de zegswijze stamt overigens uit het pauselijke recht. ${ }^{6}$

Door God's inspraak bracht de vorst God's waarheid onder de mensen. "Iustice is of the kynde and the nature of god ", een Engelse vorstenspiegel in 1411. ${ }^{7}$ De koning verbeeldde goddelijke goedheid en onderdanen moesten in de koninklijke regering God's woord erkennen: "Atque opera vestra divinum agnoscere verbum". ${ }^{8}$ In het jaar 1627 , de Engelse Attorney-General, over de koning: "yea, the very essence of justice under God upon earth is in him. ${ }^{n}$ Zonnekoning Lodewijk XIV wilde voorzichtig zijn met de leer dat koningen beter weten dan onderdanen, maar zeker, schreef hij in zijn Mémoires, er zijn momenten dat we bebalve God's gezag ook in zijn kennis delen: ${ }^{10}$

"... où tenant, pıur ainsi dire, la place de Dieu, nous semblons être participans de sa connoissance, sussi bien que de san autorité ..."

Deze denktrant maakt weer begrijpelijker waarom het toenmalige gezag met grote felheid moest optreden tegen politieke oppositie. De koning belichaamde waarheid en gerechtigheid, verzet tegen hem was opkomen voor onwaarheid, willens en wetens, dus leugen. Regerend met deze opvatting in het achterhoofd, wat kon de koning anders dan tegenspraak verbieden? Bescherming van de waarheid was een dure plicht van de vorst. Wie het ware wilde, Frankrijk 1649, moest wel hetzelfde willen als de koning; vanzelf dat het, dit werd eerder geciteerd, een "crime manifeste" heette wanneer ministers afweken van de koninklijke wil. " Het weten van de vorst was onweersprekelijk, waar hij oordeelde heerste onmiddellijk en schitterend de waarheid. Geen die door de vorst werd schuldig verklaard kon nog zijn onschuld volhouden, al meende hij oprecht anders: ${ }^{12}$

-... pourant que dans l'assurance qu'il avoit de la justice du Roi il vouloit se persuader d'être coupable pour eroire qu'il étoit justement puni ..."

5. Kantorowicz, Two bodies 142 nt. 167; Spreuken 16:20.

6. James I, Works 291; Gardiner 122; Wyduckel 96-97; Kantorowicz. Two bodies 129ff:; Von Frisob 124.

7. Frederick J. Fumivall (ed.), Hoccleve's works. III. The regement of princes A.D. 14I1-1412, Londer 1897. blz. 91 .

8. Ruth Mohl, Sndies in Spenser, Milton and the theory of monarchy. New York 1949, blz. 36.

9. Gardiner 60 .

10. Louis XIV, Ocuvres $I I, 287$.

11. Moreau II, 326.

12. Montchal II, 558, 731 . 
De absolute vorst besliste ex certa scientia, een oude standaardformule: op grond van zeker weten. Hoe zou iemand na een vorstelijk dekreet 'uit zekere wetenschap' nog moed hebben verantwoording te vragen; te vragen waarom de koning aldus had gedaan? De Italiaanse jurist Baldus, $14 \mathrm{e}$ eeuw: ${ }^{13}$

"Quod in principe est plenitudo potestatis et postquam aliquid vult ex certa scientia nemo potest ei dicere, cur facis ista ..."

De koning bracht een rechtsorde voort, en zo waar de koning was, zo waar was de rechtsorde. Als in Euklides' geometrie: De waarheid van de axioma's beslist de waarheid van heel het systeem. De koninklijke waarheid drong door tot de verste uithoeken van de samenleving, die zo helemaal meedeelde in de onfeilbaarheid van haar monarch. Een Frans geschrift over koninklijke soevereiniteit, 1646: ${ }^{14}$

\footnotetext{
"Al onze leiding moet van God afdalen. $\mathrm{Zij}$ daalt van Hem af in de harten der koningen, hoe oud ze ook zijn, om vervolgens door zijn heambten over het volk te worden verspreid. Deze leiding gebeur in de vorm van het recht dat de magistraten u dagelijks doen. Als onderkend werd dat het een koning is die u recht geeft door de handen van zijn dienaren en welk een gewicht deze naam van koning heeft en waarvoor ze staat, dan zou de koninklijke rechtspraak door iedereen beter worden ontvangen en zonder twijfel meer eerbied en verering genieten."
}

Van de waarheid des konings hing de waarheid der rechtspraak af, door heel het rijk, en daarmee de waarheid van de samenleving zelf. In de wetten, zei in 1755 een remontrance, een bezwaarschrift van het Parijse parlement, ligt de altijd ware wil van de soeverein vervat. ${ }^{15}$ De rechtspraak, die zich lang door godsoordelen had laten steunen, was nog weinig verwijderd van de overtuiging dat een rechterlijk vonnis goddelijke waarheid bevatte. Zich tegen een gewezen vonnis uitlaten gold als misdrijf, en hoger beroep werd opgevat als een strafzaak tegen de rechter; die had niet een vergissing begaan, een gebrek dat hersteld kon worden, maar hij had zich zelf schuldig gernaakt aan rechtshreuk. Men wist de gerechtigheid; haar schijnen, schreef Jean Bodin, de Franse politieke filosoof in 1576 , licht helder op, fel als de zonnegloed. ${ }^{16}$

De Nederlandse historikus Johan Huizinga bevestigt voor de $14 \mathrm{e}$ en $15 \mathrm{e}$ eeuw hoe toentertijd de pretentie van onwrikbare waarheid de samenleving doortrok. Kleinigheden kregen een vaste plaats in de kosmische hiërarchie en werden zo even noodzakelijk en eerbiedwaardig als God die boven alles troonde. De werking van het rechterlijk apparaat deelde in de algemene onontkoombararheid. ${ }^{17}$

13. R.W. en A.J. Carlyle, A history of political theory in the West VI. Edinburgh 1936, bla. $149 \mathrm{nt} .2$; Krynen 141 nt. 49; Wyduckel 80.

14. Beik 151. Beik vertaalde het Frans naar het Engels; ik zijn Engels naar het Nederlands.

15. Baker 473

16. Bodin. Six livres de la république II.3.

17. Huizinga $24,26,290,295 / 296$. 
"Daar was geen oogenblik van twijfel of de boosdoener zijn recht verdiend had. ... Het rechtsgevoel is murvast, het behoeft geen oogenblik te twijfelen: de daad richt den man, zei de oude rechtsspreuk."

Het rechtsbesef kende geen schuchterheid of weifeling. Waarom ook? Veroordeelden stemden onveranderlijk in met hun straf, de schuldbelijdenis was een vast onderdeel van de bewijsvoering en van de openbare exekutie. Uiterste zekerheid, maar in evenwicht gehouden door een ander uiterste: De steenharde gerechtigheid werd getemperd door de volstrektheid van 's konings genade. Een vorst kon zich in verheven barmhartigheid ontfermen over zijn verslagen onderdaan, hoe rechtmatig die ook aan vernietiging was prijsgegeven. De koninklijke gratie, die we twee hoofdstukken eerder, begrijpelijk, verafschuwden als een zedeloos spel met mensenlevens, komt er door de strenge eis der gerechtigheid toch anders uit te zien. De koning was onverbiddelijk maar volkomen rechtvaardig; zijn barmhartigheid, tegenpool van de zonneklare en onvergankelijke gerechtigheid, móest misschien wel zonder waarschuwing de schuldige overvallen, met de onvoorspelbaarheid van genade die niet was verdiend.

\section{$\S 2$.}

Wij noemden, twee hoofdstukken terug, de koning een verdrukker van vrijheid, een tyran die onderdanen zijn willekeur oplegde. Maar een koning in wiens mond gerechtigheid is mogen we niet verwijten dat hij haar met al zijn macht, zonder ruimte voor tegenspraak handhaaft. Indien waarheid bestaat, gerechtigheid, een absolute onvergankelijke waarde, dan behoren we onze samenleving op die waarheid te gronden. Indien het enig mens gegeven zou zijn onvermengde waarheid uit te spreken, dan rust zeker op iedereen de plicht haar of hem te gehoorzamen. Het vrijwaart de burgervrede nog niet van elke bedreiging, twist kan altijd uitbreken; maar tenminste zou onweersprekelijk zjjn wie het recht aan de zijde heeft.

Brengt de staatsmacht onze vrijheid in gevaar wanneer ze op zich neemt de objektieve waarheid te verdedigen? Nee natuurlijk. Wie zou voor zichzelf wensen strijdig met de waarheid te leven? Dergelijke vrijheid zou maar redeloze losbandigheid zijn. Echte vrijheid bestaat in harmonie met het ware; alle werkelijke waarden in deze kosmos moten immers met elkaar in harmonie zijn? Daarom kon tijdens de Franse monarchie met overtuiging worden gezegd dat het Franse volk werkelijk vrij was: "Vivre sous un souverain Roy c'est la suprême liberté." Het absolute koningschap was geen tyrannie; de koning werd pas tot tyran indien hij zijn macht tegen recht en rede wilde aanwenden: "La puissance absolue du prince et monarque ... est appelée tyrannie quand on en use contre raison". Onfeilbaar gezag kan de vrijheid niet bedreigen. ${ }^{18}$

Weer maken we de gevolgtrekking dat een strijd tegen de absolute monarch geen zin had. Zijn volkomen kennen was, zoals in het vorige hoofdstuk zijn volkomen gezag, een onmisbaar fundament van de samenleving. Het verdwijnen der koningen wordt pas weer begrijpelijk wanneer we dieper zien; de ontwikkeling van het waarheidsbegrip in de laatste eeuwen. Europa vereerde haar vorsten zolang hun waarheid werd geloofd, maar 
hun gezag werd onverdraaglijk zodra het twijfelachtige van hun kennis openbaar werd. De absolute koning verdween met de verdwijning der absolute waarbeid; de vorst ging onderuit omdat de grond onder zijn voeten werd weggetrokken.

De gedachte dat iemand onfeilbaar over waarheid kan beschikken is ons vreemd geworden. De Westerse samenleving leerde relativeren en het betrekkelijke van de menselijke oordeelsvorming wordt thans zowel in de wijsbegeerte als in de publieke opinie erkend. Filosofische skepsis en religieuze terughoudendheid hebben altijd bestaan; de theoretische overtuiging van de onvolledigheid der menselijke kennis en de gelovige bescheidenheid dat God voor eeuwig boven ons bevattingsvermogen gaat. Maar het relativisme werd de overheersende trek van de Westerse beschaving en als zodanig is het een recent verschijnsel. De vroegere leer van de koninklijke alwetendheid moge het bewijzen; zij zou nu onbestaanbaar zijn.

Waardoor werd het relatieve waarheidsbegrip de algemene leer? In de $16 \mathrm{e}$ en $17 \mathrm{e}$ eeuw was Europa nog geteisterd door godsdiensttwisten, partijen vochten met hartstocht voor de eigen, protestantse of katholieke waarheid. Een ander geluid klonk: Konden de verschillende geloven naast elkaar bestaan, vijanden in woord maar niet in daad? Het vreedzame samenleven, eerst slechts vorm, moest op den duur ook wel de inhoud der overtuigingen hun onverdraagzame scherpte ontnemen. Het besef van betrekkelijkheid spreidde zich als een donzen dek over de samenleving. En we moeten dan denken aan de Verlichte traditie van de $18 \mathrm{e}$ eeuw, een traditie immers van intelligente gedachtenwisseling als maatschappelijk beginsel; zulk gesprek heeft vanzelf de vooronderstelling dat geen van de deelnemers op zuivere waarheid kan bogen.

Een veelomvattende ontwikkeling, waaruit hier slechts een enkele naam kan worden vermeld. In verband met dit juridische onderzoek de Franse philosophe Voltaire, om zijn kruistocht tegen missers van de Franse rechtspraak. Jaren besteedde hij aan het weerleggen van vonnissen, al waren ze onder de koninklijke hoede uitgesproken; door in aparte gevallen zijn gelijk te bevechten, legde hij een belangrijk principe bloot: De zekerheid waaraan men telkens ten onrechte had geloofd, moest langzamerhand algemeen worden afgezworen. ${ }^{19}$

En Peter Gay, de Amerikaanse historikus, gaf in zijn monumentale werk The Enlightenment een ereplaats aan David Hume, die beter dan allen de gevolgen van de Verlichting heeft vooruitgezien, er bovendien zuiver naar leefde, en zo de eerste moderne ongelovige mag heten. ${ }^{20}$

"For David Hume was both courageous and modern; he understood the implications of his philosophy and did not shrink from them. ... He was willing to live with uncertainty, with no supernatural justifications, no complete explanations, no promise of permanent stability, with guides of merely probable validity; and what is more, he lived in his world without complaining, a cheerful Stoic.... Hume makes plain that since God is silent, man is his own master: he must live in a disenchanted world, submit everything 10 criticism. and make his own way."

19. Keith Michael Baker, Condorcet. From natural philosophy to social mathematics, Chicago 1975, blz. 233.

20. Peter Gay. The Enlightenment: An interpretation. I. The rise of modem paganism. New York 1968, blz. 418-419. 
Indien het geloof geen waarheid biedt, indien elke uitspraak, hoe veelbelovend ook, wordt onderworpen aan kritiek die haar ontmaskert, dan blijkt eveneens de koninklijke garantie van waarbeid in de samenleving een lege frase die geen geloof verdient. In 1792 besprak Fichte de vraag of vorsten het recht hebben hun onderdanen het vrije speuren naar warheid te verbieden; zijn betoog spitst zich toe op de pretentie dat bij koningen de waarheid kant en klaar aanwezig is. Als ze inderdaad gelijk hebben, waarom lichten zij dan hun maatregelen niet toe? Waarom leggen ze geen verantwoording af? Hoor de hardhandige ironie: ${ }^{21}$

\begin{abstract}
"Thr seyd grosmüthig, weise, gütige Vāter der Menschheit; ihr befehlt uns immer richtig zu beobachten, und immer richtig zu schliessen; ihr verbietet uns selbst zu irren, damit wir keine Irrthümer verbreiten. Edle Vormünder, das mōchten wir eben nicht gern; es ist uns selbst eben so zuwider, als euch. Der Fehler ist nur, dass wir es nicht wissen, wenn wir irren. -- Könntet ihr uns nicht, damit doch euer väterlicher Rath uns zu statten komme, ein sicheres, stets anwendbares, untrügliches Kriterium der Wahtheit geben? ...

Wolltet ihr uns nicht sagen, erlauchte Erdensöhne, in wie vielen, unter ernsten Betrachtungen durchwachten, Nächten ihr dasjenige entdeckt habt, was so viele Männer, die, von euren übrigen Herrschersorgen frei, ihre ganze Zeit solchen Untersuchungen widmen, bis jezt noch nicht haben entdecken können? oder, ob ihrs ohne alles Nachdenken, und ohne allen Unterricht, bloss durch dic Hülfe eures götlichen Genies gefunden habt?"
\end{abstract}

Met het ijzige besluit:

\begin{abstract}
"Wahr ist demnach das, wovon ihr wollt, dass es wahr sey; falsch ist das, wovon ihr wollt, dass es falsch sey. -- Warum ihrs wollt, das ist nicht unsre Frage, auch nicht die eurige. Euer Wille, als solcher, ist das einzige Kriterium der Wahrheit."
\end{abstract}

De koning werd verrassend en brutaal te kijk gezet. Allerminst een weldoener, allerminst een wijze vader, maar een machtige die naar willekeur zijn volk de eigen meningen oplegt. Willekeur werd het sleutelwoord; nog immer bepaalt dat ons denken over de oude vorsten. De uitdrukking 'absoluut', oorspronkelijk een teken van de koninklijke volmaaktheid, spreekt ons tegenwoordig van de eigenzinnigheid der koningen. Hun wijsheid was eigenwijsheid, hun gerechtigheid slechts eigengerechtigheid. De genade, bet heerlijke voorrecht van een vorst die eigenlijk geen andere keuze had dan de wetten in al hun gestrengheid toepassen, verloor haar weldadige klank; zijn we, naar huidig spraakgebruik, aan iemand's genade overgeleverd, dan verwachten we weinig goeds, hij kan met ons doen naar believen. ${ }^{22}$

Pas door deze ontmaskering kreeg het vroegere koningschap de reputatie die ten grondslag ligt aan de historische schets, twee hoofdstukken eerder; de reputatie die het nog beden ten dage bij ons heeft. De koning als het beeld van machtswellust en overnatige pretentie, na moeizame strijd overwonnen door demokratische omgangsvormen. Maar nu wordt tevens duidelijk dat de beweging meer diepgang heeft gehad. Niet slechts aan

21. Johann Gottlieb Fichte, Werke I (ed. Bayerische Akademie der Wissenschaften), blz. 180-181.

22. James Daly. "The idea of absolute monarchy in seventeenth-century England", in The historical joramal 21 (1978) 227-250: vgl, W. van Iterson. Gexchiedenis der confiscatie in Nederland, Utrecht 1957, biz. 55 . 
de koning, aan iedereen werd de toegang tot pure waarheid ontzegd. Dankzij de vorst was het mogelijk geweest tot in elke uithoek van de samenleving onweersprekelijk tussen waar en onwaar te onderscheiden; en zoals haar vorst, moest nu ook heel de samenleving deze pretentie opgeven.

"Darum", de Oostenrijkse rechtsfilosoof Hans Kelsen in 1920, "ist der Relativismus die Weltanschauung, die der Demokratische Gedanke voraussetzt. " ${ }^{23}$ Demokratie heeft openbaarheid, verkiezingen, politieke verantwoordelijkheid nodig; maar demokratie bestaat pas ten diepste wanneer niemand beweert de waarheid in pacht te hebben. De koning en de kerk met hun waan van absolute warheid werden doorzien en teruggedrongen, maar ook wie namens de koning meent te spreken, of als het ware op God's standpunt te staan, toont zich een slecht demokraat. De pretentie sluit verdraagzaamheid uit, ze heeft totalitaire trekken. Haar aanhangers zullen, wat voorheen de koningen deden, tegenspraak als majesteitsschennis veroordelen. ${ }^{24}$

"Qui se réclame de l'absolu ne voudra écouter personne; il doit se persuader que toute contestation est un crime de lèse-majesté envers l'autorité souveraine qui cautionne son attitude."

Wanneer wij dus nog eens, intussen ten derden male, de vraag willen beantwoorden hoe het Westen tot de moderne vrijheid en demokratie kwam, dan mogen we niet volstaan met die eerste omschrijving: door het bedwingen van de vorsten. De verdwijning van het harde waarheidsbegrip is een diepere stroom; zij heeft de algemene denkwijze veranderd en als éćn der slachtoffers in haar baan de koninklijke aanmatiging meegesleept. Het begrip van de vrijheid veranderde mee. Vrijheid was geweest: zich voegen naar de koninklijke regels der gerechtigheid. Nu moest het zijn: op eigen gezag een weg zoeken, zonder dat iemand anderen zijn meningen mag opleggen. Vandaar de noodzaak dat het politieke demokratisch zou worden georganiseerd. Indien niemand het alleenrecht op waarheid bezit, mag niemand als enige aan het woord zijn.

Hoe hoog de hartstocht ook loopt, hoe groot ook het belang. In 1919 moest de socialistische geleerde en schrijver Scott Nearing in New York voor de strafrechter verantwoorden dat hij zich, tegendraads, zou hebben uitgesproken tegen Amerikaanse deelname aan de Eerste Wereldoorlog. Natuurlijk gaf hij het proces de wending dat zijn vrijheid van meningsuiting werd beknot, en puntig legde hij uit waarom demokratie openbaar debat inhoudt. De jury mocht hem ongelijk geven, hij mocht ongelijk hebben, maar dat rechtvaardigde nog geen veroordeling. Want het recht dat burgers hebben zich vrijelijk te uiten, ontstaat juist uit hun recht zelf naar waarbeid te zoeken. Het is uiteindelijk een recht zich te vergissen. ${ }^{25}$

"... democracy rests on discussion; and the only way in which we can preserve denocracy is to reserve to every citizen of the denocracy the right to express the convictions that he has: the right to be right and the right to be wrong. blz. 186 . 
The Constitution does not guarantee us only the right to be correct. we have a right to be honest and in error."

Nearing's woorden hebben iets eigenaardigs dat wij, aan relativisme gewend, bijna over het hoofd zouden zien: de zelfbewustheid. Nearing leed niet onder het feilbare van zijn denken, hij ging er prat op als een recht. Maar wat is er voor moois aan zich danig te vergissen? Moeten we niet diep betreuren dat de eeuwige normen, waarheid en gerechtigheid ons ontglipten? Het doemt ons immers voorgoed tot onzekerheid, nooit zullen wij betrouwbaar weten vanwaar of waarheen. Onbegrijpelijk daarom die openlijke trots van de Duitse dichter en filosoof Gotthold Ephraim Lessing, toen hij, eind 18e eeuw, het bezit van waarheid afwees, en met valse bescheidenheid aan het zoeken naar waarheid de voorkeur gaf: ${ }^{26}$

\footnotetext{
"Wenn Gott in seiner Rechten alle Wahrheit und in seiner Linken den einzigen immer regen Trieb nach Wahcheit, obschon mit dem Zusatze, nicht immer und ewig zu irren, verschlossen hielte und spräche zu mir: wähle! ich fiele ihm in Demut in seine Linke und sagte: Vater vergib! Die reine Wahrheit ist ja doch nur für Dich allein!"
}

Een verklaring kan als volgt gaan. Het besef van eeuwige waarden paste bij de voormalige onveranderlijke maatschappij; ze waren onmerkbaar vermengd met gewoonterecht en de traditionele gang van zaken. De bestaande orde, die rust en zekerheid veilig stelde, had eeuwigheidswaarde en iedere poging te veranderen werd met wantrouwen bejegend, zelfs opgevat als een vergrijp tegen de goddelijke instellingen van altijd. De tijdelijkheid van het aardse leven werd scherp afgezonderd van God's eeuwigheid; het tijdelijke, in haar onvolmaaktheid, was afval van het eeuwige, een zonde tegen God's norm. Het behoorde zich niet te ontplooien, men diende het integendeel te beteugelen, met koninklijk vertoon van macht. ${ }^{27}$

De staatkundige werkzaamheid richtte zich dus vanzelf op het verleden. De koning zetelde in majesteit zolang de orde niet werd bedreigd; hij trad op wanneer zij onverhoopt was geschonden. Rechtspraak en wetgeving herstelden een vorige toestand. $\mathrm{Ze}$ waren als het herhalen van aloude waarheden, die in de toekomst altijd waar zouden blijven. Men zorgde angstvallig dat politieke besluiten teruggingen op vroeger gevestigd recht; voor elk handelen was een beroep op precedent vereist, en het verwerpelijke van voorstellen stond reeds vast wanneer zij een nieuwigheid behelsden. De overheid brach stabiliteit in een wisselvallige en onveilige wereld. 'Revolutie' was een onheilspellend woord, het stond voor de overwinning van tijdelijkheid en chaos op de orde. ${ }^{28}$ Maar een verandering zat in de lucht. De Cartesiaanse rede scheurde zich los uit het weefsel van de goddelijke orde. Met het instrument van de rede, als zijn persoonlijk eigendom, had de mens een eigen bron van inzicht, los van hoger gezag. De mens verwierf zo zelfstandigheid tegenover de natuurlijke omgeving, er groeide een durf om het niet meer te laten bij navolging van het bestaande. Men hoefde niet meer het oude te

26. Hans Joachim Störig, Kleine Weltgeschichte der Philosophie, (oorspr. 1950) Stuttgart 1985, blz. 383.

27. Kantorowicz, Two badies 275f: Greenleaf 28, 29.

28. Hans Maier, Die altere Deutsche Staats- und Verwaltungslchre. 2e druk München 1980, blz. 50-51. 56-57; vgl. Beik 72; Wansink 42, 73. 
bevestigen, men durfde nieuw te scheppen. De modeme wetenschap en haar erfenis, het inmiddels enorm toegenomen bestand van technische middelen, zijn een voortbrengsel van deze veranderde houding.

Men had vrede en rust boven alles gesteld, maar het bleek dat de stilte van de onverwoestbare orde doods was. Niets van beweging, en dus niets van vooruitgang. Het roerige tijdelijke werd niet langer als een bedreiging opgenomen, het was juist een medium, de voorwaarde van menselijke werkzaamheid. De Westerse mens werd trots op het tijdelijke van zijn aardse bestaan. Tijd was niet een toestand waarin gedwee het herstel van de orde, hetzij vanwege God hetzij vanwege de koning, moest worden afgewacht, tijd was de mogelijkheid stilstand te doorbreken en vooruit te streven, een betere wereld te stichten. Vergissingen werden opgewekt aanvaard als een onvermijdelijkbeid op het pad voorwaarts.

Een eerder ondenkbaar zelfvertrouwen; het laat zich zien in de ongeduldige reaktie van Jean-Jacques Rousseau op het versleten deuntje dat een volk de onrechtvaardige koning nederig moet verdragen: ${ }^{29}$

"On sait bien qu'il faut souffrir un mauvais gouvemement quand on l'a; la question serait d'en trouver un bon."

De verschuiving betrof ook het staatkundige. ${ }^{30} \mathrm{Ze}$ werkte onmiddellijk door in aardschokken als de Franse Revolutie. Het woord 'revolutie' had langzamerhand haar ongunstige klank verloren en de betekenis gewonnen van een dapper ondernemen, een grootse poging ongehoord resultaat te bereiken; pas in die zin konden de Franse revolutionairen met hun titel pronken. Ook de regelmatige gang van het staatsleven wijzigde diepgaand. De koning, het beeld van de eeuwige gerechtigheid, steeds bezig die te handhaven, werd vervangen door een staat die als werktuig diende in handen van de gemeenschap, om zowel de natuurlijke omgeving als het sociale naar eigen inzicht te vormen; de staatstaak richtte de blik naar de toekomst.

David Hume, de buitengewone man uit Schotland, heeft met scherp zintuig het nauw merkbare proces gepeild: ${ }^{31}$

"... men of an independent genius and large views, began to regulate their opinions more by the future consequences which they foresaw, than by the former precedents which were set before them; and they less aspired at maintaining the ancient constitution. than at establishing a new one, and a freer, and a better."

Deze gegevens, de omslag in de oriēntatie van het overheidsoptreden, vullen het vorige hoofdstuk aan. Daar werd opgemerkt hoe de overgang van juridische naar politieke koninklijke onschendbaarheid en ministeriële verantwoordelijkheid lag ingebed in een grootscheepse verschuiving van juridisch naar politiek denken over samenleving. Hier vinden we een vergelijkbare verschuiving. De staat heeft haar aandacht verplaatst van rechtshandhaving, herstel van het verleden, naar sturing, ontwerpen voor de toekomst. 
Dat maakt nog iets begrijpelijker waarom de oude juridische opvatting van de staatstaak moest wijken voor een moderne politieke. Bovendien kan de uitgestrektheid van deze ontwikkeling verklaren, dat de overgang nooit zuiver is vastgesteld.

\section{$\S 3$.}

Wat betekent nu de koninklijke onschendbaarheid volgens de beschouwingswijze van dit hoofdstuk? Twee hoofdstukken terug verzekerde het beginsel de openbare vrijheid van meningsuiting, als een vinding van de moderne tijd. Eén hoofdstuk terug bleek de onschendbaarheid uitdrukking van machtsvolheid; door de staatkundige ontwikkeling van de moderne tijd juist verdwenen. En thans? Moest onschendbaarheid onfeilbaarheid betekenen? Werd de spreuk The King can do no wrong letterlijk genomen, en door machthebbers afgedwongen? Het hoofddoel van ons onderzoek, de overeenkomst met het Italiaanse Mussolini ha sempre ragione, zou dan binnen handbereik zijn; we kennen de fascistische leuze immers inderdaad als een middel om het volk gedwee te houden. We zullen eerst weer de Commentaries on the laws of England opslaan, het 18e eeuwse standaardwerk van de Engelse jurist William Blackstone, beginpunt van elk onderzoek naar de regel The King can do no wrong: ${ }^{32}$

"Which antient and fundamental maxim is not to be understood, as if every thing transacted by the govemment was of course just and lawful ..."

Geen werkelijke onfeilbaarheid, meende Blackstone. Maar wat dan? We lazen in het vorige hoofdstuk van hem al een uitleg, die, hoewel ze ooit de spotlust van John Allen wekte, ons op het spoor van 's konings juridische onschendbaarheid en formele onfeilbaarheid heeft gezet. Toch geen slecht resultaat! En Blackstone had nog een tweede omschrijving:

"And, secondly, it means that the prerogative of the crown extends not to do any injury: it is created for the benefit of the people, and therefore cannot be exerted to their prejudice."

Allen, na de eerste uitleg, vond deze al even zot. Alsof nimmer een goedbedoelde uitvinding zich tegen haar makers keerde! ${ }^{33}$

"... and to argue that the prerogative cannot be exerted to the prejudice of the subject, because it was created for his benefit, is much the same as to assert. that an army, which has been raised in defence of the liberties of a country, cannot be employed for their destruction."

Het lijkt opnieuw een schot in de roos. Met speels gemak zette Allen Blackstone's woorden te kijk als een doorzichtige vergissing. Maar na de les van het vorige hoofjstuk kiezen we niet meer onbezonnen partij voor zijn gevatheid. Heeft Allen ook ditmaal lichtvaardig uitgehaald? 
De Nederlandse hoogleraar staatsrecht Buys zou ongetwijfeld zeggen van wel. Een eeuw na Blackstone, enkele tientallen jaren na Allen, schrijvend aan zijn handboek over onze grondwet, heeft hij vol overtuiging Blackstone aangehaald als "de zuivere leer" omtrent de koninklijke onschendbaarheid: ${ }^{34}$

\begin{abstract}
"Mandataris van eene corporatie, louter ingesteld om goed te doen, kan het recht om kwaad te doen nooit aan haar mandaat ontleend zijn. De persoon des Konings moge het feitelijk bedrijven, de instelling, het koningschap, kan het niet, om de eenvoudige reden dat het aan hare attributen geheel vreemd is."
\end{abstract}

Het gelijk schijnt desondanks zonder meer aan Allen's zijde. De koning mag geen kwaad doen; uiteraard. Maar de Engelse regel, èn Blackstone, èn Buys: Ze stellen dat de koning derhalve geen kwaad kán doen. Een doorzichtige drogrede. Hoe kwamen ze erbij? Buys kon, via Blackstone, verwijzen naar een autoriteit van veel langer geleden. De 13e eeuwse Engelse jurist Bracton had geschreven, woorden die nauw aansluiten bij het gedeelte dat we een paar bladzijden terug van hem lazen: ${ }^{35}$

\footnotetext{
"Ad hoc autem creatus est rex et electus. ut iustitiam faciat universis, et ut in co dominus sedeat ... Nihil enim aliud potest rex in terris, cum sit dei minister et vicarius. nisi id solum quod de iure potest ... Igitur dum facit iustitiam vicarius est regis aetemi, minister autem diaboli dum declinet ad iniuriam. Dicitur enim rex a bene regendo et non a regnando ....
}

\begin{abstract}
"Hiertue is de koning aangesteld en gekozen, opdat hij allen recht zou doen, en opdat de Heer in hem zetele ... Want niets anders kan de koning op aarde doen, omdat hij de dienaar en plaatsvervanger van God is, dan alleen dat wat hij rechtens kan ... Daarom, zolang hij gerechligheid doet is hij plaatsvervanger van de hemelse koning. maar de dienaar des duivels wanneer hij afwijkt ten kwade. Want niet vanwege het regeren, maar vanwege goed regeren wordt hij koning genoemd ..."
\end{abstract}

Ook Bracton leed dus aan de drogrede: Koning is niet zomaar iedere machthebber, iemand die betzij goed hetzij kwaad doet, naar gelang het uitkomt; koning mag uitsluitend beten wie naar recht en waarheid regeert. Koningschap en gerechtigheid vallen altijd samen. Een leer die het kennelijk eeuwen heeft uitgehouden. Kan ze dan enkel nonsens zijn, pijnlijke blunder van een verstrooide staatsrechtgeleerde?

John Allen heeft zich een beetje van de domme gehouden; hij wist zeer wel dat Blackstone's uitleg geen ongelukkige, eenmalige verschrijving was geweest. De leerstellingen van het Engelse staatsrecht brachten hem op een verschil tussen de ideële en de reële koning. De ideële koning was de ideale; hij kon geen kwaad doen, koesterde nooit slechte bedoelingen, altijd sterk, altijd aanwezig. Een onfeilbare. De reële koning liep zichthaar rond, iemand met een naam, Edward, Jakohus, Karel of George; hij bekleedde een zekere positie in het staatsbestel maar had vooral veel mensen en regelingen om zich heen die moesten voorkomen dat hij de macht zou mishruiken. De reele vorst was een feilbaar mens. 
Allen kon zijn betoog illustreren met een reeks aanhalingen uit Blackstone, die rond The King can do no wrong allerlei ideale eigenschappen groepeerde, eigenschappen die de vorst in zijn ware hoedanigheid, als staatkundige figuur zou bezitten. De wet schreef de koning absolute perfektie toe; hij kan behalve niet verkeerd doen, zelfs niet verkeerd denken. Onmogelijk dat ooit een ongepast handelen de bedoeling van de vorst zou zijn geweest, want hij kent noch dwaasheid noch zwakte. De wet verbond aan The King can do no wrong bovendien het uitgangspunt dat de vorst wordt geacht voortdurend bezig te zijn in dienst van bet algemeen belang; ook is hij nimmer minderjarig en sterft niet. De wet bepaalde, aldus Blackstone, dat in de koninklijke borst geen onderscheid is tussen het goede weten en het goede doen: ${ }^{36}$

"... as it presumes that to know of an injury and to redress it are inseparable in the royal breast ...

We raken hier aan een bijzondere overlevering van de Engelse staatsrechtelijke geschiedenis: de leer van 's konings twee lichamen, die faam geniet sinds in 1957 de historikus Ernst H. Kantorowicz aan The King's two bodies zijn klassieke werk wijdde. Het Engelse staatsrecht onderscheidde in de koning twee lichamen, een politiek en een naturrlijk lichaam, en daarmee overeenkomstig twee willen, een persoonlijke wil en een publieke wil. De persoonlijke wil van de vorst was onderhevig aan de eigenschappen en stemmingen van zijn menselijke natuur, een uiting van toevallige eigenzin. Maar de vorst, als drager van koninklijke waardigbeid, verpersoonlijkte tevens de gemeenschap; hij had een publieke wil die noodzakelijk strookte met het recht en het staatsbelang, als afbeelding van boventijdelijke, eeuwige waarheid.

Deze geleerden en juristen, uit een grijs en soms minder grijs verleden, hanteerden dus een onderscheid tussen de werkelijke en de bedoelde vorst. De koning is iets anders dan het koningschap. De persoon van de koning, een mens als wij, kan falen; maar van het koningschap, ingesteld om het goede te bewerken, is de idee van bet goede onlosmakelijk. Dus, faalt een koning, dan ontvalt hem ipso facto het koningschap. De persoon vergreep zich, maar het koningschap schittert onbevlekt als altijd. Met andere woorden, we onderscheiden de Koning-met-een-grote-K, verbeelding der volmaaktheid, en de koning-met-een-kleine-k, een werkelijke persoon. Zolang de koning goed doet dekken de twee elkaar, begaat hij een misstap dan splitsen ze ogenblikkelijk.

Het is een merkwaardig geval. John Allen's hoon valt best te begrijpen! Welke zin had het de koning een gespleten persoonlijkheid toe te schrijven, wie heeft de vondst gedaan, waarom bleef ze zo lang werkzaam? Treedt ze meer op? Wat de laatste vraag betreft: zeker. De beschrijving in dit hoofdstuk van de vorst, iemand die absolute warheid draagt en haar verspreidt door de gemeenschap wier hoofd hij is, kwam ons maar al te bekend voor; we zouden haar eigenlijk elders hebben verwacht. Het is immers de theologie, het zelfbeeld van de Rooms-Katholieke Kerk. Herhaaldelijk werd reeds opgemerkt dat de Europese koningen gedachtengoed aan de pauselijke traditie ontleenden; kennelijk heeft de kerk, behalve Romeins recht, ook haar leer van de onfeilbar- 
heid aan de koningen overgedaan. Kunnen we dan in het kerkelijke recht eveneens een tweedeling van de hoogste gezagdrager waarnemen?

De paus belichaamde, net als de koning, goddelijke waarheid; hij gaf haar de gelovigen door, zodat zij heel de kerkgemeenschap doortrok. En net als de wereldlijke rechters en bun koning, konden in afhankelijkheid van de paus diens ondergeschikte rechters, de inquisiteurs in het jaar 1553 onfeilbaar worden verklaard. ${ }^{37}$ De leer van de pauselijke onfeilbaarheid werd weliswaar pas in 1870 officieel dogma, maar ze heeft altijd min of meer geheerst. Toch is de afkondiging in 1870 niet zonder strijd verlopen; diverse tegenstanders binnen de kerk tekenden protest aan. De Engelsman William George Ward verklaarde zich voorstander; hoopvol verwachtte hij naast zijn dagelijkse Times bij het ontbijt nu ook een uitgave met onfeilbare uitspraken over aktuele vraagstukken te vinden. ${ }^{38}$

Maar de paus, onfeilbaar geacht, bleef mens; geen machtswoord vermocht hem te onttrekken aan de onvolkomenheden van het menselijke bestaan, buiten alle dwaling en misleiding. En de Roomse dogmatiek kon deze vraag niet ontlopen, gezien het onloochenbare feit dat meerdere pausen beslist vergissingen hadden begaan. De dominikaner theoloog Cajetanus, die als pauselijk afgezant in 1518 met Maarten Luther zou debatteren, had voor het probleem een oplossing bedacht. Wanneer eens een paus jammer genoeg onwaarheid verkondigde, dan deed hij dat uitsluitend als persoon; hij verviel door de ketterse uitspraak automatisch van zijn verheven ambt, dat zelf zonder een schrammetje stand hield, een betrouwbaar baken als steeds voor de gelovigen. ${ }^{39}$ De roemruchte katholieke kerkhistorikus Ignaz von Döllinger, een Duitser, verzette zich in 1870 tegen het dogma van de pauselijke onfeilbaarheid, zo krachtig dat hij een jaar later uit de kerkgemeenschap werd gestoten. Niettemin had hij altijd het leergezag van de paus verdedigd. Bij hem is het dat we Cajetanus' theorie nog eens vememen, kennelijk voor eigen rekening. ${ }^{\$ 0}$

\footnotetext{
"Sollte auch ein Papst in eine Häresie ... verfallen, so betrifft dieses doch nur die Person des Papstes, die Cathedra Petri müsste doch als Mittelpunkt der ganzen Kirche betrachtet werden. und es wäre gleichsam eine momentane Sedisvakunz. denn wenn der Papst seine Irrlehre nieht widerriefe, müsste gleich wieder ein anderer gewählt werden ...
}

\section{$\S 4$.}

Waartoe diende het uiteenvallen van de onfeilbare koning? De staatsrechtelijke uiternzettingen maken het niet duidelijk, maar het vergelijken met de pauselijke leer brengt ons op een mogelijk antwoord; een antwoord dat in de bovenstaande weergave al enigermate doorklonk, en dat veel te maken heeft met demokratische argwaan. Machthebbers vrezen altijd verlies van de macht; vergissingen die zij begaan zouden een goede reden

37. Bengl Ankarloo (ed.), Early modem European witcheraft: centres and peripheries, Oxford 1990, blz. 90.

38. Roger Auber, Le pontificar de Pie $X$ (1846-1878), Parijs 1952, blz, 302.

39. Gerhard Hennig. Cajelan und Luher. Ein histonischer Beitrag zur Begegnung von Thomismus: und Reformation. Stuttgart 1966, blz. 27-28.

40. Johann Finsterhölzl (êd.), Wegbereiter heutiger Theologie. Ignaz von Döllinger. Graz 1969, blz. 107. 
zijn hun die macht inderdaad te ontnemen. $\mathrm{Zij}$ trachten dus de indruk te wekken dat ze zich nooit vergissen, en de beschreven splitsing is een prachtige truc, waterdicht, onweerlegbaar. Ook indien het beleid zichtbaar fout liep, ook al faalde een leider hopeloos, de onderdaan moest geloven dat het Gezag-met-een-grote- $G$ volledig en geloofwaardig van kracht bleef. Dubbele misleiding dan; wat gingen ze ver in hun drang de macht te behouden!

Maar wie het onderste uit de kan wil, krijgt het lid op de neus. De monarchale theorie, indien ze er werkelijk aldus op uit was het pantser van de redenering rondom ondoordringbaar te maken, heeft het tegendeel bereikt. John Locke citeerde tegen het einde van de 17 e eeuw met smakelijk genoegen uit het geschrift van ene Barclay, een vurige monarchist die zijn best deed het recht van opstand te weerleggen. Welk recht kon een volk hebben de wapens tegen de vorst op te nemen? None at all. Geen enkel. Althans, een voorbehoud: "Nulli certe quamdiu rex manet -- None at all whilst he remains a king. " Een onschuldige, kleine opening, maar die tenslotte gapend groot werd: ${ }^{4 !}$

\footnotetext{
The people, therefore, can never come by a power uver him unless he does something that makes him cease to be a king; for then he divests himself of his crown and dignity, and returns to the state of a private man, and the people become free and superior: the power which they had in the interregnum, before they crowned him king, devolving to them again."
}

"That is, in short, not to multiply cases!", riep Locke uit. Dit eenvoudige regeltje borg weidse mogelijkheden in zich. Goed, verzet tegen de vorst is ten strengste verboden, altijd; maar de vorst, zodra hij verkeerd Joet, is geen Vorst-met-een-grote-V meer, en de gehoorzaamheid eindigt. De splitsing van de heerser in een altijd onfeilbaar beeld en een alledaags feilbaar mens versterkte het koninklijk gezag niet, maar hief het op. Wie mocht bepalen of in de heerser de scheiding tussen ambt en persoon zich had voltrokken? Geen recht had dit geregeld en geen recht kon dit regelen, want heel het monarchale stelsel berustte juist op de unieke positie van de vorst als hoogste rechter; niemand kon over hem uitspraak doen. Zijn falen wierp daarom iedereen terug op zichzelf, op het eigen oordeel. Orde en samenleving losten onmiddellijk op.

Een Franse pamletschrijver, 1649: ${ }^{42}$

"... il est constant à quiconque l'examinera de près, que dès lors qu'vn Roy abuse du pouuoir que Dieu lui donne en cette qualité, et qu'il contreuient à son deuoir, il cesse d'estre Roy et les subiets d'estre subiets."

Ieder die oordeelde dat de koning verkeerd deed, had ogenblikkelijk het recht zich te verzetten! Nee, als waarborg voor een ongeschokt koninklijk gezag mislukte de kunstgreep van de tweehoofdige koning faliekant. Heeft men zo Pandora's doos voorgoed willen verzegelen, dan werd stellig de schroef te strak aangedraaid; ze knapte, zodat het deksel wijd open sloeg. Want de theorie werkte omgekeerd uit, juist opstandige onderdanen gingen ermee aan de haal. Zij zagen de koning afwijken van het zonneklare voorschrift der gerechtigheid dat zij kenden, en wisten zonder aarzeling wat de koning had

42. Moreau I, 398. 
behoren te doen, ware hij Koning gebleven. Bestreden zij hem, dan niet uit persoonlijke, wankele mening, maar om het klaarblijkelijk schenden van de eeuwige en goddelijke gerechtigheid. "Si obediendum est Deo, diligenda est iustitia", zei een oude wet: Indien God moet worden gehoorzaamd, dan moet gerechtigheid worden gedaan. ${ }^{43} \mathrm{Op}$ stand ging tegen de koning-met-een-kleine-k; in naam van God, in naam van de gerechtigheid, in naam van de Koning-met-een-grote-K.

Eerder in dit hoofdstuk werd een citaat opgetekend uit de mond van keizer Karel V, die in 1531 de hoge waarde van de gerechtigheid beleed als volkomen norm in de staatkunde. Op de kop af vijftig jaar later, in 1581, onder bewind van Karel's zoon Philips II, verscheen in de Nederlanden een pamflet met, op het eerste gezicht, gelijkluidende bewoordingen. ${ }^{44}$

-...de Heere des Landts is alleen een bediener der gerechticheyt, een Stadhouder Gods, een Herder des volcx, een Vader des Lants, om eenen yeghelijcken recht ende gerechticheyt te bedienen. Ende daer toe wort hy vercoren, ende gehult, ende tot dien eynde wordt hem alle syne macht ende auctoriteyt ghegheven ..."

Idem non est idem: Zelfs precies hetzelfde hoeft niet altijd hetzelfde te zijn. In 1581 durfden de Nederlandse gewesten tenslotte de uiterste gevolgtrekking aan van een opstand die al jaren voortsleepte, tegen hun beer koning Philips II; zij zwoeren hem af. De gehoorzaamheid werd opgezegd, legde het Plakkaat van Verlatinge uit, omdat Philips II geweigerd had het land "met recht ende redene te regeeren". " Volkeren mochten eisen dat hun vorst over hen zou heersen volgens de gerechtigheid; bong hij af, dan was er een recht hem van zijn funktie te ontheffen. Ondanks de bedrieglijk nauwkeurige overeenkomst, was het pamflet uit 1581 niet de weerklank van de keizerlijke boodschap, maar, integendeel, van het Plakkaat van Verlatinge: een beroep op het recht van opstand. Zo had Karel V het niet bedoeld!

De koning had in de samenleving het laatste woord: vanzelfsprekend. Dit echter uitsluitend ten dienste van de gerechtigheid: vanzelfsprekend. Maar dan slaat de redenering plotsklaps door. De dienstbaarheid van de koning aan een hogere norm maakt dat ieder die in zijn recht meent te staan, met overtuiging het koninklijke beleid kan bestrijden. Goed beschouwd, is de koning er opeens niet meer. Elk oordeelt voor zichzelf. En de opstandige onderdaan mag in gemoede verwachten dat hij zijn vorst een dienst bewijst; hij schiet immers te hulp bij een moeilijke taak, de vervulling van de gerechtigheid! Met deze uitgesproken bedoeling heeft prins Willem van Oranje zich opgeworpen als hoofd van de Nederlandse opstand. Hij verdedigde gerechtigheid en was dusdoende koning Philips II eerlijk behulpzaam. Willem van Oranje in $1568:{ }^{46}$

43. Wolzendorff 151.154

44. Geurts 149

45. Z.W. Sneller. Unie van Utrech en Plakkaat van Verlatinge. De wording van den Nederlandschen staat. Rolterdam 1929. blz. 59.

46. Groen, Archives, le seric deel III, blz. 200. 


\begin{abstract}
"Nadenmaal gheen groter off meerder dienste eenighe Cke Mte [koninklijke majesteit] bewesen ende ghedaan can worden dan om met aller gerechticheyt syn landen ende ondersaten te regyren ende deselve helpen vermeerderen in gueden voorspoet ende ryckdomme tot verbeteringhe van alle syns Mts [majesteits] domeynen ..."
\end{abstract}

Bleef de vorst afkerig van dergelijke hulp en legde hij terechtwijzing naast zich neer, dan werd het verzet niet gestaakt. De norm ging boven de koning uit, men streed voor God en gerechtigheid. Opgeven zou onrecht zijn. Het Wilhelmus:

\author{
Voor Godt wil ick belijden \\ En zijner grooter macht, \\ Dat ick tot gheenen tijden \\ Den coninck heb veracht: \\ Dan dat ick Godt den Heere \\ Der hoogster Majesteyt \\ Heb mosten obediëren \\ In der gherechticheyt.
}

Eer in Nederland de oorlog met Spanje officieel eindigde (de vrede van 1648), maakte in Engeland een twist scheiding tussen vorst en parlement, hield ze onverzoenlijk uiteen en leidde tenslotte in het jaar 1642 tot burgeroorlog. Niet uit eigen naam trokken de parlementaire troepen ten strijde, maar ze beweerden op te treden voor de Koning-meteen-grote-K, tegen de persoonlijke koning, Karel I, die zich het koningsambt onwaardig had getoond door onverbeterlijk af te wijken van het ware beleid: "fighting the king to defend the King". En de strijdkreet was zeer ernstig bedoeld, al schijnt ze een zonderling en doorzichtig goedpraten, met geestige kronkels, en al werd ze reeds destijds bespot. Toen de koningin terugreizend uit Nederland op de Engelse kust landde, en onderschept en beschoten werd door de parlementaire vloot, grapte een gedicht: "Shot at, for the King's own good..." 47

We hebben 't weer over de Engelse Civil War; zij is vroeger al aan de orde geweest. Maar geleidelijk, bijna zonder het te merken, hebben we intussen een belangrijke omwenteling doorlopen. We vingen aan met demokratisering als een strijd tegen de koningen; later en beter gezegd, strijd tegen hun opgeblazen waan altijd gelijk te hebben. De splitsing van de vorstelijke waarheid in een wankel, mogelijk aanvechtbaar, en een onvergankelijk en eeuwig gelijkhebben, bevestigde even dit beeld. We moeten nu evenwel vaststellen dat bewegingen als de Nederlandse opstand en de Engelse Burgeroorlog niet por se het moderne relativisme bevorderden.

Opkomen voor demokratie en vrijheid van politieke mening? Het Engelse parlement, ontevreden over de raadslieden rondom koning Karel I, wilde hem in 1641 verbieden nog andere meningen te horen dan de hare; maar de koning antwoordde geprikkeld: Zijne Majesteit weet van geen slechte adviseurs, en het parlementaire verzoek tast andermans vrijheid van meningsuiting aan. Zou de koning dan alleen mogen vememen wat toevallig naar het believen der parlementsleden is? ${ }^{48}$ 
-... nor doth he expect that any should be so malicious as, by slanders or any other ways, to deter any that he trusts in public affairs from giving him free counsel, especially since freedom of speech is always demanded and never refused to parliaments ..."

Het Parliament riep weliswaar op tot strijd tegen de persoon van de koning, maar in naam van de Koning-met-een-grote-K. In de naam dus van waarheid en recht. De parlementaire troepen voerden niet het beginsel van demokratisch omgaan in hun vaandel, relativisme en tolerantie, maar absolutistische waarheidspretentie. Het kwam al om de hoek kijken toen in 1642 de Engelse burgeroorlog op uitbreken stond. Pamfletschrijvers keerden zich fel tegen de veronderstelling dat het Parliament in staat zou zijn onrecht te doen. ${ }^{49}$ Het parlement was de republiek zelf en de wet schreef voor dat niemand haar van kwaad mocht verdenken. De koninklijke onfeilbaarheid, naar ons oordeel niet meer dan de doorgedreven pretentie van hooghartige vorsten, werd door het Engelse Parliament zonder omhaal ingelijfd.

Onderdanen bevochten hun vorsten niet zozeer uit vrijheidslievendheid, als wel in naam van God, de Gerechtigheid, de Koning-met-een-grote-K; in naam van de eigen absolute waarheid. En opeens verliezen we uit het zicht hoe de demokratische ontwikkeling van het Europese staatsbestel is verlopen. Want we vragen meteen verder, naar andere figuren uit de geschiedenis van de Europese demokratisering. Als de genoemde volksopstanden een toevluchtsoord van intolerantie zijn geweest, schuilplaats van het absolute warbeidsbegrip, hoe verhielden zich dan de andere erkende vijanden des konings, rede, volkswil, de Franse Revolutie, tot waarheid en relativisme?

\section{$\S 5$.}

De Cartesiaanse rede heette oorspronkelijk het opeisen van ieders recht voor zichzelf te denken; beginsel van persoonlijke vrijheid. Maar Descartes zag niets in een relativering van het waarheidsbegrip. Hij twijfelde niet om de twijfel, maar hij had een hekel aan skepsis en tastte de erkende waarheden slechts aan uit bittere noodzaak, in een hartstochtelijk zoeken naar de maatstat die met algehele betrouwbaarheid tusisen waar en onwaar zou onderscheiden. ${ }^{50}$ Toen hij die norm uiteindelijk vond in het "Ik denk, ik ben", nam hij haar aan als een onomstotelijke waarheid, die niet meer moest worden aangevochten, maar een garantie was bij het vaststellen van volgende, afgeleide, even zekere waarheden.

De rationele wijsbegeerte maakte zich meester van de staatkunde; de waarheidspretentie werd er niet minder om. ${ }^{s 1}$ In de $18 \mathrm{e}$ eeuw koesterden de Franse physiokraten, een school van denkers over ekonomie en politiek, het ideaal van de 'verlichte despoot'; de monarch zou zijn rijk regeren als belichaming van de evidente waarheid, zịj het dat die thans niet meer goddelijk werd genoemd, maar redelijk, volgens moderne wetenschappelijke inzichten. Verlichte vorsten hadden het recht en zelfs de plicht hun rijk te

49. Robers 148, 319 .

50. Descartes, Discours de la méthode, in Oewres VI (ed. Adam-Tannery), blz. 29, 33.

51. Talmon, Tot. demicracy 36: Anthony Strugnell, Diderot's politics. A stedy of the evolution of Dideror's political thought after the Encyclopédie. Den Haag 1973. blz. 102-103. 152. 
vormen naar het model dat de wetenschap voorbield. Het werken voor de toekomst, dat hierboven werd beschreven als blijk van relativisme, een aanvaarden van tijdelijkheid, kon op eigen beurt met uiterste onbuigzaamheid worden toegepast. Het plan was redelijk, de samenleving moest maar met zich laten doen!

De rede verhief zich boven het beperkte inzicht van de enkele mens; wie zich op het standpunt van de rede stelde kreeg deel aan het universele en onwankelbare van haar waarheid. Een zekerheid die twijfel voorkwam. Het vaste vertrouwen op de rede, als grond van het nieuw te ontwerpen staatsbestel, heeft de Franse Revolutie mogelijk gemaakt. De Nationale Vergadering kondigde in 1789 een grondwet aan die de mogelijkheid van koninklijke tyrannie zou uitbannen; aan de grondwet vooraf wenste men een verklaring van de rechten van de mens. Verscheidene teksten werden als voorstel gepubliceerd, maar een lid van de Vergadering vond daarin alleen afzonderlijke beginselen, weliswaar door niemand weersproken, maar zonder verband. Door nauwkeurige formulering wilde hij hun volkomen, wiskundige zekerheid voor elk zichtbaar in het licht stellen. ${ }^{52}$

\footnotetext{
"... il reste à faire appercevoir la chaine qui les lie à ces vérités fondamentales qui, semblables aux axiômes des géomètres, se présentent à l'esprit dans le demier degré de l'évidence. ... nous ne saurions assez faire appercevoir la relation intime de ces mêmes principes avec les vérités élémentaires dont ils émanent; vérités également simples \& immuables. \& qu'il suffit de montrer pour les reconnoitre."
}

De volkswil als dragend beginsel van het politicke proces, die de eigenzinnigheid der monarchen moest vervangen, leed aan dezelfde kwalen als de koninklijke wil, doorliep dezelfde kronkelingen, en vlijde zich tenslotte onder de veilige bescherming van de moderne absolute heerser, die totalitair heet. De oorsprongen van het $20 \mathrm{e}$ eeuwse totalitarisme zijn nageplozen door de Israëlische historikus Jacob L. Talmon; hij kwam uit bij de Verlichting van de $18 \mathrm{e}$ eeuw. De philosophes hadden allesbehalve gerekend op het schipperen dat wij nu als kenmerk van demokratische politiek beschouwen. Ze hielden de waarheid voor redelijk en kenbaar, het publieke debat zou haar onweersprekelijk openbaren. ${ }^{53} \mathrm{Du}$ choc des opinions jaillit la vérité: De leuze was misschien ontkenning van het koninklijk absolutisme, maar tevens bevestiging van het waarbeidsabsolutisme.

De wil van het volk, geleid door de rede, kon niet mistasten; ze was onfeilbaar. Van deze altijd ware volkswil staan de omtrekken scherp afgetekend in Du contrat social, het boekje van Jean-Jacques Rousseau, uit 1762. Rousseau, de filosoof bij uitstek van de volkssoevereiniteit, stelde zich voor dat mensen, samengekomen in een politieke vorm, door hun eenheid van organisatie vanzelf een gemeenschappelijk belang zouden hebben. Verstandige burgers zouden van dit ene algemene belang, het belang van het geheel, de wenselijkheid inzien, en ze zouden het dus gezamenlijk nastreven. Een algemene wil zou zich op het algemene belang richten, en het precies dekken. De algemene wil, het woord zegt het, mocht niet het bedenksel van een enkeling zijn, maar 
harmonische uiting van de redelijke kennis in de gemeenschap. Talmon: "For the general will is in the last resort a Cartesian truth. " 54

De algemene wil behelsde klare waarheid. Rousseau stuitte toen, onvermijdelijk, op het probleem dat mensen feilbaar zijn; al gauw zal blijken dat niet iedereen over algemene belangen hetzelfde denkt. Hij loste het eenvoudig op: De volonté génírale, die altijd beantwoordt aan het algemeen belang, dus altijd waar is, moet niet worden verward met de volonté de tous, de werkelijke wil die in de mensen leeft. ${ }^{5 s}$

\footnotetext{
-Il s'ensuit de ce qui précède que la volonté générale est toujours droite el tend toujours à l'utilité publique; mais il ne s'ensuit pas que les délibérations du peuple aient toujours la même rectitude. On veut toujours son bien, mais on ne le voit pas toujours. Jamais on ne corrompt le peuple, mais souvent on le trompe, et c'est alors seulement qu'il paraît vouloir ce qui est mal."
}

De volomté génćrale dwaalde nimmer, de volonté de tous daarentegen kon zich deerlijk vergissen, en moest dan uiteraard worden terechtgewezen. Hij heett zich in andere bewoordingen verstopt, maar lang laten we ons niet misleiden: Uit het masker van demokratische theorie kijkt ons als vanouds de Koning-met-een-grote-K weer aan.

De afloop van de historie die volgde, laat zich zonder moeite voorspellen. Het voortbestaan van de gedachtenkoning moest wel meebrengen dat werkelijke personen zouden trachten zijn troon te bezetten. Een leer met vreselijke gevolgen. De. Franse Revolutie had vol goede moed het woord bevrijd en stond prompt versteld van de uitwerking. Men had verwacht dat diskussie spoedig zou leiden tot onthulling van de redelijke. waarheid, die dan bij unanimiteit zou worden aangenomen. Aan een welwillend verdragen van tegenspraak werd niet gedacht, ieder voor zich meende de onfeilbare algemene wil te verwoorden. Zeer sterk was deze denktrant bij Maximilien Robespierre, niet voor niets later de sterke man van het Schrikbewind. Debat? Robespierre zette ware beginselen uiteen, wie eerlijk dacht zou hem gelijk moeten geven. De dreigende ondertoon is niet mis te verstaan: ${ }^{\text {so }}$

\footnotetext{
"Quand j'aurai terminé ... je suis sûr que M.Guadet se rendra lui-même à mon opinion; j'en atteste et son patriotisme et sa gloire. choses vaines et sans fondement, si elles ne s'appuyaient sur les vérités imnuables que je viens de proposer."
}

Tijdens de Engelse burgeroorlog waren er wel geweest die ieder spreken van 's konings onschuld als verraad wilden straffen; zo wilde Robespierre al niet hebben dat de natie. koning Lodewijk XVI een eerlijk proces gunde. ${ }^{37}$ Een rechter zou aanvangen met de veronderstelling dat Lodewijk onschuldig was, en de argumenten waarmee advokaten

54.

55. Rousseau, Contrat social IJ.3.

56. Talmion. Tot, democracy 81.

57. Wedgwood, Charles I, blz. 20; vgl. Roberts 320; Maximilien Robespierre, "Sur le parti à prendre à l'égard de Louis XVI". 3 december 1792, in Choix de rapports, opinions el discours prononcés à la tribune nationale depuis 1789 jusqu'à ec jour; recucillis dans un ordre chranologique et hisıorique $X$, Parijs 1820, blz. 219-220. 
hem zouden verdedigen, zouden omgekeerd de Revolutie veroordelen: Robespierre beeschouwde zelfs dat als blasfemie, een lastering van het volk.

De waarheid van de rede sprong in het oog; wie zich verweerde deed dat tegen beter weten in, een boosaardig mens. Verdachten dienden voor de rechter meteen hun schuldd toe te geven; ze waren in naam van het volk aangeklaagd, ontkennen stond gelijk aann verraad. Het geloof in de eigen waarheid riep achterdocht en verdachtmakingen op, want als de werkelijkheid zich niet naar de leer gedroeg, kon dat alleen door opzettelijkee tegenwerking komen. Men had, dankzij de Schotse ekonoom Adam Smith, zekeree kennis van de ekonomie; een sluitende redenering garandeerde dat prijzen op de vrijee markt in evenwicht zouden raken. Maar de prijzen vlogen omhoog, maatregelen waren 1 vereist. Hoe kon dat? Een uitgemaakte zaak: Er was misdaad in het spel. ${ }^{58}$

De stem van het volk, het hoogste gezag, werd sluitsteen van de samenleving. Voor off tegen het volk besliste over vriendschap of vijandschap: "Depuis que le peuple françaiss a manifesté sa volonté tout ce qui est hors le souverain est ennemi." 59 Maar net alss het koninklijke gezag, dat stukbrak op de eis van absolute waarheid, verloor de werke- lijke en tastbare volkswil, die uit stemming zou blijken, alle recht op gehoorzaambeid] zodra ze niet meer strookte met de redelijke waarheid. "Car le pouvoir de la majorités

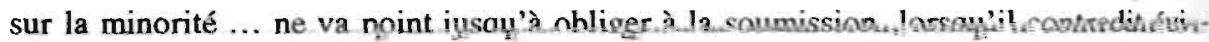
dernment la raison:" rechter miet zijn.

De: Franse Revolutie werd opgevat als vorbede van de nituwe tijht scharnier indie historighe omwentelng wan kortzidigheid on onderinkiking naar wetersetrapnelik

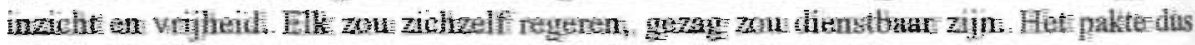
anders: wit: ${ }^{\text {a }}$

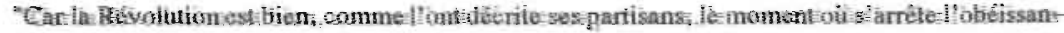

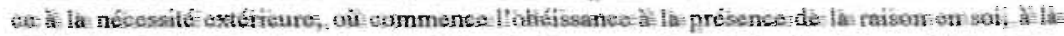

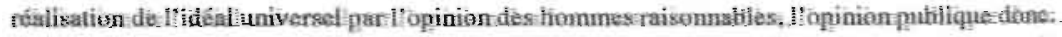

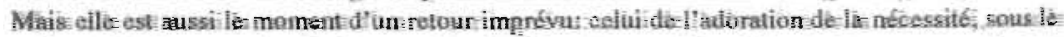

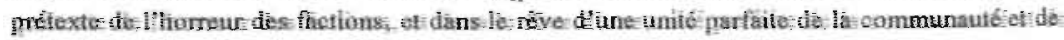

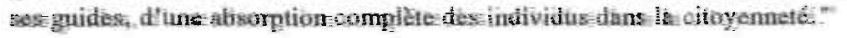

Het gelcof in de volkswil hidu met de- Frane Revolute net opn Een Emanam beweer-

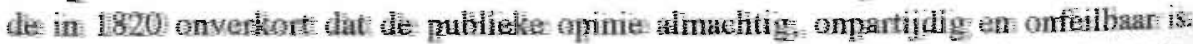

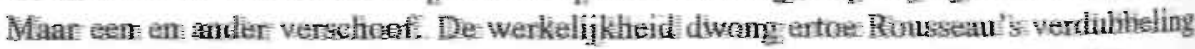

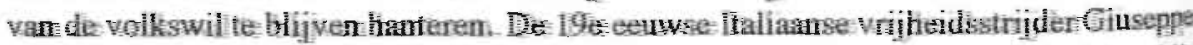

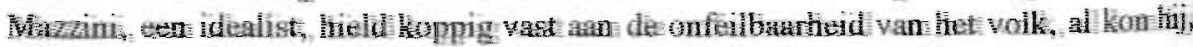

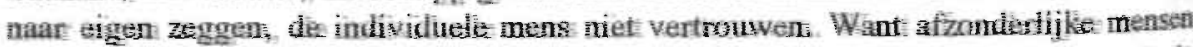
vergissen zach of misleiden zolfs hur medtomensen; het ondeelhare: volk evenwel, de

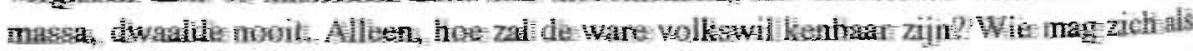

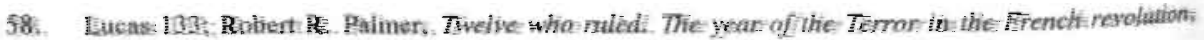
toumps 1941), Prineaion 1970 ; biz: 70 :

59. Taimon. The dimovacy : 12 .

60: Baker 499: Vgil hierboven, biz: I08 nt. 18 .

61. Baker 431 . 
haar vertegenwoordiger opwerpen? Wie anders dan een levend wezen, een mens van vlees en bloed? ${ }^{62}$

Talmon heeft de uitkomst laten zien. Rousseau gleed er al naar af, de Franse Revolutie gaf in theorie en praktijk aanzetten, en in de 19e eeuw werd de konklusie openlijk getrokken. Een verlichte voorhoede, beter nog, een enkeling, een geniale geest zou doorzien wat het volk eigenlijk behoeft en wil, hij zou eenworden met de volksgeest en haar verwerkelijken. Een Leider. Claude Henri de Saint-Simon, publicist over sociaalpolitieke zaken, deswege als voorloper van de sociologie geboekt, schreef dat een persoon de leiding op zich moet nemen van het voortdurende proces waarin de volkswil zich openbaart. De leider weet waarheen het gaat; hij belichaamt de groeiende waarheid, hij is "loi vivante", de wet in persoon. ${ }^{63}$

Weinig jaren later trad in Frankrijk een man op die beweerde zo'n levende wet te zijn, uitdrukking van de volkswil, regerend in het zuivere belang van alle maatschappelijke klassen. Lodewijk Napoleon, een neefje van de grote Franse keizer Napoleon Bonaparte, kwam kort na 1848 door een overweldigende stembusoverwinning aan de macht. Geen grootse persoonlijkheid; de meerderheid der Franse kiezers schaarde zich achter hem om de roem van zijn oom. Hij mat zich in 1852 de titel van keizer aan: Napoleon III. Het is de plicht van iedere regering, had hij eens geschreven, om verkeerde ideeen te weerstaan en ware ideeen te bevorderen. ${ }^{64}$ Een diktator in de modeme zin des woords; de eerste totalitaire heerser. Van ziju slag zouden er nog heel wat volgen.

We hoeven het totalitarisme hier niet uitvoerig te bespreken. Levend aan het einde van de 20e eeuw, kennen we de eigenschappen ervan helaas maar al te goed. Eén ding: de pretentie van absolute waarheid. Geloof in het eigen gelijk is een vast bestanddeel van de totalitaire gedachtenwereld, in fascistische en in kommunistische stelsels. Hetzij de leider, betzij de partij heeft volledige waarheid in een vast en zeker bezit. Nog maar kort geleden vertelden affiches het Oostduitse volk: "Die Lehre von Marx ist allmāchtig, weil sie wahr ist!" 65 George Orwell, die heel het moderne totalitarisme samenvatte in de benauwende verbeelding van zijn roman Nineteen eighty-four, wist ook dit aspekt te plaatsen. De regerende partij bazuint oorverdovend uit dat ze, met name in haar voorman Big Brother, over onfeilbaarheid beschikt. ${ }^{\text {to }}$

\footnotetext{
-At the apex of the pyramid comes Big Brother. Big Brother is infallihle and all-powerful. Every success, every achievement, every victory, every scientific discovery, all knowledge, all wisdom, all happiness, all virtue, are held to issue direcily from his leadership and inspiration."
}

\section{$\S 6$.}

En wij denken aan Italiē in de jaren dertig: Mussolini ha sempre ragione. Het rode draadje van de onfeilbaarheid heeft ons dus uiteindelijk van de oude koningen naar de

\footnotetext{
62. Furet/Ozouf 423: Talmon, Pol. messianism 258.

63. Talmon, Tot democracy 49, 209; Pol. messianism 260.

64. Talmon, Pol. messianism 490-49I.

65. Ewald Lang, Wendehals und Srasi-Laus. Demo-Sprïche aus der DDR, München 1990, blz. 26.

66. George Orwell, Nineteen eighty-four, in Complete works IX, blz. 216.
} 
moderne totalitaire heersers gebracht. Toen onfeilbaarheid bij de politieke leiding, nu onfeilbaarheid bij de politieke leiding. Toen de vorst een lex animata, nu de leider een levende wet. Toen de vorst uitgangspunt van alle welzijn in de gemeenschap, en nu net zo de leider, of de partij. Toen en nu dacht men in politieke vrijheid te leven; want het kan redelijkerwijze niet als een aantasten van vrijheid worden beschouwd wanneer het staatshoofd, hetzij koning hetzij diktator, zorg draagt dat zuivere waarheden in de samenleving onbelemmerd heersen.

Nog een belangrijke gevolgtrekking: Het is blijkbaar onvoldoende een streven naar politieke demokratisering gelijk te stellen met strijd tegen koningen. Vorsten moesten de les leren dat zij feilbaar waren, hun waarheid wankel; maar onderdanen hadden niet minder neiging hun gelijk boven twijfel te verheffen, en moesten niet minder wennen aan de gedachte van eigen feilbaarheid. Formele, uiterlijke aanpassing van het staatsbestel kon daarom demokratie niet voorgoed vestigen. Wanneer de pretentie van onaantastbare waarheid bleef heersen, werd spoedig de gelijkhebber weer machthebber, ondanks, nee door kiesstelsels, rationaliteit, leringen van volkssoevereiniteit heen.

Maar wat betekende nu, in dit verband, het Engelse gezegde The King can do no wrong? Kunnen we haar tenslotte eenvoudig op één lijn plaatsen met de fascistische leus Mussolini ha sempre ragione, beide uitdrukking van de leer van onfeilbaar staatsgezag? Blackstone en Thorbecke als bondgenoten van de absolute monarch en de diktator? We zagen bij Blackstone hoe hij letterlijke onfeilbaarheid afwees; een geheimzinnige schakeling van gedachte $\mathrm{kwam}$ tussenbeide, de splitsing van de vorst in koning-met-een-kleine$\mathrm{k}$ en Koning-met-een-grote-K, de koning als levende en feilbare aardbewoner, mens als wij, en de koning als beeld van eeuwige waarheid. Wat was de zin van deze eigenaardige splitsing, wat haar herkomst? Ik denk aan het volgende, theoretische, wijsgerige probleem.

Het is goed, werd hierboven vastgesteld, dat geen algemene overkoepelende waarheid bestaat, want ze zou de menselijke vrijheid belemmeren; alleen bij afwezigheid van elke absolute waarde kan de mens zich volkomen vrij, en alleen dan verantwoordelijk weten. Dan alleen wordt ieder mensenleven, ja heel de wereldgeschiedenis iets om trots op te zijn. Mensen willen hun lot in eigen handen nemen, ze willen zichzelf zijn en een betere wereld bouwen. Een heldhaftige historie! Het onvermijdelijke gebrek aan zekerheid boezemde Lessing en Nearing daarom geen vrees in; de Duitser en de Amerikaan hebben het begroet als voorwaarde van menselijke waardigheid.

Toch dringen zich vragen op. Laat de geschiedenis der mensheid, laat het leven van individuele mensen een zoeken naar waarheid wezen, een spel van vinden en vergissen. Relativisme als enig uitgangspunt. Welke zekerheid hebben we dan dat er vooruitgang zal worden geboekt? Waarom niet een teruggang, of een gesloten cirkel? Naar welke maat kunnen we het meten? Wie garandeert dat vergissingen ons vooruit helpen? Hoe of wanneer zou onweerlegbaar duidelijk worden of een maatregel juist was? Waaruit zou ooit blijken of onze inspanningen worden beloond?

Het probleem is vooral voelbaar in de politiek: Juist de overheid, met haar enorme inzet van machtsmiddelen, kan niet buiten de eis dat alles naar recht en waarheid zal geschieden. Marar het relativisme maakt elke rechtvaardiging van overheidsoptreden twijfelachtig. Hoe geloofwaardig de argumenten ook waren, een ogenblik later zullen wij wellicht de waarheid van het tegendeel ontdekken. Op welke grond valt te bepalen of de over- 
heid het recht aan de zijde heeft? En hoe zou een burger nog verzet kunnen aantekenen tegen het beleid, zonder een gemeenschappelijk en betrouwbaar kriterium waarop hij zich kan beroepen?

In onze eeuw had Bertrand Russell, groot logikus, schrijver over van-alles-en-nog-wat, allerminst een gelovige, toch veel moeite met de skepsis die hij bij David Hume aantrof. Is er geen duidelijk verschil tussen waar en onwaar, dan verdwijnt elke norm, elk onderscheid tussen goed en slecht, zin en waanzin. Er zou een wirwar van meningen zijn, zonder reële mogelijkheid zinvol te kiezen. We kunnen slechts afwachten welke de overhand krijgt. Van de staat kan geen leiding uitgaan, want daar is evenmin vaste kennis. Het gezaghebbende optreden van de overheid vervalt omdat geen enkele rechtvaardiging van haar ingrepen overal en altijd zal gelden. Zonder vaste maatstaf wordt het handelen van de staat willekeur, pure overmacht. ${ }^{67}$

"The lunatic who believes that he is a poached egg is to be condemned solely on the ground that he is in a minorily, or rather - since we must not assume democracy-- on the ground that the government does not agree with him. This is a desperate point of view, and it must be hoped that there is some way of escaping from it."

Absolute waarheid brengt de vrijheid in het nauw; een dialoog met degene die gerechtigheid belichaamt is ondenkbaar, alleen gehoorzaamheid blijft over, alle ruimte voor eigen ontplooiing van waarden valt weg. Maar indien we, anderzijds, de gedachte van algemene waarden vaarwel zeggen, dan verliest het morele oordeel elk bestaansrecht. Ieder zoekt zichzelf een weg, niemand vait enig verwijt te maken, iedereen mag alles. En we weten wel hoe dat afloopt: De sterkere wint. Zonder het beroep op een algemeen geldende gerechtigheid hebben we geen moreel verweer tegen misdadigers en machtigen. Ons rest geen andere uitweg: We moeten sterker zijn dan zij. Tegen het recht van de sterkste kunnen we maar één ding inbrengen, zelf de sterkste te zijn. Kan het gezag zich niet beroepen op hogere normen, dan is het eigenzin, willekeur, overmacht.

We worden aldus opgescheept met een buitengewoon lastig dilemma: Hogere normen bestaan niet, maar we kunnen er niet buiten; absolute waarheid is onmogelijk én onmisbaar. Een dilemma dat, naar mijn inzien, precies de splitsing van de onschendbare monarch dekt en verklaart. Kan gezag buiten een verwijzing naar hogere normen? Ontoelaatbaar, vond ook de staatsman en historikus François Guizot; deze Guizot, in 1848 minister-president van Frankrijk en toen door de revolutie ten val gebracht, hield enkele jaren eerder in een lezing zijn toehoorders voor dat soevereine macht moet samengaan met rede, waarheid en recht. ${ }^{\circ 8}$

\footnotetext{
"Concevez, je ne dis pas un peuple, mais la moindre réunion d'hommes: concevez-la soumise à un souverain qui ne le soit que de fait, à une force qui n'ait aucun droil que celui de la force, qui ne gouverne pas à tilre de raison. de justice. de vérité; à l'instant la nalure humaine se révolte contre une telle supposition: il faut qu'elle croie au droit. C'est le souverain de droit qu'elle cherche. c'est le seul auquel l'homme consente à ohéir."
}

67. Bertrand Russell. A history of Westem philosophy and its connection with political and social circumstances from the earliest times to the present day, New York 1945. blz. 073.

68. Guizot 171 . 
De 19e eeuwse politikus Guizot viel dus de 20 e eeuwse filosoof Russell bij: Gezag zonder recht is macht; het mag geen aanspraak maken op gehoorzaamheid. En een tijdgenoot van Guizot, een Nederlander, schreef, in 1841:

"Een persoon kan de hoogste magt slechts onder de voorwaarde bezitten, dat hij regt doe."

Johan Rudolf Thorbecke. ${ }^{69}$ Degene die heel Nederland nog de baas is als grondlegger van het huidige staatsbestel; degene die dit onderzoek beheerst omdat hij artikel 53 in de grondwet van 1848 zette. Gezag móet rechtvaardig zijn, of het zal niet zijn. Ligt dit probleem achter Blackstone's uitleg van The King can do no wrong, en achter de eigenaardige tweedeling van de vorst in koning-met-een-kleine-k en Koning-met-een-grote-K? Het wordt duidelijk zodra we heel de passage, Thorbecke's eigen woorden bezien:

\begin{abstract}
"Wanneer de Engelschen zeggen: de Koning kan niet dan goed doen: strekt dit niet tot waarborg bovenal van den persoon des Konings, maar van het regt en den Staat. Het beteekent niet, al wat de Koning doet, is regt; het beteekent, waar onregt is gehandeld, handelde de Koning niet; het koninklijk individu, dat onregt pleegde. houdt op Koning te zijn. Een persoon kan de hoogste magt slechts onder de voorwaarde bezitten, dat hij regt doe."
\end{abstract}

In 1846 werden deze zinnen met verve aangehaald door de advokaat Boissevain, bezig zijn kliënt Karel van Hulst vrij te pleiten van een aanklacht wegens majesteitsschennis. Een misdadige koning kon geen Koning meer zijn, want de koning is beeld Gods op aarde, vertegenwoordiger van waarheid en goedheid, levende wet. Boissevain hanteerde alle oude termen, volop. Hij haalde Guizot aan; de onschendbare koning is volstrekt niet een enkele mens, maar bij is de redelijkheid, rechtvaardigheid en onpartijdigheid zelve: ${ }^{\text {to }}$

"La royauté est tout autre chose que la volonté d'un homme, quoiqu'elle se présente sous cette forme. Elle est la personnification de la souveraineté de droit, de cette volonté essentiellement raisonnable, éclairée, juste, impartiale, étrangère, et supérieure à toutes les volontés individue!les, et qui, à ce titre, a droil de les gouvemer."

Boissevain vervolgde: ${ }^{71}$

-Het is op dien grondslag, op het wezen, op de natuur van het koningschap zelve dat zijne onschendbaarheid rust; als de personificatie van den eeuwigen, onveranderlijken, regtvaardigen wil, die alleen regt heefl op de heerschappij over de menschheid, is daadwerkelijk het axioma toepasselijk: De koning kan geen kwaad doen; hetgeen niet zeggen wil dat het koninklijk individu geen onregt kan doen; het beteekent، waar onregt is gehandeld, handelde de koning, qua ralis, niet."

En werkelijk, het dilemma van rechtvaardige staatsmacht en menselijke feilbaarbeid sluit onmiddellijk aan bij de juridische interpretatie van de koninklijke onschendbaarheid:

69. Aanteekening $I, 110$.

70. Guizot 170.

71. De staatkundige rooverlanaam, of uropisch-politische snelwagen. Rijdt af bij K. van Hulst $u$ Kampen. 1846 , deel II, blz. 42 . 
langs een grote omweg zijn we teruggekeerd bij Bracton, Blackstone en Buys: Het koningschap was goed bedoeld, de falende koning valt buiten die bedoeling en is dus ipso facto geen koning! Gezag dient onveranderlijk het goede te doen, of het mag geen gezag heten; maar geen mens is uitsluitend goed en als iemand het wel kon zijn, dan zou zijn feilbaarheid nog maken dat hij dikwijls het verkeerde bewerkt. Een riskante balans tussen onzekerheid en vastheid, die prachtig werd gevangen binnen het The King can do no wrong, de precieze scheiding tussen ideale monarch en levende persoon.

Het probleem van de rechtvaardige en toch feilbare staatsmacht moet wel oud zijn, en wie weet onoplosbaar. Het is oud; we herkennen het moeiteloos bij de $14 \mathrm{e}$ eeuwse Italiaanse jurist Baldus, in zijn uitspraak dat degene die het recht bedeelt somtijds kan dwalen, maar de gerechtigheid zelf nooit: ${ }^{2}$

"Ius enim reddens quandoque errat, sed iustitia nunquam errat."

Baldus kon niet anders dan in dezelfde adem de keerzijde erkennen, "quod ratio et iustitia sine persona nihil agit". Natuurlijk: Het mag waar zijn dat recht en rede op zichzelf, los van aardse bezoedeling, eeuwig ongeschonden glanzen; maar even zeker is dat ze, zonder een persoon die ze hier in levenden lijve wil uitdragen, op aarde alle uitwerking missen. Mens en norm zijn tot elkaar veroordeeld: Zonder norm is het menselijk handelen louter macht, zonder menselijk ingrijpen is de norm werkeloos. Alleen de zuivere norm mag maatstaf zijn; maar de maatstaf werkt pas wanneer ze in de wereldse werkelijkheid wordt aangelegd; en zodra ze daar werkzaam wordt, door bemiddeling van feilbare mensen, raakt ze onvermijdelijk besmet, tot onherkenbaar wordens toe.

Baldus schreef, kun je zeggen, voor het hoogtij der Europese koningen; een bevestiging dat het morele dilemma, de wrijving tussen vaste norm en menselijke zwakheid, van alle tijden is. Daarenboven kan hier het vermoeden dagen van nog een andere vertakking van het dilemma, en dan uit de tijd dat de koningen in Europa op hun retour waren. Het beeld van de onschendbare koning als redelijkheid, rechtvaardigheid, het wezenlijke koningschap; eeuwig, afgezonderd van de levende vorst; een abstraktie: Het roept vroegere hoofdstukken in herinnering, waar werd besproken hoe een gedachtending, de staat, zich losmaakte van de persoonlijke koning; de staat was een "Hieroglyphe der Vernunft", ontwerp van de rede, die daarin voortaan de idee van menselijke gemeenschap, van juridisch geordende samenleving kon begrijpen. Strookt het onderscheid tussen koning-met-een-kleine-k en Koning-met-een-grote-K misschien met de historische scheiding tussen vorst en staatsgedachte?

We herlezen Thorbecke's woorden: Het koninklijk individu kan onrecht doen, maar het recht en de staat niet. En Boissevain's verheven bewoordingen, ontleend aan Guizot, hebben herkenbiar de toon van Hegel; de filosoot die met zijn zware denken in belangrijke mate het moderne staatshegrip heeft gevormd. De vorst, leerde Hegel, belichaamt de eenheid van de staat, maar meer nog, hij is in die koninklijke hoedanigheid onttrok- 
ken aan de gemoedsbeweging en de wisselvalligheden van het aardse bestaan. Een teken van eeuwigheid: ${ }^{73}$

"... diese Idee des von der Willkühr Unbewegten macht die Majestät des Monarchen aus. In dieser Einheit liegt die wirkliche Einheit des Staats ... Die Majestãt besteht darin dass sie ūber alle Leidenschaft und Willkühr erhaben ist, sie ist so diese Einheit des Staats."

De staat, een theoretisch begrip, met al haar zuiverheid, kon uitsluitend in het denken bestaan. Ze diende echter tot tastbare werkelijkheid te worden, met aanwijsbare gevolgen in de wereld om ons heen. Een monarch kon als persoon de abstrakte staat handen en voeten geven. Met andere woorden, uit een leerboekje staatsrecht van de Heidelbergse universiteit, $1841:^{74}$

\begin{abstract}
"Der Souverain ist das Subject, in welchem die Staatsgewalt personificirt wird -- er ist also der Repräsentant des allgemein vernünfligen auf die Realisierung des Staatszweckes gerichteten Willens. Mit der Anerkenumg eines Individuums ... als Subject der Staatsgewalt, erhält erst der Staat practische Realität-d.h. er tritt aus der Sphäre der Gedanken in die reihe der (historischen) Erscheinungen."
\end{abstract}

Alsof er in de eeuwen tussen Baldus en Hegel niets was veranderd. Baldus zat met het probleem dat de zuivere en onvergankelijke iustitia moest worden verwezenlijkt door tijdelijke en feilbare aardbewoners; net zo kon de begripsmatige zuiverheid van de redelijke staat pas op de wereld inwerken wanneer lichamelijke beambten haar wilden vertegenwoordigen. Het lijkt niet teveel gezegd: De staatsgedachte is erfgenaam in rechte linie van de Koning-met-een-grote-K.

Lang geen onaardige vondst; maar ze dwingt tot een forse herziening van eerdere uiteenzettingen in dit boek, en ze doet allerlei vragen rijzen. Twee hoofdstukken terug, het traditionele verhaal van de Europese demokratisering, werd de staatsgedachte opgevoerd als een van de vijf vorstenbedwingers: volkswil, rechtsstaat, machtenscheiding, ministeriële verantwoordelijkheid, staatsgedachte. Het abstrakte begrip van de staat zou dan niet al te lang geleden moeten zijn gevormd, in antwoord op de macht en willekeur van de absolute monarchen. Maar nu. De staatsgedachte ontspringt uit een eeuwenoud wijsgerig probleem; heeft ze dan altijd bestaan, sluimerend misschien? We herinneren ons de leer van het Engelse Parliament, uit 1642, vlak voor het uitbreken van de vijandelijkheden met koning Karel I: ${ }^{75}$

-... for the King, by his sovereignty, is not enabled to destroy his people, but to protect and defend them: and the High Court of Parliament, and all other His Majesty's officers and ministers, ought to be subservient to that power and authority which the law hath placed in His Majesty to that purpose, though he himself, in his own person. should negleet the same."

Een weerlegging van koninklijke almacht, meenden we. De soevereiniteit blijkt thans echter niet meer dan een ander woord voor bet absolute gelijk van de parlementaire

73. Hegel, Vorlesingen 1818-1831. blz. 679, 681 .

74. Zoepfl 42.

75. Gardiner 257: hierboven, blz. 57 . 
partij; een smoesje natuurlijk, vult de hedendaagse historikus aan, waardoor het parlement straks kon volhouden niet tegen maar voor de koning te strijden. Beroep op de Koning-met-een-grote-K. Was het nieuw in 1642? Drie eeuwen eerder, in het jaar 1308, hebben Engelse edelen hun koning Edward II het onderscheid tussen kroon en koning, ambt en persoon, reeds in klare termen voorgehouden: ${ }^{76}$

\begin{abstract}
"Homage and oath of allegiance is more by reason of the crown than by reason of the king's person and is more bound to the crown than the person ... wherefore if the king by chance be not guided by reason, in the right of the crown, his lieges are bound by oath made to the crown to guide the king and the estate of the crown back again by reason, and otherwise the oath would not be kept."
\end{abstract}

Een onmiskenbare echo. De twee citaten zijn van gelijke strekking, het valt niet mee tussen beide verschil of ontwikkeling te bespeuren. Er zijn aanwijzingen dat de ouderdom van het beginsel nog veel verder terug reikt, ruim voor de tijd der Engelse monarchie. De Romeinse geschiedschrijver Tacitus wordt genoemd. En de Franse bisschop Bossuet, die in 1662 zijn koning een god noemde, deed dat in navolging van een psalm in de bijbel: "Gij zijt goden". De tekst gaat door: "Nochtans zult gij sterven als een mens", en Bossuet legde uit dat de koningen mens, en sterfelijk zijn, maar het koningschap eeuwig duurt. Werd reeds in bijbelse tijden op de koning-met-een-kleine-k en de Koning-met-een-grote-K gezinspeeld? $\pi$

Wat is de oorsprong van het onderscheid? Als we zo ver moeten teruggaan in de wereldgeschiedenis, zal het moeilijk zijn een historisch antwoord in de bronnen te vinden. Trouwens, als het onderscheid een algemeen menselijk moreel dilemma uitdrukt, zoals nu aannemelijk genoeg lijkt, dan hebben we nauwelijks behoefte aan een historisch antwoord; liever een theoretisch antwoord: Niet de vraag wie het wanneer heeft bedacht, maar hoe het wordt bedacht, en waarom. Welk doel wordt met het splitsen van de onschendbare koning gediend? De kunstgreep, hoe vernuftig ook, kan slechts machteloos de onopgeloste problematiek weerspiegelen, en maakt uiteindelijk de onvoorwaardelijke eis dat onze koning nimmer kwaad doet tot een woordenspel. In de aanhaling van Thorbecke, kort geleden, wordt de zinloosheid voor elk zichtbaar: De persoon van de koning kan weliswaar verkeerd doen, het recht en Je staat niet. Wat flauw: De onfeilbare koning is de staat, is Koning-met-een-grote-K, en is dus gewoon hetzelfde als de eeuwige gerechtigheid; vanzelf dat hij nooit ofte nimmer verkeerd doet!

Een andere moeilijkheid. We hebben de regel der koninklijke onschendbaarheid oorspronkelijk opgevat als een middel tegen hoogmoedige koningen; streven naar demokratie, een beginsel van de moderne tijd. Toen als vast kenmerk van de absolute koningen; in de modeme tijd juist verdwenen. Moeten we het vervolgens gaan zien als een regel die altijd en overal geldt, geen land of periode uitgezonderd, onafhankelijk van grondwettelijke afkondiging? Wat blijft over van de demokratische betekenis van artikel 53 van de grondwet van 1848? Weinig? Niets? Sterker nog, het tegendeel? George Orwell vond voor zijn spookstaat Nineteen eighry-four, toppunt van totalitarisme, woor- 
den die ons, aan het einde van dit hoofdstuk, in de oren klinken als een woordelijke vertaling van het befaamde grondwetsartikel: ${ }^{78}$

"For the secret of rulership is to combine a belief in one's own infallibility with the power to learn from past mistakes."

Hoe kan dat? Waar blijft het verschil tussen diktatuur en parlementaire demokratie? Een kort weerwoord lijkt afdoende. In een fatsoenlijke parlementaire demokratie heerst de onfeilbare monarch, maar hij regeert niet. Alle macht werd hem ontnomen. Regeren en rechtspreken gebeurt enkel in zijn naam, terwijl de pretentie van onfeilbaarbeid geen daadwerkelijke invloed heeft op de vorming van het politieke beleid. Maar weer Orwell. In 1984 beheerst de naam van een onfeilbare het openbare leven, Big Brother, de spreekwoordelijke diktator; maar hij vertoont zich nooit, niemand heeft hem gezien, het is niet eens zeker of hij leeft, kortom, hij staat als persoon buiten de politiek. De werkzaamheid van deze heerser en zelfs zijn aanwezigheid in het staatkundige proces worden strikt geheim gehouden: Is het niet alsof Big Brother regeert volgens de beginselen van 1848 , als een raadsel waarin niemand doordringt, en dat het staatsgebouw overeind houdt?

Zowel in Nederland als in 1984 heerst de onschendbare, en regeert niet. Om vrijheid en volksregering? Nee, maar om de grondslag van het menselijke bestaan. De onschendbare kán niet regeren, omdat hij onfeilbaarheid is; en onfeilbaarheid heeft op dit ondermaanse geen plaats. De onschendbare koning verliest zijn macht, niet door demokratische ontwikkeling, maar door de innerlijke noodzaak van zijn karakter. De vorst kan niet handelen omdat elk van zijn handelingen zou worden meegetrokken in de bevlekte feilbaarheid van al het aardse. Geen handigheid zal ons verheffen boven de feilbaarheid; de onfeilbare vorst kan niet meer zijn dan waarnemer van het politieke gebeuren. Guizot sprak het in 1840 , Boissevain haalde het in 1846 aan: ${ }^{70}$

"Quels sont les caractères du souverain de droit. les caractères qui dérivent de sa nature même? D'abord il est unique; puisqu'il n'y a qu'une vérité, une justice, il ne peut y avoir qu'un souverain de droit. Il est de plus pernanent, toujours le même: la vérité ne change point. Il est placé dans une station supérieure, étrangère à toutes les vicissitudes, à toutes les chances de ce monde; il n'est du monde en quelque sorte que conme spectateur et comme juge: c'est là son rôle. Eh bien! Messicurs, ces caractères rationnels, naturels du souverain de droit. c'est la royauté qui les reproduit extérieurement sous la forme la plus sensible, qui en paraît la plus fidele image."

Vroeger, in de inleiding van dit onderzoek, werd onder andere gevraagd naar de onmacht van de moderne konstitutionele monarch. Waarom werd hij roi fainéant, en hoe heeft het grondwetsartikel van 1848 dat bewerkstelligd, indien de onschendbaarheid toen niet is ingevoerd? De juridische onschendbaarheid met haar uitwerking in formele onfeilbaarheid droeg in het vorige hoofdstuk een antwoord aan: De formele onfeilbaarheid van een aardse en dus feilbare persoon is uitsluitend aanvaardbaar op voorwaarde 
dat die persoon geen werkelijke macht heeft. Thans, in de derde versie van het verhaal der koningen, ontdekken we een nieuw antwoord; maar in het verlengde. De onwerkzaamheid van de monarch ontstaat uit de diepere zin van zijn aanwezigheid. Hij verbeeldt materiēle onfeilbaarheid, terwijl die nu eenmaal op aarde onbestaanbaar is; hij verbeeldt volmaaktheid, en kan daarom nooit anders dan verbeelding zijn.

De onschendbare koning als noodzakelijk afwezige. Zo dan maar? Zullen we het daarbij laten? Onmogelijk! We stelden vast dat absolute waarheid niet mag bestaan, want ze zou de menselijke vrijheid en waardigheid verdrukken; maar niet alleen dat. Geheel tegenstrijdig en even klemmend, kunnen we niet buiten hogere waarheid, want zonder haar zijn we niet bij machte het recht van de sterkste te weerleggen. De wereld zou een normloze strijd van allen tegen allen zijn, en nimmer meer. Een hogere, bovenmenselijke waarde, absolute waarheid, is tegelijk onontbeerlijk en onmogelijk, noodzakelijk en onhaalbaar. The King can do no wrong omvatte juist dit nijpende dilemma.

In het vorige hoofdstuk, een vergelijkbaar geval. Het onschendbare gezag van de koning, sluitsteen van de orde, stond geen oordeel door anderen toe, want het zou onmiddellijk ophouden koninklijk gezag te zijn. Toch moest de koning, niet minder feilbaar of geneigd tot het verkeerde dan zijn onderdanen, op een of andere manier worden gemeten en gebonden aan hogere normen. Het bestaan van een onweerlegbaar hoogste gezag was enerzijds noodzakelijk, anderzijds onmogelijk. Opnieuw een cirkel; ze werd glorieus doorbroken door de uitkomst van de ministeriële verantwoordelijkheid.

Twee duidelijk verwante problemen, het ene voortgebracht door de aard van het hoogste gezag, het andere door de aard van ware kennis; en tweemaal artikel 53 van de grondwet van 1848 als oplossing. Toeval? Maar welke samenhang valt aan te wijzen? We blijven zitten met in elk geval twee tweedelingen: koning en minister, en Koning-meteen-grote-K en koning-met-een-kleine-k; we hebben er bovendien meer gezien: staat en koning, soevereiniteit en koning, koningschap en koning, kroon en koning. Komen ze overeen, overlappen ze, zijn ze identiek? Waar zijn ze goed voor, wat is hun funktie? Waar bleef, in dit hoofdstuk over de materiële onfeilbaarheid, de verantwoordelijke minister? Een rommeltje!

Toch: We vorderen. De eerste vraag van het boek was de vergelijking tussen The King can do no wrong en Mussolini ha sempre ragione; langs allerlei omwegen, wijsbegeerte, onfeilbaarheid, Orwell, naderen we langzaam maar zeker tot een beter begrip van de gelijkenis. De achterdocht dat ze maar blinde toevalligheid was, vervaagt. En we lazen in de inleiding hoe Thorbecke, zonder het te verhelpen en kennelijk zonder het te merken, onschendbaarheid van de persoon des konings en van de staat verwarde; een verwarring die na dit hoofdstuk begrijpelijker is, zij het niet volledig verklaard.

Tenslotte een andere merkwaardigheid uit de inleiding. In het vorige hoofdstuk werd de eis gesteld dat het koninklijke gezag onverkort en toch toetsbaar zou zijn. We kennen nu een dergelijk dilemma: Zou in de wereld onfeilbare kennis bestaan, dan benam haar heerschappij ons noodzakelijk én onze vrijheid én onze verantwoordelijkheid, dat is, ons recht zélf te toetsen. Een "dergelijk" dilemma? Veeleer precies hetzelfde. Een hoogste gezag is noodzakelijk en onmogelijk; ware kennis, noodzakelijk en onmogelijk. En we denken nog eens aan de ogenschijnlijke kronkel, onder andere bij Thorbecke, van de minister die ondanks zijn ondergeschiktheid en plicht tot gehoorzaamheid toch verantwoordelijk kan worden gehouden. Een vereniging van tegengestelden, coincidentia 
oppositorum; wellicht is zij toch inderdaad geen sullige ondoordachtheid, maar een diep. zinnige vondst geweest.

Het wordt tijd voor een overgang. Drie hoofdstukken over de koning achter de rug; drie versies van het verhaal der onschendbaarheid. Thans volgen weer drie hoofdstukken drie nieuwe, met samen eén versie van het verhaal der koningen, de vierde, de mythi sche. $\mathrm{Zij}$ is de moeite waard. 
De mythe 

Hoofdstuk 5

\section{De mythe van de goede Koning}

Tijdens de $19 \mathrm{e}$ eeuw, in de nasleep van de Franse Revolutie, was konstitutionele monarchie het gesprek van de dag. Vanzelf dat telkens weer de Engelse zegswijze The King can do no wrong opdook, en juristen hadden veel werk aan het aftasten van haar betekenissen. Onfeilbaarheid kwam wel ter sprake, een mogelijke betekenis, met name omdat een wet van het Duitse groothertogdom Hessen erop scheen te doelen; in 1821 werd daar vastgelegd dat onwettige handelingen nooit van 's vorsten wil uitgingen, maar alleen op misverstand konden berusten. De Duitse jurist Robert Mohl wees deze opvatting echter in 1837 krachtig af. Het was flauwekul, die allerminst het moderne konstitutionele staatsbestel mocht grondvesten.'

\footnotetext{
"Da aber diese Ficlion von der unwandelbaren Rechtsliebe des Fürsten psychologisch absurd, nach der Geschichte aller Zeiten eine handgreifliche Unwahrheit ist, so dient sie in jeder Beziehung sehr slecht zur Begrūndung einer Staatseinrichtung, welche als der Hauptpfeiler des ganzen Systemes der beschrānkten Fürstenschaft erklärt wird."
}

Een noodzakelijke afwijzing! Geen zinnig mens kan zich onfeilbaar of altijd goed noemen en ontoelaatbaar zou zijn, dat een dergelijke pretentie tot grondslag van het staatsrecht werd. Het was ronduit psychologisch absurd, The King can do no wrong letterlijk te nemen. Mohl wond er geen doekjes om en waarom zou hij ook? Er valt niets tegenin te brengen.

Toch houdt het daarmee niet op. "Psychologisch absurd", schreef Mohl, maar wat moeten we onder psychologie verstaan? De psychologie heeft sinds de leeftijd van Mohl reusachtige vooruitgang geboekt, het meest in de 20 e eeuw; eigenlijk hoort ze als een karakteristiek voortbrengsel in onze eeuw thuis. Ze haalde allerlei eigenaardigs boven water, dingen waarvan de vroegere psychologie, aftreksel van rationele wijsbegeerte, nimmer had gedroomd. Niet dat de redelijke psychologie haar inzichten hoefde opgeven; die bleven van kracht, maar ze werden door nieuwe ontdekkingen in ander licht gesteld. 
Sigmund Freud, grondlegger van de psycho-analyse en ongetwijfeld de bekendste naam uit het vak, heeft het zelf aldus onder woorden gebracht: ${ }^{2}$

\footnotetext{
"Es kommt überhaupt nicht so hăufig vor, dass die Psychoanalyse etwas bestreitel, was von anderer Seite behauptet wird; sie fügt in der Regel nur etwas Neues hinzu, und gelegentlich trift es sich freilich, dass dies bisher Übersehene und nun neu Dazugekommene gerade das Wesentliche ist."
}

Ook Freud schrikte niet van een ferme uitspraak terug. Door verwaarloosde kleinig. heden hun plaats te geven zou hij het wezenlijke kunnen ontdekken? En zelfs indien het waar was: Heeft het iets van doen met Nederlandse grondwetsgeschiedenis? Vragen die hun ontkenning als het ware reeds in zich hebben. Toch wil ik een poging wagen inderdaad iets dergelijks te laten gebeuren. Een niemendalletje, een kleine verandering van gedachte zal ons aanleiding geven de historie der ministeriële verantwoordelijkheid uit een ander oogpunt te ontwikkelen, en hulp van de psychologische wetenschap is onontbeerlijk om te verstaan wat dan zichtbaar wordt.

The King can do no wrong: Het zou uiterst onverstandig zijn een staat te bouwen op het beginsel van menselijke onfeilbaarheid. Onfeilbaarheid is redelijkerwijze absurd, onwerkelijk. We hoeven Mohl in zulk opzicht niet te bestrijden, en dat blijft zo. Desondanks kan de onfeilbaarheid in de werkelijkheid binnendringen, om daar een tastbare en belangrijke uitwerking te hebben. Een hersenschim, hoe irreëel ook, heeft uiterst reële gevolgen indien de mensen hem voor waar aannemen, en ernaar handelen. Een befaamd woord van de Amerikaanse socioloog William Isaac Thomas: ${ }^{3}$

"If men define situations as real, they are real in their consequences."

Hier wordt een belangrijke stap gezet; de overstap van koele staatsrechtelijke theorie naar mythisch volksgeloof. We begonnen ons onderzoek met het traditionele beeld van koning en onschendbaarheid, de koning als uiterlijk, opgelegd gezag, dus dwang, en als zotte waan van onfeilbare wijsheid, volkomen terecht door de onschendbaarheid onschadelijk gemaakt. Maar orde en waarheid, gemeenschap en gerechtigheid zijn hoge, noodzakelijke politieke waarden; de onschendbare koning verbeeldde en garandeerde ze. Onderdanen wisten dat. $\mathrm{Zij}$ wisten dat bij het falen van de koning de wereld zou instorten, burgeroorlog, onrecht, chaos. De gedachte was huiveringwekkend en ze werd dan ook zo ver mogelijk weggeduwd, zelfs ten koste van de redelijkheid.

Als het ondenkbare toch gebeurde, de koning deed kwaad, dan konden onderdanen zich nog vastklampen aan zijn beeld, aan de waarden door hem vertegenwoordigd. Jawel, de koning handelde onrechtvaardig, maar niet de politieke orde en de waarheid, níet, met andere woorden, de Koning-met-een-grote-K. Het volk hing met hart en ziel aan de koning; maar niet aan zijn persoon. De aanhankelijkheid gold uitsluitend de Koningmet-een-grote-K, die een ideaalbeeld was in de volksbeleving; hij alleen werd onvoor-

2. Sigmund Freud, Vorlesungen zur Einführung in die Psychoanalyse. in Gesammelte Schriften VII (ed. Internationaler psychoanalytischer Verlag). blz. 38.

3. Anton C. Zijderveld, De relativiteit van kennis en werkelijkheid. Inleiding tot de kennissociologie, Meppel z.j. (1974), blz. 68. 
waardelijk gediend, en de levende koning mocht slechts op trouw rekenen zolang hij naar de indruk van zijn volk met het ideaal samenviel.

Het is een kleinigheid: de overeenkomst van The King can do no wrong en Mussolini ha sempre ragione. Het is een kleinigheid: al dan niet in onfeilbaarbeid geloven. Een kleinigheid: onvrijheid door uiterlijke machten of door innerlijke gesteldheid. Maar een kleinigheid die een diepere betekenis van de regel der koninklijke onschendbaarheid en ministeriële verantwoordelijkheid zal blootleggen, en haar aanzien ingrijpend wijzigen; de pretentie dat dan het wezenlijke tevoorschijn zou komen, zoals Freud wilde, blijve overigens geheel voor zijn rekening.

\section{$\S 1$.}

Bestaat er zoiets als een zonderling geloof aan de onfeilbaarheid van politieke leiders'? Indien we denken van wel, dan vooral omdat het $20 \mathrm{e}$ eeuwse totalitarisme ons met de neus op dit feit drukte; laten we dus daar het onderzoek naar de mythe aanvangen: Mussolini ha sempre ragione.

De Italiaanse leuze hoorde bij het beleid van de fascistische regering. Het was niemand geoorloofd te tornen aan het gezag of aan de bovenmenselijke begaafdheid van de Duce, Benito Mussolini. Vooral de jeugd kreeg van jongsaf ingeprent dat Mussolini altijd gelijk had, en de boodschap miste haar uitwerking niet. Ze verwierf een geheimzinnige macht over het denken van Italiaanse jongeren, die, reddelous aan de fascistische opvoeding overgeleverd, gedurende Mussolini's bewind werkelijk in de alwetendheid van hun leider hebben geloofd. Het blijkt uit de grote moeite die het hun soms kostte zich aan de geestelijke betovering te ontworstelden. Ugoberto Grimaldi, een jonge Italiaan, makte het mee en getuigde: ${ }^{4}$

\footnotetext{
"Mussolini was voor ons allen, geboren in het fascislische klimaat, een uitzonderlijke persoonlijkheid op wiens altaar we minstens een deel van onze jeugd offerden. We zagen hem nooit als elke gewone sterveling [maat als] een man oneindig ver boven de anderen uit. ... Van de verschillende dogma's waarmee we moesten breken om van het fascisme los te komen, was dat van de Duce's onfeilbaarheid beslist het hardnekkigste."
}

Mussolini is in zijn tijd weergaloos opgehemeld; er kwam geen einde aan de loftuitingen. Buitenlandse joumalisten vertelden dat dankzij Mussolini de treinen in Italië (een wonder) op tijd reden en dat de leider nimmer sliep, maar zonder pauzeren voor het welzijn van Italië werkte. Aan de Duce werden zelfs genezende krachten toegeschreven; een doofstomme die hem te zien kreeg herwon daardoor het spraakvermogen. Op het tijdstip van Mussolini's geboorte, zei men, waren wonderlijke dingen gebeurd; en een krant wist te vertellen dat zijn aanwezigheid eens weldadige regen over uitgedroogde woestijn zou hebhen gebracht. ${ }^{5}$

Propaganda natuurlijk, van boven bedacht en opgelegd, met steun van dreigementen. Maar niet alleen dat; de boodschap van Mussolini's onfeilbaarheid nestelde zich dieper 
in het bewustzijn dan de meest doortrapte propaganda kon reiken. Ze vond oprecht geloof. Ging Mussolini langs, dan knielden boeren in het veld; vrouwen hielden hun kinderen omhoog en vroegen een zegen: Was dit spel, enkel veinzen, afgedwongen hulde? En overtuigde fascisten verhaalden later hoe hun eerste twijfel, die door het falen van de landspolitiek onweerstaanbaar de kop opstak, ze in ernstige gewetensnood bracht. Let wel, zij vreesden niet zozeer de harde hand van hun overheid, maar werden gekweld door een besef van grote schuld. Mussolini heeft zich weliswaar aan de Italianen opgedrongen, maar zijn boodschap is deze mensen totaal eigen geworden. ${ }^{6}$

Een moeizame worsteling om het oude geloof kwijt te raken; ze is de tragische keerzijde van de blijde hoop waarmee het ooit werd omhelsd. Hoor bijvoorbeeld het optimisme, de verwachting van een betere toekomst bij Hermann Goering, trouw dienaar van de Duitse fascistische leider Adolf Hitler, Mussolini's spitsbroeder; een ware geloofsbelijdenis, uit het jaar 1934: ?

\footnotetext{
"Wenn der katholische Christ überzeugt ist, dass der Papst in allen religiösen und sittlichen Dingen unfehlbar sei, so erklären wir Nationalsozialisten mit der gleichen innersten Überzeugung, dass auch für uns der Führer in allen politischen und sonstigen Dingen, die das nationale uns soziale Interesse des Volkes angehen, glattweg unfehlbar ist. Worin liegt nun das Geheimnis seines gewaltigen Einflusses auf seine Anhänger? Liegt es in seiner menschlichen Gûte, in seiner Charakterstärke oder in seiner einzigartigen Bescheidenheit? Liegt es vielleicht an seiner politischen Begabung, die Dinge immer richtig vorauszuahnen und vorauszuschauen, oder liegt es an seinem hervorragenden Mut oder an seiner seltenen Treue seinen Gefolgsleuten gegenüber? Ich glaube, was man auch herausgreift, man wird doch schliesslich zu dem Schluss kommen, dass es nicht nur die Summe aller dieser Tugenden ist, sondern es ist etwas Mystisches, Unsagbares, fast Unbegreifliches um diesen einzigen Mann. und wer es nicht fühlt, der wird es nieht erjagen, denn wir lieben Adolf Hitler, weil wir glauben, tief und unerschütterlich glauben, dass er uns von Gott gesandt ist. Deutschland zu retten."
}

Zou dit niets dan propaganda zijn? Een schoonklinkend praatje, bedoeld om onmerkbaar mee te slepen? We kunnen het van Reichsminister Goering verwachten; trawant van Hitler, in wiens voetspoor hij opklom tot de hoogste ambten die de Duitse staat kon vergeven, had hij er alle belang bij de Duitsers een onwankelbaar geloof in de Führer aan te praten. Maar toch: Goering's woorden hebben niet de klank van listige volksmennerij. Er is daarin een ongeveinsde opluchting die ons verhindert zijn aanhankelijkheid als louter propaganda af te doen; het zjet emaar uit dat Goering werkelijk beeft geloofd aan de uitzonderlijke gaven en de goddelijke zending van zijn Führer.

Het klopt dat de Duitse fascisten, zoals de Italiaanse, de bovenmenselijkheid van bun Leider tot ontwijfelbaar dogma verhieven; leden van de Duitse nationaal-socialistische partij legden een eed af: "Der Führer hat immer recht". ${ }^{8}$ Ze hebben het de bevolking met veel lawaai en eindeloze herhaling ingestampt, en het duurde niet lang of ontkenning van hun leer werd van overheidswege bestraft. Maar de weerklank was overstelpend. Hitler's machtsovername werd vergezeld door een golf van enthousiasme; vlaggen, optochten overal, familieleden en kennissen belden elkaar op om het goede nieuws 
door te geven. Elisabeth Gebensleben, een Duitse vrouw van goede familie, ontwikkeld, uit de kring der notabelen, schreef aan haar dochter in Nederland dat ze overweldigd door emotie in een stoel was neergeploft: "Immo, weet je dat ik vandaag bijna niet zonder tranen in mijn ogen aan de man kan denken!" 9

\begin{abstract}
"Morgenavond van halfnegen tol tien uur is er een grote betoging in Berlijn, misschien wel de grootste tot nu toe, met een toespraak van Hitler. Ik wilde dat jullie die eens konden horen, dan zouden jullie ook eens een indruk krijgen van het enorme nationale enthousiasme in Duitsland. Geen keizer kan ooil méér vereerd en gehuldigd zijn, geloof ik, dan nu Hitler. ... De mensen zijn zo massaal naar de stembus gegaan dat ze in een nij moesten staan, dat is nog nooit gebeurd, en dat heeft Hitler voor elkaar gekregen. Het is gewoon niet te begrijpen wat een enorme kracht die man heeft, geestelijk maar ook lichamelijk."
\end{abstract}

Duitsland, aangeslagen door oorlog, ekonomische tegenspoed en binnenlandse onrust, zinderde onder Hitler als bij toverslag van werkzaamheid. De tijd van zorgen, zei een Duits gedichtje, was voorbij, eindelijk brak de lente aan. Alles dankzij Hitler's wonderdoende geestkracht, die zelfs de overmatige hartslag van de zieke abt Schachleiter tot rust bracht; lachend werd opgemerkt: "Der Führer kann alles; er kann auch Kranke heilen". De geboorteplaats en woonplaatsen van Hitler trokken een stoet van pelgrims aan. Stukken omheining en handjes aarde werden als kostbaarheden meegenomen. De adem van een Duitse nationaal-socialist stokte toen, temidden van een opdringende menigte, Hitler hem even aankeek en hem de hand drukte; zijn kameraden wensten hem geluk en wilden allemaal de hand schudden die door de Führer was aangeraakt. 10

Gaarne wekten leiders de indruk dat zij onvermoeibaar arbeidden in het belang van hun volk; maar door wie anders dan door de mensen zelf is deze illusie vergroot, buitensporig, tot het beeld van de leider die altijd waakt? Goering beschreef, verwonderd en blij, hoe talloze Duitsers voor Hitler's kantoor samengroepten, dag en nacht, wétende dat hij daar werkte en aan hen dacht. "

\footnotetext{
"Zu jeder Stunde des Tages und bis tief in die Nacht hinein stehen die Volksgenossen vor der Reichskanzlei. Es hält sie dort fest das Bewusstsein, dass hinter jenen Mauern und Fenstern der Führer für das Volk, für sie selbst, die da draussen stehen und warten, arbeitet. Irgendein geheimnisvoller Bann hält sie wie fest gebunden an ihrem Platz, und wenn sie glauben, nur für einen Bruchteil von Sekunden am Fenster das Bild ihres geliebten Führers erhascht zu haben, so bricht die Begeisterung los."
}

Was het misschien de opwelling van het eerste moment, zoals mensen wel vaker al te vurig hoop vatten wanneer ze menen dat een betere tijd aanbreekt? Hebben ze spoedig de werkelijkheid onder ogen gezien, het blinde geloof bijtijds laten varen? Allerminst; de mythe bleef bijna heel de periode van Hitler's heerschappij bestaan. Toen hij zijn land een oorlog aandeed en het zware tegenslagen moest verduren, hiejd men vol: De

9. Hedda Kalshoven-Brester, Ik denk zoveel aan jullie. Een briefwisseling tussen Nederland en Duitsland 1920-1949. Amsterdam 1991, blz. 139, 145, 169.

10. Kershaw 53, 61, 66; Volker Ackermann, Nationale Totenfeiem in Deutschland. Von Wilhelm I bis Franz Josef Strauss. Eine Studie zur politischen Semiotik, Klett-Cotta 1990. blz. 159.

11. Goering 58 . 
Führer weet wat hij doet. De Führer zegt dat de toestand aan het front goed is: "und dann wird das stimmen". Een korporaal schreef in 1944 dat de voorzienigheid "unseren über alles heiss geliebten Fūhrer" had beschermd tegen de aanslag van 20 juli, in bewoordingen die aan Goering doen denken: ${ }^{12}$

"Es ist nun einmal nicht aus der Welt zu schaffen, dass Adolf Hitler der Mann ist, der Europa eine neue Ordnung bringen will und vor allem auch die Freiheit aller Völker. Wic wird das Volk gejubelt haben und mit welcher Freude wird es die Nachricht aufgenommen haben, als es hiess, der geliebte Führer lebt."

Een luitenant schreef naar huis dat hij en zijn makkers geschokt het bericht van de aanslag hadden vernomen; hun overste, dat maakte hij van hem niet eerder mee, had de tranen in de ogen. Een korporaal, in augustus van dat jaar: ${ }^{13}$

"Mein Glaube an den Führer und den Sieg ist unerschütterlich, und ich wäre sehr glüeklich, wenn Du diesen Glauben durch nichts, aber rein gar nichts zu beirren. mit mir teilen könntest. Der Führer hat stets sein Wort gehalten, und er wird es heute mehr denn je tun."

Niet alleen vrouwen, ook officieren, gehard aan het front, kregen tranen in de ogen als het om de Führer ging! Dit is meer dan effekt van slimme propaganda; meer ook dan de uitwerking van dreigementen. We zien toe bij een diepe innerlijke beroering. Dreiging kan mensen ertoe brengen zich stil te houden; maar hoe kan dreiging ze tot enthousiasme bewegen? Dreiging bezorgt mensen angst; maar dreiging kan de gevoelens van schuld, wanneer fascisten in twijfel geraakten, niet verklaren. Briefschrijvers moesten voorzichtig zijn, de autoriteiten lazen over hun schouder mee; maar de innige aanhankelijkheid die we aantreffen ging de eisen van het bewind ver vooruit.

Dit gegeven is voor ons van belang. Het blijft overeind als een paal boven water dat de fascistische heersers hun zogenaamd ware wil met geweld aan de mensen oplegden; wie hen durfde weerstaan werd gevangen, gemarteld, vernietigd. Anderzijds waren er, en niet weinigen, die de Leiders geenszins uit angst voor straffe maatregelen lieten begaan. $\mathrm{Z}_{\mathrm{ij}}$ hebben hen ongedwongen, uit eigen overtuiging gesteund. Waarom? Hadden Hitler en Mussolini niet beloofd hun land als diktator te regeren? Waarom werd hun onheilspellende optreden met enthousiasme begroet? Hoe kon het dat Hitler op zijn weg naar de top van de Duitse politiek door de verkiezingsuitslagen van een demokratisch bestel werd gesteund? Waarom ebden het enthousiasme en de steun niet weg toen het land van kwaad tot erger ging?

Goering wist bet antwoord al in 1934. Waarom de Duitsers vol blijdschap Hitler an zijn absolute macht hielpen? ${ }^{14}$

14. Goering 59. 
"Das deutsche Volk weiss, dass es jetzt wieder einen Führer besitzt. Das deutsche Volk ist dankbar, dass endlich wieder ein Mann die Zügel in seine eiseme Faust genommen hat, das deutsche Volk atmet befreit auf ... dass es nicht mehr länger gezuungen ist, sich selbst zu führen. Das ist der grosse Irrtum des vergangenen Systems im Zeichen des Liberalismus: zu glauben, das Volk wūnsche sich selbst zu führen. Nein, das Volk will geführt und regient werden ..."

Het Duitse volk heeft hartelijk ingestemd, omdat het de vrijheid als een last voelde. Een volk, beweerde Goering, wil leiderschap; het wenst zich een sterke man. De liberale leer had aan dit feit geen recht gedaan. Liberalen zagen de koning als enige, uiterlijke hinderpaal voor de vrijheid; ze meenden dat het voldoende was hem uit de weg te ruimen, het volk zou meteen de herstelde vrijheid met beide handen aangrijpen. Zij vergisten zich. Een volk heeft afkeer van vrijheid en het zal zo snel mogelijk een nieuwe vorst over zich uitroepen. Goering's antwoord, een fascistische medeleider waardig, wees brutaal de traditie van het liberalisme af. Hij stond met dit antwoord echter niet alleen; het was bij hem niet nieuw en evenmin door hem bedacht.

$\mathrm{Na}$ de liberale revoluties hadden de Westerse volkeren, bevrijd van koning en kerk, zich in de 19 e eeuw voor bet eerst vrijelijk kunnen ontplooien. Het gedrag dat toen openbaar werd trok de aandacht van sociale onderzoekers. Hun bevindingen waren verrassend, en niet onverdeeld gunstig. De vrijheid die het liberalisme had geschonken werd geenszins gretig aangenomen; integendeel, het kiezersvolk, de massa (zoals dat nu kon heten), zocht naarstig gelegenheid om haar weer af te staan. Uit de verering voor Napoleon Bonaparte en de opkomst, later, van zijn neefje Napoleon III, was duidelijk gebleken dat het volk zich gaarne onder de hoede van een geweldige autoriteit begaf.

De Fransman Gustave Le Bon, een wetenschappelijk manusje-van-alles met soms bedenkelijke tekortkomingen, legde in 1895 deze inzichten aan de lezers voor; zijn Psychologie des foules maakte bij het verschijnen grote indruk, waardoor hij sedertdien bekend staat als sociaal-psycholoog. ${ }^{\text {is }}$

"Ce n'est pas le besoin de la liberté, mais celui de la servitude qui domine toujours l'âme des foules. Leur soif d'obéissance les fait se soumettre d'instinct à qui se déclare leur maître."

Hitler en Mussolini kenden het werk van Le Bon en zij pasten diens theorie opzettelijk toe om hun ijzeren greep op het eigen volk te verwerkelijken. Aldus hebben zij, bij wijze van grootscheeps maar kwalijk sociaal experiment, aangetoond dat Le Bon zich niet had vergist. Onder mensen bestaat een zekere neiging zich aan totalitaire heersers over te geven.

Hoezo? De 20e ceuwse psychologie heeft deze vraag opgenomen; ernstiger en meer gedegen dan Le Bon, en bovendien met het politieke doel eventuele toekomstige navolgers van Hitler en Mussolini voorgoed de wind uit de zeilen te nemen. Een gestaag onderzoek met vele deelnemers; slechts enkele uitschieters kunnen hier met name worden genoemd. Freud zelf; hij behandelde het thema volgens de begrippen van de psycho-analyse, in zijn Massenpsychologie und Ich-Analyse, uit 1921. Nog twee die van zich deden spreken, beiden uit de links-intellektuele kring van de Frankfurter Schule: 
Erich Fromm, wiens Escape from freedom in 1941 verscheen, en Theodor Adomo, die samen met enkele anderen in 1950 The authoritarian personality in het licht gaf. Deze greep uit de literatuur is gegrond op enkele overwegingen. De genoemde studies lijken me, dit in de eerste plaats, het meest bekend en het meest verbreid; zij zelf en de onderzoekingen die eruit voortkwamen bestrijken een goed deel van het terrein. $Z_{e}$ bieden dan ook, dit in de tweede plaats, een omvattende verklaring voor het verschijnsel dat op de bladzijden boven werd beschreven, het geloof aan de onfeilbare leider. Want het zoeken is hier niet naar de reden dat vreesachtige mensen in de schulp kruipen wanneer het bewind hen dreigt; niet naar de reden dat misdadigers in dienst van de staat misdrijven plegen; niet naar de reden dat profiteurs van een verworden overheid voordeel willen behalen. Het zoeken is hier naar een verklaring, dat rustige, welopgevoede en lang niet laffe burgers zich uitleveren aan de waan dat een onfeilbare hen regeert, en hem vervolgens door dik en dun trouw blijven.

Eerzame en intelligente mensen hebben in hun Führer en hun Duce geloofd; ze raakten buiten zichzelf, opgetogen bij de aanblik en zelfs maar de gedachte van een man die het niet verdiende. De dingen die zij zagen, de dingen die zij dachten, kunnen de uitgelaten blijdschap niet verklaren. Waarom dachten zij die dingen te zien? We moeten wel zoeken naar een diepere drijfveer, een drijfveer waarvan zij zelf niet wisten, die echter hun kijk op de werkelijkheid beheerste, zodat ze eerlijk meenden uitsluitend af te gaan op hetgeen voor ogen was. De bedoelde psychologische literatuur heeft inderdaad een dergelijke drijfveer aangewezen; een voordeel van haar theorie is bovendien, dat die niet alleen de neiging tot aanhankelijkheid van onderdanen maar tevens de heerszucht van hun leider omvat, zodat in enen de beide helften van het totalitaire verschijnsel worden verklaard.

Als volgt. Onderdrukking heeft twee kanten. Overheersende persoonlijkheden, enerzijds, spelen graag de baas; zij proberen anderen naar hun wil te buigen, laten geen kritiek toe en houden altijd vol gelijk te hebben. Ze kunnen in de politiek zitten, als koning of diktator, maar dat hoeft niet. Hun autoritaire instelling is een psychologische soort, een karakter dat in alle geledingen van de maatschappij voorkomt. En er bestaat een keerzjde van de overheersing: onderdanigheid. De tegenhanger van de dwingeland zijn degenen die zich graag naar een sterke wil schikken; zij stellen geen prijs op vrijheid. Zij hebben net zo goed een autoritaire persoonlijkheid.

Wat bezielt de mensen die anderen aan zich willen onderwerpen, en wat bezielt degenen die hun vrijheid zonder noodzaak aan een uiterlijke autoriteit afstaan? Beiden hetzelfde: eenzaamheid en onzekerheid. Elke mens is een individu, afgesneden van de medemens, en daarom eenzaam; en elk menselijk oordeel is wankel, feilbaar, zodat ieder in onzekerheid leeft. Deze eenzaamheid en onzekerheid jagen angst aan. De mens, omdat hij ze niet verdraagt, doet een noodsprong. De sterke persoonlijkheid bindt zwakken aan zich, de zwakke persoonlijkheden hechten zich aan de sterke; de scheve verhouding, naar beider wens, geeft een zoete waan in gemeenschap te verkeren. Bovendien kan de heerser, gevleid door zijn aanhangers, aan de eigen onfeilbaarheid geloven, terwijl van hun kant de aanhangers door dienst en gehoorzaamheid aan de onfeilbaar geachte heerser deel menen te krijgen aan de absolute waarheid. Beide partijen kunnen gerust zijn. De psychologische verklaring, eenvoudig, omvattend en elegant, heeft tegelijk haar eenvoud en omvang als nadeel. Indien deze eigenschappen werkelijk algemeen zijn, een 
vast bestanddeel van de menselijke aard, wat moeten we dan aan met alle verschillen tussen personen en landen? Sommige landen werden totalitair, andere niet; landen hadden een totalitaire periode, maar die ging voorbij; sommige mensen juichten de Leiders toe, anderen verafschuwden hen. Ik mag misschien een beeldspraak wagen om deze moeilijkheid te verminderen. De behoefte aan voedsel, hoewel onmiskenbaar algemeen, heeft toch overal een andere uitwerking. Geen volk en geen mens eet eender, even veel, even vaak; en terwijl honger de een tot berusting verdooft, maakt ze de ander tot bedelaar, of drijft hem tot diefstal. Dezelfde eenvoudige omstandigheid kan dus in haar uitwerking overal aanzienlijk verschillen.

Behalve haar moeilijkheden heeft de psychologische theorie ook een belangrijk voordeel. $\mathrm{Ze}$ doet recht aan een verschijnsel dat ons in dit en de volgende twee hoofdstukken zal bezighouden, de vertekening van de werkelijkheid. De onderdanige persoonlijkheid ziet zija heerser voor onfeilbaar aan; ten onrechte. Maar een innerlijke reden noodzaakt hem hiertoe en zolang die reden niet is opgeheven wordt hij langs dit pad verder gedwongen. Hij zoekt vereniging met de heerser, houdt vol, en laat zo zijn oorspronkelijke persoon steeds meer overwoekeren door een samenstel van inbeeldingen, een korst van oneigenlijkheid die èn het ik èn de ander aan het zicht onttrekt. Deze overwoekering werd door Freud "Über-Ich" genoemd, door Fromm de "authoritarian conscience". Het autoritaire geweten beweegt zich langs een vicieuze spiraal; het zal in toenemende mate de gekozen autoriteit verheerlijken, daardoor de innerlijke onderwerping goedpraten en haar vervolgens weer aanwakkeren. ${ }^{16}$

\footnotetext{
"Simultaneously, the conscience influences the image which a person has of the external authorities. For such conscience is always colored by man's need to admire, to have some ideal, to strive for some kind of perfection, and the image of perfection is projected upon the external authorities. The result is that the picture of these authorities is, in tum, colored by the 'ideal' aspect of conscience. This is very important because the concept a person has of the qualities of the authorities differs from their real qualities: it becomes more and more idealized and, therefore, more apt to be re-internalized. Very often this interaction of internalization and projection results in an unshakable conviction in the ideal character of the authority, a conviction which is immune to all contradictory empirical evidence."
}

De psychologische benadering van het totalitarisme geeft een theoretisch raamwerk dat we hier nodig zullen hebben. Ze laat zien dat het geloof in de leider, hoewel op zich geheel onredelijk, bij nader inzien een zeer redelijke, of liever inzichtelijke bedoeling verhult. De goedgelovigen weigeren de onzekerheid van het menselijke leven aan te gaan, en zoeken hun toevlucht in de illusie dat althans een ander, tegen wie ze opzien, met onfeilbare vastheid de aardse wisselvalligheden beheerst. Het totalitaire geloof dient om de werkelijkheid te verdringen; is die weg eenmaal ingeslagen, dan wordt men al maar verder gevoerd. Al maar verder, zij het niet zonder moeite; want harerzijds zal de werkelijkheid, weggeduwd, des te meer aandringen.

16. Erich Fromm, Man for himself. An enquiry into the psychology of ethics, 2e druk Londen 1950, blz. 145. 
De reaktie van het volk ging de stoutmoedigste hoop en de vernuftigste kunde van propagandisten ver te boven. Daarom de gevolgtrekking: Duitsers en Italianen hadden de diktator reeds in zich; het beeld van de propaganda beantwoordde aan een verlangen dat vooraf al leefde. Mussolini en Hitler worden nu doorgaans minder gunstig beoordeeld dan destijds; maar ook buiten de huidige verguizing kan ieder begrijpen dat zij op den duur niet aan de hooggespannen verwachtingen voldeden. Geen mens had kunnen voldoen. Hitler en Mussolini, nog voor hun misdadigheid werd ingezien, stelden teleur; de werkelijkheid bleef achter bij de hoop, tegenvallers en afkeurenswaardigheden kwamen voor, telkens meer, en uiteindelijk zou de ramp van een verloren oorlog zich aftekenen. Hoe hebben de aanhangers van deze mannen het slechte nieuws verwerkt? Hoe rijmden zij dat met het geloof aan hun onfeilbaarheid?

Op het laatst zagen ze zich, dat is duidelijk, gedwongen van de illusie af te zien; de waan moest wijken voor de feiten. Maar een verkeerde voorstelling zou zijn dat deze gedachtengang zich naar onbewogen redelijkheid voltrok: Vroeger dacht ik, toen zag ik, nu weet ik. Eerder in dit hoofdstuk werd reeds opgemerkt dat de breuk met de oude denkwijze vaak zware tweestrijd kostte. Davide Lajolo, die ooit als vrijwilliger dienst nam, kon pas na "verschrikkelijke gewetenswroeging" de zaak van het fascisme opgeven. ${ }^{17}$ Inderdaad, zeggen dan psychologen, want jongelui als hij hadden zich uit eigen innerlijk verlangen aan de droom van onfeilbaarheid overgegeven. Het fascistische geloof zat diep in de eigen persoon en het liet zich niet zonder slag of stoot uitbannen. Wie bereid was te letten op de tastbare werkelijkheid, twijfel toeliet aan de onfeilbaarheid van de leider, raakte verwikkeld in een strijd tegen zichzelf.

Een toestand van hoge spanning. Er bestaat, heet het, "cognitive dissonance"; de verschillende gegevens die zich aan de persoon voordoen stroken niet, het wereldbeeld is innerlijk tegenstrijdig. ${ }^{18}$ Geloof en feiten botsen, en de persoon beseft niet hoe een diepliggende noodzaak hem aan het eerste bindt. De spanning, die voortdurend oploopt, moet een uitweg zoeken; de tegenstrijdigheid vereist een oplossing. En een wonderlijke oplossing werd gevonden, een uitweg, of liever uitvlucht die zonder begrip van haar eigenlijke strekking door de mensen werd toegepast: Goed, veel ging mis in het land, maar de geloofwaardigheid van de Duce werd er niet minder om. Hij wilde onveranderlijk het goede voor Italië, en hij zou het zeker bewerkstelligen als hij de kans kreeg. Maar hij werd omgeven door een kliek van valse fascisten, die hem tot verkeerde beslissingen verleidden om hun eigenbelang te hevorderen. "Als de Duce het maar wist" ${ }^{n}$, klaagden de Italianen dan zachtjes.

Men wist zelfs aan wie het lag. Van 1931 tot 1939 was Achille Starace sekretaris van de Partito Nazionale Fascista, en zo de onmiddellijke medewerker van Mussolini. Heel Italie, jong en oud, fascist en anti-fascist maakte hem belachelijk; in zijn fouten en misrekeningen zag men de oorzaak van elk fascistisch falen. Starace had echter geen eigen wil. Hij was een dienstklopper en slaafse vleier, die aan Mussolini's orders niets

17. Kown p. XX. $31,249$.

18. Het begrip natuurlijk ontleend aan Leon Festinger. A theory of cognitive dissonance. Evanston/White Plains 1957: ik neem de vrijheid het samen te smelten met meer Freudiaans gedachtengoed. 
dan zijn ijver toevoegde. Het volk greep zijn persoon aan om de kritiek op het beleid, die zich niet volledig liet onderdrukken, weg te leiden van de aanbeden Duce. Men kon eenvoudig niet geloven dat Mussolini iets te verwijten viel. De overtuiging was stellig, en een zucht van verlichting klonk door Italië toen Starace in 1939 eindelijk werd ontslagen. Alsof het daama beter is geworden!

Het geloof dat Starace Mussolini's goede bedoelingen hinderde, is zeker niet alleen bij ongeletterden te vinden, of misschien op grote afstand van de indrukwekkende leider. Galeazzo Ciano was schoonzoon van Mussolini; eens overtuigd fascist, geruime tijd minister van buitenlandse zaken, zou hij tenslotte het fascisme de rug toekeren, een afvalligheid die hij in 1944 met zijn leven betaalde. Enkele jaren eerder, in 1938, had hij geschreven: ${ }^{19}$

"Starace legt het land onder een loden mantel van persionnlijke en sektarische tyrannie en hier moeten we de belangrijkste corzaak zoeken van de rusteloosheid en het gebrek aan enthousiasme."

Hitler's aanhang koos dezelfde uitweg. In de eerste geestdrift werd gretig geloofd dat heel Duitsland opleefde, zodra Hitler "de geschiedenis in zijn handen had genomen". De ekonomie verbeterde en Hitler's gedurfue buitenlandse politiek leek met gemak te slagen, waardoor het vemederende einde van de Eerste Wereldoorlog weer enigszins werd rechtgezet. Maar al snel werd de willekeur van het bewind merkhaar, het Duitse volk kreeg te maken met ongewenste maatregelen, het werd in een oorlog betrokken en moest tenslotte vaststellen dat Duitsland weer op een rampzalige nederlaag aanstevende. Men reageerde met een scherp onderscheid tussen Hitler en zijn dienaren, de "kleine Hitlertjes", die hun chef een valse werkelijkheid voorspiegelden. De Engelse historikus lan Kershaw zocht het uit: ${ }^{20}$

"Many genuinely believed that matters. especially if unpalatable. were deliberately kept from Hitler, and that if he learned of them he would act swiftly to set things right."

De geloofwaardigheid en de betrouwbaarheid van Hitler werden op die manier waterdicht, want wat er ook verkeerd ging, het ideale beeld van de Führer bleef ongeschonden. Een slimme vondst die de regeringspropaganda vervolmaakte; toch beviel ze Hitler, die ervan hoorde, allerminst. In 1935 weersprak hij nadrukkelijk dat er een kloof zou bestaan tussen hem en de nationaal-socialistische partij: "Neen, mijne heren, de Führer is de Partij en de Partij is de Führer." 21 De officiële propaganda heeft het denkbeeld dus niet ingegeven; het kwam op uit bet volk, als een eigen, spontane aanvulling. Onbegrijpelijk, onverklaarbaar? Niet voor de aangehaalde psychologische theorie; mensen zelf hadden behoefte aan een onfeilbare leider en daardoor gedreven bedachten zij het verhaal van Hitler's kwaadwillige medewerkers: om hun illusie te beschermen. Het volksgeloof heeft Hitler vrijwel al de jaren van zijn macht begeleid. Reeds in 1934, na de verraderlijke moord op zijn oude strijdmakkers van de S.A., kon Hitler niettemin

19. Koon 109-113,241.

20. Kershaw 95 .

21. Kershaw 104 
aan populariteit winnen, want, zei men vergoelijkend, ze hadden immers door hun losbandigheid de uitvoering van Hitler's heilzame plannen in de weg gestaan. Later werd het moeilijker. De Tweede Wereldoorlog brak uit en toen de krijgskans geleidelijk in Duitsland's nadeel keerde, moest men wel het verhaal opgeven. De slag bij Stalingrad was een keerpunt; Hitler had persoonlijk op hoge toon een overwinning beloofd, en de verpletterende nederlaag kwam hard aan. Zij die het diepst gevangen zaten in de fascistische orde, leden van de partij, jongelui, die levenslang niets anders hadden gekend, hielden het langst de mythe vol. En de soldaten aan het front: ${ }^{22}$

\begin{abstract}
"When they asked themselves why they were sent the wrong type of ammunition, why there were desperate fuel shortages, why they were sometimes compelled to suffer terrible losses to no purpose, scarcely a man in the division considered fixing the blame on Adolf Hitler. Some said that the Führer simply did not know of these things. Others, that he was badly advised by those around him, above all by Bormann and Ribbentrop."
\end{abstract}

"Wenn der Führer wüsste...!", verzuchtten ze onder elkaar: een refrein dat al die jaren in Duitsland telkens had geklonken. Hitler wist niet van de misdaden en blunders die zich opstapelden; maar wat wist hij dan wel? Indien al het verkeerde hem ontging, waarom zou het andere nog wel van hem zijn? De mythe verdreef door een noodzakelijke logika de Führer uit de wereldse werkelijkheid, hij vervaagde tot een schim, ver van het alledaagse bestaan. En Hitler's gedrag in de laatste jaren van zijn heerschappij beantwoordde onwillekeurig precies aan deze logika; de grote leider, na aan de gewone man en zijn problemen, trok zich gaandeweg terug uit de openbaarheid. Hoe slechter het verloop van de oorlog, des te minder liet hij zich zien, tot de dag dat de totale nederlaag aan zijn voordeur klopte. Hij benam zich het leven, zijn Duitse onderdanen aan hun lot overlatend. Die stonden er weer helemaal alleen voor.

Het is aantrekkelijk, na de vergelijking tussen Mussolini en Hitler, de speurtocht nog even voort te zetten; ze zijn in onze eeuw lang niet de enige totalitaire heersers geweest. In 1917 eindigde het eeuwenoude regime van de Russische tsaren; hun rijk werd vervangen door de kommunistische Sovjet-Unie, die zich weldra tot een schrikwekkende totalitaire staat zou ontwikkelen. Twee mannen verwierven achtereenvolgens als leiders van de Sovjet-Unie wereldwijde bekendheid onder de schuilnamen die ze voor de omwenteling van 1917 hadden aangenomen: Lenin en Stalin. Zij deinsden niet terug voor harde maatregelen wanneer dat zo uitkwam, en hun straffe onderdrukking heeft velen het leven gekost. Maar ook ditmaal zou het eenzijdig zijn uitsluitend op de propaganda en de dreiging van boven te letten; de verering voor de leiders ontstond eerstens beneden, onder het volk.

Lenin was geschokt toen hij in kranten moest ontdekken hoe zijn talenten en zijn invloed uitermate werden overdreven. Hij trachtte het tij te keren, maar vergeefs, zoals bleek na zijn vroege dood in 1924. De achtergebleven medewerkers deelden Lenin's bezwaren

22. Max Hastings, Das Reich. Resistance and the march of the 2nd SS Panzer Division through France, June 1944, Londen 1983, blz. 32.

Een korporaal, 9 augustus 1944: "Der Führer sieht dies aber nicht ein. Seine Berater fübren ihn ins Verderben." Buchbender/Sterz. 147. 
niet; ze behandelden zijn overlijden als een nationale ramp, deels om er politieke munt uit te slaan. De uitwerking overtrof evenwel verre hun listigheid. Rouw heerste in het land en honderdduizenden trotseerden de ijzige vrieskou om Lenin de laatste eer te bewijzen. Lenin, schreef een journalist, was niet dood! Iljitsj, ja: de mens was gestorven, maar Lenin betekende eeuwige waarden, de strijd voor kommunisme; Lenin kon nooit sterven. De gedachte van Lenin's onsterfelijkheid werd bovendien verbeeld in folkloristische trant; uit Oezbekistan en de Kaukasus kwam kort na 1924 melding van een volksgeloof dat Lenin, levend en wel, heimelijk door het land reisde, om eens als staatshoofd weer te keren. ${ }^{23}$

Evengoed had men onder Lenin's gezag onverkwikkelijke dingen beleefu. In 1921 kwamen zeelieden van de vlootbasis Kronstadt in opstand; ze hadden vier jaar tenug vooropgelopen, vurige revolutionairen, maar de gang van zaken onder de nieuwe regering stond hun niet aan. Lenin liet de aantasting van het kommunistische gezag niet over zijn kant gaan, brandmerkte de muiters als reaktionairen, en onderdrukte de opstand met bloedig geweld. Tevoren, terwijl zij nog duurde, waren de mannen op Kronstadt overtuigd geweest dat Lenin door zijn naaste omgeving werd misleid; posters met beeltenissen van andere kommunistische leiders werden van de muur gescheurd, die van Lenin bleef hangen. ${ }^{24}$

De Amerikaanse anarchiste Emma Goldman bevond zich tijdens de opstand in Petrograd; haar metgezel, Sasja, vertelde ze, kon niet geloven dat de muiters voor vijanden van de revolutie werden aangezien. Iemand moest de kommunistische leiding op de hoogte stellen! 25

\footnotetext{
"Lenin and Trotsky must be misinformed by someone. ... We must go to Moseow at once, Sasha declared. It was imperative to see Lenin and Trotsky and to explain to them that it was all a horrible misunderstanding, a blunder that might prove fatal to the Revolution itself. It was very hard for Sasha to give up his faith in the revolutionary integrity of the men that had appeared as the proletarian apostles to millions throughout the world."
}

De verering voor Lenin was een flauw voorafje vergeleken bij hetgeen zijn opvolger Stalin zou aanrichten. Stalin, anders dan Lenin, meer zoals de fascistische diktators, beeft zelf zijn persoonsverheerlijking op touw gezet. Hij had het land in een klemmende greep en het is daarom moeilijk te beslissen hoeveel van de lof die hem overspoelde voortkwam uit angst en plichtmatigheid, hoeveel uit innerlijk geloof. Het hoorde bij de beersende leer: Elk moest voortdurend voelen dat Stalin aanwezig was en over de schouders meekeek. Hij wist hiervan een drukkende werkelijkheid te maken door zijn gewoonte in de nachtelijke uren her en der door het land mensen op te bellen, om ze uit te vragen of om orders te geven, soms met dreigementen. ${ }^{26}$

Maar weer was de reaktie van beneden, voorzover waarneembaar, vol oprechte blijdschap, met een verheugde aanhankelijkheid die weinig dreiging verraadt. Volgens een

23. Tumarkin $90,142,167,198$.

24. Paul Avrich, Kronstadt 1921, Princeton 1970, blz. 177.

25. Emma Goldman, Living my life II, (oorspr. 1931) Londen 1988, blz. 878.

26. Vera S. Dunham, In Stalin's time. Middleclass values in Soviet fiction, Cambridge 1976, blz. 27, 148, $254 / 255$. 
Russische generaal wist iedereen waarom het Rode Leger de Duitsers kon verslaan: "We are winning mainly because Stalin is leading us." Vooruitziend, besluitvaardig, onbevreesd, had Stalin zijn troepen naar een zekere overwinning geleid. Bevelhebbers in een benarde toestand kregen onverwachts Stalin aan de telefoon: "Hou vol!"; en hulp volgde meteen. Niets ontsnapte aan Stalin's welwillende opmerkzaamheid; wie een geslaagde wetenschappelijke uitvinding had gedaan ontving een telefonische felicitatie. Alleen al de gedachte van Stalin's voorbeeld bracht soldaten aan het front uitkomst. ${ }^{27}$

\footnotetext{
"Stalin's boundless energy and unswerving will are an inexhaustible source of inspiration and moral strength for all Soviet soldiers. When things go badly with them they always ask themselves: 'What would Stalin do in this situation?' --and always emerge victorious from the fiercest encounters."
}

De "koeljt litsjnosti", de persoonlijkheids-cultus, steeg tot ongekende hoogte. Wat er aan goeds gebeurde, waar ook in het land, op welk vakgebied, werd aan Stalin's alwetendheid dankbaar toegeschreven. Portretten en standbeelden bedekten het land; de naam van Stalin sierde straten, bergen, kanalen en fabrieken. Ook in de literatuur stond altijd Stalin bovenaan. Twee gelieven; zij vraagt hem of hij een geheime droom koestert. Hij, na enig peinzen: Jawel; een gesprek met kameraad Stalin. De worsteling van een invalide veteraan met een samenleving vol onbegrip vindt haar glorieuze ontknoping wanneer hij Stalin zelf mag ontmoeten, die hem meteen begrijpt en genadig zijn gelijk erkent. ${ }^{\star}$ De ontstellende verheerlijking, we merken het nogmaals op, is te welgemeend, te wijd verbreid, te rijk aan fantasie om geheel uit Stalin's koker afkomstig te zijn. Ze moet een onafhankelijke oorsprong hebben gehad bij de Russische burgers. Het voortdurend verkeren onder Stalin's toeziend oog gaf hun een warm gevoel van veiligheid en saamhorigheid; een aangename geestestoestand waarvan ze niet graag afstand deden. Maar ondertussen zagen zij om zich heen heilloze gebeurtenissen, arrestaties, verdwijningen, willekeur. De verschrikkelijkheid van de zuiveringen greep om zich heen; boe kon Stalin dat toelaten?

\footnotetext{
"'Wat gebeurt er allemaal, Andrej Jakovlevitsj?' vroeg Stebenev me. 'Wat gebeurt er allemaal?' Hij liep nerveus door de kamer. 'Ik kan niet geloven dat er in de Partij zoveel vijanden zijn. Ik kan het niet geloven. Kan het niet zijn dat er hogerop in de Partij en in de veiligheidsorganen ons vreemde mensen zijn? Het lijkt wel of ze met opzet de Partijkaders verwoesten. Ik wil wedden dat Iosif Vissarionovitsj hiervan niets afweet. Waarschuwingen, klachten en protesten worden onderschept en bereiken hem niet. Stalin moet op de hoogte gebracht worden. Anders geschiedt er een ramp. Morgen zullen ze jou oppakken en na jou mij. We kunnen niet stil blijven zitten.'"
}

Hetzelfde praatje: Onze opperste leider weet het niet. Ook intellektuelen als Ilja Ehrenburg en Boris Pasternak verstrikten zich in het fabeltje; Pasternak hief ooit zijn handen in wanhoop ten hemel: "Als maar iemand het eens aan Stalin vertelde! " Onder het volk werd de naam van de boosdoener gefluisterd; Nikolaj Jezjov, hoofd van de geheime dienst, had een samenzwering gesmeed, om Stalin's plaats in te nemen. Naar hem heeft

28. Dunham 73, 231. 
de volksmond die duistere periode "Jezjovsjtsjina", de Jezjov-tijd gedoopt. Stalin voedde het gerucht; hij schoof de schuld op Jezjov, ontsloeg hem en liet hem ombrengen. Nog vele jaren daama moesten historici zorgvuldig Stalin's kennis en verantwoordelijkheid naspeuren om het sprookje van zijn onwetendheid te ontkrachten; het heeft lang hardnekkig standgehouden. ${ }^{29}$

Zowel in fascistische als in kommunistische totalitaire samenlevingen werd de mythe verteld van de goede heerser omgeven door onderkoningen die hem misleiden; een merkwaardige overeenkomst. En bovendien een sterk argument voor de psychologische theorie dat mensen uit eigen behoefte aan de goede wil en de onfeilbaarheid van hun leiders geloof hechten. De feiten wezen overduidelijk anders uit, maar de kommunisten en fascisten weigerden hun overtuiging af te leggen; ze ontliepen de tegenstrijdigheid door naast de vereerde leider een boosaardige ondergeschikte te verzinnen. Zonder precies te beseffen wat ze deden, zegt de psychologie, losten deze mensen zo hun cognitieve dissonantie op.

Het 19e eeuwse liberalisme had gestreden tegen de absolute koningen en een klinkende overwinning behaald; die verliest echter veel van haar betekenis indien het waar zou zijn dat mensen lijden aan een verlangen naar heerschappij of onderdanigheid. Een enkele uitwendige autoriteit werd opgeruimd, maar de wortels van diktatuur en onvrijheid, de innerlijke staat der mensen, werd bij lange na niet aangeroerd. Een onprettige en verrassende tegenvaller. Erich Fromm bracht haar onder woorden: ${ }^{30}$

\footnotetext{
"Omdat de aandacht bij het gevecht om vrijheid in de modeme geschiedenis geheel en al gericht was op de bestrijding van oude autoriteitsvormen en beperkingen, was het niet meer dan natuurlijk dat men de vrijheid zag toegenomen alleen naar mate deze overgeleverde belemmeringen werden opgeruimd. Maar ons ontbreekt daarbij het voldoende inzicht, dat de mens zich wel van de oude vijanden der vrijheid heeft bevrijd, maar nu geconfronteerd wordt met nieuwe vijanden van geheel andere aard. Vijanden, die in diepste wezen geen uiterlijke belemmeringen zijn, maar innerlijke factoren, wardoor de volledige verwezenlijking van de persoonlijke vrijheid tot dusverre geblokkeerd wordt. ...

Wij zijn, met andere woorden, gefascineerd door de groei der vrijheid van machten buiten onszelf maar blind voor het bestaan van innerlijke weerstanden, dwangmatigheden en angsten, die de betekenis van de overwinningen van de vrijheid, op haar traditionele vijanden behaald, dreigen te ondermijnen."
}

\section{$\S 3$.}

Zou dat zo zijn? Fromm schreef alsof de strijd tegen het vroegere koningschap een strijd tegen uiterlijk gezag is geweest, terwijl de innerlijke weerstand tegen vrijheid zich pas daarna heeft geopenbaard. Goed beschouwd, een onwaarschijnlijke opvatting. Op grond van zijn theorie valt eerder te verwachten dat de onzelfstandigheid van de mensen vanouds heeft bestaan; dat ze onder de rustige hoede van het oude koningschap onopgemerkt sluimerde; dat ze na de val van de koningen, verontrust, plotseling in beweging kwam om zich een nieuwe bescherming te verschaffen, en die schijnbaar vond bij de 
20e eeuwse diktators. Zo ongeveer heeft ook Goering het vermoedelijk gezien, toen hij de blijdschap van de Duitsers verklaarde uit de omstandigheid dat ze "jetzt wieder", eindelijk weer veilig onder een Führer leefden.

De kwestic is voor dit boek van groot belang. Ter wille van de vergelijking tussen The King can do no wrong en Mussolini ha sempre ragione gingen we op onderzoek uit; nu is aannemelijk geworden dat Italianen de overdreven lijfspreuk van hun leider letterlijk hebben opgevat, en werkelijk aan zijn onfeilbaarbeid hebben geloofd. Kunnen we dan misschien ook ontdekken of The King can do no wrong in de tijd der koningen door onderdanen letterlijk is genomen? Heeft het geloof aan de alwetende heerser, als eigen aandrang in het volk, vroeger al een rol gespeeld? Is de psychologische hypothese in dit geval bruikbaar? Om haar te toetsen zullen we naar sporen moeten zoeken in de historie van het koningschap.

We weten hoe het koningschap werd omschenen door bovenaardse glans. Koningen bereisden het land met groot gevolg, in schitterend gewaad, toonbeeld van opperste waardigheid; hun nadering was een feest als de intocht van Jezus in Jeruzalem. Bijbelse teksten steunden de overtuiging dat het land rijke oogsten opbracht en het volk in welvaart leefde, waar een goede koning boven allen troonde. Eeuwenlang heerste een geloof dat de Franse en Engelse koningen over wonderdoende gaven beschikten; door handoplegging genazen zij wie aan een zekere huidziekte leed. Bedrog immers, om het volk in toom te houden? Meer dan dat. Alle partijen waren onder invloed van de koninklijke schittering. Huizinga schreef: ${ }^{31}$

"Wanneer de hofchronisten: geleerde, aanzienlijke inannen, die hun vorsten van nabij kenden, de doorluchtige personen niet anders kunnen zien en beschrijven dan in een archaïsche, hiëratische gedaante, wat moet dan voor de naieve volksverbeelding de tooverglans van het koningschap zijn gewerst!"

Hoe dacht het volk over de koning? Het is voor de geschiedwetenschap een lastige opgave door te dringen tot de gedachtenwereld van gewone mensen. $\mathrm{Zij}$ legden hun meningen en uitingen niet schriftelijk vast en wat wel werd overgeleverd stamt meestal van geestelijken, geleerden, ambtenaren, reizigers; bronnen van twijfelachtige waarde, omdat in hun weergave altijd eigen inbreng en bedoelingen de volksbeleving vervormen. Historici hebben het erop gewaagd, en het bleek toch doenlijk met wetenschappelijke voorzichtigheid uit beschikbare volksoverlevering betrouwbare kennis af te leiden. Zo kon ook worden achterhaald welk beeld van de koning het volk voor ogen stond. Verhalen en liederen spraken van de vorst; boe werd hij daarin ten tonele gevoerd?

De koning werd zeer vereerd. Een held, moedig, onoverwinnelijk, een ridder, vroom dienaar van God, rechtvaardige rechter. In Frankrijk leefde een traditie dat verdrukte onderdanen, onrecht lijdend van deze of gene, zich immer aan de voeten van de vorst konden werpen om gerechtigheid af te smeken, zodat het recht zou zegevieren. ${ }^{32} \mathrm{DE}$ edele eigenschappen van de koning werden verbeeld in tal van legenden; ze mogen ver-

31. Kantorowicz. Sel. snulies 42; James 1. Works 270; Psalm 72; Huizinga 13. Over de koninkijkte geneeskracht natuurlijk Marc Bloch, Les rois thaumaturges, Straatsburg 1924.

32. Goubert II, 28. 
duidelijken dat het volk niet alleen de officiēle leer van boven nasprak, nodig om geen machtige vorst tegen zich in het hamas te jagen. De verbeelding van het volk was de uiterlijke eis van opgelegde gehoorzaamheid aan de koninklijke wil ver vooruit. Ze getuigt van een innige verbondenheid, een vertrouwensvol opzien naar hun koning, die vaderlijk waakt over het geluk van zijn volk.

Lodewijk XIV was krap elf jaar, nog lang niet de oppermachtige en schitterende vorst die hij later zou zijn, maar wel de erkende wettige koning van Frankrijk, toen in 1649 een gedicht verscheen; "om de treurigheid te verdrijven": ${ }^{33}$

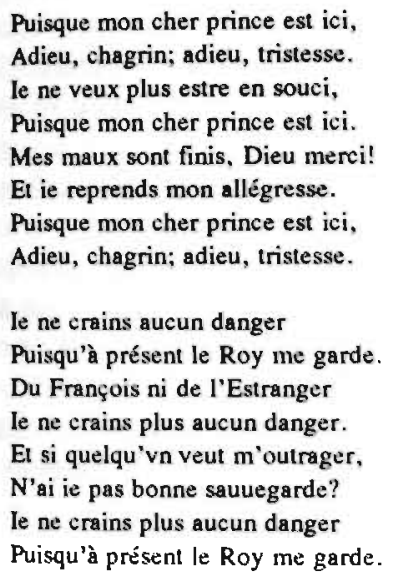

Net als bij de 20e eeuwse diktators heette het dat de koning onophoudelijk zorgde om de nood van zijn trouwe onderdanen te lenigen. Geen onderbreking, geen nachtrust hield hem van zijo taak. Het paleis van Lodewijk XIV, te Versailles; de avond valt, het leven ligt stil. Alleen de koning waakt: ${ }^{34}$

\footnotetext{
"Déjà la nuit s'avance, les gardes sont relevés aux avenues de son palais, les astres brillent au ciel el font leur course; toute la nalure repose, privée du jour. ensevelie dans les ombres; nous reposons aussi, tandis que le Roi, retiré dans son balustre, veille sur nous et sur tout l'Etat ..."
}

In Arabische overlevering, in Engeland en Rusland werd verteld dat de goede heerser door zijn rijk zwierf, ongezien, onherkend, om te weten hoe zijn volk leefde. ${ }^{35}$ Geen benauwende spionage, zoals wij zouden denken, maar een veilige bescherming tegen onrecht. Want op zijn tochten ontdekte de koning wie hem werkelijk was toegedaan, en misstanden werden met koninklijk gezag rechtgezet. In het Nederlandse taalgebied is er de historie van Karel en Elegast. Keizer Karel de Grote ontmoet tijdens een nachtelijke zwerftocht Elegast, die hij ooit had weggejaagd op verdenking van ontrouw. Samen

33. Morvau I, 515 en IJ, 533.

34. Paul Hazard, La crise de la conscience européenne. Parijs 1935, blz. 277; volgens Kantorowicz een vast thema. The king's two bodies 142 nt. 167

35. Burke 152 
beleven zij een avontuur en Karel merkt dat hij Elegast ten onrechte heeft veroordeeld; niet Elegast, een ander zweert tegen hem samen. Elegast wordt in ere hersteld. Maar al te vaak weigerde het volk te aanvaarden dat de geliefde koning was gestorven, De legende van Lenin's overleven, van zijn stille omzwervingen en verwachte terugkeer, zette rechtstreeks een eeuwenoude Russische traditie voort; over tsaren ging dikwijls hetzelfde verhaal. Bekend is de Engelse koning Arthur, wiens geschiedenis onvindbaar werd onder het aangroeisel van volksverbeelding. Arthur, op het slagveld dodelijk gewond, zou nog immer in verborgenheid de dag verwachten dat het Engelse volk zijn reddende tussenkomst nodig heeft. Evenzo andere beersers, her en der in de Europese historie; bijvoorbeeld keizer Karel de Grote. Van de 13e eeuwse Duitse keizer Frederik II werd na zijn dood geheimzinnig verteld dat hij leefde en niet leefde: "Vivi et non vivit". Met ongenaakbare koppigheid kon men vasthouden aan het beeld van de altijd goede en altijd aanwezige koning. ${ }^{36}$

Het onwrikbare vertrouwen dat de koning het wel meende en altijd voor een goede afloop zou zorgen, moest onvermijdelijk in strijd raken met de waarneembare werkelijkheid; zoals onder het $20 \mathrm{e}$ eeuwse totalitarisme. Trad ook destijds cognitieve dissonantie op? En welke uitweg zocht de spanning? Kershaw, die het gerucht van Hitler en de "kleine Hitlertjes" heeft onderzocht, verwees naar de "spreekwoordelijke" middeleeuwse koning en diens kwaadaardige raadgevers. Inderdaad: Volkeren, tijdens de Middeleeuwen maar niet alleen toen, wamen uiterst zelden hun koning op de hak. Men had genoeg te klagen, wantoestanden ontbraken niet; niemand echter maakte de koning enig verwijt. Peter Burke, Engels historikus: ${ }^{37}$

"It is as if the king can do no wrong, although he can be ill-advised by 'evil counsellors', w use the consecrated phrase."

Al mopperde het volk, stilletjes of hardop, de koning bleef buiten schot. Hij wist immers niet van het gebrek, zijn adviseurs leidden hem om de tuin! Keer op keer komt het thema in de volksverhalen terug. Heel de levensloop van de Engelse volksheld Robin Hood, een ballade die na eeuwen niets van haar plezierige charme heeft verloren, drait rond het gegeven van 's konings afwezigheid. De plaatsvervanger heeft vrij spel en perst het volk uit. Robin Hood, op de vlucht gejaagd, beschermt de verdrukten in naam van het koninklijke recht. De koning keert weer, maar niemand weet het nog; hij reist incognito rond, hoort wat gaande is, maakt zich dan bekend, herneemt daardoor zijn gezag, de getrouwen krijgen eer, de onderdrukkers worden gestraft.

Niet meer dan een jongensverhaal misschien, fraai verzinsel zonder feitelijke grond? Maar het weerspiegelt de intense overtuiging der Engelse boeren dat de koning hun tenslotte altijd recht zou doen. ${ }^{38}$ 


\begin{abstract}
"They only knew that the King was the ultimate repository of a law whose justice they acknowledged, and they saw treason against him as a betrayal of their allegiance to God himself. If they could only get past his corrupt officers, whose abuse of the trust reposed in them amounted to treason in itself, and bring their case before the King, they believed that right would be done. Their unshakable faith in the King's own justice was the most tragic of the misconceptions of the medieval peasantry, and the ballad makers and their audiences shared it to the full."
\end{abstract}

Het misverstand van 's konings onvergankelijke goedheid bleef niet beperkt tot de balladen, als een hoopvolle en dromerige sluimering in het late uur. De verontruste onderdanen, een schrijnend onrecht voor ogen, wisten met zekerheid dat hun koning dit niet bedoelde; wisten met zekerheid dat hij niet op de hoogte was; wisten met zekerheid welke raadgevers hem op het dwaalspoor brachten, en noemden hen bij name. Het kon niet uitblijven dat de bevolking zich zou roeren, eerst om de koning te waarschuwen, en indien het onrecht voortduurde, om de boosdoeners aan te pakken en zelf recht te doen. De onbegrepen overtuiging dat slechte adviseurs de vorst omringden, op zich een verzinsel, had niettemin haar harde weerslag in de werkelijkheid.

In 1381 werd Engeland opgeschud door een omvangrijke rebellie. Opstandige boeren trokken in slagorde naar Londen; met welk doel? De koning te belagen? Nee, maar om koning Richard II te verlossen van zijn "evil councillors". Hooggeplaatste dienaren van de koning werden opgespoord en gedood; hun bezittingen geplunderd. Op zaterdag 15 juni stond het leger van boeren oog in oog met de koning en zijn legermacht. De leider van de opstand, Wat Tyler, kwam naar voren om de eisen te zeggen, maar hij werd in een handgemeen vermoord. Een spannend ogenblik. Toen reed Richard II te paard, alleen, op de boeren toe en riep: "I am your King!" En zonder hem een haar te krenken, volgden zij hun koning gedwee. Het liep tragisch af; de volgzaamheid der boeren gaf hun tegenstanders de kans ze achteraf te verpletteren. ${ }^{39}$

Een halve eeuw later was het weer raak. Een storm van beschuldigingen woedde tegen William de la Porte, hertog van Suffolk, de vertrouweling van koning Hendrik VI: Suffolk liet politieke tegenstanders vermoorden, hij saboteerde de oorlog tegen Frankrijk, hij hielp de Fransen een inval in Engeland voor te bereiden, hij wilde in plaats van Hendrik VI Engels koning worden: "Suffolk wolle bere the crowne". En de koning had het niet in de gaten: "The Kyng knowith not alle". Onrust bij het volk, opstandigheid. De koning zag zich gedwougen Suffolk te ontslaan en verbande hem, waardoor hij het volk in de verdenking stijfde. Op 3 mei 1450, onderweg naar zijn ballingsoord, werd Suffolk's schip door een ander aangehouden; de Engelse opvarenden zetten hem gevangen en onthoofden hem de volgende dag. ${ }^{40}$ Het vriendelijke sprookje van de goede koning had vlijmscherpe tanden!

Het kwam dus voor dat onderdanen de adviseurs van hun vorst in diens naam achtervolgden en doodden; of zij leverden zich weerloos aan de koning uit, met rampzalig gevolg. De ernst der reakties moet toch wel betekenen dat zij hun verdachtmakingen oprecht meendea. In volle overtuiging hebben zij de onbevlekte reputatie van hun koning

40. Thomas Wright (ed.), Political poems and songs relating to English history, composed during the period from the accession of Edw. III to that of Ric. III, deel U, Londen 1861, blz. 230; Scaltergood 159-164. 
hooggehouden; in volle overtuiging het verkeerde van de politiek aan boosaardige adviseurs toegedicht. Het is een opvallende overeenkomst met de ontdekking die we voor de 20e eeuwse diktators hebben gedaan, en een krachtige bevestiging van de psychologische theorie. Laten we daarom nog even op dit pad voortgaan, meer voorbeelden verzamelen, om de mythe van de goede vorst en zijn boze raadgevers scherper in beeld te krijgen.

Eerst nog enkele gevallen uit de Engelse geschiedenis. Koning Jakobus II verloor in 1688 door een invasie vanuit Nederland zijn troon; stadhouder Willem III, die het bevel voerde, was echter niet van plan geweest de koning te onttronen. "Quade Raadslieden", luidde zijn proklamatie aan het Engelse volk, hadden de koning in hun macht gekregen, en om deze kwalijke invloed uit te schakelen, om de koning als het ware te bevrijden, was hij naar Engeland overgestoken. ${ }^{4 !}$ Rond 1776, de Amerikaanse onafhankelijkbeidsoorlog. werd nog regelmatig de schuld bij de ministers van koning George III gelegd; George Washington, aanvoerder van het Amerikaanse opstandelingenleger, noemde de Engelse troepen "the ministerial troops". Met instemming was in 1769 een Engelse petitie, die ook de Amerikaanse onvrede bestreek, door de Boston Gazette afgedrukt: ${ }^{42}$

\footnotetext{
"With great grief and sorrow we have long beheld the endeavours of certain evil-minded persons, who attempt to infuse into your royal mind, notions and opinions of the most dangerous and pernicious tendency."
}

Franse koningen werden ook in de mythe ingesponnen. De kerkscheuring van de $16 \mathrm{e}$ eeuw trok een kloof tussen de katholieke koning en zijn protestantse onderdanen; ze werden als ketters streng vervolgd. Johannes Calvijn, hun voorman, gaf in 1536 aan zijn bekende handboek van de protestantse leer een begeleidende brief mee voor koning Frans I, schrijvende dat de vervolgingen zeker te wijten waren aan valse voorlichting door ophitsers, eerder dan aan de eigen wil en het medeweten van de koning. De gedachte werkte in de volgende jaren met wisselende kracht door, bovendien vermengd met andere dan godsdienstige geschillen. De vorst, zei men, was gevangene van een bende kwaadwilligen, die zijn gezag ten eigen bate aanwendden. Een gewapende macht trok in 1560 naar Amboise om de koning te ontzetten; het plan lekte uit, mislukte, en de samenzweerders werden omgebracht. ${ }^{43}$

De hevigheid van de $16 \mathrm{e}$ eeuwse burgertwisten gaf aanleiding de vorst te verheffen tot onaantastbaar beginsel van eenheid. Frankrijk werd het land van de absolute monarchie,

41. Richard Boyer, English declarations of indulgence 1687 and 1688, Den Haag 1968, blz. 142, 150; Onno Klopp, Der Fall des Hauses Stuart und die succession des Hauses Hannover in Gross-Briannien und Irland in zusammenhange der europäischen Angelegenheiren von 1660-1714, deel IV, Wenen 1876. blz. 205-207; de deklaratie in D.v.H., Engelands staatsveranderingen, vertoond in hel leven van Jacobus den II, Haarlem 1690, blz. $880 f$.

42. John Derry, English politics and the American revolution, Londen 1976, blz. 19; Pauline Maier, From resistance to revolution. Colonial radicals and the development of American opposition to Britain. 1765-1776, New York 1972, blz. 201. 
in de 17e eeuw gevestigd door Lodewijk XIV, na een degelijke grondlegging door achtereenvolgens twee eerste ministers, die allebei ook kardinaal waren: Richelieu en Mazarin. Dit ging niet zonder verzet. De monarchie, om sterk te zijn, behoefde een vast inkomen en nieuwe belastingen waren een belangrijk onderdeel van de monarchale politiek. Maar het volk weigerde te voldoen, noemde de aanslagen onwettig, en belastingambtenaren werden mishandeld of gedood. Opstand tegen de koning? Allerminst; het volk wist toch dat bij de nieuwe belasting afkeurde, het handelde dus in zijn naam en juichte van harte: "Vive le Roi sans gabelle!" 44

Zelfs de katholieke kerk, altijd ontzien, kreeg thans verkapte belastingen opgelegd. Grote verontwaardiging. Charles de Montchal, aartsbisschop van Toulouse, leider van de kerkelijke oppositie, legde later in zijn Mémoires uit hoe het was gegaan. Koning Lodewijk XIII was vol deugd, zeer vroom, godvrezend, een vijand van het kwaad, volmaakt op de hoogte met zijn rijk. Maar de boosaardige Richelieu verdrong zijn koning, hem niets overlatend dan de schaduw en schijn van macht. Hij, Richelieu, had de verderfelijke maatregelen uitgedacht om er zelf beter van te worden, zonder twijfel tegen de wil van de koning, die, afgeschermd door zijn minister, als enige in het land niets van bet onrecht wist. Natuurlijk niet; want de vorst, indien hij ervan hoorde, zou het verhaal niet eens verdragen, maar zonder aarzelen ingrijpen. ${ }^{45}$

"Qu'un Prince si pieux \& si juste, s'il étoit averti des impietés \& des injustices ... ne pourroil même en souffrir le recit sans faire une punition exemplaire de leurs auteurs ..."

Het is waar dat Richelieu daadwerkelijk zijn koning de staatszaken zo goed als volledig uit handen nam, maar dat vermindert niet de mythische betekenis van Montchal's weergave. Hoe kon hij, buitenstaander, nauwkeurig weten welk aandeel de koning in deze politiek had, welk aandeel Richelieu? Wat rechtvaardigde zijn oordeel dat het slechte van Richelieu afkomstig was, en wat zijn verwachting dat de koning zelf onmiddellijk partij zou kiezen voor Moutchal en de geestelijkheid? Niets dan enerzijds eigenwijsheid, anderzijds hoop. Eigenwijsheid, omdat naar Montchal's stellige mening de vorst, de hoogste rechter, eenmaal goed voorgelicht, Montchal beslist gelijk zou moeten geven. En anderzijds gewoon hoop; de wens had zijn gedachte verwekt.

In 1649 brak in Frankrijk een felle verzetsbeweging los, de Fronde, opgewekt door de tenemende macht van de monarchie. Desalniettemin hebben de Frondeurs zelf krachtig weersproken dat hun oproer de koning gold. De monarchie, erkenden ze, was door God ingesteld, noodzakelijk voor de welstand van het rijk. Nee, ze wilden hun koning Lodewijk XIV (toen elf jaar oud) gehoorzaam dienen, en dat verplichtte hen juist in opstand te komen. Want kardinaal Mazarin had zich van de koning meester gemaakt, hij hield hem eronder om zelf als soeverein te regeren. Mazarin's wanbeleid, duidelijk tegen de wil van de koning, had het koninkrijk prompt in wanorde en allerlei onheil gestort. De 
opstandigen zagen het als hun taak de koning, wiens onschuld voor hen vaststond, in zijn volle recht te herstellen, zodat het land zou opbloeien. ${ }^{46}$ En Mazarin?

\begin{abstract}
"El parceque toutes ces bonnes choses ne peuuent arriver tant que le Cardinal Mazarin commandera à cet Estat auec l'insolence et la tyrannie auec laquelle il se comporte, lequel après auoir peruerti toutes les bonnes règles d'vn légitime et raisonnable gouuernement par vne extrême ignorance et malice, ... à cause de quoy ayant esté par Arrest solemnel, déclaré Perturbateur du repos public et ennemy du Roy et de son Estat, il sera incessamment poursuivy iusques, वे ce qu'il soit mis entre les mains de la lustice pour estre publiquement et exemplairement exécuté
\end{abstract}

Net als in Engeland; onderdanen die het voor hun misleide koning opnamen bedreigden de gedoodverfde boosdoener met meedogenloze straf. Ook nu valt aan te voeren dat de jeugdige Lodewijk inderdaad, volgens de roep der opstandelingen, niets met het beleid van doen had, maar weer schiet het gegeven tekort om heel de reaktie te verklaren. Waarom de overdreven felle afwijzing van Mazarin, en waarom de verwachting dat na zijn verdwijnen een elfjarig jochie het land uit bet slop zou halen? En dan te bedenken dat Lodewijk XIV, eenmaal op jaren, de teugels van het gezag nog veel strakker dan Mazarin heeft aangetrokken! Het verhaal van de goede maar onwetende koning, misleid door een slechte dienaar, heeft in 1649 een eigen leven geleid.

En het bleef van kracht, al de jaren van het Franse koningschap. Montesquieu heeft cok opgemerkt hoe de vorst werd ontzien en hij vermeldde het in zijn Esprit des lois van 1748. ${ }^{47}$

\footnotetext{
"Une preuve qu'on l'aime, c'est que l'on a de la confiance en lui, et que, lorsqu'un ministre refuse, on s'imagine toujours que le prince aurait accordé. Mème dans les culamités publiques, on n'accuse point sa personne; on se plaint de ce qu'il ignore, ou de ce qu'il est obsédé par des gens corrompus. Si le prince savait! dit le peuple. Ces paroles sont une espèce d'invocation, et. une preuve de la confiance qu'on a en lui."
}

Het volksgeloof was een halve eeuw later, kort voor en zelfs tijdens de Franse Revolutie, nog springlevend. Historici wijzen op een algemene overtuiging dat Lodewijk XVI de revolutie steunde; haar zaak was immers rechtvaardig en de koning, goede vader van zijn onderdanen, zou zeker de redelijke wensen van zijn volk inwilligen zodra hij ze vernam. ${ }^{48}$ Uitspraken en gedragingen die er tegenin gingen, werden derhalve als vanouds toegeschreven aan 's konings eigenzinnige en boosaardige raadsheren. Dit lijkt zelfs mee te spelen tijdens die gedenkwaardige bijeenkomst van de volksvertegenwordiging op 23 juni 1789 , de dag dat Lodewijk haar had opgedragen uiteen te gaan. Na zijn vertrek merkte een achtergebleven dienaar op: Heren, u hebt de wil van Zijne 353.

47. Montesquieu, L'esprit des lois XII.23; een soortgelijke opmerking trouwens bij Hegel. Vorlesumgen $1817 / 18$, blz. 201. 
Majesteit gehoord; waarop de graaf van Mirabeau verontwaardigd met donderende stem uitviel: Jawel, de wil die hem was ingegeven! ${ }^{49}$

"Oui, Monsieur, nous avons entendu les intentions qu'on a suggérées au Roi ..."

Daarna de beroemde woorden dat de Nationale Vergadering slechts door geweld van bajonetten kon worden verdreven. De revolutie zette door en Lodewijk, ondanks de eigengereidheid van Mirabeau en de zijnen, besloot verder mee te werken. Een doorslaggevend bewijs dat de koning voorheen steeds was misleid, want na opening van zaken nam hij onverwijld en van harte de volkswil tot richtsnoer van zijn beleid. Men was dus werkelijk namens de koning in opstand gekomen! In 1790 schreef een pamflet dankbaar: ${ }^{30}$

"Louis, qui veut le bien, n'est plus entouré de gens qui veulent le mal et le trompent, mais il se fie, il s'abandonne au zèle et aux bonnes intentions de l'Assemblée nationale."

De fiktie beheerste in die jaren het openbare debat, en haar gevolgen werken nu nog na: De staande term "Ancien Régime", die heden ten dage in de geschiedwetenschap steevast wordt gebruikt voor het tijdperk dat in 1789 ophield, werd destijds met opzet gevormd om uitdrukkelijk te bepalen dat de revolutie niet aan de monkarchie, maar slechts aan het regime der ondeugdelijke ministers een einde had gemaakt. "Tenslotte hield Lodewijk het niet langer uit, en hij probeerde, juni 1791, met zijn gezin naar het buitenland te ontkomen. Vergeefs. Hij werd bij Varennes herkend en gearresteerd. Het verhaal van de slechte raadgevers was nu onhoudbaar, de koning had overduidelijk tegen de revolutie gekozen. Eventjes deed een oude aanvulling opgeld: Vijanden van het volk en van de revolutie hadden de koning tegen zijn wil ontvoerd. Maar het geloof dat Lodewijk de revolutie was toegedaan nam af, en het einde van de koning, politiek en persoonlijk, naderde met rasse schreden.

Engeland en Frankrijk; nog meer? Een land van ongeletterden, van mystiek en van onbegrensde staatsmacht, eindeloze uitgestrektheid: Rusland vooral. Eeuwenlang heeft het beeld van de goede tsaar een onverbrekelijke betovering gehad. Zelfs Ivan de Verschrikkelijke werd in bescherming genomen met het sprookje dat de wreedheden van zijn bewind de schuld van ondergeschikten waren. Reusachtige opstanden hebben herhaaldelijk het land geteisterd, maar altijd in naam van de tsaar; desnoods wendde een opstandelingenleider voor zelf de echte tsaar te zijn. De tsaar, zeer met zijn volk begaan, zou het graag helpen, maar zijn vrouw, de adel, ministers weerhielden hem. Het verhaal had, ondanks de velerlei gedaanten en telkens verschillende uitwerking, onveranderlijk dezelfde opbouw en grondslag: De boze omgeving van onze vorst, die altijd goed is en altijd rechtvaardig, maakt het hem onmogelijk zijn goede wil te volvoeren. 
Door haar verbreiding, haar voortduur en haar ongeremdheid werd de Russische mythe wijd en zijd bekend. Ze werd grondig onderzocht en dan ook onmiddellijk herkend toen ze na 1917 weer opdook. Want de klacht dat Lenin en Stalin werden bedrogen had niets met de werkelijkheid te maken; het was eenvoudig bet aloude verhaal van de goede tsaar, dat zich nu zonder de minste ideologische schaamte aan de kommunistische leiders hechtte. De overeenkomst werd trouwens, aardig genoeg, ook in Hitler's Duitsland opgemerkt; een verslag in 1935 vergeleek het Duitse Wenn der Führer wiusste met de Russische overlevering dat de tsaar uitsluitend door onwetendheid zijn trouwe volk op de verlossing liet wachten. ${ }^{52}$

Geloof en ongeloof, dit was een bijzonderheid van het 19e eeuwse Rusland, konden vlak naast elkaar bestaan. De intelligentsia, op afstand van de boerenbevolking, overzag de strekking van de mythe en bestudeerde die. Sjtsjapov, hoogleraar aan de universiteit van Kazan, meldde in 1861 de hartstochtelijke verzuchting van een boer, na bloedige rellen: "Oh, liet God maar iemand, zelfs u, slechts eén woord voor ons aan de tsaar zeggen!" Tien, twintig jaar later, een verbluffend staaltje in de provincie Tsjigirin. De jonge revolutionair Iakov Stefanovitsj besloot het volksgeloof naar eigen inzicht te sturen. Hij gaf zich uit voor een gezant van de tsaar, toonde vervalste brieven van hem, en wist op die manier de onwennige boeren (ze hadden zich de aankomst van hun redder heel anders voorgesteld) aan te zetten tot vorming van een geheim revolutionair genootschap. Het liep overigens op niets uit.

Stefanovitsj kreeg later gelegenheid zijn verhaal te doen. De samenzwerende boeren, vertelde hij, waren bevreesd voor een valstrik van hun tegenstanders. Die zouden wellicht zomaar iemand als tsaar verkleden, hem hun valse opdrachten in de mond leggen. om hem zo aan de boeren voor te houden. Stefanovitsj vervolgde scherpzinnig dat deze mensen hun standpunt nimmer zouden opgeven, zelfs niet wanneer de echte tsaar voor ze stond; zou hij niet denken als zij, dan zouden ze hem ogenblikkelijk een bedrieger schelden, en hem afwijzen. Want de tsaar der boeren is een droombeeld, geen mens van vlees en bloed. ${ }^{53}$

"De plaats van deze tsaar is niet in het Winterpaleis, maar alleen in de verbeelding van het volk."

\section{$\$ 4$.}

De goede vorst, misleid en weggehouden door zelfzuchtige dienaren: We troffen hen aan als volksmenner, als diktator, als koning, als keizer, in Italië, in Duitsland, Engeland, Frankrijk, Rusland, verspreid over vele eeuwen, van de $14 \mathrm{e}$ tot de $20 \mathrm{e}$, onze eeuw. Het is alsof iedere keer met andere bezetting, met andere hoofdrolspelers en figuranten, toch precies hetzelfde toneelstuk wordt opgevoerd. Een rijke opbrengst, en het is aanlokkelijk de verzameling uit te breiden; elk eenhoofdig bewind ter wereld te onderzoeken om te bezien of het verhaal ook daar wordt verteld. Interessante vragen prikkelen de nieuwsgierigheid: Hoe algemeen komt het verbaal voor? Is het vormvast 
of kunnen we verschillen onderscheiden, in opbouw en samenstellende bestanddelen? Doorloopt, een heel boeiende kwestie, het verhaal een geschiedenis, ontwikkelt het zich, of blijft bet door de tijden been onveranderlijk?

Verleidelijke vragen; maar ze trekken het onderzoek uit haar verband. Dit boek begon met de Nederlandse grondwet en het moet met de Nederlandse grondwet eindigen; we moeten terug. Een andere vraag daarom: Wat heeft al het opgedolven materiaal, wat heeft psychologie, wat heeft cognitieve dissonantie, wat heeft de mythe van de goede koning met artikel 53 van de grondwet van 1848 te maken? Dat kan in twee hoofdstukken duidelijk worden. Hierna komt eerst een hoofdstuk, als het ware, gezien de thematische eenheid, een verlenging van het huidige, waarin de mythe van de goede koning voor Nederland wordt onderzocht; het wordt afgesloten met een korte beschouwing over het verschijusel. Vervolgens worden in een hoofdstuk de mythe en de grondwet samengebracht.

Op deze plaats dan enkel nog een tweetal zeer verscheiden en opvallende voorbeelden, beide van buiten de geschiedenis der Europese koningen, om de hardnekkigheid en de verbazende alomtegenwoordigheid van het fabeltje te benadrukken.

In voorgaande hoofdstukken werd meermaals aangewezen hoe de klassieke Europese monarchie haar theoretische inkleding van de pauselijke leer heeft afgekeken. Zo hebben de pausen ook, gedurfder dan ooit de koningen, zich onfeilbaarheid toegeëigend. Kreeg, vargen wij nu meteen, hun hoge pretentie onder gelovigen dezelfde waarde als de pretentie der koningen bij hun onderdanen? Geloofden kerkleden wellicht even innig dat hun opperheer namens God onfeilbaar was, terwijl het verkeerde in de kerk uitsluitend aan lager personeel moest worden geweten? Eén uitermate sterk voorbeeld springt in het oog, iemand die wereldgeschiedenis schreef met zijn misverstand: Maarten Luther. Luther, allerminst van plan de kerk te scheuren, hoorde boe monniken de eenvoudige gelovigen het geld uit de zak klopten met een belofte van eeuwig zieleheil, alleen om de bouw van een trotse kerk in Rome te bekostigen. Hij vatte vuur, schreef zijn befaamde 95 stellingen en maakte ze op 31 oktober 1517 openbaar; nog altijd voor protestanten de dagtekening van de Reformatie. "Wenn der Papst wüsste", beweerde Luther vol overtuiging, als de paus wist hoe het hier toegaat, dan zou hij zijn prachtige Sint Pieter het liefst platbranden, eerder dan dit toelaten. ${ }^{34}$

\footnotetext{
"Docendi sunt christiani, quod si papa nosceret exactiones venialium predicatorum, mallet basilicam beati Petri in cineres ire, quam edificari cute, carne et ossibus ovium suarum."

"Man lehre die Christen, dass wenn der Papst den Schacher der Ablassprediger wüsste, er lieher den Dom S. Petri würde zu Asche verbrennen lassen, als dass derselbe von Haut, Fleisch und Knochen seiner Schafe sollte erbaut werden."
}

Luther zou langzamerhand al dieper in moeilijkheden raken met de autoriteiten van de katholieke kerk. Lang weigerde hij te geloven dat hij het met de paus aan de stok had.

54. Stelling 50; KJemens Honselmann, Urfassung und Drucke der Ablassthesen Manin Luthers und ihre Verïffentichung, Paderborn 1966, blz. 142; H.A. van Bakel, Kleinoodiën uit Luther's nalatenschap, Amsterdam 1917, blz. 9. Ik dank de verwijzing aan mevr. Agnes Hana, Maastricht. 
Nee, de kringen rond de paus, mensen zoals kardinaal Cajetanus, die in 1518 met Luther over zijn godsdienstleer had gesproken, daar zat het kwaad! Luther ging in hoger beroep, zijn eigen woorden, van de slecht geïnformeerde paus naar de goed geinnformeerde paus. Eigenlijk had Cajetanus Luther milder bejegend dan zijn pauselijke instruktie toeliet; hij werd echter door Luther zo zwart gemaakt, dat zijn goede naam in de kerkgeschiedenis er nog eeuwen onder leed. De fiktie van de goede leider had haar werk gedaan en toen de breuk met de paus zelf, onvermijdelijk, toch kwam, had Luther andere dingen aan het hoofd dan een herziening van zijn vonnis over Cajetanus. ${ }^{\text {ss }}$

Tot 1974 was Ethiopië een keizerrijk. ${ }^{56}$ Een alleenheerschappij van het oude slag, overeenkomstig de vroegere monarchieën in Europa. Keizer Haile Selassie heerste onweersproken, hoogste rechter en hoogste wil in het land, begin en einde van de staatseenheid. Niet bij machte geheel alleen te regeren, had hij vanzelfsprekend ministers om zich heen, die hem bijstonden. En opnieuw de scheiding tussen algoede heerser en ondeugdelijke dienaren. De Minister van de Pen stond het dichtst bij de vorst, die zelf noch lezen noch schrijven kon; hij las van diens lippen de keizerlijke besluiten en schreef ze dan op.

\begin{abstract}
"Deze was de meest gehate persoon aan het hof, daar iedereen van mening was dat de wijsheid en de goedheid van Zijne Genadige Majesteit juist door de bedoelde minister werden veranderd in boosaardige en domme beslissingen, waarvan er zovele genomen werden."
\end{abstract}

De onfeilbaarheid van de keizer kon redelijkerwijze niet worden betwijfeld en de goede beslissingen waren zeker aan hem te danken. Het slechte moest dus wel van de meest nabije tussenpersoon afkomstig zijn, de Minister van de Pen.

Maar het rommelde in Ethiopië, arm en achterlijk. Nieuwlichters, bekend met de moderne wereld, wensten het land aanzienlijk te hervormen, onrust die zou uitmonden in een opstand van het leger. Tegen de keizer? Natuurlijk niet. De militairen verzekerden bij elke volgende stap dat die in naam van de keizer gebeurde. Men verwijderde slechts dienaren, die de keizer misleid en het land benadeeld hadden. Haile Selassie, zijnerzijds, vertoonde zich daarop steeds vaker in uniform, om te benadrukken dat het leger onder zijn opperbevel viel; want, was de redenering, alles in zijn rijk, ook opstand, behoorde van hem uit te gaan. De militairen, schrijft de verslaggever, handelden zo om een magisch element in het denken van het volk te ontzien.

"Dit magische element van het denken gaat ervan uit --en dat gebeurt vaak onbewust-- dat de allerhongste persoon over goddelijke eigenschappen beschikt. De hoogste is de beste. Hij is wijs en cdel, hij vergist zich nooit en heeft een goed hart. Alleen de hoogwaardigheidsbeklederszijn slecht; zij veroorzaken alle ellende. Het is zelfs zo dat als de allerhoogste zou weten wat zijn eigen mensen uithalen, hij het kwaad onmiddellijk zou herstellen zodat het leven meteen beter zou zijn! Helaas houden die geslepen schurken alles voor hun heer verborgen en daarom is het leven zo zwaar te verdragen, zo gemeen en ongelukkig."

55. Gerhard Hennig. Cajelan und Luther. Ein historischer Beitrag zur Begegnung von Thomismus und Reformation, Stuttgart 1966, blx. 80, 83; J.F.Groner, Kardinal Cajetan. Eine Gestall aus der Rejormasionszeit, Fribourg 1951, blz. 16 nt. 20.

56. Het volgende uit Kapuscinski, vooral 18, 191, 198-199, 225. 
Twee wijd uiteenliggende gevallen, die dit hoofdstuk fraai afsluiten. Samen met al de andere vergaarde voorbeelden geven ze vertrouwen dat inderdaad het sprookje van de goede maar misleide heerser door heel de wereld algemeen voorkomt; een kleurrijke illustratie bij de uitspraak die Csaba Varga, hedendaags Hongaars rechtsfiloscoof, eens deed: ${ }^{57}$

"All the way from children's tales up to the painful reality of today, we may encounter the myth of the good ruler whose wicked entourage is a source of mere suffering for the people."

En een hart onder de riem van onderzoekers als Freud en Fromm. Het ziet ernaar uit dat mensen inderdaad stelselmatig de mythe van de goede koning en zijn kwade raadgevers verzinnen; waarom dan? Kennelijk als middel tegen de gedachte dat hun opperheer zelve niet zou deugen. Iemand zei tegen mij: De gedachte is onverdraaglijk dat een koning je kan doden. Onverdraaglijk, omdat de orde bij de koning sluit. Hij is hoogste rechter, laatste toevlucht; zou hij niet rechtvaardig zijn, dan hebben onderdanen in de wereld voorgoed geen recht. Onverdraaglijk, omdat zij zich optrokken aan zijn onfeilbaarheid; zou hij falen, zou hij de waarheid niet weten, dan stonden ze met lege handen, feilbaar, zwak, onbeschermd.

Kernwoorden uit de vorige twee hoofdstukken keren hier terug, met een nieuwe zin: Formele en materiële onfeilbaarheid moeten, het hoogste gezag en de ware kennis móeten elk moment samenvallen. Door eenheid met de Koning als Gemeenschap ontvluchten mensen de eenzaambeid; door eenheid met de Koning als Gerechtigheid ontvluchten zij de onzekerheid. En ze geloven dus, krampachtig, dat de Koning ze nimmer zal begeven. Krampachtig? Welnee; iedereen kan toch zelf zien dat het de schuld van de minister is? 

Hoofdstuk 6

\section{De goede Koning in Nederland}

Nederlanders zijn mensen als alle andere; het lijkt niet overmoedig dit te beweren. Op z'n Nederlands hebben we part en deel aan al de wonderlijke eigenschappen, gebreken en verlangens die in de mensheid huizen. Mogen we derhalve bij voorbaat aannemen dat de mythe van de goede koning ook in Nederland heeft opgespeeld? Een tegenwerping is denkbaar: Nederland kende nooit een gevestigde alleenheerschappij als de Franse monarchie of het moderne totalitarisme; nooit regeerde een Grote Leider onweersproken, onweerstaanbaar over ons. Maar dat zegt niet alles. In het vorige hoofdstuk werd gezocht naar een geloof aan de alwetendheid en algoedheid van zekere personen, een geloof dat dan een psychologisch verschijnsel zou zijn; eigen aan de mensen. Het staat dus los van de precieze regels der staatsinrichting en kan, hoewel het zich misschien, natuurlijkerwijze, op hooggeplaatsten richt, overal in de samenleving optreden. Een speurtocht door de Nederlandse historie hoeft daarom niet vruchteloos te eindigen.

\section{$\S 1$.}

Nooit bestendige alleenheerschappij; wel probeersels. Nog in het nabije verleden heeft een heerser door overmacht Nederland onder zijn hoede willen nemen: Adolf Hitler, de diktatuur in persoon, bezette ons land in 1940, denkende het aan zijn gebied toe te voegen. Zijn bewind verwierf geen algemene erkenning, wist die niet eens te benaderen, maar wel werd althans een minderheid van de bevolking gewonnen. Nederlandse fascisten lieten zich de Duitse overheersing aanleunen of juichten haar zelfs toe, en verenigden zich met de Duits-fascistische beweging. Voor ons een goede plaats om de rode draad weer op te nemen: Hebben deze mensen, net als hun Duitse soortgenoten, aan Hitler's bovenmenselijke gaven en aan zijn altijd zuivere bedoelingen geloofd? Waren ze vatbaar voor de legende van een welwillende Fuhrer die last heeft van misdadige medewerkers?

Anton Mussert, voorman van de Nederlandse fascisten, maakte op 16 november 1936 persoonlijk kennis met Adolf Hitler; hij werd prompt gevangen door de bedwelmende inwerking van deze man en hij zou er van zijn leven niet meer uit loskomen. Een fatale betovering. Mussert, zijn lot welgemoed verbonden aan Hitler's wereldhistorische zending, zag zijn trouw steeds zwaarder op de proef gesteld. Hij had gerekend op een waardig bondgenootschap, als tussen gelijken, met zelfstandigheid voor Nederland, 
immers een Germaans broedervolk. Er kwam niets van terecht. Nederland werd door de Duitsers hardvochtig bezet, onderdrukt, uitgezogen. Soms voelde Mussert de twiffel opkruipen. Dan keck hij naar bet portret van zijn Führer: "Kan ik je nou vertrouwen, ja of nee?" Ja, ja, en nog eens ja! Het lag beslist niet aan Hitler. Mussert maakte zich wijs dat minderen, met name Heinrich Himmler, buiten Hitler om aasden op inlijving van Nederland, en heel zijn beleid in die jaren is een voortdurende poging tot Hitler door te dringen. Als hij het maar aan Hitler zelf kon zeggen! '

Mussert werkte zich in zijn waanbeeld vast, niet in staat zich te bevrijden, ook niet na de oorlog, toen Hitler dood was. Voor de rechter gehaald ter zake van landverraad, mikpunt van landelijke haat en spot, verweerde bij zich met vaste stem. ${ }^{2}$

"Ik heb meermalen gezegd en ik herhaal het hier: Adolf Hitler droeg ons volk geen kwaad hart toe, hij had het beste met ons voor, maar hij werd systematisch tegengewerkt door zijn omgeving. Hij had mannen om zich heen, die niet tot zijn schouders, maar tot zijn knieen reikten."

Misschien geen toeval dat hij uitgerekend op dit punt van het pleidooi, in het vuur van zijn rede, bij vergissing de aanwezigen in de rechtszaal tot hun vermaak met "mijne getrouwen" aansprak, alsof hij weer voor zijn volgelingen stond. Hier school de kem van zijn verblinding, hier lag de knoop van de tegenstrijdigheden die hij in de bange hartstocht van zijn wanhopige geloof aan Hitler met geweld moest bijeenhouden. En later:

"Ik ben er vast van overtuigd, dat Hitler het niet wist. Als U evenals ik het Führerhauptquartier had kunnen bezoeken, dan had $U$ gezien, dat het een vesting was mel vele rijen prikkeldraad er om heen. De Führer is een krijgsgevangene geweest in zijn eigen hoofdkwartier en hoorde slechts, wat anderen hem zeiden."

Maar, vroeg de voorzitter van het hof, als u dit doorzag en Hitler u dus ontviel... Mussert onderbrak: "Hij is mij nooit ontvallen! " Had Hitler niet uiteindelijk nagesproken wat Mussert altijd al had voorgezegd? In zijn politieke testament stond dat Himmler en Goering verraders waren, en ze werden alsnog uit de partij gezet. Mussert verklaarde het met "groote voldoening" te hebben vernomen; in het aangezicht van de dood had zijn Fürer hem dan toch gelijk gegeven. Mussert kon daarom oprecht aan Hitler blijven geloven en hij heeft dat waarschijnlijk tot het einde gedaan. Een bitter einde, want hij slaagde er niet in zijn rechters te overtuigen. Mussert werd ter dood veroordeeld en op 7 mei 1946 terechtgesteld. Jan Meyers, schrijver van Mussert's leven, merkte op: ${ }^{3}$

"Toen de radionieuwsdienst het bericht van Musserts executie bekend maakte, waren er mensen die elkaar opbelden om elkaar met het heuglijke feit te feliciteren. Zij geloofden misschien dat de wereld een bectje lichter en zijzelf gelukkiger waren geworden."

1. Meyers 114, 147, 184, 212, 224, 231, 233, 254

2. Rijksinstituut voor Oorlogsdocumentatie, Het proces Mussert, (oorspr. 1948) Amsterdam 1987. blz $143,195-196$

3. Meyers 291 . 
Mussert, naar het stralende voorbeeld van de geliefde Fuhrer, was ook zelf een ware leider geweest, tenminste in de ogen van zijn volgelingen. Weer het verhaal. Een Nederlandse SS'er, terug van het Russische front, wilde zo snel mogelijk met Mussert zelf spreken: "omdat ik wist dat de hele omgeving van Mussert zo rot was als een mispel." Mussert had, vertelde hij een kwart eeuw later, in zijn grenzeloze eerlijkheid gewoon niet kunnen vermoeden "dat de mensen zo gemeen waren om een heel apparaat om hem heen op te bouwen". Hij ging naar Utrecht, waar Mussert zetelde, werd natuurlijk door medewerkers opgevangen en tegengehouden. Kreeg ruzie. ${ }^{4}$

"Toen ben ik giftig geworden. Ik zeg, barsten jullie met jullie helc zooi, ik kom toch wel waar ik komen wil. Het is me nooit gelukt. Hahaha. Ze hadden toch wel gelijk."

Geen doorsnee Nederlanders, maar Nederlanders. Ze hadden zich innerlijk aan hun Leider gehecht en stopten de gedachte van zijn menselijke feilbaarheid weg achter het verzinsel dat zijn omgeving niet deugde. Mensen, verstrikt in een totalitaire wijze van denken, gedoemd tot teleurstelling, des te groter en des te rampzaliger naarmate zij verder afraakten. We hebben, een hoofdstuk geleden, de mythe van de goede leider eerst in het 20 e eeuwse totalitarisme opgezocht en aangewezen; daarna vonden we haar teng in oude monarchale samenlevingen: De mythe van de goede leider bleek de mythe van de goede koning te zijn. Zo kan het in dit hoofdstuk opnieuw gaan. Zou het ons lukken, behalve bij Nederlanders onder een modern totalitair stelsel, dan ook in vroegere tijd en omstandigheid sporen van de mythe te ontdekken?

\section{$\S 2$.}

Huizinga slaat een brug tussen Nederland en daarbuiten. Zijn Herfsttij der middeleenwen omvatte gezamenlijk de Franse en de Nederlandse beschaving van de 14e en 15 e eeuw. Een tijd, in Huizinga's woorden, van felle levendigheid en kinderlijke eenvoud. De vorst, hoogtepunt in de beleving, vereerd en vertrouwd, werd door bet volk met een mengeling van werkelijkheid en sprookje aangezien. ${ }^{s}$

\footnotetext{
"De politieke voorstellingen, waarin men leef, zijn die van het volkslied en den ridderroman. Men herleidt als het ware de koningen van zijn tijd tot een beperkt getal van typen, elk min of meer beantwoordend aan een motief uit lied of aventure: de edele, rechtvaardige vorst, de door booze raden misleide vorst, de vorst wreker van de eer van zijn geslacht, de vorst in het ongeluk door de trouw der zijnen gesteund."
}

Verbeelding bracht de tijdgenoten op het verhaal van de goede vorst die donr schurkachtige raadgevers wordt misleid; maar het vormde tevens de beoordeling van feitelijke toestanden waarin men zich bevond. Wanneer het volk misstanden te verduren kreeg, putte het kracht en geduld uit de wetenschap dat hun vorst van het lijden niet wist: "le prince n'en sçait riens". Aan een gevierde volksprediker werd te Parijs het preken 4. Armando en Hans Sleutelaar, De SS'ers. Nederlandse vrijwilligers in de Tweede Wereldoorlor. \%.p.
1978 , blz. 173-174.

5. Huizinga $9,14,70$. 
verboden, om de onrust die hij stookte; de samengelopen Parijzenaars lachten hartelijk, zeggende dat het verbod dwaasheid was, en buiten medeweten van de koning. ${ }^{6}$

"... que ce n'estoit que folye et que le roy ne savoit rien des choses dessusdictes, et que c'estoit mal fait d'avoir ordonné de faire ledit cry."

De Nederlanden, opgenomen in de onontwarbare gezagsverhoudingen van het feodale stelsel, behoorden uiteindelijk tot het gebied van de Duitse keizer, hun hoogste opperheer. De ernstige verzwakking van diens macht liet echter ten onzent de hoge adel vrij spel; hertogen en graven maakten de dienst uit en zij hielden hof als waren zij niet aan hoger gezag onderworpen. Evengoed kon ook in deze tijd het verhaal van de goede vorst tot leven komen. Van graaf Willem III werd verteld, het zou in 1336 zijn geweest, dat hij een boer in bescherming had genomen tegen de baljuw van Zuid-Holland. De baljuw ontstal de boer zijn koe, de boer wendde zich tot de graaf, die de baljuw bij zich riep, hem opdroeg de boer schadeloos te stellen en hem zwaar strafte bovendien. Bij de hoogste heer is recht! Een zeer gewild verhaal; Holland kon het drie eeuwen lang, tot de $18 \mathrm{e}$ eeuw toe, niet vaak genoeg horen en geen ander uit de vaderlandse historie is vaker afgebeeld. ${ }^{7}$

De vertelling van Willem's "Goede Justitie" tekent het geloof in de rechtvaardigheid van de heer; het onrecht kwam van de lagere autoriteit, de hogere bracht herstel. En er zijn meer voorbeelden. Het bekende gedicht over Karel en Elegast, hierboven reeds aangehaald als uiting van diepgeworteld vertrouwen in de zorg van de vorst, is een heriunering aan de oude tijd, toen nog een echte keizer, Karel de Grote, over de Nederlanden heerste. Elegast was door Karel verstoten en moest als inbreker maar zien rond te komen; wanneer echter Karel hem in het nachtelijke duister ontmoet en hem voorstelt van de keizer, dus van hemzelf te roven, wijst Elegast dat verontwaardigd van de hand. Jawel, hij viel ten onrechte bij de keizer in ongenade, maar hij blijft hem trouw, want het was slechts door verkeerde raad. ${ }^{8}$

Al heef hi mi bi kwaden rade

Mijn land genomen ende verdreven,

Ik zal hem wezen al mijn leven

Gestade vriend na mine macht.

Niets dan een schone legende, kun je zeggen, troostrijke woorden voor de vrije tijd. Maar wie zal weten of het niet toch serieus werd genomen? Rond 1400 verkeerde aan het hof der Hollandse graven de dichter Willem Hildegaersberch; hij zong over de mensen om hem heen, de graaf, de hovelingen, maar in de bewoordingen van de mythe:

6. Bemard de Mandrot (ed.). Joumal de Jean de Roye connu sous le nom de Chronique Scandaleuse 1460-1483, deel II, Parijs 1896, blz. 72.

7. Nienke B. Smits-Veldt, Een baljww in opspraak, Muiderberg 1983, bla. 17/18; Henri van de Waal, Drie ecinven vaderlandsche geschied-uitbeelding 1500-1800. Een iconolngische studie I, Den Haag 1952, blz. $258 f$.

8. Karel ende Elegast (vele edities) vs. 622-625. 
Terwijl de heer het wel goed meent, zijn de dienaren uitzuigers die het onderste uit de kan willen. Was het hem ernst? ${ }^{9}$

Die heren sijn wel soe bedacht

Dat sy niet dan recht en mienen

Mar hoer dienres, die hem dienen,

Die ruecken thonich uten braem.

Een vast thema van de middeleeuwse hofliteratuur, wordt er bij gezegd, even oud en verbreid als die literatuur zelf. Hebben de hofdichters en hun gehoor het dan ook louter als literaire vorm beschouwd? Een stijlbloempje? Hebben ze de klacht ernstig bedoeld? Of waren de dienaren werkelijk verdorven? Of anders nog, verzonnen de dichters bet verbal als handige omleiding voor kritiek die ze hun heer niet rechtstreeks durfden zeggen? Maar misschien moeten we helemaal niet proberen fantasie en werkelijkheid haarscherp te scheiden. Wordt niet onze beleving van hetgeen we meemaken dikwijls sterk gekleurd door beelden die ons uit film of romans waren bijgebleven? Soms wisselen werkelijkheid en verbeelding; zo moeten we wel opmaken wanneer we zien boe de nythe een vooraanstaande plaats bekleedde in die indrukwekkende worsteling, grondslag van de onafhankelijkheid en de onderlinge eenheid der noordelijke Nederlanden, toen ons land binnen een tachtigtal jaren de weg aflegde van verdrukking en benauwenis naar wereldmacht.

De Nederlandse gewesten vormden in de 16e eeuw geen koninkrijk, maar ze behoorden aan een gemeenschappelijke heer die toevallig ook koning was, zij het van Spanje; toen de strijd een aanvang nam, koning Philips II. De uitstraling van het koningschap heeft hoogstwaarschijnlijk in die jaren haar invloed niet gemist. Godsdienstige kwesties beroerden het land. De protestantse ketterij, door Maarten Luther aangesticht, had om zich heen gegrepen en spoedig de lage landen bij de zee bereikt, waar ze gunstig werd ontvangen. Koning Philips II, streng katholiek, hoorde met ergernis hoe de protestanten snel groeiden in getal. Hij zon op maatregelen. De ketters werden op zijn bevel zwaar vervolgd; zijn staatkundige streven een moderner, strakker bestuur in te voeren en meer belasting te heffen paste bij de godsdienstige onderdrukking, en versterkte haar. Maar het ijzeren bewind, met koninklijke macht doorgevoerd, bewerkte het tegendeel; de onrust nam toe.

Een zwervende predikant, gezocht door de autoriteiten, nergens veilig, zag tenslotte voor zich en zijn geloofsgenoten slechts deze uitweg: Hij kon aan de koning zelf schrijven. Dus maakte Guido de Brès in 1561 een tekst die de protestantse leer samenvatte, om de koning beter in te lichten; het stuk zou later bekend worden als de Nederlandse Geloofsbelijdenis. De Brès stopte er een brief bij, persoonlijk aan Philips II, op voorbeeld van Calvijn's brief in 1536 aan Frans I. Graag, schreef hij, zouden protestanten de "gherechticheyt" van hun zaak voor de koning bewijzen, maar ze werden niet bij hem toegelaten omdat vijanden zijn oren hadden vervuld met laster; booswichten die de

9. Frits P. van Oostrom, Het woord van eer. Literatuur aan het Hollandse hof omstreeks 1400, Amsterdam 1987, blz. 67.

"Thonich uten braem": Honing van de brem. 
goedheid en het geduld van de koning misbruikten. Deze woorden moesten dan Philips II onder ogen komen, men bedenke, over maatregelen die van harte 's konings eigen beslissing waren geweest: ${ }^{10}$

"... u ootmoedelic biddende, ... dat ghy niet toe en laet, dat die daer door ghiericheyt, eerghiericheyt, ende ander quade gheneghentheydt haer begheuen hebben, uwen arm, Authoriteydt, ende macht te ghebruycken om haren luste ghenoech te doene, om haer te versadighen ende veruullen met den bloede van uwen ondersaten, bewumpelende ende omhanghende alle goeden ijuer, des Godureesenheyts ende Godsdiensticheydts, onder de woorden van oproer, afwijckinghe, erghemisse ende andere, met welken sy u teghen ons ontsteken."

De brand zou alleen maar hoger oplaaien. In 1566 werden door heel het land kerkgebouwen bestormd en van de katholieke versieringen ontdaan. Philips bleef het antwoord op de heiligschennis niet schuldig; hij zond de hertog van Alva met een legermacht naar de Nederlanden om orde op zaken te stellen, waana Alva's onverbiddelijke beleid prompt het land tegen hem in het harnas joeg. Let wel: tegen Alva, niet tegen de koning. De opstandigen begrepen dat Alva's meedogenloosheid niet strookte met de aangeboren en alom bekende welwillendheid van de koning; ze vonden die bovendien volstrekt misplaatst omdat zij geen andere begeerte hadden dan algebele trouw aan hun goede vorst. Maar de wrede hertog verwrong de zuivere bedoelingen van Philips tot een eigenzinnige en baatzuchtige handelwijze en noodzaakte hen zich te verzetten. Opstand was plicht om de wil van de koning recht te doen.

Prins Willem van Oranje en de Staten van Holland en Zeeland, bondgenoten en brandpunten van het verzet, maakten in 1573 een zendbrief aan Philips II openbaar. Ze waarschuwden hem dat Alva onder 's konings naam arglistig en goddeloos regeerde. Uit haat en nijd; jaloers geworden door de heersende voorspoed badden hij en medeplichtige boosdoeners het plan opgevat zich hier te verrijken, ten koste van Zijner Majesteits bezit. De weerstand die zij wekten werd aan Spanje gerapporteerd als ketterij en rebellie tegen het wettig gezag, hetgeen de koning ertoe bracht hard in te grijpen. Jaren vol wreedheid en afpersing waren gevolgd, en de goede naam van de koning in het buitenland begon te lijden. Ondenkbaar dat hij zulks beoogde: "

"Derhalven en konnen wy ons geensins laten bedunken dat uwe Majesteit alsulken grouwelijke ongerechtigheden, grote gewelden en moedwillige dertelheid eenigsins soude willen toestaan, so verre als sy van der saken na de waerheid eenigsins waren onderricht ..."

Maar de koning wist het niet. Hij verliet zich op de berichtgeving van Alva, en de klachten van het volk bleven halverwege steken.

"... de wegen zijn tot noch toe besloten geweest, so dat ons schrijven noch ons geschrey tot uwer Majesteits ooren niet en heeft konnen doorbreken."

10. Jan N. Bakhuizen van den Brink, De Nederlandsche belijdenisgeschriflen, Amsterdam 1940, blz. 55 57.

11. Pieter C. Bor, Oorsprongk, begin en vervolgh der Nederkandsche oorlogen, beroerten, en borgerhte oneenigheden l, Ansterdam 1679, blz. 464-472. 
Weg met Alva's lasterlijke beschuldiging dat de Nederlanden de wapens opnamen tegen hun rechtmatige vorst! De hartelijkste wens der opstandelingen was hem gehoorzaam en onderdanig te dienen. Maar verzet was geboden tegen de tyrannie en misbruiken van de bloeddorstige Alva en zijn aanhang, juist met het eerlijke doel de welvaart van Zijner Majesteits erflanden te behouden. De indringende brief eindigde met een smeekbede aan andere vorsten, om bemiddeling en om hulp, opdat deze keer de klacht van het volk eindelijk de koning ter ore zou komen.

\footnotetext{
"Biddende derhalven alle Christelijke Potentaten en Vorsten, dat sy hater met een Cliristelijk medelijden over onsen nood en jammer laten bewegen, en nademael wy genueg bedaclit zijn, dat dese onse supplicatic en verklaringe, even also verdrukt en achterhouden sal worden. gelijk alle de voorgaende, so dat sy in onser Coninks handen niet en sal konnen komen, dat sy doch willen het selve sijner Majesteit aengeven en hem den selven bestellen. op dat onse recht eenmael in 't licht mach komen, en dat sijne Majesteit van so veel onschuldig bloed, dat mits dese Albanise Tyrannic vergoten word, voor God almachtig mach ontschuldigt werden."
}

De fiktie werd ver doorgevoerd. De Staten van Holland trokken de stoute schoenen aan en vaardigden voortaan zelf wetten uit; maar onveranderlijk op naam van koning Philips II, en "bij advies van onsen lieven neve", dat is Willem van Oranje. De stad Leiden had zich dapper geweerd toen Spaanse troepen haar belegerden en ontving als dank in 1575 haar universiteit; een geschenk van Philips, volgens de officiële stukken! ${ }^{12}$ De Unie van Utrecht, het verdrag dat de noordelijke Nederlanden in 1579 samenbond, naar later bleek, voorgoed, bepaalde dat men elkander zou bijstaan tegen alle gewelddadigheid "die hem yemant soude moghen aendoen vuyt ende ondert dexsel vanden naeme vande Conincklicke Majesteyt ofte van zynent weghen". De druk der feiten nam toe en de waan bezweek. In 1581 werd de trouw aan Philips bij Plakkaat van Verlatinge plechtig opgezegd; de koning, luidde het argument, had niet alleen getalmd de schuldigen te straffen, onderschepte brieven wezen bovendien uit dat hij wel degelijk zelf achter de gewraakte politiek had gezeten. ${ }^{13}$

Ons lijkt de uitkomst voorspelbaar. Wij, die de felheid van Philips' katholieke geloof kennen, en weteı hoe hij gekant was tegen de wensen van de Nederlandse opstandelingen, wij verbazen ons dat zij van zijn goede wil bleven spreken. Hebben ze het werkelijk gemeend? Vast niet. Willem van Oranje kende Philips persoonlijk; hij heeft toch beter geweten? Was het niet een slimme maskerade om de toorn van de koning te ontgaan, een kunstgreep die verzoening tussen vorst en volk alsnog gemakkelijk maakte? Maar de teksten schijnen te goeder trouw, ze zijn anderszins nauwelijks te rijmen. Was de omweg, indien opzettelijk, zoveel handiger dan een eerbiedig vertoog, rechtstreeks aan de vorst? Kon men heus menen Philips gunstiger te stemmen wanneer zijn beleid onder mom van kwade raadslieden voor 'arglistig' en 'bloeddorstig' werd uitgemaakt? Is er een mythe van Philips' koninklijke goedheid geweest? In elk geval eindigde zij dan in 1581; de feiten waren haar te machtig geworden. Ook een argument tegen de psychologische hypothese: Het koningsgeloof kan afbrokkelen en verdwijnen, het heeft klaar-

12. De Vrankrijker 90, 124

13. Z.W. Sneller, Unie van Utrecht en Plakkaat wan Verlatinge. De wording van den Nederlandschen staar, Rotterdam 1929, blz. 35, 73 . 
blijkelijk niet de blijvende en onverwoestbare algemeenheid die eraan wordt toegeschreven. Of wel? Een mythe verging, maar dé mythe, ik zou bijna zeggen: de Mythe-mereen-grote-M, bestond ongehinderd voort. Ze werd niet doorzien en hoefde zich maar te verplaatsen on elders, in een andere tijd en bij andere mensen, een nieuw leven te beginmen. Een toneelstuk, werd hierboven al gezegd, dat met andere bezetting, met andere hoofdrolspelers en figuranten, telkens weer als nieuw en als vanouds kan worden opgevnerd. De Nederlandse geschiedenis laat het treffend zien.

\section{$\S 3$.}

De opstand tegen koning Philips II heeft het Nederlandse volk zeer aangegrepen. De benauwde jaren van geloofsvervolging, het opgedrongen doch hopeloze gevecht van een klein en verdeeld land met de Spaanse supermacht, de nederlagen, de opluchting van de eerste geslaagde tegenzetten -- het grifte zich alles in de Nederlandse geheugens, als een bron voor eeuwen van nationaal besef en van nationale mythologie. Eén lichtende persoonlijkheid beheerste de herinnering: Prins Willem van Oranje, de aanzienlijke edelman, rijk en begaafd, die alles opgaf om het verdrukte landje te redden, zijn zelfopoffering voltooiend door als martelaar te sterven, vermoord. Willem's magedachtenis werd nog lang gekoesterd, vooral in strenger protestantse gemeenschappen, waar de vijandschap tegen Spanje en het katholicisme levendig bleef: "de predikanten willen geen kwaad woord van hem horen". Hier vond waarschijnlijk het gezegde "Van de prins geen kwaad weten" haar oorsprong; minder vriendelijke uitlatingen over de prins waren ongewenst. ${ }^{14}$

De glans van Willem's onbaatzuchtigheid straalde uit over zijn nageslacht. Oranje hoorde bij Nederland, Oranje had niets dan Nederland's belang op het oog. Oranje was door God aangesteld en met uitzonderlijke begaafdheid toegenust om Nederland's welvaart te bevorderen. Prins Maurits, zoon en opvolger van Willem I, bracht door gelukkige oorlogvoering het opstandige Nederland in veiligheid. Hij werd met eer en dank overladen, lofdichten roemden "de meer als menschelijcke volmaecktheden van Uwe Vorstelycke Deuchden", Maurits' moed, verstand, kennis van zaken, de kracht en majesteit van zijn lichaamsbouw, ziju soberheid. Al wat hij zei had belang, maar hij was niet stijf, integendeel vol geestigheid. 's Ook stadhouder Willem II, later, werd bovenmate geprezen: "een wonder deser eeuwe", een "Hoogwijsen, verre-sienden Vorst", edelmoedig, dapper, bescheiden, wars van vleierij. Dag en nacht bepeinsde hij Nederland's voordeel: ${ }^{16}$

Die tot welvaer van ons Landt,

Alle mocyten neemt ter hand:

Die soo veele naere nachten.

Over-brenght met swaer gedachten

14. Huisman 75; Frederik A. Stoett, Nederlandsche spreekwoorden, spreekwijzen, uildrukkingen en gezegde' II. (owrspr. 1902) Zutphen 1943, blz. $189 / 190$.

15. Rax 62, 182, 319-321.

16. Groenveld 65-67; vgl. Bax 92, 174. 
Hoewel de stadhouder in de Republiek der Zeven Verenigde Nederlanden beslist niet de positie van vorst bekleedde, met enig recht zelfs een ambtenaar heette, geloofde het volk graag dat de Oranjes over Nederland als koningen regeerden. Steun werd gevonden in de protestantse neiging Nederland's geschiedenis naar bijbelse begrippen op te vatten; God had de Oranjes aan Nederland geschonken, zoals vroeger de koningen in bet Oude Testament aan het volk Israël. ${ }^{17}$ Bovendien de prinselijke titel, eigenlijk ontleend aan het prinsdom Oranje, een grondgebied in Zuid-Frankrijk; maar een dergelijk juridisch onderscheid was te fijnzinnig voor de gewone mensen, die bet eenvoudigweg over 'de prins' hadden, niet over de 'prins van Oranje', en daardoor zo goed als onbereikbaar werden in hun overtuiging dat Oranje over Nederland soeverein was. De pamflettist Joban de Wit probeerde er wat aan te doen. ${ }^{18}$

\footnotetext{
"Vele van de slechte gemeente, die gemeenlijck noch verstant van de regering ofte politie, noch kennisse van saecken hebben, dickwils niet verder sien, dan haer neus langh is; ... siende dat de princen van Orangien exerceerden soodanigen hoogen macht, dat men daer-en-boven veele abusive manieren van spreecken hadde ingevoert .... dat men den selven meesten tijdts noemden den prince, ende niet den prince van Orangien; daer door gemeent wierde, dat den prince van Orangien, prince van den Lande was, daer nochtans de Staeten ende niemant anders prince van den Lande zijn .... ende hy prince van Orangien ende nergens meer."
}

Machteloze verontwaardiging; de aanhangers lieten zich niet van hun stuk brengen. Zij dachten de stadhouder koning en zouden hem koning blijven denken. "Conink is hij, en Conink moet hy blyven, en wel doen", riep de Delftenaar Willem Meerman uitbundig over Maurits. Toen stadhouder Willem II in 1650 onverwachts stierf, nog maar 24 jaar oud, weeklaagde een dominee van de kansel: ${ }^{19}$

"... dat de Staet was onthoofdet, datter geen Koningh in Israel was; dat de Staet in twist, confusie, ende in duygen soude vervallen."

Sombere voorspellingen in de Nederlandse Republiek, herkenbaar afkomstig uit de overlevering van het monarchisme; zonder Oranje geen welzijn, dus de dood van de stadhouder kondigde onheil aan voor heel het land. De hoop, zoals gebruikelijk, werd gevestigd op de eerstvolgende in de erfelijke lijn. Willem III was na de dood van zijn vader gehoren en er zouden jaren overheen gaan eer hij gereed kon zijn het landsbestuur aan te vatten; maar onophoudelijk gistte de volkswens dat de prins zo snel mogelijk tot stadhouder zou worden benoemd. Oorlog legde het handelsverkeer stil, van de prins werd uitkomst verwacht, binnenlandse opstootjes, de aanwezigheid van de prins kon het

17. Bax 180; Huisman 74-85.

18. D.H. [Johan de Wit], Public gebed, ofte consideratien, teegens hes nominatim biddem in de publique kercken voor particuliere persoonen; en specialijcken voor den jegenwoordigen Heere Prince van Orangien, Amsterdam 1663, blz. 42-43. Zic ook Rowen, John de Will 399.

19. Bax 189, 270; Wicquefor I, 328; Lieuwe van Aitzema, Historie of verhael van saken van staes en oorlogh. in/ende omirent de Vereenigde Nederlanden, beginnende mel den jare 1650 en eyndigende met het begin van 't jaer 1654, deel VII, 's Gravenhage 1662, blz. 126. 
verbelpen. Het nageslacht, meende Wicquefort, zou de oren nauwelijks geloven wanneer het hoorde van de zotte verwachtingen bij deze mensen. ${ }^{20}$

"Il y a longtemps qu'ils sont infatués de cette fausse et sotte opinion, que tout le bonheur et le salut de l'Estat dépendent de la nomination d'un Chef, quand il ne seroit mesme qu'inaginaire, et incapable d'agir."

Desondanks werd ruim twintig jaar geen stadhouder benoemd, want de Oranje-liefde was niet algemeen. In hogere kringen, waar de benoeming zou moeten vallen, bestond wantrouwen tegen bet stadhouderschap. De regenten vonden het een bedreiging voor de onafhankelijkheid en de bewegingsvrijheid, die zij als de winst van tachtig jaren oorlog zagen. Ze dachten aan 1618. Een kerkelijk meningsverschil sloeg over naar de staat en twee vooraanstaande bondgenoten in de strijd tegen Spanje, Maurits, de militaire leider, en raadpensionaris Johan van Oldenbarnevelt, spil van de Nederlandse politiek, stonden plotseling als vijanden tegenover elkaar. Maurits beschikte over bet leger en dat gaf de doorslag; Oldenbarnevelt werd ter dood gebracht, zijn medestanders in het bestuur werden vervangen. Joost van den Vondel mocht in zijn treurspel Palamedes laten doorschemeren dat Maurits door de raadgevingen van vrienden was opgestookt en misleid, hij kon de verdenking niet bedwingen dat Maurits ook zelf misschien naar alleenheerschappij stond. ${ }^{21}$

En had niet jaren later, na stadhouder Frederik Hendrik en het einde van de oorlog met Spanje, Willem II in 1650 een ware staatsgreep gepleegd? Hollandse regenten, vooral het machtige bestuur van de stad Amsterdam, gaven aan zijn wensen niet toe, waarop de prins, zoals Maurits in 1618, met militaire macht wilde doordrukken. Hij nam bij verrassing een aantal regenten gevangen en stuurde bovendien troepen naar Amsterdam om de stad te bezetten. Een ongehoorde daad van eigenmacht; het land trilde nog na van de schok toen Willem uit het leven werd weggerukt. De schrik voor Oranje zat er bij de regenten meteen goed in en zeker niet iedereen heeft daarom bet overlijden van de prins even hartstochtelijk betreurd als de dominee van zo even. In een Amsterdamse kerk viste de diaken behalve enkele goudstukken ook een briefje uit de kollektebus; jarenlang werd het door elk orangistisch pamflet met afschuw naverteld: ${ }^{22}$

De Prins is doodt, Mijn Gaef vergroot;

Noyt blijder Maer,

In tachtich Jaer.

Oranje was dus, door de eigenaardige staatsrechtelijke verhoudingen, in Nederland openlijk onstreden; anders dan bijvoorbeeld de Franse koning kon zijn. De roekeloosheid van Willem II maakte bij sommigen scherpe afkeuring los, bij anderen, aanhang door dik en dun, juichende instemming. Maar bovendien een derde reaktie, en wel bij de meer bezadigde en verstandige pamflettisten. Zij lieten geen misverstand bestaan of

21. Bax 84-91.

22. Aitzema 126. 
ze de aanslag veroordeelden, en toch kwam de prins, "dat Jonge Princelijcke hooft", er genadig af; hij was namelijk in zijn hart een goedaardige jongeman "die noyt uyt hem selven soo een grouwelijk stuk werk soude gedacht/ik laat staan uytgevoert of begonnen hebben". ${ }^{23}$ Hij was derhalve door slechte mensen opgehitst. Wat had je gedaan, werd in een pamflet aan de provincie Holland gevraagd, wanneer de prins je in handen was gevallen? $?^{24}$

"Holl. Ick wilde hem net als eer en deugt bewesen hebben; maer ick soude willen weten hebben, wie syn raders tot sulcke perniticuse ende vervloeckte desseynen waren, en die soude ick straffen als Schelmen en Verraders toekomt, andere ten exempel ..."

Meerdere namen werden genoemd: Sommelsdijk, Musch, Renswoude, Capellen. En dat terwijl Sommelsdijk en Capellen de prins zijn onbesuisde plan hebben ontraden; Capellen was geschokt toen de prins hem achteraf van de gebeurtenissen op de hoogte bracht. Er was sprake van strafvervolging, vooral tegen Sommelsdijk, maar dankzij een amnestie, die politiek wijzer leek, gingen de verdachten vrijuit. ${ }^{25}$ Het bleef daarom bij vinnige beschuldigingen in de pamfletten, zoals deze klacht, schijnbaar woorden van Willem zelf, tot zijn raadgevers, verraders van hem en van het vaderland:

\footnotetext{
Pluymstrijkers Duyts en Frans, vyandelijke vrienden,

'i Zy Aerssens, of Renswou Capelle, en and're meer,

Uw radeloose raadt, verraderlijcken diende,

Tot onrust van ons Land, en rooving van mijn Eer:

'k Verfocy, maar ach! te laat, 't rampspoedelijk betrachten

Van uw vervloeckten raad, die niet kan zijn verschoont ...
}

Het kon niet uitblijven: Een onmiskenbaar geval van de goedwillende vorst misleid door schurkachtige raadsheren. De innerlijke behoefte dat een onfeilbare en altijd goede persoon b:nnen handbereik zal zijn, liet zich thans door Oranje bevredigen. Vandaar ten onzent het onomstotelijke geloof dat stadhouderschap en Nederland's welvaren altijd bijeen hoorderl; dat het land zou vergaan zonder stadhouder. Het lag minder aan de verdiensten van Oranje, maar was veeleer, nauwelijks of niet betrokken op de feiten en figuren van bet moment, een overlevering van eeuwen her. Toch konden de jaren van 1650 tot 1672 een schrille bevestiging van haar aangrijpende werkelijkheid schijnen, voor ieder die het volksgeloof deelde.

Het eerste Stadhouderloze Tijdperk: De regenten hadden de vrije hand en bedreven politiek naar eigen inzicht; de jeugdige Willem III, ambteloos, bezorgde hun geen last.

23. Groenveld 69-71; Geschreven anwoord op eenige vragen, rakende de helegering van Amsterdam, en den heer van Sommelsdyk, Leiden 1651, blz. 9.

24. Hel nae-gedruckse Hollanis praaujen: Tusschen vier personen, een Geldersman, een Hollander, een Vries, en een Brabander, aengaende de souverainiteyl van Syn Hoogheyt, en tol justificatie vande Ed. Mog. Heeren Staten wan Hollands, en de achibare heeren Burgemeesiers en Regeerders der stods Amsterdam. Hei eersie deel, Brussel 1650, blz. 11.

25. Poelhtkke, Geen blijder maer 64-65; Dez., in Getre. Vereeniging vot beoefening van Geldersche geschiedenis, oudheidkunide en rech. Bijtagen en mededelingen LXVI (1972), blz. 172-1173; Rowen, John de Win 33, 53, 63, 681 . 
Het werd in den lande met moeite verdragen, temeer omdat de Republiek terugviel. Tweemaal in die twintig jaar moest Nederland door militair optreden haar handelsbelan. gen tegen Engels opdringen verdedigen; kostbare oorlogen, de eerste werd verloren, de tweede niet gewonnen, die het verlangen naar Oranje aansterkten. Toen de klap op de vuurpijl: 1672, het rampjaar. Nederland werd verrast door een vijandige overmacht en in enkele weken tijd grotendeels onder de voet gelopen. Het leger bracht geen weerstand op, de vestingen waren verwaarloosd, de troepen zonder discipline, de bevelhebbers onervaren, kortom, zoals een orangist nog tachtig jaar ema samenvatte: ${ }^{26}$

"... en un mot que la République étoit sans Stadhoudre ..."

Ekonomische teruggang, een rampzalige oorlog, natuurlijk, want de vorst ontbrak. En hoe kwam dat? Een vast bestanddeel in het verhaal van de goede koning is de heerszucht van de misleidende dienaar. De minister bedriegt zijn heer om zelf koning te spelen, hij is niet tevreden met de maatschappelijke plaats die hem werd toebedeeld; hij wil hogerop. Een zonde tegen God's ordening, volgens het wereldbeeld van de Great chain of being, met als gevolg dat heel die orde verstoord raakt. De ambitieuze minister voert heel het land ten verderve. Deze leer heeft, lijkt me, doorgewerkt in de beschamende gebeurtenissen van het jaar $1672 .{ }^{27}$

Het Stadhouderloze Tijdperk is de grote tijd van raadpensionaris Johan de Witt; vaardig en onvermoeibaar gaf hij leiding aan de binnenlandse en buitenlandse politiek van de Republiek der Zeven Verenigde Nederlanden. Maar hij belichaamde ook het streven der regenten om een terugkeer van het oude stadhouderschap te voorkomen en hij trok daardoor de haat van het volk op zich. Hij zou macht en eigen voordeel zoeken, uit jaloezie de prins weghouden, zelf op diens plaats willen zetelen. Na de eerste oorlog met Engeland was ons in 1654 als voorwaarde van vrede gesteld dat Willem III nooit stadhouder zou worden, en juist de provincie Holland, waar De Witt vandaan kwam, had het meest toegegeven; een vals maar buitengewoon hardnekkig gerucht ging daarop rond dat deze voorwaarde eigenlijk door De Witt was bedacht. ${ }^{28}$ Toen de bepaling trouwens later verviel, heeft Holland alsnog voor de eigen provincie het stadhouderschap afgeschaft: bet Eeuwig Edikt van 1667.

De Witt's feitelijke beleid doet er minder toe; het volk was overtuigd, liet zich de verdachtmaking niet uit het boofd praten, en zou zich er te zijner tijd naar gedragen. De wilde paniek van 1672 en de benevelende Oranje-mythe verenigden zich vanzelf in de onbeheerste kreet dat alleen de stadhouder het land kon redden. En De Witt moest verdwijnen. Op 20 augustus 1672 werden hij en zijn broer door een uitzinnige menigte

26. Hisioire du stadhouderai depuis son origine jusqu'a present. Par Mr. L'Abbé Raynal. Revâe, comigée. châriée, \& purgée de ses faussetés par Mr. Rousset, Amsterdam 1749, blz. 135.

27. Over de Great chain, hierboven, blz. 50, 56, 79; het verhaal dat cen raadsheer de stadhouder tracht te verdringen heeft wellicht al invloed gehad op de twist tussen Maurits cn Oldenbamevelt, Bax 143/144. $165-166,210,337$.

28. Rowen, John de Will 853; vgl. Spiegel der waarheid, ofle t'samensprekinge nasschen een Aminiaan ende vroom patriot, waar,inne krachtig vertoont ende bewesen word, dat door de quade directie ende toeleg van eenige heerschende regenten tor Amsterdam, ons land in den voorgaanden, en desen oorlog is ingewickelt met Vrankryk, z.p. 1690, blz. 12, 19, 49, 51. 
beestachtig afgemaakt. Men verminkte de lijken en beroemde zich nadrukkelijk op het bezit van Johan's afgesneden vingers; de vingers die het Eeuwig Edikt hadden ondertekend en bezworen. Dit alles tot tevredenheid van velerlei orangisten, die het een gerechte straf en desnoods een godsgericht prezen. Nog lang daama zou het vermanende kommentaar luiden dat de haat tegen Oranje de gebroeders De Witt noodlottig was geworden. In zoverre terecht: Niets had meer invloed gehad op de laffe moord dan het geloof dat Oranje en Oranje alleen aan het hoofd mocht staan. Herbert Rowen, De Witt's biograaf: ${ }^{29}$

"It was as rivals to the prince of Orange that they had been hated and slain."

Ondertussen was Willem III overhaast tot stadhouder benoemd; tevens opperbevelhebber van leger en vloot. De zon die in 1650 was ondergegaan, schreef een opgeluchte pamflettist, ging eindelijk weer op. Een ander vertrouwde dat God's hulp thans nabij was: "Ende sal ongetwijffelt Godt Almachtigh alsdan sijne zegenende handt wederom over ons brengen". ${ }^{30}$ De stemming sloeg om en werkelijk, de Republiek overleefde het rampjaar, wonder boven wonder. Dankzij De Witt's dood; orangisten leken te geloven dat die een einde maakte aan al 's lands kwalen. En dankzij prins Willem III natuurlijk, wiens naam alleen, naar men zei, goed was voor twintigduizend man. ${ }^{31}$ Het geloof in Willem's uitzonderlijke greep op de gebeurtenissen, heilzaam aangewend ten hate van de Republiek, moet na die wonderbaarlijke uitredding duizelingwekkend zijn geweest. Niettemin, al stemden feiten en geloof eventjes overeen, ondanks het overweldigende sukses, en ongeacht de verdiensten van Willem III als veldheer en diplomaat: Het blijft mythologie.

De psychologische theorie maakt duidelijk dat het orangisme, evenals haar tegenlangers in de landen rondom, bepaald geen oordeelkundige waardering voor de vorst was, of wellicht liefde voor zijn persoon; het was eigenlijk niet meer dan een hangen aan zijn sprookje, aan de Koning-met-een-grote-K, die slechts een ander woord is voor het eigen gelijk, of ook voor: het eigen hachje. Er mót iemand op deze wereld zijn die mij uiteindelijk gelijk geeft; er móet iemand zijn die mijn leven redt en het in goede banen leidt. Slechts zolang stadhouder Willem III althans enigermate aan deze eisen voldeed kon de geliefdheid standhouden. Daarom: Zou eventueel blijken dat Willem IIl anders wilde dan zijn aanhangers, zou hij niet beantwoorden aan hun gedachten en verlangens, ze zouden hem zonder aarzeling verloochenen. Noodtoestand of geen noodtoestand, rampjaar of geen rampjaar.

Juli 1672, oproer in de stad Rotterdam. Burgers dromden samen bij het raadhuis, zittende regenten werden voor verraders uitgemaakt, ze moesten hun plaats aan Oranjegezinde regenten afstaan, en er moest een gerechtelijke procedure komen. De prins, op

29. Rowen, John de Will 882; Roorda 89; Huisman 82.

30. De heldere dageraed verschenen over de provintien van Hollandi. Zeelandt, \&c. in den jare MDCLXXII. Verhalende alle die donckere wolcken seden de doods van den laesten stadthouder, over de selve landen; die nu wederom zijn over gewaeyt, oft staen op te klaren, met den nieuwen sladhouder den Prince van Oranje, z.p. 1672, blz. 1, 7; Genees-middelen voor Hollants qualen venoonende de quade regeringe der Loevesieinse factie, Antwerpen 1672, blz. 16.

31. Wicquefor IV, 305, 491, 536. 
verzoek van de Rotterdamse stadsbestuurders, weersprak in een eigenhandige brief dat onder hen verraders schuilden en beval dreigend dat de burgerij zich rustig zou houden. Met onverwacht resultaat. ${ }^{32}$

\begin{abstract}
"Cette leure ayant estê apportée à Rotterdam, fit un effet bien contraire à celuy qu'on s'en estoit promis. Le peuple disoit, qu'elle estoit fausse, que c'estoit un trompette travesty qui l'avoit apportée, et que sçachant que ce n'estoit pas l'intention du Prince d'Orange, on n'y obeiroit point."
\end{abstract}

Een bazuin met valse klank, werd ogenblikkelijk luid geroepen, omdat de prins nimmer zou aanbevelen wat wij, het volk, afkeuren. De prins wil wat rechtvaardig is en rechtvaardig is wat wij rechtvaardig vinden. Wij weten wat de prins wil, want de prins wil wat wij willen! Die zogenaamde Oranje-gezindheid, de trots van onze vaderlandse geschiedenis, was op de keper beschouwd alleen maar gezindheid; met Oranje had ze weinig uit te staan. Een dubbelzinnige, onwerkelijke verering die aan de stadhouder, indien hij haar ooit heeft doorzien, geen groot genoegen kan hebben gedaan.

Driekwart eeuw na het rampjaar scheen de geschiedenis zich tot in detail te berhalen. Willem III was in het jaar 1702 gestorven; hij liet geen kinderen na en de Republiek belandde nogmaals in een stadhouderloos tijdperk. Een tijd van onbehagen, want de Republiek verviel; andere landen drongen haar opzij. Iedereen merkte hoe de oude glorie aan het verbleken was. In 1747 brak oorlog uit. Franse troepen rukten op naar zuidelijk Nederland, de herinnering aan 1672 herleefde, paniek greep om zich heen. Oranje moest weer in het zadel! Willem IV, uit een andere tak van het geslacht, werd op de golfslag van een volksbeweging omhoog getild, uiterlijk en tastbaar symbool van de hoop dat men het wonder van 1672 ten tweeden male zou beleven. Een onbeschrijfelijke opwinding, een roes van feesten. Het was op straat al Oranje wat de klok sloeg. de belofte van een gouden toekomst werd door een stroom van heldhaftige gedichten verzekerd; wie zich afkerig of zelfs maar afzijdig hield liep overal gevaar van misbandeling.

Op 21 juni gebeurde het te Den Haag dat een Delftse vrouw, die de prins tijdens ziju intocht in Den Haag mocht aanschouwen, ter plekke dood bleef; "waerschynlyk door de overstelping van een onmatige blydschap". Haar laatste woorden: ${ }^{33}$

"God zy gedankt, dat ik den Prins, waer by my zoo lang naer verlangt is, gezien heb."

Alsof de mythe des te harder moest schreeuwen naarmate zij aan kracht inboette. De dreiging van 1747 kon in de schaduw van 1672 niet staan, en nog minder Willem IV in die van zijn voorganger de Derde. Willem IV liet zich de verheffing overkomen maar had niet de minste behoefte de opgedragen macht te besteden. Spoedig deed dus het oude verhaal weer opgeld. De oorlog verliep niet beter dan tevoren, waarom? Bimnen-

32. Roorda 77; Wicquefort IV, 540; andere voorbeelden van "opstand in naam van de prins" bij Dekker, Holland in beroering, 47-49, 83 .

33. Nederlandsche jaerboeken, inhoudende een verhael van de merkuuerdigste geschiedenissen, die worgevallen zyn binnen den omtrek der Vereenigde Provintien, sederd het begin van 't jaer 1747 , deel. Amsterdam 1748, blz. 419. 
landse hervormingen bleven uit, waarom? Men zag de regenten van de stadhouderloze tijd nog rustig op hun vroegere plaats zetelen, dus het antwoord lag voor het grijpen: De regenten zaten de prins in de weg, zij verhinderden al het goede dat bij in de zin had. Opstanden verontrustten nog geruime tijd het land, en volkomen in strijd met zijn uitgesproken wil werd de prins door de burgerij gedwongen zittende regenten te vervangen.

Willem baron Bentinck was een gedreven orangist die de teleurstelling met lede ogen zag; voortdurend probeerde hij uit alle macht de prins tot daden op te porren. Zonder veel sukses. Dit wetende, moest hij rapporteren dat volgens bet volksgeloof de prins werd tegengewerkt. ${ }^{34}$

\begin{abstract}
"Cette idée, que le Prince est gêné et embarrassé par ceux de l'ancienne cabale, qui l'empêchent de faire tout le bien qu'il voudroit, est généralement répandue et se manifeste en différentes formes. Ceux qui sont au fait en croyent quelque chose; ceux qui sont moins au fait en croyent beaucoup d'avantage, et le menu peuple, le moins informé de tous, dit que le Prince n'a pas le pouvoir qu'il devoit avoir pour redresser les abus et le veut faire Comte de Hollande avec un pouvoir souverain."
\end{abstract}

Gedurende twee maanden, augustus en september 1748, woedde in Amsterdam de Doelisten-beweging. ${ }^{35}$ De burgerij verwoordde haar onvrede in een reeks eisen en trachtte de prins daarvoor te winnen. Een delegatie bezocht hem op Huis ten Bosch en vroeg hem persoonlijk naar Amsterdam te komen. Willem stribbelde tegen, moest er toch aan geloven, reisde onwillig naar Amsterdam, waar hij in een zee van enthousiasme plonsde. Met tranen in de ogen, herhaaldelijk zijn spijt betuigend, ontsloeg hij de oude regenten. Tijdens het verblijf, nog een delegatie, weer andere eisen. Een warrig onderhoud, wederzijds misverstand. De prins, drong men aan, moest zélf beslissen; Willem vond dat hij onder druk werd gezet, want de beslissing lag reeds bij hem. Wat wilden ze nou? Wel, luidde het antwoord, de prins had ieders volle vertrouwen, maar zijn raadgevers werkten hem tegen. De gezette Bentinck hoorde het gesprek aan; en ontplofte bij deze woorden. De prins schreef mismoedig aan zijn vrouw dat hij er niets meer mee te maken wilde hebben. ${ }^{36}$

\footnotetext{
"In de ces gens a été assez impoli pour dire qu'ils se fioient bien à moi, que j'étois porté à leur faire justice et à leur donner pleine liberté, mais que mes Raeden m'en détoumoient, ce qui a mis notre gros ami dans une furieuse colère. ... Dieu veuille préserver cette ville de malheurs. J'en lave mes mains."
}

Tot in het verre noorden, Friesland en Groningen, waarheen Willem IV een jaar later afreisde om in arren moede ook daar namens het volk de krachtige heerser te spelen,

34. Groen, Archives, $4 \mathrm{e}$ scrie deel I, blz. 221, 223, 225

35. Pieter C.A. Geyl, Revolutiedagen te Amsterdam (Augustus-September 1748). Prins Willem IV en de Doelistenbeweging, Den Haag 1936; Rowen, Princes of Orange 176-181.

36. Groen, Archives, 4e serie deel I, blz. 265-266; Rowen, Princes of Orange 179/180. Geyl, die de Oranjes gaarne kleiner beschreef dan ze hadden geleken, makkte ditmaal Willem IV kleiner dan hij was gewcest: hij schoof de prins in de schoenen dat deze gebeurtenis hem "genoegen deed"; ten onrechte. Revolutiedagen te Amsterdam 109/110. 
klonk bij elke grief opgewekt: "Wij gaan na de Prins, die zal ons wel in 't gelijk stellen". ${ }^{37}$ De Hollandse stad Haarlem beleefde zijn deel van het nationale rumoer, dat aldaar eind 1749, begin 1750 het hoogtepunt bereikte. Burgers van Haarlem, aangestoken door de Amsterdamse koorts, legden in september 1748 bij hun stadsbestuur een felle petitie over; ze kondigden meteen maar aan het straks de burgemeesters te zullen wijten indien de eisen niet werden ingewilligd: ${ }^{38}$

"want wij zullen nooit gelooven, dat het aen onzen geliefden Erfstadhouder zal manqueren."

Een belangrijk twistpunt, door heel Nederland, was de belasting geweest. De muitende bevolking bereikte dat de oude heffingen, die door gehate pachters werden geinnd, verdwenen; maar de staat kon uiteraard niet zonder geld en bedacht een nieuwe bron van inkomsten. Ze heette in de wandeling "Collecte" en zou op 1 januari 1750 van kracht worden. De Haarlemse burgerij protesteerde luidruchtig. Stadhouder Willem IV vernam het en zond, kort voor de jaarwisseling, een duidelijke brief aan de burgemeesters: Het protest mocht ze niet afleiden, ze dienden de Collecte door te zetten. Het leek de burgemeesters daarop een goed idee de brief openbaar te maken, omdat de burgers, die aanhoudend beweerden de prins te willen gehoorzamen, hun verzet dan wellicht zouden staken. ${ }^{39}$

\begin{abstract}
"Deezen brief, welks afdrukzelen onder de burgerije wierden gemeen gemackt, hielden zeer veelen niet alleen verdagt, maer (schandlijk bestaen!) wierpen denzelven ook aen stukken gescheurd als vals en verdight op 't vijer, daer men op het raedhuis den gewoonen wagt houd, zeggende "De prins heeft in Groningen wel getoond hoe hij de zacken geschikt wil hebben. De impositiën zijn immers tegen zijn gevoelen en goedkeuring doorgedreeven ... En hij zou aen Haerlem zulk een brief zenden ... Weg, weg, 't zijn loopjes."
\end{abstract}

De spanning liep op, wapens kwamen tevoorschijn. Men vreesde dat het stadsbestuur de belasting met geweld zou innen. Toen, op 2 januari 1750, 's morgens om kwart over zeven, galoppeerde uit het niets een troep ruiters de stad binnen; ze vertrokken ook meteen weer, maar het kwaad was geschied. De stad raakte in rep en roer, de poorten moesten dicht, de schutterij kwam in het geweer. De burgemeesters spraken voor het raadhuis een almaar aangroeiende menigte toe; ze ontkenden bij hoog en bij laag dat de ruiterij op hun bevel was binnengerukt, waardoor de woede des te erger werd aangewakkerd: Verraders, aan één stuk door hebben jullie de prins dwarsgezeten! 
"... onder andere zeer sterk aandringende, dat de vastgestelde collecte ook zoude zyn tegen de intentie van Zyne Doorlugtige Hoogheyd, waer van ten vollen waren overtuygd, terwyl ook de regenten niets anders deden dan Hooggem: Zyne Hoogheyd op alle wijze tegenstaan, ende dat Zyn Hoogheyd telkens ende in alle zaken wierde overstend, en alzoo genoodzaakt te doen dat tegen des zelfs begeerte was ... terwyl al, wat Burg: ook avanceerden tol complecte wederlegginge van die ongegronde zaken, niets anders effectueerde dan de gemoederen hoe langs hoe meer op te zetten, als declarerende noyt omtrent de ingevoerde collecte van andere gedachten te zullen worden, dan wanneer uyt de mond van Zyn Hoogheyd zelfs zulks zouden verstaan ..."

De prins zelf moest zich uitspreken. Burgers en burgemeesters werden het eens dat een gezantschap de Haarlemse verlanglijst naar Den Haag zou brengen. De eerste wens: Laat de prins het oppertoezicht van de staatsfinanciën hebben. Maar de gebeurtenissen waren Haarlem te vlug af. Willem IV gaf legereenheden opdracht de stad te bezetten en de orde te herstellen: eindelijk een man van stavast, maar helaas als tegenstander van zijn gelovige onderdanen. De militairen onderdrukten de opstand vlot, en nu de wind uit een andere hoek woei werd opeens alom gemopperd dat zij het werk van oproerkraaiers was geweest. Toch hadden ordentelijke burgers vast geloofd aan hun eigen gelijk en aan de vriendelijke instemming van de prins; wat er zo gauw van hun stellige overtuiging werd, de geschiedschrijver weet het niet te vermelden. ${ }^{41}$ De werkelijke stadhouder had het mooie sprookje van de Haarlemse burgerij aan stukken geslagen en het was meteen weg, spoorloos. Voorgoed?

Bentinck prees de hardhandigheid, vol verwachting: Nu zou de oude luister van Oranje weerkeren, een gebaar volstond! ${ }^{42}$ Hij werd zwaar teleurgesteld. Willem IV stierf vermoeid in 1751; zijn echtgenote prinses Anma nam de regering over, want Willem $V$ was een kleuter. Aan bet bof verscheen een buitenlandse edelman, Lodewijk Ernst hertog van Brunswijk-Wolfenbüttel, oorspronkelijk aangetrokken als militair adviseur; hij werkte zich op tot vertrouwensman der Oranjes en werd zelfs belast met de opvoeding van Willem V. Toen de prins in 1766 de meerderjarigheid bereikte en voortaan in volle rechten het stadhouderschap zou bekleden, was zijn voornaamste zorg dat de hertog bij hem bleef. De twee sloten een overeenkomst, de Acte van Consulentschap, die Brunswijk tot Willem's vaste adviseur maakte; aan niemand anders dan de prins zou hij voor zijn raad rekenschap en verantwoording schuldig zijn. Destijds niet ongebruikelijk, maar een bittere pil voor Bentinck, die de geheime afspraak onderhands vernam; smadelijk verdrongen, meende hij dat de hertog op de hoogste macht uit was: ${ }^{43}$

\footnotetext{
"... et qu'enfin son plan est de ne laisser au jeune prince-stadhouder que les apparences du pouvinir et d'en conserver pour lui seul toute la réalité."
}

Het vroegere slachtoffer van de mythe werd moeiteloos dader van de mythe. Hij werkte de prins tegen, dacht uitsluitend diens verkeerde raadgever te treffen, en bleef voor zichzelf overtuigd dat de prins hem groot gelijk zou geven zodra hij hem in eell gesprek de zaak had kunnen uiteenzetten. ${ }^{44}$ Was Bentinck een toevallige enkeling, lijdend aan

41. De Jongste 331,333

42. De Jongste 336

43. Groen, Archives, Se serie deel J, blz. 21-26, 31; Bootsma 95-99; Rowen, Princes of Orange 198 .

44. Nijhoff $116 / 117$. 
de persoonlijke wrok van een afgewezen minnaar tegen zijn rivaal? Uiteindelijk zouden zeer velen worden aangegrepen door hevige afkeer van Brunswijk en een vast geloof dat deze met zijn adviezen Nederland in de afgrond stortte.

De Republiek, ooit een macht die internationaal meetelde, zakte in deze jaren al verder af. In 1776 verklaarden dertien gebiedsdelen in Amerika zich onafhankelijk van de Engelse koning; de stad Amsterdam, eigenzinnig als altijd, handelde vrijelijk met de rebellen. wekte zodoende Engeland's boosheid en sleepte, eind 1780, beel de Republiek mee in oorlog. Een gevoelige afgang; Nederland had tegen het Engelse geweld niets in te brengen en leed meteen zware verliezen. Zodra de eerste nederlagen bekend werden, brak een vloed van schotschriften los. Aan wie anders kon het liggen dan aan die buitenlander, de dikke hertog die steeds bij de prins rondhing? Hij bebeerste de prins, hij heulde met de Engelsen, speelde door verraad hun de Nederlandse vloot in handen. In Den Haag brak eens 's nachts brand uit; onder blussers en toeschouwers ging het rond: ${ }^{45}$

"Was 't bij den Dikken Donder, wij souden het laten branden en steken geen hand aan 't werk."

In het jaar 1781, de achtste juni, meldde zich een gezantschap uit het midden der Amsterdamse stadsbestuurders op Huis ten Bosch, het stadhouderlijk paleis van Willem V. De deftige heren waren naar Den Haag afgereisd om bij de prins beklag te doen over de mislukkingen van het oorlogsbeleid, "met attributie van die zaeken aen quaede Raetslieden". Werd het niet hoog tijd dat deze hertog van Brunswijk uit 's prinsen naaste omgeving verdween? Het lag immers allemaal aan hem; "niemand, ja niemand" hield de prins verdacht, zoals de leider van de delegatie geruststellend verzekerde: ${ }^{46}$

"... dat Burgemeesteren Hem Heere Prince van Orange volkomen vertrouwden, maar den Heere Hertog in 'I geheel niet ...

De haat tegens deezen Heer, was by groot en klein ten top gereezen ... Dit liep byzonder in 't oog der geenen, die daaglyks rondom en by Zyn Hoogheid waren, van zyne beste vrienden, van Lieden die ontwyffelbaar aan zyn belang verbonden waren: zy hadden my te meermaalen gezegd, dat zoo lang de Hertog den geest van Zyne Hoogheid zoodanig zou regeeren, de zaaken slecht zouden gaan."

De prins, die achteraf eigenhandig aantekening maakte, doorstond het gesprek met tegenzin. Hij liet zich geen stroop om de mond smeren en wees de "gekke" vriendelijkheden zonder waardering van de hand. Zijn standpunt, onwrikbaar, zou zolang de affaire-Brunswijk duurde geen duimbreed verschuiven: Hij zag de gebreken van de hertog "zoo wel als iemand", maar bij zou zich "een allerondankbaerst schepsel" vinden, een grote lafaard indien hij de hertog, die hem een tweede vader was geweest. zonder zweem van protest aan de volkswoede prijsgaf. Dat was hetgeen de Amsterdamse stadsraad van hem vergde: ${ }^{47}$ 
-... om Zijne Hoogheil den heere Hertogh te sacrificeeren aen de woede des volks, soo als weleer de Raetpensionaris de Witt, en dat ik niet wilde zijn bloet op mij quam; dat ik praefereerde terstond te sterven dan te leeven met zon een blaem ..."

De prins weigerde af te zien van omgang met de hertog; hij zou de indruk wekken, zowel binnen als buiten 's lands, dat er althans iets van waarheid in de kwaadaardige geruchten stak. Wat moest er van Nederland en haar veelgeroemde vrijheid worden als het volk door lawaaiig misnoegen publieke personen uit hun ambt kon zetten, zonder vorm van proces of schijn van recht? Want de hertog was onschuldig. Willem $V$ hoorde diens advies maar besloot onafhankelijk; juist enkele politiek gevoelige, zeer omstreden beslissingen van de afgelopen tijd had hij in afwijking van Brunswijk's oordeel doorgezet. $^{48}$

"Ik zeide ook dat de heer Hertogh invloed op mij hadde, wanneer ik vond dat zijn raed goed was, zooals ik meest altijd hadde gevonden, en dat ik niet blindelings de advisen van wie het nok was volgde, en dat zij niet moesten denken dat zij met een kint te doen hadden ..."

Willem V verkJaarde zich herhaaldelijk vastbesloten zijn adviseur te redden, hij stoof nu eens woedend op, huilde dan weer van ellende, en bereikte niets. Orangisten die hem van mabij kenden wisten heel beslist dat de prins sterk verlangde onder de plak van de hertog vandaan te zijn; hij zou van vreugde een meter in de lucht springen wanneer het zover kwam. ${ }^{49}$ In 1782 trok Brunswijk zich terug naar Den Bosch, weg van het stadhouderlijk hof. Overigens, de oorlogvoering werd er niet beter op. Toen de genadeslag. In 1784 brachten tegenstanders van de hertog de Acte van Consulentschap in de openbaarheid; het was alsof een bom barstte. Het dokument bewés immers dat Brunswijk door zijn raadgevingen de Republiek had geregeerd; bewees dat persoonlijk gewin en verraad het land in dit onbeil hadden gestort. ${ }^{50}$ In vlammende verontwaardiging werd strafvervolging geèist. De prins kon het tij niet langer keren. Brunswijk was in de Republiek ongewenst, zelfs onmogelijk, en hij verliet het land in oktober 1784 .

Einde 18e eeuw; de binnenlandse twisten, het was tijdens het Doelisten-oproer van 1748 reeds merkbaar geweest, kregen een andere kleur door allerlei nieuwerwetse denkbetelden, redelijkheid, verlichting, volksregering. Nederlanders begonnen herziening van het staatsbestel te overwegen; eerder waren al voorstellen gedaan, binnen de kring der overheid, maar thans ontstond een algemene diskussie, en bovendien doken moderne, revolutionaire eisen op. Willem $\mathrm{V}$ had geen vernieuwingsdrang en zag slechts zorgvuldige handhaving van het bestaande als zijn taak; in de ogen der progressieven, die aldus konden aansluiten bij de oude verdenking dat Oranje oppermacht begetrde, werd de prins toen tot een absolute vorst die weigerde zijn onderdanen een stem in het kapittel te geven.

De laatste oorlog met Engeland werd a] volgens de nieuwe denkwijze opgevat. Amerika stond voor Verlichting en demokratie, Engeland voor koningschap; de Nederlandse Republiek had daarom zonder voorbehoud partij voor de Amerikaanse vrijheidsstrijders

48. Rendory I, 191, 197; Groen, Archives, Se serie deel III, blz. 288; Hardenbroek V, 363.

49. Hardenbroek II, $620,623 \mathrm{en} \mathrm{V,} \mathrm{310,387,} \mathrm{397,} \mathrm{425,} \mathrm{451.}$

50. De Beaufor 227. 
moeten kiezen. Maar Nederland had geaarzeld, daama halfslachtig oorlog gevoerd, en glansloos verloren. Hoe kwam dat'? De Gelderse edelman Joan Derk van der Capellen tot den Pol zag het ineens helder als de dag: Willem V. monarchaal denkend, was de natuurlijke bondgenoot van de Engelsen; hij had Amerika niet willen steunen en toen de oorlog desondanks uitbrak, zijn best gedaan haar snel te verliezen. Capellen's pamflet Aan het volk van Nederland, anoniem verschenen in 1781, verwekte grote opschudding: "ja Vorst Willem, het is alles Uw schuld! " 11

Een late bevestiging dat de stadhouders in de Republiek niet onaantastbaar waren; ze hadden hier behalve trouwe aanhang ook geduchte vijanden. Daarbij nu de opkomst van revolutionair gedachtengoed; Willem $\mathrm{V}$ had geen ander antwoord dan behoudzucht en zwak karakter, zodat de Oranje-mythe onvermijdelijk baar magische werking verloor. Toch heeft de progressieve richting zich niet met demokratische beginselvastheid vierkant tegen het stadhouderschap gekeerd. Oranje-gezinden zeiden van wel, maar de anonieme schrijver van het belangrijke pamflet Grondwettige herstelling, dat in decentber 1784 verscheen, weersprak dergelijke beschuldigingen. Zijn voorstellen strekten tot voordeel van Nederland, dus de stadhouder, wiens belang met bet landsbelang samenviel, zou ze beslist goedkeuren. Het was dwaasheid dit tegen te spreken. ${ }^{52}$

\begin{abstract}
"Dat alle poogingen der Vaderlandlievende Herstellers in deeze dagen geenzins zyn de vitwerking van cenen blinden, van eenen toomloozen haat tegen het Stadhouderschap en het Huis van Oranje. ... Men heeft het alleen op die dwaalende begrippen gemunt, welke door onkundige of verkeerde, en by de Natie verdachte Raadslieden den Stadhouder ingeboezemd worden. ... Wat zou het derhalve anders wetzen, dan het Stadhouderschap als eene Waardigheid. tegen het algemeen welzyn strydig, en bygevolg voor den Staat nadeelig, af te schilderen, wanneer men staande wilde houden, dat de Stadhouder de hervormingen, geschikt om de Natie magtig en aanzienlyk te maaken, met geene goede oogen zou aanschouwen? Zou het Stadhouderschap eenen anderen grondslag hebben dan de welvaart der Republiek, waartoe het ingesteld is?"
\end{abstract}

\title{
$\S 4$.
}

Tot hier, voorlopig, de Nederlandse geschiedenis. Weer de verleiding: Laten we doorgaan, laten we trachten de levensloop van de mythe ditmaal min of meer volledig na te trekken; Nederland, klein, met een overzichtelijke geschiedenis en toegankelijke bronnen, leent zich er vast goed voor. Maar we hebben, steeds op zoek naar bet koningsgeloof, al grasduinend tenslotte meer dan genoeg anekdotes verzameld; het is goed nu eens terug te zien en de balans op te maken. Waar ging het ook alweer om, in dit en het vorige hoofdstuk? Samengevat:

Er bestaat zoiets als de mythe van de goede koning die door zijn slechte raadsheren wordt misleid. Mensen menen dikwijls dat de hoogste gezagsdrager in bun samenleving

51. W.F. Wertheim en A.H. Werheim-Gijse Weenink (eds.), Aan hel volk van Nederland. Het democritisch manifest van Joan Derk van der Capellen tol den Pol 1781. Weesp 1981, blz. 130.

52. De schrijver, anders dan Capellen, is nog steeds onbekend; zie Grondwellige herstelling, wan Nederlands staatswezen zo voor het algemeen bondgenoolschap, als voor hel bestuur van elke byzondere provincie, geschikt om het voomaam doehvit aan te toonen, waer boe de poogingen van goede regenten en de requesten van vaderlandschlievende burgers moeten strekken, deel I, Amsterdam 1784, blz. 39. 40. 
door naaste medewerkers wordt verhinderd zijn goede en wijze plannen uit te voeren. Dit verhaal komt betrekkelijk algemeen voor; het heeft bij alle verschillen, naar tijd en plaats, een duidelijke gelijkvormigheid. Het is verbeelding, mythe; want het staat los van de werkelijkheid, gaat een eigen gang, wat de feitelijke verhouding tussen vorst en medewerkers ook zij. De mensen weten niet dat ze in een waan verkeren, ze geven zich er niet in vol bewustzijn aan over, maar houden baar voor de werkelijke toestand; het is een mythe: zij geloven. De eenheid van vorm in de verscheidenheid van gevallen vraagt eén samenhangende verklaring; die is ter beschikking in de psychologische wetenschap.

Deze stelling kan op alle onderdelen worden aangevochten. Hoe algemeen is het verhaal van de goede vorst en zijn boosaardige raadsheren, en hoe eenvormig? Was het inderdaad verhaal, of was het gewoon werkelijkheid? Hebben de mensen het verhaal geloofu, of doorzagen ze het, en bedienden ze zich ervan? Heeft het zin met de psychologie in zee te gaan, of kunnen we ons zonder haar theorieën redden? Punten van twijfel, die we onder ogen moeten zien.

Hoe vaak komt de mythe van de goede koning nu eigenlijk voor? De vraag mikt op alles wat in deze twee hoofdstukken werd verzwegen. Enig materiaal werd neergelegd, maar wat een magere steekproef, gemeten naar de omvang van heel de Nederlandse geschiedenis en zeker naar de omvang van de wereldgeschiedenis! Zou niet een overgrote meerderheid van andersgezinde opvattingen en uitingen vindbaar zijn, zelfs een warreling van allerbande uitspraken, kriskras dooreen, zonder richting of lijn? Vaak allerminst gunstig over de vorst, en misschien juist het tegendeel van de hier bedoelde mythe, vol lof voor de minister? Is er niet in de geschiedenis een stoet van uitverkoren volkshelden, dikwijls struikrovers en opstandelingen, allesbehalve vorstelijke personen? Zijn er naast 's konings raadsheren niet vele andere slachtoffers van bijgeloof geweest, en historisch van meer belang: Joden, heksen, zigeuners, minderheden?

Allemaal waar. Er is in de opsomming willekeur, zij het een opzettelijke willekeur. Het materiaal werd bijeengezocht met het oog op de psychologische hypothese, met in gedachten het vermoeden van een algemeen koningsgeloof. Al het andere bleef daarom buiten beschouwing. De beperking is echter onvermijdelijk in het onderzoek; en ze beneemt de verzamelde gebeurtenissen en gebeurtenisjes hun waarde niet. De wijde verspreiding van het materiaal en het gemak waarmee telkens meer voorvallen werden opgedolven pleiten voor de gevolgtrekking dat het verhaal van de goede onwetende koming een duidelijke algemeenheid heeft. En andere mythen zitten deze niet in de weg; ze bewijzen ten overvloede dat mythen voorkomen en reèle uitwerking hebben, terwijl de mythe van de koning haar erkenning niet behoeft te veroveren dor een bewijs dat ze als enige in de wereld voorvalt.

Bestaat het verhaal van de goede koning? De gevallen die wel werden aangehaald: Tonen ze niet meer verschil dan overeenkomst? Het vereerde opperhoofd kan kennelijk koning zijn, keizer, partijleider, paus, president en zelfs een ingebeelde monarch, zoals de stadhouders. En de ondeugdelijke omgeving van de vorst: nu eens de adel, dan een minister, regenten, zomaar een vertrouweling, zijn vrouw. Werkt de mythe niet telkens anders uit? Soms brengt ze tot gewelddadigheid en oproer, in alle soorten en maten, sons tot berusting. Er is niet én verhaal; er zijn er vele. Maar evenmin laat de onderlinge herkenbaarheid zich wegwuiven; belangrijke historische verschillen, van tijd en 
plaats en deelnemers, bekleden zichtbaar een zelfde harde vorm, die onveranderlijk bestaat: leider en ondergeschikten, goed en kwaad, en vooral de alom weerkerende, door haar vormvastheid verbluffende klacht, dat de vorst het eens moest weten. Al de gegeven voorbeelden passen treffend in één schema.

Maar wellicht zagen de onderdanen het gewoon goed; hun vorst werd verdrongen, de medewerker verknoeide uit eigenbelang het landsbestuur. Neem de vorsten die reeds als kleuter hun troon beklommen, voorzien van een wilskrachtige voogd of minister; zij hadden uiteraard weinig in te brengen. Alleen, waarom de woede? Waarom de onredelijke klacht dat de minister, niet per ongeluk, maar door kwaadaardigheid het land verdierf, en waarom, dit bovenal, de onwezenlijke hoop dat persoonlijke leiding of zelfs maar aanwezigheid van de minderjarige vorst uitkomst zou brengen? En niet zelden lag de verhouding tussen koning en minister net andersom; had de minister afgeraden, de koning toch doorgezet, dan liep het volk evengoed tegen de minister te hoop. Hoe kon men trouwens weten welke krachtsverhouding tussen die twee bestond? Hetzelfde verhaal, dezelfde reakties, wat zich ook tussen koning en raadsheer had afgespeeld; de verdachtmakingen en de bedreigingen richtten zich klaarblijkelijk altijd tegen de raadsheer, los van de feitelijke toestand.

Een heel lastige kwestie: Hebben protesterende onderdanen de fiktie geloofd, of hanteerden ze die als een handige manier om onvrede te luchten zonder de toom van hun oppermachtige vorst over zich af te roepen? Rechtstreekse kritiek werd immers als majesteitsschennis zwaar bestraft? Anderen wisten niet goed raad met deze vraag. Daniel Field, Amerikaans historikus, onderzocht de mythe van de tsaar; hij beschreef haar als oprecht geloof, maar draaide op het einde van zijn boek bij: Het was boerenslimheid geweest, een sluwe oplossing voor rebelse Russen om de straf van de tsaar te ontgaan. ${ }^{53}$ De Nederlandse opstand tegen koning Philips II zorgt eveneens voor onzekerheid; de geschiedschrijfster Johanna Oudendijk noemde bet beroep op 's konings eigenlijk goede wil een "gekozen juridische figuur", haar vakgenoot Ivo Schöffer schreef, niet helemaal zeker van zijn zaak: ${ }^{54}$

"Het lijkt erop dat hoe vaker men zich achter die schijn van legaliteit opstelde hoe meer men erin ging geloven."

Rond 1800 besloot de Leidse hoogleraar Adriaan Kluit op grond van zijn bronnen dat de vaderlandse opstandelingen eerlijk niet de bedoeling hadden gehad Philips te bestrijden. ${ }^{35}$

"Het Volk, als Volk, en de burgerijen stonden niet in die gedachten, en geloofden en verklaarden ter goeder trouwe, dat alle pogingen, of wederstand, slechts gericht waren tegen den gehaten Alba ..., doch geenszins tegen den Koning zelve of zijne wettige Oppermacht: of men

54. Oudendijk 276: Ivo Schüfter e.a., De Lage Landen van 1500 rot 1780, (oorspr. 1978) Amsterdam 1988. bl\%. 117.

55. Adriaun Kluit, Historie der Hollandsche staatsregering, tor aan het jaar 1795, deel I, Amsterdam 1802, biz. $55 / 56$. 
moet alle die ingezetenen, in den aanvang der opluikende vrijheid, voor valsch en leugenachtig houden."

Hebben zij oprecht aan de vorst geloofd, of hadden ze een slimme omweg verzonnen voor het uiten van politieke afkeuring? Met andere woorden, mythe of methode? Veel wijst op een waarachtig geloof. Het was als middel vaak onnodig; niet altijd, niet overal hoefden mensen hun leiders omzichtig te behandelen. Nederlanders konden tijdens de Republiek straffeloos bun gemoed luchten, ook als het de stadhouders betrof, desnoods anonien; Mussert voor zijn rechters had van Hitler niets meer te vrezen. En welke zin had het de fiktie stug vol te houden wanneer burgeroorlog of revolutie eenmaal openlijk was uitgebroken en men reeds slag leverde met de koninklijke legers?

Het middel was bovendien zo handig niet. Het was dikwijls uiterst ondoelmatig, bepaald ongeschikt om de gemoederen te bedaren; de koninklijke maatregelen, eenmaal op rekening van de minister geschreven, werden als uitpersing en wreedheid des te feller aan de kaak gesteld! Het vrijwaarde niet van strafvervolging; de ministers van Philips II vielen niet minder dan hun vorst onder de bescherming van het vervaarlijke majesteitsrecht. ${ }^{36}$ Meende Mussert nu heus zijn zaak te verbeteren door koppige betuiging van trouw aan Adolf Hitler? Juist een rondborstige erkenning dat de Führer hem smadelijk had bedrogen kon hem wellicht het fatale vonnis ter zake van landverraad besparen. Het zogenaamd "handige middel" bracht de mensen geenszins in veiligheid maar in moeilijkheden; ze vroegen niet door, gaven zich weerloos over aan de koninklijke macht of haastten zich hoogstpersoonlijk naar de vereerde leider om hem te waarschuwen, en werden meteen onschadelijk gemaakt.

Was de klacht tot de koning gemeend? Wie zal uitmaken of mensen menen wat ze zeggen? Weten ze het zelf precies? De oprechte toon van de protesten is een enigermate ongrijpbaar aspekt, maar belangrijk: Pasternak's wanhoop in het avonddonker van een Moskouse straat; de zenuwachtig ijsberende Stebenev; Luther's hartstochtelijke bewering dat de paus het niet weet; de treurigheid van Willem IV die het maar niet kon begrijpen; de woedeuitbarstingen van Bentinck en Willem V; de Hagenaars die volgens eigen zeggen Brunswijk's hertogelijke residentie graag zouden zien afbranden. Een spel? Een publiek gebeim? Maar de bloedige gevolgen: Werd de minister bij wijze van staatkundige handigheid gelyncht? Indien het volk diplomatiek poogde te doen alsof, waarom werden dan de ministers lang niet alsof doodgeslagen?

Methode of mythe? Het hoeft niet ja of nee, zwart of wit te zijn. Sommigen geloofden, anderen niet; sommigen minder, anderen meer. De Russische student Stefanovitsj geloofde zeker niet, de boeren van Tsjigirin, die hij voor zijn karretje spande, wel. Zij die in hogere kringen verkeren kunnen beter weten dan het gewone volk; zo was het bijvoorbeeld gelegen, meldde Bentinck, met de geruchten omtrent Willem IV, diens heilzame plannen, en de weerstrevende regenten. Ook valt te vermoeden dat de leiders van de Nederlandse opstand, Willem van Oranje, zijn broer Lodewijk, goed ingelicht,

56. Joost úe Damhouder, Pructycke ende handhouck in criminele zaeken, Leuven 1555, blz. 89: "Den raédUDe senatcurs zijn deel vanden tichame vanden Princen"; vgl. P.B. de Troeyer, Lamoraal van Egmon. Een critische studie over zijn rol in de jaren 1559-1564 in verband met het schuldvraagstuk, Brussel 1961, blz. 122 . 
Philips' ware standpunt hebben geweten. ${ }^{57} \mathrm{En}$ in 1650 , naar aanleiding van prins Willem II's bokkesprong, zijn veldtocht tegen de stad Amsterdam, werd opgehaald hoe de stadhouder van Friesland in 1626 de burgerij van zijn gebied tegen de haren had gestreken. Oproer, het raadhuis van Leeuwarden en het stadhouderlijke hof werden bezet."

"Waer over den Stadholder soo beschaemt was, dat hy eenige dagen niet van syn Hof dorste
komen; soo ontbood hy by hem eenen Mr. Wiben wibrandij, zynde een bedaagt gauw man, syn
uyrwerck-maker, een menniste vermaender, ende vraegde hem raedt, wat hy hierin doen soude;
die riedt hem, Dat hy eenige van de gene, die hem tor dat werck geraden hadde, aen de Borgers
overleveren soude, waer op de Stadholder uytborst, en seyde: Warense my soo na niet ick soude
wel weten wal ickse doen soude (men seyde daer na, dat syn wijf het hem geraden hadde)..."

Een doopsgezinde voorganger wist precies hoe laat het was; de oproerige burgerij kennelijk niet, want waarom zou zij anders haar woede op een adviseur koelen? Uit de tijd van de Franse Revolutie werd een soortgelijke anekdote verteld door de eerste kamenier bij koningin Marie Antoinette, mevrouw Campan, in haar gedenkschriften. Haar schoonvader bracht eens laat op de avond een boodschap over aan koning Lodewijk XVI, namens de graaf van Inisdal, die buiten op antwoord wachtte: Edellieden stonden gereed om de koning uit het land te brengen, in veiligheid; hij hoefde maar op te staan. Lodewijk speelde kaart en zweeg. ${ }^{59}$

\begin{abstract}
"Enfin la reine dit: 'Il faut pourtant bien dire quelque chose à Campan.' Alors le roi adressa ces propres mots à mon beau-père: 'Diles à $M$. d'Inisdal, que je ne puis consentir à ce qu'on m'enlève.' La reine insista pour que M.Campan observât de rendre fidèlement cette réponse. 'Vous entendez hien, ajouta-t-elle, le roi ne peut consentir à ce qu'on l'enlève.' $M$. le Comte d'Inisdal fut très-mécontent de la réponse du roi, et sortit, en disant: 'J'entends, il veut d'avance jeter tout le blàme sur ceux qui se dévoueront."
\end{abstract}

De koning zei niet te kunnen toestaan dat hij werd ontvoerd, en de graaf van Inisdal doorzag onmiddellijk de strekking van deze woorden; mislukte de poging, dan bleef de vorst ongeschonden de vader van zijn revolutionaire volk, de toegewijde helpers zouden de schuld krijgen en zelfs zware straffen riskeren als koningsontvoerders. Een sprekend bewijs dat de mythe tevens als een spel werd gespeeld: De kringen rond de vorst voerden met ernstige gezichten hun toneelstuk op, het lagere volk werd geacht alles vonr waar aan te nemen.

De laatste twee gevallen zouden ons een heel eenvoudige en korte verklaring kunnen ingeven voor het verhaal van de goede-koning en zijn slechte adviseurs: Het is gewoon outworpen door de hoogste machthebbers, die zich zo voorgoed beveiligden tegen elke aanval op hun macht, tegen alle kritiek op bun beleid. Maar wat een doortrapte sluw-

58. Het nae gedrucke Hollanis praatjen: Tusschen vier personen, een Geldersman, een Hollander, ten Vries, en een Brabander, aengaende de souverainiteyt van Syn Hoogheyl, en tot justificatie randen Ed. Mog. Heeren Staten van Holland, en de achibare heeren Burgemeesters en Regeerders der shet Amsierdam. Hel eerste deel, Brissel 1650, blz. 10/11.

59. Mémoires sur la vie privée de Marie-Antoinette, reine de France et de Navarre; suivis de souvenirs el anecdores historiques sur les règnes de Louis XIV, de Louis XV el de Louis XVI. Par Mme. Campan. lectrice de mesdames, el première femme de chambre de la reine, deel II, Parijs $1822, \mathrm{blz}$. $103-104$. 
heid schrijven we deze mensen dan toe, wat een meedogenloze eigenbaat! En hoe lang zouden ze hun truc verborgen kunnen houden? Hoe lang zouden ze erin slagen nietsvermoedende medewerkers aan te werven? En verscheidene historische gegevens weerspreken deze lezing. Hitler heeft zich in zijn tijd uitdrukkelijk tegen de fiktie gekeerd, hij wilde niet weten van een scheiding tussen hem en de andere fascisten: "Neen, mijne heren, de Führer is de Partij en de Partij is de Führer". ${ }^{\infty}$ Stadbouder Willem IV werd alleen maar bedroefd van het overweldigende vertrouwen in zijn goedwillendheid, en Willem $V$ deed er alles aan om zijn raadsman, Brunswijk, tegen de fiktie te beschermen. Het koningsgeloof is meer dan alleen geniepig eigenbelang der machthebbers. Mythe of methode? De twee kunnen dus bij tijdgenoten dooreenlopen; het gebeurde dat de een geloofde, de ander niet. En meer nog. Bovendien valt te ontdekken, wanneer we opnieuw terug gaan in de Franse geschiedenis, dat niet slechts tijdgenoten, maar ook enkele mensen beide werelden in zich konden verenigen. Het lijkt volkomen tegenstrijdig. Wie in alle ernst voor werkelijkheid aanziet dat zijn vorst goed doet terwijl de raadgever het land zelfzuchtig uitbuit, kan niet tegelijk beseffen dat hij deze overtuiging om een bepaalde reden koester, onathankelijk van de ware toedracht. En omgekeerd: Wie inziet dat hij een zekere toestand verzint omdat het goed uitkomt, kan niet tegelijkertijd die toestand oprecht voor waar houden. Toch gebeurde dat. Frankrijk 1649, de Fronde. Een pamflettist schreef aan de koning dat diens onschuld ontwijfelbaar was en daarenboven het kostbare anker waardoor het schip van staat niet afdreef: ${ }^{61}$

"... non seulement on n'accuse vostre Maiesté de rien, mais on considère son innocence comme l'ancre sacrée qui nous reste et qui peut nous garantir du naufrage ..."

Dit zou nog kunnen: We weten dat de rechtvaardigheid van onze koning boven twijfel is verheven, en gelukkig maar, want deze eigenschap moet het land behouden. Een tweede tekst ligt iets moeilijker. De schrijver dacht, en hield kennelijk voor waarheid, dat ministers onwettige bevelen van hun vorst afpersten; tegen diens koninklijke wil, want daarvan moest men steeds aannemen dat ze strookte met de wet.

"... lettres de cachet sous le nom du Roy, extorquées par de mauuais Ministres contre ses intentions, lesquelles on doit tousiours présumer n'estre point contraires aux loix de l'Estat at à la lustice."

Een ronduit verbijsterende tekst komt van Charles de Montchal, aartsbisschop van Toulouse, die steen en been klaagde over de arrogantie en machtswellust van Irankrijk's eerste minister Richelieu. Montchal presteerde het op eén en dezelfde bladzijde het verhaal van de goede koning en zijn bonsdardige ninister als methode voor te schrijven en vervolgens als mythe toe te passen; in bewoordingen die geen twijfel overlaten of hij zijn beschuldiging echt meende. ${ }^{62}$

60. Kershaw 104; vgl. hierboven, blz. 147

61. Dit en het volgende citaat uit Moreau II, 434, 498.

62. Montchal II, 458 . 


\begin{abstract}
"C'est une maxime d'Etat certaine qu'en une Monarchic toutes les Graces doivent êire attribuées au Souverain, \& toutes les rigucurs à ses Ministres, qui sont obligés de le décharger d'envic \& la prendre sur eux-mêmes, afin que les traits des medisances s'arrêtent à eux, \& n'aillent pas contre la Majesté du Prince, qui en seroit diminuée..."
\end{abstract}

Niet maar als verschijnsel onderkend, zelfs ten stelligste als methode aan de onderdanen van elke monarch opgelegd. In één adem door vertelde Montchal hoe de kerkelijke vergadering van Mantes in 1641 een delegatie naar de koning zond om hem haar nood te klagen. Richelieu had de hoogwaardigheidsbekleders met list en geweld bij Lodewijk XIII vandaan gehouden, want anders hadden ze beslist al hun wensen verkregen!

\footnotetext{
"... que s'il n'eût pas empeché par ses artifices \& violences les Députés de cette Assemblée de Mantes d'avoir accès au Roi pour lui faire connoitre ces vérités \& représenter leurs raisons, il n'y avoit sorte de graces \& soulagement qu'ils n'eussent obtenu de sa bonté. Mais comment pourrions-nous puiser de l'eau, quand nous sommes repoussés de la fontaine, ou jouir de la lumiere, quand on met des obstacles entre nous \& le Soleil?"
}

Nog éenmaal de vraag: Bestaat de mythe van de goede koning of niet? Opmerkelijk is dat meerdere waarnemers het verschijnsel hebben aangewezen, filosofen, historici, journalisten, doorgaans onafhankelijk van elkaar, in de eigen tijd, op eigen terrein, soms met nadrukkelijke vermelding dat het geloof echt was, en diep zat. En het materiaal dat in deze hoofdstukken werd vergaard geeft zeker aanleiding zo te denken; bet omvat evenwel ook een grote verscheidenheid die niet gemakkelijk in een enkel schema is in te passen.

Maar waarom eigenlijk de zorgelijke afweging? Heden ten dage heeft niemand meer moeite te erkennen dat mensen bereid zijn met beel hun hart aan de goede bedoelingen, de bovenaardse talenten en zelfs de onfeilbaarheid van een ander te geloven; niemand meer moeite te erkennen dat onder de mensen een geheinzzinnig mechanisme verborgen gaat, waardoor zij in geval van dreiging of tegenslag onmiddellijk en meedogenloos een zondebok aangrijpen. Het is vast bestanddeel van onze kenuis omtreut het menselijke. gebleken tijdens huiveringwekkende uitbarstingen van totalitarisme, opgediend door de gedragswetenschappen en zonder veel voorhehoud aanwezig in de tijdschriften en het dagelijkse gesprek; gemeenplaats nog eer het gemeengoed werd.

Een algemeen verschijnsel vergt een algemene verklaring: psychologische theorie kan haar bieden. Mensen verdragen de wisselvalligheid van hun aardse bestaan niet, zij wensen zich een hechte orde, een onomstotelijke waarheid, een ouwrikbare zekerheid en de vurige wens schenkt het leven aan de eerlijke gedachte: Zelf niet in staat de verlangde stevigheid te vestigen, zoeken ze haar buiten zichzelf, bij een sterk ogende persoonlijkheid, en wanen haar oprecht en in volle ernst bij die vereerde leidsman aanwezig. Maar hun verbeelding van de werkelijkheid, opgestuwd door een intense behoefte, houdt hen voortdurend bezig. Want de tegenvallers die in onze wereld nooit ontbreken verstoren de rust; ze mogen niet van de leider afkomstig zijn, en moeten dus worden toegexchreven aan iets of iemand anders, een kwalijke invloed. Waar de koning wordt tot idool, daar moet een ander duivel zijn: de raadsheer.

Het algemente en verstrekkende van de theorie schijnt tegen haar te spreken en haar bruikbaarheid te venninderen. Hoe kan zij, indien deze ene eigenschap in alle mensen leeft, de aanzienlijke verschillen tussen personen, landen en bistorische perioden verant- 
woorden? Niet iedereen, niet elk land is monarchaal of totalitair, en niet altijd. De theorie laat voldoende numte voor verschil. De beboefte aan innerlijke zekerheid is het beginsel, maar zij kan op tal van manieren uitwerken. $\mathrm{Zij}$ kan een verbinding aangaan met personen, deze of gene, koning of niet. Of met abstrakties, hersenspinsels; ondanks hun onwerkelijkheid kunnen die gerustheid geven, en sterker nog, zij dienen het doel beter dankzij hun onwerkelijkheid. Levende personen, koningen, helden, voldoen ook pas wanneer ze onder een laag van fantasie zijn verdwenen. De theorie schrijft niet voor wie of wat het voorwerp van verering zal zijn; evenmin wie of wat de zondebok wordt. In cén greep omvat ze vele verschijnselen, zonder de variatie te ontkennen.

De nythische koning is Koning-met-een-grote-K. Hem worden de eigen opvattingen toegedicht, omdat ze daardoor minder wankel en feilbaar schijnen. De Koning-met-eengrote-K, zagen we twee boofdstukken terug, is niets anders dan de gerechtigheid zelf; nu blijkt dat hij met zijn koninklijke gerechtigheid niets anders is dan toevluchtsoord van het eigen grote gelijk der onderdanen. Natuurlijk: Week de werkelijke koning af van hun verwachting, dan gaven zij hun droom niet op; ze fantaseerden een boosaardige raadsheer en straften hem, of in het uiterste geval verklaarden ze dat de persoon van de koning door zijn falen vanzelf het koningschap had verbeurd, zodat ze hem naar eer en geweten konden beoorlogen. Opstand in naam van de koning, van de Koning-met-eengrote-K, de gerechtigheid, strijd voor de eigen waarheid.

En het samenlopen van mythe en methode? De psychologische theorie verklaart inderdaad dat mensen hartstochtelijk aan de koning hebben geloofd, maar zij vereist het tevens. Wie zich aan de mythe gevangen geeft, doet het om zijn onzekerheid te ontvluchten; hij moet de mythe voor werkelijkheid houden, want ze zou haar troostende werking verliezen zodra hij haar doorzag. Een theoretische noodzakelijkheid, die de gevolgtrekking uit het bistorische materiaal bevestigt, dat het koningsgeloof oprecht werd gemeend. Toch kan de theorie ook het samengaan van mythe en methode opvangen. Psychologisch beschouwd is de mythe reeds een methode; ze wordt om duidelijke redenen toegepast, zij het onbewust. Bewustzijn is het ware verschil tussen mythe en methode: de mythe werkte onbewust, de methode bewust, maar ze beoogden hetzelfde: de koning beschermen tegen kritiek.

Citaten als die van aartsbisschop Montchal brengen ons dus op de grens van het bewustzijn, in een schemerduister van weten en niet weten, doen en beseffen. De theorie dic we ter verklaring benutten ziet hier geen zwarigheid. Jawel, een mens kan de volstrekte tegenstrijdigheid van mythe en methode, bewust en onbewust in zich verenigen; de weg van bewustwording loopt langs allerlei schakeringen van halfbewustzijn. Heel raadselachtig, die overgang van mythe naar methode! En ze is, met al haar vaagheid en wisselingen, allerminst een bijkomstigheid, iets om eventjes zijdelings af te handelen. Integendeel, ze is de grondslag van het volgende hoofdstuk. 

Hoofdstuk 7

\section{De mythe van het goede 1848}

Waardoor werd dit onderzoek op gang gebracht? Door een puur toevallige, weinig belovende vergelijking tussen twee staatsspreuken: The King can do no wrong en Mussolini ha sempre ragione. De regel van de koning die geen kwaad kan doen werd ontleed; op het eerste gezicht een kaal en overduidelijk beginsel van staatsrecht, hield zich evenwel achter haar een oerwoud schuil van denkbeelden omtrent gemeenschap en waarheidsbegrip, een oerwoud waarin toen een smal paadje is gekapt. Vervolgens voerde nadere studie van de Italiaanse leuze tot nieuwe, andersoortige overwegingen. Het Mussolini ha sempre ragione was letterlijk opgevat, het had geloof gevonden. Waarom? Het antwoord van sommige psychologen luidde, dat in de mensen een angst wroet voor de onzekerheid van het bestaan, een verlangen naar blijvende voorspoed; deze innerlijke drijfveer verleidt hen de garantie van zekerheid buiten zich zelf te zoeken en zelfs haar aanwezig te wanen bij de grote leider, die met eén woord mag heten: de Koning.

We redeneerden van Mussolini's leuze naar de mythe; zou het ook mogelijk zijn de zaken nu om te draaien en van de mythe naar het Engelse The King can do no wrong toe te werken? Twee hoofdstukken terug hebben we al de mythe van de diktators en de mythe van de koningen met elkaar verbonden door het overeenkomstige verhaal van de boze raadgevers; de Engelse spreuk heeft zich daar evenwel nog niet vertoond, of het moet zijn geweest in de woorden van Peter Burke, die het volksgeloof uit de historische bronnen las: "It is as if the king can do no wrong ...".' Uit niets blijkt dat hem het Engelse staatsrecht voor de geest zou hebben gezweefd; zijn uitspraak is een onwillekeurige vingerwijzing, vluchtig, nauwelijks merkbaar. Een andere, Nederlandse historikus, Jan Poelhekke, heeft wel verder gezien, als het ware in een flits, marr hij maakte er geen werk van. Het ging over de aanslag van stadhouder Willem II op Amsterdam in 1650; de jongeling werd gespaard, zijn raadgevers moesten het ten ourechte ontgelden. Poelhekke: ${ }^{2}$

Geen blijder maer 41. 
"Zeer zekur, wij bevinden ons hier niet in de sfeer van onze moderne constitutionele monarchieïn met hun steunpilaar van 'onschendbaarheid', maar even moeten wij er toch wel aan denken. Het thema van de slechtberaden vorst kan trouwens bogen op een heel wat hoger ouderdom dan onze grondwetten. "

Daar liet hij het bij. Jammer, en ook vreemd, want zijn doorkijkje kondigde zomaar belangrijke verschuivingen van inzicht aan. Het stond immers nog vast dat de koninklijke onschendbaarheid en de ministeriële verantwoordelijkheid ten onzent in 1848 waren ingevoerd, om het staatsbestel te moderniseren; hoe kan het beginsel dan van hoge ouderdom zijn, niet alleen elders, maar in ons eigen land? Poelhekke had zijn redenen om niet door te zoeken; wij hebben de onze om het wel te doen.

We leerden, scherper misschien dan Poelhekke kon, bet eeuwenoude sprookje van de misleide koning onderscheiden. Burke schreef dat de koning bij onderdanen geen kwaad kon doen, omdat hij in hun staatkundige kritiek altijd werd ontzien; zij behoedden hem uit innerlijke weerhouding voor schennis van zijn majesteit. De sprookjeskoning was in de volksbeleving onschendbaar. Hangt deze spontane onschendbaarheid samen met onze grondwettige? Het tweede bestanddeel van de mythe maakt bet vermoeden reeds bijna tot zekerheid. De koning deed in de verhalen nooit kwaad, aldus Burke, maar, vervolgde hij, de koning kreeg soms van zijn raadsheren vals advies. Raadsheren, dienaren: niet zelden worden ze ministers genoemd. Steeds samen dus, deze twee, onafscheidelijk, de goede koning en de boosaardige minister.

$\mathrm{Nu}$ wordt de vergelijking van sprookje en grondwet pas goed nodig. Het oude verhaal zegt dat de koning goed wil en de minister niet deugt; de grondwet zegt: De Koning is onschendbaar; de ministers zijn verantwoordelijk. Dezelfde hoofdpersonen, dezelfde tweedeling, dezelfde rol in het politieke spel. Laten we daarom, zij het voorzichtig, vragenderwijze, de volgende veronderstelling wagen: Zou het zo kunnen zijn dat een verband bestaat tussen de mythe van de goede koning misleid door kwaadwillige adviseurs enerzijds en artikel 53 van de grondwet van 1848 anderzijds?

Een spannende veronderstelling, die de grenzen van de gebruikelijke staatsrechtbeofening overschrijdt. Poelhekke stond zichzelf niet toe haar uit te werken, en schreef terughoudend: Even moeten wij er toch wel aan denken. Eventjes maar?

\section{$\S 1$.}

De geschiedenis van The King can do no wrong, zoals de landstaal van de regel het al aanduidt, werd naar algemene overtuiging in Engeland geschreven. Zij ging vooraf aan de $19 \mathrm{e}$ eeuwse bepalingen van de Nederlandse grondwet en verdient daarom aandacht. eer we art. 53 nogmaals bezien. Het uitgangspunt was, dit werd eerder in het boek uiteengezet, dat de absolute koningen volstrekte en onweerstaanbare macht verlangden, om naar eigen luim te kunnen regeren. Hun tegenstanders, vrijheidlievende adel en burgers, hadden het middel van de ministeriële verantwoordelijkheid ontworpen om de hoogmoedige oppermacht der koningen te breken. De strijd, die zich over eeuwen uitstrekte, had in het Engeland van de 17e eeuw hefaamde slachtoffers genaakt: de hertog van Buckingham en de graaf van Strafford.

Maar in 1966 verscheen van een Amerikaanse historikus, Clayton Roberts, een diepgaand boek over de Engelse staatkundige geschiedenis. De lotgevallen van Buckingham 
en Strafford werden daarin ook behandeld, met een slotsom die afweek van de heersende leer. Volgens Roberts bestond ten tijde van hun leven en werken eigenlijk geen grondwettelijk geschil en geen machtsstrijd tussen koning Karel I en het Parliament. ${ }^{3}$ Weliswaar werden over en weer beschuldigingen geuit van ongrondwettig streven naar oppermacht, maar het koninklijke optreden was niet onrechtmatig en het Lagerhuis, anders dan Karel I vreesde, bedoelde geenszins de koninklijke macht in te palmen. Wat scheidde dan wel de partijen?

Leden van het parlement verkeerden in de vaste overtuiging dat Buckingham en Strafford onder dekking van het vorstelijk gezag hun eigen belang najoegen. Geroepen hun vorst in gehoorzame bescheidenheid van advies te dienen, namen deze mannen de gelegenheid te baat om zichzelf te verhogen. Zo waren zij schuldig geworden aan vernederende mislukkingen in de strijd met de buitenlandse vijand, aan godsdiensttwisten, aan de betreurenswaardige staat van het koninkrijk, aan al de rampen van de afgelopen tijd. Roberts schreef dat het geloof aan Buckingham's schuld onjuist was en ouredelijk, maar het werd met hartstocht beleden. In 1628 nam het Lagerhuis een resolutie aan: ${ }^{4}$

"... the excessive power of the Duke of Buckingham and the abuse of that power are the chief cause of these evils and dangers to the King and Kingdom."

Karel I waarschuwde dat het gewraakte beleid zijn koninklijke wil was en dat de parlementaire kritiek de koning in zijn eer trof; maar kreeg per omgaande ten antwoord dat hij niet zelf had gesproken: "It is not vox regis". Sir Robert Phelips: ${ }^{5}$

"... if anything falls out unhappily, it is not King Charles that advised himself, but King Charles misadvised by others and misled by disordered counsels."

Hun vorst ging vrijuit; hij hoorde met andermans oren en zag met andermans ogen, misleidende adviezen brachten hem op een dwaalspoor. Wij weten heel goed, sprak Sir John Eliot, wie bij voortduur het oor van de koning heeft. Tussen hem en ons is een bedrieglijke bril, waardoor hij ons slechts vertekend kan zien. ${ }^{6}$

"If there were no false glasses between us and the King, our privileges and his prerogative would stand well together."

De verkeerdheden van het staatkundig beleid waren geheel en al te wijten aan het stoken van zijn minister, de verraderlijke Buckingham. Het kon immers niet de minste twijfel lijden dat de koning persoonlijk instemde met de juiste overtuigingen van zijn onderdanen. John Pym: ${ }^{7}$ 
"It is certain the King has the same ends that we have..."

"Great is the love and piety of his Majesty to his subjects, and therefore it may be easily judged, his abhorring this man that would draw him from justice and piety."

Als de koning niet naar wens reageerde, vanzelf, want Buckingham schermde hem af, telkens weer wonnen diens verderfelijke influisteringen bet van de parlementaire klachten, die door hem verkeerd werden uitgelegd. De leden van het Lagerhuis verloren hun geduld, ze moesten de bedrieglijke raadgever uit de weg ruimen opdat de vrije goede wil van de koning onbelemmerd zou heersen. Ze dreigden met impeachment, een strafrechtelijke procedure die het Lagerhuis kon aanspannen voor het Hogerhuis, dat als rechter oordeelde. De impeachment, niet anders dan alle rechtspraak in het koninkrijk, vloeide ten laatste voort uit de hoge rechtsmacht van de koning; het vonnis zou ook in 's konings naam worden uitgesproken. Wat het Lagerhuis wilde was dat de verdachtmakingen door een koninklijke uitspraak zouden worden erkend. De parlementariërs maakten de procedure tegen Buckingham namens Karel I aanhangig; zij pleegden opstand in naam van de koning. ${ }^{8}$

Denkbeelden in den lande strookten met de parlementaire haat tegen 's konings naaste dienaar. Alom hief men het glas op de gezondheid van John Felton, de man die Buckingham ombracht eer het Parliament haar plannen had kunnen volvoeren. En een gedichtje liet Buckingham na zijn dood vanuit het graf aan het woord: ${ }^{9}$

I that my countrey did betray,

Undid that King that let mee sway

His sceptre as I pleas'd; brought downe

The glorie of the English crowne

With Judas then I shall inherit

Such portion as all traytors meritt

Strafford deed zelf aan de mythe. Hij maakte als lid van het Lagerhuis de debatten over Buckingham mee en hij, de man die de vorst sluitsteen van het politieke gewelf noemde, wist ten stelligste dat de misstanden niet voor rekening van de koning kwamen: ${ }^{\text {in }}$

"We know the King cannot have knowledge himself of these things."

Toen Buckingham antwoordde dat hij op bevel van de koning had gehandeld, riep Strafford dat de laffe verontschuldiging zijn bloed deed koken. Waarom? Omdat hij principieel voorvechter was van het heginsel der ministerièle verantwoordelijkheid? Dan is zijn latere houding onbegrijpelijk, verwerpelijk. Zelf eerste minister geworden, uitvoerder van koninklijke opdrachten, heeft ook hij zich met een verwijzing naar zijn meester tegen kritiek verdedigd. Was de aanhanger van parlementaire invloed om der wille van zijn loopbaan plots monarchist geworden? Waarschijnlijker is dat Strafford nimmer ministeriële verantwoordelijkheid op het oog heeft gehad; én eerst, én later was trouw 
aan de koning zijn parool. Hij had indertijd Buckingham voor een boze raadsheer aangezien en hij kon, daar hij het mythische niet doorgrondde, onmogelijk begrijpen dat hetzelfde mechanisme thans hem inspon.

Want Strafford, ruim tien jaar na Buckingham, viel op zijn beurt ten prooi aan het geloof dat 's lands eerste minister misdadige politiek voerde. Leden van het Lagerhuis geloofden dat Strafford zijn koning bedroog; alleen zo was bijvoorbeeld te verklaren dat de goede vorst, van zuivere berichtgeving verstoken, de gerechtelijke procedure tegen baron Mountnorris, die toch duidelijk onrechtmatig was, in een open brief had goedgekeurd. "

"For the King's letter justifying the proceedings against Mountnorris, it is written on his infor mation, and if the King's ministers misinformed him, he is just befurc Gord and men, and they must answer for it."

Beroering in het Lagerhuis, de leden beraadslaagden, ze hielden toespraken, ze riepen, ze zetten alles op alles om hun koning te bevrijden uit de noodlottige omarming van zijn minister. Weer werd de impeachment ingezet, opstand in naam van de koning. Strafford stond terecht voor bet Hogerhuis en het Engelse volk, meer nog dan de parlementsleden op Strafford gebeten, volgde alles met argusogen. Men verheugde zich alvast op het vonnis: ${ }^{12}$

\footnotetext{
"A more joyous Maytide had rarely been welcomed in London. Every inn and every house in the city was crowded with visitors; everyone spoke of the feasts and dancing there would be after Black Tom Tyrant's death, and the good times coming for England."
}

De beschuldiging tegen Strafford, volgens zijn Engelse biografe "palpably false", kon in een eerlijk proces niet tot veroordeling leiden; de impeachment, hoezeer gewenst, was kansloos. Het Lagerhuis nam daarom het recht in eigen hand, verklaarde bij Act of Attainder Strafford schuldig aan verraad en legde hem de doodstraf op, die zou worden voltrokken door onthoofding. De koning hoefde nu alleen nog het vonnis te bekrachtigen. Maar waarom talmde hij? Verhitte gemoederen, een volksoploop bij het paleis. Koning Karel I doorleefde een zware tweestrijd. Hij wist dat Strafford zich terecht op koninklijk bevel had beroepen en hij vermocht niet de beweerde onwettigheid van zijn maatregelen in te zien; Strafford was onschuldig. Maar het Parliament had hem ter dood veroordeeld; buiten wachtte een aangroeiende menigte rumoerig en dreigend op Karel's ondertekening van het vonnis. Wat te doen? Innerlijk verscheurd raadpleegde hij enkele bisschoppen. Een van hen verklaarde dat de koning zowel een publiek als een persoonlijk geweten had, hij mocht als koning een daad verrichten die hij als mens verafschuwde. De oude leer van 's konings twee lichamen; in zijn koninklijke hoedanigheid bandelde een vorst voor de staat, gebonden aan het openbaar belang, en in zijn natuurlijke, menselijke hoedanigheid naar persoonlijke voorkeur.

11. Roberts 89.

12. Dit citaat en de volgende uit Wedgwood, Strafford 285, 330, 337, 341, 343. 
De koning gaf toe; hij tekende het doodvonnis, met tranen in de ogen: "My Lord of Strafford's condition is happier than mine". Het laatste beletsel was tenslotte weggevallen en op woensdag 12 mei 1641 beklom Strafford het schavot.

\begin{abstract}
"A deafening shout rose from the multitude as the executioner lifted the bleeding head; from the outer edge of the crowd gentlemen and burghers rode out into the country at full gallop shouting to all they passed as they clattered through the villages, 'His head is off? His head is off?' Bonfires flamed on every hilltop, blazed in every market-place, as soon as it was dusk windows were lighted with candles, and shattered by the angry crowds if they were left dark."
\end{abstract}

Wat een buitensporige, een uitzinnige blijdschap! Het proces tegen Strafford gaat door voor een mijlpaal op de weg naar konstitutionele monarchie; werd zo gevierd dat Engeland eell stap vooruit naar vrijheid en parlementair stelsel bad gezet? Neen. De hartstocht was ongezond en opgeblazen; ze hadden in ernst gemeend dat Strafford Engeland's welzijn in de weg stond, en dat zijn dood onder beulshanden een tijd van volmaakt geluk inluidde. Diepe teleurstelling moest wel spoedig volgen: "They promised us all should be well if my lord Strafford's head were off, and since then there is nothing better. ${ }^{n}$

\title{
$\S 2$.
}

De koningsmythe, blijkt nu, doortrok bet tragische wedervaren van de eerste ministers Buckingham en Strafford; zal dat gegeven ook invloed hebben op onze zienswijze van de geschiedenis der ministeriële verantwoordelijkheid? We hervinden uit die geschiedenis doorslaggevende elementen in de mythe, maar hun betekenis wordt total anders. De strafrechtelijke verantwoordelijkheid, en in Engeland en later in Nederland de oorsprong van de volle ministeriële verantwoordelijkheid, doelde niet zij-het-nog-onbeholpen op demokratische zeggenschap, zij was emstige reaktie op het vemeende onrecht dat de boze raadgever pleegde. De eis dat een ministeriële handtekening koninklijke besluiten zou vergezellen beoogde niet volksregering, maar het vergemakkelijken van de strafrechtelijke procedure tegen 's konings dienaar; zo zou tenminste het bewijs dat hij de staatkundige misdrijven op zijn geweten had, voortaan snel rond zijn. ${ }^{13}$

De Housc of Commons ontwrong de koninklijke majesteit haar persoonlijke recht ninisters te benoemen: Om de hoogste macht wegens demokratisch beginsel over te nemen? Niet volgens de beschouwing van de mythe. Parlementaire bemoeienis met de keuze vall ministers was in het algemeen onwettig en onwenselijk, en uitsluitend beperkt toelaatbaar omdat de ministers soms, buiten medeweten van de koning, als boeven in zijn naam hadden geregeerd. John Pym, leider van de hetze tegen Strafford, sprak een half jaar na zijn overwinning op deze minister in het Lagerhuis, november $1641:^{14}$

"We have suffered so much by councillors of the King's choosing, that we desire him to advise with us about it."

14. Gardiner 164, 200, 205; Roberts 47, 105, 110. 
De opstandigen trachtten de vorst ministers naar hun zin op te dringen; niet om de macht te hebben, maar omdat de huidige ministers niet deugden. Het is een moeilijk aanvaardbare omkering van zaken. Men begreep toch dat de koninklijke macht in andere handen zou overgaan, het werd toch ronduit gezegd? In Engeland door koning Karel I zelf: Als ik bewillig, antwoordde hij in 1642 op een parlementair verzoekschrift, dan zal ik nog met alle eerbied worden omringd; ik mag dan voor het gezicht nog wel koning zijn, maar zonder inhoud, want niets van werkelijke macht zal mij overblijven. ${ }^{15}$ Van de andere zijde echter werd deze aantijging stelselmatig weersproken. De opstandigen verlangden allerminst in plaats van de koning te regeren; niets zouden zij liever zien dan een wijze en krachtige vorst, en juist daarom, om zijn wijze wil vrij te maken van kwalijke invloeden, juist daarom was het hun plicht te zorgen dat zijn verkeerde raadgevers werden vervangen door goede.

Er schijnt een misverstand te zijn geweest. Engelse parlementsleden ontkenden dat zij op 's konings macht zouden azen; moeten we hun roep als manoeuvre of sluwheid afdoen? Niet noodzakelijk. Na twee hoofdstukken over het sprookje van de onwetende koning en zijn boze raden mogen we rustig aannemen dat hun ontkenning oprecht was. Ze leefden eerlijk in de overtuiging namens de vorst in diens belang te werken. Maar de koning en zijn nabije medewerkers moesten bet anders zien. Hun speelruimte werd gestaag kleiner, belaagd door de goedwillende onderdanen, die niet rustten eer ze de staatszaken naar eigen hand hadden gezet. De koning klaagde aanhoudend dat hem zijn macht werd afgenomen; de roerige onderdanen begrepen hem niet, want hun heilige doel was de belemmeringen voor vrije uitoefening van koninklijke macht op te ruimen. En sterker nog. Hun mythe schilderde reeds de koning af als machteloze marionet. $\mathrm{Zij}$ wreven de minister al het kwade aan, het kwade dat de politiek en heel het land in een klemmende greep hield; waar konden zij dan nog de heilzame werking van hun vorst aanwijzen? Hoe rijmden ze dat de goede, scherpziende, wijze koning desondanks die schurkachtige minister vlak naast zich niet doorhad en toeliet dat hij het land verdierf? De leden van de House of Commons begeerden niet dat de vorst macht zou afstaan, maar hun verhaal, het verhaal van de ongeneselijk onwetende koning, maakte hem een staatkundige nul lang voor hij het in werkelijkheid werd.

Koning Karel I, in bet nauw gebracht slachtoffer van de bemoeizuchtige welwillendheid zijner onderdanen, liet het naar aanleiding van weer een parlementair verzoekschrift bij monde van zijn dienaar vlijmscherp overbrengen: ${ }^{16}$

\footnotetext{
"In the beginning it calls us a good, a just, a wise, a judicious Prince ... But if we be wise and judicious, how comes it to pass we are thus ignorant of imminent dangers, as the same Remonstrance would make us? And if we be gnod and just, how is it that what our wisdom sees amisi in the State, or the ministers of it, is not punished or amended?"
}

We zijn uitgegaan van de traditionele geschiedschrijving der ministeriële verantwoordelijkheid, een rationele weergave, die gevestigd leek. Nu hebben we midden in die geschiedenis, onlosmakelijk verweven met bekende elementen, de inwerking van de 
koningsmythe aangetroffen. Is het vervolgens mogelijk de beide beschouwingswijzente verenigen? Of zou het zo zijn dat een van de twee overheerst, en de ander als het ware in zich opneemt? Een samengaan lijkt ondoenlijk, de twee versies vormen elk voor zich een volledig beeld, onverenigbaar, maar tevens verhindert het materiaal van de historische bronnen een, welke ook van de beide versies terzijde te schuiven. Beide laten zich onloochenbaar uit de stukken aflezen, soms dicht bijeen. In 1642 protesteerde Karel I nogmaals dat zijn eigen handelen in het geding was wanneer het parlement de boze raadslieden achtervolgde: 17

\footnotetext{
"... that our own immediate actions, which we avow on our honour, might not be so roughly censured and wounded under the common style of 'evil counsellors."
}

Een protest dat ons trouwens een belangrijke gevolgtrekking aan de hand doet. Het verhaal van de goede misleide vorst, hierboven besproken, heeft de vraag doen rijzen of het misschien een slimme vinding was van heersers die aldus hun oppermacht vijwaarden van de dreiging der openbare kritiek; hier blijkt voor de zoveelste keer van niet. Koning Karel I heeft zich aanboudend verzet tegen pogingen door aantasten van ministers hem buiten schot te houden. De vondst werd tegen zijn uitgesproken wil toegepast.

De koning wilde van het verhaal af, maar Lagerhuis en Hogerhuis hielden in een gezamenlijke verklaring voet bij stuk; zij moesten optreden volgens het beginsel dat de koning geen kwaad doet.

"... according to the maxim in law [that says that] the King can do no wrong, but if any ill be committed in manters of state, the Council, if in matters of justice, the judges, must answer for it."

In dezelfde uitwisseling geloof en regel, sprookje en staatsrecht bijeen. Het herinnert aan een andere tweedeling, uit het vorige hoofdstuk: mythe en methode. Ook toen lazen we hoe op een en dezelfde bladzijde de onschendbare koning als staatkundige regel en als mythisch geloof werden aaneengeschakeld, door de Franse aartsbisschop Montchal. Kennelijk hebben we hier opnieuw die verhouding, dat probleem onder ogen. Daarom, voor de geschiedenissen van Buckingham en Strafford, nu nogmaals die vraag: Bedienden onderdanen zich opzettelijk van bet verhaal van de goede koning, een handige methode, een staatsrechtelijke regel, of hebben zij werkelijk geloofd, bevangen door een mythe? En weer is een keuze uitgesloten.

Een enkeling is aanwijsbaar, tientallen jaren eerder, George Buchanan in 1570, die de mythe als methode onmiskenbaar heeft doorzien: ${ }^{18}$

"... lest they should ... appear to be violators of their oath and fidelity promised to the King. they proclaimed [that they] were not against him but against his wicked councillors." 
Maar de emotionele uitroepen van Pym en Strafford, hierboven aangehaald, worden tot onbegrijpelijke hoogstandjes van toneelkunst indien we ze als doelbewuste methode moeten opvatten. Zinloos toneel bovendien, want de koning was de eerste om de kunstgreep te verwerpen. En onverantwoordelijk toneel; want werkelijke woede werd opgewekt, die Buckingham en Strafford het leven kostte. Historici beoordelen de kwestie verschillend. Roberts houdt het erop dat Pym serieus was; de Engelse Christopher Hill durft geen beslissing te nemen, en Veronica Wedgwood, eveneens Engelse, schijnt toch aan doorgestoken kaart te denken. ${ }^{19}$ Het is ook moeilijk de paniekerige uitroepen op waarde te schatten, en geen van drieën legt verband met de algemene mythe van de slechte raadgevers des konings of met de mogelijke psychologische verklaring, die samen immers sterk voor een serieus geloof spreken.

Martin Butler, hedendaags Engels onderzoeker van literatuurgeschiedenis, naderde dichter tot deze aspekten. Hij wees op het onvoorwaardelijk koningsgeloof: "ie ne puis douter des parolles d'vn Roy", en gaf het een plaats in het toenmalige eenheidsdenken, volgens welk de maatschappelijke samenhang, verbeeld in de vorst, boven alles ging. Tijdgenoten konden de gedachte van een scheiding tussen koning en parlement niet verdragen; die twee waren, zeiden ze met volmaakte helderheid, "soe rooted in our Loyall hearts that wee cannot disioynt them". In deze omstandigheden, oordeelde Butler, was het verhaal van de misleide koning geen openlijk spel maar gevolg van onmacht, een poging althans in gedachten de afschuwelijke nachomerrie van het onenige koninkrijk te verdringen: ${ }^{20}$

\footnotetext{
"It is tempting to dismiss such devices as merely devices, fictions which enabled men io imply indirectly what they could not say openly, but to do so not only underestimates the unwillingness of men to initiate change which might have unknown conseguences, but diminishes the reality of the conflict in minds exposed for the first time to genuinely new ways of thinking."
}

Mythe of methode? Overtuiging of staatsrechtelijk beginsel? Of alletwee? Het zal, op een of andere manier, het laatste moeten zijn. We kunnen uit de tijd van Karel I een hele serie citaten ophalen, waarvan elk voor zich de twee omvat, met steeds weer de bizarre overgang tussen weten en niet-weten. Had de koning bet zelf bevolen? Ik kan het niet geloven! En zelfs: een smerige belastering van Zijne Majesteit! Onze koning zou nooit zoiets doen! En dan de vreemde wending: Want de wet zegt dat hij nooit verkeerd doet. ${ }^{2 !}$ 


\begin{abstract}
"And if there have been any commands ... pretended, the Duke's misinformations have procured them; for the laws of England teach us that Kings cannot command ill, or unlawful things." (1626)

"It cannot be imagined of the King that he will at any time or in any case do injustice to his subjects. It is a maxim of our law that the King can do no wrong." (1628)

"... supposing even that he had not done that worse than all this, of now seeking to excuse himself therein by entitling it to his majesty; nay, my lords, I will say that if his majesty hinself were pleased to have consented or to have commanded, which I cannot believe; yet this could no way satisfy for the duke, or make any extenuation of the charge ..." (1628)

"But for the excuse under which he seeks to shelter himself, that is, the king's command, this adds more to his offence; a foul aspersion on his majesty, and wrong to his gracious master; for he could not but know that the king's command, in things illegal, is utterly frustrate, and of no effect ..." (1642)
\end{abstract}

De vermenging van mythe en methode is even onontkoombaar als onoplosbaar. Loopt het onderzoek hier dood? Misschien toch niet. De psychologie die we al eerder te hulp riepen, met haar theorieën van bewust en onbewust zieleleven, verwerkt deze verschijnselen zonder enige moeite. Er is dan een wonderlijke wisselwerking tussen het onbewuste en het bewuste; de onzichtbare behoefte aan zekerheid, die een zichtbare schijnwerkelijkheid van goede koning en slechte raden voor ogen tovert, kan ook zelf de weg naar het licht afleggen. De kennis van haar bestaan en uitwerking komt het verst, maar er zijn allerlei schaduwen, halftinten van bewustzijn. Bijvoorbeeld aartsbisschop Montchal, die keurig onder woorden wist te brengen hoe belangrijk het was de koning te ontzien; je zou denken dat het spel voor hem geen geheimen had. En pal daarop ontzag hij inderdaad zijn koning, maar volkomen oprecht, verontwaardigd om het schandelijke bedrog van Richelieu.

De psychologische hypothese redt ons uit het dilemma van mythe en methode; zij doet nog meer. In de inleiding tot dit boek werden verscheidene vragen gesteld, waaronder die naar de oorsprong van de ministeriële verantwoordelijkheid. Wie had deze "geniale oplossing" bedacht, hoe was ze ontstaan? Alle geschiedschrijving raakte het spoor kwijt in de grijze oneindigheid van het verleden. Indien we met de psychologie het zwaartepunt van de menselijke geestelijke aktiviteit mogen zoeken in de woelingen van het onbewuste, dan is het vermoeden gegrond dat daar het idee van de ministeriële verantwoordelijkheid haar afkomst heeft; een theoretisch vermoeden, dat door de aangehaalde historische teksten wordt bevestigd. De koningsmythe, spontaan en ongezien, heefi zich tot grondwettig beginsel verhard. Een diepe gemoedsbeweging, heftig, onvoorspelbaar en gevaarlijk, vond woorden en vestigde zich, getemd en nuttig tussen de regels van het staatsrecht.

Zo ongeveer heeft ook Christopher Hill, kenner van de Engelse Civil War, de historische ontwikkeling begrepen. In een artikel bracht hij een grote hoeveelheid citaten als bovenstaande bijeen, veegde ze eigenlijk eenvoudig op een hoop. Zonder ze te ordenen of te analyseren, zonder verwijzing naar de algemeenheid van het koningssprookje. zonder eventuele psychologische verklaringen te behandelen, heen en weer geslingerd tussen de mogelijkheden van mythe en methode, kwam hij tot de volgende uitspraak: ${ }^{n}$ 
"Somewhere along the line the docirine that the king is literally incapable of wrong-doing had been replaced by the later constitutional doctrine."

\section{$\S 3$.}

Het blijkt dat de Engelse geschiedenis der koninklijke onschendbaarheid, schijnbaar helder en puur staatsrechtelijk, heimelijk heeft gediend als schuilplaats van mythische onredelijkheid; de verantwoordelijke ministers, niet bet aangrijpingspunt van een groeiende demokratie, niet aangesproken wegens eigen daden, waren slachtoffer van volkswoede, de zondebok waarop onderdanen hun onbehagen en wraakzucht afwentelden. En de oude vraag, nog eenmaal in dit boek, moet worden gesteld: En Nederland? Zijn ook in Nederland de staatsrechtelijke en de mythische geschiedenis van de koninklijke onschendbaarheid verstrengeld geweest? De staatsrechtelijke geschiedenis zagen we beginnen in de $18 \mathrm{e}$ eeuw, de mythische lieten we daar eindigen: Is het mogelijk aansluiting te maken? Zeker wel; we kunnen staatsrecht en koningsgeloof, mythe en methode keer op keer dooreen zien lopen, een onloochenbare maar onduidelijke vermenging, door tijdgenoten niet of nauwelijks opgemerkt.

Willem baron Bentinck, zich steeds beijverend om zijn Oranje-vorst te steunen en diens positie te verbeteren, deed in maart 1749 de aanbeveling dat stadhouder Willem IV zich zou omringen met een raad van ministers, maar zweeg over ministeriële verantwoordelijkheid. Enkele dagen later kwam het onderwerp ter sprake aan het ziekbed van prinses Anna, naar aanleiding van pamfletten vol hoon, tegen de prins maar veel meer nog tegen Bentinck. Zonder het algemene van de mythe te erkennen, laat staan haar werkelijk te doorgronden, trok de prinses een vergelijking met de ministeriële verantwoordelijkheid in Engeland. Ten onrechte, vond Bentinck, omdat naar Nederlands recht de prins zelf regeerde en niet de ministers in zijn naam; de Engelse regel had niets uit te staan met het onderscheid dat pamfletschrijvers tussen prins en dienaar maakten.

\footnotetext{
"J'allai à midi voir comment se portoit la Princesse. L'on me fit entrer dans la chambre où Elle étoit au lit. Le Prince, Mrs. de Burmania et Grovestins et Melle $C$. de Wassenaer debout autour đu lit. La conversation étant par hasard tombée sur les satyres qu 'on avoit faites à Amsteruam, je dis que je ne les avois pas lues, que j'y avois jetế les yeux et que j'avois vu que le Prince y étoit daubé aussi bien que d'autres. "Oui," dit le Prince, "j'y suis daubé mais rien en comparaison de vous; vous y êtes bien autrement accommodé" (ou l'équivalent). A quơi la Princesse dit: "cela n'est que juste." "Pourquoi cela est-il juste Madame?" lui dis-je. "Parce," dit la Princesse, "qu'il est juste que l'on tombe sur les inférieurs plutôt que sur les supéricurs." "C'est ce dont je ne conviens pas du tout Madame," repondis-je, "et je voudrois bien savoir par quelle règle de droit. "La Princesse dit quelque chose bas, que je n'entendis pas bien, parce que j’étois loin du lit, mais $j$ 'entendis qu'elle dit à la fin qu'elle m'avoit rendu muet. Sur quoi je dis que je n'avois pas entendu ce que S.A.R. avoit dit et que je n’avois pas osé la prier de le répéter, et en même temps je m'approchai un peu du pied du lit. Alors Elle me dit qu'en Angleterre le Roi n'étoit responsable de rien et n'étoit jamais taxé, mais les ministres. A quoi je lui dis que c'étoit vrai, et que par les loix d'Angleterre cela étoit considéré ainsi; mais que pour cela il s'en faloit bien qu'on n'en put faire une règle générale. "Et pourquoi?", dit la Princesse. "Parce qu'en Angleterre," dis-je, "le Roi ne fait rien mais les ministres font tout. Le Roi ne peut même rien faire, et tout ce que le Roi feroit expédier sans la contresignature des ses ministres n'est comptí pour rien et $n$ 'est rien en effet. De sorte que les ministres savent ce qu'ils font et ce qu'ils prennent sur eux; $\mathrm{et}$ alors il est juste (fair play) qu'ils en soient responsables. Et sans cela
} 
il seroit trìs injuste de les en rendre responsables en Angleterre aussi bien que d'ailleurs." Après quoi la conversation changea et personne des assistants ne s'en étoit mêlé.

De tout cela je conclus que Madame la Princesse est prête à rejetter sur ceux, qui servent le Prince ou qui sont employez par lui, la faute et le blâme des mauvais succès, soit que les avis donnés par eux aient été suivis ou non, et soit qu'ils y aient eu part ou non. La fausseté de ce principe saute aux yeux. Et les consequences en sont si terribles, qu'il n'y a point de précaution trop forte à prendre pour se garantir des embarras inextricables, où doivent se trouver ccux qui sont employez par le Prince, tant qu'un principe pareil règnera."

La faussetí de ce principe saute aux yeux: Ieder begrijpt meteen dat deze onevenwichtigheid in de openbare kritiek aangaande koning en minister heel oneerlijk is. Merk. waardig hoe men de overeenkomst tussen staatsrecht en mythe wist aan te raken, maar niet bij machte was haar geheel te zien. En een half jaar tevoren nog had een protesterende Austerdammer zijn volle vertrouwen in de prins uitgesproken, toevoegend, tot boze verontwaardiging van Bentinck, dat 's prinsen adviseurs hem hinderden; niemand dacht er kennelijk aan deze gebeurtenis thans bij het gesprek te betrekken. ${ }^{23}$

Ook de Zeeuwse staatsman Laurens Pieter van de Spiegel werd eerder aangehaald. ${ }^{24}$ In 1782, op zijn beurt, adviseerde hij prins Willem V een ministerraad te vormen. Een belangrijk voordeel noemde hij niet dan met enige aarzeling: Raakte het volk misnoegd, dan werden uitsluitend de ministers getroffen en de prins zou, als in Engeland de koning, immer vrijuit gaan. Van de Spiegel wijdde in dezelfde memorie woorden aan de hertog van Brunswijk, die destijds het mikpunt was van de nationale haat als een verraderlijke buitenlander die door zijn adviezen aan de prins de ondergang van het land bewerkstelligde. Kennelijk zonder gedachte aan de ministeriële verantwoordelijkheid die hij een bladzijde verder bepleitte, niet inziende dat die aldus reeds werd toegepast. betoogde hij dat de hertog weg moest, hoe groot ook zijn verdiensten,

"en hoe ongelukkig het zy zonder eenigen schyn van bewys, voor cene opgevatte volksmeening te moeten struikelen ..."

Hoeveel heeft Van de Spiegel begrepen? Het is een vraag die voor alle betrokkenen geldt, en die steeds aan een eenduidig antwoord ontsnapt. De Amsterdamse burgemeesters die 8 juni 1781 de prins bezochten met hun dringende verzoek dat hij de hertog valn Brunswijk zou wegzenden: Hebben zij de lasterlijke praatjes geloofd? Enerzijds, naar eigen zeggen, wel. Ze zeiden de prins dat ze Brunswijk "in 't geheel" niet vertrouwden, en de Franse gezant briefde naar huis dat ze stellig overtuigd waren van Brunswijk's "verdorven" bedoelingen. Tegelijk beweerden ze herhaaldelijk de beschuldigingen op te vatten "als verdichtzelen van allen grond ontbloot". In deze onzekerheid komeu mythe en staatsrecht opnieuw bijeen. Al berustte de haat tegen de hertog alleen op laster, en al had de prins natuurlijk raadgevers nodig, en ook onweersprekelijk het recht hen zelf te kiezen, toch zou het politieke gezag haar werking missen wanneer deze

23. Groen, Archives, 4e serie deel 1, blz. 266, 368-370; hierboven, blz. 63, 179.

24. G.W. Vreede (ed.), Mr. Laurens Pieter van de Spiegel en zijne tijdgenooven (1737-1800), deel I., Middelburg 1875, blz. 68; hierboven, blz. 64 . 
raadgevers niet nationaal een goede naam hadden. Ondanks de vrije macht van zijn hoge ambt, had de prins terdege te rekenen met de publieke opinie. ${ }^{25}$

Een kalme en wijze opmerking, die voor onze ogen de staatkundige behoefte aan een ministerraad en het sprookje van de valse hertog samen laat uitmonden in een vertrouwensregel, herkenbaar voorloper van bet stelsel dat ten onzent na 1848 geldend werd: ${ }^{26}$

\footnotetext{
"Burgemeesteren geloofden met de gansche Natie, dat Zyne Hoogheid te veel, en te byzonderlyk zyn vertrouwen op den Heer Hertog stelde: en waren die gedachten al eens bovenmaatig, zy namen zeekerlyk het zoo onontbeerlyk vertrouwen, tusschen Zyne Hoogheyd en de Regenten geheel weg."
}

Wie heeft wat begrepen? Stadhouder Willem V zeer veel. Al de jaren van de affaireBrunswijk lag hem "levendig in 't geheugen" hoe het anderhalve eeuw terug de Engelse koning Karel I en diens eerste minister graaf Strafford was vergaan; de prins zag een sterke gelijkenis met hetgeen hij moest beleven, en hij koesterde hun historie als een emstige waarschuwing. Het was, zei hij tegen Gijsbert Jan van Hardenbroek, afgevaardigde voor Utrecht ter Staten-Generaal, een schandelijke daad van Karel geweest dat hij zijn raadgever en beste vriend had opgeofferd, om zichzelf te redden. De prins wilde standhouden. Nog in juli 1784, toen openbaarmaking van de Acte van Consulentschap de volkswoede reeds tot een nieuw en nu beslissend hoogtepunt opzweepte, weinig maanden voor Brunswijk's definitieve vertrek uit Nederland, schreef hij hem: ${ }^{27}$

\footnotetext{
"Alles zal ik echter nog beproeven, om U te bchouden, want nooit zal ik vergeten Karel I en den graaf Strafford."
}

De prins oordeelde hard over Karel I; hij heeft vermoedelijk niet geweten van Karel's zware innerlijke strijd en wroeging, en hoe de koning door een bisschop was overgehaald Strafford's doodvonnis te tekenen met een beroep op de traditionele Engelse leer van 's konings twee lichamen. En waarschijnlijk niemand heeft opgemerkt hoe de zelfde leer, zonder enig verband met stelregels van Nederlands staatsrecht, in het woelen rond Brunswijk's persoon door de nood der omstandigheden spontaan opdook. In staatkundige kringen van de Republiek werd de standvastigheid van Willem V gewaardeerd; hij kon, erkende men, als man van eer zijn vertrouwde voogd niet aan de laster en de woede van het volk prijsgeven. Maar de landelijke onrust moest tot bedaren komen, en daartoe was vereist dat de hertog het veld ruimde. Joachim Rendorp, woordvoerder van de Ansterdamse stadsraad, voelde waar de schoen wrong en hoopte dat de stadhouder in zijn publieke hoedanigheid wel zou doen, wat hij als mens moest verfoeien: ${ }^{28}$

28. Rendorp I, 178/179; Hardenbroek II, 631 . 


\begin{abstract}
"Men kon schier niet verwachten, dat Hy gewillig daar toe zou komen. Doch alhoewel de verwachting gering was, was $\mathrm{Ik}$ niet volstrekt zonder hoop, van den Vorst te verkrygen, 't geen de Mensch, de gemoedelyke Mensch, zou weigeren, zoo deez' gemoedelyk Mensch, kon gerust gesteld worden."
\end{abstract}

Als vorst echter kon de prins nog veel minder inschikken. Het was hem zonneklaar dat de beslissing Brunswijk heen te zenden hem werd opgedrongen; zijn vrijheid van handelen stond op het spel, de vrijheid van bandelen die een hoogste autoriteit toekwam, dal wil zeggen zijn macht. Wat zou overblijven van het stadhouderlijk gezag indien hij aan willekeurige wensen van ondergeschikten moest toegeven? Wat zou de wil van de prins er nog toe doen als een ministerraad op voorzeggen van het volk hem dwingende adviezen deed? Hij zou niets meer bijdragen dan zijn handtekening, eenvoudig te vervangen door een stempel: ${ }^{29}$

"Zij willen mij onder curatele brengen, en dat sal ik niet lijden; ik moet in staet zijn om mijn posi waer te nemen of niet. Wel ras sal er bij soo een raid nog een stempel volgen, ten einde zij mijn naem maer voor mij tekenen wanneer en soo dikwerf sij het goed vinden ..."

Willem V was aan zijn ambt verplicht inmenging in de stadhouderlijke bevoegdheid tegen te gaan. De burgemeesters van Amsterdam moesten toch begrijpen dat zij met bun opdringen deze bevoegdheid aantastten? Erger nog, zo was bun eigenlijke opzet. Voor Willem V leed het geen enkele twijfel dat op zijn wettig gezag werd geaasd, en hij wierp de Amsterdamse delegatie op 8 juni 1781 deze beschuldiging tegen. De heren, beduusd, ontkenden. Zij wilden slechts de hertog kwijt, ze dachten dat een ministerraad de prins goed zou doen, maar geenszins beoogden ze zijn macht te verkleinen, geenszins staatsrechtelijke nieuwigheden in te voeren; de stadhouder zou "'t voomame Spil, op welke alles zou draayen, gebleeven zyn". Het debat sleepte zich voort, welles en nietes, beide partijen spraken volkomen langs elkaar heen. ${ }^{30}$

De prins hamerde op zijn beschuldiging maar vond bij niemand gehoor, en velen deden hun uiterste best hem ervan af te brengen. Hardenbroek kon eenvoudig niet geloven dat mensen "die niet geheel harssenloos waeren" tot een dergelijke samenzwering in staat zouden zijn; het zat hem dwars: ${ }^{31}$

"... maer hetgeen mij het meest hinderde was de preventie van Sijn Hoogheydt, die aan die menschen gevaerlijke cogmerken toeschreef, die ik door kortsigtigheydt of gebrek van onderrigt niet bespeuren konde ..."

Hierbovec werd een misverstand aangewezen dat kennelijk heeft geheerst tussen koning Karel I en zijn opstandige onderdanen. De koning merkte op dat zijn vrijheid zelf te beslissen onder druk van het volk verdween; de onderdanen dachten echter hun goede vorst te bevrijden uit de knellende diktatuur van zijn ambitieuze raadgevers, totdat de koninklijke onmacht achteraf officieel staatsrecht werd. Blijkens de teksten zat de $18 \mathrm{e}$

31. Hardenbroek II, 567, $624,627,628$. 
eeuwse Nederlandse politiek gevangen in hetzelfde misverstand; en het is wel buitengewoon tragisch dat prins Willem V, die de geschiedenis inging als een volstrekt onbeduidende figuur, noch naar oordeel noch naar karakter opgewassen tegen de vraagstukken van zijn tijd, juist verder dan alle anderen de staatkundige en historische betekenis van de hetze tegen Brunswijk heeft overzien, maar het hun niet kon duidelijk maken. Want hij had het door, de enige: ${ }^{32}$

"... dan, dat dit alles op seer kwade en funeste gronden lag, want dat nimmer geene revolutie of grote verandering in een constitutie bij trouble tijden was gesogt en voorgevallen, of men hadde sorgvuldig steets de persoon, die aan 't hoofd der regering was, in den beginne gemenageert, gepresen, jac goede woorden selfs gegeven, gelijk nu ook geschiede, maer 't waere doelwit was, soo sagjes van "t een tot het ander te komen, en dus doende eene gantsche onkeer der regering te verwekken \&uc. ..."

De stem van een die roept in de woestijn. De prins had er al geen heil van verwacht dat Brunswijk naar Den Bosch vertrok, en inderdaad, de geruchten van diens kwalijke invloed hielden onverminderd aan. Zie je wel, reageerde Willem, dat het niet om Brunswijk ging maar om de hoogste macht? Maar sinds het najaar van 1784 , toen de hertog uiteindelijk het land verliet, vernederd, uitgejouwd: Toen had de mythe van de goede heerser en zijn slechte omgeving toch haar rol uitgespeeld? Toen kon de prins toch gerust zijn?

Op zondag 4 september 1785 braken in Den Haag ongeregeldheden uit; Orauje-gezinden vochten met tegenstanders, en leken aan de winmende hand. Het Haagse garnizoen, onder bevel van de stadhouder, had weinig aan de vechtpartij gedaan, en de Staten van Holland, ontevreden, gaven toen zelf, zonder prins Willem V erin te kennen, het garmizoen opdracht tot krachtiger optreden. Een duidelijke inbreuk op de bevelsmacht van de prins, die woedend genoegdoening eiste en bovendien ogenblikkelijk op zoek ging naar zijn aanstellingsbrief, om haar in te leveren en ontslag te nemen als stadhouder; maar alleen een smid kon de sloten van het archief verbreken en deze omstandigheid remde 's prinsen ongeduldige voortvarendheid nog even. Een dag later verscheen een gezelschap heren, die de prins sussend toespraken. Alles zou immers weer in orde komen, mits de prins toeliet dat zijn ondergeschikten zelf voor hun gedrag verantwoordelijk werden gesteld, waardoor ieder zou verstaan dat de prins geen schuld had aan hun laksheid... ${ }^{33}$

"Dan de Prins, met een furie opstaande, wierp sijne handschoenentegen de gront, sloeg op de tafel, liep de kamer door als een uitsinnig mensch, vloekte, raasde verschrikkelijk, sey tegen de Princes, ... dat hij, Prins, dit landt verliet: wilde zij mede gaan met haer kinderen, sij kunde het doen, en wilde zij blijven, omme gouvernante in sijn plaats te worden, zij konde het doen. Dat wel voelde waer van daan hem de kwaatoverkwam; dat, sedert hij, Prins, den raad van den Herog verlaten hadde, hij geen segen meerder in sijn doen en laten hadde ondervonden etc., vertrekkende daerop de kamer uit. Een quartier daernaa wederkerende, begon deselve scene alweder, en dat selfs tot eene derde maal toe ..." 
Hoe het de prins te moede was toen zijn voorspellingen die niemand had aanvaard uitkwamen, en zelfs toen nog zonder dat iemand zijn gelijk begreep? Zulke scènes konden de reputatie van Willem V geen goed doen; de bedeesde onbenul, onzeker stappend aan het handje van zijn voogd de hertog, verwierf in een ommezien tevens de naam van een driftige stijfkop, die naar niemand luisteren wilde. Het zij zo; maar Willem's wanhopige machteloosheid, eenzaam worstelend in het aangezicht van de koningsmythe, heeft ongetwijfeld enige kracht ter verklaring èn verontschuldiging.

\section{$\S 4$.}

De feiten zijn bekend. Stadhouder Willem V verliet Den Haag, vestigde zich in Nijmegen, zijn echtgenote prinses Wilhelmina wilde terug, werd bij Goejanverwellesluis aangehouden, haar broer de koning van Pruisen zond daarop in 1787 ziju leger over onze grenzen, de stadhouder werd hersteld, maar niet voor lang; 1795 de intocht der Fransen, het einde van de Republiek, het einde van het stadhouderschap. Na een onnstige en tenslotte ook ongelukkige tijd herrees Nederland in 1813 als onafhankelijke staat, een monarchie; de zoon van stadhouder Willem $V$ keerde weer als koning Willem I. Onder zijn kToon werden België en Nederland verenigd. Voor heel Europa enerverende jaren, vol razendsnelle ontwikkelingen, ingrijpende staatkundige veranderingen, haastig en tegen de zin van velen doorgedrukt, maar van blijvende waarde en nooit meer voorgoed ongedaan gemaakt.

Jaren die daarom nog altijd door geschiedschrijvers aandachtig worden bestudeerd; overgangstijd, afbakening van historische tijdperken. Jaren evenwel, hoe belangrijk ook, die naar het schijnt de mythe van de goede koning niet konden beroeren. Toen na alle emotionele wederwaardigheden, na strijd en verzoening, Oranje terugkeerde, nu werkelijk naar geldend staatsrecht als monarch, van Nederland en België, hervatte de mythe haar spel alsof er niets was gebeurd; een ander decor, andere spelers, hetzelfde script. We vroegen in voorgaande gevallen telkens naar mythe of methode: Hebben onderdanen hun beschuldiging tegen ministers gemeend of gebruikten ze haar als een kunstgreep on koninklijke toorn te ontlopen? De vraag blijft ons bezighouden, maar ze wordt er niet gemakkelijker op; ze verschuift bovendien tot een andere: Kunnen we enig zicht krijgen op de weg die de koninklijke onschendbaarheid heeft afgelegd van versluierde mythe tot erkend staatsrechtelijk beginsel? Want we naderen het doorslaggevende jaar 1848 . In 1819 verscheen te Brussel een anoniem pamflet, gewijd aan de ekonomische toestand van bet Verenigd Koninkrijk: De l'état actuel du Royaume des Pays-Bas, et des moyens de l'améliorer. Naar omvang eigenlijk een boek; het omvatte twee delen van samen bijna vijfhonderd bladzijden, en werd een jaar later nog gevolgd door een derde deel. Een onophoudelijke aanklacht van het regeringsheleid. De opsomming van wantoestanden was zonder einde, landbouw, industrie, handel en scheepvaart kwijnden, de armen werden belast, er was onvoldoende kapitaal, de staatsfinanciën waren een rü̈ne, de staatsschuld bankroet, de bevolking ging achteruit, burgeroorlog dreigde, buitenlandse vijanden loerden op hun kans.

Al nam de schrijver geen blad voor de mond, al had hij geen goed woord voor de politieke leiding van het land, toch aarzelde hij niet zich een vriend van de koning te noemen. Want alle ellende was de schuld van de ministers, die haar opzettelijk veroor- 
zaakten, niet door onbekwaamheid, nee maar in hun doortraptheid. Aan de koning lag het niet; "onmogelijk" en "absurd", de veronderstelling dat deze heilloze politiek volgens zijn wil zou zijn! Willem I verkeerde in onwetendheid, brieven drongen niet tot hem door, en als hij ervan zou horen zou bij ogenblikkelijk zijn ministers verwijderen. ${ }^{34}$

"... je me bornerai à dire que l'amour du prince pour ses sujets est un gage assuré pour la nation qu'il destituera les ministres actuels aussitòt que la vérité parviendra jusqu'à son trônc."

Het boek was een uiterste poging Willem I te bereiken. Geen ongelukkige vergissingen maar daadwerkelijke ministeriële kwaadaardigheid bedreigde 's lands toekomst, een krachtige ingreep, alleen zware straffen konden het geweld der ministers keren, en de schrijver richtte zich daarom tot de vorst met een ware smeekbede: ${ }^{35}$

"Que Votre Majesté daigne seulement se délivrer des ministres, etc., vos ennemis, sire, comme ceux de son peuple, et qu'elle daigne les remplacer par des ministres ... qui prennent pour règle de leur conduite celle de répondre à la confiance de Votre Majesté. Dès le même instant tous les maux du royaume cesseront; le déficit des revenus pubilics sera comblé. et l'air retentira des cris de joie et d'une ivresse générale."

Dramatische bewoordingen, verdacht door hun overdrijving. Kon de schrijver dit menen, heeft hij werkelijk geloofd dat de goede koning een onwetend instrument, speelbal van zijn misdadige ministers is geweest? Ja: ${ }^{36}$

"Ce que je viens d'avancer est de la plus exacte et de la plus rigoureuse vérité."

Hij hoefde ook helemaal niet verbaasd te zijn van deze toestand. Altijd, schreef hij, daarmee trouwens de uitkomst van onze vorige twee hoofdstukken keurig bevestigend, door alle eeuwen hadden ministers getracht hun koning te verdringen, ten koste van zijn en 's lands belang. Om die reden ook was het bewonderenswaardig en een reden tot dank voor heel de mensheid dat de Engelsen hun staatsrechtelijke grondregel The King can do no wrong hebben bedacht; want deze regel heeft als natuurlijk gevolg dat al het verkeerde, onder 's konings naam geschied, het werk van de ministers is, die dus er voor verantwoordelijk moeten zijn.

En weer de bizarre overgang, waaraan we langzaam wennen. In volle overtuiging wordt heweerd dat de koning het kwaad niet doet, een weergave van pijnlijke werkelijkheid, tegelijk dat de koning uit hoofde van staatsrechtelijke beginselen geen kwaad doet, dat wil zeggen, het wordt bem voor de vorm niet toegeschreven. Mythe en methode; met nu, voor het eerst, een openlijke verwijzing naar de grondwettige koninklijke onschendbaarheid en ministeriële verantwoordelijkheid. ${ }^{37}$

\footnotetext{
34. Van der Stracten II, 3, 78.

35. Van der Siracten I, 323-324, 349.

36. Van der Straeten I, 331, 337/338

37. Van der Straeten II, 39-40.
} 
"C'est cette maxime sublime qui a environné le trône de la Grande-Bretagne de l'éclat le plus majestueux, puisqu'elle assimile les rois à la divinité qui ne se fait connoitre aux hommes que par ses bienfaits.

Elle a fondé le bonheur des sujets sur une base inébranlable, puisqu'elle les couvre d’un ćgide impénétrable aux efforts du despotisme et de la tyrannie, car encore une fois le mal qui se fait au nom du Roi étant l'ouvrage de ses ministres, ceux-ci en doivent être punis, et c'est la crainte salutaire d'un châtiment inévitable qui les retient dans le devoir ..."

Is mede dit boek de reden geweest dat koning Willem I in 1820 uit zijn slof schoot? ${ }^{38}$

"Waarom beschuldigen zij de ministers? Wat zijn de ministers? Volstrekt niets ..."

Precies de machteloze woede van zijn vader, stadhouder Willen V; als men al dacht de vorst te plezieren door zijn ministers de schuld te geven, dan wel zeer ten onrechte. De schrijver van het pamflet werd achterhaald: Ferdinand van der Straeten, geboren in Gent, te Brussel gevestigd als eigenaar van een brasserie, iemand die levenslang studie maakte van ekonomische theorieën en processen. Er volgde een geruchtmakend strafproces, vol ongelukkige verwikkelingen. Van der Straeten werd veroordeeld tot een boete van 3000 gulden, maar de Belgische publieke opinie had inmiddels zijn zijde gekozen en het bedrag werd ruim gedekt door de opbrengst van een nationale inzameling. Van der Straeten wist van geen ophouden, publiceerde meer, werd opnieuw vervolgd, de moeilijkheden knakten zijn gezondheid, en hij overleed in $1823 .{ }^{39}$

Nog andere onenigheid kwam voor tijdens de bewindsperiode van Willem I. In het protestantse Nederland, na angstige spanning van Spaans-katholieke overheersing vijjgevochten, was van de weeromstuit het leven voor katholieke gelovigen lange tijd moeilijk geweest, in het verborgene, op de grens van onwettigheid. De revolutionaire omwentelingen van rond 1800 brachten hun gelijkberechtiging en meer bewegingsvijheid, maar het oude wantrouwen werkte nog door en koning Willem I, door afkomst uit protestantse traditie, meer nog door zijn moderne, verlichte opvattingen, streek katholieke onderdanen dikwijls tegen de haren in. Het was weunen, voor alle partijen. Een notaris in het noorden van Willem's Verenigd Koninkrijk nam op zich de katholieken een eigen plaats en een eigen herkenbaar geluid te geven: Joachin George le Sage ten Broek.

In een stroom van brochures en in de artikelen die hij voor eigen tijdschrifjes maakte, werden door een onvermoeibare Le Sage ten Broek de katholieke opvatingen uitgelegd: en onverschrokken bestreed hij al het onrecht dat de katholieke burgers door politiek en maatschappij hadden te lijden. Politiek onrecht, Le Sage ten Broek wist precies waar dat van kwam: Ministers, verbeten vijanden van het katholicisme, hadden koning Willem I allerlei onzin op de mouw gespeld en hem zo tot onrechtvaardige maatregelen verleid. Telkens weer uitte Le Sage ten Broek daarom de wens dat iemand de goede vorst op de hoogte zou brengen, zodat hij de kwalijke invloed van de lieden rondom 
hem zou kunnen tegengaan; "Och! of de Koning het wist!", was de kop van een artikel in 1823.

"Deze uitboezeming, die wij dikwijls gehoord hebben en nog dagelijks hooren, is, inderdaad, een treffend bewijs van kinderlijk vertrouwen op den Monarch: het is een onloochenbare getuigenis van de zekere bewustheid, dat de Koning regtvaardig en goed is; dat hij, als een vader in vele grieven zijner kinderen voorzien en dezelve wegnemen zou, indien ze hem bekend waren."

Een geluk bij een ongeluk: De ministers deugden niet, als het aan hen lag was het met de katholieken snel gedaan; maar de koning was een bolwerk van zuivere gezindheid, een zekere toevlucht voor verdrukte gelovigen. De kerk was veilig, want de veelgeliefde, de vaderlijke, de rechtschapen koning had op de grondwet, die recht voor allen beloofde, zijn onwankelbare eed gezworen. ${ }^{41}$

"Gelukkig zijn wij in het koningrijk der Nederlanden, tegen alle onderdrukking der Kerk gewaarborgd, zoo lang als onze tegenwoordige Grondwet bestaat: want onze regtvaardige Koning heef dit stellig verklaard: hij heeft den staat en de vrijheden der catholijke Kerk verzckerd en zijn koninklijk devies is: Je maintiendrai!!!"

Leve WILLEM de Regtvaardige! de Welbeminde! Heeft Le Sage ten Broek het werkelijk geloofd? Of heeft hij opzettelijk zijn koning gespaard, uit angst voor koninklijke wraak? Nee; ook in persoonlijke briefwisseling, onbespied, zuchtte hij: "De goedgezinde Koning kan niet tegen den stroom op." Zijn biograaf, zonder hulp van de psychologie of kennis van de mythe, weet niet goed raad met de kwestie; het despotisme kwam, in tegenstelling tot Le Sage ten Broek's beweringen, ontwijfelbaar van Willem zelf, maar: "Het lijkt mij onmogelijk om aan te nemen, dat dit niet eerlijk en oprecht gemeend zou zijn. " Met het besluit: Le Sage ten Broek "kon wonderlijk naïef gelooven aan wat hij wenschte. ${ }^{n} 42$

Overigens had Le Sage ten Broek alle reden tot voorzichtigheid. Zijn gedreven schrijven was de autoriteiten een doom in het oog, en zij zochten gelegenheid hem een lesje te leren. $\mathrm{Na}$ jaren van ongeduldig wachten grepen ze in 1827 hun kans. Le Sage ten Broek, herstellend van een zware ziekte en halfblind, werd gearresteerd en drie maanden vastgehouden; men zag af van vervolging omdat eigenlijk niemand aan het strafbare van zijn uitspraken geloofde en geen rechter bereid zou zijn hem te veroordelen. Desondanks een gevoelige slag die Le Sage ten Broek tot aanpassing van toon of denkwijze kon brengen, maar daarvan is geen blijk; voor en na hield hij het erop dat slechte ministers onder het schild van de goede koning onheil stichtten. Wel had zijn manier van doen iets omslachtigs, misschien toch van schrik, toen hij in 1829 een Koninklijke Boodschap op de korrel nam; zijn tekst brengt ons nog eens in de ongrijpbare scheme-

41. De godsdiensnriend $10(1823) 124$.

41. De godsdiensinriend 19 (1827) 17 .
42. G. Gorris, J.G. Le Sage ten Broek en de eersie faze van de emancipatie der katholieken, 2 din. Amsterdam 1947-1949; deel I, 192-193, decl II, 257-258. 
ring van mythe en methode, de overgang van koningsgeloof naar grondwettelijke onschendbaarheid.

Deze Koninklijke Boodschap tussen haakjes, de beruchte Koninklijke Boodschap van 11 december 1829, behelsde niets dan koning Willem's geheel eigen en krachtige overtuiging. ${ }^{43}$

\begin{abstract}
"Nog mogen wij zonder vrees, voor den kerker, ons gevoelen vrijmoedig uiten, en onze aanmerkingen maken, zoo wel op eene aanspraak van den troon, en op eene Koninklijke Boodschap, omdat zij als het werk van eenen minister beschouwd worden, en derhalve niet de geringste inbreuk op de koninklijke onschendbaarheid, welke ons heilig is, maken kunnen, ... en zouden wij dan, bij de innige overtuiging, dat de welwillendste, dat de regtvaardigste der vorsten, meer dan ooit bedrogen wordt; dat sommige raadslieden der kroon, zich tusschen den vorst en het volk stellende, aan den eenen kant, bronnen van tweedragt openen, de gemoederen ontrusten; achterdocht inboezemen, en de liefde jegens den Vorst in de harten doen verkoelen; terwijl zij aan den anderen kant, de ware oorzaken van dat alles, voor het vorstelijk oog verbergende, den vaderlijken Koning, diets maken; dat de gisting der natie, waarvan zij de bewerkers zijn, het gevolg is van de vrijheid der drukpers, en dat diensvolgens, de kerkers weder moeten geopend worden voor elken schrijver, dien zij verkiezen uit den weg te ruimen; opdat de stem der waarheid niet eindelijk tot den troon doordringe. Mogten onze aanmerkingen iets ter voorlichting onzer volksvertegenwoordigers omhelzen! Mogten zij onder het oog des Konings komen!"
\end{abstract}

Fraaier nog is een tekst, later in hetzelfde jaar, 1830, toen Le Sage ten Broek zichtbaar op grond van de mythe uiteenzette dat de koning onschendbaar, en de ministers verantwoordelijk moeten zijn. ${ }^{44}$

\begin{abstract}
"Men beweert, dat het vemederend voor den Vorst is, als zijn minister aan iemand anders dan aan hem verantwoordelijk zou zijn: juist het tegendeel is waar, de ministeriele verantwoordelijkheid veronderstelt in den Koning, eene soort van onfeilbaarheid: de Koning kan geen kwaad doen; deeze leer behoort onafscheidelijk tot de leer der ministeriele verantwoordelijkheid. Als de Koning alles met cigene oogen zien en lezen kon; indien hem geene valsche berigten gegeven geene heilzame inlichtingen onthouden wicrden, dan zou niemand zich over onbillijkheid te beklagen hebben. Maar hoc zal de Vorst weten, of een minister hem bedriegt, misleidt en de waarheid voor hem verborgen houdt? Vooral, wanneer een minister zich magtig genoeg waant. om door middelen van geweld, de stem der waarheid te smooren, en haar te beletten tot den troon door te dringen en tevens alleen de loftuigingen van vleijers onder het koninklijk oog te brengen, en daardoor tracht te bewijzen, dat alle die zijne handelwijze laken, kwaadwilligen, oproerigen en revolutionairen zijn?

Neen, zegt het grondwettig stelsel, en het catholicismus juicht zulks toe; de Koning is een veel te verheven wezen, dan dat hij misleidt of bedrogen zou mogen worden; de Vorst moet hiervoor beveiligd worden door de verantwoordelijkheid zijner ministers."
\end{abstract}

De strafrechtelijke onaangenaambeden rond de publikaties van Le Sage ten Broek en de Belgische Van der Straeten, en het verhitte partijkiezen der Belgen tegen de overheid tijdens Van der Straeten's proces, waren voorbode van meer en ernstiger moeilijkheden. Tussen koning Willem I en de zuidelijke provincies van bet rijk, waar voomamelijk katholieken woonden, ontstond verwijdering die onstuitbaar verergerde en uitliep op 
rebellie, burgeroorlog, en de onafhankelijkheid van Belgiě. De koning weigerde te geloven aan een fatale afloop en verzette zich koppig tegen de scheiding zolang zijn koningschap duurde. En het zou wellicht ook te simpel zijn de afloop, naderhand, als onvermijdelijk te bestempelen, want beiderzijds heerste onduidelijkheid. De Belgen hebben zeker niet van stonde aan staatkundige zelfstandigheid gezocht. Weliswaar klonk een roep "Weg met de koning!", maar een andere overheerste: "Vive le Roi, a bas les ministres". Men hoefde, men wilde Willem I echt niet kwijt; hij was de beste aller koningen, wijs, ijverig, vol goede bedoeling. Maar zijn ministers: die gevaarlijke mannen deugden volstrekt niet. Vierenveertig Brusselse notabelen zonden op 28 augustus 1830 een dringende petitie aan de koning opdat hij het "système funeste" van zijn ministers zou doorbreken. ${ }^{45}$

"Pleins de confiance dans la bonté de V.M. et dans sa justice, ils n'ont députés vers Vuus leurs concitoyens, que pour acquérir la douce ccrtitude, que les maux dont on se plaint seront aussitôt réparés que connus."

De ongeruste burgers wisten ook nauwkeurig wie het was die de goedwillende vorst naar zijn pijpen liet dansen: Cornelis Felix van Maanen, minister van de koning en diens voornaamste adviseur. De Prins van Oranje, die later, in 1848, als koning Willem II geschiedenis zou schrijven, was naar het zuiden afgereisd om de Belgische grieven te onderzoeken; met een zekere opluchting, maar tegelijk slecht op zijn gemak om het, naar hij wist, onrechtvaardige van de haat tegen Van Maanen, schreef hij op 2 september 1830 aan zijn vader dat de zuidelijke provincies met Van Maanen's aftreden genoegen zouden nemen. ${ }^{46}$

"... tout peut se pacifier ici dans le Midi, une personne seul se retirant,-tout s'arrangera alors el rentre dans le calme el l'ordre--: c'est notre pauvre, bon, loyal Van Maanen.

De prins had in zijn brief pauvre eenmaal, bon tweemaal, loyal driemaal onderstreept. Van Maanen zelf ontving uit Brussel bet volgende bericht: ${ }^{47}$

\footnotetext{
"Het is onhegrijpelijk hoc een ieder om zoo te zeggen, ja zelfs vele door Uwe Exc. begunstigde personen, zich tegen Uwe Exc. uitlaten. Het geroep à bas van Maanen had de overhand, en men vindt het op alle muren geschreven. Al wat de Koning gedaan heeft dat aan de Zuidelijken niet aangenaam of voordeclig is, welk departement zulks ook moge aangaan, wordt thans vitsluitend aan Uwe Exc. verweten, en die verwijtingen zijn mijns inziens niet zonder groot nut voor de koninklijke familie persoonlijk. "
}

Noord-Brabant, ook een overwegend katholieke provincie, zou niet met de afscheiding meegaan; maar Brabantse kranten volgden het verloop der gebeurtenissen op de voet en ze gaven van harte plaats aan de wekroep van een briefschrijver, dat "eenieder zijn offer op het altaar des vaderlands brenge en tone, dat dár, waar de ministeriële roede roeke- 
loos durft te slaan, de hand des volks tegenwoordig is om de wonde te zalven". En de medewerkers van deze kranten schreven zelf niet anders, hun vaste thema was de onwetendheid en de goede wil des konings. Alle bezwaren en verlangens liepen uit op dit: "In eén woord: beterschap van het ministerie". ${ }^{48}$

"Wij hopen, dat on/c geceerbiedigde Koning, die niets dan het geluk van zijn volk beoogt, de klaiysttm van zovecl duizenden verhore, en de ingeving zijner trouweloze dienaren, die Hem omringen, verwerpe."

Eens te minder kunnen we ontkonen aan deze vaststelling, dat de algemene afschuw van bet ministeriële wanbedrijf oprecht was. Het blijft verbazingwekkend. De minister moest weg op verlangen van de publieke opinie; precies het stelsel van de ministeriele verantwoordelijkheid in een konstitutionele monarchie. Het was evenwel niet on demokratische redenen, het was om de verkeerdheid van de minister dat zijn verwijdering werd geëist. En om de ervaring met die ene slechte minister moest ook als regel voorgoed gelden dat ministers strafrechtelijk verantwoordelijk zouden zijn. In België ging een pamflet rond met een reeks eisen aan de regering. ${ }^{49}$ Nummer 2:

"L'ćloignement du ministère de l'infâme et odieux Van Maanen."

En nummer 7:

"La responsabilité pénale des ministres, établie par une loi. "

Geleidelijk, door de uiteenzettingen van Van der Straeten en Le Sage ten Broek, en door de Belgiscle opstand, komt ons beter voor ogen te staan hoe in het $19 \mathrm{e}$ eeuwse Nederland het verband kan zijn geweest tussen de mythe van de goede koning en de staatsrechtelijke onschendbaarheid en ministeriële verantwoordelijkheid. Uit het geloof aan de boosaardigheid van deze minister, vloeide vanzelf voort dat men zijn ontslag en bestraffing, en vervolgens blijvende wetgeving tegen slechte ministers moest eisen. Maar de ministeriële verantwoordelijkheid was toch ten laatste bedoeld als politiek beginsel, om de volksinvloed aan de macht te laten? Het wonderlijke is, los van de vraag of ministers inderdaad verkeerd deden, dat in de opgewonden beschuldigingen aan hun adres de politieke ministeriële verantwoordelijkheid al volledig werkzaam was: ministers dienden te wijken wanneer de volksstem zulks vorderde, en de koning bleef buiten schot.

Heeft ientand dit ingezien? Er is een tekst overgeleverd uit de tijd van de Belgiscle onathankelijkheidsoorlog, zeldzaam en glashelder, over de verhouding tussen Willen I en zijn zuidelijke onderdanen: ${ }^{50}$

48. E.R.M. Hoffman, Noord-Brabant en de opsiand van 1830, Tilburg 1974, blz. 14, 32, 60.

49. Gertetson I, 168.

So. Charles de Leutre, Histaire de la révolution belge de 1830. Encyclopédie populaire I, Brusel zj. blz. 14 
"Aussi les individus gardèrent du respect et une certaine affection pour lui, tandis que les masses accumulèrent toute leur haine sur $\mathrm{M}$. Van Maanen, en qui elles personnifiaient le système du roi, obéissant ainsi instinctivement à cette loi de la responsabilité ministérielle que Guillaume avait refusé d'écrire dans la constitution."

En dan was er de Nijmeegse onderzoeksrechter Emmanuel Frans Joseph van den Gheyn, met het volgende verhaal. ${ }^{\text {st }}$ In het jaar 1831 , toen de Belgische revolutie iedereen van slag bracht, hadden plaatselijke autoriteiten wilde geruchten over een opstand in de buurt van Nijmegen al te zwaar opgevat, en zich door nodeloos krijgshaftig vertoon belachelijk gemaakt. Van den Gheyn moest als rechter ter instruktie de zaak behandelen, zijn plichtsgetrouwe en zorgvuldige aanpak viel bij de betreffende gezagsdragers niet in de smaak, en een intrige bewerkstelligde spoedig zijn ontslag. De eerlijke rechter en vader van elf minderjarige kinderen zat prompt zonder inkomen. Hij schreef het schrijnende onrecht hartstochtelijk toe aan de laaghartige misleiding van de minister van justitie Van Maanen, een "beginsellooze draaijer" en "staatkundige huichelaar", die zijn vorst door "valsche rapporten" misleidde en zo een "ministerieele dwingelandij" wist te stichten.

Vele jaren bleef de "gemartelde" Van den Gheyn hardnekkig vechten tegen het wederrechtelijk ontslag; in 1847 publiceerde hij het hele verhaal, met de gewisselde stukken. Onder andere zijn petitie aan Willem I, nog uit 1831, geschreven om de "steeds welmeenenden koning" beter in te lichten.

"De onschuld behoeft zich slechts, met gepasten eerbied, aan te melden bij onzen, hoogsiregtvaardigen, koning, wiens edele bedoelingen steeds, boven allen twijfel, verheven zijn, om dadelijk regl te erlangen."

Maar, vertelde Van den Gheyn, zijn eerbiedig, dit billijk, dit rechtmatig, dit grondwettig verzoek bleef onbeantwoord. Allemaal door Van Maanen; die onderschepte 's konings post en daarom kon de noodkreet der gestrafte onschuld de goede vorst niet bereiken. In 1834 probeerde Van den Gheyn het nog eens; hij verwees naar de grondwettige onschendbaarheid van de koning en benadrukte op dezelfde bladzijde overdadig dat Van Maanen door zijn kwaadwilligheid en sluwheid de beilzame besluiten van de goede vorst bad verhinderd.

\footnotetext{
"Twe Majesteit word, door den ondergetcekenden, te midden van al zijn, schuldeloos, onuitdnukbaar, zielslijden, diepeerbicdig, volgens pligt, steeds gehuldigd, als het onschendbaar hoofd van onzen grondwertigen staat; maar 200 lang de vorsten de eigenschappen der Godheid niet besitten, zal het den staatsburger, die het slagtoffer was van onregt, met koninklijk gewaad, door ministerieële sluwheid bedekt, steeds volkomen vrijstaan, om den Koning - hoe hoog ook boven zijne medeburgers, door de Grondwet verheven - te mogen beschouwen, als een, voor misleiding en dwaling vatbaar MENSCH, aan wien de Gronchwet van elk, vrijzinnig Landsbestuur, tot algemeen heil des vaderlands, deze menschelijke onvolmaaktheid niet toereken; doch juist daarom, moet het onderwerpelijk, blijkbaar, onregt het strafbaar bedrijf wezen van den, aan de Grondwet veranwoordelijken staatsdienaar, die de vermetelheid had, van onder
}

51. Verdediging van den regter ler instructie, bij de voormalige regibank van eersten aanleg, te Nijmegen: Mr. Emmanuel, Frans, Joseph, van den Gheyn, door hem zelven voorgedragen aan het verstandige publiek, Den Haag 1847, vooral blz. 52, 70-71. 
bedricgelijke schijnredenen, eenen ongrondwettigen matregel uit te Jokken; of zich met de uitvoering van den zelven. tegen eed en pligt, durfde belasten. Dit verantwoordelijk feit drukt hier met dubbele zwaartekracht op dien hoogen staatsdienaar, welke met den veel beteekenenden naam van Minisler van Justitie prijkt, en zich echter niet ontzag, om, ten aanzien van eenen, willekeurig ontslagen, Regter ter Insinuctie, en geschorsien, van zijne wedde beroofden, Regter, alle wetten, en beginselen van regtvaardigheid te venrappen, onder schijnbaar wettigen, vorm, na zijnen, koninklijken, Heer en Meester, allerlei, misleidende, onwnarheid te hebben durven voorspicgelen ..."

Een lang citaat, zoals vaker in dit hoofdstuk. Maar het zijn bijzondere teksten, die telkens weer prachtig laten zien hoe eigenaardig mythe en staatsrecht vermengd konden zijn. De koning is onschendbaar; krachtens de grondwet. Hij is zeer verheven; krachtens de grondwet. Onfeilbaar; krachtens de grondwet. En hij weet niet van het onrech, want de minister is een regelrechte schavuit, die hem bedriegt en met valse voorwendselen eigenzinnig regeert in naam van de vorst!

We kunnen de verstrengeling nogmaals herkennen in een citaat dat vroeger al een plaatsje kreeg, in de traditionele weergave van de geschiedenis der koninklijke onschendbaarheid; toen lazen we erover heen. Mythe en staatsrecht in dezelfde tekst bijeen, maar toch messcherp gescheiden. De schrijver haalde een koninklijke troonrede door het slijk: "schadmteloos Staatstuk", "stuitende aanmatiging", "officiële logentaal". Harde woorden, die desondanks geen enkel gevaar voor kwetsing van de koninklijke majesteit opleverden. De koning was immers naar zijn aard grondwettig onschendbaar, dus onbereikbaar veilig voor kritiek. En bovenal: Hij had de troonrede belemaal nier zelf geschreven; dat hadden beslist zijn ministers gedaan. ${ }^{52}$

\footnotetext{
${ }^{n}$ Wij stellen Hem niet, wiens mond ze uitsprak, verantwoordelijk voor de woorden die anderen Hem ingaven; vooreerst, omdat het geheel in strijd is met alle constitutionele begrippen, dat eenige aansprakelijkheid op het hoofd des Staats ruste, en dus al van zelfs het regstvermoeden bestaan moet, dat elke daad cn elk woord door Hem, in zijne hoedanigheid van Koning, verrig of gesproken, afkomstig is van zijn bestuur, dat er de verantwoordelijkheid van dragen moet; en ten andere, omdat aan dit Staatstuk onze Koning zeer stellig geheel vreemd is, en hier dus het regtsvermoeden met de daadzaak overeen stemt. De Koning kan dat stuk niet gesteld hebben; in de eerste plaats omdat hij Koning is; en ten tweede, omdat Zijne Majesteit de Hollandsche taal niet genoeg magtig is, om zoo vele ronde volzinnen te kunnen zamenstellen."
}

Het verhaal van de goede misleide vorst, in het Nederland van de vroege 19e eeuw sterk aanwezig en zichtbaar verweven met het openbare debat over koninklijke onschendbaarheid en ministeriële verantwoordelijkheid, heeft nog een andere, nauwere band met de grondwetsherziening van 1848. In de gespannen jaren vooraf werd luider en luider om de herziening geroepen; de koning hield zich doof. Hoe kon dat? De logika van de koningsmythe, onverslaanbaar, had het antwoord gereed. Strafrechtelijke verautwoordelijkheid voor de ministers zou de gewichtigste bijdrage van een nieuwe grondwet noeten zijn, en vanzelfsprekend dat zittende ministers, beducht voor hun macht, bevreesd dat hun spel uit zou zijn, alles op alles zetten om de herziening in de 
kiem te smoren. Smoesjes genoeg om de niets vermoedende vorst ertegen op te hit$\operatorname{sen} !^{53}$

"... wij zeggen het zonder vleijerij, Willem II bezit een edel hart en eigenschappendie hem tot een'der beste Koningen zouden maken, indien hij niet door Raadslieden, ministers zeggen wij, omringd ware, die den band, welke de Natie aan den Koning hecht, losrukken, die hem beletten de stem zijner onderdanen te hooren, en den toegang voor deze tot hem, als het ware, te versperren."

Een citaat uit 1847. Ook nu weer wist men de boosdoener bij name te noemen: Floris Adriaan van Hall. Het is zeker dat de beide koningen Willem I en Willem II gekant waren tegen de ministeriële verantwoordelijkheid en haar invoering hoogstpersoonlijk aflielden; het is zeker dat de voorname liberale politikus Van Hall reeds in 1829 voor invoering pleitte, en sedertdien voor invoering bleef pleiten; maar alom maakte men zich wijs dat juist hij herziening in de weg stond. Van Hall, man van behoud, zou degene zijn die de rechtmatige roep des volks niet tot de vorst liet doordringen. De mythe van de goede koning die door slechte raadslieden is omringd, merkt een geschiedschrijver, zij het slechts terloops op. ${ }^{54}$ De spanning steeg voortdurend, Van Hall werd uitgemaakt voor alles wat lelijk is, smeekbeden aan koning Willem Il, die maar niet reageerde. Was de inkapseling der ministers dan ondoordringbaar? 0 koning, verwijder hen toch uit uw nabijheid en zie hoe blij het volk zal zijn!"ss

\footnotetext{
"Oui, Sire, éloignez ceux qui sacrifient à leur coupable ambition et votre popularité et l'avenir de votre dynastie. Cette nation n'attend qu'un mot de vous pour se ranger de nouveau à vos còtes, plus dévouée, plus enthousiaste que jamais. Ce mot, vous le savez, c'est le mot Réforme!"
}

Een balf jaar later had de schrijver van deze zinnen zijn geduld verloren. Als de koning gewoon niet luisterde, als hij bleef heulen met zijn ministers, dan was hij, koning of niet, als mens geen knip voor de neus waard. In april 1847 had hij voor Willem II geen enkele waardering meer, en het is alsof hij zich meteen terugtrok, van de levende persoon, de koning-met-een-kleine-k, op het koningschap, de koning als zodanig, de Koning-met-een-grote-K. De mens had teleurgesteld, maar de koning bleef in ere; ook trouwens om het voorschrift der wet.

\footnotetext{
"Or, nous n'éprouvons plus pour Guillaume Il ni sympathie, ni estime personnelles. Si nous respectons le Roi, c'est comme tel, et parceque, en refusant de payer au chef de l'Etat le respect voulu par les lois, nous commettrions une infraction à ces lois."
}

Maar een scheiding van persoon en ambt kon alleen maar kunstmatig zijn. Willem II zelf belichaamde het ambt en daarmee de hoop op betere tijden. Een kleine drie nraanden later, juli 1847, zag dezelfde publicist weer op naar de koning:

53. Robijns 177, 240; Van der Straeten II, 41; vgl. Bischof 17

54. Sirtema van Grovestins 131; Suttorp 42, 64; J.J. Giele, De pen in de aanslag. Revolutionairen rond 1848. Bussum 1968, blz. 30, 34, 36, 73

55. Dit en de volgende citaten uit Robijns $227-228,241$. 
"Le Roi n'a qu'un mot à dire et la nation courra encore se ranger sous sa bannière. Que le Roi dise seulement: Que veut mon peuple?"

We vissen hier echter in troebel water. De mannen die rond 1848 deze geluiden lieten horen waren niet achtenswaardig, maar lawaaiig en ongestadig, steeds het middelpunt van roddels, steeds financieel rommelend, steeds in aanraking met de rechter; randfiguren van de geschiedenis. Ook verwisselden zij onverwachts hun opdringerige betuigingen van aanhankelijkheid, die naar bet zich laat aanzien toch niet van overtuiging waren gespeend, voor venijnige en onbetamelijke aanvallen tegen de koning; dan weer zeiden ze de koning hoogstens te ontzien wegens wettelijk voorschrift. Desalniettemin voorbeelden van de mythe. En behalve deze onbetrouwbare publicisten, heeft bovendien het statige en gezaghebbende tijdschrift van de gezeten burgerij, De Gids, beweerd dat het uitblijven van de grondwetsherziening te wijten was aan onwilligheid van ministers: ${ }^{36}$

"Zoo wij van de tegenwoordige ministers, wier belang het best gediend schijnt met het behoud, waarvan zij zich zoo ijverige voorstanders toonen, weinig toenadering tot het hervormingsvoorstel wachten, verre $z i j$ het van ons hetzelfde te meenen van den geëerbiedigden persoon des Konings. De belangen van Koning en Volk zijn uit haren aard identisch, de sympathie tusschen beiden is altijd gereed te herieven, hoe lang zij ook gescheiden werden door eene aristokratie, die zich tusschen beiden indrong."

Tenslotte, bevrijdend, 1848. Men zag voor ogen dat de welwillende koning het eindelijk begreep, zijn ministers heenzond, zich aan het hoofd van zijn volk stelde en ou zonder talmen de vurig begeerde grondwetsherziening op gang bracht. De journalist Van Andringa de Kempenaer, een uit het bedoelde rijtje van lawaaimakers en intriganten, verklaarde achteraf trots hoe het allemaal in zijn werk was gegaan. Lange tijd had hij vergeefs geprobeerd door het schild van ministers heen de vorst te bereiken, om hem op de hoogte te brengen van de werkelijke stand van zaken. In februari 1848 was het dan toch gelukt, hij kreeg de koning te spreken en zie, onmiddellijk stortte de heerschappij der ministers in! ${ }^{57}$

"Den dag van den 27n Februarij 1848, dat ik tot den Koning werd toegelaten! den dag, dat de poort en de zalen van het Paleis op de Kneuterdijk mij weder werden geopend, toen de cipier Floris Adriaan van Hall en zijne sbyren, de toenadering tot den Koning niet meer konden versperren aan waarheid lievende en met warmen gloed voor het Vaderland blakende, aan den Koning zeer gehechte dienaren, wierdt 's lands teerling geworpen! Ja ik verklaar het hier openlijk, dat mijne overredingskracht en mijne daarop gevolgde berigten aan den Koning krachtig hebben bijgedragen, om een de Jonge van Campens Nieuwland, een J.C. Baud, cen van Doorn van West-Cappelle, een van Hall enz. van den Ministerieżlen zetel te zien aftreden of uil den Raad te zien verwijderen.

De partij van het halstarrige behoud is toen voor altoos de genadeslag toegebragl geworden, de Koning stelde zich aan de spits van het volk, een Donker Curtius, een Luzac. Thorbecke, de Kempenaer, van Dam van Isselt, enz., de kem der vrijzinnige vooruitgaande mannen, wierden in den Raad geroepen en beklommen den Ministeriěclen Zetel ..."

56. De Gids 9 (1845) M., blz. 94

R.L van Andringa de Kempenaer, Eene geschiedkundige bijdrage, tol eene juiste waardeering der staakundige gebeunenissen in Nederland, in de maand maan 1848, Den Haag 1848, blz. 22-23. 
Een andere druktemaker, Van Bevervoorde werd op 8 maart bij de koning gehaald en mocht na lang wachten zijn verhaal doen. Volgens het verslag in zijn krantje, de Courrier Batave, had de koning hem gezegd, ${ }^{\$ 8}$

"dat hij demonstraties wenste om zich van het juk van zijn ministers te ontdoen en dat hij tot verdergaande concessies bereid was."

Sic. Het schuim van de mythe. Nogmaals, deze mensen waren lastig, lawaaimakers, twijfelachtige getuigen. Maar in hun overspanwen relaas is een kern van waarheid; iedereen heeft gezien hoe de koning tot tweemaal toe op de stoep van zijn paleis verscheen om Van Bevervoorde warm de hand te drukken, ter gelegenheid van de blijde optochten in maart 1848, na het bekend worden van Willem's ommezwaai. En waarom zouden uitsluitend degelijke mensen en betrouwbare berichten hun invloed op 1848 hebben gehad? Bovendien, nog eens: $\mathrm{Zij}$ stonden niet alleen met hun geloof aan de vorst. Ook de nette en gematigde Gids nam in 1848 een gedicht op: ${ }^{s 9}$

\footnotetext{
De koning heeft gesproken, Het volk van Holland juicht; De hoogmoed ligt verbroken.

De onbuigbare onwil buigt.

De koning liet zich hooren:

Ik sluit aan 't volk mij aan!

En Holland is herboren,

De vrijheid krijgt bestaan.
}

Later lichtte het tijdschrift toe:

\begin{abstract}
"De koning heefl op het gewigtig tijdstip, waarop eene beslissende keuze noodzakelijk was, den moed gehad, zich te ontslaan van dienaren, wier streven - schoon wij er gaame de vrucht eener opregte, schoon voor ons onverklaarbare overtuiging in zien willen- in strijd was met den wil, het belang, de behoefte der natie."
\end{abstract}

$\S 5$.

Wij hebben vroeger, als uitgangspunt voor dit onderzoek, bet statsrecht rond de koninklijke onschendbaarheid bekeken; daarna de mythe van de goede koning ontdekt, en de opvallende overeenkomst tussen beide. De koning, volgens het recht, staat boven de partijen; in de mythe niet anders. Wanneer in oude monarchieèn politieke fakties om de voorrang streden, dan beweerden zij steeds in naam van de koning op te treden, zodat het koningschap als bet ware boven hun twist stond, algemeengeldig en ontwijfelbaar. Verwezen aangevallen ministers naar de opdracht van hun vorst, dan beriepen hun tegenstanders zich gelijkelijk op de wil van de koning, met een kleine dan wel een grote $\mathrm{K}$; zo hebben we nu Harer Majesteits ministers maar ook "Her Majesty's loyal opposition". Kritiek raakt de koning nier; naar staatsrecht en naar mythe. Klagende onder- 
danen zeiden dat hun kritiek niet tot de koning doordrong, hun delegaties bereikten hem niet; nu dringt evenmin iemand tot de vorst door omdat de lijn bij de minister ophoudt. De koning staat buiten de dagelijkse politieke werkelijkheid; volgens het staatsrecht en volgens de mythe. De boze raadgevers, fluisterde men, beroofden hun vorst van alle macht en lieten hem niets dan de schijn, het uiterlijk. Nu weet iedere Nederlander dat de ministers het beleid voeren en de vorstin feitelijk buiten de politieke macht staat, ondanks, misschien, allerlei onbekende informele invloed. De koning kan geen kwaad doen, in staatsrecht en mythe. Onderdanen waren eenvoudig niet bereid of in staat hun vorst enig kwaad toe te denken; thans geldt als wettelijk beginsel dat aan de vorst geen kwaad wordt toegeschreven.

In mythe en in staatsrecht is het ongeoorloofd dat ministers zich vrijwaren door beroep op koninklijk bevel. In de mythe omdat het een verschrikkelijke gedachte was dat de gewraakte politiek, het verderfelijke beleid bet werk zou zijn van de koning zelf; niemand hebbe de euvele moed bém te beschuldigen! Laat nooit een minister volhouden dat de misdadige maatregelen hem door de vorst waren opgedragen. Nu mogen ministers zich niet op de koning beroepen omdat het demokratische proces dan verstoord raakt. De koning benoemt en ontslaat de ministers, maar bij wordt geacht dat te doen naar de inspraak van het volk. In de mythe, omdat parlementaire ministers tenminste juiste besluiten zouden nemen en de koning niet bedriegen. In het staatsrecht, omdat de demokratie het vereist.

Terwijl de twee, mythe van de goede koning en staatsrechtelijk beginsel van onschendbaarheid en ministeriële verantwoordelijkheid, elkaar precies dekken, blijkt daarenboven uit historische stukken dat ze op beslissende momenten samengaan. Er is geen ontkomen aan: Tussen mythe en staatsrecht bestaat een onderling verband. Maar welk? Niet zodanig dat de een geheel in de ander oplost. Ondanks hun stellige gelijkenis worden de twee ook gescheiden door een wereld van verschil; anders had iedereen de gelijkenis wel opgemerkt. De verwijzingen, zover ik kon nagaan, zijn evenwel schaars en vaag. Wat dan brengt mythe en staatsrecht samen, en wat houdt ze uiteen?

De een moet de ander niet opheffen, maar er zijn argumenten voor een zeker overwicht aan de zijde van de mythe. Het verhaal van de goede koning heeft een aanzienlijk grotere verbreiding, historisch en geografisch, dan de staatsrechtelijke onschendbaarheid, die slechts in enkele Westeuropese staten, in een beperkte historische periode voorkomt; het zou dus de meer fundamentele partner kunnen zijn. En artikel 53 van de grondwet van 1848 bevatte, zuiver rechtshistorisch beschouwd, zoals nader onderzoek leerde, niets nieuws; de onschendbaarheid bestond vanouds en de ministeriële verantwoordelijkheid is zeker niet zomaar en louter door dat artikel ingebracht: Grond voor een vermoeden dat ook in 1848 niet zozeer staatsrechtelijke bervorming als wel bet geloof aan de vorst de diepe en blijvende indruk heeft gemaakt.

Een verklaring moet derhalve voldoen aan verscheidene voorwaarden. Het lijkt me dat nogmaals de psychologie uitkomst biedt. We stelden indertijd de vraag of het verhaal vall goede koning en slechte raden hetzij mythe, oprecht geloof, hetzij methode, opzettelijke kunstgreep is geweest. Het bleek dat de twee, aan weerszijden van de bewustzijnsgrens, nevengeschikt konden bestaan. Iets dergelijks geldt hier. De mythe is het diepere, eigen aan de mens, wijd verspreid, onzichtbaar; op sommige plaatsen kwam zij bovengronds als beginsel van staatsrecht, maar het verband werd niet gezien. Zo 
heeft, zou de psychologie zeggen, het onpeilbare vat van het onbewuste een zeker overwicht op de bewuste gedachtenvorming; een invloed die moeilijk te schatten is omdat tussen bewust en onbewust altijd een scherpe scheiding van kracht blijft; beinvloeding onttrekt zich daarom noodzakelijk aan het oog.

Het verband werd niet gezien: Op de voorgaande bladzijden konden slechts enkele getuigen worden aangevoerd die steeds een enkel onderdeel hadden opgemerkt, zoals de geschiedschrijvers Poelhekke, Hill, en stadhouder Willem V, die volstrekt niet uit de voeten kon met het onbewuste, ongrijpbare van de mythische overtuiging zijner aanhangers. En Thorbecke? Zijn uiteenzetting over de onschendbaarheid van de vorst werd al vroeg in dit boek overgenomen: ${ }^{\infty}$

\begin{abstract}
"Laat de onschendbaarheid van den Vorst in de Constitutie der voorouderen onder Philips II met zooveel woorden geschreven zijn. Wat zij deden, bleef volkomen regt. Lang streden zij, niel tegen den Landsheer, maar tegen zijn gouvernement. Eerst toen alle uitzigt was verdwenen om door Philips immer op eene met de wezenlijke eischen des Lands strokende wijs te worden geregeerd, zwoeren zij zijn persoon af."
\end{abstract}

Een handige, ontwijkende formulering; was er destijds volgens Thorbecke onschendbaarheid of niet? En geen woord over het koningsgeloof. De tekst bewijst vooral dat hij het sprookje níet heeft gezien. Wie wel? Hierboven, het citaat over Van Maanen en de Belgische opstandelingen; de schrijver sloeg de spijker feilloos op de kop met zijn waarneming dat zij door hun trouw aan Willem I en hun veroordelen van de minister al instinktief gehoorzaamden aan de bedoeling der ministeriële verantwoordelijkheid. Maar de helderste, verreikendste uitspraak, uniek, vond ik bij de bewonderenswaardige Benjamin Constant, theoretikus van de ministeriële verantwoordelijkheid; een uitspraak die het schrijven van dit boek overbodig had kunnen maken: ${ }^{61}$

\footnotetext{
"Il est assez remarquable qu'un instinct confus ait de tout temps averti les hommes. de cette vérité. Si le roi savait! n'est autre chose que le sentiment précédant la doctrine: mais connme la doctrine n'avait jamais été énonoée, ce sentiment, cet instinct confus ont été la cause d'erreurs. très-dangereuses. De ce qu'on sentait vaguement que le pouvoir royal était par sa nature une autorité neutre, qui, renfermée dans ses limites, n'avait pas de prérogatives nuisibles, on en a conclu qu'il n'y aurait pas d'inconvénient à l'investir de ces prérogatives, et la neutralité a cessé."
}

Wonderbaarlijk genoeg kon deze zelfde Benjamin Constant, hoe scherpzinnig ook, slechts zes bladzijden verder vol overtuiging uitvaren tegen de verschrikkelijke ministers die kwaad doen en dan ook nog met buitensporige brutaliteit hun misdrijf aan de koning toeschrijven; om die kwalijke praktijken eens en voor al uit te bannen moet boognodig worden vastgelegd dat de koning nimmer kwaad doet. De koningsmythe is niet gauw uit het veld geslagen! 


\begin{abstract}
"Que de fois jadis nous avons vu des ministres, ennemis du chef de l'Etat et de la nation, affecter une douleur hypocrite, et se plaindre d'être contraints à exécuter des vexations qu'euxmêmes avaient provoquées! Ils joignaient au crime de faire le mal, le crime presque aussi grand de l'attribuer au pouvoir suprême. ... Pour mettre un terme à ce manége constant des ministres, il faut qu'il soit enfin constaté que le Roi ne peut rien faire qui soit attaquable ou illégal."
\end{abstract}

\title{
$\S 6$.
}

Het is dus gelukt. Ons was de opgave gesteld twee zinspreuken om hun woordelijke gelijkenis ook innerlijk te verbinden: The King can do no wrong en Mussolini ha sempre ragione. Inderdaad komen zij samen in het verhaal van de goede heerser en zijn slechte raadgevers. Beide spreuken kunnen staan voor het onverwoestbaar geloof in de leider, beide spreuken hebben hun vaste tegenhanger in het Si le roi savait! en in het overeenkomstige Wenn der Führer wüsste! Als onze onfeilbare leider eens wist hoe het hier toegaat, hij maakte korte metten.

Andere, afgeleide vragen, die tijdens het boek al steeds werden behandeld, kunnen thans op grond van de mythe vollediger dan ooit worden beantwoord. Waarom heeft koning Willem II in het jaar 1848, onwettig, onnodig en beledigend, zijn ministers niet ingelicht toen hij tot grondwetsherziening had besloten? Omdat de wythe zelfs hem in de ban had; hij gaf voet aan het gerucht dat ministers hem van het volk scheidden. Waarom de brandende wens dat koninklijke onschendbaarheid en ministeriële verantwoordelijkheid grondwetsartikel zouden worden, terwijl ze strikt genomen al golden? Waarom de uitbundige vreugde op bet bericht van Willem's ommezwaai? De koningsmythe; met stijgende spanning had men geloofd dat ministers buiten 's konings medeweten het land verdierven, geklaagd en gehoopt dat de koning eens zou ingrijpen. Onbeschrijfelijke opluchting in die maand maart; eventjes leek de mythe waar, en alles zou beter worden. Hoe konden toenmalige staatslieden wijzen op gevallen van ministeriële verantwoordelijkheid lang voor 1848 ? Hoe konden Belgen beweren dat de regeling lang geleden in hun land al had bestaan? Omdat de mythe van alle tijden is; soms onzichtbaar, soms duikt ze op, en de gevolgen kunnen dan heel goed vergelijkbaar zijn met Nederland in de 19e eeuw. Wat de oorsprong is van het grondwettelijke beginsel der koninklijke onschendbaarheid en ministeriële verantwoordelijkheid? Wie het bedacht heeft? Niemand; het komt voort uit het geloof aan een altijd goede koning, die het kwaad alleen toelaat omdat hij onwetend is van het wanbedrijf zijner ministers. Het staatsrechtelijke beginsel kan, afhankelijk van omstandigheden, overal ontstaan waar de mythe is.

Waarom heeft Thorbecke onschendbaarheid van de persoon des konings en onschendbaarheid van de oppermacht, lees: van de staat verward? We konden eerder al het onderscheid tussen staat en koning vergelijken met andere verdubbelingen, zoals kroon en koning, koningschap en koning. Achter deze tweetallen ontwaarden we de dialektiek van Koning-met-een-grote-K en koning-met-een-kleine-k, de scheidslijntussen onfeilbaar buitenwerelds ideaal en feilbare, aardse sterveling. Nu past ook de tweeling van koning en minister in dit geheel, en is het bovendien mogelijk de oorzaak van de splitsingen onder woorden te brengen.

De innerlijke dwang of, laten we zeggen, de onbewuste wil onfeilbaarbeid op aarde tastbaar, bereikbaar te achten, brengt gelovigen onvermijdelijk in botsing met de gebroken werkelijkheid: De koning valt tegen. $\mathrm{Zij}$ raken in cognitive dissonance. Ogen- 
blikkelijk maakt het denken een onnaspeurlijke sprong: Zeker, we beleven een teleurstelling, maar dat komt door de minister, door de koning-met-een-kleine-k; de Koningmet-een-grote-K zal ons helpen zodra hij ervan hoort. Werkt de gebeimzinnige verwarring van dit nauwelijks waarneembare spel door in de staatsgedachte en de regel van koninklijke onschendbaarheid? Ik meen van wel.

De 19e eeuwse Nederlandse jurist Buys noemde het "de zuivere leer" dat niet de koning maar het koningschap onschendbaar is; het koningschap was in het volksbelang bedoeld en kon er dus niet vanaf wijken. Honderd jaar voor hem, de Engelse jurist Blackstone: The King can do no wrong betekent niet een onfeilbare koning; maar het recht van de kroon is ingesteld om recht te doen, en recht kan nooit onrecht doen. We zijn nu, lijkt me, in staat dezelfde gedachtensprong te herkennen in het volgende citaat. De Nederlandse schrijver ervan, in de $18 \mathrm{e}$ eeuw, deed mee aan de mythe van de goede koning. Hij beweerde in genen dele de stadhouders van wangedrag te beschuldigen, maar waarschuwde tegen hun raadgevers. Het sprak immers vanzelf dat de prinsen van Oranje het goed met Nederland voorhadden, want: ${ }^{62}$

"Zou het Stadhouderschap eenen anderen grondslag hebben dan de welvaart der Republiek, waartoe het ingesteld is?"

Volop reden om de spot van John Allen, ooit over Blackstone uitgestort, weer op te roepen. Welk ambt was ooit ten kwade bedoeld? Zal goede bedoeling goede uitkomst garanderen? Het is alsof de schrijver ergens voelde hoe zwak zijn vertrouwen in de persoon van Oranje gegrond was, en zich daarop snel in veiligheid bracht met zijn verwijzing naar de abstraktie van het stadhouderschap; een noodsprong natuurlijk, een ouredelijk argument dat zijn zaak zeker niet kon redden. Verraadt deze tekst niet hoe het de mythe was die de overstap van koning naar koningschap, van koning naar staat heeft voortgebracht? Mij dunkt, het is bijna onmogelijk mythe en staatsrecht dichter bijeen te brengen.

De mythe van de goede koning en zijn boosaardige raadslieden verklaart ook waarom de ministeriële verantwoordelijkheid haar zichtbare historische loopbaan als een strafrechtelijke verantwoordelijkheid moest beginnen. Niet uit onbeholpenheid van demokratische groentjes, maar omdat de ministers schavuiten waren; raadslieden die hun heer en meester bedrogen, zijn macht inpalmden, en zich zo schuldig maakten aan schending van de koninklijke majesteit. Gevaar bestond dat zij hun gerechte straf zouden ontlopen; daarom grepen parlementariërs in met de impeachment.

Waarom werd in Nederland voor 1848 een heel ander debat inzake de ministeriële verantwoordelijkheid gevoerd, namelijk over de vraag boe ministers straf konden ontvangen voor daden die in opdracht van de vorst waren gepleegd? Juristen en staatslieden vernamen de luide my thische roep om strafrechtelijke ministeriële verantwoordelijkheid, konden die niet doorzien, namen haar over, maar stonden toen voor de taak, omdat ze beseften dat de koning zelf regeerde, haar te rechtvaardigen. Eigenlijk rechtvaardigden zij lyach-justitie. 
Ze bedachten twee oplossingen. Ten eerste, de koning kon het beleid overlaten aan de ministers; hun verantwoordelijkheid vloeide dan voort uit eigen beslissingsbevoegdheid. Laat de ministers regeren, en ontneem de koning zijn macht: Merkwaardigerwijze, precies de verhouding die volgens het geloof in de goede koning reeds bestond, maar dan ten onrechte; precies het woedende verwijt van de gelovigen aan de minister! Ten tweede, ook indien ministers ondergeschikt waren aan een regerende koning, konden ze verantwoordelijk worden gesteld; geen mens mag door een beroep op bevel van hogerhand zich aan persoonlijke verantwoordelijkheid onttrekken. De oplossing van Johan Rudolf Thorbecke: ${ }^{63}$

\footnotetext{
"Het is geene verantwoordelijkheid van een ander, die de minister overneemt. Zij kleeft aan zijn eigen feit, aan de medewerking, waartoe hij zich verbond. "

"Een fiksch man doet voor uitwendigen, onredelijken dwang onder, maar weigert er het werktuig van te zijn."
}

Al komt een bevel van de koning, toch gehoorzaamt de minister uitsluitend in geval hij door vrije overtuiging met het bevel instemt. Het antwoord lijkt ondenkbaar, een vierkante cirkel. Immers, voor het bevel is wezenlijk dat de ander gehoorzaamt, volledig los van eigen opvattingen, enkel omdat het bevel bevel is. Zou hij te rade gaan bij eigen overwegingen, en pas toegeven zodra die met de opdracht stroken, dan handelde hij, goed beschouwd, niet op grond van de opdracht, maar op grond van zijn overwegingen. Het bevel zou niet meer kracht hebben gehad dan een advies. Zo zag ook Blackstone het: ${ }^{64}$

"... and obedience is an empty name, if every individual has a right to decide how far he himself shall obey."

Heeft Thorbecke een bok geschoten? Misschien niet. Al in de inleiding werd de vergelijking getrokken met een heel andere gelegenheid: het proces te Neurenberg, in 1946, tegen de Duitse oorlogsmisdadigers uit de fascistische tijd. Een tijd waarin de mythe van de onfeilbare heerser aantoonbaar voorkwam, en de vraag zou kunnen rijzen waarom toen niet een regel van onschendbaarheid en ministeriële verantwoordelijkheid is ontstaan. Omdat de tijd te kort was, en Hitler's afgang te duidelijk, te vernietigend? Maar tijdens het Neurenbergse proces speelde zich iets af, uiterst interessant, dat sterk gelijkt op de oude monarchale staatsrechtelijke ontwikkeling.

Het proces was de strafrechtelijke reaktie op de misdrijven van een strak hiërarchisch stelsel. De hoogste leider en grootste boosdoener, Adolf Hitler, had zich door zelfmoord aan deze afwikkeling onttrokken; onbereikbaar zoals vroeger de koning juridisch onbereikhaar was. De gevangen leiders van zijn rijk voerden steevast pleidooi dat zij verplicht waren geweest de orders van Hitler, rechtmatig staatshoofd, op te volgen, en per slot van rekening was alles dus zijn schuld: Befehl ist Befehl. Net zo deden vroeger beschuldigde ministers beroep op het bevel van de koning. 
De aanklager voor de Verenigde Staten, Robert Jackson, heeft toen als het ware, zonder het te beseffen, de rol der oude parlementen op zich genomen. Engelse parlementariërs beantwoordden het ministeriële verweer met hun weerwoord dat de ministers door valse informatie de koning tot de verkeerde opdrachten hadden verleid; zij hadden het oor des konings en waren daarom zelf verantwoordelijk. ${ }^{\text {ss }}$ En op 26 juli 1946 wierp Jackson tegen dat de éne hoge leider, ondanks zijn absolute bevelsmacht, afhankelijk is van zijn medewerkers; wat zij hem voorschotelen moet hij als waarheid zien, en zonder hun willige medewerking is zijn bevel krachteloos. ${ }^{6}$

\begin{abstract}
"But let me for a moment turn devil's advocate. I admit that Hitler was the chief villain. But for the defendants to put all blame on him is neither manly nor true. We know that even the head of a State has the same limits to his senses and to the hours of his day as have lesser men. He must rely on others to be his eyes and ears for most that goes on in a great empire. Other legs must run his errands; other hands must execute his plans. ... These men had access to Hitler, and often could control the information that reached him and on which he must base his policy and his orders."
\end{abstract}

Ondergeschikte medewerkers mogen dan ondergeschikt heten, ze zijn evengoed verantwoordelijk. Het was Thorbecke's oplossing om koninklijke onschendbaarheid en ministeriële verantwoordelijkheid te verenigen; het was bijna op de kop af honderd jaar later het antwoord van de geallieerde overwinnaars op de uitvluchten van misdadige medewerkers in een totalitair systeem. Is er in alle verwarring van koningsmythe, onfeilbaarheid en onmachtigheid wellicht toch een belangrijke regel tevoorschijn gekomen? Is met alle kromme stokken toch een rechte slag geslagen?

Of niet? Het is opvallend dat de leer van Thorbecke, die dus ook de leer van Neurenberg 1946 mag beten, ondanks de algemene erkenning die zowel Thorbecke als Neurenberg ten deel viel, kennelijk niet volledig inburgerde; zij wordt in Nederland straffeloos weersproken, en niet door de minsten. In 1948 (inderdaad honderd jaar na 1848) sprak de scheidende sekretaris-generaal van het departement van Buitenlandse Zaken, woorden die een kwart eeuw later nog instemmend werden aangehaald: ${ }^{67}$

\footnotetext{
"De secretaris-generaal is de chauffeur van het voertuig, dat gevormd wordt door de ambtenaren van het Departement. De minister van buitenlandse zaken en de eventuele staatssecretarissen zijn de passagiers, die aangeven naar welke bestemming de auto moel worden gereden en welke route moet worden gevolgd. De bepaling, welke de bestemming is, behoort het prenogaticf van de verantwoordelijke minister te blijven. De chauffeur zal slechts kunnen waarschuwen, dat de gekozen weg niet de kortste of de juiste is en dat wellicht door het volgen van een andere route het doel beter of sneller kan worden bereikt. Als de minister voet bij stuk houdi moet de chauffeur echter aan de bevelen gehoorzamen, zelfs all zou hij op die manier tegen een boom moeten rijden!"
}

65. Roberts 50. 70; vgl. hierbsven. blz. 57 .

66. The trial of German major war criminats by the international military tribunal sitting at Nuremberg Germany. Speeches of the chief prosecutors ... a the close of the case against the individual defendanss, Londen 1946, blz. 30-31.

67. H.N. Boon, Afscheidsaudiëntie. Tien studies over de diplomatieke praktijk, Rotterdam 1976, blz. 124. 
Dat is een eind bij Thorbecke weg. Op welke enorme afstand van hem het politieke debat in Nederland kan staan, wordt nog duidelijker wanneer ministerraad en parlement spreken over de staatsrechtelijke verantwoordelijkheid van ambtenaren. Ongewenst, oordeelde het kabinet op 4 november $1980:{ }^{68}$

\begin{abstract}
"Ongewenst voerts omdat een merkwaardige verhouding zou ontstaan wanneer een aan de minister ondergeschikte amblenaar, die zonder bezwaren zijnerzijds is opgeireden, door het parlement zou worden terechtgewezen. ... Een verantwoordingsplicht zou een ambtenaar een te zelfstandige positie geven ten opzichte van de minister en zou afbreuk doen aan de positie van de minister en de regering. De kans op pressie om ambtenaren ten koste van de minister meer bevoegdheden tc geven, lijkt reëel; toegeven aan een dergelijke druk zou echter tot een, ook volgens ons, onaanvaardbare vergroting van ambtenarenmacht leiden. "
\end{abstract}

Hier zijn wel een paar uitroeptekens op hun plaats. Precies, bijna letterlijk hetzelfde debat als indertijd ten aanzien van koning en minister gevoerd, nu ten aanzien van minister en ambtenlaar. De koning vreesde dat invoering van ministeriële verantwoordelijkheid bem zijn macht zou kosten, maar het volksgeloof antwoordde, dat de koning zijn macht allang aan de arrogante minister had verloren; invoering van verantwoordelijkheid zou de minister juist intomen. En nu: Vrees dat de ministers hun macht over de ambtenaren zouden verliezen indien die zelf verantwoordelijk zouden worden. Hetzelfde argument is ertegen ingebracht, dat geen minister nog kan overzien wat zijn departement zoal verricht; de feitelijke macht ligt daar al. De kennis en het begrip van wat rond 1848 werd gedacht en bedoeld zijn wel ver weggezakt!

Deugde Thorbecke's theorie van bevel en verantwoordelijkheid? Hedendaagse Nederlandse historici vinden van niet; het was in hun ogen maar een papieren konstruktie. ${ }^{6}$ Van tweeën een: Of de ministers zijn gehoorzaam, en dan niet verantwoordelijk, of zij beslissen zelf, en de koning verliest zijn oppermacht. Het zijn twee vragen uit de inleiding van dit boek: Waarom, in de eerste plaats, verloor de koning zijn koninklijke macht; is een verband aanwijsbaar met de mythische roi faineant, die ook door zijn ministers buiten de zaken wordt gehouden? En wat, dit in de tweede plaats, is de waarde van de vreemde poging mensen zowel ondergeschikt als verantwoordelijk, zowel gehoorzaam als vrij te noemen? Twee vragen die blijven prikkelen, ook nu we aan het einde zijn van de vierde versie van het verhaal der koningen, de mythische. Twee vragen op welke al het gevondene, al het geschrevene zich lijkt toe te spitsen. Daarom aan die twee kwesties nog een enkel woord, in hetgeen toch eindelijk het laatste boofdstuk zal moeten worden.

69. Boogman 94; Bornewasser 89 . 
Uitleiding 

Hoofdstuk 8

\section{God als het beeld van de Koning}

The drama's done.

Why then here does any one step forh??

Herman Melville, Moby Dick

Het boek is, eigenlijk, af. En wel om twee redenen, de ene prettig, de andere onprettig. We vingen aan met het "beroemde" artikel 53 van de grondwet van 1848, hebben vervolgens een reeks vragen verzonnen en die, zo goed en kwaad als het ging, beantwoord. Een geslaagde afloop, en dus het juiste moment om een punt te zetten. Dit enerzijds; anderzijds: Na alle oprakelen van gegevens, historisch, filosofisch, psychologisch is artikel 53 volstrekt onduidelijk geworden. Het bleek een waaier van de meest verschillende en zelfs onderling strijdige betekenissen te omvatten, en welke de ware zou mogen heten valt niet uit te maken. En dat terwijl het artikel, hoeksteen van het Nederlandse staatsrecht, naar zeggen "geen enkel misverstand wekt"; de ontdekking is niet mals.

Welke waarde heeft een woord nu werkelijk? We dachten aan een hard teken, een betrouwbare drager van vaste betekenis; maar het letterlijk gelijkluidende woord kan dus in dienst staan van de meest strijdige doelen. Misschien zullen we niet meer voorbij deze ontdekking komen; misschien moet zij het laatste zijn. Niet het scherp omlijnde zwart-op-wit hepaalt de zin van grondwets- en andere teksten, maar vage menselijke bedoeling, die onuitgesproken en desnoods onopgemerkt kan zijn. Een onbekende straatschrijver trok zijn konklusies; in het najaar van 1991 bekladde hij een pijler van de Maastrichtse Kennedy-brug met het neerslachtige besluit:

"I won't use words again. They don't mean what I mean. They don"t say what I said. It's just the crust of a meaning, with realms underneath. ${ }^{\text {* }}$

Ook een reden om een punt te zetten, maar een onprettige. Indien elk leunen op woordbetekenis verraderlijk is, en indien het woord enkel hetekenis beeft door het toevallige gebruik, op dat moment, eenmalig, dan zou daaruit volgen dat mensen elkaar nooit bereiken. Hun woord op zich voldoet niet, het brengt de boodschap niet over; maar welk middel hebben zij tot hun beschikking om het eerdere woord uit te leggen? Geen 
ander dan meer woorden. De redenering loopt dood, en het zou nutteloos zijn nog enig woord aan wat ook te wijden.

De zwartgallige humor der graffiti. En wij? Zo somber hoeven we niet te eindigen! Wij houden ons aan de 20 e eeuwse Oostenrijkse filosoof Ludwig Wittgenstein, die hetzelfde heeft gezegd als de aangehaalde anonieme schrijver, zij het ernstiger, wijsgerig. Het onwrikbare woord, het harde teken waarop we rekenden, is dood; het heeft geen werking. Maar in het dagelijkse gebruik komt het woord tot leven, het werkt en dient doelen. Woorden behouden gerust gebruikswaarde. '

"Jedes Zeichen scheint allein tot. Was gibt ihm Leben? -- Im Gebrauch lebt es. Hat es da den Iebenden Atem in sich? - Oder ist der Gebrauch sein Atem?"

Gebruikswaarde; het woord heeft slechts waarde in en door het gebruik. Het is nutteloos een woord te koesteren, apart te houden als een woord voor altijd; het wordt onmiddellijk onttrokken aan het dagelijkse verkeer, verliest haar werkende kracht, slaat dood. Het woord wint haar waarde uitsluitend door het gebruik; maar in het gebruik is het tevens blootgesteld aan alle risiko's van misbruik en misverstand. Het menselijke woord, om haar bovenmenselijke waarde op een voetstuk geplaatst, heeft daardoor die waarde reeds verloren. Alleen indien het beschikbaar is voor openlijk gebnuik, indien het zich mengt in de wereld waar het niets dan betrekkelijkheid, ontoereikendheid en ronduit gebrekkigheid lijkt te kunnen inbrengen, alleen dan zal kunnen blijken of er in het woord een echte en wie weet blijvende waarde school.

Het geldt voor de grondwetstekst, het geldt voor de omvangrijke tekst die nu achter ons ligt. We kunnen het woord niet afzweren, we kunnen het evenmin voorgoed veilig stellen; het woord leeft bij de gratie der risiko's van dagelijks gebruik. Het is goed dit alles te beseffen, want we moeten met het woord nog even door. Het is gewenst, als het ware na het voltooien van dit boek, een paar draden uit het weefsel ervan samen te binden, opdat geen losse eindjes blijven slingeren. Drie onderwerpen worden straks nog, in achtereenvolgens drie paragrafen besproken: Ten eerste, hoe komt, in het licht van de koningsmythe, de geschiedenis van de politieke vrijheid in Europa eruit te zien? Ten tweede, noopt het vereiste van menselijke vrijheid tot opheffen van de monarchie, of is een vereniging denkbaar? Ten derde, kan een dergelijke vereniging samenhangen met artikel 53 van de grondwet van 1848, en met Thorbecke's interpretatie van dat artikel? Drie onderwerpen, of liever drie hespiegelingen, die net buiten het gepleegde onderzoek staan, er toch rechtstreeks uit voortvloeien, en het te zamen pas goed afronden. Ze staan een eindweegs af van het alledaagse, en eens te meer zal het maar de vraag zijn of woorden werkelijk zin hebben; een boodschap kunnen overdragen.

\section{$\S 1$.}

Het grondwetsartikel-zonder-misverstand verborg een reeks zeer uiteenlopende betekenissen, sommige zelfs vierkant in strijd met elkaar. De tegenstelling tussen de eerste en de vierde, laatste versie van het verhaal der koningen overheerst. Volgens de traditio- 
nele leer van de koninklijke onschendbaarheid zou de Westerse beschaving, autoritair geregeerd, in de greep van bijgeloof en mythen, zich geleidelijk hebben ontwikkeld tot een vrijere staatsvorm, demokratisch, gegrond op de rede. Het Europa van de koningen werd, na de burgerlijke revoluties, het Europa van het liberalisme. Een sluwe kunstgreep, het tweespan onschendbaarheid en ministeriële verantwoordelijkheid, heeft bij ons zoals in Engeland de macht van de koning uitgeschakeld, zijn mythe stevig ingekapseld.

We leerden echter zien dat de mythe niet alleen de mythe van de koning is, maar de mythe van de koning en zijn kwaadaardige raadgever. Een geringe verschuiving, met reusachtige gevolgen. Want wat blijkt? De rede heeft in genen dele de mythe overwonnen en buiten werking gesteld; maar omgekeerd, de mythe heeft moeiteloos de rede aan zich dienstbaar gemaakt. Johan Rudolf Thorbecke, de man van ijzeren discipline en streng logische redeneertrant, de man die zich nooit vergiste ${ }^{2}$, heeft de mythe niet kunnen bedwingen; hij heeft haar (wat een ironie!) ongezien de ereplaats gegeven in zijn trotse prestatie, de grondwet van 1848:

"De Koning is onschendbaar; de ministers zijn verantwoordelijk."

Het is een schoolvoorbeeld van psychologische theorie. Dachten de liberalen door redelijkheid het bijgeloof te verdringen? Ze hebben de mythe van het geloof in God en koning niet doorgrond, haar alleen bestreden, weggeduwd, haar niet erkend en uitgewerkt, maar zoals het heet, verdrongen. En verdringing helpt niet tegen onbewuste behoeften; die zoeken zich een andere uitweg en woekeren gewoon door. Zo komt het dat de ingespannen poging een gezuiverd, helder, rationeel staatsbestel te ontwerpen, geheel onbedoeld en ongemerkt de koningsmythe als wachtwoord heeft meegekregen. Maar wat moeten wij nu verstaan onder politieke vrijheid, en vrijheid in het algemeen? De traditionele, rationele opvatting van de koninklijke onschendbaarheid zegi: strijd tegen God en koning; vrijheid bestaat in afwezigheid van uiterlijk gezag. De mythische interpretatie van de koninklijke ouschendbaarheid, in dit boek de vierde versie van het verhaal der koningen, vordert een ander antwoord. Onvrijheid, zegt de psychologie die deze mythische interpretatie steunt, komt niet van buiten; zij komt voort uit innerlijke faktoren. Angst voor onzekerheid verleidt mensen hun veiligheid elders te zoeken, bij een persoon die zij sterk wanen of bij een abstrakt ideaal. Het resultaat is uiterlijke dwang, maar innerlijke behoefte roept baar op.

Wat is bevrijding, emancipatie? Bewustwording; men dient de eigen behoefte aan zt:kerheid en veiligheid te onderkennen, te erkenuen, en kan haar dan enigermate beteugeten. of liever begeleiden. Emancipatie is ook volwassenwording. En dit vanouds. Vrocger al werd gezegd dat politieke vrijheid en volwassenheid samenhangen, met dien verstande dat men enkel aan uiterlijke vrijheid dacht. Het gezag van de koning, zijn voogdij over het volk zou worden opgeheven, opdat de meerderjarige het leven naar eigen ourdeel kon inrichten. Zo kunnen kinderen tijdens de puberteit uitsluitend zien dat het de ouders zijn die hun ontluikende vrijheid in de weg staan; ooit zullen ze, hopelijk, begrijpen dat ze vooral zichzelf in de weg zaten. 
De innerlijke onvrijheid moet worden aangepakt. Is dat gebeurd? Kunnen we tekenen van een dergelijk proces bespeuren? Bij de burgerlijke, liberale revoluties hoeven we het niet te zoeken. We hebben in het bovenstaande keer op keer gemerkt hoe daar de mythische onschendbaarheid, het geloof bij onderdanen aan de algoedheid van hun vorst, een drijvende kracht kon zijn; ze was door alle woelen heen onverzwakt werkzaam, een diepere stroom boven welke de omwentelingen niet meer dan rimpelingen schijnen. De mythe van de Franse koning keerde na de revolutie terug als de mythe van Napoleon, de Russische mythe van de goede tsaar verplaatste zich in een ommezien, ongemerkt en onveranderd, naar de heersers van de kommunistische revolutie. En Nederland: Indrukwekkende strijd tegen de Spaanse overheersing; de mythe bleef. De snelle opeenvolging van staatkundige veranderingen, allerminst kleinigheden, in de Franse tijd; de mythe bleef.

Heeft ons art. 53 iets bijgedragen aan de innerlijke bevrijding van de mythe? Nee; het is voor de mythe niet meer dan een ongewild voertuig geweest, het bracht haar op papier zonder haar zichtbaar te maken. Het maakte de mythe niet zichtbaar, niet eens voor het koningschap, laat staan haar eigenlijke, psychologische achtergrond, in het algemeen. Integendeel, de traditionele opvatting dat het artikel paste in een strijd tegen tyrannieke vorsten, beeft de mythe juist langer aan het oog onttrokken. De leer dat demokratie afwezigheid van koningen is, afwezigheid van uiterlijke belemmeningen voor de vrijheid, kon op deze manier steviger postvatten.

Waar bleef, in westerse demokratieën, de koningsmythe? Ik weet het niet. Sekteleiders, popsterren en film-acteurs, de verhalen komen vooral uit Amerika, kunnen ook vandaag de dag enorme emotie opwekken, tot volslagen verering toe; zoals vroeger van de koning, wordt ook van hen wel verteld dat ze niet echt dood zijn, maar wachten op een gelegenheid voor bun glorieuze come-back. In 1991 meldde een Amerikaans krantje, het heeft zich, overigens, op sensatie toegelegd, dat de voormalige president John F. Kennedy nog zou leven, bijna dertig jaar nadat hij werd vermoord. Een uitvoerig verslag, verlucht met foto's van een vergrijsde Kennedy. De krant ontving eeu stroom van brieven; negentig procent schreef niet te geloven dat Kennedy nog leeft, maar: "het is wel heel prettig om dat even te denken". ${ }^{3}$ Een opmerkelijke reaktie. De mensen onderkennen het verlangen een geliefde leider levend te wanen, geven er als bet ware even liefkozend aan toe, maar blijven er niet in steken. Dat mag bewustwording heten!

Een Joodse Amerikaan die naar eigen zeggen jarenlang heeft meegedraaid in het moorddadige wereldje van de mafia, waar, goed beschouwd, een nimmer aflatende oorlogstoestand heerst, vernam het nieuws van de aanslag op president Kennedy met een schok. ${ }^{4}$

\footnotetext{
"At first I was in shock. Nobody hits the president. And I was speaking professionally. At least one person has to be invincible, and that should be the president. It disturbs the whole order if you think the president can get rubbed out."
}

3. NRC-Zaverdags biju'vegsel 4 januari 1992, blz. 2

4. Michael Milan, The Squad. The US govemment's secret alliance with organized crime, New York 1989, blz. 220 . 
De Nederlandse vertaling heeft voor invincible: onschendbaar. Het is alsof in dit citaat de juridische en mythische onschendbaarheid samenkomen.

Een medewerker van de Israëlische geheime dienst, eens vurig zionist, later teleurgesteld en Israël ontvlucht, vertelt hoe hij gebreken van de Israëlische maatschappij steevast toeschreef aan lager personeel, terwijl de hoogste gezaghebbers, de klinkende namen, onveranderlijk waarachtig zouden zijn. ${ }^{s}$

\begin{abstract}
"My own idea of Israel as I was growing up was as the land of milk and honey. That any hardships were worth it. I believed it was a country that would do no wrong, would not inflict evil on others, would set an example for all nations to see and to follow. If there was anything wrong financially or politically in the country, I always imagined this was at the lower echelons of government -- with the bureaucrats, who would eventually clean up their act. Basically, I believed there were people guarding our rights, great people like Ben-Gurion, whom I really admired."
\end{abstract}

Het aloude verhaal van de goede maar onwetende vorst en zijn ondeugdelijke, misleidende adviseurs is niet weg. Zelfs in 's werelds meest bekende en machtigste demokratie, op de hoogste posten kan het ontspringen, even duister en even verwarrend als altijd. De Amerikaanse minister van buitenlandse zaken George P. Shultz kreeg in 1986 lucht van geheime onderbandelingen tussen zijn land en Iran; Iran zou zorgen dat Amerikaanse gijzelaars in het Midden-Oosten werden vrijgelaten, en in ruil Amerikaanse wapens ontvangen. Ontoelaatbare koehandel, vond Shultz; en president Ronald Reagan wist het niet! ${ }^{6}$

\footnotetext{
"A political tidal wave, I felt sure, was bearing down on President Reagan and would, in my opinion, destroy his presidency unless the arms-for-hostages dealings were stopped immediately. ... I felt that the president was clearly being deceived and misled by his staff in the White House. I knew that now I must fight for the President by fighting against members of his own staff."
}

Een merkwaardig en ondoorzichtig steekspel volgde. Shultz trachtte hardnekkig Reagan te bereiken, kon hem inderdaad op vergaderingen en onder vier ogen toespreken, maar slaagde er niet in duidelijkheid te verkrijgen. Reagan zei dat Shultz' mededelingen nieuw voor hem waren, later dat hij alles precies wist en dat het wel goed zat, nog weer later werd hij boos op Shultz: "History will never forgive us if we don't do this!" Reagan kon maar niet geloven, zuchtte Shultz, dat er iets mis was met de Iraanse ruil. Shultz heeft gevangen gezeten in de mythe van Reagan's goede wil en onwetendheid; ze beheerst zijn memoires. Als minister van buitenlandse zaken moest hij werken in een sfeer van gevaarlijk avonturisme en panische angst voor de Russen, een sfeer die hij verafschuwde en voortdurend bestreed, en die hij vol overtuiging weet aan de medewerkers van de president. Het is, schrijft de recensent, "een eigenaardig aspect van deze memoires. Ronald Reagan komt in dit boek eigenlijk helemaal niet uit de verf." Shultz

6. George P. Schultz, Turmoil and triumph: my years as Secrezary of State, New York 1993, blz. 263, $267,734,788,792,807,828,829,832 / 833,838$. 
geeft af op mensen rond president Reagan, maar neemt Reagan zelf nadrukkelijk in bescherming, alsof die buiten de gang van zaken stond. Lezers van Shultz' memoires zullen daarentegen meteen begrijpen dat al de dwaasheden van het Amerikaanse beleid met Reagan's medeweten en steun gebeurden. ${ }^{7}$

\footnotetext{
"Hoewel Shultz dat een enkele maal wel wil toegeven, is zijn analyse er over het algemeen toch op gericht Reagan buiten schot te houden. De president wilde het goede, namelijk hetzelfde als Shultz, en dat dat er niet van kwam was het gevolg van het feit dat zijn staf hem misleidde, manipuleerde en voorloog. ... Omdat hij nauwelijks kan toegeven dat zijn baas in veel gevallen de opdrachtgever van zijn bureaucratische vijanden was, is Shultz wel gedwongen de president af te schilderen als cen half demente bejaarde, die een groot deel van de tijd geen flauw idee had wat er aan de hand was."
}

Waar bleef de mythe van de goede koning? Er is nog een antwoord mogelijk. Het geloof aan de koning, zagen we, is ten diepste geloof aan een idee, aan een abstraktie; de Koning-met-een-grote-K. Met behulp van een beetje theorie en bovendien enige historische stukken viel aannemelijk te maken dat de moderne staatsgedachte erfopvolger van deze mythische en ideële Koning werd. Is de staat enkel een nieuw en ander woord, een moderne en verkapte variant voor de vroegere goede heerser? Enkele treffende overeenkomsten tussen het beeld van de koning, zoals we het hier leerden zien, en bet begrip van de moderne staat, zijn aanwijsbaar.

We spreken van demokratische rechtsstaat: Het volk regeert, en het regeert naar recht. Een tweeẻenheid waarin we zonder mankeren de tweespalt van het oude koningschap herkennen, de moeizame betrekking tussen gezag en kennis, tussen formele en materiële onfeilbaarheid. Wie garandeert dat het hoogste gezag altijd recht zal doen? Niets en niemand. Net als vroeger weet het recht geen andere oplossing dan geloof alleen; "het democratisch bijgeloof, dat wet is volkswil en volkswil is recht". Geen andere oplossing dan enkel hoop; hoop dat de goede inborst der volksvertegenwoordigers hen zal aanzetten vrijwillig het recht in acht te nemen. Oud: ${ }^{8}$

"Een werkelijke oplossing is dit nict. ... Maar wettelijk is de beperking, die deze macht zichzelf oplegt, van haar eigen goedvinden athankelijk. "

Demokratische rechtsstaat: De term heeft in het maatschappelijk protest een heel andere, een veel zwaardere lading dan in de onbewogen geschriften van de staatsrechtgeleerden. De felle verontwaardiging dat zoiets in een demokratische rechtsstaat niet mag voorkomen, heeft minder te maken met kennis van de geldende wetten, dan wel met het oude beroep op de koning: Ik vind dit dermate onrechtvaardig dat het beslist niet kan stroken met het uiteindelijke beginsel van onze samenleving. Of anderszins: Het voortdurende beroep op de demokratische rechtsstaat, die dan opeens, niet voor niets, verzorgingstaat heet, kon best 's die oeroude wroetende wens verhullen, dat er ten allen tijde iets of iemand zal zijn die elk probleem weet op te lossen en die in staat is alle nood te lenigen. 
Aardig is hoe oude volkssprookjes over de koning herkenbaar terugkeren als beginselen van staat en staatsrecht. Het volk vertelde dat de vorst overal door het land zwierf om zijn goede en slechte onderdanen te leren kennen; dat de vorst zonder rust, dag en nacht zwoegde om de welvaart van het land te verzekeren; dat de vorst niet gestorven was, maar leefde. Zo moeten wij nu geloven dat het staatsgezag overal in denl lande geldt, elke lacune vult, ons dag en nacht overkoepelt, zonder ooit te verdwijnen of in te storten. Een rivier, zei Willem Bentinck, die voortdurend en altijd stroomt. De konstitutionele monarch verbeeldt deze juridische werkelijkheid, schrijven de staatsrechtgelterden. Blackstone noemt het een beginsel van Engels recht dat de koning nooit sterft, en dat hij, in zijn gerechtshoven, alom tegenwoordig is. Bovendien: ${ }^{y}$

"... the law intends that the king is always busied for the public good ..."

Ook Buys vermeldde "het beginsel dat het koninklijk gezag nimmer kan slapen". ${ }^{10} \mathrm{De}$ mythe van de goede koning is dichter bij ons dan je zou denken. We horen in de verte weer de kinderstemmen:

Kinderen slaap maar zacht

Juliana houdt de wacht

Maar dit wisten we! Hebben we in vele bladzijden noeste arbeid, van schrijver én lezers, geen stap vooruit gezet? We wisten toch van den beginne dat de mythe van het gezag nog altijd leeft en vele aanhangers heeft, kinderen, ouden van dagen, eenvoudigen van geest. Mensen die de ingewikkelde verhoudingen van bet staatsbestel niet begrijpen, aangepaste informatie behoeven, een overzichtelijk en aardig schouwspel; om hen is bet dat Nederland, waar het verder keurig demokratisch toegaat, een ouderwetse koningin heeft, gelukkig zonder macht. Maar het doel van de geschiedenis blijft, onaantastbaar. dat de afhankelijkheid zal worden opgeheven, de mythe ontmaskerd; toenemen van emancipatie, vervolmaking van vrijheid.

\section{$\$ 2$.}

Een onderzoek gewijd aan het politiek bedrijf hoort wellicht te eindigen met een beleidsaanbeveling. Welke dat zou moeten zijn, valt niet moeilijk te bedenken: Weg met de monarchie. En wel omdat vrijheid het wezen is van de mens. Alleen als vrije kan de mens op haar of ziju gedrag worden aangesproken; alleen als vrije kan de mens verantwoordelijkheid dragen; alleen als vrije kan de mens beantwoorden aan de menselijke waardigheid. Vrijheid: Omstandigheden buiten de mensen mogen hun handelen niet bepalen; het moet gegrond zijn op eigen oordeel, opbloeien uit innerlijke keuze.

Alles zit vast op het onderscheid tussen innerlijk en uiterlijk. De vrije mens, het indivi$\mathrm{du}$, om werkelijk ten diepste individu te heten, moet in zich een beginsel van volstrekte uniciteit hebben, los van al het andere, absoluut. Slechts wanneer de grond van zijn 
bestaan volkomen zelfstandig is, alleen maar innerlijk, van niets anders ter wereld, dus van niets uiterlijks afhankelijk, slechts dan mag de mens zeggen individu, vrij te zijn. De vrije mens is, in wijsgerige termen, subjekt: degene die oordeelt, subjektief, voor zichzelf, en leeft naar dat oordeel; datgene waarover wordt geoordeeld, het onderwerp van het oordeel, is objekt.

Monarchie en individuele vrijheid zijn water en vuur. De juridisch onschendbare koning, sluitsteen van de maatschappelijke orde, oordeelt allen en wordt zelf niet geoordeeld. Hij zou dan, wijsgerig gesproken, het subjekt bij uitstek zijn, maar ten koste van de subjektiviteit der onderdanen: zij verworden onder het exclusieve koninklijke oordeel tot objekten, willoze dingen. " De onfeilbare koning stelt een algemeen geldende wet, objektieve regel; zij laat de mensen geen keuze en doodt daarom hun vrijheid, hun wezenlijke subjektiviteit. De mythische onschendbare koning betekent ontkennen van eigen subjektiviteit; de gelovige onderdaan weigert de vrijheid, verlangt de veiligheid van onpersoonlijke maatstaven en bindt zich derhalve aan een medemens, wanende dat die objektiviteit heeft.

Weg met de monarchie! De geschiedenis bewijst toch onomstotelijk dat zij geen aardse werkelijkheid kan zijn? De mensen verhieven een vorst boven allen, opdat bij elke twist zou kunnen smoren; maar de eis van zijn totale onoverwinnelijkheid dwong hen zijn macht nooit meer op de proef te stellen. Hij werd buiten de twisten gehouden, een staatkundige nul. De mensen verlangden dat de vorst altijd gelijk beeft; en dus vermeed hij voortaan iedere aanraking met dagelijks bedrijf, want nergens anders dan aan de wal staan stuurlieden die nimmer falen. De mensen droomden zich een koning van onwankelbare en onvergankelijke goedheid; hun droom maakte hem tot een machteloze, die niet beseft hoe ministers het land besturen buiten hem om. ${ }^{12}$

Een van beiden moet wijken, de koning of de vrijheid, en reeds lang stond de uitslag vast. Onmacht is het noodlot van de koning; want vrijheid is het noodlot van de mens. Het lot: De mens is veroordeeld vrij te zijn, werd door de Franse filosoof Jean Paul Sartre geschreven. ${ }^{13}$ Noch waarheid noch vaste norm bestaat om de zekere weg te wijzen, niets dat zich weet te onttrekken aan de invreting van twijfel. De mens moet wel zelf kiezen. Ongeoorloofd dat een gezag zich zou verheffen boven bet bewegen van de vrije en gelijke mensen. Uitoefening van gezag kan nooit anders dan willekeur zijn; de enig denkbare rechtvaardiging van een dergelijke ingreep, namelijk beroep op waarheid en bogere norm, is voor altijd uitgesloten.

De mythe van de Koning-met-een-grote-K moet vooral worden afgewezen; zij is bet geloof, tegen de onontkoombare onzekerheid in, dat desondanks anderen voor ons of wij namens een ander het goede doen. Het is een beroep op eigen oprechtheid, dat Sartre de mensen streng verbiedt. Zij moesten immers beter weten! Wie oprechtheid en

11. Uiterst merkwaardig is de levensloop van de regel "oordelen en door niemand worden geoordeeld". leder lid in de gemeenschap van geèmancipeerde gelovigen oordeelt zonder te worden geoordecld, schreef de apostel Paulus, I Kor. 2:15; de toepassing van het woord vernauwde zich echter geleidelijk tot uitsluitend het hoofd van de gemeenschap. Zie Koeniger $2730 f$.

12. Hierboven, blz. 91-92, 132, 199, 221, 234.

13. Deze en de volgende verwijzingen naar Sartre uit Willem Luijpen, Inleiding tot de existentiele fenomenologie, (oorspr. 1969) Utrecht/Antwerpen 1980, blz. 211, 247, 371, 387. 
ernstig streven inroept om zich te rechtvaardigen, beseft in zijn hart heel wel de eeuwige voosheid van de poging, een uitvlucht om de willekeur van het eigen handelen niet onder ogen te zien. Diegene maakt zich schuldig aan valsheid, kwade trouw; een lafaard, zei Sartre hardvochtig, die zijn onontkoombare vrijheid verbergt, haar niet durft erkennen, en daarom buiten zichzelf verwijst: De Koning, God, de Geschiedenis, de Waarheid-met-een-grote-W zal mij in het gelijk stellen.

Alsof, vult een ander aan, het geloof in eigen oprechtheid de mensen niet juist tot groter misdaden verleidt: ${ }^{14}$

\footnotetext{
"Everyone unfortunate enough to have experience of oppression knows that it is better to fall into the hands of a wicked man who understands that he is wicked than into the hands of one who conceives himself to be serving a Higher Purpose. The merely wicked oppressor, be his motive cruelty, greed or the lust for power, may one day tire of his wickedness and tum to better ways. But the oppressor who thinks of himself as serving God, or History, or the Party, will never reform because his impulses of human decency appear to him as temptations to be resisted."
}

Waarheid onbestaanbaar, gezag dwingelandij, geloof oneerlijk. Wat blijft over? Gemeenschap? Mensen kunnen toch samenleven? Maar nee; het beginsel van absolute vrijheid, dat is, absolute individualiteit, sluit omgang tussen mensen uit. De kern van persoonlijke individualiteit moet onmededeelbaar zijn; kon zij aan anderen worden medegedeeld, dan ware er een grond van verstandhouding, een gemeenschappelijk beginsel, alleen al een gemeenschappelijk verstaan van de taal waarin de boodschap wordt overgedragen, dat dieper ligt dan de individualiteit. Is het individu geroepen, ja principieel verplicht tot het uiterste de eigenheid te verwezenlijken, dan is hij genoodzaakt zich steeds meer onverstaanbaar te maken. Vrije individualiteit en gemeenschap zijn omgekeerd evenredig; terwijl de eerste toeneemt, neemt de tweede af.

Sartre heeft uit deze redenering scbrikbarende gevolgen opgemaakt. De vrije mens kan geen tweede vrije mens naast zich velen. De auder, enkel door zijn pretentie mens te zijn, subjekt als ik, stelt mij een grens en verbiedt me die te overschrijden: zijn individualiteit. Een sta-in-de-weg, onafhankelijk van mijn vrije wil, voor het verwezenlijken van eigen doelstelling. Die ander heeft de baan, de auto, het huis dat ik zou willen hebben; dat ik zou moeten kúnnen hebben, ware ik werkelijk vrij. Iedere medemens, louter door er te zijn, bezet ruimte die dan mij niet meer ter beschikking staat, zodat mijn vrijheid onvolkomen is.

De ander, enkel door met mij te zijn, stelt me een wet, zijn wet; een mij uiterlijke norm. Het vrij gevormde oordeel van enig subjekt, voor hem innerlijk en eigen, is voor elk tweede, derde, vierde subjekt niet meer dan een norm van buiten; andermans persoonlijke en dus willekeurige norm, die daarom hun menselijke waardigheid aantast, hen verlaagt tot objekten, dode dingen. Er is geen ontkomen aan! Vrijheid moet eenzaamheid zijn, zoals gemeenschap noodzakelijk onvrijheid is. Sartre besloot: "L'enfer c'est les Autres." 
De idee vau de vrijheid, geheel doorgedacht, de Vrijheid-met-een-grote-V, leidt onherroepelijk tot willekeur, eenzaamheid, burgeroorlog. Ieder voor zich en allen tegen allen. Weg met de monarchie? Het wil me niet uit de pen. Wij kunnen het in de burgeroorlog die hieruit volgt, de sterksten en de slimsten bezetten alle plaatsen, niet uithouden; het moet toch mogelijk zijn een beginsel te stellen zodat ieders recht op eigen en voldoende. leefruimte vaststaat. Moeten we berusten in een wereld vol oorlog, honger, vervuiling, misdaad, marteling, om de eenvoudige reden dat we geen norm kunnen aanwijzen volgens welke de uitbuiter kan worden veroordeeld? Moeten we de burgeroorlog eenvoudig op haar beloop laten, hopend op een snel einde, zodat we weer rust hebben? Moge de sterkste winnen, en spoedig!

We kunnen het niet laten, we zien overal verhoudingen die onloochenbaar verkeerd zijn, schreeuwend onrecht, we móeten ingrijpen! Maar met welk recht? We willen slechts werken en ingrijpen op grond van een hogere waarheid, we willen niet zomaar opgaan in de burgeroorlog, we willen zo niet recht doen dan toch oprecht zijn. Maar de verhoopte norm bestaat niet en geen mens mag zich het recht toeëigenen namens haar te spreken. Een ernstige gespletenheid, die vaker in dit boek tevoorschijn kwam: Waarbeid is onmogelijk maar onmisbaar. En de gespletenheid, deze tegenstrijdigheid loopt vanzelf over in een tweede: Gezag, een plaats waar de knoop wordt doorgehakt, is onnogelijk en onmisbaar.

Kon de Koning maar altijd weten! Konden gezag en kennis maar altijd samenvallen en altijd samen gelden! Ze kunnen het niet, om de feilbaarheid, om de vrijheid van de mens. Feilbaarheid is de werkelijkheid, menselijke vrijheid een eis. Toch blijft er een hang naar waarheid, naar normen, en naar een gezag dat zich met degelijke kennis in dienst stelt van die normen, ten goede van allen. Of waarheid, of vrijheid? Of gezag, of vrijheid? Het is een tastend zoeken naar evenwicht, evenwicht tussen gezag en vrijheid, tegenstrijdig en toch beide nodig. Het thema van gezag en vrijheid, in hun haatliefde verhouding, keert dan ook in de geschiedenis van het westerse politieke denken telkens terug. Laat hier de $18 \mathrm{e}$ eeuwse staatsman en grondlegger van het konservatisme in de politiek, Edmund Burke, het mogen zeggen: ${ }^{\text {15 }}$

\footnotetext{
"To make a government requires no great prudence. Seltle the scat of power; teach obedience: and the work is done. To give freedom is still more easy. It is not necessary to guide; it only requires to let go the rein. But to form a free govemment; that is, to temper together these opposite elements of liberty and restraint in one consistent work, requires much thought, deep reflection, a sagacious, powerful, and combining mind."
}

Weg met de monarchie? De gevolgtrekkingen verleiden ons tot dwaasheid. Moeten we nu echt geloven dat er geen mens is dan de enkele mens? Moeten we voor zoete koek slikken dat niemand ooit de ander kan bereiken? Wie het daarbij wil laten, miskent een onontkoombaar gegeven in het menselijke aanzijn, even fundamenteel als de persoonlijke vrijheid: dat de mens kind is. Absoluut individu? Jawel; maar wie was hij eer zijn ouders samenkwamen? In de belangrijkste beslissing van alle, of hij wel individu wilde 
zijn, is hij niet gekend! Dan valt hij in handen van ouders, machteloos en onwetend overgeleverd aan hun gemeenschap, overgeleverd aan hun waarheid, overgeleverd aan de waan dat zij altijd enkel zijn belang beogen en het kunnen bewerkstelligen bovendien. Geen betere samenvatting van al de onmogelijkheid en al de noodzakelijkheid der menselijke relatie, van al de onmogelijkheid en al de noodzakelijkheid van gezag en waarheid, dan de opvoeding waarmee elk menselijk leven begint; de feitelijkheid van het kindschap. De opvoedeling is mens, subjekt in volle rechten, en niemand kan zijn beslissingen voor hem nemen of zijn verantwoordelijkheid uitwissen. Kinderen moeten zichzelf opvoeden! De opvoeder kan, onvermijdelijk, slechts eigen waarden aandienen, waarden die de ander, de pupil dus vreemd en uiterlijk zullen zijn. En dat terwijl de andere mens weerloos is; hij krijgt oneigenlijke waarden opgedrongen. In strijd met alle beginselen; ontoelaatbaar.

Maar opvoeding werkt, zij is overal, en onvervangbaar. Waaron? De opvoeder, meester van de situatie, kan door meerderheid van kennis en overzicht de ander zodanig begeleiden dat niet ieder obstakel onoverkomelijk, iedere verwarring een dwaalweg zal zijn; hij maakt het op die manier de ander juist mogelijk meer zichzelf te worden. Een ondenkbare maar noodzakelijke, een wonderlijke tegenstrijdigheid! Anderen hoeven mij met hun oordeel niet te bedreigen; het kan juist in welwillendheid dienen om mij meer tot mijzelf te brengen. Het is een beeld van alle menselijke omgang. Laat vrijheid, zelfontplooiing, groei het fundamentele gegeven van 's mensen Dusein heten; we danken onze groei immer aan de wisselwerking tussen eigen streven en andermans weerstreven; aan opvoeding.

En het is een beeld van de onschendbare Koning. Weg met de monarchie? Niet met het koningschap. De symbolische waarden van het koningschap, gemeenschap, waarheid, bestaanszekerheid verhinderen mijn vrijheid niet; ze zijn de voorwaarden die me mogelijk maken zelfontplooiing en vrijheid na te streven. Leert de wijsbegeerte of de psychologie dat zekerheid in dit leven onvindbaar is en derhalve niet moet worden gedacht? Waar werkelijk, overeenkomstig de zuivere theorie, elke bestaanszekerheid ontbreekt, daar kunnen mensen zich niet in vrijheid ontplooien; zij leveren strijd om het bestaan. Zijn de waarden van bet koningschap inderdaad afwezig, dan vervalt vrijheid tot burgeroorlog en chaos, recht van de sterkste.

Weg met de monarchie? Niet eens met de koning. Indien een abstraktie, de staat, het koningschap de wet zou stellen, dan ware die wet een dood gedachtending, een ijzeren regel die de onderdanen van hun vrijheid en leven berooft. De wet moet een levende wet zijn. Niemand anders dan een levende mens mag opvoeden; alleen degene die uit eigen ervaring weet wat het is mens te zijn, zal kunnen verstaan hetgeen omgaat in zijn pupil, subjekt als hij. Alleen de opvoeder die zelf leeft kan meeleven met de wendingen van andernans leven, om onverwachte ontwikkeling, voortkomende uit de individualiteit van die ander, telkens opnieuw te toetsen.

Mooie woorden. Is er nu geen vuiltje meer aan de lucht? Neen; integendeel. Het uiteindelijke blijft ongezegd en onzegbaar. Hoe zou de volstrekt tegenstrijdige werkzaamheid van de opvoeder ooit kunnen slagen? Waardoor zal de Koning ooit zijn bestaan 
rechtvaardigen? Het allerlaatste antwoord, onbevredigend en desondanks het laatste, zal moeten luiden: door genade.

\section{$\S 3$.}

De spraak van deze tekst wordt wel erg verheven! Het aantal hoofdletters neemt navewant toe: Koning, Gemeenschap, Waarheid, Geloof, Geschiedenis, Genade. Waar moet dat heen? Naar een volgend en laatste onderwerp, een hoogtepunt van verhevenheid, een grotere hoofdletter nog dan de vorige: God. Het goddelijke, zoals het werd gedacht in de westerse, christelijke traditie, heeft met het koungschap veel gemeen. Dit aspekt kreeg aandacht in het hoofdstuk over de traditionele opvatting der koninklijke onschendbaarheid en ministeriële verantwoordelijkheid: Rationalisering en demokratisering hadden en God èn de koning gedwongen zich terug te trekken uit het dagelijkse leven; ze werden beiden roi fainéant. Het koningschap veranderde in volgende hoofdstukken van perspektief, en het is gemakkelijk de vergelijking ook dan voort te zetten. Zoals de koning groudslag van de sociale, zo is God grondslag van de kosmische orde. Alles hegiut bij hem, alles berust in hem, zonder hem geen samenhang. God stelt de wet. In eeu hechte maatschappelijke orde, doortrokken van koninklijk gezag, moest elk misdrijf worden opgevat als krenking van 's konings eer: crimen laesae maiestatis. In God's wereldorde is iedere misstap, hoe nietig ook, een vertreden van goddelijke majesteit. ${ }^{17}$ Ongeoorloofd is het, onmogelijk dat een schepsel aan God verantwoording zou vragen van ziju beleid; onmogelijk dat een tak het recht van de boom, waarin hij rust, zou betwijfelen. Noch tot de onschendbare koning, noch tot God kan enig onderdaan zeggen: Cur ita facis? Wat doet ge? ${ }^{18}$

God is ab-soluut; legibus solutus. Hij staat boven zijn eigen wetten. Een onduldbare toestand? Een blijvende vernedering van de mens? Willekeur? Geenszins. God is, behalve almachtig, ook de zuiverste belichaming van het goede en alwijze. Hij geeft waardevolle en heilzame wetten, en het gebrek aan verantwoording mag geen bezwaar heten, want God houdt zich vrijwillig aan de wet, zonder dwang; een oude Joodse rabbijnse traditie heeft het zo gezegd, lang voor de Westeuropese monarchale theorie deze oplossing in het midden bracht. God geeft goede wetten en gedraagt zich naar deze wetten; hij kan eenvoudig niet anders, omdat hij zelf het goede is, zelf de wet in persoon, lex animata! ${ }^{19}$

Laat daaron geen mens de goddelijke oppermacht een beknelling van zijn vrijheid noemen; want wie zou wensen in strijd met het goede te handelen? Vrijheid mag niet worden mishruikt on verkeerd te doen; ware vrijheid bestaat in overeenstemming met God's wet: Servire Deo vera libertas. God is het goede; God is waarheid. Maar het kwaad in de wereld dan? Ondanks God's almacht en goedheid gaat er heel wat fout,

16. Zeg ik met de Nederlandse filosoof Willem Luijpen, bladzijde 351-352 van zijn mooic Inleiding ror de existentiele fenomenologie. (oorspr. 1969) Utrecht/Antwerpen 1980.

17. Huizinga 24, 250, 264; Sellert 253.

18. Job 9:12; Daniel 4:35.

19. Moreau 1, 452; Blackstone I, 40; Baker 190; David Daube, Collecled studies in Roman law I (ed. David Cohen en Dieter Simon), Frankfurt am Main 1991, blz. 549-551. 
waarom? Hier duiken de splitsingen van de koningsmythe weer op. Het kwaad zou komen door de invloed van een duivel, van mindere goden, of door het besluit van wat wel "God's raad" heet, in onderscheid van zijn wil: Het kan gebeuren dat God's hogere wijsheid hem verplicht af te zien van handelen waaraan hij volgens zijn natuurlijke goedheid de voorkeur zou geven. ${ }^{20}$

God is een droombeeld van het westerse ordenende denken, gevormd en gevuld niet dezelfde begrippen als de monarchie. Tot zover niets nieuws onder de zon. Maar bezinning op het theologische stelt ons in staat de problematiek van dit boek scherper dan voorheen te formuleren en haar tenslotte, in zekere zin, tot rust te brengen. Het gaat vooral om de twee vragen die uit het vorige hoofdstuk overbleven: Waarom werd de koning telkens weer onherroepelijk machteloos, een onwerkelijke schim? En: Vanwaar de zonderlinge vereniging van gehoorzaamheid en eigen verantwoordelijkheid?

De twee vragen ontstaan uit het vraagstuk van de verhouding tussen koning en minister; die in het klein de verhouding van koning en onderdaan bleek te zijn, en weerspiegeling van het eeuwenoude vraagstuk van gezag en vrijheid. Het thema van gezag en vrijheid kwam pas in de vorige paragraaf duidelijk aan het licht, maar het heeft heel het boek lang op de achtergrond meegespeeld. We kunnen het vraagstuk van koning en minister, koning en vrijheid hier met andere woorden benoemen als het vraagstuk van God en mens. De problematiek blijkt dezelfde, de behandeling vergelijkbaar.

God heet de koning der koningen; de absolute oorsprong van de wereldorde, het beginsel van kosmische eenheid. En de mensen; een ontelbare, warrelende menigte, met ieder in zich de felle eis erkend te worden als subjekt, als een vrije, dat wil zeggen iemand met een uiterste grond in zichzelf, absoluut, uniek, onmededeelbaar.

Theologie en filosofie vragen zich af of zij God transcendent zullen noemen dan wel immaneut. Bevindt God zich, verbeven, buiten en boven de kosmische orde, als haar wet en haar maat? Dan zou er geen beginsel van zelfstandigheid overblijven voor zijjn nietige schepselen, de mensheid; hoe zouden zij zich onder God's oordeel staande bouden? Of is ieder bestanddeel van de kosmos haar eigen god, schuilt in alles en iedereen een persoonlijke kern van goddelijkheid? Dan konden we de vrijheid der mensen begrijpen, hun recht een eigen weg te gaan; maar indien geen heginsel van eenheid bestaat, geen beginsel dat zich verheft boven de warreling van individueel menselijk bewegen, en daarvan onafhankelijk is, hoe zou er ooit een einde komen aan de voortdurende misverstanden en pijnlijke botsingen, de staat van uitzichtloze burgeroorlog?

Transcendent of immanent, eenheid of verscheidenheid, vrijheid of orde? Het moge onlogisch klinken, een ondenkbaarheid: Ik zou ieder die gedurende het boek heeft meegedacht willen uitnodigen van beide walletjes te eten. De sleutel tot het antwoord (als het die naam mag hebben) schuilt in het beeld van de opvoeding, waamee de vorige paragraaf eindigde. God is het beeld van de Koning, de Ander, de opvoeder bij uitstek. Wel, laat er maar een ander zijn, met een eigen absolute bestaansgrond, een unieke subjektiviteit; waarom zou bij miju subjektiviteit, mijn vrijheid bedreigen? Wij 
kunnen van elkaar leren, want de ander toont mij door de ander te zijn dat ik ik ben. Ik ben pas goed mijzelf wanneer de ander echt anders is. ${ }^{21}$

\begin{abstract}
"Ce que Dieu nous propose essenticllement, ce n'est pas de nous fondre en lui ni les uns dans les autres, comme si l'amour consistait à abolir les personnes et leur diversité. Ce qu'il nous propose, et en vue de quoi il nous a faits, c'est une réciprocité, un rapport où les liberés -- la sienne, la nôtre, celle des autres - bien loin de disparaitre, sont appelćes à s'articuler, à s'harmoniser, à jouer l'une avec l'autre."
\end{abstract}

Zo het spel. Een spel van vrijheid, individualiteit, afwisseling. Dat zich toch niet in algemene aanhang en ijver mag verheugen.' De gevoelige omgang der wederzijdse opvoeding, om de ander meer tot zichzelf te brengen, wordt altijd weer verstoord en zelfs vervangen door een schema van wederzijdse afhankelijkheid en overheersing; om de ander meer tot mij, onder mij te brengen.

\footnotetext{
"Jeu délicat, difficile et toujours menacé: ma pente spontanée, c'est d'essayer d'absorber autrui, de le soumettre, de le plier à mon service, pour rester scul maître du terrain. Par la force, en m'imposant. Ou, plus subtilement, en m'écrasant de manière servile, à défaut d'être le plus fort. Car se rendre indispensable à l'autre, c'est encore, à défaut de mieux, essayer d'avoir barre sur lui. - Ceci à l'égard du prochain. Mais à l'égard de Dieu aussi, nous sommes toujours tentés de le mettre dans notre jeu, pour ne pas avoir à entrer dans le sien."
}

God als de Ander bij uitstek; ook het subjekt bij uitstek. De opvoeder die zijn wet stelt, maar de wet van de vrijlueid, de wet van het subjektieve. En de pupil verstaat het niet. Onvolwassen, in de puberteit, kan bij de wet slechts zien als een heersende en willekeurige norm, hem door een hoogmoedige ander opgelegd. Niet bij machte zich aan de norm te onttrekken, haar spel niet waarderend, reageert hij dubbelzinnig. Enerzijds verlaagt hij de norm tot een uiterlijke leefregel -- wat ze om der wille van zijn menselijke waardigheid perse niet mocht worden! En anderzijds hemelt hij haar hoog op en vergt van zich en iedereen de uiterste nauwlettendheid in het betrachten. ${ }^{22}$

\footnotetext{
"D'une part, nous tendons à ramener la loi à son minimum, dans une observance extérieure seulement, et réticente, celle de la lettre et non de l'esprit. Et d'autre part, nous tendons à majorer, à survaloriser la soumission que nous lui concédons. ... On pourra mềme ajouter des prescriptions à la loi, pour renforcer ce processus de propre justice. Par là même on augmentera la différence de compontement entre ceux qui observent toute la loi et ceux qui en prennent à leur aise. Et les observants seront encore confortés dans leur bonne conscience: cet orgueil raffiné d'être ceux qui plient humblement sous la loi."
}

En dan zien we opeens weer de onschendbare koning voor ons. We beschuldigden hem van overmacht en willekeur; we beschuldigden hem ons te beheersen en ons tot objekt van zijn oordeel te maken. Hij het enige subjekt, wij de onderdanen. Moeten we nu merken dat het andersom is geweest? Het moge kloppen dat de koning zijn volk vernederde tot willoze wezens. Maar de konstitutionele monarchieën hebben, omgekeerd. 
de vorst tot willoos wezen gemaakt, speelbal van de zogenaamde volkswil. Precies de dubbele, tegenstrijdige reaktie van het laatste citaat. De koning werd zeer verheven, onschendbaar, onfeilbaar, een godheid, zeiden ze, die nimmer kwaad, enkel goed doet. ${ }^{23}$ Maar wat is goed? Goed is wat wij goed vinden; dat heeft hij maar te doen. 's Konings subjektiviteit, die symbool en voorwaarde was van de algemeen maatschappelijke erkenning der subjektiviteit, werd beledigend genegeerd.

Oeroude theologische beelden geven dit uitstekend weer. God, staat geschreven, heeft de mens naar zijn beeld geschapen, kinderen, met een beginsel van zijn goddelijkheid. Maar de uitverkorenen verlangen deze vrijheid niet. Wat zij beogen is een god die hun levensvragen beantwoordt; beantwoordt naar hun zin, althans, want het andere, eigenlijke antwoord lusten ze niet. Een god die bun leven veilig laat verglijden; dat wil zeggen, een god die simpelweg hun uitgesproken wensen vervult, zonder overweging of het anders wellicht beter voor ze zou zijn. Kortom, niet de God die hen naar zijn beeld maakte, maar een god die zij naar hun beeld maken. Een god die objekt is, Jood en blind, zonder wil. Koning Willem I, waardig zoon van stadhouder Willem V, zijn scherpzinnige vader, heeft deze kant van de zaak buitengewoon raak getroften toen bij in 1829 uitbarstte: ${ }^{24}$

"On veut me faire roi constitutionnel, semblable à ces dieux des païens qui os haben et non loquunur; qui pedes habent et non ambulant."

Vlijmscherpe bijbelse spot. De heidense afgoden hebben een mond maar spreken niet; ze hebben benen maar verzetten geen stap: Moet ik, de koning! zo'n ledepop worden? Vergelijkbaar is de woede van de Engelse koning Edward VII, op schrift gesteld door admiraal John Fisher, die wel van vuurwerk hield: "No one has got me in their pockets, as some of them think they have!" 25 De mensen doen het vooral met aanzienlijken, maar niet minder met elkaar; de ander opsluiten in het eigen denkraam, om hem zo te bemachtigen, in te lijven als steun en bijdrage voor persoonlijk streven. Tegelijk moet de fiktie van zijn macht en zelfstandigheid zorgvuldig bewaard blijven, want we mogen niet eens zelf doorkrijgen dat geen levende ander, maar slechts een machteloze verbeelding onze toeverlaat is.

Door de gedachtengang belanden we nogmaals bij een antwoord op de voortdurende vraag naar 's konings machteloosheid. Allerlei antwoorden, tijdens het verloop van ous onderzoek gevonden en bezien, toereikend en minder toereikend, lopen hierop uit. We vonden het zo vanzelfsprekend: Wil je iets, grijp bet dan! Maar willen luebhen, willen vasthouden is juist noodzakelijk kwijt raken. Wie gemeenschap, waarheid, zekerheid voorgoed wil vestigen, een veilig bezit voor eeuwig, heeft ze al verloren. De ander, de Ander bij uitstek, belichaning van die schone waarden, geeft zich slechts in litt ongrijpbare spel van de subjektiviteit, dat ieders vrijheid en individualiteit voortdurend gaande

23. Chateaubriand 270; Van der Straeten II, 40; Emmanuel F.J. van den Gheyn, Verdediging van den regier ler instruitie, bij de voormalige regrbank van eersten aunleg. le Nijmegen. Den Haag 1847, blz. 78. $144,145$.

24. Hierboven, blz. 20; Psalm 115:5-7.

25. Hicrhoven, blz. 94. 
houdt. In tijdelijkheid behoren we ons te bewegen; de tijdelijkheid, die we vrezen om haar onzekerheid, is het enige medium waarin dit spel kan gedijen.

De vraag naar de onmacht van de onschendbare koning; het thans gevonden antwoord schijnt mij het diepste toe, en moet daarom het laatste zijn. Eén vraag resteert. Hoe kon Thorbecke toch proberen de gehoorzame en ondergeschikte minister een persoonlijke verantwoordelijkheid toe te schrijven? Omdat zijn leer spoedig uit het Nederlandse staatsrecht verdween, en thans wordt afgedaan als een "papieren constructie", schijnt de vraag naar de oorsprong ervan onbelangrijk, geschiedkundig, interessant voor specialisten. Was het wel meer dan een politieke nevel, opzettelijk verbullend, een poging de vorst gerust te stellen, alsof diens macht niet zou worden aangetast?

Maar Thorbecke heeft de theorie nimmer vaarwel gezegd; tegen het jaar 1870, toen volgens latere leringen het parlementaire overwicht voorgoed was gevestigd, en de koning bedwongen, tekende hij nog aan: ${ }^{26}$

"Le roi règne et ne gouverne pas is geen juist woord. De koning bestuurt en regeert wel degelijk, maar in samenwerking met zijn ministers, die verantwoordelijk zijn."

De overeenkomst met uitspraken van het Neurenbergse Hof in 1946 mag ten overvloede aannemelijk maken dat Thorbecke's theorie meer is geweest dan wereldvreemd verzinsel vall en kamergeleerde. Kunnen we dan in zijn staatsrecht van koning en minister een diepere zin ontdekken?

De theologie, hier aangestipt, met haar bijzondere leer van de verhouding tussen God en mens, mag nog eens dienst doen. God als de ander tegenover mij; de ander met overwicht zelfs, die opvoedt, leiding geeft en toch de vrijheid van zijn pupil niet aantast omdat hij die juist wenst te ontwikkelen. Het beeld kan worden uitgebreid tot een omvattende geschiedbeschouwing; de wereldgeschiedenis een gedurige wisselwerking tussen God en mens, een doorgaande groei en opvoeding, zodat God's wet zich gaandeweg meer ontvouwt en meer eigen wordt aan de mens. Opvoeding de zin van bet mensenleven; opvoeding de zin van de mensheidsgeschiedenis.

Een dergelijke geschiedvisie bestaat. ${ }^{27} \mathrm{Zij}$ heeft, bemerkte ik zo'n beetje toevallig, een herkenbare vertegenwoordiger in het $19 \mathrm{e}$ eeuwse Nederland: Jeronimo de Bosch Kemper, de liberale staatsrechtgeleerde, journalist, historikus, socioloog. In 1860 vatte hij de boodschap van zijn standaardwerk De wetenschap der zamenleving als volgt samen: ${ }^{28}$

26. F.L. van Holthoon, "De genese van Thorbeckes organische staatsleer", in Bijdragen en mededelingen betreffende de geschiedenis der Nederlanden 101 (1986), blz. 190.

27. Eigenlijk alleen bij Russische filosofen, en met name bij de eminente $19 e$ eeuwse wijsgeer Vladimir Sergejevitsj Solovjov, volgens Nikolaj Berdjajev, Het Russische denken in de 19 e en 20 eerw. Aspecten en perspectieven, Amsterdam 1947, blz. 151, 153; hoewel Berdjajev geloof verdient, lijkt hij t(x-h in dit geval grote figuren uit de westerse wijsbegeerte, vooral Hegel, te miskennen.

28. Jeronimo de Bosch Kemper, De wetenschap der zamenleving, 2 dln. Amsterdam 1860-1863; deel I, 697 en deel II, 795. 
"De geheele geschiedenis der wereld is een doorgaand bewijs, dat de menschen, naar mate zij meer Gods wetten kennen en meer Zijn wil uit zelfstandige overtuiging trachten te volbrengen, meer zelfbewuste medearbeiders in Gods schepping worden. "

Zelfbewuste medearbeiders, schreef De Bosch Kemper. Wie zich laat leiden door de wetten van de scheppende God is daarom nog geen automaat; hij is kind, opvoedeling, en toename in keonis van God's wet is toename in bewust, vrij en verantwoordelijk leven. De tegenstrijdigheid, als steeds.

En niet slechts De Bosch Kemper. Johan Rudolf Thorbecke was meer dan jurist en grondwetschrijver; hij had een open oog voor godsdienstige en wijsgerige vraagstukken, onderzocht de stelsels die in zijn tijd opgang maakten. en trachtte hun betekenis voor de toenmalige politieke en maatschappelijke ontwikkeling te peilen. Als twintiger, op studiereis in Duitsland, sloot hij innige vriendschap met de Duitse filosoof Karl Christian Friedrich Krause. Krause, die een prettig mens moet zijn geweest, opgewekt onder zware tegenslagen, is in de geschiedenis van de wijsbegeerte obscuur, wellicht een zonderling. Maar hij heeft evengoed de naam gegeven aan een wijsgerig-theologisch stelsel dat én de transcendentie én de immanentie van het goddelijke samenhoudt: het "panentheïsme". Een Nederlandse volgeling sprak hem na: ${ }^{29}$

\begin{abstract}
"Sommigen scheiden God en de wereld, anderen beschouwen beide als één. De ecrsten missen de kennis der alomtegenwoordigheid, de laatsten die der persoonlijkheid Gods. In de wijsbegeerte van Krause daarentegen leeren wij inzien, dat God als Opperwezen boven en buiten de wereld staat, maar dat tevens de wereld in God als één, zelfstandig, geheel wezen moet gedacht worden; zoodat beide partijen gedeeltelijk regt hebben, en de fout alleen daarin gelegen is, dat zij een eenzijdig begrip voor het alomvattende houden."
\end{abstract}

En Thorbecke schreef, in 1835, eer hij het strijdperk van de dagelijkse staatkunde betrad: ${ }^{30}$

\footnotetext{
"Ieder levend wezen is, in de Goddelijke ordening, boven den tijd, met eenen, aan hetrclve bijzonder eigen, aanleg geschapen, dien men zijn oorspronkelijk of grondbegrip noemen kan. Het beslaat, in het heelal dier ordening, als één geheel of organisch zamenstel, van begrippen gedacht, zijne bijzondere plaats, als individueel lid. Zijn leven is de zelfontwikkeling van zijnen aanleg onder den vorm des tijds. Deze zelfonrwikkeling is zijne wereldschepping, binnen de grenzen van het hem verleend vermogen, in verband met andere levende wezens. Het wezen lect, om zelfstandig, met vrijheid, op te bouwen wat in hem is."
}

Hoogdravende hersenspinsels? Met deze woorden, voegt een geschiedschrijver toe, heeft Thorbecke het uiteindelijke doel van zijn liberalisme weergegeven. Thorbecke heeft ernaar gestreefd deze wijsgerige zienswijzen door te voeren in zijn staatkundige arbeid. De gevolgtrekking valt ons als een rijpe appel in de hand. Zelfbewuste medearbeiders Gods, zelfstandige en vrije wezens die God's plan vervullen, zelfstandige verantwoordelijke ambtenaren, die een ondergeschikte plaats bekleden en toch in vrijheid naar eigen

29. D. Burger, Het opklimmende deel der wijsbegeene, volgens K.C.F. Krause, vour Nederlanders bewerkt, Rotterdam 1845, blz. 83

30. De Wit 39 
inzicht binnen de orde meewerken: De overeenkonst in klank tussen theologie en staatsrecht kan geen toeval zijn. Het Thorbeckiaanse stelsel van artikel 53 van de grondwet van 1848 heeft diepgaande theologische en wereldhistorische vraagstukken in een notedop samengevat:

"De Koning is onschendhazr; de ministers zijn verantwoordelijk."

God en mens, gezag en vrijheid, koning en onderdaan, koning en minister. We komen er per slot van rekening bij uit dat het artikel, in dit licht, niets oploste, maar alleen de kwestic van eeuwen her weerspiegelt, om niet te zeggen, verstopt. Noch een machteloze koning, noch een machteloze minister lag in de bedoeling; geen van beide zou trouwens een werkelijke uitkomst bieden. We zijn even ver als altijd, met dien verstande dat we blijven steken in wisselwerking, het gevoelige zoeken van een evenwicht tussen eenheid en verscheidenheid. vrijheid en gemeenschap. En nergens zijn we dichter bij het antwoord dan in de relatie, steeds weer oud en steeds weer nieuw, tussen ouders en kinderen.

"Vourwaar zeg ik u: Indien gij u niet verandert, en wordt gelijk de kinderkens, zo zult gij in het koninkrijk der hemelen geenszins ingaan." 


\section{Een woord achteraf}

Wat is het schrijven van een boek als dit? In vergelijking met de oeverloosheid van al hetgeen gebeurde en al hetgeen gebeurt, in vergelijking met de mer à boire van al wat ooit werd gezegd en ooit geschreven, hoe zou dit weinige verwerkte materiaal een onderzoeker in staat stellen met een gerust hart uitspraken te doen? Hoe zal hij weten, zonder bet overblijvende, alles te bezien, of zijn keuze en afbakening niet willekeurig zijn geweest, bezijden de ware verhoudingen? Hij kent niet eens het eigen standpunt, en de invloed ervan op zijn waarnemen!

Het is als stonden wij aan het strand van een onmetelijke zee. Plotseling wilde het mij toeschijuen dat de altoosdurende beweeglijkheid van het oneindige water een samenhang bevatte; golvingen die op elkaar leken, elkaar versterkten, te zamen een duidelijke golfstroom vormden. Wat mooi, dat moeten de anderen weten: Kijk daar 's, gauw dan! Maar hoe wijs je in dat onafzienbare klotsen die ene golf aan? Welke bedoel je, die, daar, of die? Allen wijzen nu, wéderzijds misverstand. Zelf opnieuw kijken. Waar was het toch? Door de wind al een eind verderop, natuurlijk, en vervormd. Waar? Het zoeken begint van voren af aan.

Het was heerlijk deze keer, de voeten in het zand, de haren in de wind; fijn dat we samen waren. Morgen weer?

Oktober 1993 



\section{Literatuurlijst}
A. Onschendbaarheid en ministeriële verantwoordelijkheid

Walter Bagehot,

The English constitution, in The works and life of Walter Bagehot V, Londen 1915, blz. 116-366

A.D. Belinfante en J.L. de Reede,

Beginselen van Nederlands staatsrecht, 1le druk Alphen aan de Rijn 1991

Raoul Berger,

Impeachment: The constitutional problems, Cambridge (Mass.) 1973

Hermann Bischof,

Ministerverantwortlichkeit und Staatsgerichtshöfe in Deutschland, Giessen 1859

William Blackstone,

Commentaries on the laws of England, $4 \mathrm{dln}$.; (oorspr. 1765-1769) reprint

Chicago 1979

J.A. Bornewasser,

"Ministeriële verantwoordelijkheid vór en na 1848", in C. B. Wels (ed.),

Vaderlands verleden in veelvoud. Opstellen over de Nederlandse geschiedenis na

1500, deel II, 2e druk Den Haag 1980, blz. 71-99

Jeronimo de Bosch Kemper,

Handleiding tot de kennis van het Nederlandsche staatsregt en staatsbestuur, 2e druk Amsterdam 1865

Joliannes Bosscha,

Kroon en ministers. Amsterdam 1863 
Henry de Bracton,

De legibus et consuetudinibus angliae, ca. 1215. G.E. Woodbine (ed.), Bracton on the laws and customs of England, 4 dIn.; Cambridge (Mass.) 1968-1977

\section{J.K.I. Buddeus,}

Die Ministerveruntwortlichkeit in constitutionellen Monarchien. Monographie eines alten Geschüftsmannes, Leipzig 1833

Johan Theodoor Buys,

De grondwet. Toelichting en kritiek, 3 dln.; Amhem 1883-1888

Johan Theodoor Buys,

Studiën over staatkunde en staatsrecht, Arnhem 1894

Zechariah Chafee,

Three human rights in the Constitution of 1787, Lawrence 1956

François-René de Chateaubriand,

De la monarchie selon la charte, (oorspr. 1816) in Oeuvres completes XXVI-1, Parijs 1837, blz. 266ff

Benjamin Constant,

Cours de politique constitutionnelle, 3e druk Brussel 1837

A.H. Dodd,

The growth of responsible government from James the First to Victoria, Londen 1956

Hans von Frisch,

Die Verantwortlichkeit der Monarchen und höchsten Magistrate, Berlijn 1904

Samuel R. Gardiner,

The constitutional documents of the Puritan Revolution 1625-1660, 3e druk Oxford 1906

C.A. Godin de Beaufort,

Proeve over de strafrechtelijke verantwoordelijkheid der ministers in de constitutionele monarchie, Utrecht 1873

Friedrich Greve,

Die Ministerverantwortlichkeit im konstitutionellen Staat, unter besonderer Berücksichtigung der Verfahren gegen den Minister von Scheele im Herzogtum Holstein 1855/56, Berlijn 1977

Guillaume Groen van Prinsterer, Bijdrage tot de herziening der grondwet in Nederlandschen zin, Leiden 1840 
Guillaume Groen van Prinsterer, Grondwetherziening en eensgezindheid I, Amsterdam 1849

Guillaume Groen van Prinsterer, Adviezen in de Tweede Kamer der Staten-Generaal, 2 dln.; Utrecht 1856-1857

François P.M. Guizot, Histoire générale de la civilisation en Europe, depuis la chute de l'empire romuin jusqu'à la Révolution française, Brussel 1840

Franz Hauke, Die Lehre von der Ministerverantwortlichkeit. Eine vergleichende Studie zum osterreichischen staatsrechts, Wenen 1880

Georg Wilbelm Friedrich Hegel, Vorlesungen über Rechtsphilosophie 1818-I831, deel IV, ed. Karl-Heinz Ilting, Stuttgart 1974

Georg Wilhelm Friedrich Hegel, Vorlesungen. Ausgewählte Nachschriften und Manuskripte I: Vorlesungen über Naturrecht und Staatswissenschaft Heidelberg 1817/1818, ed. C. Becker e.a., Hamburg 1983

Christopher Hill,

"Political discourse in early seventeenth-century England", in $A$ nation of change and novelty. Radical politics, religion and literature in seventeenth-century England, Londen 1990, blz. 24-55

W.S. Holdsworth, A history of English law, 12 dln. + Reg., Londen 1922-1938

David Hume, The philosophical works III (ed. T.H.Green en T.H.Grose), Londen 1882, reprint Aalen 1964

Oswald de Kerchove de Denterghem, De la responsabilité des ministres dans le droit public belge. Gent-Parijs 1867

Enust H. Kossmann, "Over de koning die geen kwaad kan doen", in Politieke theorie en geschiedenis. Verspreide opstellen en voordrachten, Amsterdam 1987, blz. 117-126

Roelof Kranenburg, Het Nederlands staatsrecht, (oorspr. 1924/1925) Haarlem 1958 
H.G. Lagemans,

De leer der ministeriële verantwoordelijkheid en hare toepassing in het Nederlandsche staatsregt, Leiden 1855

Alexander Frederik de Savornin Lohman,

Onze constitutie, Utrecht 1901

Henc Th.J.F. van Maarseveen,

"Ministeriële verantwoordelijkheid", in Nederlands juristenblad (1965), 495-507

Robert Mohl,

Die Verantwortlichkeit der Minister in Einherrschaften mit Volksvertretung, rechtlich, politisch und geschichtlich entwickelt, Tübingen 1837

Pieter Jacobus Oud,

Het constitutioneel recht van het Koninkrijk der Nederlanden, 2 dln.; $2 \mathrm{e}$ druk Zwolle 1967

Richard Passow,

Das Wesen der Ministerverantwortlichkeit in Deutschland, Tübingen 1904

C.W. van der Pot en A.M. Donner, L. Prakke,

Handboek van het Nederlandse staatsrecht, 12e druk Zwolle 1989

Clayton Roberts,

The growth of responsible government in Stuart England, Cambridge 1966

Herman van Sonsbeeck,

Proeve over de zelfstandigheid en onafhankelijkheid der regterlijke magt, $2 \mathrm{dln}$.; Zwolle 1829

A.A.H. Struycken,

Het staatsrecht van het Koninkrijk der Nederlanden, 2e druk in Veraumelde werken V, Arnhem 1928

Johan Rudolph Thorbecke, Aanteekening op de grondwet, 2 dln.; 2e druk Amsterdam 1841-1843

Johan Rudolph Thorbecke, Parlementaire redevoeringen, 6 dln.; Deventer 1860-1870

Johan Rudolph Thorbecke,

Historische schetsen, 2e druk Den Haag 1872. C.H.E. de Wit (ed.), Thorbecke en de wording van de Nederlandse natie, SUN Nijmegen 1980 
Johan Rudolph Thorbecke,

De onuitgegeven parlementaire redevoeringen, $6 \mathrm{dln}$.; Groningen en Gouda 1900-1910

W. Verkade,

Overzicht der staatkundige denkbeelden van Johan Rudolph Thorbecke (1798-1872), Armhem 1935

J.C. Voorduin,

Geschiedenis en beginselen der grondwet voor het Koningrijk der Nederlanden, volgens de beraadslaging deswege gehouden bij de beide kamers der StatenGeneraal, uit de oorspronkelijke staatsstukken opgemaakt, en aan den Koning opgedragen, Utrecht 1848

H.A. van Wijnen,

Van de macht des konings. Mythe en werkelijkheid van de constitutionele monarchie, Amsterdam 1975

Heinrich Zoepfl,

Grundsaetze des allgemeinen und des constitutionell-monarchischen Staatsrechts, Heidelberg 1841

B. Koningschap en totalitarisme

John Allen,

Inquiry into the rise and growth of the royal prerogative in England, Londen 1849

Paul Avrich,

Russian rebels 1600-1800, 2e druk Londen 1973

William Beik,

Absolutism and society in seventeenth-century France. State power and provincial aristocracy in Languedoc, Cambridge 1985

Ortwin Buchbender en Reinhold Sterz,

Das andere Gesicht des Krieges. Deutsche Feldpostbriefe 1939-1945, München 1982

Peter Burke,

Popular culture in early modern Europe, Londen 1978

Martin Butler,

Theatre and crisis 1632-1642, 2e druk Cambridge 1987 
Literatuurlijst

Alfred Cobban,

Edmund Burke and the revolt against the eighteenth century, (oorspr. 1929) reprint U.S.A. 1978

Robert Conquest,

The great terror. A reassessment, New York 1990

Daniel Field,

Rebels in the name of the tsar, Boston 1976

John Gilissen,

Historische inleiding tot het recht, Antwerpen 1981

Hermann Goering,

Aufbau einer Nation, 2e druk Berlijn 1934

Pierre Goubert,

L'Ancien Régime, 2 dln.; Parijs 1973

W.H. Greenleaf,

Order, empiricism and politics. Two traditions of English political thought

1500-1700, Londen 1964

Jürgen Habermas,

Strukturwandel der Offentlichkeit. Untersuchungen zu einer Kategorie der bürgerlichen Gesellschaft, (oorspr. 1962) Darmstadt 1983

Frederik W. N. Hugenholtz,

Drie boerenopstanden uit de veertiende eeuw. Vlaanderen 1323-1328, Frankrijk

1358, Engeland 1381. Onderzoek naar het opstandig bewustzijn, Haarlem 1949

Johan Huizinga,

Herfstij der Middeleeuwen. Studie over levens-en gedachtenvormen der veertiende en vijftiende eeuw in Frankrijk en de Nederlanden, (oorspr. 1919) 7e druk Haarlem 1950. (De paginering is gelijk aan die in de Veramelde werken.)

James I,

The political works of -, reprinted from the edition of 1616, with an introduction by Charles Howard Mcllwain, Cambridge 1918

Ernst H. Kantorowicz,

The king's two bodies. A study in mediaeval political theology. Princeton 1957

Erast H. Kantorowicz,

Selected studies, New York 1965 
Ryszard Kapuscinski,

De Keizer. Macht en ondergang van Ras Tafari Haile Selassie I, (oorspr. 1978) Amsterdam 1990

Ian Kershaw,

The 'Hitler-myth'. Image and reality in the Third Reich, Oxford 1987

Albert Michael Koeniger,

"Prima sedes a nemine iudicatur", in dez. (ed.), Beiträge zur Geschichte des christlichen Altertums und der Byzantinischen Literatur. Festgabe Albert Ehrhard zum 60. Geburtstag (Bonn 1922) 273-300

Tracy H. Koon,

Believe. Obey. Fight. Political socialization of youth in fascist Italy 1922-1943, Chapel Hill 1985

Jacques Krynen,

"De nostre certaine science... Remarques sur l'absolutisme législatif de la monarchie médiévale française", in André Gouron en Albert Rigaudière (eds.), Renaissance du pouvoir législatif et genèse de l'état, Montpellier 1988, blz. 131-144

Louis XIV,

Oeuvres, $6 \mathrm{dln}$; ; Parijs 1806

Arthur O. Lovejoy, The great chain of being. A study of the history of an idea, (oorspr. 1936)

Cambridge (Mass.) 1982

Louis Marin,

Le portrait du roi, Parijs 1981

Roj A. Medvedev,

Laat de geschiedenis oordelen. Ontstaan en gevolgen van het Stalinisme, Amsterdam 1973

Piero Melograni,

"The cult of the Duce in Mussolini's Italy", in Joumal of contemporary history 11 (1976), 221-237

Charles de Montchal, Mémoires de Mr. de Montchal, archevêque de Toulouse, contenant des particularitez de la vie et du ministère du Cardinal de Richelieu, 2 dln.; Rotterdam 1718

C. Moreau.

Choix de Mazarinades, 2 dln.; Parijs 1853 
David Parker,

The making of French absolutism, reprint Londen 1986

V.J. Scattergood,

Politics and poetry in the fifteenth century, Londen 1971

Wolfgang Sellert,

Studien- und Quellenbuch zur Geschichte der deutschen Strafrechtspflege I,

Aalen 1989

Jacob L. Talmon,

The origins of totalitarian democracy, Londen 1952

Jacob L. Talmon,

Political messianism. The Romantic phase, Londen 1960

Nina Tumarkin,

Lenin lives! The Lenin cult in Soviet Russia, Cambridge (Mass.) 1983

C. Veronica Wedgwood,

Strafford 1593-1641, Londen 1935

C. Veronica Wedgwood,

Poetry and politics under the Stuarts, Cambridge 1960

C. Veronica Wedgwood,

The trial of Charles I, 2e druk Londen 1964

Kurt Wolzendorff,

Staatsrecht und Naturrecht in der Lehre vom Widerstandsrecht des Volkes gegen rechtswidrige Ausübung der Staatsgewalt, Breslau 1916

Francis D. Wormuth,

The royal prerogative 1603-1649. A study in English political and constitutional ideas, New York 1939

Dieter Wyduckel,

Princeps legibus solutus. Eine untersuchung zur frühmodernen Rechts-und Staatslehre, Berlijn 1979

C. Franse Revolutie

The French Revolution and the creation of modern political culture, $3 \mathrm{dln}$.; Pergamon Press Oxford New York etc., 1987-1989 
Keith Michael Baker (ed.),

Volume I: The political culture of the Old Regime

Colin Lucas (ed.),

Volume II: The political culture of the French Revolution

François Furet en Mona Ozouf (eds.),

Volume III: The transformation of political culture 1789-1848

D. Nederlandse geschiedenis

J. Bax,

Prins Maurits in de volksmeening der 16e en 17 e eeuw, Amsterdam 1940

W.H. de Beaufort,

"De hertog van Brunswijk", in Geschiedkundige opstellen, Amsterdam 1893,

blz. $173-230$

J.C. Boogman,

Rondom 1848. De politieke ontwikkeling van Nederland 1840-1858, Bussum 1978

Nicolaas A. Bootsma,

De hertog van Brunswijk 1750-1759, Assen 1962

H.T. Colenbrander (ed.),

Het ontstaan der grondwet, 2 dln.; Den Haag 1908-1909

Rudolf M. Dekker,

Oproeren in Holland gezien door tijdgenoten. Ooggetuigeverslagen van oproeren in de provincie Holland ten tijde van de Republiek (1690-1750), Assen 1979

Rudolf M. Dekker,

Holland in beroering. Oproeren in de 17 e en 18 eeuw, Baarn 1982

J.P. Duyverman,

Uit de geheime dagboeken van Aeneas Mackay, dienaar des konings 1806-1876,

Houten 1987

Frederik Carel Gerretson,

Muiterij en scheuring 1830, 2 dln.; Leiden 1936

Frederik Carel Gerretson,

"Gesprekken met den koning 1826-1839", in Bijdragen en mededelingen van het Historisch Genootschap 57 (1936), 110-226 
P.A.M. Geurts,

De Nederlandse opstand in pamfletten 1566-1584, (oorspr. 1956) Utrecht 1983

Guillaume Groen van Prinsterer (ed.),

Archives ou correspondance inédite de la Maison d'Orange-Nassau, 5 series 23 dln.; voltooid door Th. Bussemaker en F.J.L. Krämer, Leiden 1835-1915

S. Groenveld,

De prins voor Amsterdam. Reacties uit pamfletten op de aanslag van 1650, Bussum 1967

Gijsbert Jan van Hardenbroek,

Gedenk.schriften, 6 dln.; F.J.L. Krämer en A.J. van der Meulen (eds.), Amsterdam 1901-1918

Cornelis Huisman,

Neerlands Israël. Het natiebesef der traditioneel-gereformeerden in de achttiende eelw, Dordrecht 1983

J.A.F. de Jongste,

Onrust caan het Spaarne. Haarlem in de jaren 1747-1751, z.p. 1984

J.Z. Kannegieter,

"Concept-grondwet op last van koning Willem I in het jaar 1832 samengesteld door

E. Canneman, M. Piepers en H. van Royen, met bijbehoorende stukken", in

Bijdragen en mededelingen van het Historisch Genootschap 52 (1931) 21-172

Jan Meyers,

Mussert. Een politiek leven, Amsterdam 1984

D.C. Nijhoff,

De hertog van Brunswijk. Eene bijdrage tot de geschiedenis van Nederland gedurende de jaren 1750-1784, Den Haag 1889

Johanna K. Oudendijk,

"Den coniuck van Hispaengien heb ick altijt gheeert", in Dancwerc. Opstellen aangchoden aan prof. dr. D.Th. Enklaar ter gelegenheid van zijn vijfenzestigste verjuardag, Groningen 1959, blz. 264-278

Jan J. Poelhekke,

Geen blijder maer in tachtigh jaer. Verspreide studien over de crisisperiode 1648-1651, Zutphen 1973 
Joachim Rendorp, Memorien diendende tot opheldering, van het gebeurde, geduurende den laatsten Engelschen oorlog, 2 dln.; Amsterdam 1792

\section{M.J.F. Robijns,}

Radicalen in Nederland (1840-1851), Leiden 1967

D.J. Roorda,

Het rampjaar 1672, Bussum 1971

Herbert H. Rowen,

John de Witt, grand pensionary of Holland, 1625-1672, Princeton 1978

Herbert H. Rowen,

The princes of Orange. The stadholders in the Dutch Republic, Cambridge 1988

C.F. Sirtema van Grovestins (ed.),

Gedenkschriften van den grauf Van der Duyn van Maasdam en van den baron Van der Capellen, Amsterdam 1853

Ferdinand van der Straeten,

De l'état actuel du Royaume des Pays-Bas, et des moyens de l'améliorer, 2 dln.; Brussel 1819

Leendert Christiaan Suttorp,

F.A. van Hall en zijne constitutioneele beginselen, Amsterdam 1932

C.A. Tamse (ed.),

De monarchie in Nederland, Amsterdam/Brussel 1953

Paul van 't Veer, Maar Majesteit! Koning Willem III en zijn tijd. De geheime dagboeken van minister A.W.P. Weitzel, Amsterdam 1969

A.C.J. de Vrankrijker,

De motiveering van onzen opstand. De theorieën van het verzet der Nederlandsche opstandelingen tegen Spanje in de jaren 1.565-1581, Nijmegen 1933

C.W. de Vries,

Het grondwettig koningschap onder koning Willem III I849-1870, Den Haag 1946

H. Wansink,

Politieke wetenschappen aan de Leidse universiteit 1575-1650, Utrecht 1981 


\section{W.J. van Welderen Rengers,}

Schets eener parlementaire geschiedenis van Nederland van 1849 tot 1891, 4e druk met aantekeningen van C.W. de Vries, Den Haag 1948

Abraham de Wicquefort,

Histoire des Provinces-Unis des Pais-Bas, depuis le parfait établissement de cet état par la paix de Munster, 4 dln.; Amsterdan 1861-1874

C.H.E. de Wit, zie Thorbecke, Historische schetsen 


\section{Samenvatting}

Het bijgaande boek behandelt een regel van Nederlands staatsrecht: "De Koning is onschendbaar; de ministers zijn verantwoordelijk". Deze regel in haar schijnbare eenvoud verbergt velerlei diepgaande betekenissen, van juridische, maar ook van historische, psychologische, theologische aard. Het boek is daarom tevens een speurtocht naar de diepere gronden van monarchie, een onderzoek van koning en koningschap. Nieuwe gegevens komen boven water, oude standpunten kunnen worden aangevuld of verbeterd, maar de slotsom moet luiden dat het monarchale, als verbeelding van samenleven, waarheid, mythe, gezag en vrijheid, een blijvend vraagstuk is, raadselachtig, een waagstuk voor altijd.

Het boek begint met De Koning in 1848. De Nederlandse koning Willem II, verschrikt door plotseling uitbarsten, in heel Europa, van revolutionair geweld, liet onder zijn gezag een snelle en ingrijpende grondwetsherziening doorgang vinden. De hernieuwde grondwet van 1848 bevatte onder andere artikel 53: "De Koning is onschendbaar; de ministers zijn verantwoordelijk. " Dit artikel werd algemeen hoger aangeslagen dan de andere; het bleef sedertdieu ongewijzigd en behield de reputatie van een hoeksteen in het bouwwerk der Nederlandse staat.

Wat droeg artikel 53 aan? Het heeft naar heersend oordeel De Koning als machteloze gevestigd. Terwijl de Nederlandse koning voorheen waarlijk regeerde, hoogste gezag, hoogste beslissende instantie, verloor hij thans zijn macht aan de ministers. Het zwaartepunt van macht en beleid kwam te liggen bij de ministers, die krachtens hun ministeriële verantwoordelijkheid openheid van zaken geven aan het parlement, de volksvertegenwoordiging, die het laatste woord heeft.

Maar dan Een inval; en andere problemen. De inval betreft de Engelse tegenhanger van hetgeen in Nederland de "koninklijke onschendbaarheid" heet, het beginsel The King can do no wrong, dat evenzo geldt als uitdrukking van koninklijke onmacht; maar eensklaps springt in het oog dat deze regel sprekend lijkt op een Italiaanse spreuk, Mussolini ha sempre ragione, "Mussolini heeft altijd gelijk", die geenszins onmacht maar, integendeel, ongeremde oppermacht van de hoogste leider aangeeft. Nader onderzoek in de tijd van 1848 leert vervolgens dat toonaangevende staatslieden en juristen, anders dan wordt gedacht, wiet het plan hadden door artikel 53 de koning zijn macht afhandig te maken, maar die veeleer wilden beschermen. De belangrijkste maker van de nieuwe grondwet, Johan Rudolf Thorbecke verdedigde levenslang een stelsel 
volgens hetwelk de koning voluit zou regeren, dus bevelen, en de ministers verantwoordelijk zouden zijn voor bun medewerking.

Deze orièntatie in de materie van de koninklijke onschendbaarheid levert aldus drie vragen op: Ten eerste, wat stelt de gelijkenis tussen de Engelse en de Italiaanse staatsspreuk voor? Ten tweede, waarom verloor de koning zijn hoge regeermacht? Ten derde, wat is de zin van Thorbecke's leer der ministeriële verantwoordelijkheid, waarin ministers. hoewel ondergeschikt aan de vorst en dus verplicht hem te gehoorzamen, toch op hun gedrag worden aangesproken, alsof zij een keuze hadden gehad?

Deze Vragen, en een methode, worden ten grondslag gelegd aan de gang van zaken in het boek. De drie vragen gaan heel het boek lang mee; heel het boek lang wordt voortdurend gezocht naar benodigde antwoorden, volgens een procedure die kennelijk niet rechtlijnig kan zijn. Want het koningschap blijkt een veelzijdig versclijusel, een figuur met vele gezichten. De verscheidenheid wordt in het boek aldus uitgedrukt, dat het verhaal der koningen als het ware meerdere versies heeft; het boek telt er vier. In elke versie luiden de antwoorden op de drie vragen anders, en soms zijn ze onderling in tegenspraak. De eerste en de vierde versie van het verhaal der koningen worden aangeboden als elkdars uiterste tegenvoeter; de eerste heet de traditionele, rationele versie, gesteld tegenover de vierde, mythische versie, die is bedoeld als de eigenlijke bijdrage van het boek. De eerste drie versies zijn samengebracht in drie hoofdstukken over De Koning, een boekdeel, terwijl de behandeling van de vierde versie een eigen boekdeel beslaat, De mythe, dat weer drie hoofdstukken omvat.

In het hoofdstuk De Koning als beeld Gods wordt het traditionele verhaal der Europese koningen verteld. De koning stond voor uiterlijk, opgelegd gezag, dat haar steun had in mythische voorstellingen $(\S 1)$; maar een staatkundige beweging leidde tot de moderne liberale demokratische rechtstaat. Het beginsel van redelijkheid en wetenschap ondergroef de mythe, het uiterlijk gezag der vorsten werd vervangen door een innerlijke grond van gezagsuitoefening, de volkswil (\$2). De ontwikkeling van de regel der koninklijke onschendbaarheid en ministeriële verantwoordelijkheid, in Engeland, waar zij haar oorsprong heeft ( $\$ 3$ ), en in Nederland $(\$ 4)$, past in deze geschiedenis. De koning werd onschendbaar verklaard, boven de politieke werkelijkheid verheven, zijn ministers zouden in naam van het volk beleid voeren. Terwijl het gezag van de koning, zoals van God, verdween, mocht zijn mythe slechts voortleven als onwerkelijkheid, zorgvuldig ingekapseld, zonder invloed op de redelijke gang van zaken ( $\$ 5$ ).

In deze traditionele versie van de geschiedenis der Europese koningen liggen de twee spreukeu The King can do no wrong en Mussolini ha sempre ragione ver uiteen, enig verband is onvoorstelbaar. De koning verloor de macht aan het volk, via de ministers. Thorbecke's stelsel van regerende vorst en verantwoordelijke minister is een vergissing geweest. of een list om de koning te verhullen wat met hem zou gebeuren; het heeft geen verder belang. Of toch? Het stelsel werd ook in het buitenland aangehangen, bij Duitse juristen tot in de 20 e eeuw (\$6).

De Koning als gemeenschap is de koning als hoogste rechter. Zijn definitieve uitspraak, het laatste vonnis, zelf niet meer aantastbaar, voorkomt dat meningsverschillen de menselijke samenleving opbreken; de onschendbare koning is hier, in de tweede versie van het verhaal der koningen, de knoop van alle draden in het weefsel der gemeenschap $(\$ 1)$. Een netelig probleem rijst evenwel: Wie zal verzekeren dat het 
hoogste woord, zelf immers formeel onweersprekelijk, ook naar inhoud rechtvaardig is? Enig onathankelijk oordeel daarover in de samenleving is ontoelaatbaar; het zou onmiddellijk de werking van de onschendbare koning opheffen. Ministeriële verantwoordelijkheid bracht de oplossing: De koning behoudt zijn hoogste macht, hij beslist definitief, maar men spreekt de uitvoerders van zijn wil aan, de ministers; zij hoeven niet onschendbaar te zijn $(\$ 2)$. Onschendbaarheid was niet onmacht maar juist de onweerstaanbare macht van de koning; zij is ook niet in 1848 ingevoerd maar voortgezet. Het verband met de fascistische leuze Mussolini ha sempre ragione wordt in deze versie wat meer begrijpelijk.

Duidelijker wordt ook waarom de ministers verantwoordelijk moesten zijn bij ongeschonden macht van de vorst; de konstruktie diende om de eenheid der samenleving te redden. Maar -waarom verloor de koning dan toch zijn macht? Er daagt iets van een inzicht dat de positie van de onschendbare koning onmogelijk is; een uiterste oordeel, in handen gelegd van een feilbaar mens, al heet-ie koning, mag nooit aan zichzelf worden overgelaten; mag dus nooit uiterste oordeel blijven (\$3). Heeft 1848 deze onschendbaarheid beoogd? Maar die is juist in de modernisering van Europa's staten geheel verdwenen! Het bouwsel der liberale demokratische rechtstaat kent de funktie van de vorst als laatste rechter niet meer ( $\$ 4)$. Dat kon, zonder gevaar van burgeroorlog, door de ontwikkeling van de redelijkheid; de rede nam de plaats van de koning in, zij werd de laatste rechter op wie ieder zich zou verlaten, en zij zorgde dat mensen ondanks ruzies kunnen samenleven ( $\$ 5$ ).

's Konings opgelegd gezag vernietigen? De rechtvaardigheid van 's konings besluiten verzekeren? Dergelijke kwesties konden niet spelen toen men nog De Koning als Gerechtigheid zag. Eertijds werd verkondigd dat de koning recht en waarheid belichaamde; bij was onfeilbaar, zijn hoogste gezag steeds verenigd met ware kennis $(\$ 1)$. Een diepere stroom dan de uiterlijke strijd tegen de koningen wordt zichtbaar; pas het algemeen aanvaarden van de opvatting dat geen mens ter wereld kan beschikken over onfeilbare waarheid, heeft ook het grenzeloze gezag van de koning ondraaglijk gemaakt, en demokratisering is niet zozeer strijd tegen vorsten, als wel strijd, meer algemeen, tegen de hooghartige pretentie van onfeilbaarheid. Abșolute waarheid bestaat niet, en gelukkig maar; want alleen indien absolute waarbeid niet en nergens bestaat, en door geen mens wordt geweten, kunnen alle mensen zich in vrijheid naar eigen inzicht ontplooien ( $(2)$.

Wat betekent, in deze derde versie, de koninklijke onschendbaarheid, of liever, de spreuk The King can do no wrong? Onfeilbaarheid? De juristen pasten evenwel een tweedeling toe: Niet de persoon van de koning, maar het koningschap is onfeilbaar; niet de koning-met-een-kleine-k, maar de Koning-met-een-grote-K (\$3). De splitsing doortrekt de geschiedenis van o.a. het Engelse staatsrecht, en het merkwaardige is dat juist opstandige onderdanen haar aangrepen; zij beriepen zich ter rechtvaardiging van hun strijd tegen de koning op de abstraktie van diens koningschap: Fighting the king to defend the King (\$4). Dan blijkt dat de vroegere politieke bewegingen, die in de traditionele versie anti-monarchaal, demokratisch heetten, via het beroep op de altijd ware Koning-met-een-grote-K, feitelijk de pretentie van onfeilbaarheid hebben voortgezet; de historische lijn van deze bewegingen voert rechtstreeks naar moderne diktatoriale stelsels ( $\$ 5$ ). 
Onfeilbaarheid als pretentie van oude koningen, onfeilbaarheid als pretentie van moderne diktators; de twee spreuken The King can do no wrong en Mussolini ha sempre ragione vallen al bijna samen. Maar die splitsing in de Engelse spreuk? Ze weerspiegelt een oeroud dilemma: Gezag moet onveranderlijk rechtvaardig zijn, maar het wordt altijd door feilbare mensen verwezenlijkt. De splitsing van koning-met-een-kleine-k en Koning-met-een-grote-K volgt rechtsstreeks uit dit dilemma; en deze splitsing schijnt dan opeens precies de splitsing van koning en minister, zoals in het vorige hoofdstuk uiteengezet, te dekken: De koning zou nooit kwaad doen indien de feilbaarheid via de minister wordt aangepakt. Is er een verband? Nog een verband doemt op. In het vorige hoofdstuk werd een inwendige onmogelijkheid van het monarchale ontdekt; en die wordt hier treffend aangevuld door een andere: Net als de formele onaantastbaarheid van het koninklijk vonnis, noodzaakt de onfeilbaarheid van de vorst hem een symbool, een politieke afwezigheid te worden ( $\$$ ).

$\mathrm{Na}$ het deel over De Koning het deel over De mythe; De mythe van de goede Koning. De geschiedenis van de 20e eeuwse diktatoriale stelsels heeft geleerd dat diktatuur niet alleen van boven komt, vanuit de machthebbers. Mussolini legde zijn sempre ragione uiterlijk op, maar onderdanen aanvaardden het bovendien door innerlijke drijfveren, de behoefte aan een sterke man. De moderne psychologie analyseert deze behoefte en voert haar terug op angst voor vrijheid, die onvermijdelijk eenzaamheid en onzekerheid meebrengt $(\$ 1)$. Innerlijke mechanismen veroorzaken daarmee in verband een merkwaardig verschijnsel, te zien onder Mussolini, onder Hitler, onder Lenin en Stalin: Wanneer afkeurenswaardige gebeurtenissen in het land plaatsvinden, en daarom de vraag rijst hoe dat kan, onder het bewind van de onfeilbare en goede heerser, dan wordt de schuld al gauw geschoven op naaste medewerkers, die buiten medeweten van hun chef kwaad stichten; het telkens weerkerende verhaal van de goede heerser en zijn boosaardige medewerkers maakt dat bet vertrouwen op de goede wil van de diktatoriale heerser overeind kan blijven (\$2).

Dit verhaal komt voor onder moderne diktators, het kwam ook voor onder vroegere koningen in Engeland, Frankrijk, Rusland, onder een paus en een Afrikaanse keizer, een steeds herhaald refrein van de goede koning en zijn slechte raadsheren $(\$ 3, \S 4)$. En we vinden bovendien De goede Koning in Nederland. Onder 20e eeuwse diktatuur, in de Middeleeuwen, maar niet minder in de twee eeuwen van het stadhouderschap der Oranjes, hebben Nederlandse burgers gemeend dat hetgeen verkeerd ging in de openbare zaken moest worden toegeschreven aan de invloed van boosaardige adviseurs van de goede vorst $(\$ 1, \S 2, \S 3)$. Een toetsing van het verschijnsel is nodig: Hoe algemeen is het? Is het geloof oprecht, of doorgestoken kaart? De gevolgtrekking lijkt billijk dat het sprookje van de goede koning en zijn boze raadgevers overal kan ontspringen, en dat het geen truc is, maar echt geloof, voortvloeiend uit sterke innerlijke, onbewuste behoefte aan het beeld van een onfeilbare ( $\$ 4)$. Het is een mythische onschendbaarheid. Dan kont De mythe van het goede 1848 openbaar. Het sprookje van goede koning en slechte raadsheer lijkt precies te passen bij het Nederlandse grondwettelijke stelsel van onschendbare koning en verantwoordelijke minister, vrucht van 1848 . Kunnen we de twee overeenbrengen? Inderdaad. De Engelse geschiedenis der ministeriële verantwoordelijkheid is vol van de mythe; het parlement vroeg niet verantwoordelijkheid voor ministers om de koning zijn macht te ontnemen, maar omdat naar heilige overtuiging 
de ministers boeven waren, dienaren die hun vorst bedrogen $(\$ 1)$. De historische teksten laten dikwijls uitstekend zien hoe de mythe en het staatsrechtelijk beginsel verweven waren $(\$ 2)$. In Nederland blijkt hetzelfde, tijdens de stadhouders $(\$ 3)$ en na 1813 , onder de koningen van Oranje. Duidelijk is zichtbaar hoe de mythe uitvloeide in de dringende eis dat het beginsel van koninklijke onschendbaarheid en ministeriële verantwoordelijkheid grondwetsartikel zou worden $(\$ 4)$. Er zijn enkele blijken dat de overeenkomst van mythe en staatsrecht vroeger ook is opgemerkt (\$5).

In deze vierde versie van het verhaal der koningen, de mythische, komen The King can do no wrong en Mussolini ha sempre ragione werkelijk bijeen; beide uitdrukking van het geloof aan een goede heerser wiens weldadige bedoelingen door kwaadaardige medewerkers worden vernietigd. De onmacht van de vorst heeft nogmaals een verdiepte betekenis; het sprookje dat de koning het niet weet beeldt hem vanzelf al af als een politiek afwezige. Het stelsel van de verantwoordelijke dienaar: Onderdanen geloofden dat de minister de bevelen van zijn vorst ontdook, en dát school achter de roep om ministeriële verantwoordelijkheid, straf voor ministers, juist omdat ze ondergeschikt waren. De koele staatsrechtelijke leringen van Thorbecke hebben in dit opzicht gewerkt als goedpraten van de mythische roep om een zondebok $(\$ 6)$.

$\mathrm{Na}$ de vier versies van het verhaal der koningen, na de sterke tegenstelling tussen eerste en vierde, rationele en mythische versie, nog een afrondend hoofdstuk, God als het beeld van de Koning. De Westerse staatsstelsels waren gedemokratiseerd, aldus de eerste versie, door het uitbannen van de koning en zijn mythe. De vierde versie daarentegen toont artikel 53 van de grondwet van 1848 als een overwiuning van het mythische; de redelijkheid heeft het mythische niet bedwongen, niet eens doorzien, maar het juist de ereplaats gegeven als hoeksteen van het bestel. De mythe van de goede heerser en zijn slechte adviseurs speelt nog op als vanouds, zelfs in de hoogste regionen van demokratische staten. Werkelijke demokratisering moet dan worden opgevat als innerlijke bevrijding; zij is zeker nog geen rustige verworvenheid, voorgoed veiliggesteld, van de westerse demokratie ( $\$ 1$ ).

Is, in elk geval, individuele vrijheid toch voor altijd het laatste woord? Moeten gemeenschap, gerechtigheid, geloof, de waarden die de koning verbeeldde, eenvoudig wijken voor de vrijheid? Maar vrijheid zonder de drie waarden van het monarchale is losbandigheid, burgeroorlog, chaos. Het monarchale is wat het in de tekst steeds meer bleek te zijn: Ter wille van de menselijke vrijheid onmogelijk, en tegelijk, ter wille van de menselijke waardigheid, ook noodzakelijk ( $\$ 2)$. De onmacht van de koning werd ten ourechte als demokratie beschouwd; zij komt voort uit misverstand, een ontkennen van de noodzaak van het koninklijke, een misverstand dat de vrijheid tot burgeroorlog maakt, en haar teniet doet.

Het mooist komt de problematiek uit de verf wanneer we niet meer het monarchale maar het goddelijke bezien als de verbeelding van de drie waarden. Meer nog dan de koning symboliseert God gemeenschap, gerechtigheid, geloof. En ook hier het voortdurende en levendige dilemma, dat de Godsidee enerzijds, als symbool van hogere waarden, noodzakelijk is, en anderzijds, een bedreiging van menselijke zelfstandigheid en verantwoordelijkheid, onmogelijk. In deze spanning ontwaren we tenslotte de theologische partner van Thorbecke's staatsrechtelijke ineenvlechten van koninklijke 
bevelsmacht en ministeriële vrijheid en verantwoordelijkheid; Thorbecke zelf heeft deze theologie ook uitdrukkelijk aangehangen.

Vergelijking van het monarchale en het goddelijke voert daarom tot de gevolgtrekking dat eenheid en verscheidenheid, gezag en vrijheid, waarheid en feilbaarheid samenhoren in een noodzakelijke en onmogelijke verwevenheid, coincidentia oppositorum (\$3). 


\section{Summary}

If only the king knew.........!

Of authority and knowledge, inviolability and infallibility, and their histories

This study discusses a rule of Dutch constitutional law: "The King is inviolable; the Ministers are responsible." In spite of its apparent simplicity, this rule has several dimensions, a legal, but also an historical, psychological and theological dimension. The book is therefore also a quest into the underlying motives for the monarchy, an investigation of the phenomena of king and kingship. New information emerges and old views may be complemented or adapted, but the conclusion must be that the monarchal image, representing human coexistence, truth, myth, authority and freedom, remains an enig$\mathrm{ma}$, an ever-lasting hazardous venture.

The book commences with The King in 1848. Shocked by the sudden outbreak of revolutionary violence all over Europe, Dutch King Willian II put through a quick and thorough revision of the Constitution. Article 53 of the new 1848 Constitution read: "The King is inviolable; the Ministers are responsible." This article was held in higher regard than the others; it was never amended and maintained its reputation as the corner stone of the edifice of the State.

What did article 53 introduce? The accepted view is that it established The Powerless King. Whereas previously the King of the Netherlands, as the highest authority and decision-maker, had truly reigned, due to this provision he lost his power to the ministers. The nucleus of power and policy came to rest with the ministers, who by virtue of their ministerial responsibility were accountable to parliament, which as representative of the people, had the final say.

Then there is The brain wave; and other problems. The brain wave refers to the English equivalent of what is called in the Netherlands 'royal inviolability', i.e. the principle of 'The King can do no wrong', which is also an expression of royal impotence; but there is the sudden realization that this rule bears a striking resemblance to the Italian maxim Mussolini ha sempre ragione (Mussolini is always right), which is not about impotence, but, on the contrary, about the unlimited authority of a supreme leader. A more detailed investigation into the events of 1848 subsequently reveals that prominent statesmen and jurists did not intend, as has been thought, to relieve the King of his power, but rather to protect it. Throughout his life, Johan Rudolf Thorbecke, the 
most prominent of the framers of the new Constitution, defended a system in which the King would reign in full, and therefore command, whereas the ministers would be responsible for their cooperation.

This preliminary exploration of royal inviolability produces three questions. First: is there more than a superficial similarity between the English and Italian constitutional maxims, and if so, to what degree?; second: why did the King lose his supreme command?; and third: what is the sense of Thorbecke's doctrine of ministerial responsibility, according to which ministers, although subordinate to the monarch and consequently held to obedience, are accountable for their acts, as if they had a choice?

These Questions, and a method form the Leitmotiv of the dissertation. They feature throughout the book and answers to these questions are sought using a method which cannot be rigid, since Kingship turns out to be a multi-faceted phenomenon, having a variety of appearances. The tale of kings has many versions; this diversity is reflected by the four versions in the book. Each version provides different and sometimes contradictory answers to the three questions. The first and fourth version of the tale of kings are presented as each other's antipodes; the first is the traditional, rational version, whereas the fourth is the mythical one, intended as the most significant contribution of the study. Part one describes the first three versions in three chapters on The King. The second part discusses the fourth version, The Myth, in three chapters.

The chapter entitled The King symbolizing God tells the traditional tale of European kings. The King was the symbol of external, imposed authority, which was reinforced by the mythical image $(\$ 1)$; however, reformist constitutional movements led to the modern bourgeois-progressive, democratic state based on the rule of law. The principle of rationality and science undermined the myth, the external authority of the monarch was replaced by an internal justification of authority, the will of the people $(\$ 2)$. The evolvement of the rule of royal inviolability and ministerial responsibility in England, where it originated $(\S 3)$ and in the Netherlands $(\$ 4)$ is part of the tale. The King was declared inviolable, elevated beyond political reality and the ministers were to conduct the country's policy in the name of the people. Whereas the authority of the King, as that of God, ceased, his myth was to survive as a non-reality, carefully encapsulated, without any impact on the rational approach to conducting the affairs of state $(\$ 5)$.

In this traditional version of the history of the European kings, the two maxims 'The King can do no wrong' and 'Mussolini ha sempre ragione' share no common features, there is no correspondence imaginable. The King lost his power to the people by way of the ministers. Thorbecke's system of reigning king and responsible ministers has either been a mistake, or a ruse to conceal from the king what was to happen to him; the question no longer bears relevance. Or does it? The system was also supported abroad, even up to the twentieth century by German jurists $(\$ 6)$.

The King symbolizing the Society is the king as the supreme judge. His final judgment, his ultimate verdict, not subject to review, prevents differences of opinion from disintegrating human society; in this second version of the tale of kings, the inviolable king is the "keystone which closeth up the arch of order and government." (\$1) A thorny problem arises though: who is to ensure that such a final judgment, which after all cannot be contradicted, is also just in substance? Any independent assessment of it by society itself cannot be allowed; it would immediately eliminate the inviolable king. 
Ministerial responsibility was devised to resolve this dilemma: the King will naintain his supreme power, his decisions shall be final, but the executors of bis will, the ministers, shall be answerable; no need for them to be inviolable ( $\$ 2$ ). Inviolability was not equated with impotence, but with the irresistible power of the king; an idea that was not introduced in 1848 , but that rather was carried on. In this version, the relation with the fascist motto 'Mussolini ha sempre ragione' can be more readily understood.

It also becomes more clear why ministers were to be responsible while the king's power remained intact; this construction served to preserve the unity of society. But how did de King come to lose his power after all? There is the dawning of an awareness that the position of the inviolable king is inherently untenable; a final judgment, in the hands of a fallible man, be he named king, must not stand by itself; in other words must not be ultimate $(\$ 3)$. Was this inviolability envisaged in 1848 ? It has precisely disappeared with the modernization of European states! The edifice of the bourgeois-progressive, democratic Rechtsstaat no longer embraces the concept of the king as final judge $(\$ 4)$. Thanks to the development of rationality this could happen without the risk of civil war; Reason was substituted for the King, becoming the ultimate judge on whom everyone could rely, making it possible for people to coexist in spite of their differences $(\$ 5)$. Destroying the King's imposed authority or ensuring that the King's decisions are just decisions? These questions could not be asked when the people still saw the King as symbolizing Justice. In former times, it was propounded that the King was the embodiment of law and justice; he was infallible, his supreme authority in conformity with true knowledge ( $\$ 1$ ). A deeper current than the external struggle against the kings reveals itself; only after it was accepted that no man on earth could own the infallible truth did the unlimited authority of the king become insufferable; the process of democratization is not so much a struggle against monarchs as a more general struggle against the arrogant pretension of infallibility. There is no absolute truth, which is just as well, because only if absolute truth neither exists nor is known by any human being, can people freely develop according to their own views ( $\$ 2$ ).

What is the meaning of royal inviolability, or rather, the maxim 'The King can do no wrong' in this third version of the story? Infallibility? Jurists entertained a vision of duality: not the king as a person, but kingship, the institution, is infallible; not the king with a small ' $k$ ', but the King with a capital ' $K$ ' $(\$ 3)$. This differentiation pervades the history of, for instance, English constitutional law, and it is rather striking that it was precisely the rebellious subjects who seized on this division; in justifying their struggle against the king they invoked the abstraction of his Kingship: 'Fighting the king to defend the King' ( $\$ 4)$. It becomes evident, therefore, that the earlier political movements, characterized in the traditional version as anti-monarchy and democratic, have in fact perpetuated the pretension of infallibility by invoking the King-capital ' $\mathrm{K}$ ' who can't be wrong; historically, the line leads directly from these movements to modern dictatorial systems ( $\$ 5$ ).

Infallibility as the pretension of the old kings and also as the pretension of modern dictators; the rwo maxims 'The King can do no wrong' and 'Mussolini ha sempre ragione' almost match here. But what about that distinction in the Englis' maxim between king-small ' $k$ ' and King-capital ' $K$ '? It reflects an ancient dilemma: authority must be invariably just, but is always exercised by fallible individuals. The distinction 
stems directly from this dilemma and all of a sudden seems to correspond perfectly to the division king/ministers, discussed in the previous chapter: the king could never do wrong if fallibility could be handled through the ministers. Is there a connection? Yet another connection becomes visible. In the preceding chapter, the inherent impossibility of the monarchy was uncovered; it is aptly complemented here by a second impossibility: just like the formal inviolability of a royal verdict, the infallibility of the monarch forces him to become a symbol, a political absentee (\$ 6).

The part dealing with The King is followed by the part discussing The Myth; The Myth of the Good King. The history of twentieth-century dictatorial systems shows that dictatorship is not imposed from above, by the powers that be. Mussolini did impose his sempre ragione externally, but his subjects' acceptance of the maxim was also motivated by an internal need for a strong leader. This need is analyzed by modern psychology, which retraced it to a fear of freedom, for with freedom inevitably come loneliness and insecurity $(\$ 1)$. In this context, internal mechanisms cause a remarkable phenomenon, which can be observed under Mussolini, Hitler, Lenin and Stalin: when deplorable things happen in a country and the question as to how this is possible under the rule of an infallible and benevolent ruler is raised, the finger is readily pointed at the close aids, who, unbeknownst to their superior, commit evil; the recurring story of the good ruler and bis evil aids ensures that the belief in the good will of a dictatorial ruler refuse's to die (\$2).

It is a story of modern dictators, but it also holds true for the earlier kings of England, France and Russia, and for a Pope and an African emperor; there is always the refrain of the good king and his evil advisors $(\S 3, \S 4)$. And there is The Good King in the Netherlands. Under twentieth-century dictatorship, in the Middle Ages, but equally during the two centuries of stadtholdership by the Princes of Orange, Dutch citizens have felt that what went wrong in public affairs should be attributed to the influence of the malicious advisors of the good monarch $(\S 1, \S 2, \S 3)$. This belief in the King needs to be tested: how general and how sincere is it? Or was it perhaps a pretence? It seems fair to conclude that the fairy tale of the good king and his evil advisors may spring up anywhere, and that it is no trick, but a genuine belief, stemming from a strong internal, unconscious need for an image of infallibility.

Subsequently The myth of good old 1848 surfaces. The fairy tale of the good king and his evil advisor seems to tie in with the Dutch constitutional system of inviolable king and responsible ministers, the product of 1848. Can we relate the two? We can indeed. The myth pervades the history of ministerial responsibility in England; parliament did not ask for responsibility of ministers to enable it to remove the king's power, but because it was firmly believed that ministers were scoundrels, servants who deceived their royal master $(\$ 1)$. The historical texts frequently offer a fine view of how myth and constitutional principle were interwoven ( $\$ 2$ ). In the Netherlands this can also be observed under the stadtholders ( $\$ 3$ ) and after 1813 , under the rule of the Orange Kings. It can be clearly seen here low the myth eventually led to the pressing demand that the principie of royal inviolability and ministerial responsibility be enacted in the Constitution $(\$ 4)$. There is evidence that the correspondence between myth and constitutional law has been spotted earlier in literature ( $\$ 5$ ). 
In the fourth, the mythical version of the tale of kings, the maxims 'The King can do no wrong' and 'Mussolini ha sempre ragione' truly merge; they are both expressions of belief in a good ruler whose beneficent intentions are destroyed by evil helpers. The impotence of the monarch carries yet a deeper meaning; the fairy tale of the unaware king automatically pictures him as politically absent. As for the system of the responsible servant: the subjects' belief that ministers sidestepped their monarch's orders was the underlying motive for the call for ministerial responsibility, penalties for ministers, precisely because they were subordinates. In this context, the detached constitutional teachings of Thorbecke served as a guise for the mythical call for a scapegoat $(\$ 6)$.

These four versions of the tale of kings, dominated by the strong contradistinction between the first, the rational, and the fourth, the mythical version, are followed by a concluding chapter: God symbolizing the King. According to the first version, Western constitutional systems had been democratized by doing away with the mythical king. The fourth version, however, presents article 53 of the 1848 Dutch Constitution as a victory for the mythical element; rationality did not prevail over the mythical element, not even did it see through it, but rather bestowed on it the honour of becoming the comerstone of the constitutional system. The myth of the good ruler and his evil advisors still plays a role, even in the highest echelons of democratic states. Consequently, true democratization must be seen as internal liberation; it cannot as yet be regarded as a possession quietly enjoyed by Western democracies, secured forever. $(\$ 1)$ Is individual freedom the last word, in any case? Must society, justice, belief, those values embodied by the King, simply give way to freedom? But surely, freedom without these three values of the monarchal element is tantamount to lasciviousness, civil war and chaos. The monarchal element proves to be: intolerable for the sake of human freedom, yet indispensable for the sake of human dignity $(\$ 2)$. The impotence of the king had been wrongly perceived as democracy; the result of a mistaken view, a denial of the necessity of the royal element, a misconception that turns freedom into civil war, ultimately destroying it.

This is best perceived when we regard the divine instead of the monarchal as the representation of the three values. Even more than the king, God symbolises community, justice, belief. Also here the lively dilemma persists that the divine image as a symbol of higher values is indispensable, yet intolerable, because of the threat to human independence and responsibility. In this conflict, we ultimately perceive the theological companion to Thorbecke's constitutional interweaving of royal command and ministerial discretion and responsibility; Thorbecke himself was an avowed proponent of this theology.

Consequently, a comparison of the monarchal and the divine must result in the conclusion that unity and diversity, authority and freedom, truth and fallibility go together as indispensable yet impossible correlates, a coincidentia oppositorum ( $\$ 3$ ).

Translation: Mrs. Louise Rayar Mrs. Caroline Squirrell-Maks 



\section{Register}

\section{Adomo 144}

Allen 76,115

Alva $170-171$

Amsterdam 174, 179, 182, 188, 193, 203. 206

Andringa de Kempenaer 218

Anna, prinses, 64, 73, 181, 203

Archimedes 99

Aristoteles 50,80, 92

Arthur 154

Augustinus 78

Augustus 51

\section{Bagehot 69-71}

Baldus $88,107,129-130$

Barclay 118

Bentinck $63-64,73,179,181,187,203-204$, 235

Bevervoorde 219

Blackstone $75-76,82,90,114-116,126,128$, $129,224,235$,

Bodin 57, 107

Boissevain $66,73,81,128-129,132$

le Bon 143

de Bosch Kemper 65, 244-245

Bosscha 16

Bossuet 50, 131

Boswell 75

Boudewijn 18-19, 69

Bracton 52, 87-88. 105, 115, 129

de Bris 169

Brunswijk 181-183, 187, 189 .

204-207

Buchanan 200

Buckingham 59-60, 194-198, 200-201

Burke, Ldmund, 84, 238

Burke, Peter, 154, 193-194

Butler 201

Buys 17, 28, 33, 34, 39, 115, 129, 223, 235

Bynkershoek 63

\author{
Cajetanus $117,161-162$ \\ Calvijn 156, 169 \\ Mme. Campan 188 \\ Capellen tot den Pol 184 \\ Case 45 \\ Chateaubriand $72,91,243$ \\ Ciano 147 \\ Clarke 70 \\ Colardeau 67 \\ de Coninck 31 \\ Constant $72,91,92,221$
}

Daalder 24-25

Danby 61

Koning David 88

Den Haag 178, 181-182, 207-208

Descartes $53-54,99,112,121,123$

Dollinger 117

Donker Curtius 65, 73, 218

Donner 19, 22

Dostojevski 53

Drees 23

Dryden 83

Edward II 131

Edward IV 91

Edward VII 94, 243

Ehrenburg 150

Eliot 59,195

Ellesmere 97-98

Euklides 84-85, 107

Falck 28

Felton 196

Fénelon 50, 77

Fichte 101, 110

Field 186

Filmer $86-87$

Fisher 94, 243 
Frans I 156, 169

Frederik Hendrik 174

keizer Frederik II 106, 154

koning Frederik II 52

Freud 138-139, 143, 145, 146, 163

Fromm 144-145, 151. 163

Gay 109

Gebensleben 141

Geurge III 156

E.F.J. van den Gheyn 215,243

Th. V.H. van den Gheyn 34, 72

God 50, 53-55, 64-71, 105-107, 119-121, 240-

246

Goejanverwellesluis 208

van Goens 64

Goering 140-143, 152, 166

Goldman 149

Grimaldi, Ugoberto, 139

Groen van Prinsterer 27, 94-95

Guizot 127-129, 132

Haarlem 180,181

Haile Selassie 162

van Hall 28, 32, 35-36, 39, 217-218

van Hardenbroek 205

Hegel 54, 57, 68, 84, 99, 101, 129, 130, 158,

244

Heine 70

Hendrik IV 77

Hendrik VI 155

Hildegaersberch 168

Hill 93, 201, 202, 221

Hinmler 160

Hitler 140-143, 146-148, 154, 160, 165-166. $187,189,224.225$

Hobbes 77

van Hogendorp 20, 31, 34

van Houten 22, 69, 79

Huizinga $107,152,167$

van Hulsi $66,81,128$

Hume $54,87,90,109,113,127,238$

graaf Inisdal 188

Israël $104,173,233$

Ivan IV 159

Jackson 226

Jakobus I $50,52-54,78-79,88$

Jakobus II 156

Jezjov 150-151

Johnsoin 75-76, 82, 89-90

Juliana 23,235
Kant 54, 57, 66, 70-71, 84, 99

Kantorowicz 87, 116, 131

Karel de Grote 153-154, 168

Karel I 52, 59-61, 85-86, 98, 120, 130, 195$197,199-201,205-206$

Karel II 93

Karel V 105, 119

Keir Hardie 94

Kelsen 111

Kennedy 229, 232

Kerchove de Denterghem 96

Kershaw 147, 160

Kluit 186

Kossmann 98

Krause 245

Lagemans 33-34, 39, 72, 96

Lajolo, Davide, 146

Lampe 70

Laukhard 95

Le Bon 143

Leeuwarden 188

Lenin $148-149,154,160$

Lessing 112,126

Lintjens 65

Locke 56, 86-87, 118

Lodewijk XIII 157, 190

Lodewijk XIV 49-51, 58, 79, 80, 106, 153, 156-158

Lodewijk XV1 95, 123, I58, 188

Loisel 54

Lovejoy 50

Luther $117,161-162,169,187$

van Maanen 96, 213-215, 221

Mackay 16, 94

Maistre 84-86

Marie Antoinette 188

Marin 92, 98

Marx 125

Maurits $172-174,176$

Mazarin 157-158

Mazzini 124

Meerman 173

Metternich 15

Meyers 166

Mirabeau 158, 159

Mohl 137-138

Montchal 106, 157, 189-191, 200, 202

Montesquieu 56, 97, 158

Mountnorris 197

Musch 175

Musser 165-167, 187 
Mussolini 24-26, 29-30, 40-44, 114, 125-126, $133,139,140,142,143,146-148,152,193$, 222

Napoleon III 125,143

Nathan 88

Nearing 111-112, 126

Neurenberg 39-41, 225-226, 244

Newcastle 93

Nicolaas П 66

Oldenbamevelt 174,176

Orwell 125,131-133

Oud $39,61,83,89,234$

Oudendijk 186

Pastemak 1S0, 187

Phelips 195

Philips II 36, 119, 169-172, [86-187, 22 ]

Plato 50. 105

Pothekke 193-194, 221

Pym 195, 198, 201

Reagan 233-234

Rendorp 205-206

Renswoude 175

van het Reve $52-53$

Richard II 155

Richelieu 157, 189-190, 202

Roberts 194-201

Robespierre 123-124

Robin Hood 154

Rousseau 54, 113, 122-125

Rowen 177

Rusland $66,85,153,159,160$

Russell 127, 128

Sage ten Brock 210-212, 214

Saint-Simon 125

Sante 236-237

Schachleiter 141

Schaepman $22,69,79,82$

Schöffer 186

Shultz 233-234

Sjtsjapov 160

Smith 124

Sommelsdijk 175

Sonsbeeck 54, 100

van de Spicgel 64, 204
Stalin $148-151,160$

Starace 146-147

Stebenev 150,187

Stefanovitsj 160, 187

van der Straeten 35, 209, 210, 212, 214, 217 , 243

Strafford 59-61, 79, 194-198, 200-201, 205

Struycken 57

Suffolk 155

Tacitus 52, 131

Talmon 121-125

W.I. Thomas 138

Thomas van Aquino 88

Thorbecke $16,28,35-41,65-66,71-73,76,82$, $91,94,100-102,126,128-129,131,133,218$, $221,222,224-226,231,244-246$

Tyler, Wat, 155

Varga 163

Victoria 69,72

Voltaire 109

Vondel 174

Vondeling 23

Ward 117

Washington 156

Wedgwood 201

Wentworth, zie Strafford

Wicquefort 62,174

van Wijnen 18,22

Wilhelm II 66

graaf Willem UI 168

Willem van Oranje $119,170-172,187$

stadhouder Willem II 172-173, 193

stadhouder Willem III $63,94,156,173,175$ -

178

stadhouder Willem IV $63,178-181,187,189$, 203

stadhouder Willem V 64, 181-184, 187, 189, 204-208, 210, 221, 243

koning Willem I $20-21,35,60,64-65,81,94$, $96,208-215,217,221,243$

koning Willem II $15-16,21,40,65-66,213$, $217-218,222$

koning Willem III $21-22,40,93,94$

de Wit 62,173

de Witt 176,183

Wittgenstein 230 



\section{Charel B. Krol}

Schrijver dezes werd geboren te 's-Gravenhage, de negende december negentienhonderdzestig. Hij kxeeg te Voorburg allerlei bijgebracht dat geschikt is als voorbereiding op het volgen van wetenschappelijk onderwijs, zoals lezen, rekenen, wiskunde, natuurkunde, Grieks; van 1967 tot 1978. Hij liet zich te Rijswijk, de Nederlands Gereformeerde Kerk, onderrichten in het theologische, te Leiden, aan de Rijksuniversiteit, van 1978 tot 1987, in de geschiedwetenschap, het recht en de wijsbegeerte. Werd te Harderwijk doorkneed in de beginselen van de Russische grammatika. Doceerde in 1988 enkele maanden Encyclopaedie der Rechtsgeleerdheid aan de Universiteit van Amsterdam. Verhuisde dan naar sjoen Mestreech, waar de Rijksuniversiteit Limburg hem van 1989 tot 1994 gelegenheid gaf dit amalgama van wetenschappen, onderzoeksvaardigheden en belangstellingen te verenigen in een onderzoek naar de voorwaarden van staatsrecht en gezag, de mythe van de goede Koning. De rest komt nog. 



\section{Ius Commune reeks}

Reeds verschenen:

M. Faure, (ed.), Aansprakelijkheid voor het nucleaire risico

R. Seerden, Publiekrechtelijke grensoverschrijdende samenwerking tussen decentrale overheden

C. Flinterman, A.W. Heringa, L. Waddington, (eds.), The evolving role of parliaments in Europe; L'évolution des parlements en Europe

G. Samuel, The foundations of legal reasoning

G. Smaers, Gedetineerden en mensenrechten

Ch. B. Krol, Als de Koning dit eens wist...!

Binnenkort te verschijnen:

P. Rambach, Die deliktische Haftung Minderjähriger und ihrer Eltern im französischen, belgischen und deutschen Delikasrecht

M. Faure, J. Vervaele, A. Weale, (eds.), Environmental Standards in the European Union in an Interdisciplinary Framework

H. Schneider, Anerkennung von Diplomen in der Europäischen Gemeinschaft

L. Waddington, Disability, Employment and the European Community 
Een boekenreeks waarin de gemeenschappelijke grondsiagen in đe rechtstelsels van de Ianden binnen de Europese gemeenschap cen: traal staan. De lus Commune Reeks bevat zowel horizontaal rechtsvergelijkende studies als anderzoeken naar de doorwerking van verdragsteksten in nationale eteisels. Alle klassieke domeinen van het recht worden bestraken. De boeken worden uitgegeven in verscheidene Europese talen en staan onder auspiciēn van METRO, het rechtswetenschappelijk onderzoeksinstituut van de Rijksuniversiteit Limburg. Mastricht.

Wist onze Koning or maar van. beslist, hij zou het onmiddellijk rechtzetten! Door de tijden been klonk telkens weer deze zelfde verzuchting: Het gaat verkeerd in ons land, hoe kan dat? Hoe kan dat tech, want onze Koning, onze Tsaer, onze Führer is immers de goedheid zelve; ondenkbaar dat hif de wantoestand siet zou verhelpen zodra bii ervan hoorde, Hij weet het dus niet. En waarom aiet? Mensen in zija naaste omgeving, raadsheren, ministers, bedriegen de Koning en houden hem af van de heilzame maatregelen die hij meteen zou treffen - als hij wist hoe het er werkelijk voer staat.

Geloof in de goedheid van de Koning: geloot in de kwasdaardigheid der ministers. Het is uit historische bronnen aanwijstaar dat deze mythe is ingeslopen in de Nederlandse grondwet. Rechtstraeks in verband met de mythe ontstond een wezenlijk heginsel van Nederlands staatsrecht: De Koning is enschendbaar: de ministers zijn verantwoerdelijk.

Als de Koning maar wist wat wij weten, want wif weten het wel. Onderdanen die menen dat hun kennis juist is, zullen ook mesen dat do Koning hun kennis moet overnemen. De Koning is niet slechts een historische ligum, deze of gene meer of minder geslaagde heerser. Hij is symbool van verheven begrippen. waarheid, gerechtigheid. geedheid, God. Een onderzeek aangaande het beeld van de onschendbare Kaning kan zodoende inzicht verschaffen hoe mensen met deze waarden willen omgaan.

Van zulk onderzoek, verricht aan de Rijksuniversiteit Limburn, wordt hierbij tenslotte verslag gelegd. 